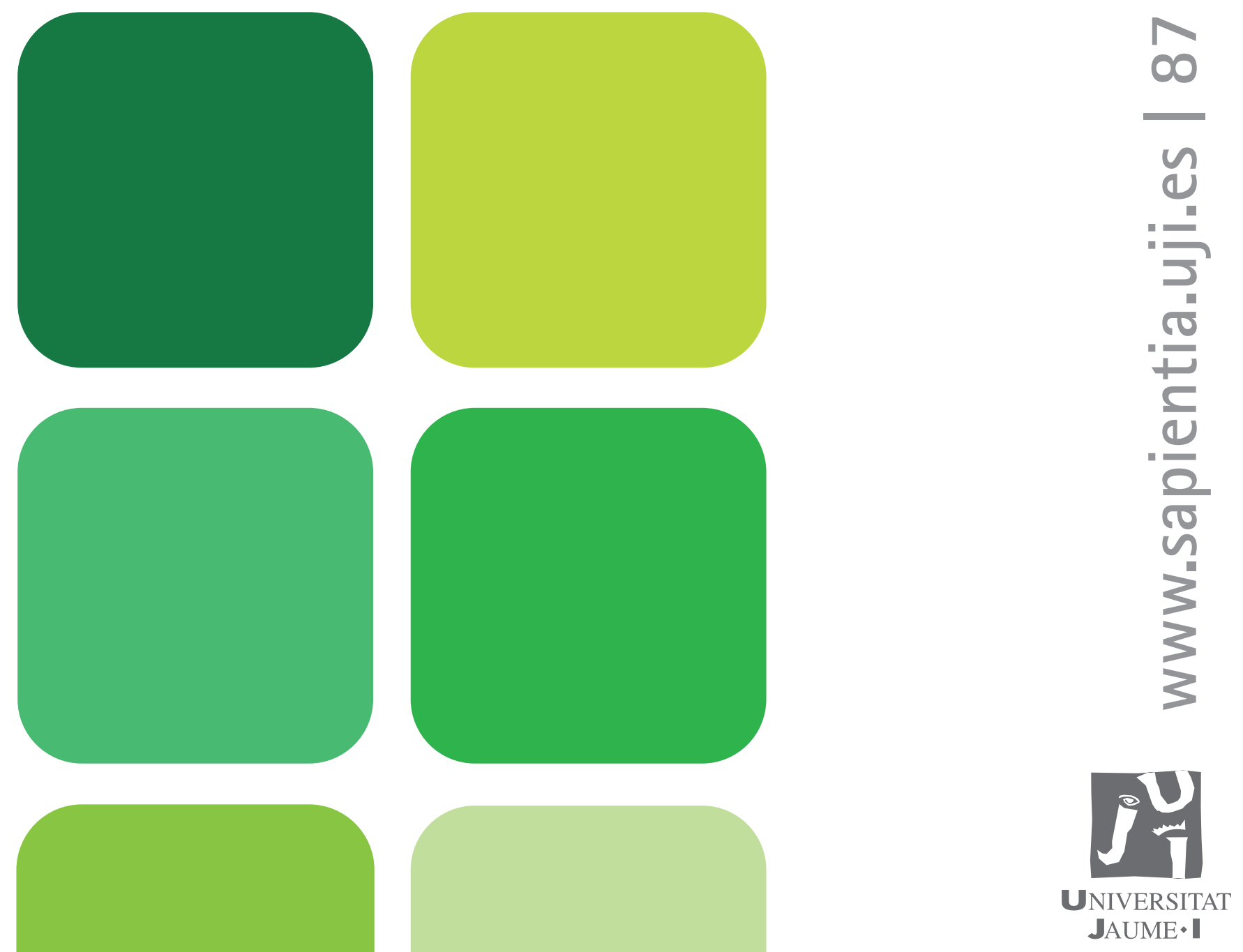

Mecànica i resistència de materials

Óscar Martínez Ramos 


\title{
Mecànica i resistència de materials
}

\author{
Óscar Martínez Ramos
}

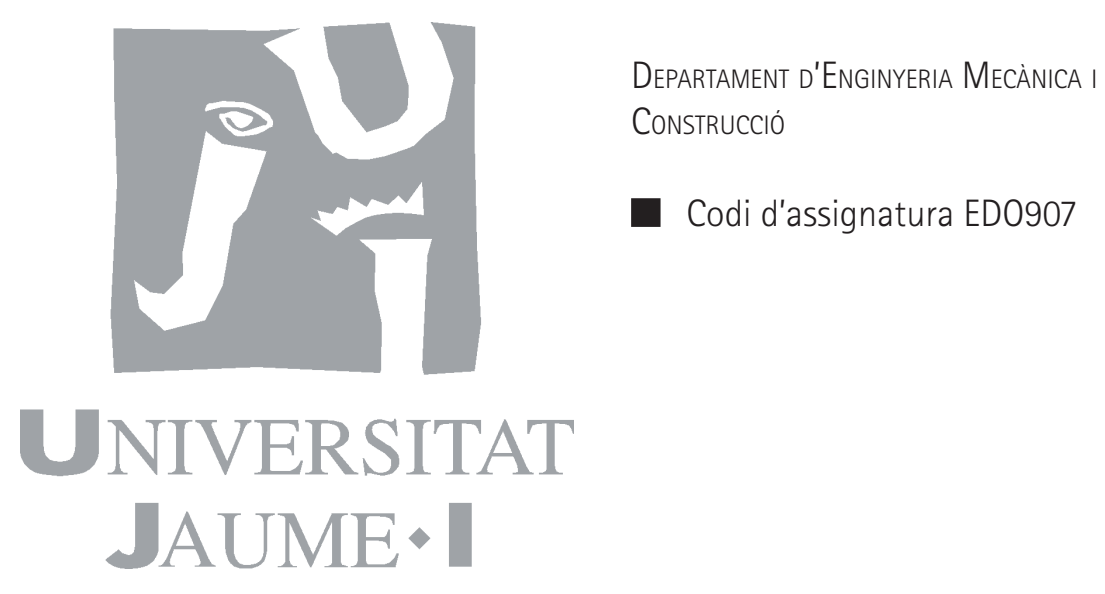


Tamquam ex ungue leonem.

Johann Bernouilli

Edita: Publicacions de la Universitat Jaume I. Servei de Comunicació i Publicacions Campus del Riu Sec. Edifici Rectorat i Serveis Centrals. 12071 Castelló de la Plana http://www.tenda.uji.es e-mail: publicacions@uji.es

Col·lecció Sapientia, 87

www.sapientia.uji.es

Primera edició, 2014

ISBN: 978-84-695-9563-3

Publicacions de la Universitat Jaume I és una editorial membre de l'UNE, cosa que en garanteix la difusió de les obres en els àmbits nacional i inter-

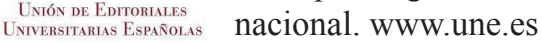

\section{(c) (i) (2)}

Reconeixement-Compartirlgual

CC BY-SA

Aquest text està subjecte a una llicència Reconeixement-CompartirIgual de Creative Commons, que permet copiar, distribuir i comunicar públicament l'obra sempre que s'especifique l'autor i el nom de la publicació fins i tot amb objectius comercials i també permet crear obres derivades, sempre que siguen distribuïdes amb aquesta mateixa llicència.

http://creativecommons.org/licenses/by-sa/3.0/legalcode 
Índex

Pròleg

Introducció

Tema 1. Estàtica de sistemes

1.1. Introducció

1.2. Estàtica de forces

1.2.1. Principis d'estàtica

1.2.2. Moment d'una força respecte a un punt

1.2.3. Moment d'una força respecte a un eix ...

1.2.4. Composició de forces. Força i moment resultant .

1.3. Condicions d'equilibri

1.3.1. Principi de petita deformació

1.3.2. Principi de Saint-Venant

1.3.3. Càrregues estàtiques o quasiestàtiques

1.3.4. Forces internes i externes

1.4. Enllaços i reaccions

1.4.1. Graus de llibertat

1.4.2. Càrregues

1.4.3. Enllaços o lligadures

1.5. Sistemes isostàtics i hiperestàtics

1.6. Càlcul de reaccions

1.6.1. Sistemes isostàtics plans

1.6.2. Sistemes isostàtics espacials

Problemes proposats

Tema 2. Esforços interns

2.1. Concepte de sòlid i prisma mecànic

2.1.1. Concepte de sòlid

2.1.2. Prisma mecànic

2.2. Equilibri i concepte de tensió

2.3. Definició d'esforços interns

2.4. Càlcul d'esforços interns

2.5. Lleis i diagrames d'esforços

2.6. Propietats dels diagrames d'esforços

2.6.1. Diagrama d'esforços axials

2.6.2. Diagrama d'esforços tallants

2.6.3. Diagrama de moments flectors

Problemes proposats 
Tema 3. Fonaments d'elasticitat

3.1. Introducció

3.2. Vector tensió

3.3. Relació entre esforços i tensions

3.4. Deformacions

3.5. Relació entre tensions i deformacions

3.5.1. Llei de Hooke

3.5.2. Llei de Hooke generalitzada

3.6. Determinació de les propietats mecàniques

3.6.1. Elasticitat i plasticitat

3.6.2. Assaig de tracció

3.6.3. Comportament a compressió

3.6.4. Diagrames idealitzats

3.7. Efecte de la temperatura

3.8. Influència del temps

3.9. Concepte de fallada i coeficient de seguretat

3.9.1. Concepte de fallada

3.9.2. Coeficients de seguretat

3.10. Criteris de trencament i plastificació

3.10.1. Criteri de Rankine o de la màxima tensió normal

3.10.2. Criteri de Tresca o de la màxima tensió tangencial

3.10.3. Criteri de Von Mises o de la màxima energia de distorsió

3.11. Principi de superposició

Problemes proposats

Tema 4. Esforç axial

4.1. Introducció

4.2. Distribució de tensions en la secció

4.2.1. Hipòtesi de Bernouilli

4.2.2. Principi de Saint-Venant

4.2.3. Efecte de concentració de tensions

4.2.4. Tensions sobre una superfície obliqua

4.3. Deformacions longitudinals

4.3.1. Variacions de longitud. Allargaments i acurtaments

4.3.2. Variació unitària de volum

4.4. Desplaçaments de les seccions

4.5. Estructures de barres

4.5.1. Mètode dels nucs

4.5.2. Mètode de les seccions

4.5.3. Compatibilitat de desplaçaments

4.6. Elements hiperestàtics

Problemes proposats

Tema 5. Flexió - tensions

5.1. Introducció

5.2. Tipus de flexió

5.3. Relació entre esforços i distribució de càrrega 
5.4. Distribució de tensions normals. Llei de Navier

5.5. Flexió simètrica

5.6. Flexió asimètrica

5.7. Flexió composta

5.8. Bigues compostes o mixtes

5.9. Distribució de tensions tangencials en flexió

Problemes proposats

Tema 6. Flexió - deformacions

6.1. Introducció

6.2. Equació general de l'elàstica

6.3. Rigidesa a flexió. Bigues simples i mixtes

6.4. Mètode de Maxwell-Mohr

6.5. Interpretació gràfica del mètode de Maxwell-Mohr

6.6. Sistemes hiperestàtics

Problemes proposats

Tema 7. Torsió

7.1. Introducció

7.2. Tensions degudes a torsió

7.3. Gir de les seccions

7.4. Perfils massissos no circulars

7.5. Torsió per a perfils de paret prima

7.6. Perfils tubulars

Problemes proposats

Tema 8. Vinclament

8.1. Introducció .

8.2. Càrrega crítica d'Euler

8.3. Esveltesa .

8.4. Disseny d'elements

Problemes proposats

Annex A. Mètodes d'unió

A.1. Introducció .

A.2. Unions cargolades

A.2.1. Disposicions constructives

A.2.2. Formes de trencament de les unions cargolades

A.2.3. Cargols d'alta resistència

A.3. Unions soldades

A.3.1. Resistència de les soldadures a topall .

A.3.2. Resistència de les soldadures en angle

Problemes proposats

Annex B. Coneixements previs - sistemes d'unitats

B.1. Introducció

B.2. Sistema internacional (sI) 
B.2.1. Unitats i símbols

B.2.2. Prefixos

B.3. Altres sistemes d'unitats

B.4. Factors de conversió

Problemes proposats

Annex C. Coneixements previs - àrees i centres de gravetat

C.1. Introducció

C.2. Àrees

C.3. Centre de gravetat, centre de masses i centroide

Problemes proposats

Annex D. Coneixements previs - moments d'inèrcia

D.1. Introducció

D.2. Definició

D.3. Eixos principals d'inèrcia

D.4. Altres definicions

D.5. Moments d'inèrcia coneguts

D.6. Teorema de Steiner

Problemes proposats

Solucions als problemes proposats

Bibliografia . 


\section{Pròleg}

El material que es presenta a continuació correspon al temari complet de l'assignatura Estructures I: Mecànica i Resistència de Materials, del Grau d'Enginyeria d’Edificació a la Universitat Jaume I de Castelló.

A causa de l'absència d'un text bàsic adaptat al temari complet del curs, amb aquest manual volem dotar l'alumne d'una eina bàsica per a enfrontar-se a l'estudi i preparació de l'assignatura. Ha de tindre's en compte que l'ús d'aquest text no serà suficient si no es complementa amb altres materials, com ara les presentacions de classe, una col·lecció addicional de problemes resolts i proposats, exàmens d'altres convocatòries, etc.

En tant que es tracta d'una matèria eminentment pràctica, en aquest document hem seguit la següent estructura en cadascun dels temes. En primer lloc farem una introducció teòrica. A continuació anirem desenvolupant el tema i intercalarem exemples d'aplicació, que són els que veritablement possibilitaran la comprensió plena dels conceptes. Finalment, en cadascun dels temes, si escau, trobarem uns exercicis resolts i d'altres proposats, en els quals només donarem el resultat numèric, a fi que l'alumne vaja avaluant el seu nivell de domini sobre els continguts. L'alumne ha de saber que el simple fet d'estudiar i comprendre els exercicis resolts que s'arrepleguen en el llibre no és garantia d'èxit, si no va acompanyat del treball personal en la resolució dels exercicis proposats.

Estructures I no és un ens aïllat de la resta de matèries de coneixement, ja que suposa una evolució natural des de la física que els alumnes han cursat tant en batxillerat (o altres estudis secundaris) com ja dins del propi grau, en l'assignatura Física I, i té continuïtat en les assignatures Estructures II i Estructures III. Per aquesta raó, hi ha uns coneixements previs que haurien de tindre's en començar el curs. És conegut que no sempre s'arriba a l'inici amb la base teòrica adequada, per la qual cosa s'han afegit uns annexos al final de l'obra, on es repassen de manera molt succinta els aspectes mínims necessaris corresponents a sistemes d'unitats, àrees, centres de gravetat i moments d'inèrcia.

L'autor vol mostrar el seu agraïment als companys de l'Àrea de Mecànica dels Mitjans Continus i Teoria d'Estructures, en especial a Lola Martínez Rodrigo, sense l'ajuda de la qual els inicis en el món de la docència universitària hagueren sigut més difícils. Així mateix, es vol agrair el suport al Departament d'Enginyeria Mecànica i Construcció, i a la Universitat Jaume I per la iniciativa en la publicació de materials docents lliures. 


\section{Introducció}

«L'enginyeria estructural és l'art de modelitzar materials que no comprenem del tot, en formes que no podem analitzar d'una manera precisa, per a suportar esforços que no podem avaluar adequadament, de manera que el públic en general no tinga cap raó per a sospitar de la nostra ignorància.»

Hugo Corres Peiretti, doctor enginyer de CCP

L'assignatura Estructures I: Mecànica i Resistència de Materials porta l'alumne des de la introducció inicial de l'estàtica de sistemes, a través del càlcul d'esforços interns, passant de manera molt succinta a través de la teoria de l'elasticitat, fins a la resistència de materials clàssica, adaptada a l'àmbit de l'enginyeria d'edificació.

La resistència de materials té com a objectiu fonamental determinar la resposta de les estructures quan estan sotmeses a les diferents accions que les poden afectar durant la seua construcció o vida útil.

En aquesta part de l'assignatura, que és la fonamental del curs, s'estudien els diferents esforços a què pot estar sotmesa una peça, com a conseqüència de les accions, avaluant la tensió a la qual s'arriba en els seus punts, així com la deformació que es produeix en ella.

Els materials que utilitzem en el domini de l'enginyeria estructural han de complir uns requisits de resistència (no s'han d'excedir les tensions admissibles), de rigidesa (no han de produir-se deformacions superiors a uns límits) i d'estabilitat (una vegada separat un punt de la seua posició d'equilibri com a conseqüència d'una acció, cessada l'acció, el punt ha de retornar a la seua posició d'equilibri). Els límits corresponents a aquests requisits vénen marcats avui en dia per la normativa vigent.

Els dos tipus de problemes als quals ens enfrontem en resistència de materials són, d'una banda, els problemes de dimensionament, i d'altra, els problemes de comprovació. En els problemes de dimensionament, suposem que la geometria de l'estructura ha sigut ja definida. El que busquem llavors és trobar les dimensions més adients perquè les peces siguen capaces de suportar els esforços que es produeixen, sense deformar-se més enllà dels límits. En els problemes de comprovació, les dimensions estan ja definides, i es tracta de verificar si s'excedeixen els límits de tensió i deformació.

No obstant això, pràcticament des que l'home va aparéixer a la Terra, ha necessitat que els materials que utilitzava compliren uns requisits de resistència mecànica. Per tal d'aconseguir-ho va recórrer al mètode d'assaig-error, que s'ha utilitzat en totes les èpoques i que encara ara segueix utilitzant-se. Aquest mètode va permetre a hòmens de totes les èpoques fabricar ferramentes i realitzar construccions, que si 
bé van complir la seua comesa, fins al punt que algunes van arribar fins als nostres dies, a simple vista pot observar-se que no responen a un disseny d'enginyeria, tal com el concebem en l'actualitat, és a dir, disten molt de ser òptims en la utilització de materials. En eixa època merament empírica, els requisits constructius es basaven només en un compendi de bones pràctiques que estaven més o menys avalades per l'experiència. El tractat més antic que es conserva sobre edificació és De Architectura de l'arquitecte romà Marcus Vitruvius Polio, escrit probablement al voltant de l'any $15 \mathrm{aC}$, i que va ser utilitzat fins a l'edat mitjana.

Encara que Leonardo da Vinci i Galileu Galilei ja havien realitzat experiments per a determinar la resistència mecànica de fils d'aram, barres i bigues, no hi ha evidències d'estudis formals i sistemàtics del comportament mecànic dels materials anteriors al segle XVII, quan s'inicia a Europa una ràpida expansió de l'interés per aquesta ciència durant eixe segle $i$ el següent, gràcies a les aportacions de Robert Hooke (linealitat entre tensions i deformacions), els germans Johann i Jakob Bernouilli (equació de l'elàstica per consideracions d'equilibri), Leonhard Paul Euler (mètodes energètics, vinclament) i Charles Coulomb (flexió i torsió, criteris de plastificació), entre d'altres. En el segle XIX, la resistència de materials es va establir de manera pràcticament definitiva amb els treballs de Thomas Young, Claude Louis Marie Henri Navier i Adhémar Jean Claude Barré de Saint-Venant. Altres noms cèlebres en l'estudi de l'elasticitat i resistència de materials són Augustin Louis Cauchy, Père de Gabriel Léon Jean Baptiste Lamé, Benoit Paul Émile Clapeyron, George Green, William John Macquorn Rankine, Gustav Robert Kirchoff, Otto Christian Mohr i ja en el segle xx, Stepan Prokofevitx Timoxenko, qui va recopilar i va divulgar el que fins al moment era únicament un compendi de teories.

L'elasticitat i la resistència de materials formen part de la mecànica racional, que és una disciplina de la física. Com podem veure a la figura 1.1, aquesta disciplina està emmarcada dins de la mecànica dels mitjans continus, en la qual s'aborda el sòlid com a deformable, i l'objectiu és determinar la resistència (tensions) i la rigidesa (deformacions) d'un sòlid sotmés a un sistema de forces en equilibri estàtic, per al qual no hi ha moviment net. En la física clàssica es considera que el moviment és una conseqüència de l'acció de forces mecàniques. El fet que un sistema estiga en repòs no indica que sobre ell no actuen forces, sinó que aquestes forces es troben contrarestades o equilibrades per unes altres de la seua mateixa espècie.

Aquesta assignatura planteja una metodologia per a resoldre els problemes reals més freqüents que ens podem trobar, independentment del material utilitzat. En la realitat, les estructures resistents poden ser de molts diversos materials, i pot donar-se una casuística de geometries i tipus de càrregues pràcticament infinita. És per això que resulta necessari fer tota una sèrie d'idealitzacions sobre el material, mitjans de sustentació i càrregues. 


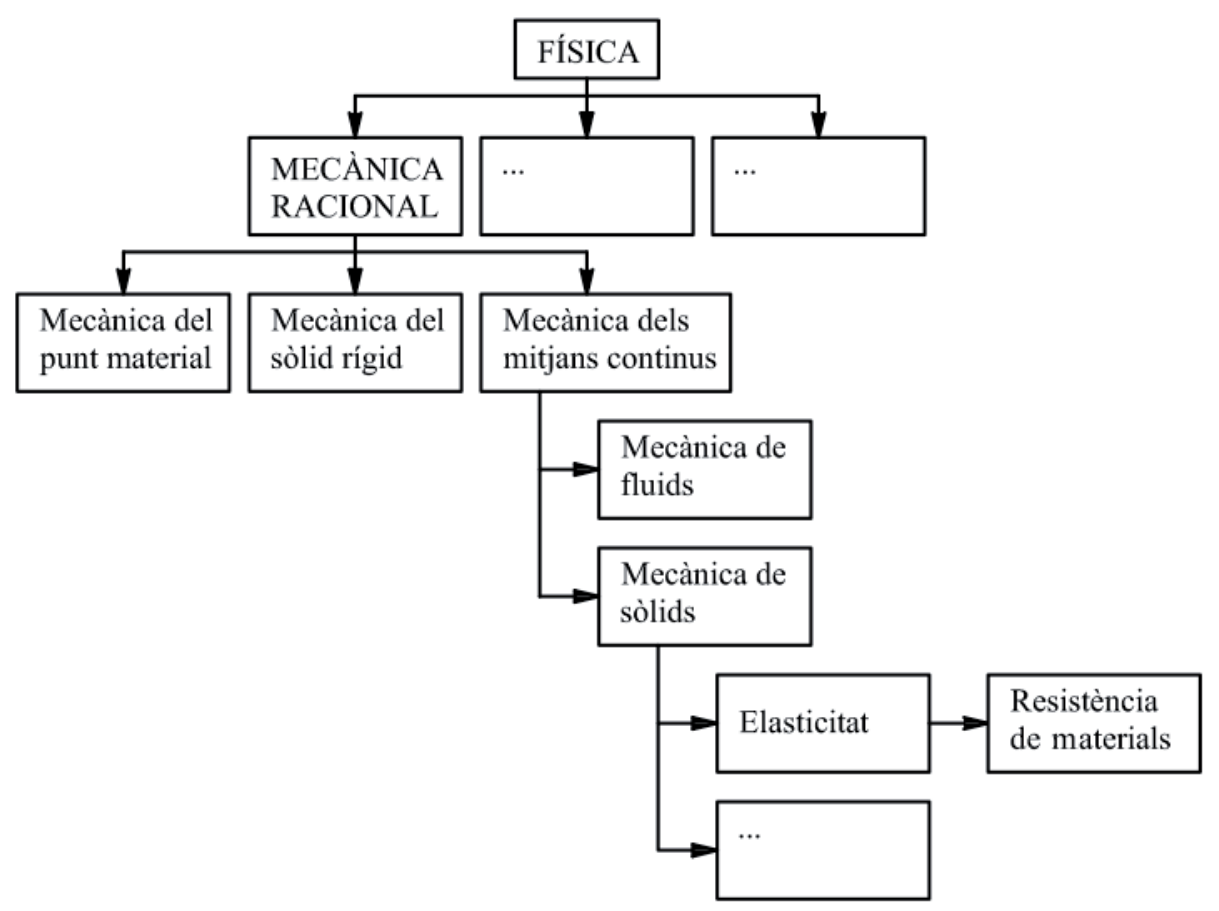

Fig. I.1. Situació de l'elasticitat i la resistència de materials dins de la física

Pel que fa al material, el considerarem com a elàstic, encara que els sòlids reals no sempre ho són (depén del tipus de material i també de les condicions ambientals i de càrrega en les quals es trobe el sòlid).

Una altra de les idealitzacions que realitzem en resistència de materials fa referència als mitjans de sustentació, ja que pràcticament treballarem sempre amb suports simples, articulacions i encastos. No obstant això, val a dir que en les situacions reals no es tractarà, en la majoria d'ocasions, de cap d'aquests casos teòrics sinó de situacions intermèdies.

Finalment, pel que fa a les accions, tractarem de forces i moments puntuals, així com de forces distribuïdes. Açò no deixa de ser una nova idealització ja que, per exemple, en tots els casos reals les forces són aplicades sobre una major o menor superfície, encara que finalment les assimilem a una força puntual.

En Estructures I abordarem l'estudi d'elements senzills, tipus barra, i analitzarem, en casos molt concrets, sistemes de diversos elements, encara que sempre serà en un nombre reduiit. Aquestes barres estaran sotmeses a unes càrregues que estaran predeterminades en els exercicis concrets (sense estudiar el seu origen) $i$ analitzarem els efectes que aquestes càrregues produeixen en les barres (tensions i deformacions).

En successives assignatures que són continuació d'aquesta, Estructures II i III, s'estudiaran sistemes més complexos d'estructures, es caracteritzaran els materials d'una manera més rigorosa, es realitzarà una previsió de les accions que actuen sobre elles, com a conseqüència de l'ús o de l'exposició a l'ambient, i s'analitzarà l'adequació de les estructures a la normativa vigent, segons el material de què estiguen fetes. 


\section{TEMA 1}

\section{Estàtica de sistemes}

\subsection{Introducció}

Les diverses branques de la física estudien el comportament dels materials davant de determinades situacions de càrrega o sotmesos a esforços diversos. Aquests materials poden ser sòlids, líquids o gasosos i romandre en repòs o estar en moviment.

Per al present tema, així com per a la resta de l'assignatura, considerarem els sòlids que romandran en repòs. En la física, el moviment és una conseqüència de les forces que actuen sobre un cos. La situació estàtica no es produeix només com a conseqüència de l'absència de forces que actuen sobre el sòlid, sinó també quan aquestes forces són contrarestades per altres de la mateixa espècie.

En aquest tema tractarem el concepte de força com a magnitud vectorial; analitzarem l'equilibri que es produeix en els sistemes i estudiarem la manera en què aquests sistemes es relacionen amb el seu entorn.

Com ja hem mencionat anteriorment, quan un sistema de forces actua sobre un sòlid provoca unes deformacions sobre ell. No obstant això, aquestes deformacions seran molt menudes i generalment no influiran en l'equilibri dels cossos. Com a conseqüència, en els problemes d'equilibri estàtic d'aquest tema, es considerarà el sòlid com a rígid.

\subsection{Estàtica de forces}

\subsubsection{Principis d'estàtica}

Les forces representen les accions que uns cossos exerceixen sobre altres i les tractarem com a magnituds vectorials. Per tant, per tal de definir una força és necessari conéixer quatre elements: el punt d'aplicació, la direcció, el sentit i la magnitud. De manera gràfica, representarem les magnituds vectorials mitjançant una fletxa, la punta de la qual indica la seua direcció i sentit; de vegades, la longitud de la fletxa serà indicativa de la magnitud. Quan escrivim és costum col·locar una fletxa sobre la lletra o el símbol que representa el vector.

El mòdul d'un vector és un escalar corresponent a l'arrel quadrada de la suma dels quadrats de cadascuna de les components del vector. Quan escrivim podem representar-ho mitjançant el mateix vector entre dues barres verticals, o amb la 
lletra corresponent al vector sense la fletxa superior. A l'obra utilitzarem ambdues notacions indistintament.

Les forces reals són de dos tipus: forces de volum (pes, forces magnètiques, etc.) i forces de superfície (espenta de terres, fregaments, etc.). A causa de les simplificacions que realitzarem, en resistència de materials utilitzarem forces puntuals, en les quals considerarem concentrada tota la força en un únic punt, i forces distribuïdes, en les quals farem un repartiment de la càrrega al llarg de l'element barra.

Atés que estem considerant el sòlid com a indeformable, l'efecte d'una força sobre el cos no es modifica si es trasllada la força a qualsevol altre lloc de la seua línia d'acció, per la qual cosa les forces aplicades sobre un cos rígid es representaran com un vector lliscant.

Principi de les forces concurrents. L'efecte que produeix en un cos rígid l'aplicació d'un sistema de forces concurrents en un punt A és equivalent al d'una única força, $\vec{F}$ anomenada resultant i aplicada també en $\mathrm{A}$, igual a la suma vectorial de totes les forces concurrents.

Segons açò, l'efecte que té una força sobre un cos és equivalent al que tenen les projeccions d'aquesta sobre els eixos d'un triedre trirectangle. De manera inversa, podem compondre forces concurrents en una d'equivalent que produïsca el mateix efecte. És l'anomenat principi del paral-lelogram: la resultant de dos vectors és la diagonal del paral·lelogram en què els dos vectors són costats adjacents. Si cal restar dos vectors, el que farem serà sumar l'oposat d'un d'ells.
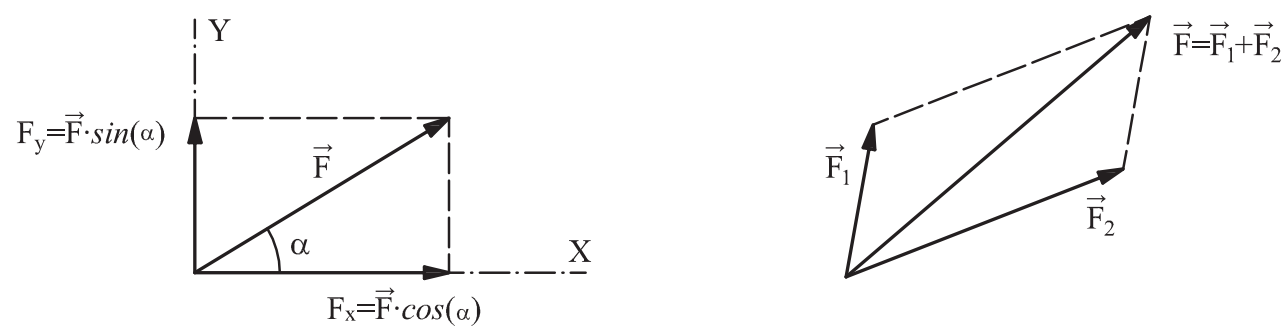

Fig. 1.01. Descomposició i composició de forces

\subsubsection{Moment d'una força respecte a un punt}

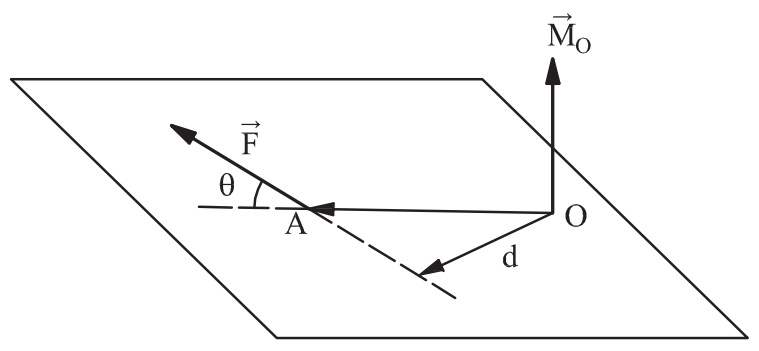

Fig. 1.02. Moment d'una força respecte a un punt 
El moment d'una força $\vec{F}$ aplicada en un punt A respecte a un punt $\mathrm{O}$ és una magnitud vectorial representada pel vector $\vec{M}_{O}$ lligat al punt $\mathrm{O}$ definit per: $\vec{M}_{O}=$ $O A \times \vec{F}$.

Fem les següents consideracions:

- El vector $\vec{M}_{O}$ és perpendicular al pla engendrat per la línia d'acció de $\vec{F}$ i el punt $\mathrm{O}$ i el seu sentit és tal que $\overrightarrow{O A}, \vec{F}$ i $\vec{M}_{O}$ constitueixen un triedre directe (regla de la mà dreta o del cargol).

- El moment $\vec{M}_{O}$ és independent de la posició en la seua línia d'acció, és a dir, és independent del punt $\mathrm{A}$, ja que $\vec{F}$ és un vector lliscant.

- El moment d'una força respecte a un punt qualsevol que pertany a la seua línia d'acció és nul.

- Les unitats de mesura del moment en el sistema internacional són els newtons multiplicats per metre $(N \cdot m)$.

Si només ens interessa la magnitud, perquè ja coneixem la direcció, prendrem un punt perpendicular des d'O fins a la línia d'acció i obtindrem la distància $\mathrm{d}$.

$$
\left|\vec{M}_{O}\right|=|\overrightarrow{O A}| \cdot|\vec{F}| \cdot \sin (\theta)=|\vec{F}| \cdot \mathrm{d}
$$

On:

- d és la mínima distància que existeix entre el punt O i la línia d'acció de la força $\vec{F}$.

- $\theta$ és l'angle que forma la línia definida per $\overrightarrow{O A}$ i la direcció de $\vec{F}$.

\section{Exemple 1.1}

Donada la força $\vec{F}$ aplicada en el punt A, la direcció de la qual pot deduir-se de la figura següent, calculeu el moment que produeix respecte al punt $\mathrm{C}$.

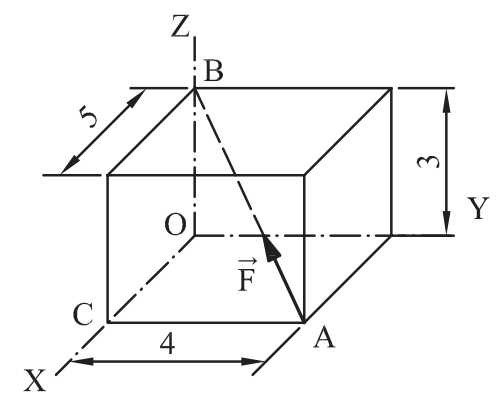

Fig. 1.03. Exemple 1.1 
Dades:

- El mòdul de la força és $|\vec{F}|=2 \mathrm{kN}$.

- Les dimensions del paral·lelepípede estan en metres.

Coneixem les coordenades dels punts $\mathrm{A}(5,4,0), \mathrm{B}(0,0,3)$ i $\mathrm{C}(5,0,0) \mathrm{m}$.

El vector de direcció és: $\vec{v}_{A B}=(0,0,3)-(5,4,0)=(-5,-4,3) \mathrm{m}$.

Farem unitari el vector dividint-lo pel mòdul:

$$
\left|\vec{v}_{A B}\right|=\sqrt{(-5)^{2}+(-4)^{2}+3^{2}}=5 \sqrt{2} m \quad \vec{n}_{A B}=\frac{\vec{v}_{A B}}{\left|\vec{v}_{A B}\right|}=\left(\frac{-5}{5 \sqrt{2}}, \frac{-4}{5 \sqrt{2}}, \frac{3}{5 \sqrt{2}}\right)
$$

El vector força l'obtindrem multiplicant la magnitud pel vector de direcció:

$$
\vec{F}=2 \cdot\left(\frac{-5}{5 \sqrt{2}}, \frac{-4}{5 \sqrt{2}}, \frac{3}{5 \sqrt{2}}\right)=(-1,41,-1,13,0,85) k N
$$

Determinarem les coordenades del vector que uneix el punt respecte al qual volem calcular el moment (C) amb el punt d'aplicació de la força (A).

$\vec{v}_{C A}=(5,4,0)-(5,0,0)=(0,4,0) \mathrm{m}$

El moment serà el producte vectorial:

$$
\vec{M}=\vec{v}_{C A} \times \vec{F}=\left|\begin{array}{ccc}
\vec{i} & \vec{j} & \vec{k} \\
0 & 4 & 0 \\
-1,41 & -1,13 & 0,85
\end{array}\right|=\left|\begin{array}{c}
3,39 \\
0 \\
5,66
\end{array}\right| k N \cdot m
$$

\subsubsection{Moment d'una força respecte a un eix}

El moment d'una força $\vec{F}$ respecte a un eix e és la magnitud escalar $M_{e}$ obtinguda en projectar sobre l'eix el moment de la força $\vec{F}$ respecte a un punt qualsevol del mateix eix.

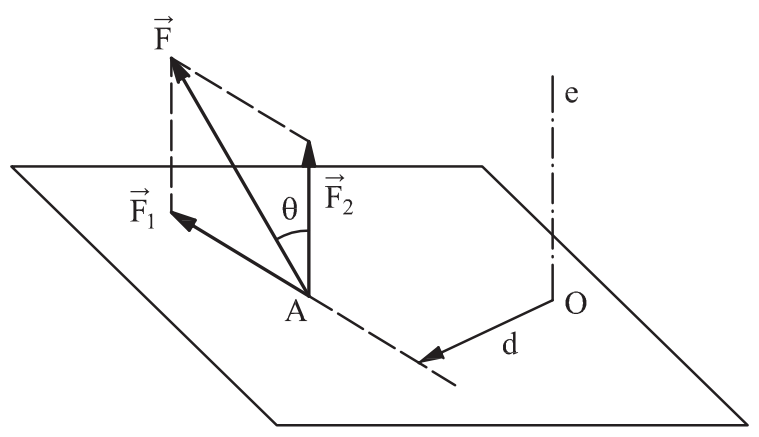

Fig. 1.04. Moment d'una força respecte a un eix 


$$
M_{e}= \pm \vec{F}_{1} \cdot d= \pm \vec{F} \cdot d \cdot \sin (\theta)
$$

On:

El vector $\vec{F}_{1}$ : component de $\vec{F}$ perpendicular a l'eix e.

- $d$ : distància del punt $\mathrm{O}$ a la línia d'acció de $\vec{F}_{1}$.

- $\theta$ : Angle que formen $\vec{F}$ i l'eix.

Si la força $\vec{F}$ talla $(d=0)$ o és paral-lela a l'eix e $(\sin (\theta)=0)$, el moment de la força respecte a aquest eix és nul. El moment $M_{e}$ és independent del punt triat per a calcular-lo i és positiu si el moment de $\vec{F}_{1}$ respecte al punt $\mathrm{O}$ porta el sentit positiu de l'eix e.

Per tal de calcular el moment d'una força respecte a un eix, cal procedir de la manera següent:

- Descompondre la força en les direccions paral·lela i perpendicular a l'eix.

- Determinar el moment respecte a l'eix de les components no paral·leles i que no tallen l'eix multiplicant el seu valor per la distància mínima entre l'eix i les seues respectives línies d'acció.

Una altra manera de realitzar el càlcul és obtindre el moment respecte a qualsevol punt de l'eix e, i posteriorment projectar aquest vector sobre l'eix donat.

\section{Exemple 1.2}

Donada la següent biga voladissa sotmesa a les forces que es mostren en la figura, determineu el moment resultant de totes les forces respecte als eixos de coordenades.

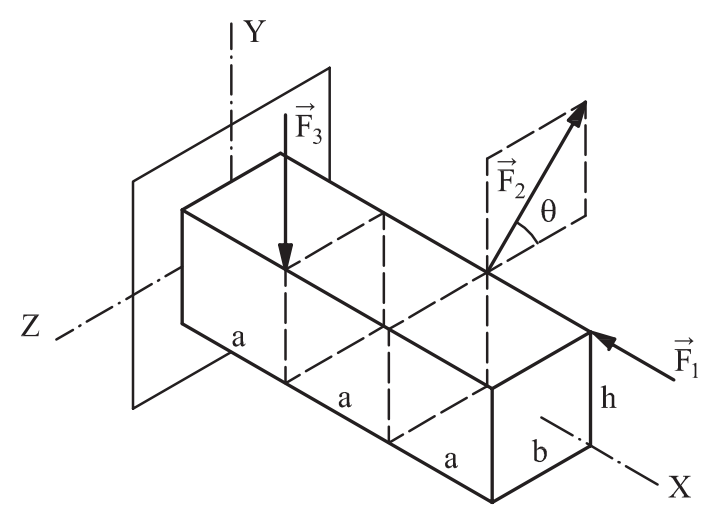

Fig. 1.05. Exemple 1.2 
Dades:

- Les dimensions de la peça són: $a=1,2 m ; b=0,4 m ; h=0,6 m$.

- Els mòduls de les forces són $F_{1}=20 \mathrm{kN} ; F_{2}=5 \mathrm{kN} ; F_{3}=10 \mathrm{kN}$.

Calcularem quin moment genera cadascuna de les forces respecte a cadascun dels eixos, i al final sumarem les components de les tres forces. Si les forces són paralleles o perpendiculars als eixos de coordenades, les deixarem com estan. Si són obliqües a algun dels eixos, les descompondrem segons aquells eixos.

Força $\vec{F}_{1}$ :

- És paral·lela a X, per la qual cosa no genera moment respecte a aquest eix: $M_{1 X}=0$.

- És perpendicular a Y, i n'està separada una distància igual a $b / 2$ d'ell. El moment que produeix la força és positiu segons la regla del cargol, i té un valor: $M_{1 Y}=F_{1} \cdot b / 2=4 k N \cdot m$.

- És perpendicular a Z, i n'està separada una distància igual a $h / 2$ d'ell. El moment en aquest cas també és positiu, pel mateix raonament: $M_{I Z}=F_{1} \cdot h / 2$ $=6 \mathrm{kN} \cdot \mathrm{m}$.

Força $\vec{F}_{2}$ :

Com que és obliqua, la descompondrem en les direccions Y i Z. Necessitem calcular l'angle.

$$
\theta=\arctan \left(\frac{h}{b}\right)=56,31^{\circ}
$$

- $F_{2 Y}=F_{2} \cdot \sin (\theta)=4,16 k N$.

- $F_{2 Z}=F_{2} \cdot \cos (\theta)=2,77 \mathrm{kN}$.

Com que la força talla l'eix X, el moment respecte a aquest és zero, la qual cosa es pot demostrar analitzant les dues components per separat.

- $M_{2 X}=F_{2 Y} \cdot b / 2-F_{2 Z} \cdot h / 2=0$. En pròximes ocasions no serà necessari el càlcul d'aquest moment si resulta evident que talla l'eix i per tant és zero.

- $M_{2 Y}=F_{2 Z} \cdot 2 a=6,66 \mathrm{kN} \cdot \mathrm{m}$.

- $M_{2 Z}=F_{2 Y} \cdot 2 a=9,98 \mathrm{kN} \cdot \mathrm{m}$.

Força $\vec{F}_{3}$ :

- $M_{3 x}=F_{3} \cdot b / 2=2 \mathrm{kN} \cdot \mathrm{m}$. 
- $M_{3 Y}=0$ (per ser paral·lela a l'eix).

- $M_{3 Z}=-F_{3} \cdot a=-12 \mathrm{kN} \cdot \mathrm{m}$.

En resum, la resultant dels moments segons els tres eixos serà:

- $M_{O X}=M_{1 X}+M_{2 X}+M_{3 X}=2 \mathrm{kN} \cdot \mathrm{m}$.

- $M_{O Y}=M_{1 Y}+M_{2 Y}+M_{3 Y}=10,66 \mathrm{kN} \cdot \mathrm{m}$.

- $M_{O Z}=M_{I Z}+M_{2 Z}+M_{3 Z}=3,98 \mathrm{kN} \cdot \mathrm{m}$.

Realment, el que ens indica aquest resultat és que el moment és un vector amb components:

$$
\vec{M}_{O}=\left(M_{O X}, M_{O Y}, M_{O Z}\right)
$$

\subsubsection{Composició de forces. Força i moment resultant}

Sistema equivalent: és aquell sistema que exerceix el mateix efecte que un altre sobre un sòlid rígid. Un sistema de forces qualsevol que actua sobre un cos rígid pot sempre reduir-se a un sistema equivalent, compost per una força resultant $\vec{R}$ aplicada en un punt triat arbitràriament i un moment resultant $\vec{M}_{O}$, que serà la suma dels moments que cadascuna de les forces del sistema inicial exerceixen sobre el punt considerat.
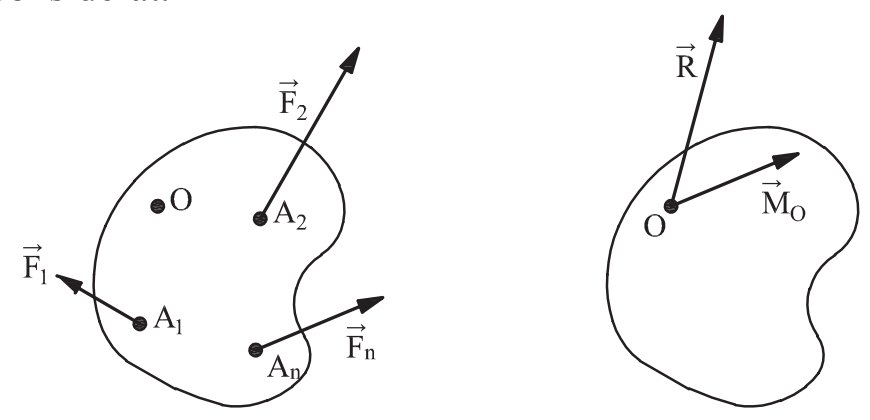

Fig. 1.06. Sistemes equivalents

Els dos sistemes de la figura són equivalents si es compleix:

$$
\begin{aligned}
& \vec{R}=\vec{F}_{1}+\vec{F}_{2}+\ldots+\vec{F}_{n}=\sum_{i=1}^{n} \vec{F}_{i} \\
& \vec{M}_{O}=\vec{O}_{1} \times \vec{F}_{1}+\vec{O}_{2} \times \vec{F}_{2}+\ldots+\vec{O} A_{n} \times \vec{F}_{n}=\sum_{i=1}^{n} \vec{O} A_{i} \times \vec{F}_{i}
\end{aligned}
$$


Les components de $\vec{R}$, en un sistema de coordenades amb origen en $\mathrm{O}$, es corresponen amb la suma de components de cadascuna de les forces. Les components de $\vec{M}_{O}$ són la suma dels moments de cadascuna de les forces respecte a cada eix de coordenades.

$$
\begin{gathered}
\vec{R}=\left(R_{X}, R_{Y}, R_{Z}\right)=\left(\sum_{i=1}^{n} \vec{F}_{i X}, \sum_{i=1}^{n} \vec{F}_{i Y}, \sum_{i=1}^{n} \vec{F}_{i Z}\right) \\
\vec{M}_{O}=\left(M_{O X}, M_{O Y}, M_{O Z}\right)=\left(\sum_{i=1}^{n} \vec{M}_{O i X}, \sum_{i=1}^{n} \vec{M}_{O i Y}, \sum_{i=1}^{n} \vec{M}_{O i Z}\right)
\end{gathered}
$$

\section{Exemple 1.3}

Calculeu la força i el moment resultant sobre el punt $\mathrm{O}$ del sistema de forces que actuen sobre el prisma volat.

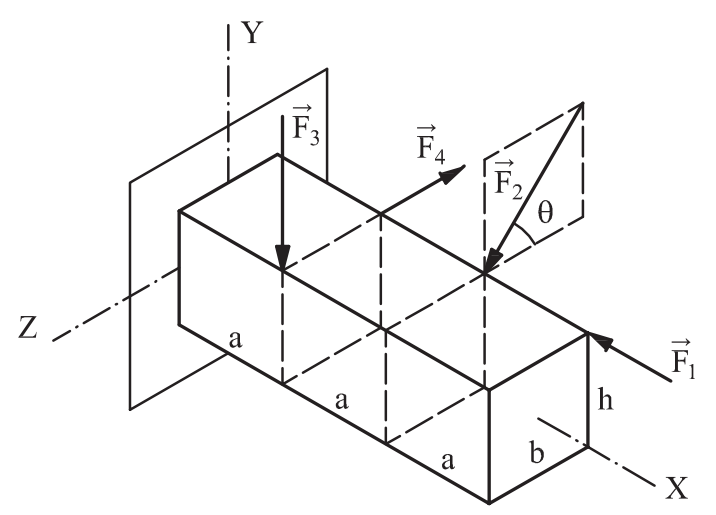

Fig. 1.07. Exemple 1.3

Dades:

- Les dimensions de la peça són: $a=1,2 m ; b=0,4 m ; h=0,6 m$.

- Els mòduls de les forces són $F_{1}=30 \mathrm{kN} ; F_{2}=15 \mathrm{kN} ; F_{3}=10 \mathrm{kN} ; F_{4}=20 \mathrm{kN}$.

La primera cosa que hem de fer és expressar els vectors força per les seues coordenades. Com que l'angle és el mateix que a l'exercici anterior, no el calcularem una altra vegada.

$$
\begin{array}{ll}
\vec{F}_{1}=\left(\begin{array}{l}
F_{1 \mathrm{X}} \\
F_{1 \mathrm{Y}} \\
F_{1 \mathrm{Z}}
\end{array}\right)=\left(\begin{array}{c}
F_{1} \\
0 \\
0
\end{array}\right)=\left(\begin{array}{c}
30 \\
0 \\
0
\end{array}\right) k N & \vec{F}_{2}=\left(\begin{array}{l}
F_{2 \mathrm{X}} \\
F_{2 \mathrm{Y}} \\
F_{2 \mathrm{Z}}
\end{array}\right)=\left(\begin{array}{c}
0 \\
-F_{2} \cdot \sin (\theta) \\
F_{2} \cdot \cos (\theta)
\end{array}\right)=\left(\begin{array}{c}
0 \\
12,84 \\
8,32
\end{array}\right) k N \\
\vec{F}_{3}=\left(\begin{array}{c}
F_{3 \mathrm{X}} \\
F_{3 \mathrm{Y}} \\
F_{3 \mathrm{Z}}
\end{array}\right)=\left(\begin{array}{c}
0 \\
-F_{3} \\
0
\end{array}\right)=\left(\begin{array}{c}
0 \\
-10 \\
0
\end{array}\right) k N & \vec{F}_{4}=\left(\begin{array}{l}
F_{4 \mathrm{X}} \\
F_{4 \mathrm{Y}} \\
F_{4 \mathrm{Z}}
\end{array}\right)=\left(\begin{array}{c}
0 \\
0 \\
-F_{4}
\end{array}\right)=\left(\begin{array}{c}
0 \\
0 \\
-20
\end{array}\right) k N
\end{array}
$$


La força resultant serà el vector que té com a coordenades la suma de les coordenades dels vectors força donats.

$$
\vec{R}=\left(\begin{array}{l}
F_{1 \mathrm{X}}+F_{2 \mathrm{X}}+F_{3 \mathrm{X}}+F_{4 \mathrm{X}} \\
F_{1 \mathrm{Y}}+F_{2 \mathrm{Y}}+F_{3 \mathrm{Y}}+F_{4 \mathrm{Y}} \\
F_{1 \mathrm{Z}}+F_{2 \mathrm{Z}}+F_{3 \mathrm{Z}}+F_{4 \mathrm{Z}}
\end{array}\right)=\left(\begin{array}{c}
30 \\
-22,48 \\
-11,68
\end{array}\right) k N
$$

El mòdul d'aquesta força resultant és:

$$
|\vec{R}|=39,27 \mathrm{kN}
$$

Podem determinar la direcció de la força resultant dividint el vector pel mòdul.

$$
\vec{n}_{R}=\frac{\vec{R}}{|\vec{R}|}=\left(\begin{array}{c}
0,764 \\
-0,573 \\
-0,297
\end{array}\right)
$$

Les components d'aquest vector són els denominats cosinus directors, és a dir, els cosinus dels angles que el vector forma amb cadascun dels eixos de coordenades. Per tant, podem determinar aquests angles.

$\alpha=\arccos (0,764)=40,18^{\circ}$

$\beta=\arccos (-0,573)=124,98^{\circ}$

$\gamma=\arccos (-0,297)=107,30^{\circ}$

Calcularem el moment resultant de cada força respecte a cada eix.

$$
\begin{aligned}
& M_{1 \mathrm{X}}=0 \\
& M_{1 \mathrm{Y}}=F_{1} \cdot b / 2=6 \mathrm{kN} \\
& M_{1 \mathrm{Z}}=F_{1} \cdot h / 2=9 \mathrm{kN} \\
& M_{3 \mathrm{X}}=F_{3} \cdot b / 2=2 \mathrm{kN} \\
& M_{3 \mathrm{Y}}=0 \\
& M_{3 \mathrm{Z}}=F_{3} \cdot a=-12 \mathrm{kN}
\end{aligned}
$$$$
M_{2 \mathrm{X}}=0
$$$$
M_{2 \mathrm{Y}}=-F_{2 \mathrm{Z}} \cdot b / 2=-19,97 \mathrm{kN}
$$$$
M_{2 Z}=F_{2 Y} \cdot h / 2=-29,95 k N
$$$$
M_{4 \mathrm{X}}=-F_{4} \cdot h / 2=-6 \mathrm{kN}
$$$$
M_{4 \mathrm{Y}}=F_{4} \cdot a=24 \mathrm{kN}
$$$$
M_{4 Z}=0
$$

El moment resultant serà la composició dels anteriors:

$$
\vec{M}_{O}=\left|\begin{array}{l}
\sum_{i=1}^{n} \vec{M}_{O i X} \\
\sum_{i=1}^{n} \vec{M}_{O i Y}, \\
\sum_{i=1}^{n} \vec{M}_{O i Z}
\end{array}\right|=\left(\begin{array}{c}
-4 \\
10,03 \\
-32,95
\end{array}\right) k N \cdot m
$$

Igual que en el cas anterior, podem calcular la direcció del vector i els angles que forma amb els eixos de coordenades. 


$$
|\vec{M}|=34,68 k N \quad \vec{n}_{M}=\frac{\vec{M}}{|\vec{M}|}=\left(\begin{array}{c|l}
-0,115 & \alpha=\arccos (-0,115)=96,62^{\circ} \\
0,289 & \beta=\arccos (0,289)=73,19^{\circ} \\
-0,950
\end{array}\right) \quad \begin{aligned}
& \gamma=\arccos (-0,950)=161,86^{\circ}
\end{aligned}
$$

\subsection{Condicions d'equilibri}

En primer lloc, és necessari definir el concepte d'estructura, tal com l'entendrem en l'assignatura: és un sistema de cossos units entre si que suporta les càrregues previstes amb una certa seguretat, sense experimentar moviments relatius ni de conjunt, a excepció dels deguts a les deformacions elàstiques. Per tant, admetrem en tota l'assignatura el principi de petita deformació.

\subsubsection{Principi de petita deformació}

Els sòlids reals, davant de l'acció de forces exteriors, es deformen. Tanmateix, aquestes deformacions són normalment tan menudes que no influeixen en l'estat de repòs o moviment dels cossos. És per això que plantejarem les equacions d'equilibri considerant la geometria no deformada de l'element.

Pot succeir que les deformacions siguen tan grans que les forces varien, de manera no negligible, l'efecte que produeixen sobre l'estructura, com a conseqüència del moviment del punt d'aplicació de la força. En tal cas, el mètode de anàlisi és diferent, però excedeix l'abast d'aquest llibre i es tractarà en assignatures més avançades.

Això queda aclarit a la figura següent:

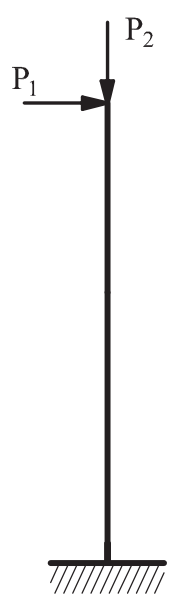

a)

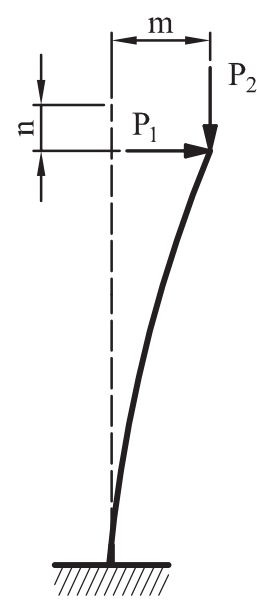

b)

Fig. 1.08. Variació de l'efecte de les forces com a conseqüència de les deformacions 
En el cas $a$ tindrem a l'encast un moment flector $\mathrm{M}=\mathrm{P}_{1} \cdot \mathrm{h}$. En el cas $b$, l'efecte es veu incrementat per la deformació, i el moment a l'encast serà: $M=P_{1}(h-n)$ $+\mathrm{P}_{2} \cdot \mathrm{m}$.

En tot cas, com ja hem dit, considerarem les deformacions com a negligibles des del punt de vista de l'estàtica, per la qual cosa treballarem sobre l'estructura abans de deformar-se.

\subsubsection{Principi de Saint-Venant}

Aquest principi estableix que el valor de les forces interiors als punts d'un sòlid, situats prou lluny dels llocs d'aplicació de les càrregues, depén molt poc de la manera concreta d'aplicació de les càrregues. A causa d'aquest principi en molts casos podrem substituir un sistema de forces per un altre estàticament equivalent, la qual cosa pot conduir a la simplificació del càlcul.

\subsubsection{Càrregues estàtiques o quasiestàtiques}

Diem que les càrregues són estàtiques quan romanen aplicades un temps infinit, mentre que les denominem quasiestàtiques quan el temps d'aplicació és relativament prolongat. Les càrregues que s'apliquen en un temps molt reduït es denominen dinàmiques, i encara que no les tractarem en l'assignatura, les sol-licitacions internes que produeixen són sensiblement majors que si foren estàtiques o quasiestàtiques. Les càrregues dinàmiques tenen importància en edificació perquè són les que produeixen alguns tipus d'accidents, com per exemple l'impacte d'un cotxe sobre una columna d'un garatge. Les diferents normatives d'accions ens donen una guia de com tractar aquest tipus de càrregues als edificis, però això serà matèria d'assignatures posteriors.

\subsubsection{Forces internes i externes}

Definirem ara els tipus de forces que apareixen en les estructures:

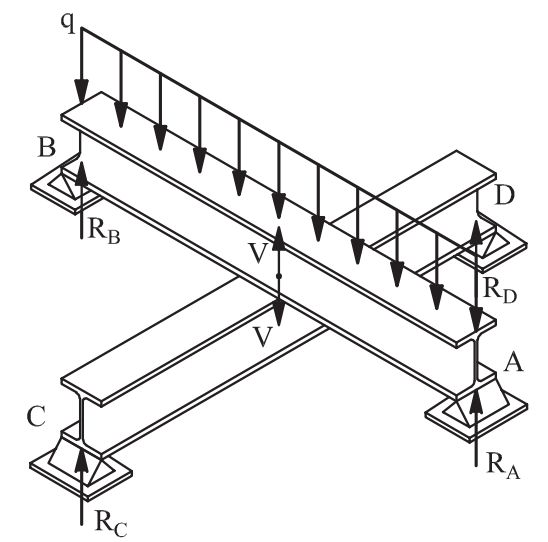

Fig. 1.09. Estructura i forces que actuen sobre ella 
- Denominarem forces internes a aquelles que són exercides per uns elements del sistema sobre els altres. En el cas de la figura són les dues forces $V$, que es produeixen com a conseqüència del principi d'acció-reacció.

- Forces externes són aquelles que provenen d'altres sistemes i són exercides sobre els elements del sistema considerat. Poden ser forces exteriors aplicades sobre el sistema $(q)$ o les reaccions del elements de sustentació $\left(R_{A}, R_{B}\right.$, $R_{C}$ i $\left.R_{D}\right)$.

Principi d'acció-reacció. Tercera llei de Newton. Quan una partícula $i$ exerceix una força $F_{i j}$ (acció) sobre una altra partícula $j$, la partícula $j$ exerceix sobre $i$ la mateixa força amb sentit contrari (reacció). Açò significa que les forces internes s'anul·len dos a dos i en qualsevol sistema de partícules es compleix que:

$$
\begin{gathered}
\sum \vec{F}_{\text {int }}=0 \\
\sum \vec{M}_{0}\left(\vec{F}_{\text {int }}\right)=0
\end{gathered}
$$

sent $\mathrm{O}$ un punt qualsevol del sòlid.

Condició d'equilibri: per tal que un sistema compost d'un únic cos o diversos cossos sense mobilitat interna (excepte deformacions elàstiques molt menudes) estiga en equilibri sotmés a $\mathrm{n}$ forces externes, ha de complir-se que la força resultant $\vec{R}$ i el moment resultant $\vec{M}_{O}$ del sistema de forces externes respecte a qualsevol punt siga nul.

\begin{tabular}{|c|c|}
\hline Condicions d'equilibri en 3D & Condicions d'equilibri en 2D \\
\hline$\left.\vec{R}=\sum_{i=1}^{n} \vec{F}_{i}=\left|\begin{array}{l}\sum_{i=1}^{n} \vec{F}_{i X} \\
\sum_{i=1}^{n} \vec{F}_{i Y} \\
\sum_{i=1}^{n} \vec{F}_{i Z}\end{array}\right|=\mid \begin{array}{l}0 \\
0 \\
0\end{array}\right)$ & $\vec{R}=\sum_{i=1}^{n} \vec{F}_{i}=\left|\begin{array}{l}\sum_{i=1}^{n} \vec{F}_{i X} \\
\sum_{i=1}^{n} \vec{F}_{i Y}\end{array}\right|=\left(\begin{array}{l}0 \\
0\end{array}\right)$ \\
$\left.\vec{M}_{0}=\sum_{i=1}^{n} \vec{M}_{0 \mathrm{i}}=\left|\begin{array}{l}\sum_{i=1}^{n} \vec{M}_{i X} \\
\sum_{i=1}^{n} \vec{M}_{i Y} \\
\sum_{i=1}^{n} \vec{M}_{i Z}\end{array}\right|=\mid \begin{array}{l}0 \\
0 \\
0\end{array}\right)$ & $\vec{M}_{0}=\sum_{i=1}^{n} \vec{M}_{0 \mathrm{i}}=\sum_{i=1}^{n} \vec{M}_{i Z}=0$ \\
\hline
\end{tabular}

Per al cas general, com que tenim tres eixos, considerant una força i un moment per eix, obtindrem les sis equacions generals d'equilibri del cos rígid. En els casos freqüents que podrem considerar bidimensionals, amb forces coplanàries, les 
equacions corresponents a les forces es redueixen a dues, i l'únic moment a considerar serà el $\mathrm{Z}$, per tant tenim tres equacions.

\subsection{Enllaços i reaccions}

Els sòlids estan habitualment sotmesos a l'acció de la gravetat terrestre i no surant en l'espai, motiu pel qual tindran una relació amb l'entorn, siga la Terra o altres sistemes situats en ella (considerarem que aquest entorn també és estàtic). Per tant, es produiran forces mútues entre el sistema considerat $i$ aquells amb què es relaciona, segons la tercera llei de Newton.

Les diverses forces que apareixen com a conseqüència de la interacció del sistema amb l'entorn depenen del tipus d'enllaç que tinguen amb aquest entorn. Les forces que hi apareixen es denominen reaccions.

\subsubsection{Graus de llibertat}

Els graus de llibertat (GDL) d'un sòlid són el nombre de magnituds independents que determinen inequívocament la seua posició; dit d'una altra manera, el nombre de possibles moviments. Un punt en l'espai pot moure's en tres direccions independents definides pels eixos de coordenades i també pot girar al voltant dels tres eixos, per la qual cosa el nombre de graus de llibertat en aquest cas és sis. Quan considerem un cas pla, el nombre de moviments independents possible per al sòlid és dos, i el nombre de girs és $u$, motiu pel qual el nombre de graus de llibertat serà tres.

\subsubsection{Càrregues}

Denominem càrregues les forces externes aplicades sobre l'estructura i que són la causa de les seues deformacions. Les càrregues típiques que utilitzarem en l'assignatura són: forces i moments puntuals o forces distribuïdes. Aquestes últimes poden ser perpendiculars a la línia mitjana o paral·leles, i ser uniformes o variables.

La representació gràfica d'aquestes càrregues serà la següent:

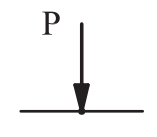

a)

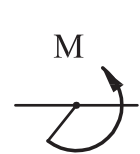

b)

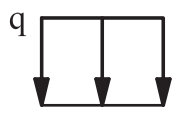

c)

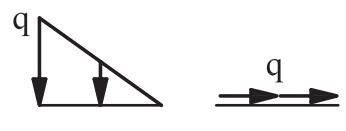

d)

e)

Fig. 1.10. Tipus de forces: $a$ ) força puntual; $b$ ) moment puntual; $c$ ) força distribuïda uniforme; d) força distribuïda variable; $e$ ) força axial distribuïda 


\subsubsection{Enllaços o lligadures}

Els enllaços o lligadures són els elements d'unió que impedeixen o limiten els moviments relatius i de conjunt de l'estructura. Les lligadures poden ser internes o externes.

- Lligadures internes: són aquelles que limiten el moviment relatiu d'uns elements del sistema respecte a altres elements, també del sistema.

- Lligadures externes: són aquelles que limiten el moviment d'elements del sistema respecte a una referència externa.

Un enllaç limita o coacciona totalment o parcialment el moviment d'un sistema. Com a conseqüència exerceix una força (o moment) sobre el sistema que s'oposa al moviment. A aquesta força se la denomina reacció de l'enllaç.

En un enllaç apareixeran tantes reaccions independents com a graus de llibertat o moviments siguen coaccionats.

En els casos reals, els enllaços que es presenten són de molt diverses tipologies, $i$ les possibilitats són pràcticament infinites. Els enllaços coaccionen en major o menor mesura un moviment, encara que moltes vegades no l'eliminen del tot. Davant de tal casuística, s'entén la necessitat d'establir una sèrie d'enllaços típics als quals haurem d'assimilar els reals. Aquests seran: l'encast o nuc rígid (elimina totalment tots els desplaçaments i tots els girs), el suport fix o articulació (elimina tots els desplaçaments, però permet els girs) i el suport simple o suport mòbil (permet els girs i també algun moviment). No cal dir que en casos tridimensionals podríem tindre enllaços que foren combinacions dels anteriors, perquè permeten alguns desplaçaments i/o alguns girs concrets.

La representació gràfica dels enllaços que tractarem serà:

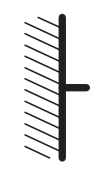

a)

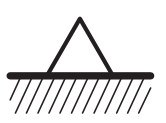

b)

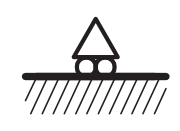

c)

Fig. 1.11. Tipus d'enllaços: $a$ ) encast; $b$ ) suport fix; $c$ ) suport mòbil

La línia gruixuda representa el lloc extern al sistema al qual està vinculat l'enllaç. A la figura $11 a$ podria ser una paret vertical, i en les altres dues una superfície horitzontal qualsevol.

Analitzem ara els tres tipus d'enllaços en el pla i quines reaccions produeixen. 
Suport simple o mòbil. Aquest tipus de suport només coacciona un moviment, el perpendicular a la superfície sobre la qual es recolza. Per tant, només apareixerà una reacció, que sempre serà perpendicular al pla de recolzament. En el cas de ser una lligadura interna, aquest suport és d'una colissa, que permet el desplaçament al llarg de la ranura, però no en direcció perpendicular.

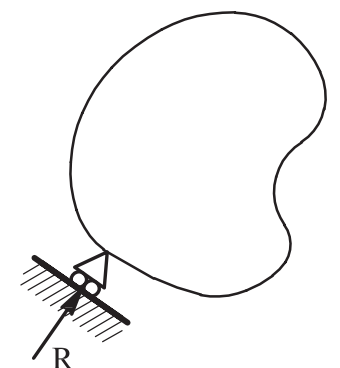

a)

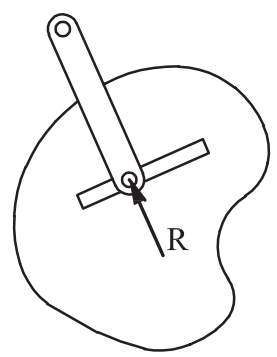

b)

Fig. 1.12. Suport mòbil: $a$ ) extern; b) intern

Si tres suports simples estan fixats sobre un sòlid, aquest sòlid romandrà estàtic, a menys que les reaccions dels tres suports siguen paral·leles o que les línies d'acció de les tres es tallen al mateix punt.

Suport fix o articulació. És un enllaç que exerceix dues coaccions sobre el sòlid, de manera que li impedeix el desplaçament en les dues direccions possibles, però permet el gir al voltant del punt al qual està lligat. La conseqüència d'això és que apareixerà una força de reacció que no portarà una direcció coneguda en un principi, sinó que caldrà descompondre-la en les dues direccions dels eixos coordenats $i$ calcular-les com a forces independents. En la figura següent, $R_{1} i R_{2}$ són les forces descompostes de la reacció. La descomposició de la força pot fer-se en les dues direccions ortogonals que ens interessen per a la resolució del problema concret.

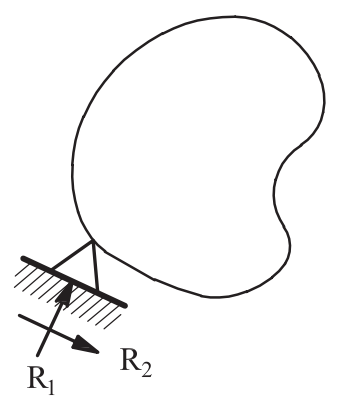

a)

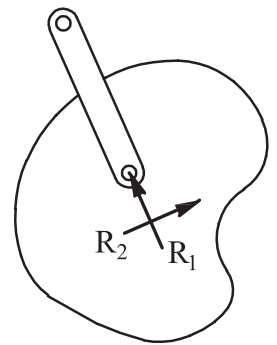

b)

Fig. 1.13. Suport fix: $a$ ) extern; $b$ ) intern

Quan el suport mòbil és un enllaç intern es denomina articulació o nuc. Els sistemes que estan formats per peces unides entre elles amb aquest tipus de enllaç es diuen estructures articulades. 
Un cas més complicat és quan més de dues barres concorren en un mateix nuc. En aquest cas, el nuc li lleva a cadascuna de les barres dos graus de llibertat, corresponent a dues translacions. Tanmateix, l'eix de cadascuna de les barres conserva els dos graus de llibertat. Per tant, el nuc suprimeix 2(n-1) graus de llibertat sobre les $n$ barres que uneix.

Per a tindre un cos en equilibri estàtic necessitem com a mínim un suport fix i un mòbil, excepte en el cas que la línia d'acció del suport mòbil passe pel punt al qual està unit el suport fix.

Encast o nuc rígid. Elimina tot moviment possible sobre el punt al qual s'ha fixat, o el moviment relatiu en el cas de ser un enllaç intern. Això genera, com en el cas anterior, una força de reacció que pot ser descomposta en les direccions perpendiculars que ens interessen.

A més, a causa de l'impediment del gir, apareixerà un moment de reacció, representat per $\mathrm{M}$ a la figura 1.14 .

Un únic encast serà suficient per a assegurar l'equilibri estàtic d'un sistema.

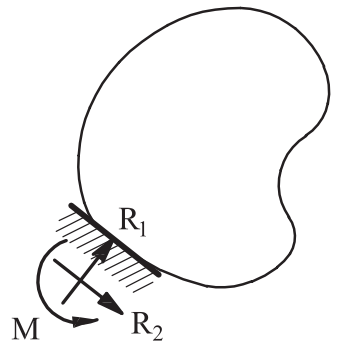

a)

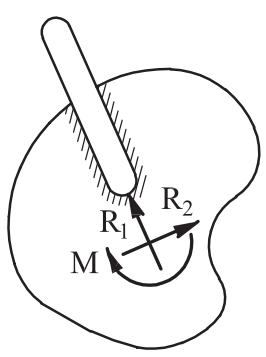

b)

Fig. 1.14. Encast: $a$ ) extern; $b$ ) intern

Un cas interessant que estudiarem a continuació és el de les barres articulades als seus extrems, anomenades bieles o tirants. En aquest cas, el sòlid s'uneix a l'entorn mitjançant una barra articulada als seus extrems; per tant, el nuc d'unió és articulat. L'efecte que això produeix és la possibilitat de gir del nuc d'unió i, encara que es permetrà el moviment del nuc, aquest moviment estarà limitat per la pròpia barra. Així doncs, el sòlid podrà moure's descrivint una corba al voltant del nuc oposat de la biela, si considerem gran deformació, o en la direcció perpendicular a la línia que uneix els extrems de la biela, si considerem petita deformació. Tot això serà estudiat més àmpliament en el tema corresponent a l'esforç axial. En definitiva, l'efecte serà similar a l'existència d'un suport mòbil $i$, com a conseqüència d'això, apareixerà una reacció que portarà la direcció de la barra (en cas de barra recta), que és el moviment coaccionat, i és igual a la reacció de la barra a l'altre costat i a l'esforç axial que apareixerà en la biela. 


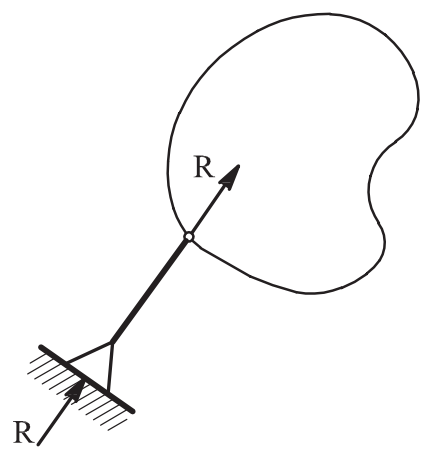

Fig. 1.15. Enllaç mitjançant biela

Si el cos està lligat mitjançant dues bieles no paral·leles, l'efecte és el mateix que tindria un suport fix colllocat al punt d'intersecció de les barres, o les seues prolongacions (a la figura 1.16 es representa per A). En el cas de haver-hi tres bieles no concurrents ni paral·leles, això seria equivalent a un encast.

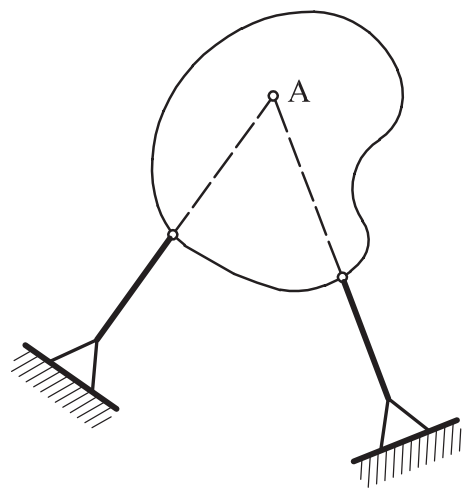

a)

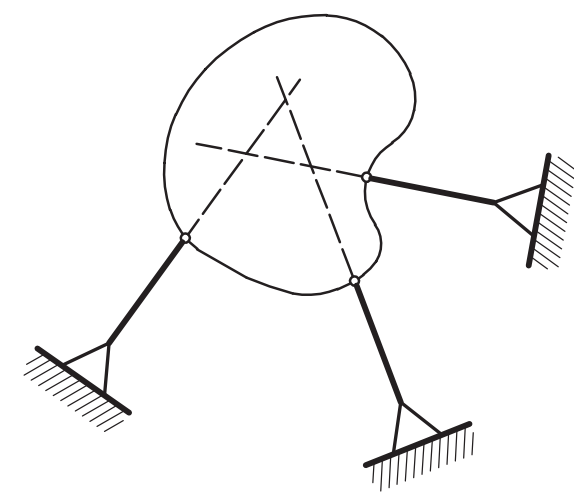

b)

Fig. 1.16. Enllaç mitjançant més d'una biela: $a$ ) equivalent a suport fix en A; b) equivalent a encast

\subsection{Sistemes isostàtics i hiperestàtics}

Com ja hem mencionat adés, els sistemes que considerem en aquesta assignatura són estàtics. Per tal d'assegurar aquesta immobilitat, les coaccions què imposen els enllaços han de ser igual de nombroses que els graus de llibertat de que disposa la peça: en un sistema espacial, haurem de tindre sis coaccions i en un sistema pla (bidimensional) haurem de tindre'n tres. Si el nombre de graus de llibertat es menor, igual o superior al nombre de coaccions, anomenarem el sistema d'una manera o una altra, i aquest sistema es comportarà de manera diferent. Si anomenem C el nombre de coaccions:

- GDL $>$ C. El sistema té capacitat per a moure's. Per tant, és inestable des del punt de vista de l'estàtica i s'anomena mecanisme. En el cas tridimensional, açò succeeix si $\mathrm{C}<6$ i en el cas bidimensional, si $\mathrm{C}<3$. 
- $\mathrm{GDL}=\mathrm{C}$. Els enllaços exteriors són els estrictament necessaris per a impedir el moviment de conjunt que produirien les càrregues, i el sistema s'anomena isostàtic o estàticament determinat.

- GDL $<$ C. Hi ha més coaccions que graus de llibertat; el sistema també és estàtic, però hi ha més coaccions de les necessàries. En aquest cas diem que tenim un sistema hiperestàtic o estàticament indeterminat. En el cas tridimensional, açò succeeix si C > 6 i en el cas bidimensional, si $\mathrm{C}>3$.

Ambdós paràmetres (CDG i C) estan relacionats mitjançant un nou concepte, el grau d'hiperestatisme (GH), de manera que:

$$
\mathrm{GH}=\mathrm{C}-\mathrm{GDL}
$$

Això fa que puguem fer l'anterior classificació en funció del grau d'hiperestatisme:

- $\mathrm{GH}<0$. Mecanismes.

- $\mathrm{GH}=0$. Sistemes isostàtics.

- $\mathrm{GH}>0$. Sistemes hiperestàtics.

En aquesta assignatura no estudiarem els mecanismes, ja que formen part d'unes altres matèries relacionades amb sistemes mòbils, com ara la mecànica de màquines.

El grau d'hiperestatisme indica el nivell de sobrerestricció de la mobilitat de l'estructura. Les estructures isostàtiques tenen el nombre mínim de coaccions necessàries per a assegurar l'equilibri, de manera que si n'eliminem alguna, el sistema es converteix en un mecanisme. Per contra, en una estructura hiperestàtica podem llevar tantes coaccions com grau d'hiperestatisme tinguen, i aquesta estructura romandrà en equilibri.

\section{Exemple 1.4}

Determinar el grau d'hiperestatisme de les estructures següents:

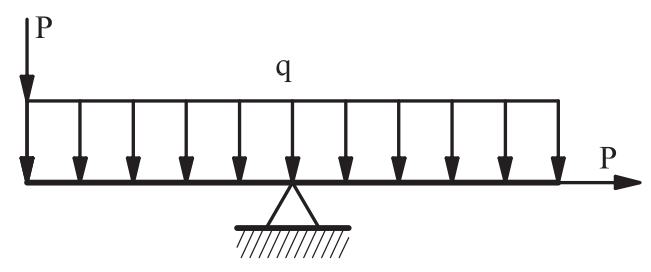

Fig. 1.17. Exemple 1.4.a

Com que és un cas pla, el nombre de graus de llibertat és tres. 
Tenim un únic enllaç que coacciona dos moviments (desplaçaments horitzontal i vertical), per tant:

$$
\mathrm{GH}=\mathrm{C}-\mathrm{GDL}=2-3=-1
$$

El sistema és un mecanisme; per tant, és estàticament inestable. La biga pot girar respecte al seu punt de recolzament.

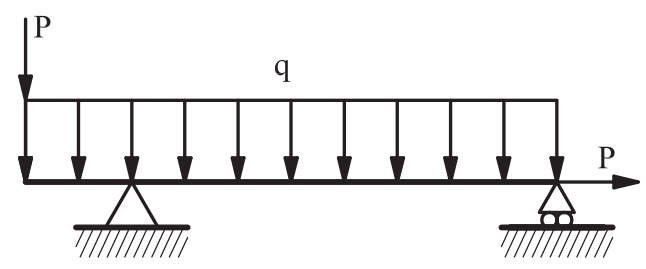

Fig. 1.18. Exemple 1.4.b

Per la mateixa raó que abans, $\mathrm{GDL}=3$.

Tenim un suport fix que coacciona dos moviments i un suport mòbil que en coacciona només un.

$$
\mathrm{GH}=\mathrm{C}-\mathrm{GDL}=3-3=0
$$

El sistema es isostàtic, o estàticament determinat. La biga no pot girar ni moure's en cap direcció, té les coaccions mínimes per a romandre en equilibri.

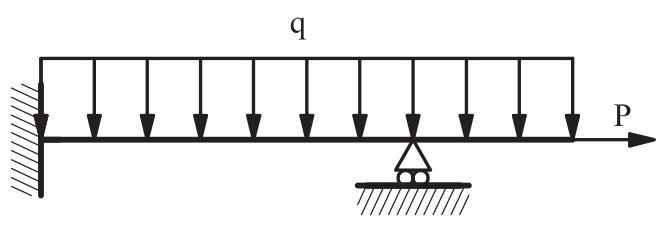

Fig. 1.19. Exemple 1.4.c

Ací també tenim GDL $=3$.

L'encast proporciona tres coaccions, perquè no permet el moviment ni el gir del punt. El suport mòbil introdueix una altra coacció. Tenim un total de quatre coaccions.

$$
\mathrm{GH}=\mathrm{C}-\mathrm{GDL}=4-3=1
$$

El sistema és hiperestàtic (o estàticament indeterminat) de grau 1. La biga està sobrerestringida; té el que s'anomenen enllaços superabundants. Si hi eliminem alguna restricció de moviment, el sistema romandria en equilibri.

Hi ha alguns casos en els quals, malgrat tindre un nombre de coaccions igual o superior al necessari per a estar en equilibri, el sòlid pot ser inestable, perquè els enllaços no són eficaços. Aquest és el cas dels sistemes plans en els quals totes les reaccions són paral·leles, o totes són concurrents. 


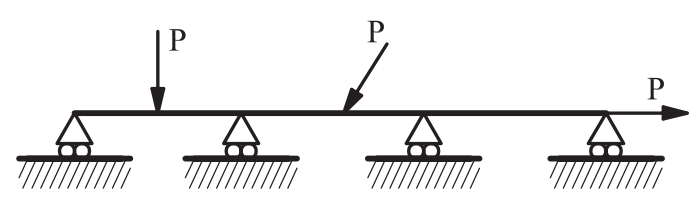

Fig. 1.20. Sistema inestable per tindre totes les reaccions paral·leles

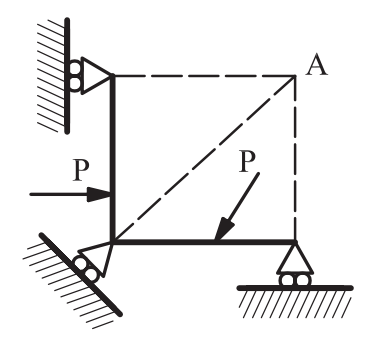

Fig. 1.21. Sistema inestable per ser totes les reaccions concurrents en A

\subsection{Càlcul de reaccions}

Resoldre un sistema suposa calcular els esforços en les seues barres, i per a fer-ho és necessari conéixer totes les reaccions que generen els enllaços externs. En funció del grau d'hiperestatisme podem tindre les següents situacions:

- Mecanisme: com ja hem dit, no treballarem sobre mecanismes. Així doncs, seran estructures que caldrà evitar dins d'aquesta disciplina.

- Sistema isostàtic: el nombre d'equacions d'equilibri estàtic disponibles per a resoldre el sistema és suficient i les reaccions poden ser calculades sense cap altra consideració.

- Sistema hiperestàtic: el nombre d'equacions d'equilibri estàtic disponibles és menor que el nombre de reaccions (incògnites). Per tant, cal fer una sèrie de suposicions basades en la deformació elàstica de les parts del sistema. Aquestes suposicions, que anomenarem condicions de compatibilitat, seran les que ens donaran les equacions addicionals per a resoldre el sistema. Cada condició de compatibilitat ens proporcionarà una equació addicional. Per tant, necessitarem tantes condicions de compatibilitat com grau d'hiperestatisme tinguem al sistema. La resolució dels sistemes hiperestàtics s'estudiarà dins del capítol corresponent a cadascun dels esforços que tractarem més endavant.

\subsubsection{Sistemes isostàtics plans}

En un sistema isostàtic pla tindrem tres reaccions externes que restringiran tres graus de llibertat (gir en Z i desplaçaments en X i Y). Per tal de calcular aquestes tres reaccions utilitzarem les tres equacions d'equilibri estàtic: 


$$
\begin{gathered}
\sum F_{X}=0 \\
\sum F_{Y}=0 \\
\sum M_{O Z}=0
\end{gathered}
$$

Aquestes equacions seran suficients per a resoldre el sistema perquè tindrem tres equacions amb tres incògnites. Les dues primeres equacions corresponen al sumatori de forces en les direccions X i Y respectivament. Si les reaccions que tenim al sistema no porten la direcció de cap dels eixos, descompondrem la reacció segons $\mathrm{X}$ i Y, i considerarem cada component dins del sumatori respectiu. La tercera equació correspon al sumatori dels moments que generen totes les forces que actuen sobre el sistema (càrregues i reaccions) respecte a un punt qualsevol de l'estructura. Com que no importa el punt respecte al qual farem el sumatori de moments, triarem aquell que ens resulte més convenient en cada situació. En general buscarem un punt en el qual hi haja el major nombre possible de reaccions. D'aquesta manera desapareixeran de l'equació de moments, ja que no provoquen moment respecte al punt.

\section{Exemple 1.5}

Calculeu les reaccions del sistema següent:

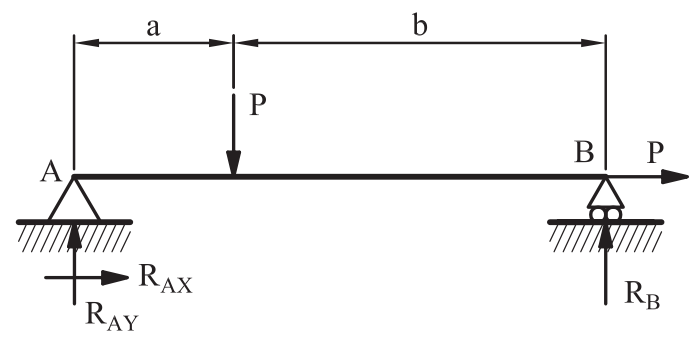

Fig. 1.22. Exemple 1.5

En primer lloc, col·loquem les reaccions corresponents a cadascun dels enllaços amb les puntes de les fletxes (direccions dels vectors) apuntant en un sentit arbitrari. A la figura podem veure com al suport fix A hem colllocat dues reaccions $i$ al suport mòbil B una reacció perpendicular al pla de recolzament. En segon 1loc, apliquem les equacions d'equilibri estàtic:

$\sum F_{X}=0 \rightarrow R_{A X}+P=0 \rightarrow R_{A X}=-P$

Com que el sumatori està igualat a zero, és indiferent que prenguem les forces que van en un sentit com a positives o com a negatives. La qüestió és que les forces que van en un sentit tinguen signe contrari a aquelles que van en sentit contrari. En aquest cas, com que a priori ambdues forces van cap a la dreta, posem el signe positiu per a totes dues. Una vegada resolta l'equació, el signe negatiu obtingut vol 
dir que el sentit que havíem suposat per la reacció és incorrecte i, per tant, la força va en sentit contrari al dibuixat a la figura.

$\sum F_{Y}=0 \rightarrow R_{A Y}+R_{B}-P=0$

Aquesta equació té dues incògnites. Com que no podem resoldre-la encara, plantejarem la tercera equació. Prendrem moments respecte d'un dels punts que tenen reaccions, en aquest cas, respecte d'A, encara que seria el mateix si consideràrem $\mathrm{B}$.

$\sum M_{A}=0 \rightarrow P \cdot a-R_{B} \cdot(a+b)=0 \rightarrow R_{B}=P \cdot \frac{a}{a+b}$

Com veiem, el signe dels moments que provoquen $\mathrm{P} i \mathrm{R}_{\mathrm{B}}$ ha de ser contrari, però és indiferent si un és positiu o és positiu l'altre.

Ara ja podem utilitzar l'equació anterior per aïllar $\mathrm{R}_{\mathrm{AY}}$.

$R_{A Y}=P-R_{B}=P-P \cdot \frac{a}{a+b}=P \cdot \frac{b}{a+b}$

Les dues reaccions verticals ens han eixit amb signe positiu. Això representa que la consideració inicial del sentit de les forces havia sigut correcta.

\section{Exemple 1.6}

Calculeu les reaccions del sistema següent, format per una única barra de longitud L:

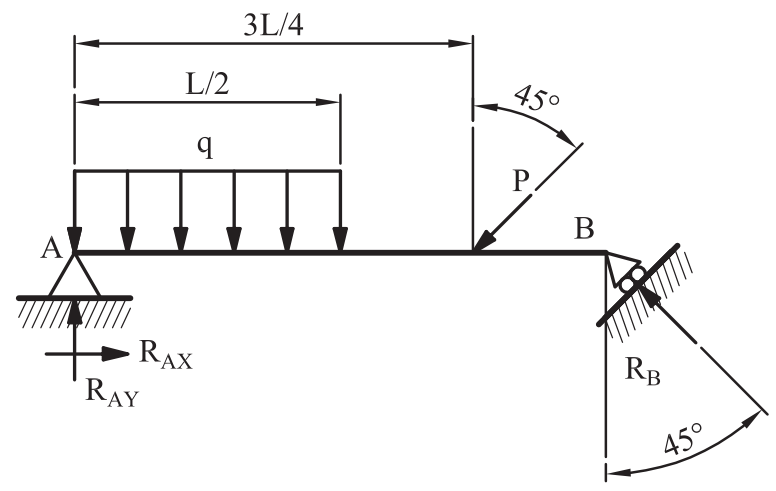

Fig. 1.23. Exemple 1.6

En aquest cas tenim algunes circumstàncies especials: d'una banda tenim la càrrega distribuïda, d'una altra banda la força puntual i la reacció que estan inclinades respecte als eixos. La càrrega distribuïda la substituirem, als efectes de càlcul de reaccions, per la seua resultant situada en el centre de gravetat de la figura que forma la càrrega. En aquest cas, com que la càrrega és uniforme, considerarem que la figura és un rectangle de base L/2 i altura q. Per tant, la resultant serà equivalent a l'àrea del rectangle (base per altura) i el centre de gravetat està al punt mitjà. Pel 
que fa a les càrregues inclinades, és necessari descompondre-les segons els eixos $\mathrm{X}$ i Y.

Les equacions d'equilibri estàtic, si prenem els moments al voltant del punt B, són les següents:

$\sum F_{X}=0 \rightarrow R_{A X}-P \cdot \sin (45)-R_{B} \cdot \sin (45)=0$

$\sum F_{Y}=0 \rightarrow R_{A Y}-q \cdot \frac{L}{2}-P \cdot \cos (45)+R_{B} \cdot \cos (45)=0$

$\sum M_{B}=0 \rightarrow R_{A Y} \cdot L-q \cdot \frac{L}{2} \cdot \frac{3 L}{4}-P \cdot \cos (45) \cdot \frac{L}{4}=0$

Notem que quant a la força $\mathrm{P}$, només genera moment la component vertical, perquè la línia d'acció de la component horitzontal passa pel punt B. La mateixa cosa trobem a les reaccions en $\mathrm{A}$, ja que la línia d'acció de $\mathrm{R}_{\mathrm{AX}}$ també passa per $\mathrm{B}$.

En la tercera equació només tenim una incògnita i podem aïllar $\mathrm{R}_{\mathrm{AY}}$.

$R_{A Y}=q \cdot \frac{3 L}{8}+P \cdot \frac{\sqrt{2}}{8}$

Aquest resultat podem introduir-lo en la segona equació, i obtenim:

$R_{B}=q \cdot L \frac{\sqrt{2}}{8}+\frac{3}{4} \cdot P$

I entrant en la primera equació:

$$
R_{A X}=q \cdot \frac{L}{8}-P \cdot \frac{\sqrt{2}}{8}
$$

\section{Exemple 1.7}

Calculeu les reaccions de la següent biga voladissa encastada de longitud L.

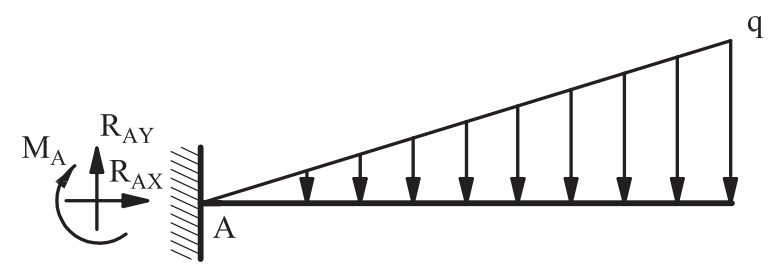

Fig. 1.24. Exemple 1.7

Aquest cas té la particularitat que la càrrega és distribuïda però no uniforme, sinó que té forma triangular. La resultant és per tant l'equivalent a l'àrea del triangle de base L i altura q, i estarà situada en la posició del centre de gravetat, és a dir, a 2/3 del vèrtex o a $1 / 3$ de la base.

$\sum F_{X}=0 \rightarrow R_{A X}=0$

$\sum F_{Y}=0 \rightarrow R_{A Y}-\frac{1}{2} \cdot L \cdot q=0$

$\sum M_{A}=0 \rightarrow M_{A}+\frac{1}{2} \cdot L \cdot q \frac{2}{3} \cdot L=0$ 
La primera equació ens dóna un resultat directe. La segona, també, simplement hem d'ailllar $\mathrm{R}_{\mathrm{AY}}$.

$R_{A Y}=\frac{L \cdot q}{2}$

En la tercera també és directe l'aïllament: $M_{A}=\frac{-q \cdot L^{2}}{3}$.

El signe negatiu ens indica que el moment no gira en sentit horari com havíem suposat, sinó en sentit antihorari.

En el cas que existisquen ròtules intermèdies, cadascuna introduirà una equació addicional al sistema, per la qual cosa serà possible tindre una coacció més i el sistema romandrà estàtic.

Les ròtules són capaces de transmetre forces, però no moments, i és aquesta propietat la que ens dóna l'equació addicional. Aquesta equació serà que la suma de moments generats per totes les forces a un costat de la ròtula respecte d'ella és zero. Podem triar sobre quin costat farem el sumatori de moments, però no podem utilitzar ambdós perquè les dues equacions que obtindríem serien combinació lineal de l'equació de moments que utilitzem per l'equilibri global.

\section{Exemple 1.8}

Calculeu les reaccions del sistema donat a la figura següent, en la qual els punts B i $\mathrm{D}$ són ròtules.

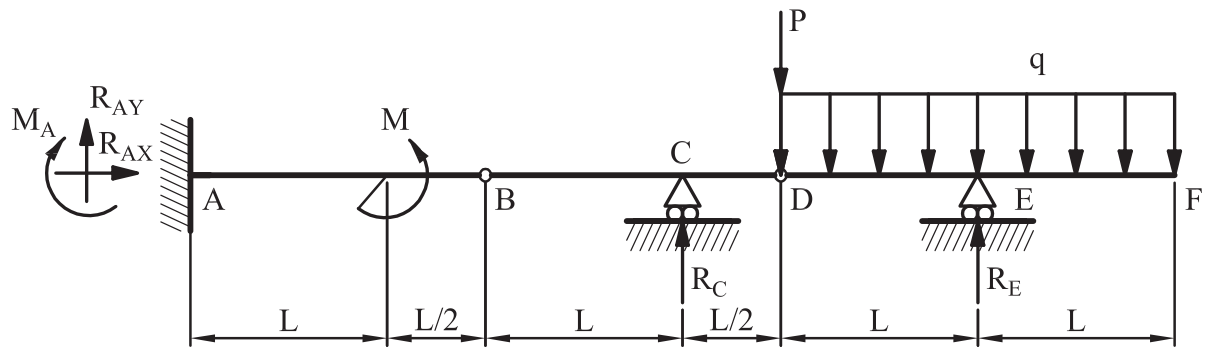

Fig. 1.25. Exemple 1.8

Trobem al sistema cinc reaccions, que poden ser calculades mitjançant les tres equacions d'equilibri, més les dues equacions de les ròtules. Plantegem doncs les equacions de l'estàtica:

$\sum F_{X}=0 \rightarrow R_{A X}=0$

$\sum F_{Y}=0 \rightarrow R_{A Y}-\frac{1}{2} \cdot L \cdot q=0$

$\sum M_{A}=0 \rightarrow M_{A}+\frac{1}{2} \cdot L \cdot q \frac{2}{3} \cdot L=0$

De la primera obtenim el valor de la reacció horitzontal en A, però no podem obtindre cap reacció més de les altres dues equacions. 
Si analitzem l'estructura, ens adonem que a la dreta de D només tenim una reacció $\left(\mathrm{R}_{\mathrm{E}}\right)$. Si plantegem l'equació de la ròtula $\mathrm{D}$ per la seua dreta, podrem obtindre-la.

$\sum M_{\text {dta.D }}=0 \rightarrow q \cdot 2 L \cdot L-R_{E} \cdot L=0 \rightarrow R_{E}=q \cdot 2 L$

La ròtula $\mathrm{B}$ també ens proporciona una equació. Podríem estar temptats de prendre moments a l'esquerra de $\mathrm{B}$, pensant que hi ha menys elements, però el fet és que a l'esquerra hi ha dues incògnites, mentre que a la dreta només n'hi ha una, pel fet de ser coneguda ja $R_{F}$.

$$
\begin{aligned}
& \sum M_{d t a . B}=0 \rightarrow-R_{C} \cdot L+P \cdot \frac{3}{2}+q \cdot 2 L \cdot \frac{5}{2} L-R_{E} \cdot \frac{5}{2} L=0 \rightarrow \\
& \rightarrow-R_{C} \cdot L+P \cdot \frac{3}{2}+q \cdot 2 L \cdot \frac{5}{2} L-q \cdot 2 L \cdot \frac{5}{2} L=0 \rightarrow R_{C}=\frac{3}{2} P
\end{aligned}
$$

Si ara entrem en la segona equació d'equilibri:

$R_{A Y}+\frac{3}{2} P-P-q \cdot 2 L+q \cdot 2 L=0 \rightarrow R_{A Y}=\frac{-P}{2}$

I finalment, entrem en l'equació restant.

$M_{A}=M+\frac{3}{2} P \cdot \frac{5}{2} L-P \cdot 3 L-q \cdot 2 L \cdot 4 L+q \cdot 2 L \cdot 4 L=M+\frac{3}{4} P L$

\subsubsection{Sistemes isostàtics espacials}

En un sistema isostàtic espacial tindrem sis reaccions externes, les quals restringiran els sis graus de llibertat (desplaçaments en $\mathrm{X}, \mathrm{Y}$ i Z, gir en $\mathrm{X}, \mathrm{Y}$ i Z).

Per tal de calcular aquestes sis incògnites disposem de sis equacions d'equilibri estàtic, que són:

$$
\begin{array}{ll}
\sum F_{X}=0 & \sum M_{O X}=0 \\
\sum F_{Y}=0 & \sum M_{O Y}=0 \\
\sum F_{Z}=0 & \sum M_{O Z}=0
\end{array}
$$

Arribem així a un sistema de sis equacions amb sis incògnites.

El punt genèric $\mathrm{O}$ respecte del qual prendrem el sumatori de moments és arbitrari. 


\section{Problemes proposats}

1.1. Sobre el cos rígid en forma de paral·lelepípede rectangular de la figura actuen les forces $\mathrm{F}_{1}, \mathrm{~F}_{2} \mathrm{i}_{3}$. Trobeu la resultant dels seus moments respecte al punt $\mathrm{O}$.

Dades: $\mathrm{F}_{1}=28 \mathrm{kN} ; \mathrm{F}_{2}=18 \mathrm{kN} ; \mathrm{F}_{3}=12 \mathrm{kN} ; \mathrm{a}=1,2 \mathrm{~m} ; \mathrm{b}=0,4 \mathrm{~m} ; \mathrm{h}=0,6 \mathrm{~m}$.

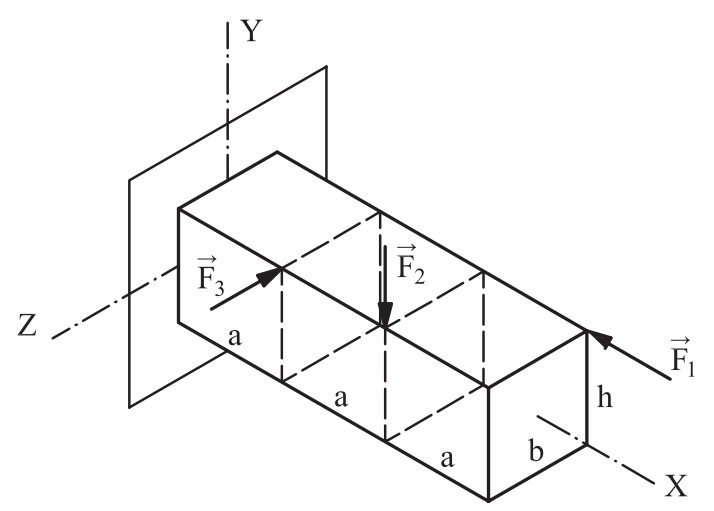

Fig. P-1.01

1.2. Trobeu el moment de la força $F_{1}$ respecte a l'eix $\mathrm{Z}$ i el moment de la força $F_{2}$ respecte a l'eix BC.

Dades: $\mathrm{F}_{1}=12 \mathrm{kN} ; \mathrm{F}_{2}=7 \mathrm{kN} ; \mathrm{OA}=0,8 \mathrm{~m} ; \mathrm{OB}=1,6 \mathrm{~m} ; \mathrm{OC}=2,4 \mathrm{~m}$.

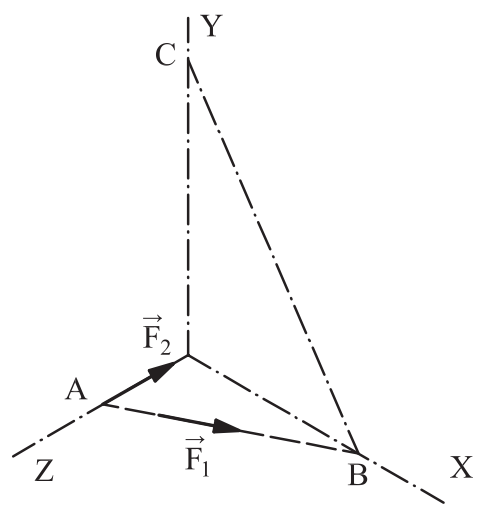

Fig. P-1.02

1.3. Una estructura espacial, l'eix de la qual està contingut en el pla horitzontal, està encastada en la seua secció extrema $\mathrm{i}$ sotmesa a les càrregues de la figura. Determineu les reaccions en l'encast. Aclariment: un encast tridimensional dóna lloc a tres reaccions i tres moments als tres eixos de l'espai. Es considerarà que el signe de les reaccions és positiu si el vector porta la direcció de l'eix corresponent.

Dades: $\mathrm{P}=50 \mathrm{~N} ; \mathrm{Q}=70 \mathrm{~N} ; \mathrm{a}=0,1 \mathrm{~m}$. 


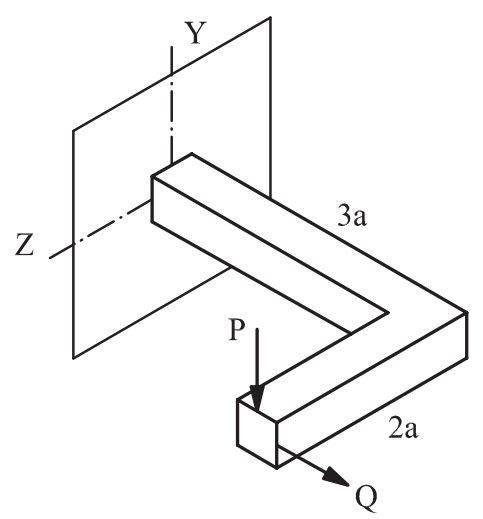

Fig. P-1.03

1.4. Determineu les reaccions en la biga representada.

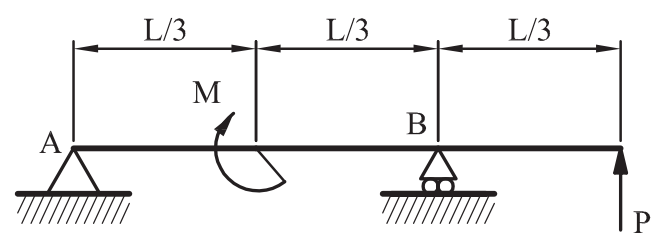

Fig. P-1.04

Dades: $\mathrm{M}=18 \mathrm{kN} \cdot \mathrm{m} ; \mathrm{P}=32 \mathrm{kN} ; \mathrm{L}=6 \mathrm{~m}$.

1.5. Determineu les reaccions en la biga representada.

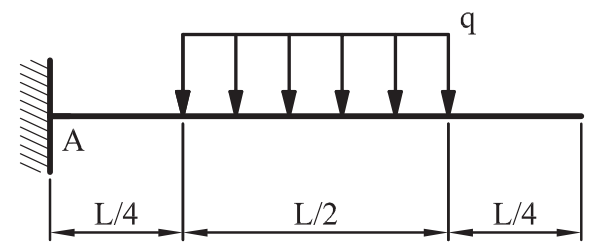

Fig. P-1.05

Dades: $\mathrm{q}=6 \mathrm{kN} / \mathrm{m} ; \mathrm{L}=6 \mathrm{~m}$.

1.6. Determineu les reaccions en la biga representada.

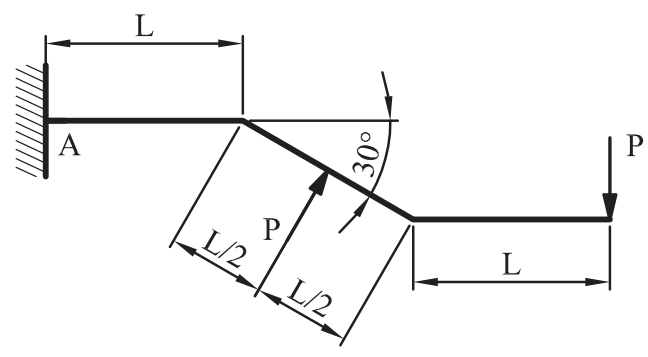

Fig. P-1.06

Dades: $\mathrm{P}=4 \mathrm{kN} ; \mathrm{L}=2 \mathrm{~m}$. 
1.7. Determineu les reaccions dels enllaços de l'estructura de nucs rígids de la figura (cotes en metres).

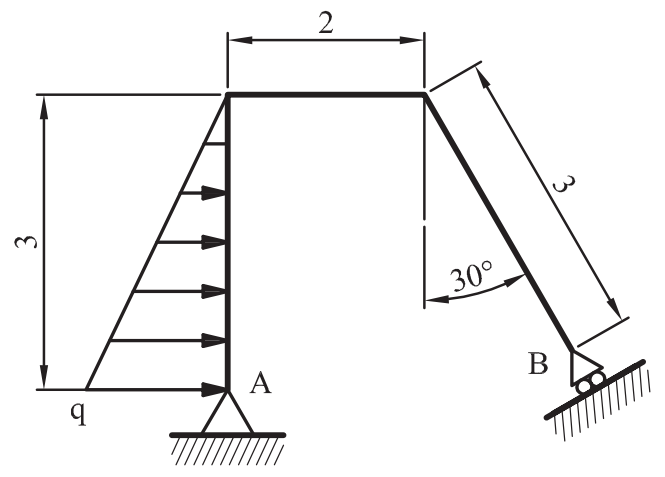

Fig. P-1.07

Dades: $\mathrm{q}=12 \mathrm{kN} / \mathrm{m}$. 


\section{TEMA 2}

\section{Esforços interns}

\subsection{Concepte de sòlid i prisma mecànic}

\subsubsection{Concepte de sòlid}

Com ja hem comentat a la introducció, la resistència de materials fa una sèrie d'idealitzacions i formula certes hipòtesis de partida. Aquestes hipòtesis permeten la simplificació de la casuística, pràcticament infinita, que se'ns pot presentar en la realitat, i permet l'estudi analític de multitud de problemes freqüents que es produeixen en l'enginyeria estructural.

Les diverses disciplines de la física fan una idealització de la realitat, d'una manera que els resulte convenient als seus interessos. En la física clàssica considerem tota la massa d'un cos concentrada en un únic punt. En mecànica del sòlid rígid, importa la forma del cos, $i$ entren en joc els moments d'inèrcia $i$ altres paràmetres geomètrics; però el sòlid és rígid (indeformable). En mecànica dels mitjans continus, el sòlid és deformable.

Els sòlids reals, en general, no són continus: poden tindre imperfeccions, inclusions d'aire, impureses, etc. D'altra banda, tampoc seran homogenis, ja que poden tindre variacions en la seua composició, per exemple, com a conseqüència del procés de fabricació. En determinats casos, tampoc seran isòtrops, és a dir, que les propietats podran variar en funció de la direcció considerada de l'espai, com és el cas de la fusta, que varia molt les seues propietats segons l'orientació de les fibres. Així mateix, els sòlids reals es comporten de manera elàstica únicament en un rang de tensions determinat.

En resistència de materials, el sòlid considerat serà un sòlid elàstic, que té les propietats de ser deformable, continu, homogeni i isòtrop. Per tant, estem fent una idealització de la realitat, i limitant el rang de tensions en el sòlid a aquell en què el seu comportament roman elàstic.

\subsubsection{Prisma mecànic}

Al sòlid que utilitzarem en resistència de materials el denominarem prisma mecànic. El prisma mecànic és el sòlid elàstic, continu, homogeni i isòtrop que es genera en desplaçar-se una superfície plana al llarg d'una línia mitjana que uneix els centres de gravetat de les seccions. Aquesta línia pot ser corba, però no ha de tindre canvis bruscos de curvatura. Així mateix, totes les seccions planes han d'estar situades de 
manera perpendicular a la línia mitjana i no han de ser necessàriament iguals entre si: s'admet la variació de forma, sempre que no siga brusca.

Com podem veure a la figura, habitualment estudiarem les seccions planes perpendiculars a la línia mitjana. Encara que res ens impediria estudiar seccions amb altres inclinacions, no és freqüent en edificació tractar aquestes seccions, llevat d'alguns casos especials que veurem més endavant.

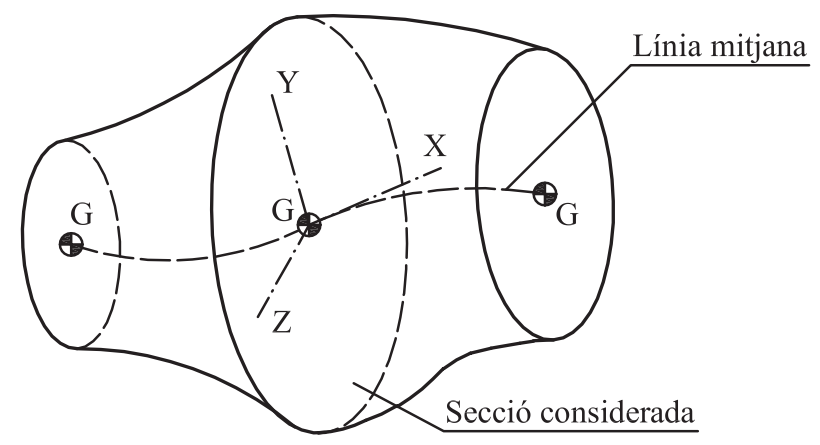

Fig. 2.1. Prisma mecànic

Els prismes mecànics es poden subdividir en funció de les seues dimensions predominants:

Barra. És el prisma mecànic en el qual una dimensió predomina enfront de les altres dues. En concret, la longitud de la línia mitjana és molt major que les dimensions de la secció transversal, com per exemple, les bigues i els pilars d'un edifici. Aquest és el prisma mecànic típic que utilitzarem en l'assignatura, encara que n'hi ha d'altres.

Placa. És un cos limitat per dos plans, la separació dels quals (gruix) és xicoteta en comparació amb les altres dues dimensions. En edificació trobem, per exemple, les lloses, els forjats, etc.

Corfa. La definició és semblant a la de placa, llevat que en aquest cas les superfícies no són planes. Com a exemple podem citar els dipòsits circulars, voltes de túnel, etc.

Hi ha alguns elements concrets en edificació en els quals no predomina cap de les tres dimensions, com són, per exemple, les sabates de fonamentació.

Com veiem, en els edificis coexisteixen, o poden coexistir, tots els tipus de prismes mecànics, relacionats entre si i amb l'entorn pels mitjans d'unió. 


\subsection{Equilibri i concepte de tensió}

Imaginem un sòlid elàstic sotmés a forces de qualsevol tipus, de manera que les càrregues i les reaccions són tals que el sòlid roman en equilibri.

Com vam estudiar al tema anterior, això vol dir que es compliran les equacions d'equilibri estàtic:

$$
\begin{aligned}
& \sum \vec{F}=0 \\
& \sum \vec{M}_{0}=0
\end{aligned}
$$

S'entén que aquestes equacions representen tots els sumatoris de forces i moments que siguen necessaris, segons que el cas siga bidimensional o tridimensional.

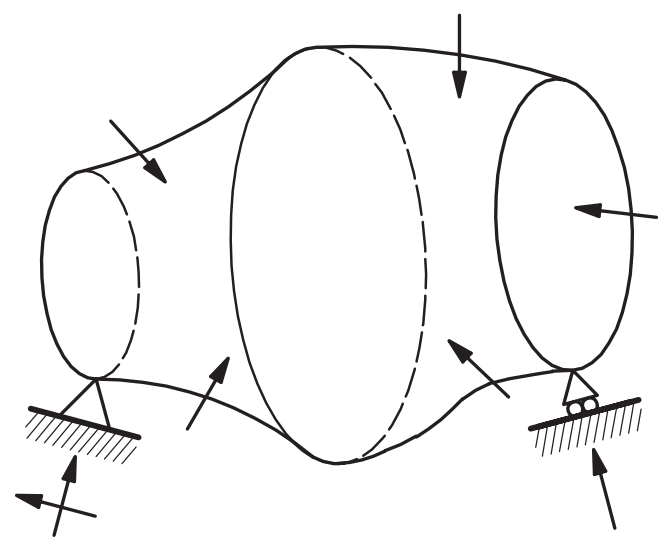

Fig. 2.2. Sòlid elàstic en equilibri

Si el sòlid està en equilibri en el seu conjunt, les seues parts també ho han de estar. Quan parlem de les parts, volem dir tant els elements complets (com ara bigues) com porcions d'aquests elements, incloent els punts com a elements diferencials. És a dir, si tallem el sòlid per un pla qualsevol i separem les parts en les quals es divideix, ambdues parts estaran en equilibri.

Si analitzem les parts resultants, ens adonarem que no poden estar en equilibri si no és perquè apareixen forces al pla de la secció (forces internes) que contraresten les forces externes. Aquestes forces són les que una de les parts exerceix sobre l'altra.
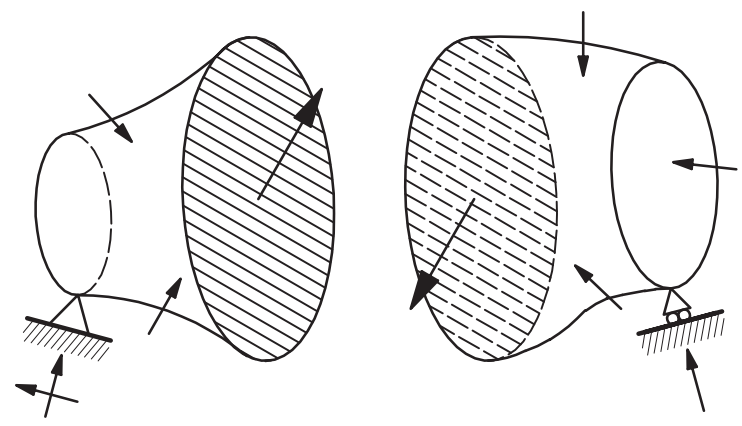

Fig. 2.3. Parts del sòlid elàstic en equilibri. Forces internes que hi apareixen 
Realment, el que apareix a la secció no és una força, sinó una distribució contínua de forces en tota la superfície. A aquesta distribució contínua l'anomenarem tensió, i la representarem amb la lletra grega sigma $(\sigma)$. La tensió te unitats de força dividida per unitat de superfície: en el sistema internacional, newton dividit per metre quadrat $\left(\mathrm{N} / \mathrm{m}^{2}\right)$, que també pren el nom de pascal $(\mathrm{Pa})$.

Definirem un sistema de referència local en cada secció que analitzem (habitualment perpendicular a la línia mitjana). L'origen és el centre de gravetat de la secció recta. L'eix X serà perpendicular a la secció (per tant, tangent a la línia mitjana). Els eixos Y i Z seran els eixos principals d'inèrcia de la secció.

La tensió té propietats de vector, és a dir, té magnitud i sentit. Per tant, l'esmentada distribució de tensions pot ser descomposta segons els tres eixos coordenats. Les components que porten la direcció de l'eix X es denominen tensió normal. Les components que porten les direccions dels eixos Y i Z es denominen tensió tangencial.

A fi d'entendre el concepte, suposem que la magnitud siga igual en tota la secció i que el sentit del vector siga el mateix que el de l'eix corresponent. En aquest cas, podem representar les tensions de les següents figures:

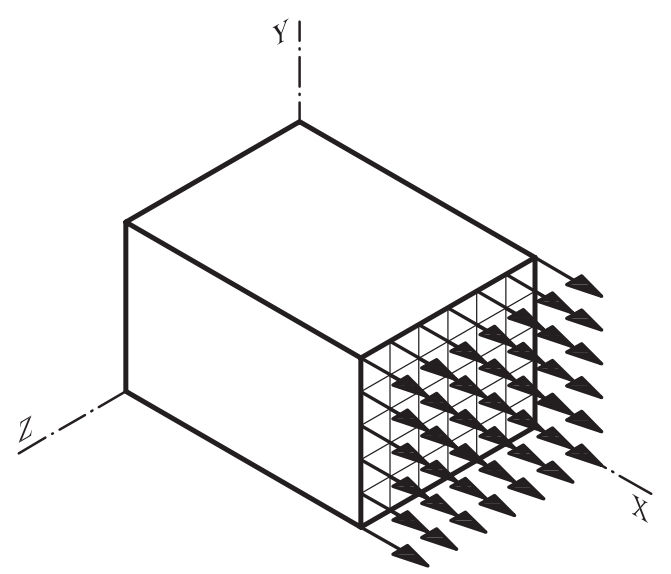

Fig. 2.4. Distribució constant de tensions normals

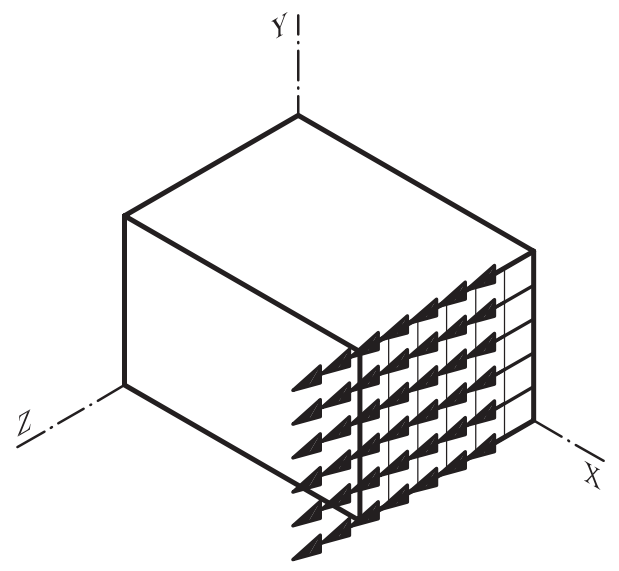

Fig. 2.5. Distribució constant de tensions tangencials en la direcció Z 


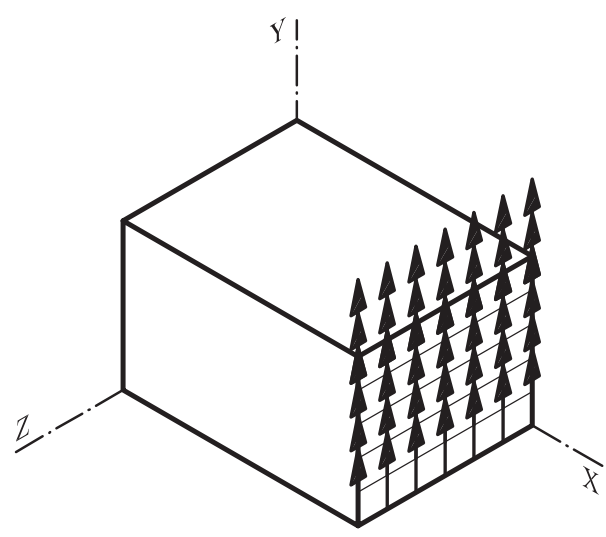

Fig. 2.6. Distribució constant de tensions tangencials en la direcció Y

La distribució de tensions sobre la secció serà la mateixa (però amb signe contrari) a un costat i un altre després de separar el sòlid, a causa del principi d'accióreacció. Un cop eliminada una de les parts, per a mantindre l'equilibri de la part conservada, s'haurà d'acomplir que la resultant de la distribució de forces en la secció equilibre les forces exteriors que actuen sobre aquesta part conservada. Això constitueix el principi del mètode de l'equilibri per a resoldre els esforços que apareixen a la secció. D'una altra banda, la part eliminada també haurà d'estar en equilibri amb la distribució de tensions sobre la secció. Aquest és el principi del mètode de les seccions.

\subsection{Definició d'esforços interns}

Com ja hem dit, l'equilibri ha de mantindre's amb la distribució de tensions que apareix en la secció. Aquest equilibri, des d'un punt de vista teòric, és equivalent al que proporcionaria la resultant de la força i la resultant del moment.

La resultant esmentada hauria de calcular-se amb una integral d'àrea, en tant que es tracta de una distribució contínua.

$$
\vec{R}=\int_{\Omega} \vec{o} d \Omega
$$

La resultant la considerarem situada al centre de gravetat de la secció. Com que cadascun dels punts $\mathrm{O}$ de la secció està separat una distància del centre de gravetat, cada porció diferencial de força produirà un moment respecte al centre de gravetat.

$$
\vec{M}=\int_{\Omega}(\overrightarrow{O G} \times \vec{o}) d \Omega
$$

Per definició, una secció tindrà una única resultant de forces i de moments, que serà la mateixa per a tots els punts de la secció (al contrari que la tensió, que pot ser diferent per a cada punt). 
Les resultants de forces i de moments són dos vectors que poden ser descompostos segons els eixos locals de la secció. Cadascuna d'aquestes components l'anomenem esforç, i té assignat un nom concret.

$$
\vec{R}=\left(N \vec{\imath}+V_{Y} \vec{\jmath}+V_{Z} \vec{k}\right) \quad \vec{M}=\left(M_{T} \vec{\imath}+M_{Y} \vec{\jmath}+M_{Z} \vec{k}\right)
$$
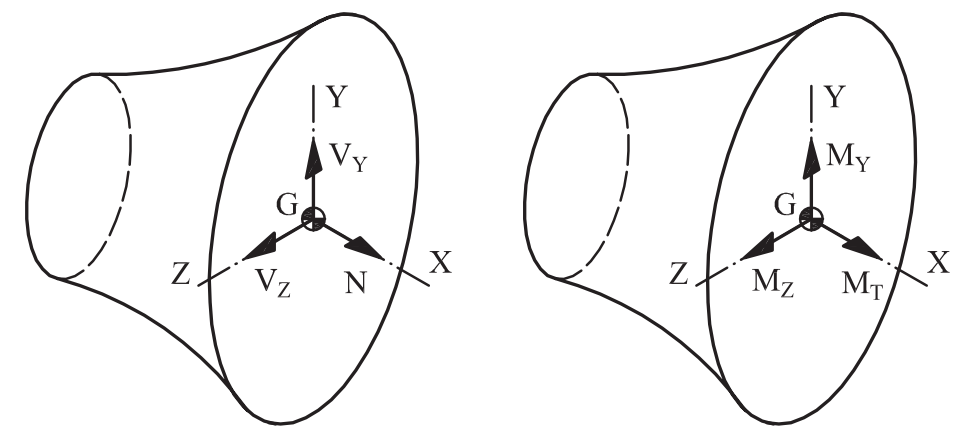

Fig. 2.7. Descomposició de les resultants de força i de moments

- Esforç axial $(N)$. Resistència que oposen cadascuna de les parts contigües de la secció a ser separades en la direcció longitudinal. Dóna lloc a traccions i compressions en la peça.

- Esforç tallant $\left(V_{Y} \mathrm{i} V_{Z}\right)$. Resistència que oposen dues seccions contigües a ser separades per lliscament de l'una sobre l'altra al pla de la secció.

- Moment torçor $\left(M_{T}\right)$. Resistència que oposen dues seccions contigües a ser separades quan es retorcen girant al voltant de l'eix longitudinal X.

- Moment flector $\left(M_{Y}\right.$ i $\left.M_{Z}\right)$. Resistència que oposen dues seccions contigües a ser separades quan la biga es corba segons els plans XY o XZ.

Aquestes components (esforços) són eines que utilitzarem en resistència de materials, però hem de ser conscients que realment el que apareix en la secció és una distribució de tensions. Tanmateix, en resoldre una estructura, el càlcul de tensions no pot fer-se directament, sinó que primer haurem de calcular els esforços i a partir d'aquests calcularem les tensions.

\subsection{Càlcul d'esforços interns}

Els esforços en una secció determinada d'un sòlid els calcularem, com hem fet en la introducció teòrica, separant el sòlid en dues parts i llevant-ne una. Llavors plantejarem l'equilibri estàtic de la part conservada (o l'eliminada, segons el mètode) i obtindrem els esforços com a conseqüència de la resolució del sistema d'equacions. 
És molt important definir un conveni de signes per als esforços que apareixen en la secció, siga la d'una part o de la contigua.

En la secció esquerra (que habitualment serà la part conservada) situem un triedre directe, però en la part dreta (habitualment l'eliminada), el triedre serà invers.
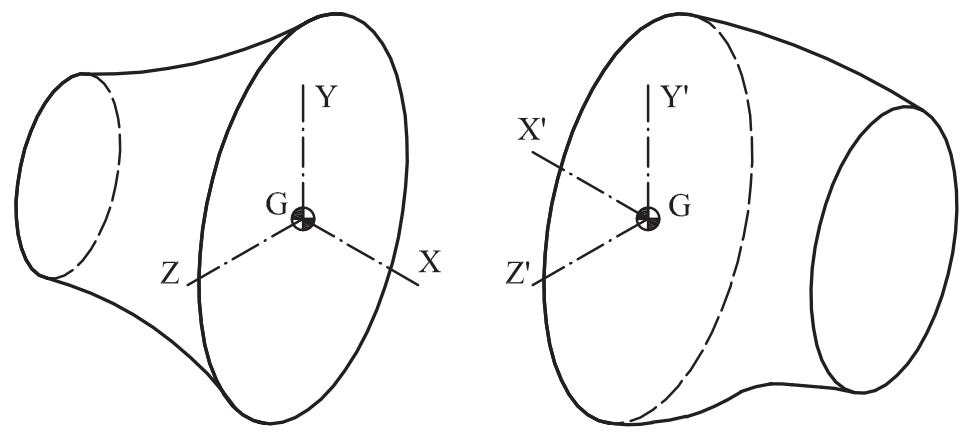

Fig. 2.8. Triedres en les seccions d'estudi

En la secció de la part esquerra, els esforços (forces i moments) tindran signe positiu, si porten la direcció positiva de l'eix corresponent. A l'altre costat, en la part dreta, pel principi d'acció-reacció, els esforços hauran de ser de mateixa magnitud i signe contrari (s'han d'anul-lar dos a dos). Com que el signe de l'esforç ha de ser el mateix, en la secció dreta, alguns esforços seran positius encara que no porten la direcció de l'eix. Això queda aclarit a la figura següent:
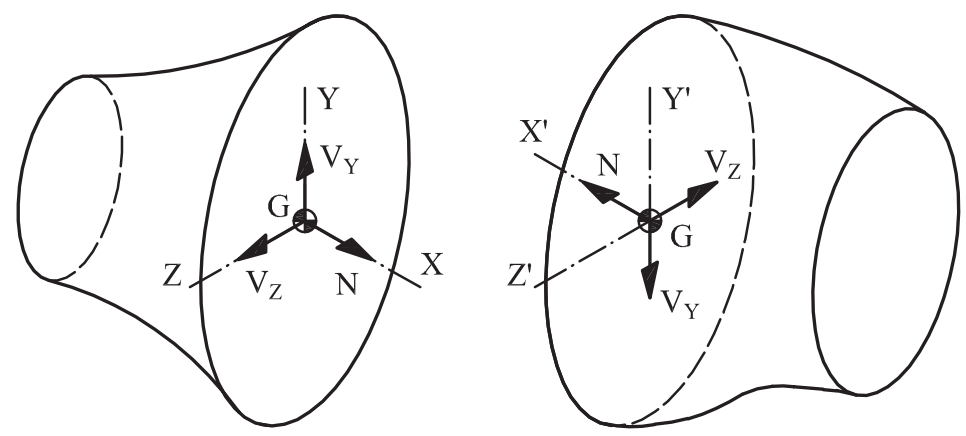

Fig. 2.9. Sentit positiu dels esforços en una secció

En el cas dels moments, el conveni de signes és el mateix, i la figura 2.9 seria equivalent, només substituint-hi $N$ per $M_{T}, V_{Y}$ per $M_{Y}$ i $V_{Z}$ per $M_{Z}$.

Bona part dels casos que estudiarem en el curs seran bidimensionals. En aquests casos alguns esforços són zero $\left(V_{Z}=M_{T}=M_{Y}=0\right)$. El criteri de signes en dues dimensions és el de la figura:
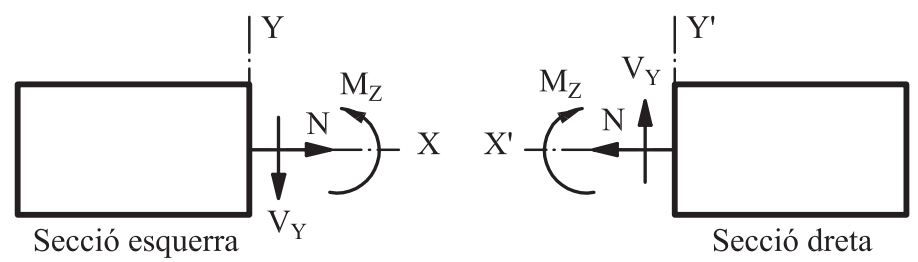

Fig. 2.10. Sentit positiu dels esforços en una secció en un cas bidimensional 


\section{Exemple 2.1}

En l'estructura de la figura, calculeu els esforços de la secció que es troba en $\mathrm{x}=3 / 4 \mathrm{~L}$.

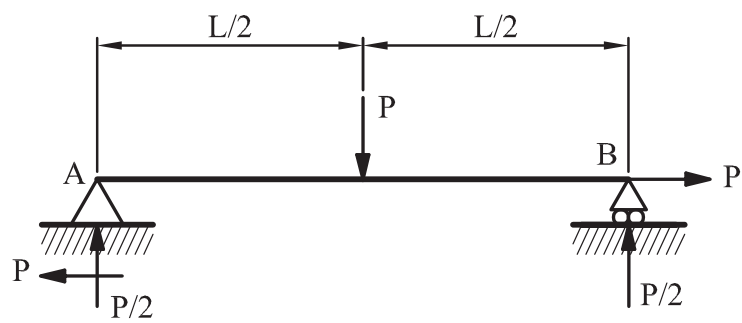

Fig. 2.11. Exemple 2.1

La primera cosa que hem de fer és calcular les reaccions. Com que ja hem fet aquest exemple al tema 1, obviarem el càlcul de reaccions. El seu valor està representat a la figura 2.11 .

Fem un tall a la distància $\mathrm{x}=3 / 4 \mathrm{~L}$ i llevem la part de l'esquerra. Col·loquem els esforços en la secció en el seu sentit positiu.

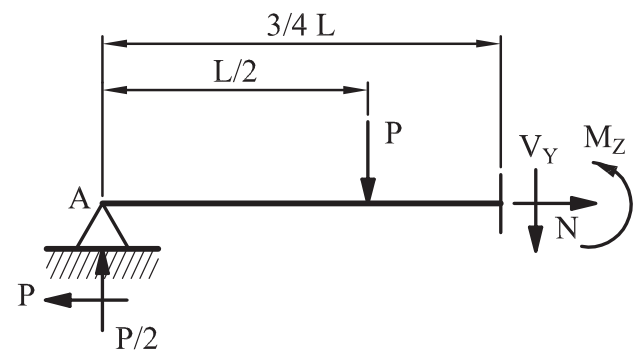

Fig. 2.12. Exemple 2.1

Plantegem l'equilibri a la part conservada:

$\sum F_{X}=0 \rightarrow N=P$

$\sum F_{Y}=0 \rightarrow \frac{P}{2}-P-V_{Y}=0 \rightarrow V_{Y}=-\frac{P}{2}$

$\sum M=0 \rightarrow \frac{P}{2} \frac{3 L}{4}-P \frac{L}{4}-M_{Z}=0 \rightarrow M_{Z}=\frac{P L}{8}$

\subsection{Lleis i diagrames d'esforços}

Al punt anterior hem vist com calcular els esforços en una única secció. Molts cops ens interessarà obtindre una funció que ens proporcione l'esforç de totes les seccions d'una biga, és a dir, una funció $\mathrm{f}(\mathrm{x})$ depenent de la variable $\mathrm{x}$ (distància sobre l'eix). En tal cas, farem la mateixa operació del tall, però el situarem a una 
distància genèrica x i plantejarem l'equilibri, de manera que ens donarà valors per als esforços que seran dependents de $\mathrm{x}$.

Les funcions que determinen els esforços canvien quan canvien les forces que es troben a la part conservada. Per aquesta raó necessitarem fer un tall cada cop que apareix una força nova, segons anem avançant per la biga. A l'exemple 2.1 necessitaríem fer dos talls, el primer d'ells per trobar unes lleis d'esforços que foren vàlides des de $\mathrm{x}=0$ fins $\mathrm{a} \mathrm{x}=\mathrm{L} / 2$, $\mathrm{i}$ el segon tall per les lleis al tram des de $\mathrm{x}=$ $\mathrm{L} / 2$ fins a $\mathrm{x}=\mathrm{L}$.

Aquestes funcions, a les quals denominarem lleis d'esforços, poden ser representades gràficament. La representació de les lleis d'esforços són el que anomenem diagrames d'esforços.

Per conveni, habitualment es representen els esforços axial, tallant i torçor positius cap a dalt, però els moments flectors positius cap a baix. La justificació és que el diagrama de flectors dibuixat d'aquesta manera s'assembla en molts dels casos a la deformada de la biga.

En tot cas, per tal de no induir a error, dibuixarem el símbol corresponent a l'esforç, positiu o negatiu, d'entre els següents:

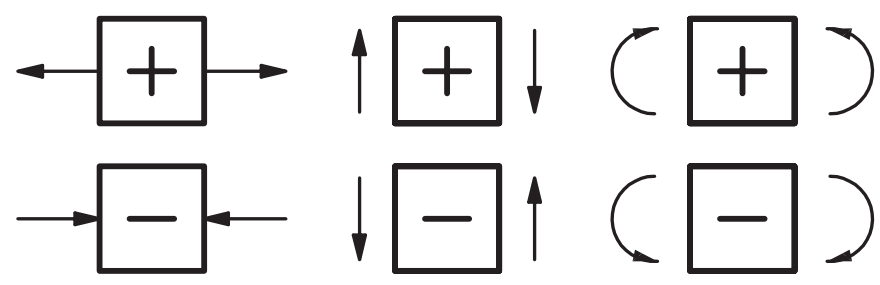

Fig. 2.13. Conveni de signes dels esforços

En resum, la metodologia que seguirem per a realitzar els diagrames d'esforços serà:

- Determinar les reaccions.

- Col-locar els eixos locals de l'element (X longitudinal, Z ixent del paper i Y formant el triedre directe).

- Realitzar talls imaginaris successius entre càrregues externes (incloses les reaccions) i eliminar una de les parts del prisma.

- Equilibrar, en el prisma conservat, les forces externes amb els esforços que apareixen en la secció (mètode de les seccions).

- Representar gràficament les funcions matemàtiques obtingudes (lleis d'esforços). 
En aquesta obra només utilitzarem el mètode de l'equilibri per a calcular les lleis d'esforços. Si el lector té interés a conéixer el mètode de les seccions, el remetem a la bibliografia proposada.

\section{Exemple 2.2}

Determineu les lleis d'esforços i representeu els diagrames corresponents en l'estructura de l'exemple 2.1.

Considerem resoltes les reaccions del sistema.

Com que hi ha una única força, necessitem fer dos talls, el primer entre A i la força i un altre entre la força i B.

Primer tall $(0 \leq \mathrm{x} \leq \mathrm{L} / 2)$

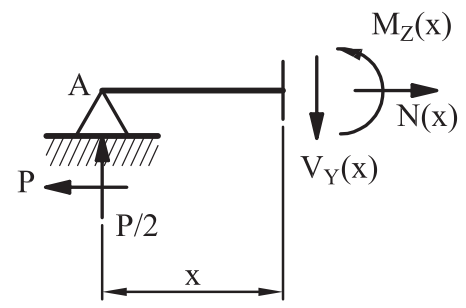

Fig. 2.14. Exemple 2.2

Plantegem l'equilibri de la part conservada, prenent moments sempre al punt de tall.

$$
\begin{aligned}
& \sum \overrightarrow{F_{X}}=0 \rightarrow N(x)=P \\
& \sum \overrightarrow{F_{Y}}=0 \rightarrow \frac{P}{2}-V_{Y}(x)=0 \rightarrow V_{Y}(x)=\frac{P}{2} \\
& \sum \vec{M}=0 \rightarrow \frac{P}{2} x-M_{Z}(x)=0 \rightarrow M_{Z}(x)=\frac{P}{2} x
\end{aligned}
$$

Segon tall $(\mathrm{L} / 2 \leq \mathrm{x} \leq \mathrm{L})$

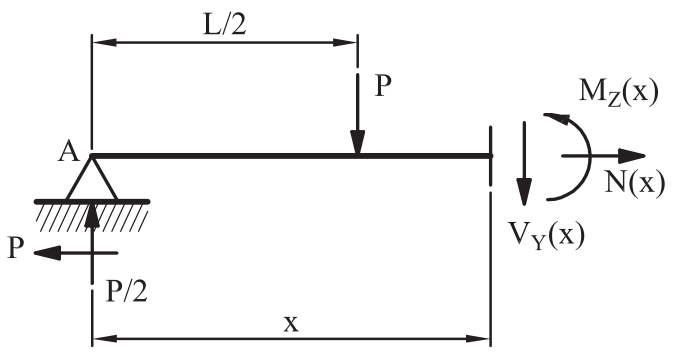

Fig. 2.15. Exemple 2.2 
Plantegem igualment l'equilibri:

$\sum \overrightarrow{F_{X}}=0 \rightarrow N(x)=P$

$\sum \overrightarrow{F_{Y}}=0 \rightarrow \frac{P}{2}-P-V_{Y}(x)=0 \rightarrow V_{Y}(x)=-\frac{P}{2}$

$\sum M=0 \rightarrow \frac{P}{2} x-P\left(x-\frac{L}{2}\right)-M_{Z}(x)=0 \rightarrow M_{Z}(x)=\frac{P}{2}(L-x)$

Representació dels diagrames:

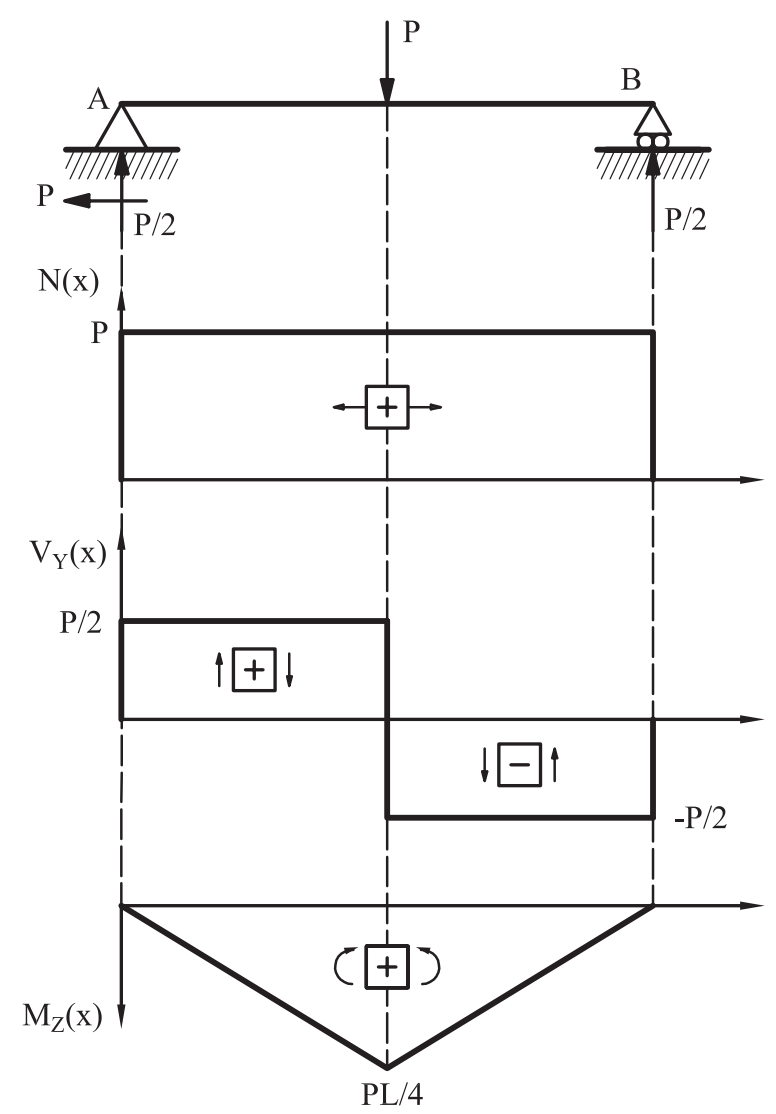

Fig. 2.16. Exemple 2.2

\subsection{Propietats dels diagrames d'esforços}

\subsubsection{Diagrama d'esforços axials}

Els esforços axials apareixen com a conseqüència de l'existència de càrregues que porten la direcció de l'eix longitudinal de la peça. Podem remarcar les següents propietats interessants:

1. La derivada de la llei d'esforços axials $N(x)$ en un tram és igual a la funció de càrrega axial distribuïda $q_{x}(x)$ que actua sobre el tram, canviada de signe, si aquesta es defineix positiva en el sentit de l'eix x local de la barra. 
2. Com a conseqüència, l'ordre del polinomi $N(x)$ en un tram sempre és el de la càrrega axial distribuïda més una unitat.

- Càrregues puntuals $\rightarrow N(x)$ constant.

- $\mathrm{q}_{\mathrm{X}}(\mathrm{x})$ constant $\rightarrow N(x)$ lineal.

- $\mathrm{q}_{\mathrm{X}}(\mathrm{x})$ lineal $\rightarrow N(x)$ parabòlic.

- Etc.

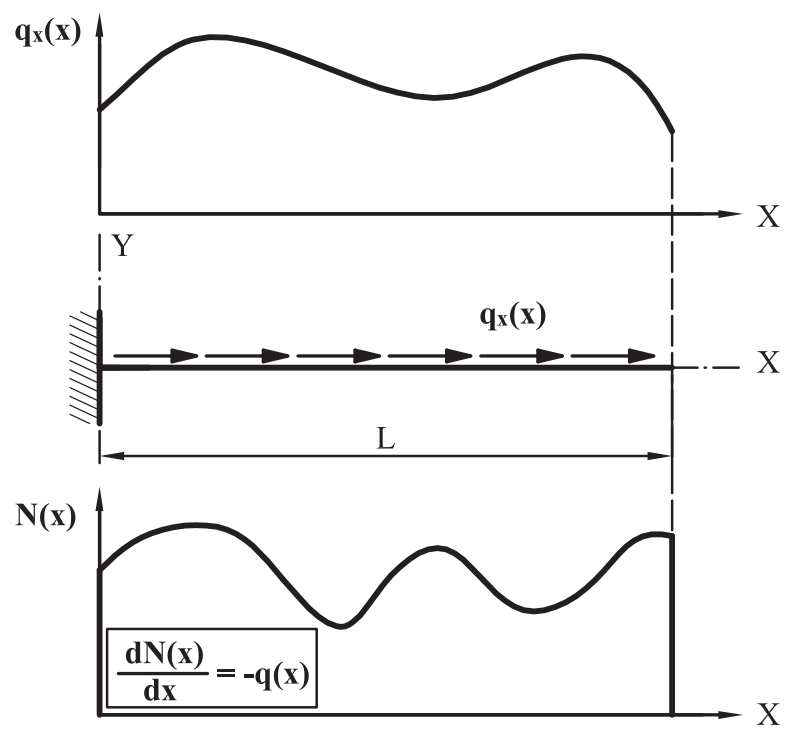

Fig. 2.17. La derivada de l'esforç axial és la funció de càrrega distribuïda

\section{Exemple 2.3}

Calculeu i dibuixeu la llei d'esforços axials en el cas que la càrrega distribuïda siga constant i de valor $q_{X}(x)=q_{0}$.

La reacció a l'encast serà $R_{X}=q_{0} \cdot L$.

La llei d'esforços axials serà, per tant, $N(x)=q_{0} \cdot L-q 0 \cdot x=q_{0}(L-x)$.

Això és una distribució lineal amb valors extrems: $N(x=0)=q_{0} \cdot L ; N(x=L)=0$. 


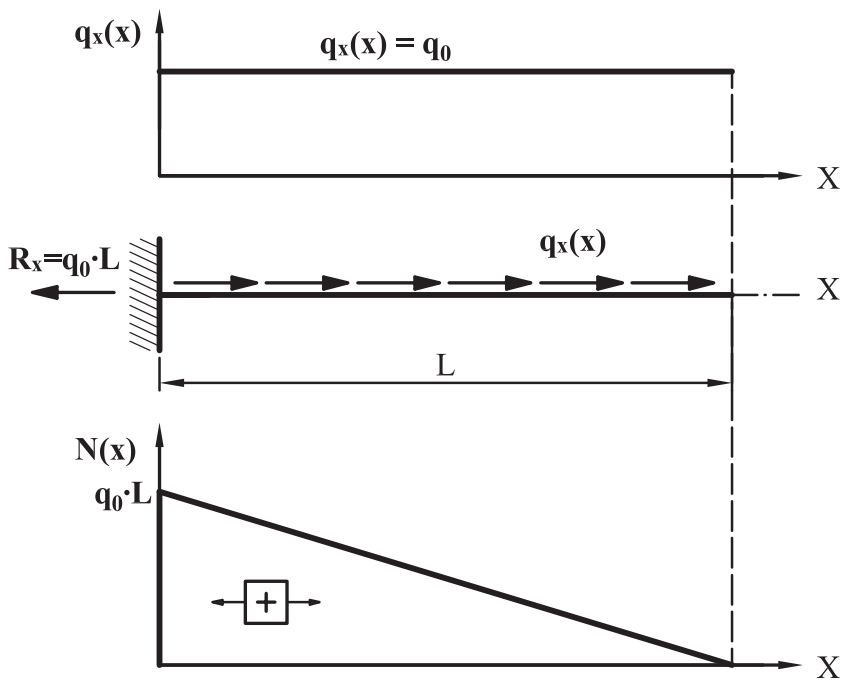

Fig. 2.18. Exemple: càrrega distribuïda constant - esforç axial lineal

3. Sempre que existisca una càrrega puntual aplicada en la direcció axial de l'element, al diagrama d'axials $N(x)$ apareixerà una discontinuïtat de valor absolut igual al mòdul de la càrrega.

4. En una coacció horitzontal situada en l'extrem d'un element, l'esforç axial sempre serà igual (en valor absolut) al mòdul de la reacció en la direcció de la barra.

5. En un extrem lliure l'esforç axial serà nul en absència de càrregues axials aplicades. En presència d'elles serà igual al seu valor.

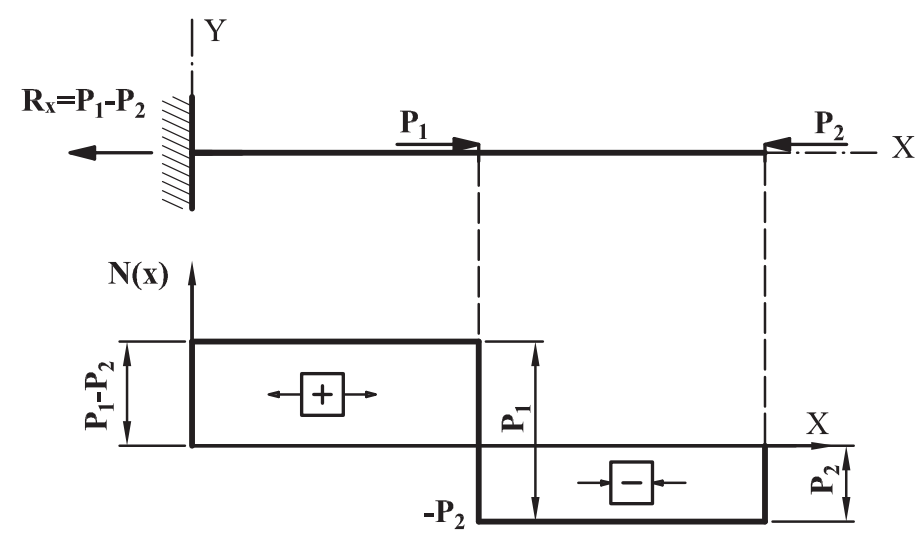

Fig. 2.19. Diagrama d'axials de barra amb càrregues puntuals

\subsubsection{Diagrama d'esforços tallants}

Els esforços tallants es produeixen quan apareixen càrregues perpendiculars a l'eix longitudinal de la peça. Les propietats fonamentals que podem destacar-hi són: 
1. La derivada de la llei d'esforços tallants $V_{Y}(x)$ en un tram és igual a la funció de càrrega transversal distribuïda $q_{Y}(x)$ que actua sobre ell, positiva en el sentit de l'eix Y local de la barra.

2. Com a conseqüència, l'ordre del polinomi $V_{Y}(x)$ en un tram és sempre el que tinga la càrrega transversal distribuïda més una unitat.

- Càrregues puntuals $\rightarrow V_{Y}(x)$ constant. (Fig. 2.21.a)

- $q_{Y}(x)$ constant $\rightarrow V_{Y}(x)$ lineal. (Fig. 2.21.b)

- $q_{Y}(x)$ lineal $\rightarrow V_{Y}(x)$ parabòlic. (Fig. 2.21.c)

- Etc.

3. Sempre que existisca una càrrega puntual aplicada en la direcció transversal a l'element, al diagrama de tallants $V_{Y}(x)$ apareixerà una discontinuïtat (salt) de valor absolut igual al mòdul de la càrrega. Això podem comprovar-ho al punt d'aplicació de la càrrega $\mathrm{P}$, a l'exemple 2.2.

4. En un extrem lliure, $i$ en absència de càrregues transversals puntuals aplicades, el valor del tallant serà nul.

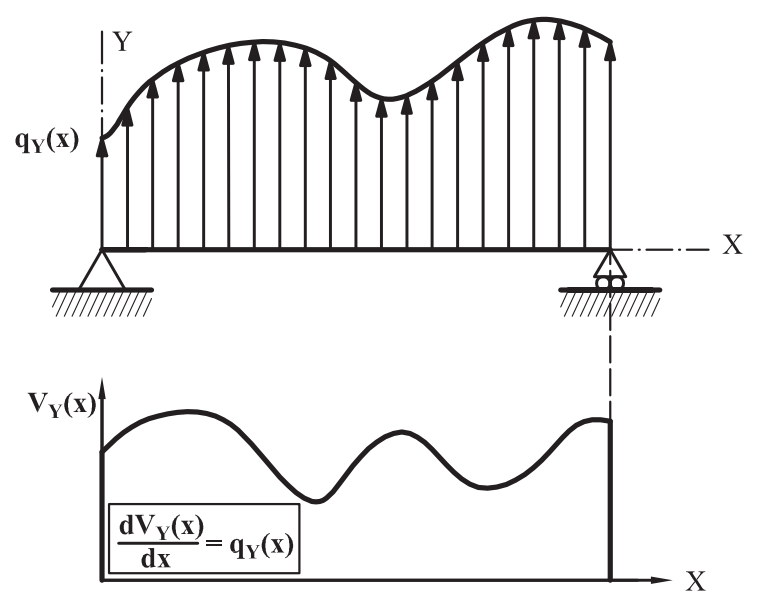

Fig. 2.20. La derivada de l'esforç tallant és la funció de càrrega distribuïda

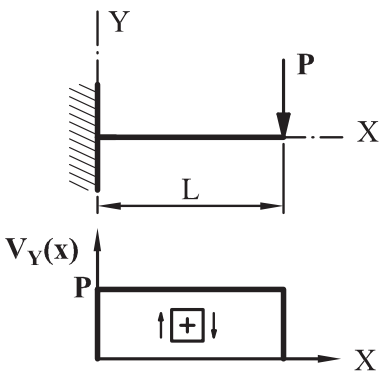

a)

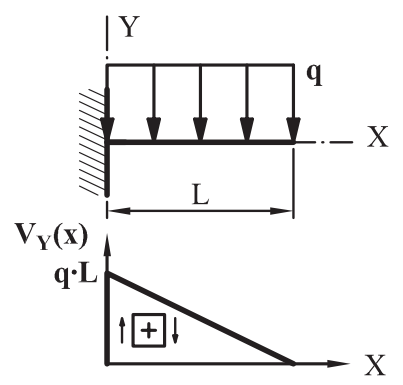

b)

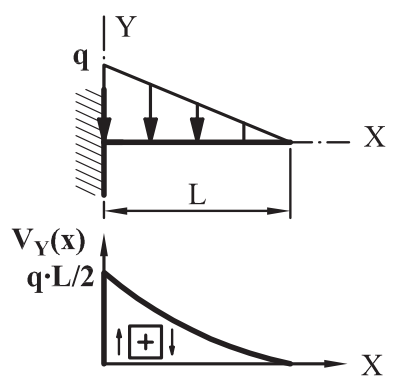

c)

Fig. 2.21. L'esforç tallant té un grau més que la càrrega 
5. Les reaccions són equivalents a forces exteriors: produeixen un salt al diagrama. Per això, en una coacció d'extrem, la qual limite el desplaçament transversal de la secció extrema d'un element, l'esforç tallant serà igual (en valor absolut) al mòdul de la reacció en la direcció perpendicular a l'element.

Les dues característiques anteriors podem apreciar-les a la figura 2.22:

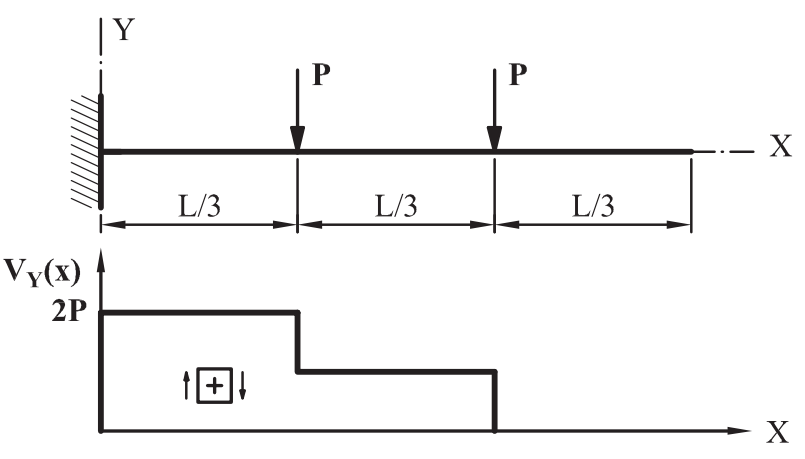

Fig. 2.22. Característiques dels diagrames d'esforç tallant

\subsubsection{Diagrama de moments flectors}

1. En un extrem encastat el valor del moment flector en la secció en valor absolut serà igual al moment en 1'encast. (Fig. 2.23.a)

2. La derivada de la llei de moments flectors $M_{Z}(x)$ és igual a la llei d'esforços tallants $V_{Y}(x)$. Per tant, els màxims relatius de la funció del moment flector es trobaran on el tallant s'anul·le (derivada igualada a zero). (Fig. 2.23.b i c)

3. Com a conseqüència d'això, l'ordre del polinomi $M_{Z}(x)$ en un tram sempre supera en una unitat el del tallant $V_{Y}(x)$.

- $V_{Y}(x)$ nul $\rightarrow M_{Z}(x)$ constant. (Fig. 2.23.a)

- $V_{Y}(x)$ constant $\rightarrow M_{Z}(x)$ lineal. (Fig. 2.23.b)

- $V_{Y}(x)$ lineal $\rightarrow M_{Z}(x)$ parabòlic. (Fig. 2.23.c)

- Etc. 


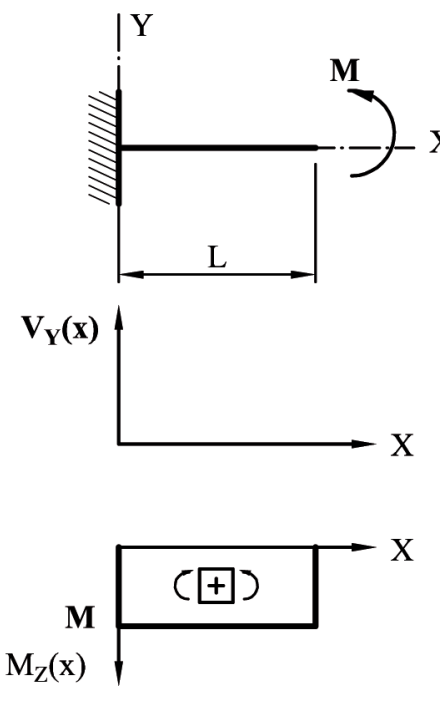

a)
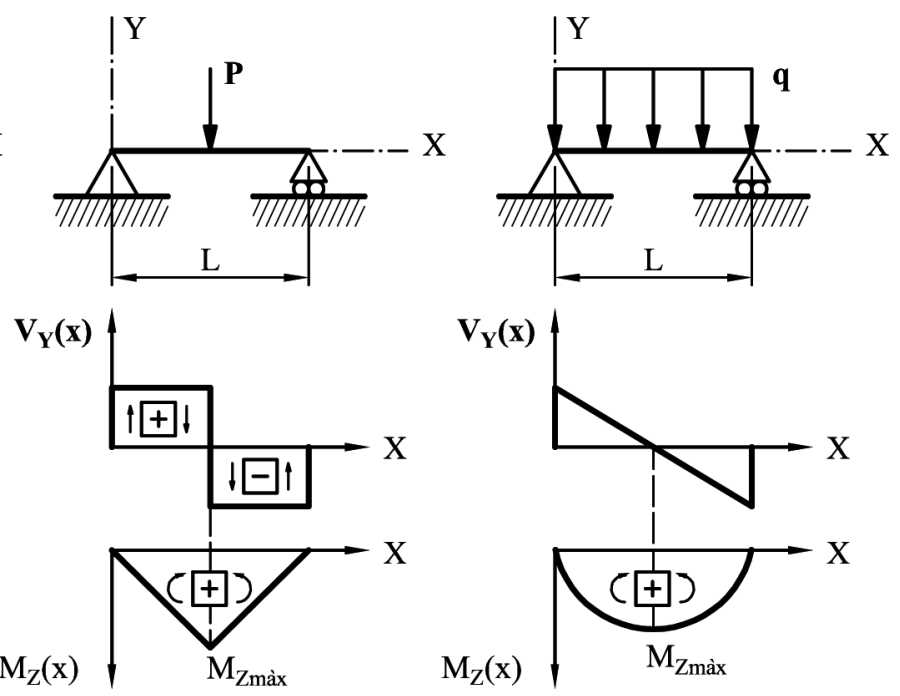

b)

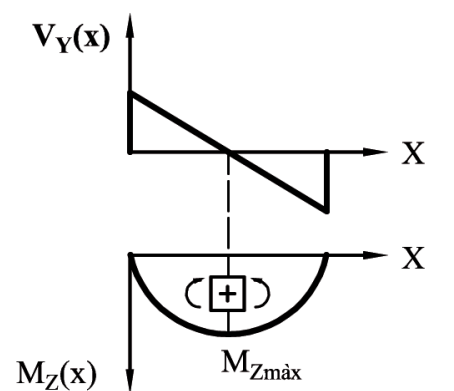

c)

Fig. 2.23. La llei de moment flector té un grau més que la llei d'esforç tallant

4. Sempre que sobre una secció d'un element hi ha un moment extern puntual aplicat, apareix una discontinuïtat en el diagrama de moments flectors $\mathrm{M}_{\mathrm{Z}}(\mathrm{x})$, igual (en valor absolut) al mòdul del moment.

5. En un extrem lliure o articulat d'un element, en absència de moments externs puntuals aplicats, el valor del moment flector en la secció és nul.

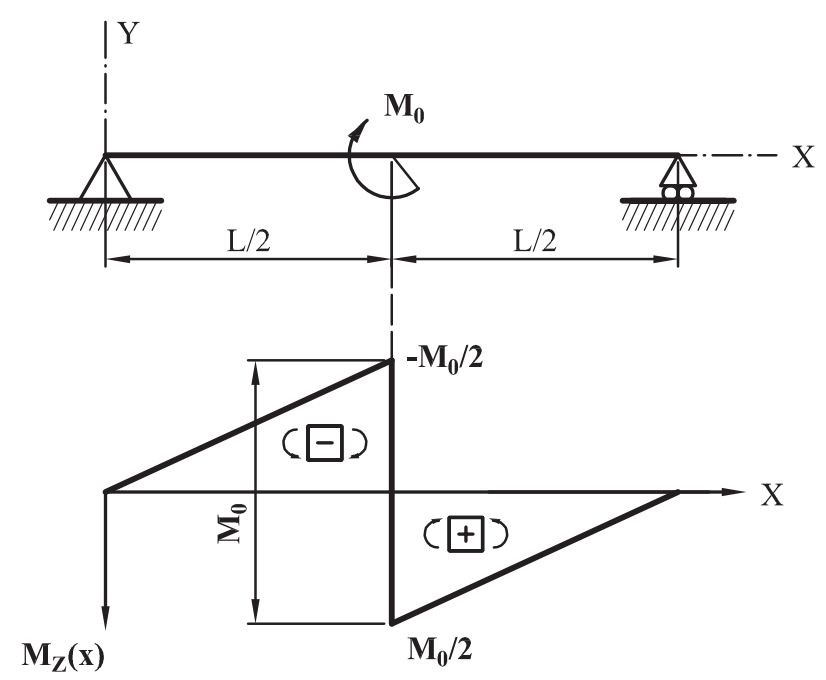

Fig. 2.24. Propietats dels diagrames de moment flector 


\section{Exemple 2.4}

Calculeu i representeu les lleis d'esforços en la biga de la figura.

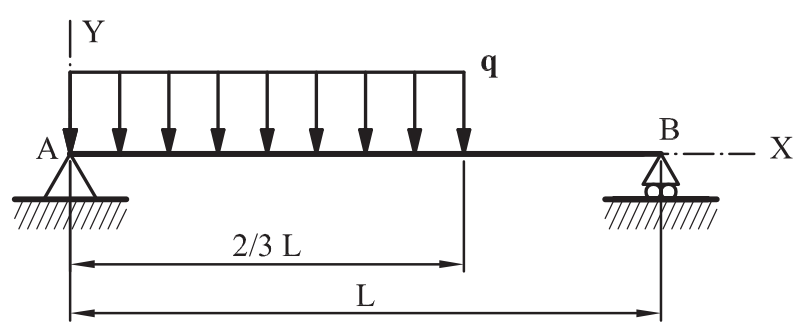

Fig. 2.25. Exemple 2.4. Enunciat

En primer lloc calcularem les reaccions. La resultant de la càrrega distribuïda és $Q=$ $=\frac{2}{3} q \cdot L \mathrm{i}$ i està situada a una distància $x_{Q}=\frac{1}{2} \frac{2}{3} L=\frac{L}{3}$.

$\sum \overrightarrow{F_{Y}}=0 \rightarrow R_{A}+R_{B}=Q$

$\sum \overrightarrow{M_{A}}=0 \rightarrow Q \cdot x_{Q}=R_{B} \cdot L$

De la segona equació obtenim $R_{B}=\frac{2}{9} q \cdot L \mathrm{i}$ i de la primera equació $R_{A}=\frac{4}{9} q \cdot L$.

Com que tenim dos trams de càrregues, hem de fer-hi dos talls.

Primer tall $(0 \leq \mathrm{x} \leq 2 / 3 \mathrm{~L})$

La resultant de la força és ara $Q(x)=q \cdot x$ situada a una distància $x_{Q}=\frac{x}{2}$ del tall.

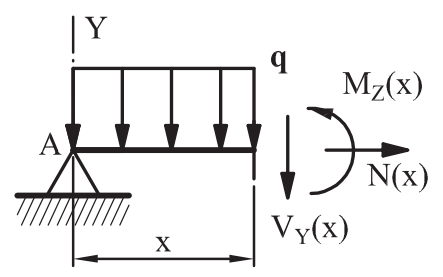

Fig. 2.26. Exemple 2.4. Primer tall

$\sum \overrightarrow{F_{X}}=0 \rightarrow N(x)=0$

$\sum F_{Y}=0 \rightarrow R_{A}-q \cdot x-V_{Y}(x)=0 \rightarrow V_{Y}(x)=R_{A}-q \cdot x$

$\sum M=0 \rightarrow R_{A} \cdot x-q \frac{x^{2}}{2}-M_{Z}(x)=0 \rightarrow M_{Z}(x)=R_{A} \cdot x-q \frac{x^{2}}{2}$

Segon tall $(2 / 3 \mathrm{~L} \leq \mathrm{x} \leq \mathrm{L})$

Com que la força distribuïda ja s'ha acabat, la substituïm per la seua resultant aplicada en el centre de gravetat (punt mitjà, en aquest cas). 


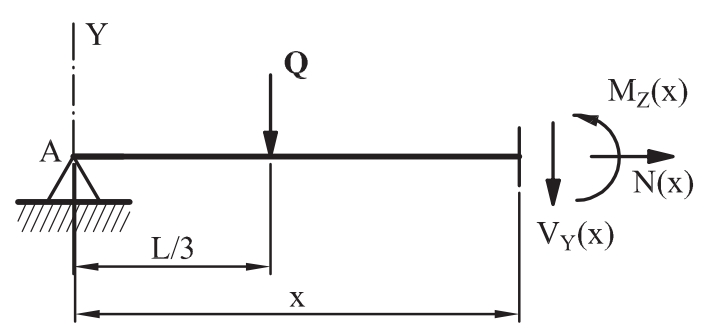

Fig. 2.27. Exemple 2.4. Segon tall

$\sum \overrightarrow{F_{X}}=0 \rightarrow N(x)=0$

$\sum \overrightarrow{F_{Y}}=0 \rightarrow R_{A}-Q \cdot-V_{Y}(x)=0 \rightarrow V_{Y}(x)=R_{A}-Q$

$\sum M=0 \rightarrow R_{A} \cdot x-Q\left(x-\frac{L}{3}\right)-M_{Z}(x)=0 \rightarrow M_{Z}(x)=R_{A} \cdot x-Q\left(x-\frac{L}{3}\right)$

Per a fer la representació gràfica d'aquestes funcions (obviarem la d'axials) hem de fer les següents consideracions:

- En A, l'esforç tallant dóna un salt equivalent a la reacció $\mathrm{R}_{\mathrm{A}}$. A continuació, la llei és lineal i baixa fins a un valor igual a $R_{B}$ en $x=2 / 3 \mathrm{~L}$. En l'últim tram, l'esforç roman constant, fins que en $B$ tenim el salt de valor $R_{B}$ que tanca el diagrama.

- Els moments flectors comencen en A amb un valor nul (articulació d'extrem sense moment puntual aplicat). La llei al primer tram és parabòlica i el màxim del moment arriba quan el tallant (derivada del moment) s'anul·la.

Per a trobar el màxim, anul·lem l'esforç tallant $V_{Y}(x)=R_{A}-q \cdot x=0$ i aïllem: $x=\frac{4}{9} L$

En aquest punt (que està en el primer tram) el moment és:

$M_{Z m a ̀ x}\left(x=\frac{4}{9} L\right)=\frac{4}{9} q L \frac{4}{9} L-\frac{q}{2}\left(\frac{4}{9} L\right)^{2}=\frac{8}{81} q L^{2}$

La distribució parabòlica continua fins $\mathrm{a} x=2 / 3 \mathrm{~L}$, on el moment té un valor $M_{Z}\left(x=\frac{2}{3} L\right)=\frac{2}{27} q \cdot L^{2}$

A partir d'aquest punt, el diagrama és lineal, i acaba en zero al punt B. La representació dels esforços és, doncs: 


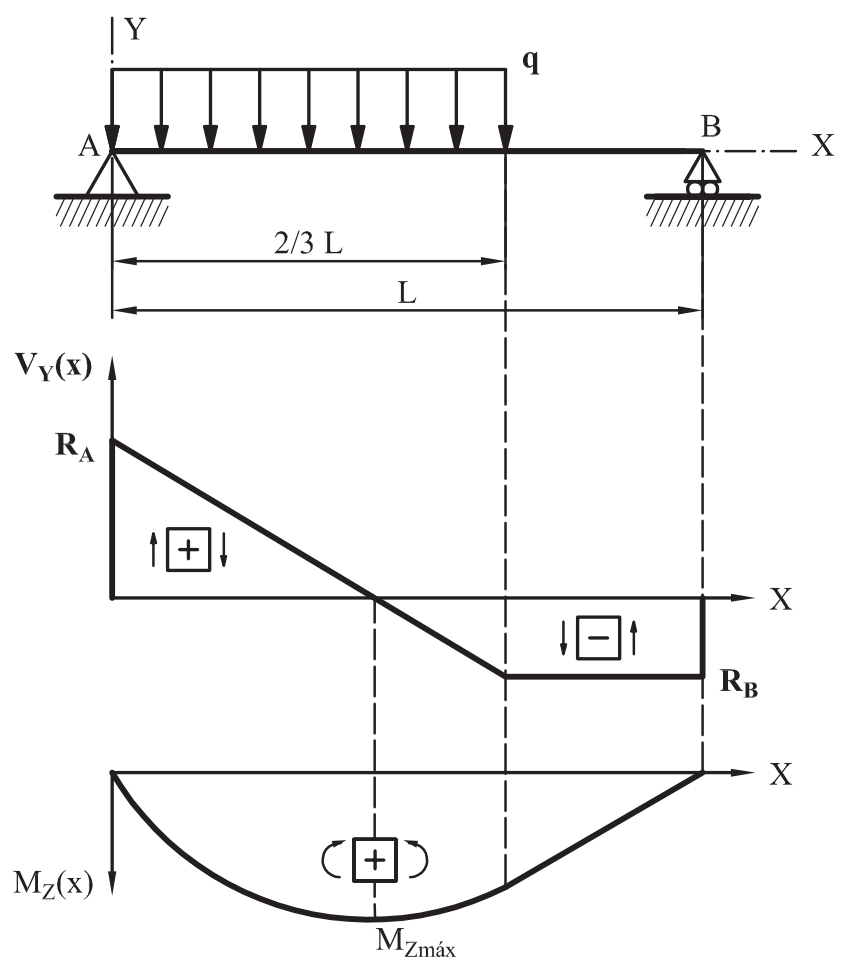

Fig. 2.28. Exemple 2.4. Diagrames

\section{Exemple 2.5}

En el sistema de la figura, determineu les lleis i els diagrames de tallants i flectors, acotant els valors més significatius, i estimeu la deformada.

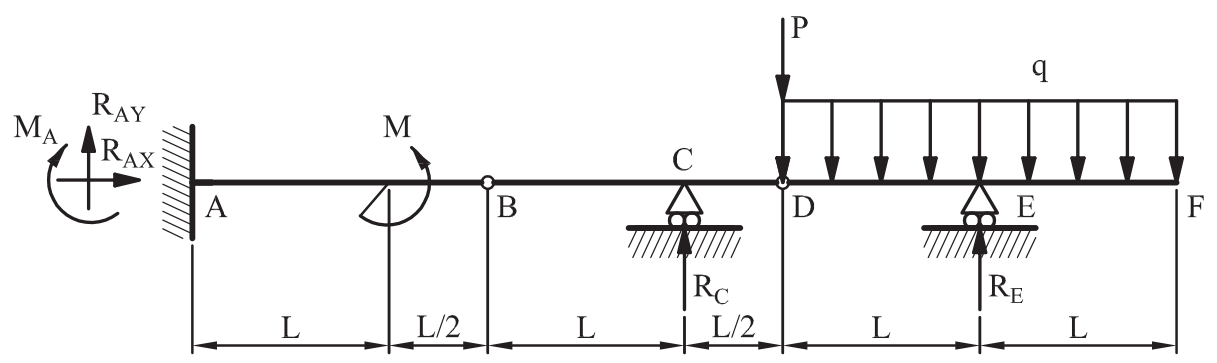

Fig. 2.29. Exemple 2.5

Dades: $\mathrm{L}=4 \mathrm{~m} ; \mathrm{P}=100 \mathrm{kN} ; \mathrm{q}=20 \mathrm{kN} / \mathrm{m} ; \mathrm{M}=400 \mathrm{kN} \cdot \mathrm{m}$.

Aquest és el mateix problema que a l'exemple 1.8, però amb valors numèrics. Com que les reaccions ja les vam calcular al tema 1, no les tornarem a calcular, només donarem els valors: 
$R_{A X}=0$

$R_{A Y}=-\frac{P}{2}=-50 k N$

$M_{A}=M+\frac{3}{4} P L=700 \mathrm{kN} \cdot \mathrm{m}$

$R_{C}=\frac{3}{2} P=150 \mathrm{kN}$

$R_{E}=q \cdot 2 L=160 \mathrm{kN}$

En aquest tipus de situacions, hem de dividir les lleis en trams, realitzant tants talls en la barra com trams amb esforços diferents tinguem.

Comencem per l'esquerra, tallant la barra entre A i el punt d'aplicació de M $(0 \leq \mathrm{x} \leq 4 \mathrm{~m})$.

En el punt del tall dibuixarem els esforços amb el seu sentit positiu, segons el criteri de signes.

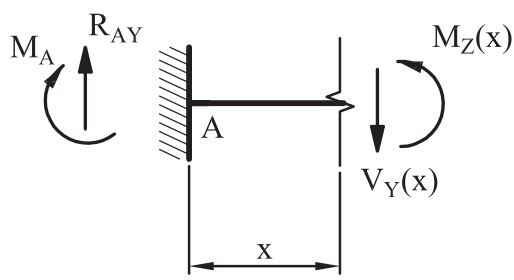

Fig. 2.30. Exemple 2.5. Primer tall

Plantegem l'equilibri d'aquest subsistema:

$V_{Y}(x)=R_{A Y}=-50 \mathrm{kN}$

$M_{Z}(x)=M_{A}+R_{A Y} \cdot x=700-50 x \mathrm{kN} \cdot \mathrm{m}$

Segon tall $(4 \mathrm{~m} \leq \mathrm{x} \leq 10 \mathrm{~m})$

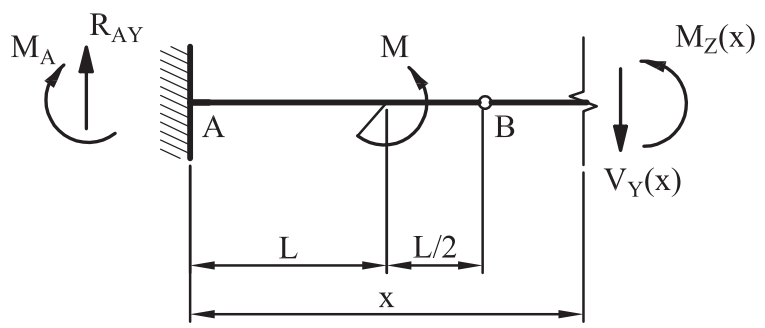

Fig. 2.31. Exemple 2.5. Segon tall

Malgrat estar la ròtula al tram, aquesta no té cap efecte sobre les lleis o els diagrames, per això el tram s'allarga fins a l'aparició de la nova càrrega (reacció en C). Plantegem l'equilibri d'aquest subsistema: 
$V_{Y}(x)=R_{A Y}=-50 \mathrm{kN}$

$M_{Z}(x)=M_{A}+R_{A Y} \cdot x-M=300-50 x \mathrm{kN} \cdot \mathrm{m}$

Tercer tall $(10 \mathrm{~m} \leq \mathrm{x} \leq 12 \mathrm{~m})$

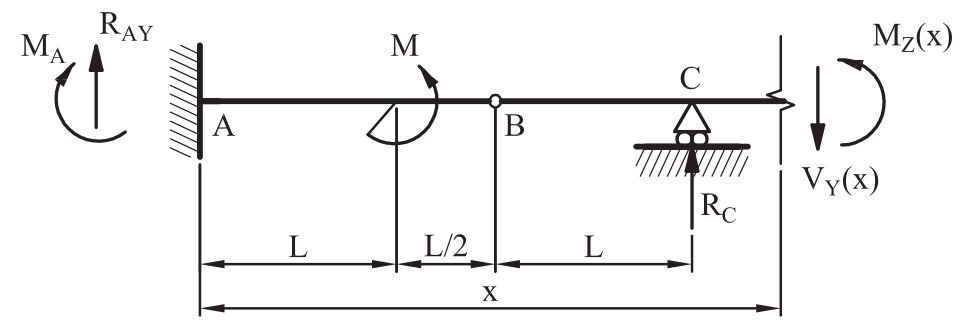

Fig. 2.32. Exemple 2.5. Tercer tall

Plantegem l'equilibri d'aquest subsistema:

$V_{Y}(x)=R_{A Y}+R_{C}=100 \mathrm{kN}$

$M_{Z}(x)=M_{A}+R_{A Y} \cdot x-M+R_{C}(x-10)=-1200+100 x \mathrm{kN} \cdot \mathrm{m}$

Quart tall $(12 \mathrm{~m} \leq \mathrm{x} \leq 16 \mathrm{~m})$

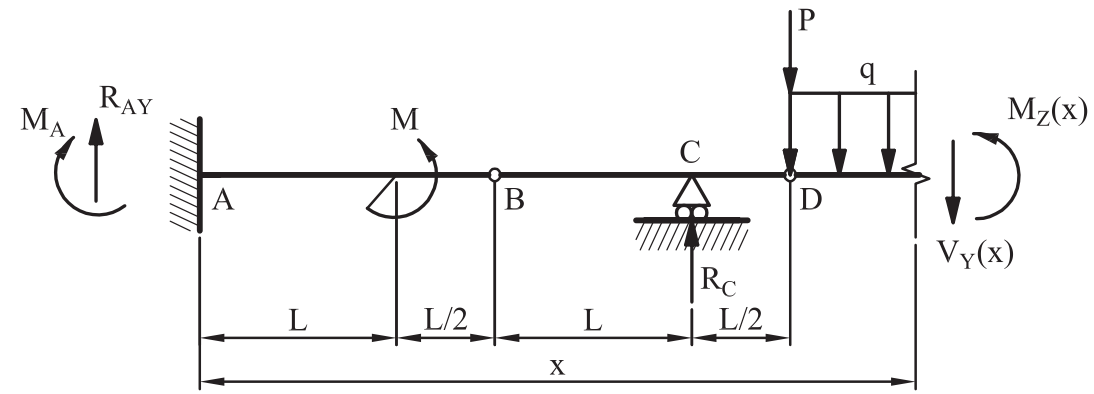

Fig. 2.33. Exemple 2.5. Quart tall

Plantegem l'equilibri d'aquest subsistema:

$$
\begin{aligned}
& V_{Y}(x)=R_{A Y}+R_{C}-P-q(x-12)=240-20 x k N \\
& M_{Z}(x)=M_{A}+R_{A Y} \cdot x-M+R_{C}(x-10)-P(x-12)-\frac{q}{2}(x-12)^{2} \\
& M_{Z}(x)=-10 x^{2}+240 x-1440 \mathrm{kN} \cdot \mathrm{m}
\end{aligned}
$$

Últim tall $(16 \mathrm{~m} \leq \mathrm{x} \leq 20 \mathrm{~m})$

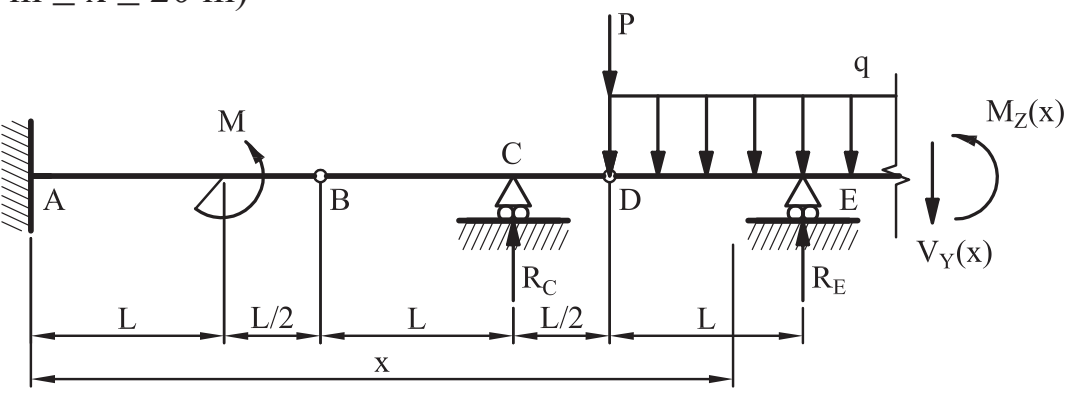

Fig. 2.34. Exemple 2.5. Últim tall 
Plantegem l'equilibri d'aquest subsistema:

$$
\begin{aligned}
& V_{Y}(x)=R_{A Y}+R_{C}-P-q(x-12)+R_{E}=400-20 x k N \\
& M_{Z}(x)=M_{A}+R_{A Y} \cdot x-M+R_{C}(x-10)-P(x-12)-\frac{q}{2}(x-12)^{2}+R_{E}(x-16) \\
& M_{Z}(x)=-10 x^{2}+400 x-4000 \mathrm{kN} \cdot \mathrm{m}
\end{aligned}
$$

Ja podem dibuixar els diagrames, donant valors als punts extrems de cadascun dels trams:

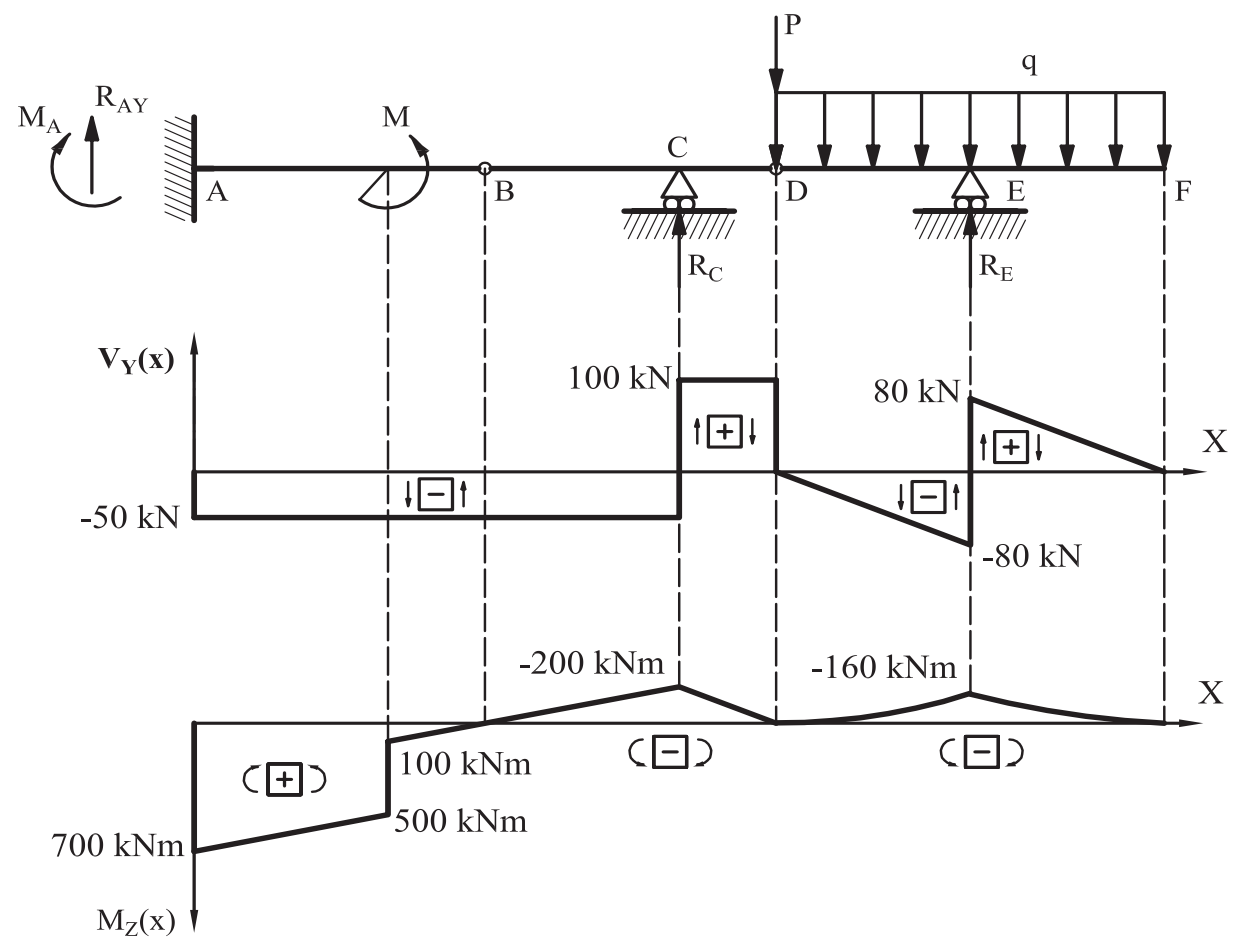

Fig. 2.35. Exemple 2.5. Diagrames d'esforços

Notem com al pas per les ròtules, el moment és zero en ambdós casos. Recordem que les ròtules són incapaces de transmetre moments. És interessant adonar-se del salt que es produeix al diagrama de flectors, al punt d'aplicació del moment puntual $\mathrm{M}=400 \mathrm{kN} \cdot \mathrm{m}$.

\section{Estimació de la deformada}

Resulta molt interessant, en els problemes de resistència de materials i els d'estructures, imaginar com es deformen les bigues. No es tracta encara de resoldre l'equació de l'elàstica i representar-la (cosa que farem en el tema de flexió), més aviat es tracta de desenvolupar la intuïció.

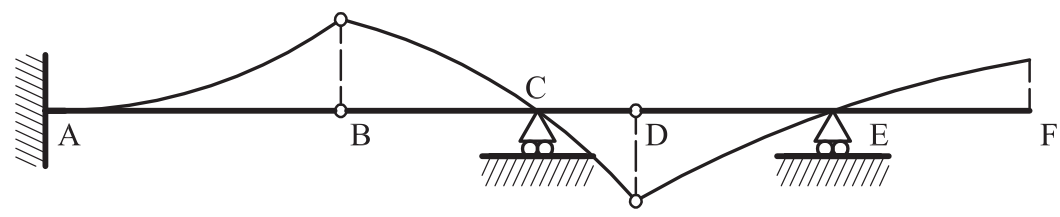

Fig. 2.36. Exemple 2.5. Estimació de la deformada 
Notem com a l'eixida de A, el pendent és horitzontal, a causa de l'encast, i es va flexionant de manera suau fins al punt $\mathrm{B}$. A les ròtules no tenim una continuïtat en el pendent del gràfic, com sí que succeeix als recolzaments D i E, per la qual cosa el comportament és diferent, com s'aprecia a la figura.

\section{Exemple 2.6}

Calculeu i dibuixeu la llei d'esforços tallants en el cas que la càrrega distribuïda siga variable i de valor màxim $\mathrm{q}_{0}$.

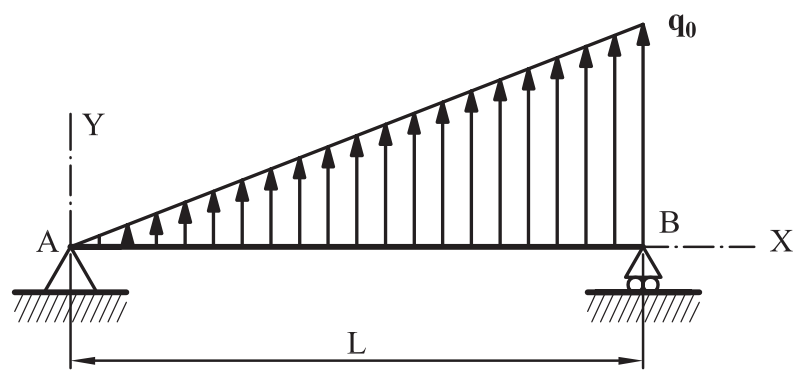

Fig. 2.37. Exemple 2.6. Enunciat

Dades: $\mathrm{L}=3 \mathrm{~m} ; \mathrm{q}_{0}=12 \mathrm{kN} / \mathrm{m}$.

Necessitem buscar la funció de la càrrega. Per trobar-la d'una manera senzilla, podem fer una operació de semblança de triangles, com mostra la figura:

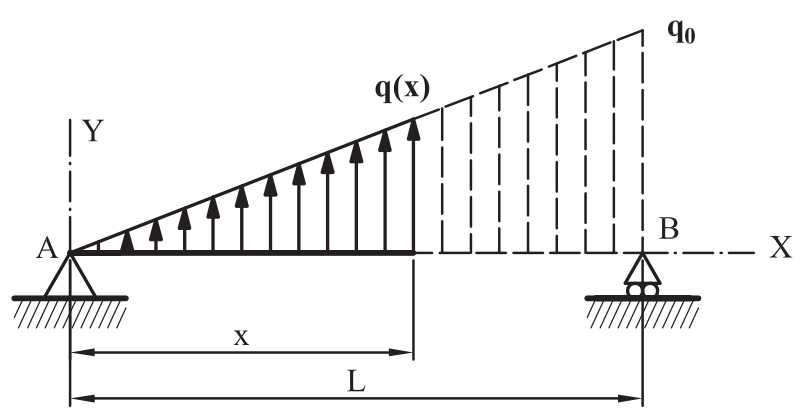

Fig. 2.38. Exemple 2.6. Càlcul de la funció de càrrega

$\frac{q_{0}}{L}=\frac{q(x)}{x} \rightarrow q(x)=\frac{q_{0}}{L} x$

La resultant de la força distribuïda es pot calcular de dues maneres. La primera, més formal:

$Q=\int_{0}^{L} q(x) d x=\int_{0}^{L} \frac{q_{0}}{L} x d x=\left[\frac{q_{0}}{L} \frac{x^{2}}{2}\right]_{0}^{L}=\frac{1}{2} q_{0} L$ 
La segona és adonar-nos que la resultant és l'equivalent a l'àrea d'un triangle de base $\mathrm{L}$ i altura $\mathrm{q}_{0}$. Això serà sempre així, de manera que si l'àrea que forma la càrrega és coneguda, no tornarem a fer la integral.

De la mateixa manera, podríem buscar la posició de la resultant mitjançant el càlcul integral:

$$
x_{G}=\frac{1}{Q} \int_{0}^{L} x \cdot q(x) d x=\frac{1}{Q} \int_{0}^{L} \frac{q_{0} x^{2}}{L} d x=\frac{1}{Q}\left[\frac{q_{0}}{L} \frac{x^{3}}{3}\right]_{0}^{L}=\frac{2}{q_{0} L} \cdot \frac{q_{0} L^{3}}{3 L}=\frac{2}{3} L
$$

També ací ens adonem que la posició de la resultant és el centre de gravetat del triangle, i de la mateixa manera, a partir d'ara recorrerem al càlcul simplificat sempre que siga possible.

Plantegem l'equilibri per a calcular les reaccions (suposem que les reaccions verticals apunten cap a baix):

$\sum \overrightarrow{F_{X}}=0 \rightarrow R_{A X}=0$

$\sum \vec{F}_{Y}=0 \rightarrow R_{A Y}+R_{B}=Q$

$\sum \overrightarrow{M_{A}}=0 \rightarrow Q \cdot x_{Q}=R_{B} \cdot L$

De la segona equació obtenim $R_{B}=\frac{1}{3} q_{0} \cdot L$ i de la primera equació $R_{A Y}=\frac{1}{6} q_{0} \cdot L$.

Com veiem, hem encertat el sentit de les reaccions.

Com que la càrrega té una distribució contínua en tota la biga, només és necessari fer-hi un tall i les lleis que obtindrem seran vàlides per tota la barra.

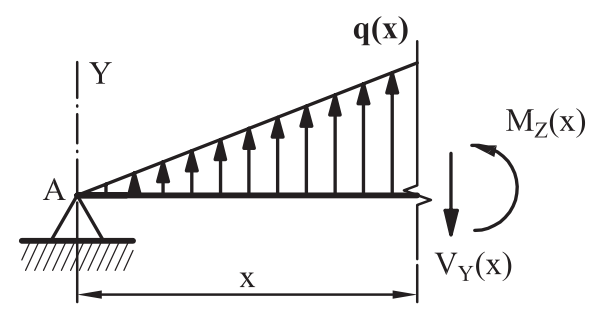

Fig. 2.39. Exemple 2.6. Primer i únic tall

Hem de plantejar l'equilibri d'aquest subsistema (obviarem el càlcul d'axials, ja que és evident que és zero). La resultant de la força distribuïda depén de x:

$Q_{x}=\frac{1}{2} x q(x)=\frac{1}{2} x \frac{q_{0} x}{L}=\frac{q_{0} x^{2}}{2 L}$

La resultant estarà situada en: $x_{Q x}=\frac{2}{3} x$. 
$\sum \overrightarrow{F_{Y}}=0 \rightarrow V(x)+R_{A Y}-Q_{x}=0 \rightarrow V(x)=\frac{q_{0} x^{2}}{2 L}-\frac{q_{0} L}{6}$

$\sum \overrightarrow{M_{A}}=0 \rightarrow M(x)+R_{A Y} x-Q_{x}\left(x-\frac{2}{3} x\right)=0 \rightarrow M(x)=\frac{q_{0} x^{3}}{6 L}-\frac{q_{0} L x}{6}$

La distribució d'esforços tallants és una paràbola de grau 2, i per tant, la distribució de moments és una paràbola de grau 3. Si igualem el tallant a zero, obtindrem el punt on el moment és màxim. Aquest punt és $x_{\text {màx }}=1,732 \mathrm{~m}, \mathrm{i}$ el moment val $\mathrm{M}_{\mathrm{Z}}\left(x_{\text {max }}\right)=-6,93 \mathrm{kN} \cdot \mathrm{m}$.

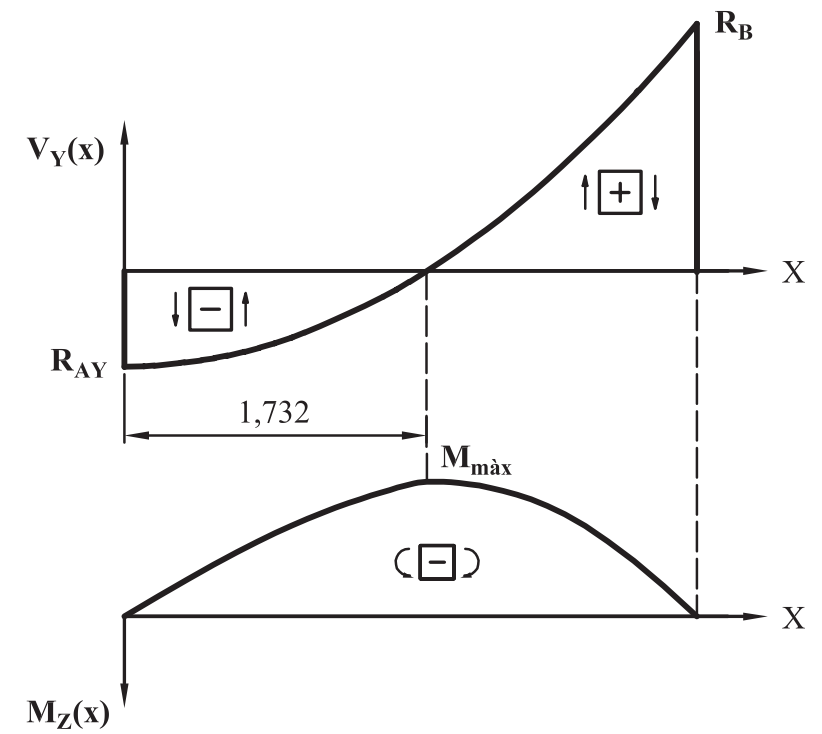

Fig. 2.40. Exemple 2.6. Diagrames d'esforços

Si tenim una càrrega amb forma trapezoïdal, pot resultar pesat treure la funció de la distribució de càrregues. En tal cas, podem fer una descomposició en un rectangle $\mathrm{i}$ un triangle i operar com als exercicis anteriors.
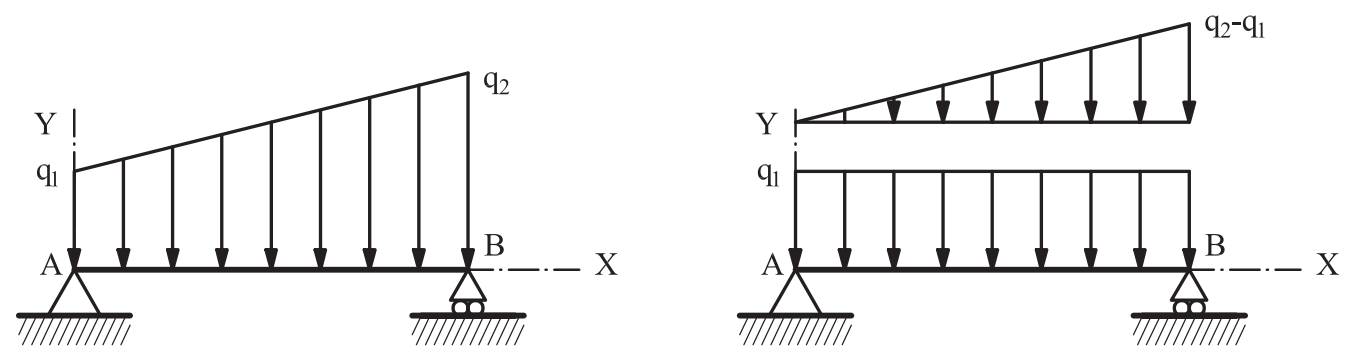

Fig. 2.41. Una càrrega trapezoïdal pot descompondre's en una de triangular i una de rectangular 


\section{Exemple 2.7}

Representeu els diagrames d'esforços en la biga voladissa següent, sotmesa a una càrrega distribuïda amb una inclinació de $60^{\circ}$ respecte a l'horitzontal.

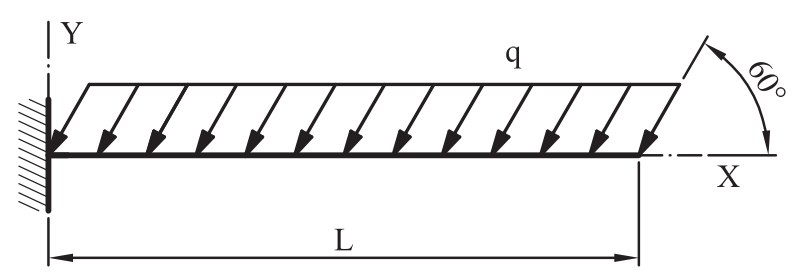

Fig. 2.42. Exemple 2.7

Dades: $\mathrm{q}=200 \mathrm{kN} / \mathrm{m} ; \mathrm{L}=3 \mathrm{~m}$.

Descompondrem la càrrega distribuïda en les components paral·lela i perpendicular a l'eix X.

$$
q_{X}=q \cdot \cos (60)=100 \mathrm{kN} / \mathrm{m}
$$

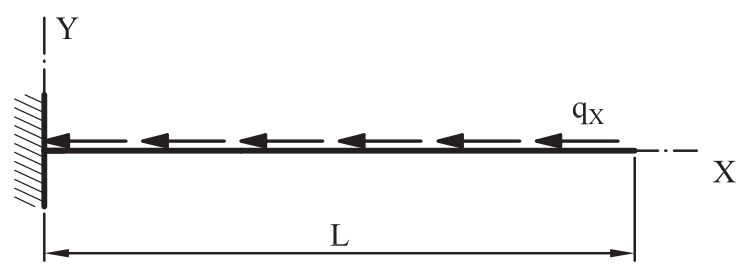

Fig. 2.43. Exemple 2.7. Descomposició horitzontal de la càrrega

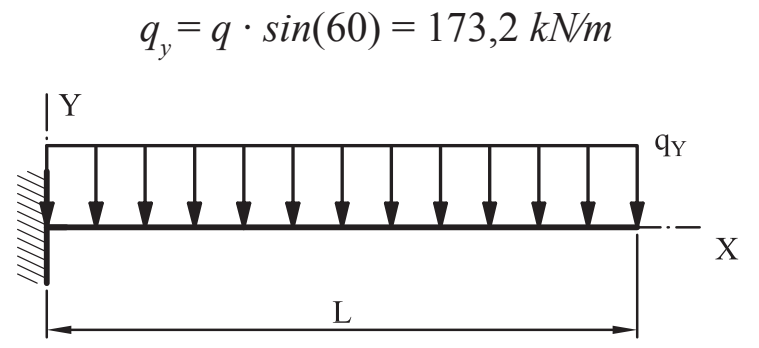

Fig. 2.44. Exemple 2.7. Descomposició vertical de la càrrega

La component $q_{X}$ produirà només esforços axials. La component $q_{Y}$ produirà tallants i moments flectors.

Calculem les reaccions. La resultant de la component $q_{X}$ serà $Q_{X}=q_{X} \cdot L$. No ens importa on estiga situada perquè no genera moment flector. La resultant de $q_{Y}$ serà $Q_{Y}=q_{Y} \cdot L$ i està situada al punt mitjà de la biga. 
$\sum F_{X}=0 \rightarrow R_{A X}=q_{X} \cdot L=300 \mathrm{kN}$

$\sum \overrightarrow{F_{Y}}=0 \rightarrow R_{A Y}=q_{Y} \cdot L=519,62 \mathrm{kN}$

$\sum M_{A}=0 \rightarrow M_{A}=q_{Y} \frac{L^{2}}{2}=-779,42 \mathrm{kN} \cdot \mathrm{m}$

Calculem les lleis d'esforços a la barra. Només cal fer-hi un tall:

$$
\begin{aligned}
& \sum \overrightarrow{F_{X}}=0 \rightarrow N(x)=q_{X} x-R_{A X}=100 x-300 \mathrm{kN} \\
& \sum \overrightarrow{F_{Y}}=0 \rightarrow V_{Y}(x)=R_{A Y}-q_{Y} x=519,62-173,21 x \mathrm{kN} \\
& \sum \vec{M}_{A}=0 \rightarrow M_{Z}(x)=-q_{Y} \frac{x^{2}}{2}+R_{A Y} x-M_{A}=-86,60 x^{2}+519,62 x-779,42 \mathrm{kN} \cdot \mathrm{m}
\end{aligned}
$$
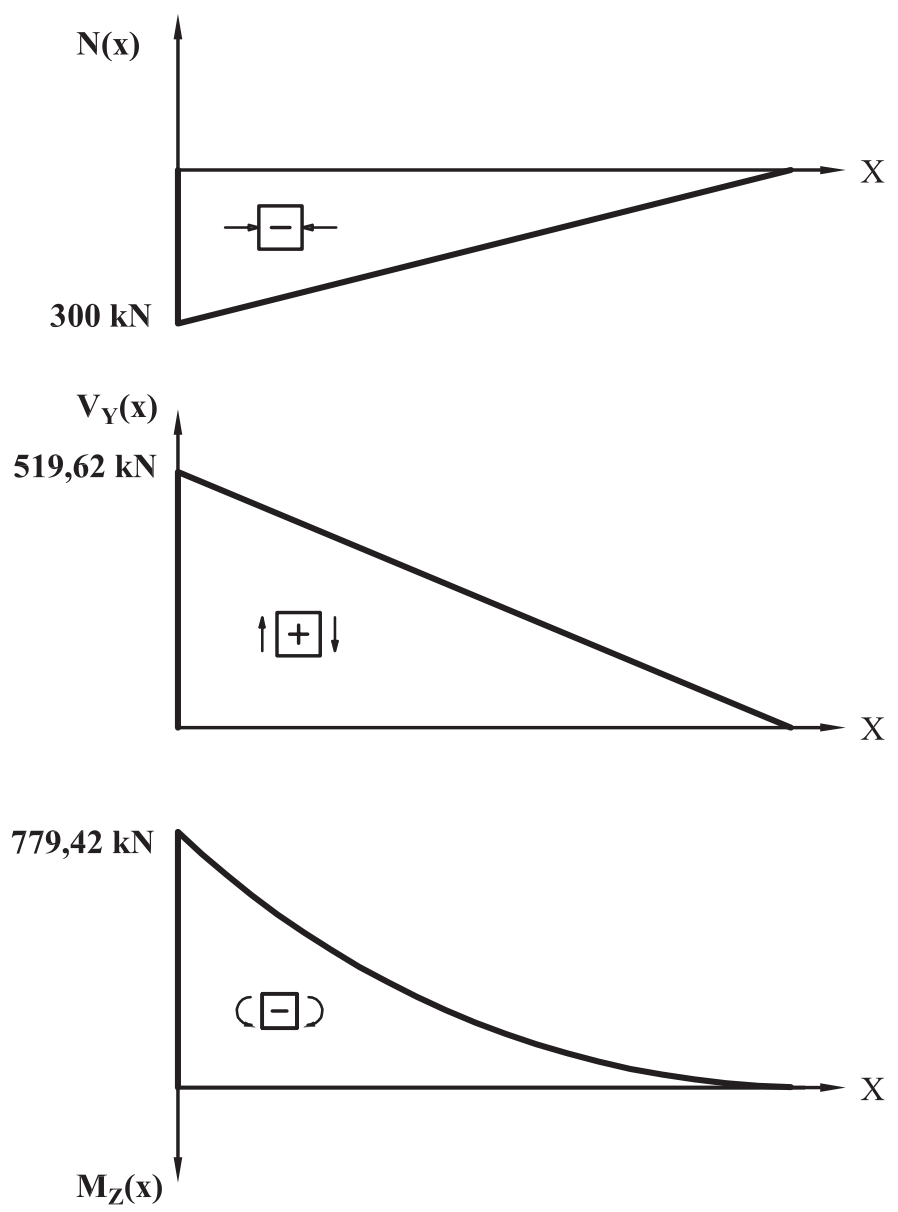

Fig. 2.45. Exemple 2.7. Diagrames d'esforços 


\section{Exemple 2.8}

Calculeu les lleis d'esforços i representeu els diagrames corresponents a la biga voladissa de la figura, sotmesa a una càrrega axial distribuïda, tal com es mostra a la figura 2.46 .

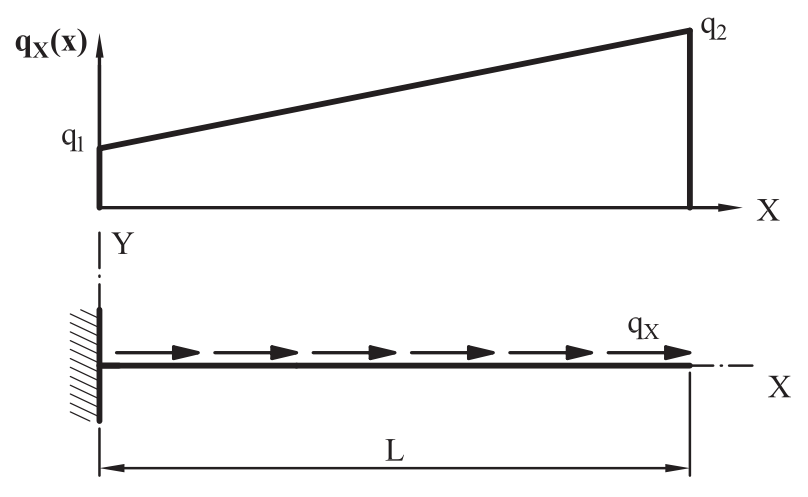

Fig. 2.46. Exemple 2.8. Enunciat

Dades: $\mathrm{L}=6 \mathrm{~m} ; \mathrm{q}_{1}=3 \mathrm{kN} / \mathrm{m} ; \mathrm{q}_{2}=9 \mathrm{kN} / \mathrm{m}$.

En primer lloc calcularem la funció de la càrrega axial.

Com que és lineal, la funció ha de tindre la forma $(x)=a+b \cdot x$.

Donarem els dos valors coneguts per a obtindre les constants:

$x=0 \rightarrow q(x)=3 \mathrm{kN} / \mathrm{m} \rightarrow a=3 \mathrm{kN} / \mathrm{m}$

$x=6 m \rightarrow q(x)=9 \mathrm{kN} / \mathrm{m} \rightarrow b=1 \mathrm{kN} / \mathrm{m}^{2}$

Per tant: $q(x)=3+x$.

Com que no hi ha cap altra força, la reacció serà igual a la resultant de la càrrega distribuïda:

$R_{A X}=\int_{0}^{L} q(x) d x=\int_{0}^{L}(3+x) d x=\left[3 x+\frac{x^{2}}{2}\right]_{0}^{L}=36 k N$

Farem un únic tall a una distància genèrica $\mathrm{x}$. La llei d'esforços axials és:

$$
N(x)=R_{A X}-\int_{0}^{x} q(x) d x=36-3 x-\frac{x^{2}}{2}
$$

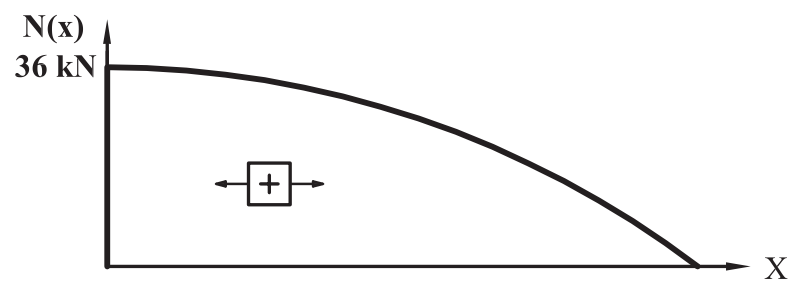

Fig. 2.47. Exemple 2.8. Diagrama d'axials 


\section{Exemple 2.9}

Representeu els diagrames acotats d'esforços de l'estructura de la figura (cotes en metres).

Dades: $\mathrm{q}=200 \mathrm{kN} / \mathrm{m} ; \mathrm{P}=300 \mathrm{kN}$.

Aquest és un exemple de sistema de més d'un element. El nuc C és rígid, per la qual cosa no permet el gir i sí que permet la transmissió de tot el moment flector que li arriba, d'una biga a l'altra.

Les reaccions són de càlcul immediat, mitjançant les equacions d'equilibri, pel fet de ser una estructura isostàtica.

En aquest tipus d'estructures és important diferenciar entre els eixos globals de tot el sistema (els que estan representats a la figura 2.48) i els eixos locals de cadascuna de les barres. Definirem uns eixos globals per a tota l'estructura i ens hi referirem per plantejar l'equilibri global. Definirem uns eixos locals, en els quals l'eix X portarà la direcció de la biga, per plantejar l'equilibri de les parts de l'estructura, $\mathrm{i}$ d'aquesta manera calcular les lleis d'esforços en cadascuna de les barres.

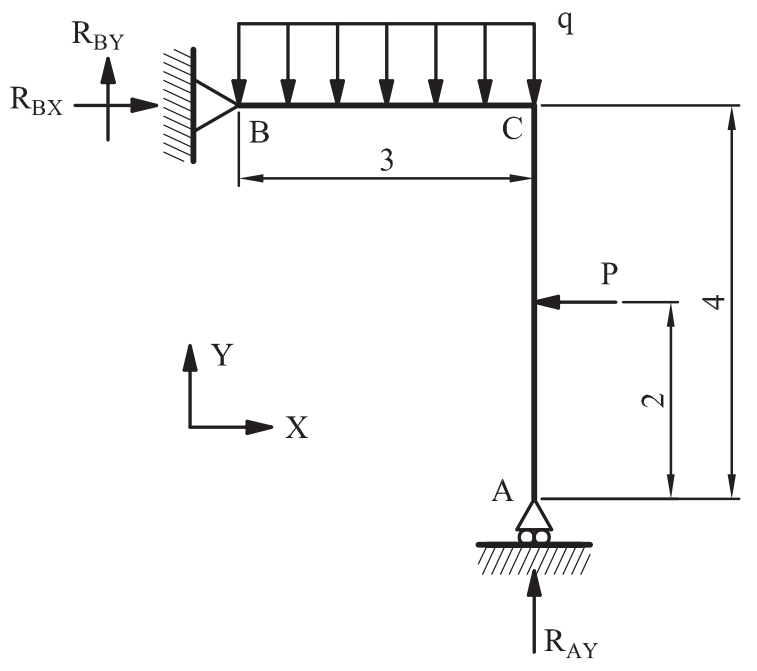

Fig. 2.48. Exemple 2.9. Enunciat

$$
\begin{array}{ll}
\sum \overrightarrow{F_{X}}=0 \rightarrow R_{B X}-P=0(1) & d e_{(1)} \rightarrow R_{B X}=P=300 \mathrm{kN} \\
\sum \overrightarrow{F_{Y}}=0 \rightarrow R_{B Y}+R_{A Y}=3 q_{(2)} & d e_{(3)} \rightarrow R_{A Y}=500 \mathrm{kN} \\
\sum \overrightarrow{M_{B}}=0 \rightarrow q \frac{3^{2}}{2}-2 P+3 R_{A Y}=0{ }_{(3)} & d e_{(2)} \rightarrow R_{B Y}=100 \mathrm{kN}
\end{array}
$$

Lleis d'esforços. Per a la biga B-C, només hi ha un tram. Definim els eixos locals $(\mathrm{x}-\mathrm{y})$ i escrivim les equacions d'equilibri. 


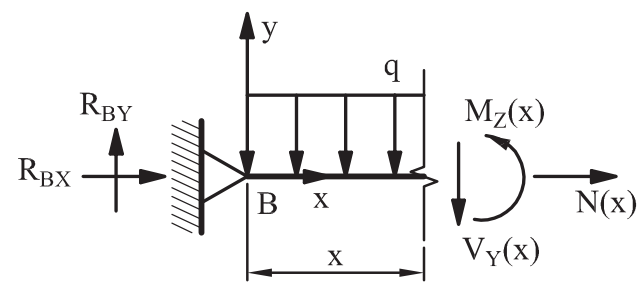

Fig. 2.49. Exemple 2.9. Tall a la biga B-C

$\sum F_{x}=0 \rightarrow N(x)+R_{B X}=0 \rightarrow N(x)=-300 k N$

$\sum F_{y}=0 \rightarrow R_{B Y}-q \cdot x-V_{y}(x)=0 \rightarrow V_{y}(x)=100-200 x k N$

$\sum M=0 \rightarrow R_{B Y} x-q \frac{x^{2}}{2}-M_{z}(x)=0 \rightarrow M_{z}(x)=100 x-200 \frac{x^{2}}{2}$

Com podem veure, la distribució d'axials és constant i de compressió, la de tallants és lineal i la de flectors és una paràbola quadràtica.

Obtindrem valors significatius dels diagrames de tallants i flectors.

$$
\begin{aligned}
& x=0 \rightarrow V_{y}(x)=100 \mathrm{kN} \\
& x=0 \rightarrow M_{Z}(x)=0 \\
& x=3 m \rightarrow V_{y}(x)=-500 \mathrm{kN} \\
& x=3 m \rightarrow M_{Z}(x)=-600 \mathrm{kN} \cdot \mathrm{m}
\end{aligned}
$$

El diagrama de tallants s'anul-la en un punt de la barra:

$\mathrm{V}_{y}(x)=0=100-200 x \rightarrow x=0,5 m$

En aquest punt existirà un màxim relatiu de la funció de moments:

$x=0,5 \mathrm{~m} \rightarrow M_{Z}(x)=75 \mathrm{kN} \cdot \mathrm{m}$

Com ja hem dit, és un màxim relatiu, i en aquest cas no ens dóna el màxim moment flector en valor absolut, però si el màxim moment positiu.

Per a la barra A-C, també definirem un sistema d'eixos locals. Hem de fer dos talls, un abans de la càrrega $\mathrm{P} i$ un després. 
Primer tall $\left(0 \leq x^{\prime} \leq 2 \mathrm{~m}\right)$

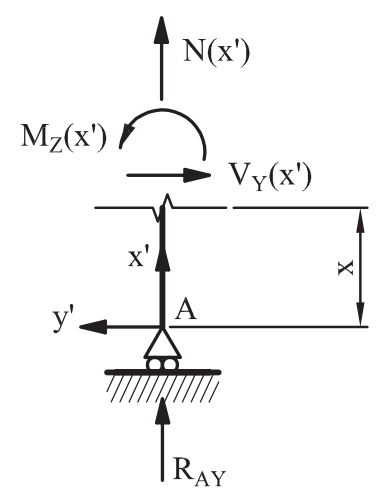

Fig. 2.50. Exemple 2.9. Primer tall a la biga A-C

$\sum \overrightarrow{x^{\prime}}=0 \rightarrow N\left(x^{\prime}\right)+R_{A Y}=0 \rightarrow N\left(x^{\prime}\right)=-500 k N$

$\sum \overrightarrow{F^{\prime}}=0 \rightarrow V_{y \prime}\left(x^{\prime}\right)=0$

$\sum M=0 \rightarrow M_{z^{\prime}}(x)=0$

Segon tall $\left(2 \mathrm{~m} \leq \mathrm{x}^{\prime} \leq 4 \mathrm{~m}\right)$

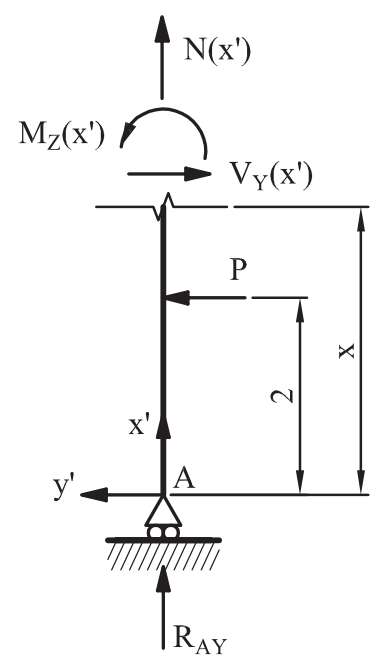

Fig. 2.51. Exemple 2.9. Segon tall a la biga A-C

$$
\begin{aligned}
& \sum \overrightarrow{F_{x \prime}}=0 \rightarrow N\left(x^{\prime}\right)+R_{A Y}=0 \rightarrow N\left(x^{\prime}\right)=-500 k N \\
& \sum \overrightarrow{F_{y \prime}}=0 \rightarrow P-V_{y^{\prime}}\left(x^{\prime}\right)=0 \rightarrow V_{y^{\prime}}\left(x^{\prime}\right)=300 k N \\
& \sum \vec{M}=0 \rightarrow P\left(x^{\prime}-2\right)+M_{z \prime}\left(x^{\prime}\right)=0 \rightarrow M_{z^{\prime}}\left(x^{\prime}\right)=-300\left(x^{\prime}-2\right)
\end{aligned}
$$

Els esforços són tots constants, excepte el moment flector al segon tram. Tenim una distribució lineal de moment, amb valors extrems:

$$
\begin{aligned}
& x^{\prime}=2 \rightarrow M_{Z \prime}=0 \\
& x^{\prime}=4 \rightarrow M_{z^{\prime}}=-600 \mathrm{kN} \cdot \mathrm{m}
\end{aligned}
$$


El resultat és coherent: quan tenim un nuc rígid (que pot transmetre moments) el moment a un costat $i$ un altre ha de ser el mateix. Vist d'una altra manera, el nuc ha d'estar en equilibri. Si observem els altres esforços, també ha de mantindre's l'equilibri, encara que no sempre és evident a primera vista. En aquest cas, podem fixar-nos que, a causa de l'angle de $90^{\circ}$ que formen ambdues barres, $1^{\prime}$ axial de la barra B-C, en passar a la barra A-C, es converteix en tallant, i el tallant de B-C es converteix en axial en A-C. En ambdós casos ens referim al valor absolut, el signe dependrà del criteri que seguim i de l'orientació dels eixos locals.

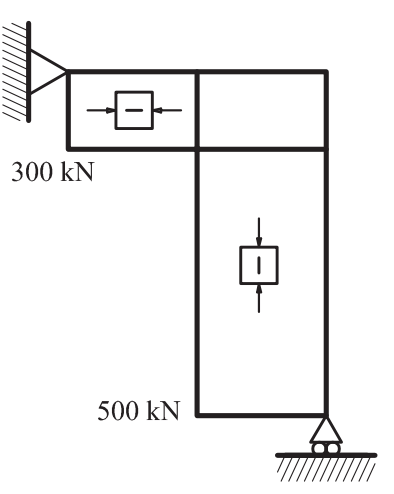

a)

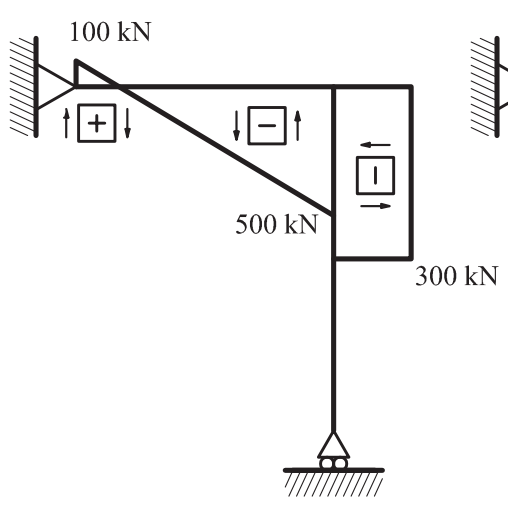

b)

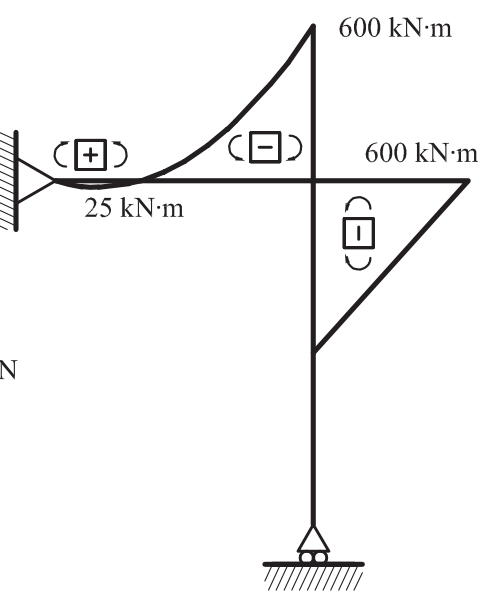

c)

Fig. 2.52. Exemple 2.9. Diagrames d'esforços: $a$ ) axials; $b$ ) tallants; $c$ ) moments flectors

Per a representar els diagrames, hem de fer un nou supòsit quant a la posició dels esforços positius. En aquests casos d'estructures formant pòrtics o semipòrtics, representarem cap l'exterior els axials i tallants positius, i els negatius cap a l'interior. Tanmateix, els moments els representarem en sentit contrari.

\section{Exemple 2.10}

Representeu els diagrames d'esforços de l'estructura porticada de la figura.

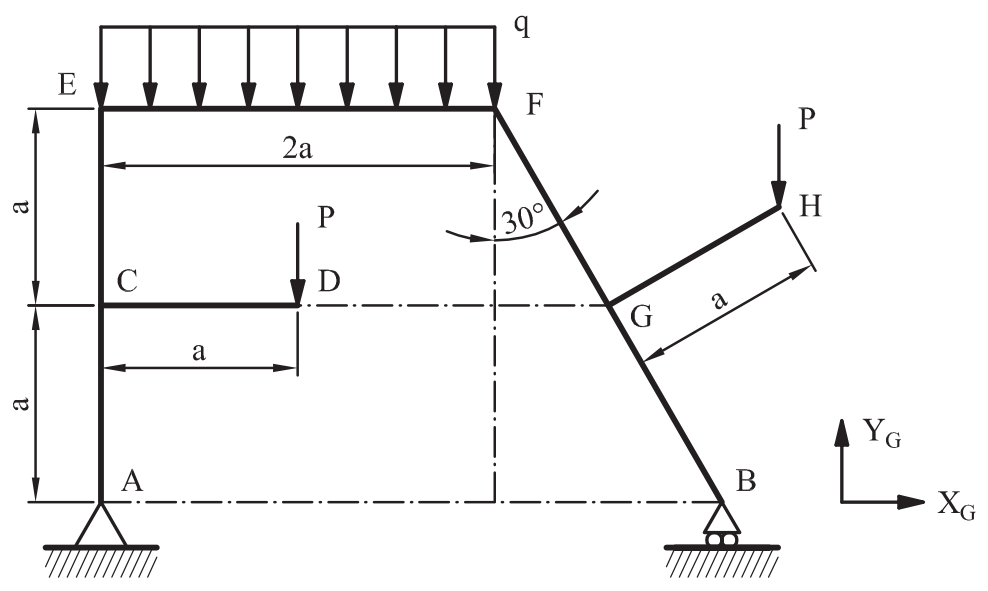

Fig. 2.53. Exemple 2.10. Enunciat 
Dades: $\mathrm{a}=1 \mathrm{~m} ; \mathrm{P}=10 \mathrm{kN} ; \mathrm{q}=2 \mathrm{kN} / \mathrm{m}$.

Equilibri global de l'estructura. Utilitzarem els eixos globals.

$\sum \overrightarrow{F_{X}}=0 \rightarrow R_{A X}=0$

$\sum \overrightarrow{F_{Y}}=0 \rightarrow R_{A Y}+R_{B Y}-2 P-q 2 a=0$

$\sum \overrightarrow{M_{A}}=0 \rightarrow R_{B Y}\left(2 a+2 \operatorname{atan}\left(30^{\circ}\right)\right)-P a-q 2 a^{2}-P\left(2 a+\operatorname{atan}\left(30^{\circ}\right)+\operatorname{acos}\left(30^{\circ}\right)\right)=0$

De l'última equació podem aïllar

$R_{B Y}=15,35 \mathrm{kN}$

De la segona equació:

$R_{A Y}=8,65 \mathrm{kN}$

Càlcul de les lleis d'esforços. Hem de definir eixos locals per a cadascuna de les barres. A la figura 2.54 hem representat la posició dels eixos locals.

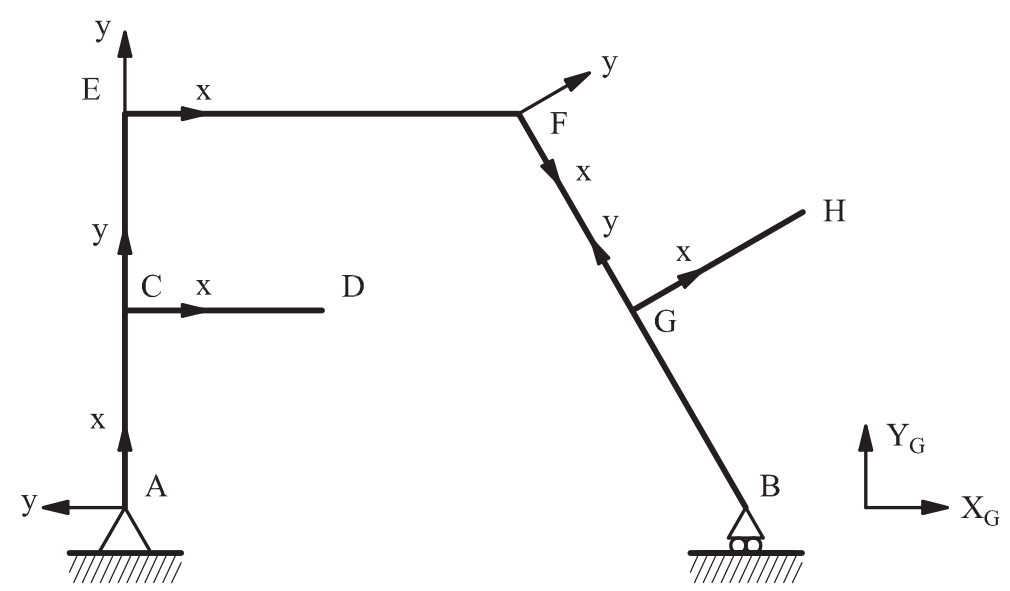

Fig. 2.54. Exemple 2.10. Eixos locals de les barres

Barra A-C

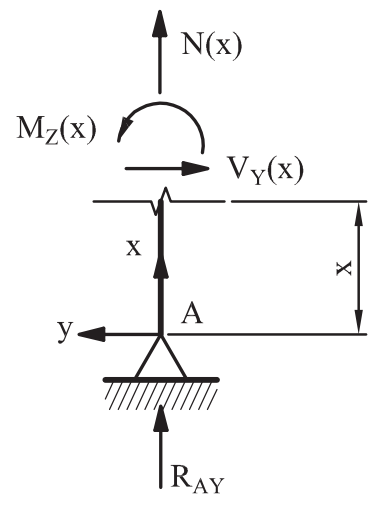

Fig. 2.55. Exemple 2.10. Barra A-C 
$\sum \overrightarrow{F_{x}}=0 \rightarrow N(x)+R_{A Y}=0 \rightarrow N(x)=-8,65 k N$

$\sum F_{y}=0 \rightarrow V_{y}(x)=0$

$\sum M=0 \rightarrow M_{z}(x)=0$

\section{Barra C-D}

En aquest cas ens convé fer el tall i eliminar la part esquerra. Hem de recordar que posarem els sentits positius dels esforços a la secció:

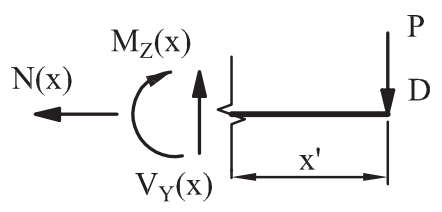

Fig. 2.56. Exemple 2.10. Barra C-D

Com que l'origen del sistema d'eixos locals està situat en C però estem tallant per l'altre costat, farem un canvi de variable: $x^{\prime}=a-x$.

$\sum F_{x}=0 \rightarrow N\left(x^{\prime}\right)=0 \rightarrow N(x)=0$

$\sum \vec{F}_{y}=0 \rightarrow V_{y}\left(x^{\prime}\right)-P=0 \rightarrow V_{y}\left(x^{\prime}\right)=P \rightarrow V_{y}(x)=P$

$\sum M=0 \rightarrow M_{z}\left(x^{\prime}\right)+P \cdot x^{\prime}=0 \rightarrow M_{z}\left(x^{\prime}\right)=-P \cdot x^{\prime} \rightarrow M_{z}(x)=-P(a-x)=10(x-1)$

Les distribucions d'axials i tallants són constants. La de moments flectors és lineal, amb valors extrems:

$x=0 \rightarrow M_{z}(x)=-10 \mathrm{kN} \cdot \mathrm{m}$

$x=1 m \rightarrow M_{z}(x)=0$

\section{Barra C-E}

En aquest cas, com que la barra C-D està unida amb un nuc rígid, l'eliminarem i afegirem al punt $\mathrm{C}$ els esforços que transmet la barra sobre el punt.

Una altra manera de veure-ho és pensant que traslladem la força $\mathrm{P}$ al punt $\mathrm{C}$, i com a conseqüència afegim un moment corresponent al trasllat. 


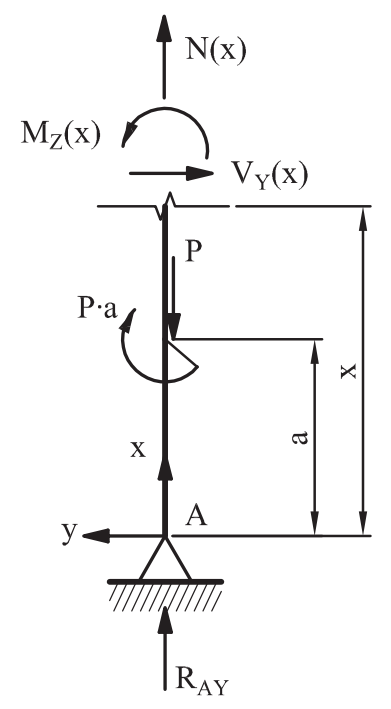

Fig. 2.57. Exemple 2.10. Barra C-E

$\sum F_{x}=0 \rightarrow N\left(x^{\prime}\right)=0 \rightarrow N(x)=0$

$\sum \overrightarrow{F_{y}}=0 \rightarrow V_{y}\left(x^{\prime}\right)-P=0 \rightarrow V_{y}\left(x^{\prime}\right)=P \rightarrow V_{y}(x)=P$

$\sum M=0 \rightarrow M_{z}\left(x^{\prime}\right)+P \cdot x^{\prime}=0 \rightarrow M_{z}\left(x^{\prime}\right)=-P \cdot x^{\prime} \rightarrow M_{z}(x)=-P(a-x)=10(x-1)$

Barra E-F
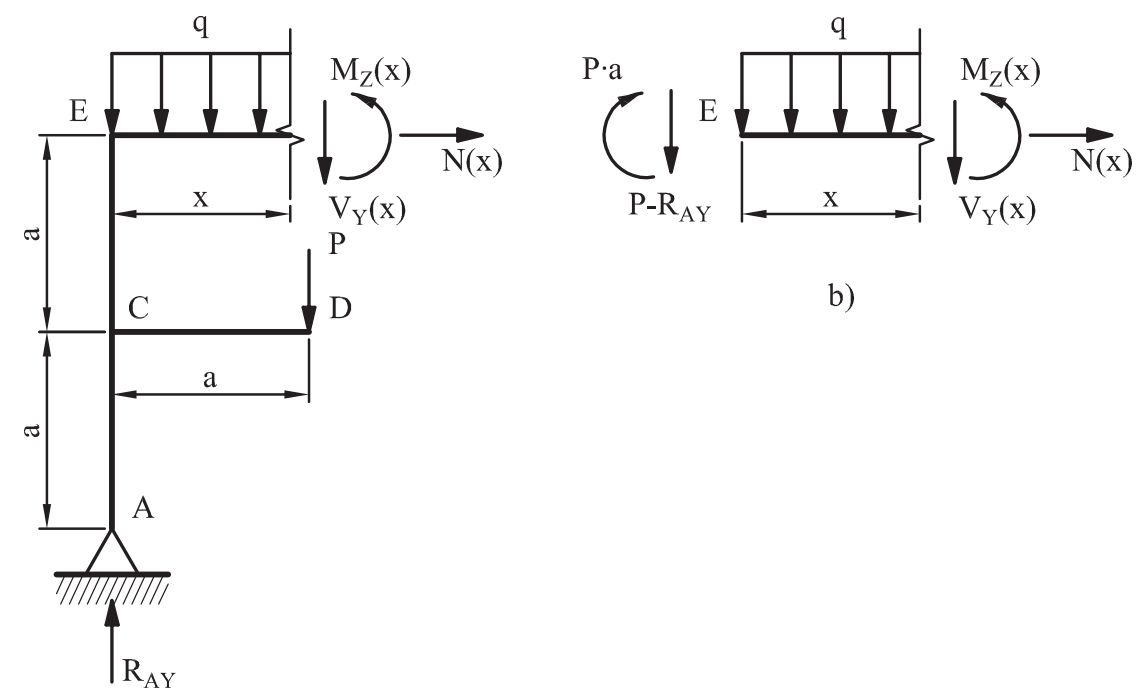

b)

a)

Fig. 2.58. Exemple 2.10. Barra E-F: $a$ ) opció $1 ; b$ ) opció 2

En aquest cas, podem fer dues coses. La primera és fer un tall, deixant la part esquerra de l'estructura completa, amb totes les barres. La segona és substituir totes les barres inferiors pels esforços que generen sobre el nuc E (podem obtindre'ls directament dels diagrames de la barra anterior). 
Independentment de la manera de plantejar-ho, els resultats han de ser els mateixos.

$\sum \overrightarrow{F_{x}}=0 \rightarrow N(x)=0$

$\sum \vec{F}_{y}=0 \rightarrow V_{y}(x)=-P+R_{A Y}-q \cdot x=-1,35-2 \cdot x k N$

$\sum M=0 \rightarrow M_{Z}(x)=P \cdot a-\left(P-R_{A Y}\right) x-q \frac{x^{2}}{2}=10-1,35 x-x^{2} k N \cdot m$

La llei de tallants és una recta, amb valors extrems:

$x=0 \rightarrow V_{y}(x)=-1,35 k N$

$x=2 m \rightarrow V_{y}(x)=-5,35 k N$

Com que no s'anul·la dins de la barra, tampoc hi haurà un màxim relatiu de la llei de moments flectors. Aquesta llei serà una paràbola quadràtica, de la qual obtindrem alguns valors:

$$
\begin{aligned}
& x=0 \rightarrow M_{z}(x)=10 \mathrm{kN} \cdot \mathrm{m} \\
& x=1 \mathrm{~m} \rightarrow M_{z}(x)=7,64 \mathrm{kN} \cdot \mathrm{m} \\
& x=2 \mathrm{~m} \rightarrow M_{z}(x)=3,29 \mathrm{kN} \cdot \mathrm{m}
\end{aligned}
$$

\section{Barra F-G}

En aquest cas també tindríem les dues opcions esmentades abans.
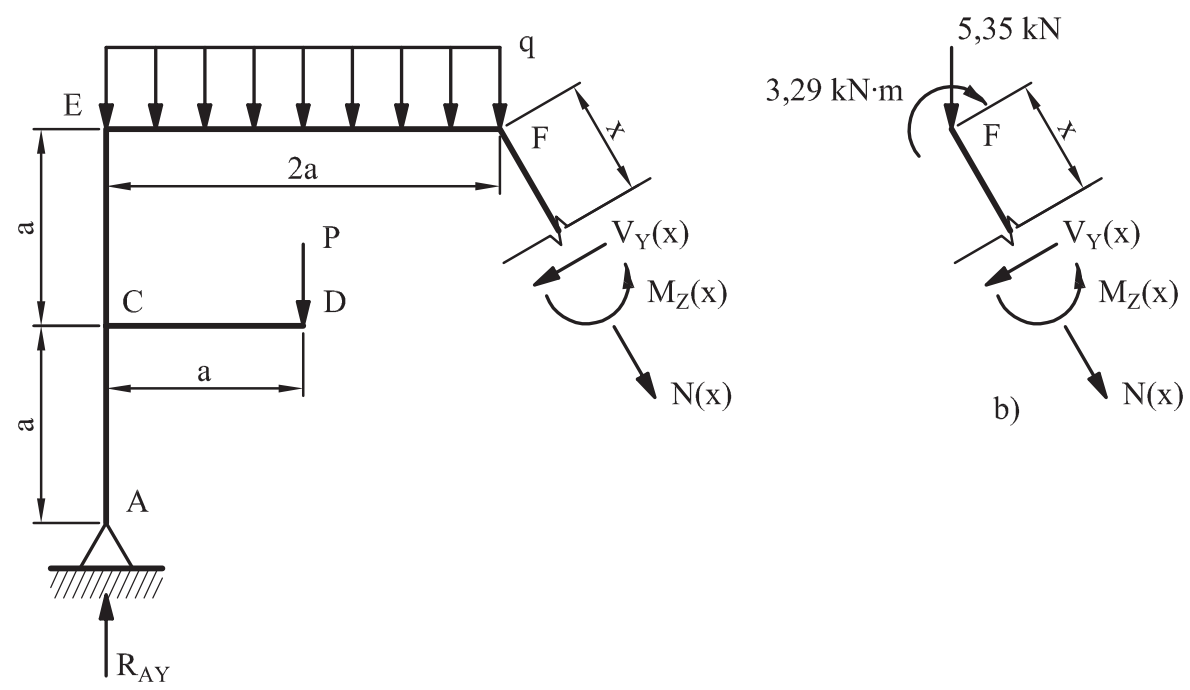

a)

Fig. 2.59. Exemple 2.10. Barra F-G: $a$ ) opció $1 ; b$ ) opció 2

Optarem novament per la segona. Hem de plantejar l'equilibri segons els eixos locals, i per aquesta raó, hem de descompondre la força vertical. 


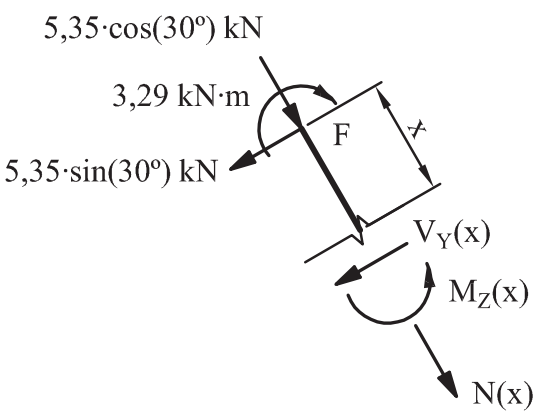

Fig. 2.60. Exemple 2.10. Barra F-G. Descomposició de la força vertical

$\sum F_{x}=0 \rightarrow N(x)=-5,35 \cos \left(30^{\circ}\right)=-4,63 k N$

$\sum F_{y}=0 \rightarrow V_{y}(x)=-5,35 \sin \left(30^{\circ}\right)=-2,68 k N$

$\sum M=0 \rightarrow M_{z}(x)=3,29-5,35 \sin \left(30^{\circ}\right) x=3,29-2,68 x \mathrm{kN} \cdot \mathrm{m}$

El diagrama de flectors serà una línia recta, amb valors extrems:

$$
\begin{aligned}
& x=0 \rightarrow M_{z}(x)=3,29 \mathrm{kN} \cdot \mathrm{m} \\
& x=1,155 \mathrm{~m} \rightarrow M_{z}(x)=0,20 \mathrm{kN} \cdot \mathrm{m}
\end{aligned}
$$

\section{Barra G-H}

En aquesta barra és d'aplicació el raonament fet per a la barra C-D. Canviem la variable igualment: $x^{\prime}=a-x$.

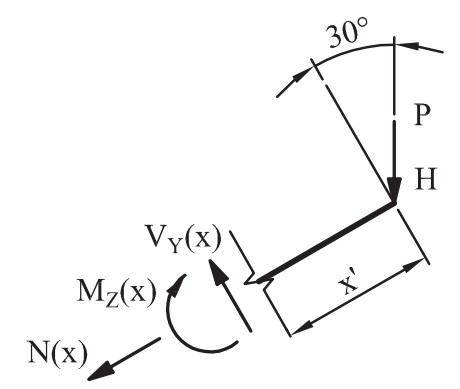

Fig. 2.61. Exemple 2.10. Barra G-H

La força P ha de ser descomposta segons els eixos locals.

$\sum F_{x}=0 \rightarrow N(x)=-P \sin \left(30^{\circ}\right)=-5 k N$

$\sum F_{y}=0 \rightarrow V_{y}(x)=P \cos \left(30^{\circ}\right)=8,66 \mathrm{kN}$

$\sum M=0 \rightarrow M_{z}\left(x^{\prime}\right)=P \cos \left(30^{\circ}\right) x^{\prime} \rightarrow M_{z}(x)=8,66(1-x) k N \cdot m$

El diagrama de flectors serà una línia recta, amb valors extrems:

$x=0 \rightarrow M_{z}(x)=8,66 \mathrm{kN} \cdot \mathrm{m}$

$x=1 \mathrm{~m} \rightarrow M_{z}(x)=0 \mathrm{kN} \cdot \mathrm{m}$ 
Barra G-B

Arribats a aquest punt, podríem fer la mateixa cosa que hem fet fins ara. Tanmateix resulta més fàcil conservar la part dreta de l'estructura tallada.

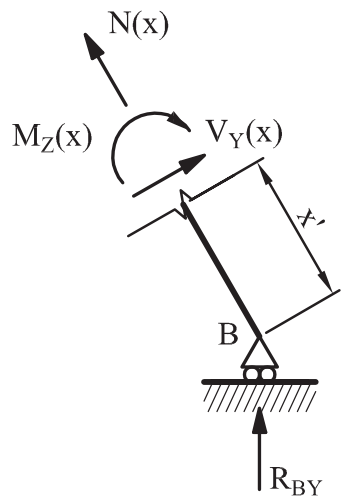

Fig. 2.62. Exemple 2.10. Barra G-B

Hem de fer un canvi de variable:

$x^{\prime}=\frac{a}{\cos (30)}-x$

La reacció l'hem de descompondre segons els eixos locals.

$$
\begin{aligned}
& \sum \overrightarrow{F_{x}}=0 \rightarrow N(x)=-R_{B Y} \cos \left(30^{\circ}\right)=-13,30 \mathrm{kN} \\
& \sum F_{y}=0 \rightarrow V_{y}(x)=-R_{B Y} \sin \left(30^{\circ}\right)=-7,68 \mathrm{kN} \\
& \sum M=0 \rightarrow M_{z}\left(x^{\prime}\right)=R_{B Y} \sin \left(30^{\circ}\right) x^{\prime} \rightarrow M_{z}(x)=7,68(1,155-x)=8,86-7,68 x \mathrm{kN} \cdot \mathrm{m}
\end{aligned}
$$

El diagrama de flectors serà una línia recta, amb valors extrems:

$$
\begin{aligned}
& x=0 \rightarrow M_{z}(x)=8,86 \mathrm{kN} \cdot \mathrm{m} \\
& x=1,155 \mathrm{~m} \rightarrow M_{z}(x)=0 \mathrm{kN} \cdot \mathrm{m}
\end{aligned}
$$

Representació dels diagrames d'esforços:

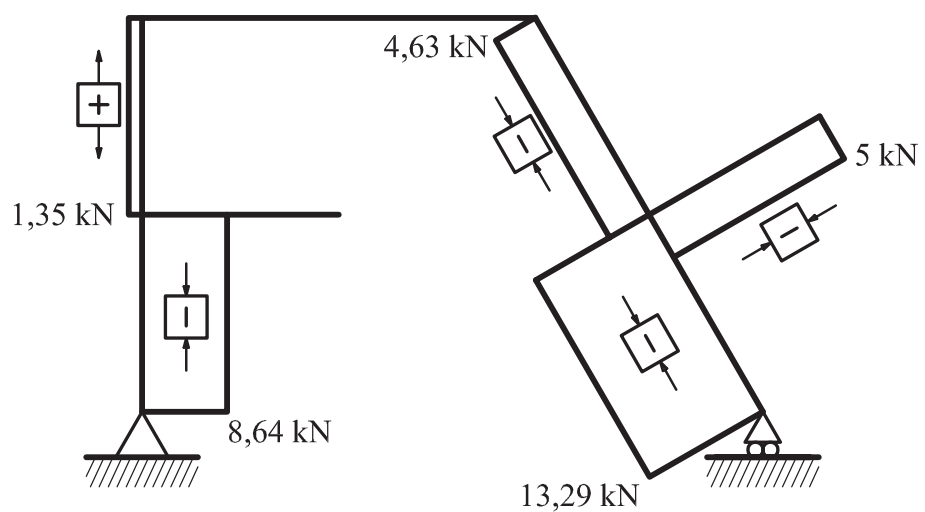

Fig. 2.63. Exemple 2.10. Diagrama d'axials 


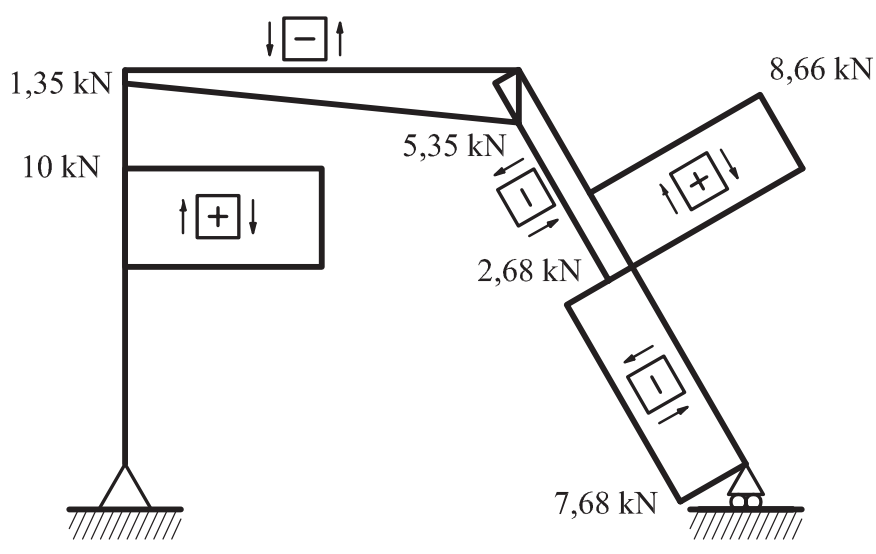

Fig. 2.64. Exemple 2.10. Diagrama d'esforços tallants

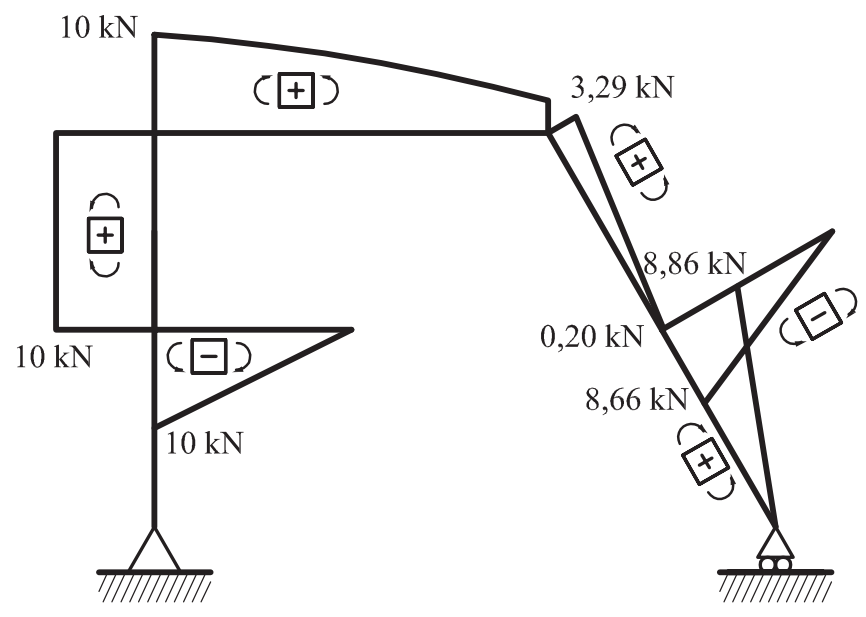

Fig. 2.65. Exemple 2.10. Diagrama de moments flectors

En aquest cas particular, la representació amb el criteri de posició dels moments positius que hem mencionat a l'exercici anterior fa que els diagrames de moments de les diverses barres se superposen entre ells. Per aquesta raó, per tal de deixar els diagrames més clars, els representarem amb el criteri de dibuixar els moments positius cap a l'exterior.

Podem apreciar que es manté l'equilibri als nucs d'unió de les barres (C, E, F i G). En particular, al nuc $\mathrm{G}$ podem veure com la suma dels moments que generen les barres F-G i G-H dóna el mateix resultat que el moment que genera la barra G-B, i per això podem afirmar que es compleix la condició d'equilibri de moments al nuc. 


\section{Exemple 2.11}

Coneixem que el diagrama de moments flectors d'una biga amb múltiples recolzaments és el de la figura:

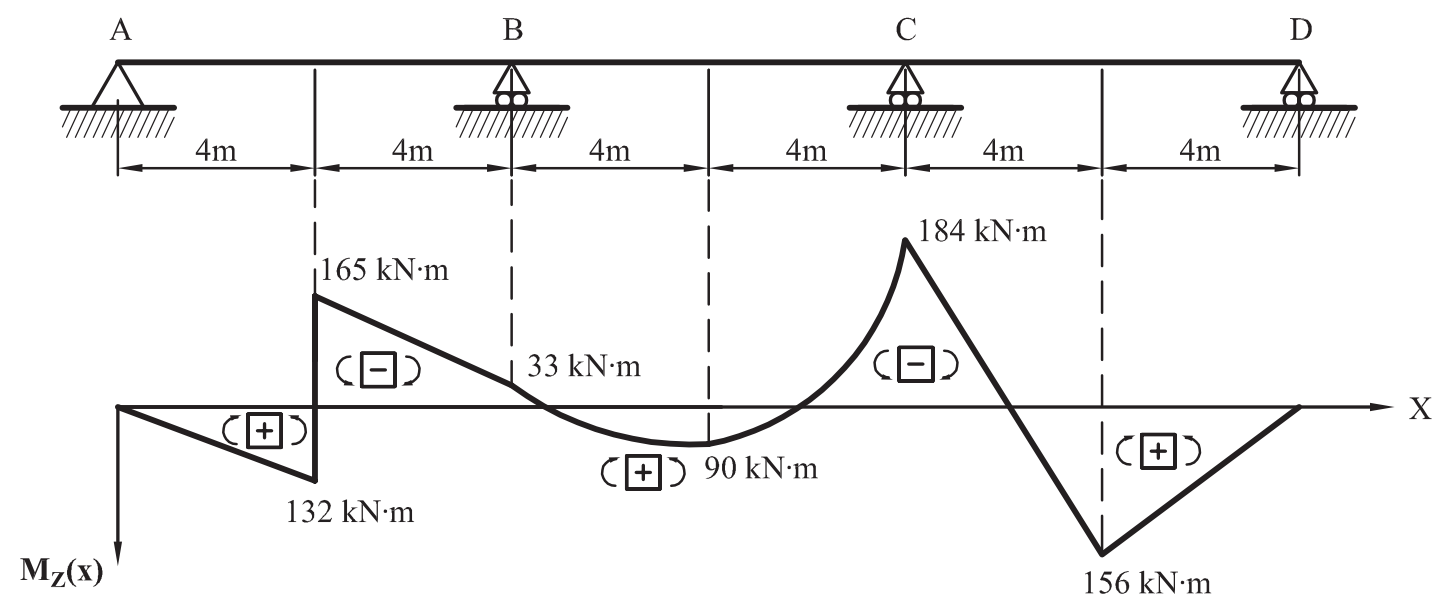

Fig. 2.66. Exemple 2.11. Enunciat

a) Determineu les càrregues a què es troba sotmesa $\mathrm{i}$ les reaccions.

b) Trobeu l'abscissa dels punts de pas per zero del diagrama.

c) Representeu el diagrama d'esforços tallants, indicant els seus valors.

d) Estimeu la deformada.

$\mathrm{El}$ gràfic al tram $\mathrm{B}-\mathrm{C}$ és una paràbola quadràtica. El valor donat per al punt $\mathrm{x}=12$ $\mathrm{m}$ no és un màxim relatiu de la funció. La resta de trams son línies rectes.

Primer tram $(0 \leq \mathrm{x} \leq 4 \mathrm{~m})$

Com que no hi ha variació del pendent del diagrama, deduïm que no hi ha cap càrrega aplicada en aquest tram.

$M_{Z}(x)=R_{A} x$

$M_{Z}(x=4 m)=R_{A} \cdot 4=132 \mathrm{kN} \cdot \mathrm{m}$

$R_{A}=33 \mathrm{kN}$

Segon tram $(4 \mathrm{~m} \leq \mathrm{x} \leq 8 \mathrm{~m})$

Es produeix un salt al diagrama de moments. Açò només pot ser degut a un moment aplicat.

El valor d'aquest moment serà:

$M=165+132=297 \mathrm{kN} \cdot m$ (sentit antihorari) 
Tercer $\operatorname{tram}(8 \mathrm{~m} \leq \mathrm{x} \leq 16 \mathrm{~m})$ :

Tenim una distribució de moments representada per una paràbola quadràtica. Açò suposa que tenim una càrrega uniformement repartida $(q)$.

$$
\begin{aligned}
& M_{Z}(x)=R_{A} x-M+R_{B}(x-8)-q \frac{(x-8)^{2}}{2} \\
& M_{Z}(x=12 m)=90 \mathrm{kN} \cdot m=R_{A} \cdot 12-M+R_{B}(12-8)-q \frac{(12-8)^{2}}{2} \\
& M_{Z}(x=16 m)=-184 \mathrm{kN} \cdot m=R_{A} \cdot 16-M+R_{B}(16-8)-q \frac{(16-8)^{2}}{2}
\end{aligned}
$$

Açò és un sistema de dues equacions amb dues incògnites, en el qual les solucions són:

$$
\begin{aligned}
& R_{B}=47,37 \mathrm{kN} \\
& q=24,81 \mathrm{kN} / \mathrm{m}
\end{aligned}
$$

Quart tram $(16 \mathrm{~m} \leq \mathrm{x} \leq 20 \mathrm{~m})$

Com que ja hem passat la càrrega $q$, hem de considerar la seua resultant situada en el punt mitjà.

$$
\begin{aligned}
& M_{Z}(x)=R_{A} x-M+R_{B}(x-8)-q \cdot 8(x-12)+R_{C}(x-16) \\
& M_{Z}(x=20 \mathrm{~m})=159 \mathrm{kN} \cdot \mathrm{m}=R_{A} \cdot 20-M+R_{B}(20-8)-q \cdot 8(20-12)+R_{C}(20-16) \\
& R_{C}=203,13 \mathrm{kN}
\end{aligned}
$$

Cinqué tram $(16 \mathrm{~m} \leq \mathrm{x} \leq 20 \mathrm{~m})$

Com que al punt $\mathrm{x}=20 \mathrm{~m}$ varia el pendent del diagrama de flectors, però continua sent lineal, podem deduir que existeix en aqueix punt una càrrega puntual aplicada $(P)$.

$$
\begin{aligned}
& M_{Z}(x)=R_{A} x-M+R_{B}(x-8)-q \cdot 8(x-12)+R_{C}(x-16)-P(x-20) \\
& M_{Z}(x=24 \mathrm{~m})=0 \mathrm{kN} \cdot \mathrm{m} \\
& R_{A} \cdot 24-M+R_{B}(24-8)-q \cdot 8(24-12)+R_{C}(24-16)-P(24-20)=0 \\
& P=124 \mathrm{kN}
\end{aligned}
$$

Calculem mitjançant l'equació d'equilibri:

$R_{D}=q \cdot 8+P-R_{A}-R_{B}-R_{C}=38,97 k N$

Càlcul dels passos per zero. Hi ha un pas per zero en $\mathrm{x}=4 \mathrm{~m}$.

En la distribució parabòlica hi ha 2 passos per zero:

$$
R_{A} \cdot x-M+R_{B}(x-8)-q \frac{(x-8)^{2}}{2}=0
$$


És una equació de segon grau. Substituïm i calculem: $\begin{gathered}x=8,44 \mathrm{~m} \\ x=14,04 \mathrm{~m}\end{gathered}$

En el quart tram també hi ha un pas per zero:

$R_{A} x-M+R_{B}(x-8)-q \cdot 8(x-12)+R_{C}(x-16)=0$

Substituint i calculant: $x=18,16 \mathrm{~m}$.

Diagrama d'esforços tallants:

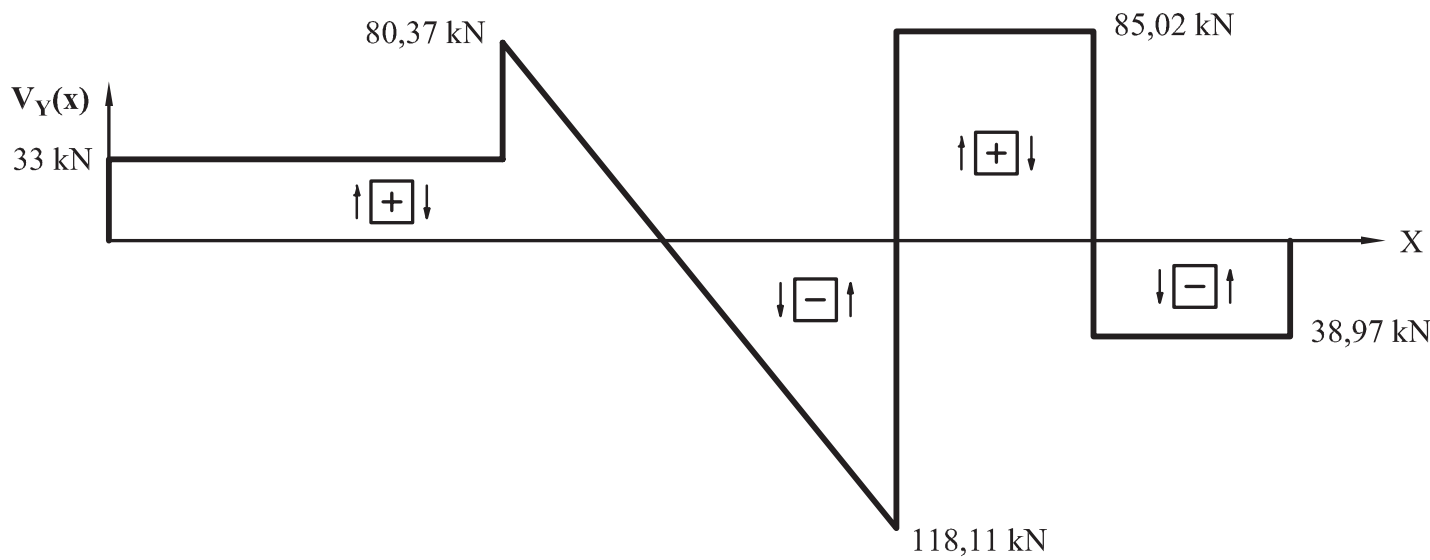

Fig. 2.67. Exemple 2.11. Esforços tallants

Estimació de la deformada:

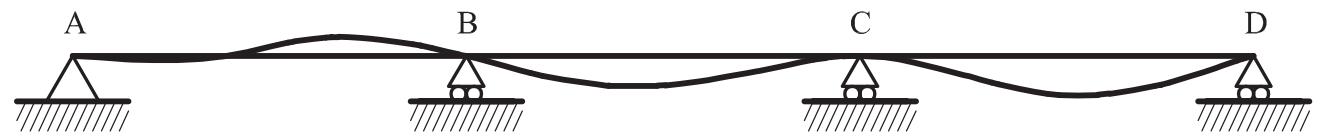

Fig. 2.68. Exemple 2.11. Estimació de la deformada 


\section{Problemes proposats}

2.1. Calculeu les lleis i representeu els diagrames d'esforços.

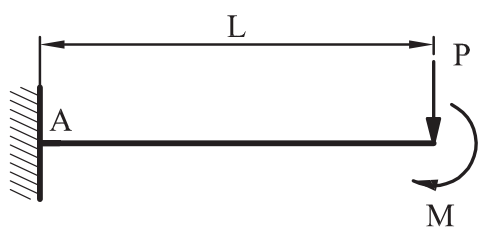

Fig. P-2.01

Dades: $\mathrm{P}=10 \mathrm{kN} ; \mathrm{M}=15 \mathrm{kN} \cdot \mathrm{m} ; \mathrm{L}=5 \mathrm{~m}$.

2.2. Calculeu les lleis i representeu els diagrames d'esforços.

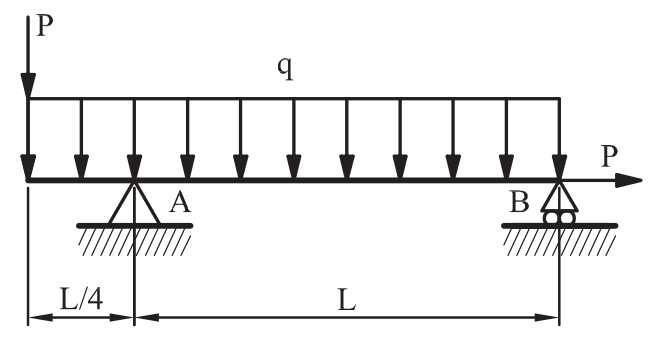

Fig. P-2.02

Dades: $\mathrm{P}=10 \mathrm{kN} ; \mathrm{q}=5 \mathrm{kN} / \mathrm{m} ; \mathrm{L}=4 \mathrm{~m}$.

2.3. Calculeu les lleis i representeu els diagrames d'esforços.

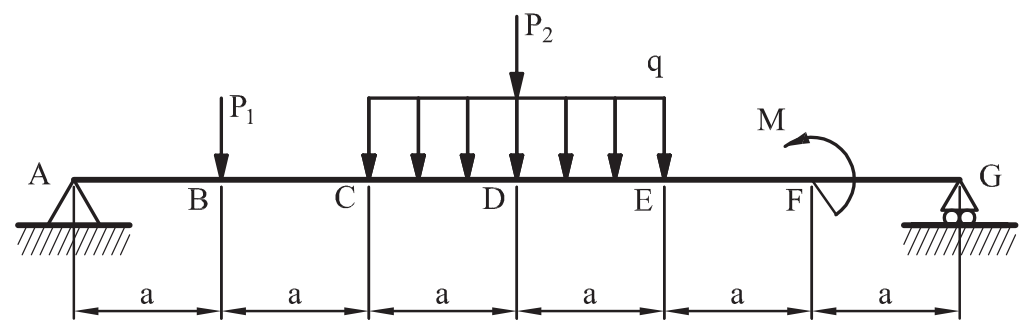

Fig. P-2.03

Dades: $\mathrm{P}_{1}=10 \mathrm{kN} ; \mathrm{P}_{2}=20 \mathrm{kN} ; \mathrm{q}=10 \mathrm{kN} / \mathrm{m} ; \mathrm{M}=10 \mathrm{kN} \cdot \mathrm{m} ; \mathrm{a}=1 \mathrm{~m}$. 
2.4. Calculeu les lleis i representeu els diagrames d'esforços.

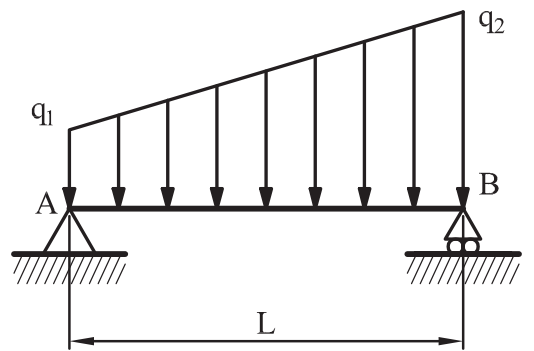

Fig. P-2.04

Dades: $\mathrm{q}_{1}=2 \mathrm{kN} / \mathrm{m} ; \mathrm{q}_{2}=5 \mathrm{kN} / \mathrm{m} ; \mathrm{L}=5 \mathrm{~m}$.

2.5. Calculeu les lleis i representeu els diagrames d'esforços.

Dades: $\mathrm{q}_{1}=1 \mathrm{kN} / \mathrm{m} ; \mathrm{q}_{2}=2 \mathrm{kN} / \mathrm{m} ; \mathrm{P}_{1}=4 \mathrm{kN} ; \mathrm{P}_{2}=5 \mathrm{kN} ; \mathrm{P}_{3}=3 \mathrm{kN} ; \mathrm{a}=1 \mathrm{~m}$.

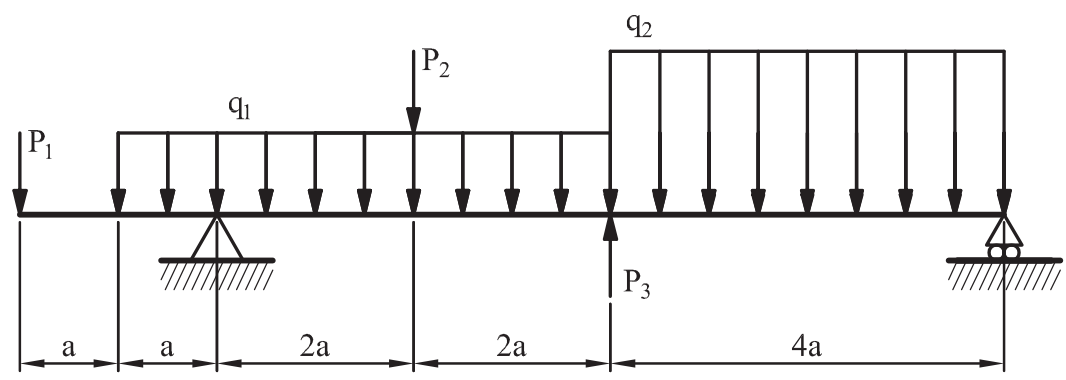

Fig. P-2.05

2.6. Calculeu les lleis i representeu els diagrames d'esforços.

Dades: $\mathrm{P}_{1}=10 \mathrm{kN} ; \mathrm{P}_{2}=5 \mathrm{kN} ; \mathrm{P}_{3}=2 \mathrm{kN}$.

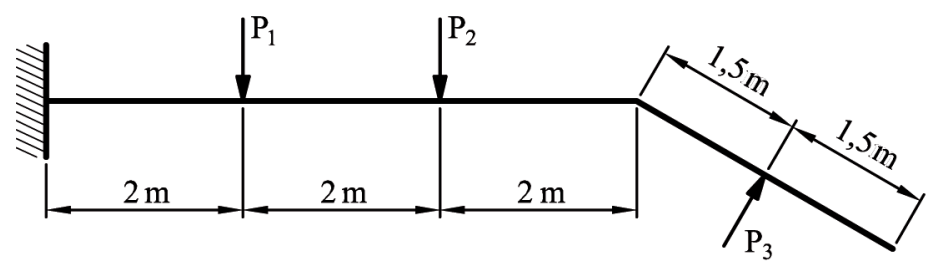

Fig. P-2.06 
2.7. Calculeu les lleis i representeu els diagrames d'esforços.

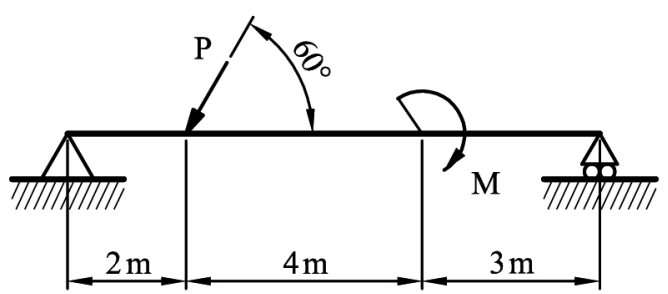

Fig. P-2.07

Dades: $\mathrm{P}=4 \mathrm{kN} ; \mathrm{M}=2 \mathrm{kN} \cdot \mathrm{m}$.

2.8. Calculeu les lleis i representeu els diagrames d'esforços.

Dades: $\mathrm{P}=5 \mathrm{kN} ; \mathrm{M}_{1}=2 \mathrm{kN} \cdot \mathrm{m} ; \mathrm{M}_{2}=2 \mathrm{kN} \cdot \mathrm{m}$.

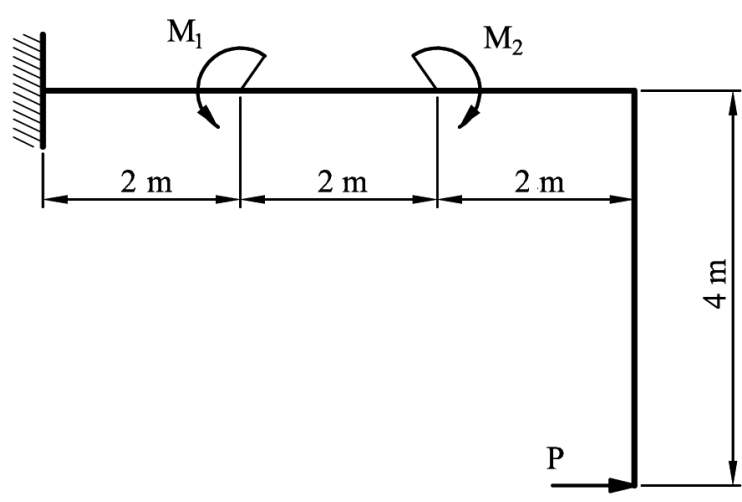

Fig. P-2.08

2.9. Calculeu les lleis i representeu els diagrames d'esforços.

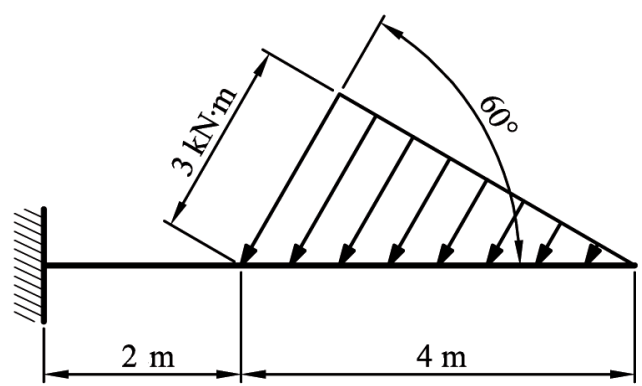

Fig. P-2.09 
2.10. Calculeu els diagrames d'esforços axial, tallant i flector corresponents al següent sistema pla acotant els valors més significatius i expressant els resultats en funció de P, q i a.

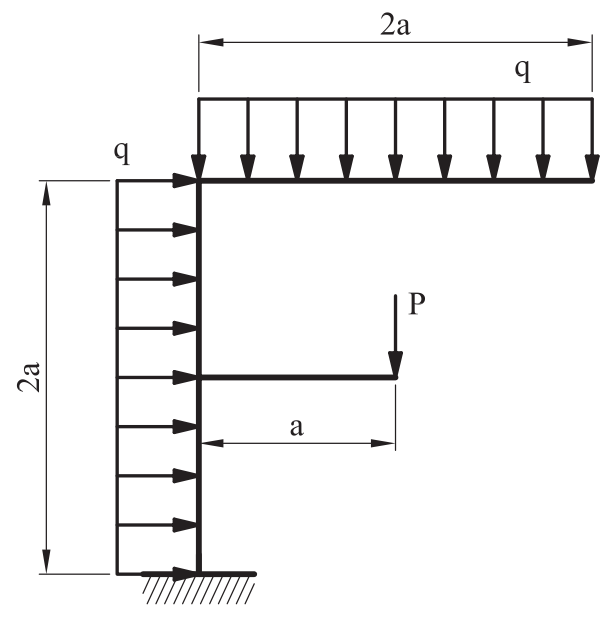

Fig. P-2.10

2.11. Calculeu les lleis i representeu els diagrames d'esforços.

Dades: $\mathrm{q}=20 \mathrm{kN} / \mathrm{m} ; \mathrm{M}=40 \mathrm{kN} \cdot \mathrm{m}$.

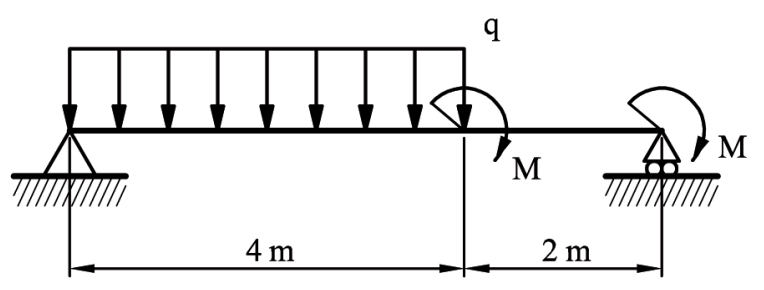

Fig. P-2.11

2.12. Coneixem que el diagrama de moments flectors d'una biga és el de la figura:

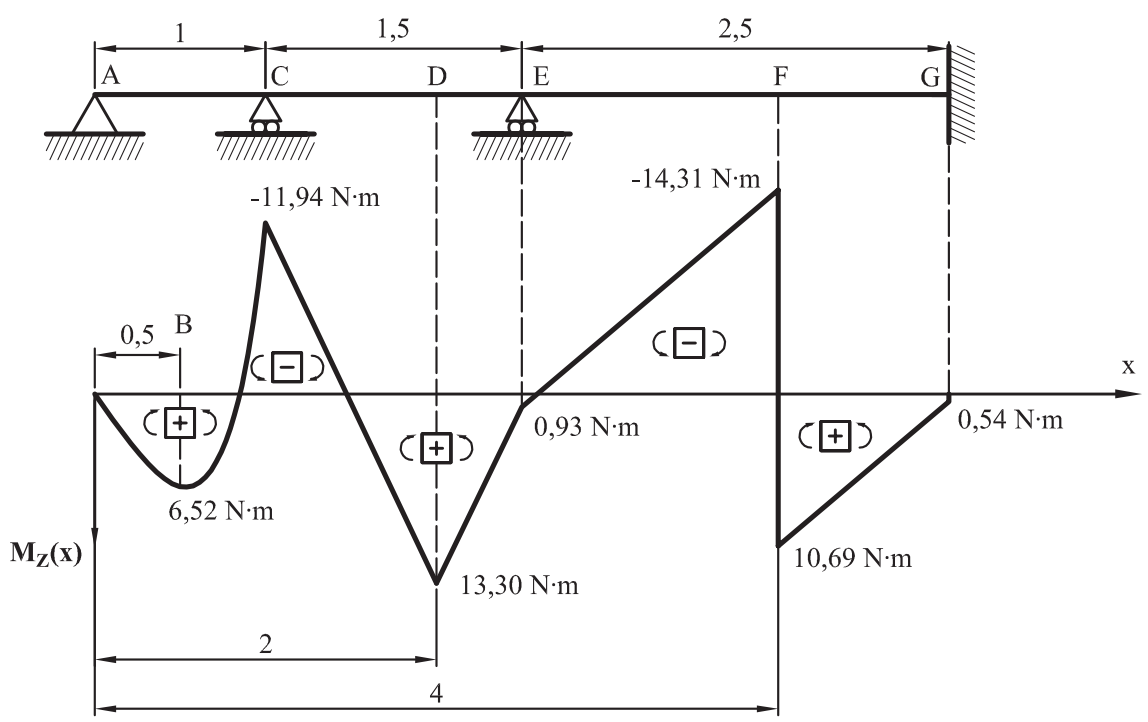

Fig. P-2.12 
a) Determineu les càrregues a què es troba sotmesa i les reaccions.

b) Trobeu l'abscissa dels punts de pas per zero del diagrama.

c) Representeu el diagrama d'esforços tallants, indicant els seus valors.

d) Estimeu la deformada.

Entre $\mathrm{A}$ i C el diagrama és una paràbola quadràtica, i en la resta de biga és lineal. El valor per a $\mathrm{x}=0,5 \mathrm{~m}$ no és un màxim relatiu en el diagrama de flectors, és simplement el valor al punt.

2.13. Calculeu les lleis i representeu els diagrames d'esforços en l'estructura de la figura, on $\mathrm{C}$ és una ròtula.

Dades: $\mathrm{q}=2 \mathrm{kN} / \mathrm{m} ; \mathrm{P}=10 \mathrm{kN}$.

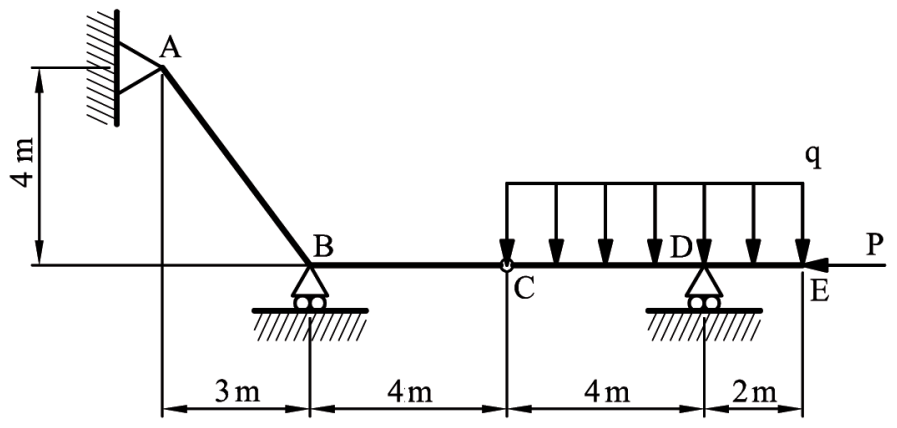

Fig. P-2.13

2.14. Calculeu les lleis i representeu els diagrames d'esforços dels exemples i problemes del tema 1 . 


\section{Fonaments d'elasticitat}

\subsection{Introducció}

La teoria de l'elasticitat planteja el comportament d'un punt d'un sòlid elàstic que, com a conseqüència d'unes accions externes, està sotmés a unes tensions determinades.

Aquesta disciplina, en altres titulacions, es desenvolupa en bona part del curs, i s'hi dedica pràcticament la meitat del temps. En aquesta assignatura, per les seues característiques, el contingut d'elasticitat ha sigut retallat fins a un únic tema introductori (el present).

L'elasticitat i la resistència de materials són disciplines que van lligades i que difícilment poden dissociar-se. Encara que l'objectiu eminentment pràctic d'aquest curs fa que l'assignatura es centre bàsicament en la part de resistència de materials, no podem oblidar-nos d'aquesta vinculació que té amb l'elasticitat, de la qual forma part consubstancial.

Per totes aquestes raons, el tema següent no és un tractat extens i detallat de tota la teoria de l'elasticitat, sinó més aviat una eina amb la qual pretenem que l'alumne siga capaç de tindre una visió global de l'àmbit de la matèria. En relació amb el que s'ha exposat anteriorment, al tema no es faran demostracions teòriques ni desenrotllaments matemàtics complexos.

\subsection{Vector tensió}

Com ja explicàrem al tema 2 , quan dividim un sòlid elàstic que estava en equilibri, les parts resultants també han d'estar en equilibri. Aquest equilibri és possible perquè apareix una distribució continua de tensions en la secció. La tensió és la conseqüència de les forces que els punts contigus de la part eliminada exerceixen sobre els punts de la secció.

La tensió depén del punt considerat, és a dir, cadascun dels punts de la secció tindrà una tensió que, en general, serà diferent de la que pot tindre qualsevol altre punt (encara que també poden ser iguals). Per a calcular la tensió d'un punt, estudiarem el seu entorn elemental d'àrea $(\Delta \Omega)$, i la força que la part eliminada fa sobre la conservada $(\Delta \mathrm{F})$. La tensió del punt serà el resultat del límit:

$\vec{\sigma}=\lim _{\Delta \Omega \rightarrow 0} \frac{\Delta \vec{F}}{\Delta \Omega}=\frac{d \vec{F}}{d \Omega}$ 
La tensió és una magnitud vectorial. La direcció del vector pot ser qualsevol, encara que sempre podrem descompondre-la segons la direcció perpendicular al pla de tall (tensió normal, $\sigma_{n}$ ), i una altra direcció continguda dins del pla (tensió tangencial, $\tau)$. Aquestes components prenen el nom de components intrínseques, perquè no depenen del sistema de referència utilitzat i per a cada vector tensió i cada pla tenen el mateix valor. Aquestes components les tractarem com a escalars.

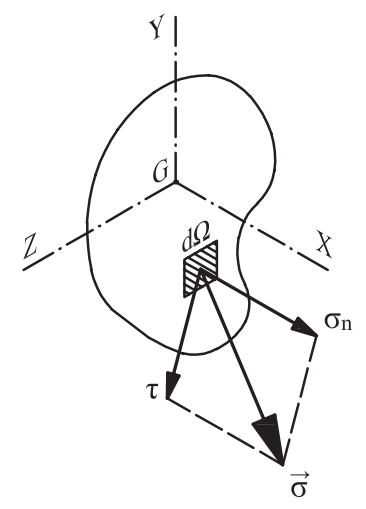

Fig. 3.1. Descomposició del vector tensió

Com que hem fet una projecció ortogonal del vector, les components intrínseques formen un triangle rectangle amb el vector, i per tant pot aplicar-se el teorema de Pitàgores:

$$
|\sigma|=\sqrt{\sigma_{n x}^{2}+\tau^{2}}
$$

Habitualment els eixos amb els quals treballarem seran els eixos principals d'inèrcia de la secció considerada. La tensió tangencial també pot ser descomposta segons aquests dos eixos, de manera que, en general, considerarem dues tensions tangencials.

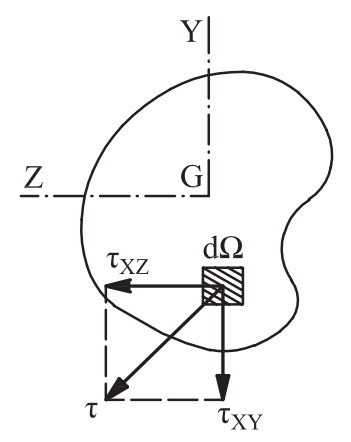

Fig. 3.2. Descomposició de la component tangencial del vector tensió

Enunciem uns factors dels quals depén el vector tensió:

- El punt. El vector tensió serà diferent per a cada punt dins d'un sòlid.

- El pla de tall. Si tallem un sòlid per dos plans diferents, el vector tensió en un mateix punt serà diferent segons a quin pla estiga referit. 
- La part del sòlid conservada. Per al mateix punt i per al mateix pla de tall, el vector tensió tindrà la mateixa direcció però sentit contrari, segons que conservem una part o l'altra.

Necessitem un conveni de signes per a les components intrínseques del vector tensió. Si eliminem la part dreta del sòlid, considerarem com a positives les components si porten la direcció dels eixos principals d'inèrcia. Si eliminem la part esquerra, seran positives si porten la direcció oposada a l'anterior.

Valors positius de la tensió normal impliquen tracció de les fibres longitudinals que passen pel punt. Per contra, els valors negatius impliquen compressions de les fibres.

Òbviament existeixen infinits plans de tall possibles, la qual cosa implica que podríem tindre infinits vectors tensió diferents per a cada punt. Això moltes vegades no resulta operatiu: necessitem una manera de caracteritzar l'estat de tensions d'un punt d'una altra manera.

Imaginem un sòlid elàstic en el qual volem estudiar l'estat de tensions d'un punt P. Fem un tall al sòlid per un pla normal (perpendicular) a l'eix X. Hem vist que apareixerà al punt un vector tensió, que portarà una direcció qualsevol, que podrà ser descomposta segons els tres eixos de l'espai. Imaginem ara que sobre el mateix punt, fem un nou tall mitjançant un altre pla, però aquesta vegada normal a l'eix Y. Apareixerà un vector tensió diferent, que també podrà ser descompost segons els tres eixos. La mateixa cosa ocorrerà quan tallem el sòlid per un pla normal a l'eix Z.

Imaginem ara que aïllem el punt $\mathrm{P}$ i el seu entorn diferencial, que serà un prisma recte infinitament menut, els costats del qual tindran com a dimensions $\mathrm{dx}, \mathrm{dy}, \mathrm{dz}$.

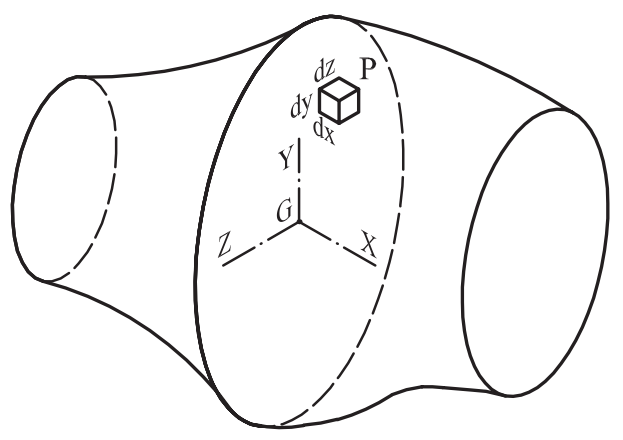

Fig. 3.3. Entorn diferencial del punt $\mathrm{P}$

Cadascuna de les sis cares del paral·lelepípede elemental serà el tall de sòlid per un pla normal als eixos i apareixerà en ella un vector tensió diferent. Quan el parallelepípede és suficientment menut, podem considerar que totes les cares passen per $\mathrm{P}$ i que les tensions en les cares són les tensions al punt.

A la figura 3.4 representem el prisma diferencial, en el qual només estan dibuixades les tres cares que queden vistes, encara que en les tres que queden darrere existiran també les components de tensions corresponents. 


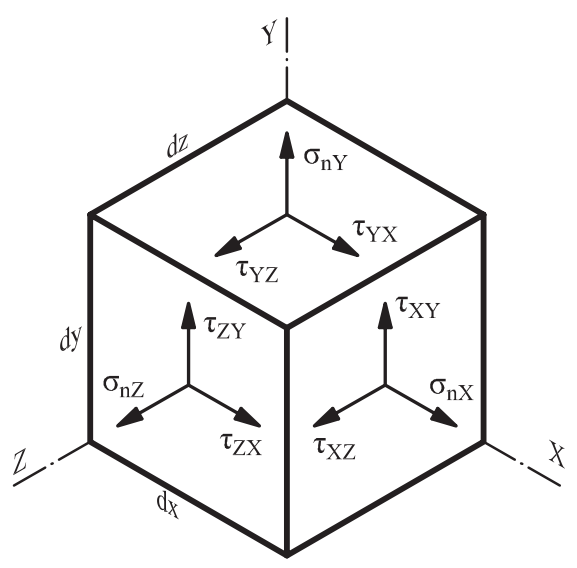

Fig. 3.4. Paral·lelepípede elemental

A primera vista pot paréixer que ara hem de treballar amb tres tensions per cadascuna de les sis barres, en total díhuit tensions. Tanmateix, ja sabem que si un sòlid està en equilibri, les seues parts també ho han d'estar, encara que siga un xicotet prisma diferencial. Per tant, per a mantindre l'equilibri, les tensions de les cares oposades han de ser iguals. Això ens deixa el nombre de tensions en nou.

Pot demostrar-se també que les tensions tangencials són iguals dos a dos (teorema de reciprocitat de les tensions tangencials), de manera que:

$$
\begin{aligned}
& \tau_{X Y}=\tau_{Y X} \\
& \tau_{X Z}=\tau_{Z X} \\
& \tau_{Y Z}=\tau_{Z Y}
\end{aligned}
$$

D'aquesta manera el nombre de tensions distintes s'ha reduït fins a sis.

Aquestes tensions poden ser encadellades en una matriu que es denomina tensor de tensions i que podem utilitzar per fer els càlculs complets relatius a la teoria de l'elasticitat.

$$
[T]=\left[\begin{array}{lll}
\sigma_{n X} & \tau_{X Y} & \tau_{X Z} \\
\tau_{X Y} & \sigma_{n Y} & \tau_{Y Z} \\
\tau_{X Z} & \tau_{Y Z} & \sigma_{n Z}
\end{array}\right]
$$

El tensor de tensions té les mateixes unitats que la tensió.

Com que el vector tensió depén del pla de tall, evidentment les tensions sobre el prisma diferencial dependran de la seua orientació, és a dir, dependran del sistema de referència triat. A la figura, es representa el prisma diferencial en un nou sistema de referència. Les tensions que apareixeran en les seues cares seran diferents a les tensions que apareixien en el sistema anterior. 


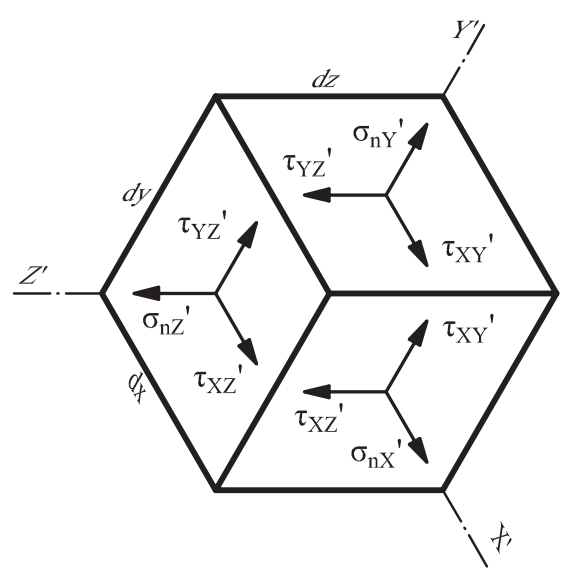

Fig. 3.5. Paral·lelepípede elemental en sistema de referència $X^{\prime} Y^{\prime} Z^{\prime}$

Pot demostrar-se que sempre existeix una orientació dels eixos a l'espai (com a mínim), en la qual totes les tensions tangencials es fan zero i només trobem al punt tensions normals. Aquestes direccions dels eixos les anomenem direccions principals. Les tensions normals que apareixen en les cares del prisma són les tensions principals.

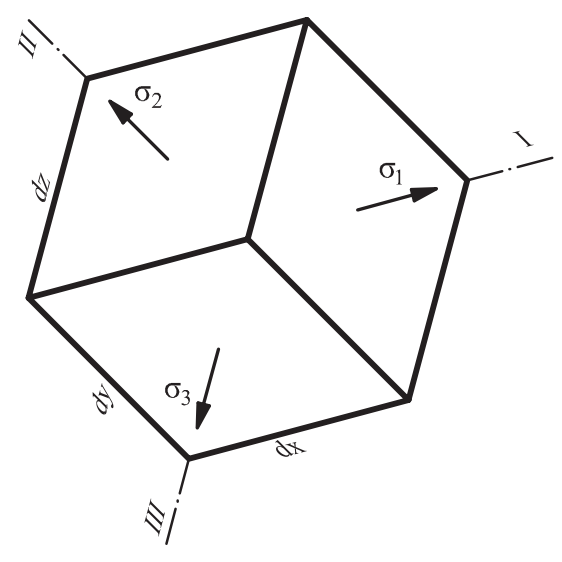

Fig. 3.6. Direccions i tensions principals

En els casos més habituals d'estructures d'edificació podem assumir que algunes tensions seran zero: $\sigma_{n Y}=\sigma_{n Z}=\tau_{Y Z}=0$. Treballarem en la assignatura segons aquest supòsit.

$[T]=\left[\begin{array}{ccc}\sigma_{n X} & \tau_{X Y} & \tau_{X Z} \\ \tau_{X Y} & 0 & 0 \\ \tau_{X Z} & 0 & 0\end{array}\right]$ 


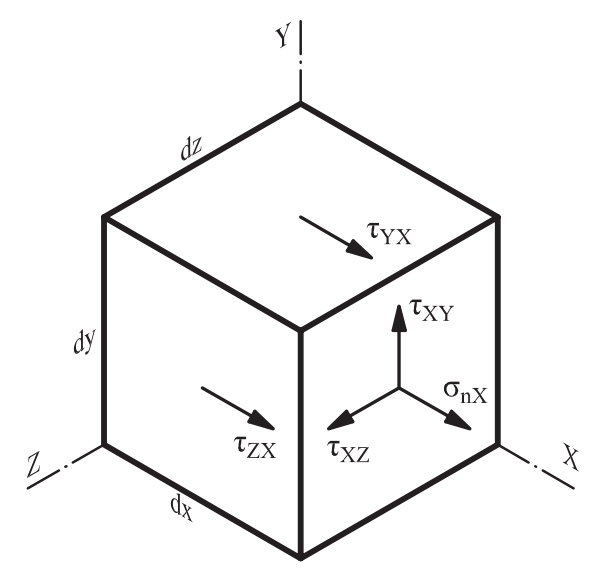

Fig. 3.7. Cas freqüent en estructures d'edificació

El càlcul de les tensions principals i de les direccions principals es realitza normalment utilitzant l'àlgebra matricial, fent un càlcul d'autovectors i autovalors del tensor de tensions. No obstant això, a causa de la simplificació que hem fet, poden extraure's unes equacions equivalents que ens eviten l'ús de les matrius. Les tensions principals poden calcular-se, sota el supòsit anterior, com a:

$$
\begin{aligned}
& \lambda_{1}=\frac{1}{2}\left(\sigma_{n X}+\sqrt{4 \tau_{X Y}^{2}+4 \tau_{X Z}^{2}+\sigma_{n X}^{2}}\right) \\
& \lambda_{2}=\frac{1}{2}\left(\sigma_{n X}-\sqrt{4 \tau_{X Y}^{2}+4 \tau_{X Z}^{2}+\sigma_{n X}^{2}}\right) \\
& \lambda_{3}=0
\end{aligned}
$$

Aquests tres valors corresponen a les tensions principals i han de ser ordenats de major a menor, de manera que $\sigma_{1}>\sigma_{2}>\sigma_{3}$.

El coneixement de les direccions principals no serà transcendent en la major part dels casos, per la qual cosa passarem per alt el seu càlcul dins d'aquest curs.

\subsection{Relació entre esforços i tensions}

Com ja hem mencionat, el que apareix realment en una secció d'un sòlid elàstic és una distribució contínua de tensions. No obstant això, quan fem l'anàlisi d'una estructura, el que nosaltres podem calcular són els esforços que té cadascuna de les seccions.

Els esforços són la reducció al centre de gravetat de la secció del sistema de forces per unitat de superfície. Aquesta reducció ens dóna una força resultant i un moment resultant, que descompondrem segons els eixos principals d'inèrcia. D'aquesta manera obtindrem els sis esforços amb els quals hem treballat al tema 2. 
La reducció mencionada anteriorment pot escriure's de la següent manera:

$$
\begin{array}{ll}
N=\iint_{\Omega} \sigma_{n X} d A & M_{T}=\iint_{\Omega}\left(\tau_{X Z} \cdot y-\tau_{X Y} \cdot z\right) d A \\
V_{Y}=\iint_{\Omega} \tau_{X Y} d A & M_{Y}=\iint_{\Omega} \sigma_{n X} \cdot z d A \\
V_{Z}=\iint_{\Omega} \tau_{X Z} d A & M_{Z}=-\iint_{\Omega} \sigma_{n X} \cdot y d A
\end{array}
$$

Aquestes relacions ens servirien per calcular els esforços a partir de les tensions. Tanmateix, el que podem fer habitualment en els casos reals és calcular els esforços i deduir les tensions a partir d'aquests esforços. Només amb les equacions anteriors no som capaços de fer aquesta deducció: necessitem trobar expressions que ens relacionen els esforços amb tensions però en sentit invers. Això serà el que farem als pròxims temes, quan analitzarem els diferents esforços que es poden donar, i les tensions vinculades a ells.

Comparativa entre esforços i tensions:

\begin{tabular}{|l|l|}
\hline Esforços interns & Tensions \\
\hline $\begin{array}{l}\text { Depenen de la secció considerada } \\
(\mathrm{x}) \text {, però no del punt dins de la } \\
\text { secció }(\mathrm{y}, \mathrm{z})\end{array}$ & Depenen del punt $(\mathrm{x}, \mathrm{y}, \mathrm{z})$ \\
\hline Dimensions: & Dimensions: \\
$\mathrm{N}, \mathrm{V}_{\mathrm{Y}}, \mathrm{V}_{\mathrm{Z}}$ són forces & Força dividida per superfície \\
$\mathrm{M}_{\mathrm{T}}, \mathrm{M}_{\mathrm{Y}}, \mathrm{M}_{\mathrm{Z}}$ són moments & \\
\hline $\begin{array}{l}\text { Unitats (sI): } \\
\mathrm{N}, \mathrm{V}_{\mathrm{Y}}, \mathrm{V}_{\mathrm{Z}}: \mathrm{N}\end{array}$ & $\mathrm{N} / \mathrm{m}^{2}$ \\
$\mathrm{M}_{\mathrm{T}}, \mathrm{M}_{\mathrm{Y}}, \mathrm{M}_{\mathrm{Z}}: \mathrm{N} \cdot \mathrm{m}$ & \\
\hline
\end{tabular}

\subsection{Deformacions}

L'elasticitat i la resistència de materials estan caracteritzades pel fet que els elements en estudi són deformables, a diferència del que s'esdevé en la mecànica, l'estàtica i la dinàmica.

Les deformacions ocorren en els sòlids reals com a conseqüència de l'existència de tensions. Es deuen a la necessitat dels materials de variar la distància entre els àtoms per a transmetre forces.

Les deformacions són variacions de posició dels diferents punts del sòlid: les fibres canvien la seua dimensió i la seua orientació. 
Les deformacions amb les quals treballem en elasticitat i resistència de materials són molt menudes. Això vol dir que no és possible predir, segons les teories que es plantegen, el comportament de materials que es deformen en gran mesura, com ara les molles, les suspensions de cotxe, les peces de cautxú, etc.

Per a conéixer el procés de deformació d'un cos és necessari analitzar la deformació d'un dels paral·lelepípedes elementals en l'entorn dels punts que en formen part. Aquesta deformació del paral-lelepípede pot ser descomposta en una translació, una rotació i una deformació pura. La translació i la rotació únicament produeixen un desplaçament del prisma, però no varien la seua forma. La deformació pura modifica la forma original del paral·lelepípede: els punts varien les seues distàncies relatives. És aquesta deformació la que ens interessa realment.

El concepte de deformació té un cert paral·lelisme amb el concepte de tensió. La deformació també és un vector (que denominarem amb la lletra èpsilon: $\vec{\varepsilon}$ ), i cadascun dels punts del sòlid està associat a un vector deformació. Aquest vector pot ser descompost segons els eixos del sistema de referència $i$ les tres components també es denominen components intrínseques. La diferència és que la deformació no està relacionada amb un pla, com el vector tensió, sinó que depén d'una direcció determinada.

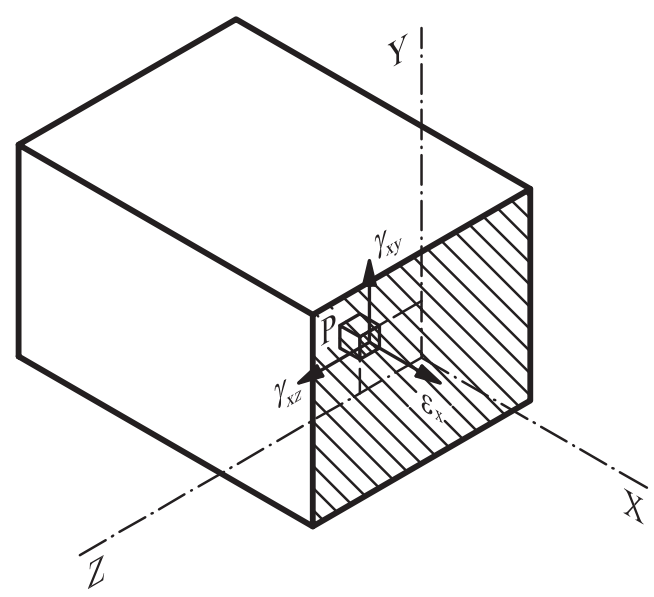

Fig. 3.8. Descomposició del vector deformació en l'entorn diferencial del punt $\mathrm{P}$

Si considerem la direcció X (l'eix de l'element barra):

La component del vector deformació que té la direcció de l'eix X és denomina deformació longitudinal unitària, i es representa per $\varepsilon_{\mathrm{X}}$. La deformació longitudinal unitària representa la variació de longitud que experimenta una fibra del material que originàriament era paral·lela a l'eix X. En presència de deformacions longitudinals unitàries, les seccions planes romanen planes després de deformar-se.

La deformació longitudinal unitària és l'allargament, en tant per u, d'una fibra paral·lela a l'eix X. Per tant:

$\varepsilon_{X}=\frac{\Delta L_{X}}{L_{X}}$ 
El numerador i el denominador de la fracció estan en metres, per la qual cosa la deformació longitudinal no té dimensions, és adimensional. L'ordre de magnitud amb el qual treballarem en l'assignatura serà $10^{-4}-10^{-6}$ (petita deformació).

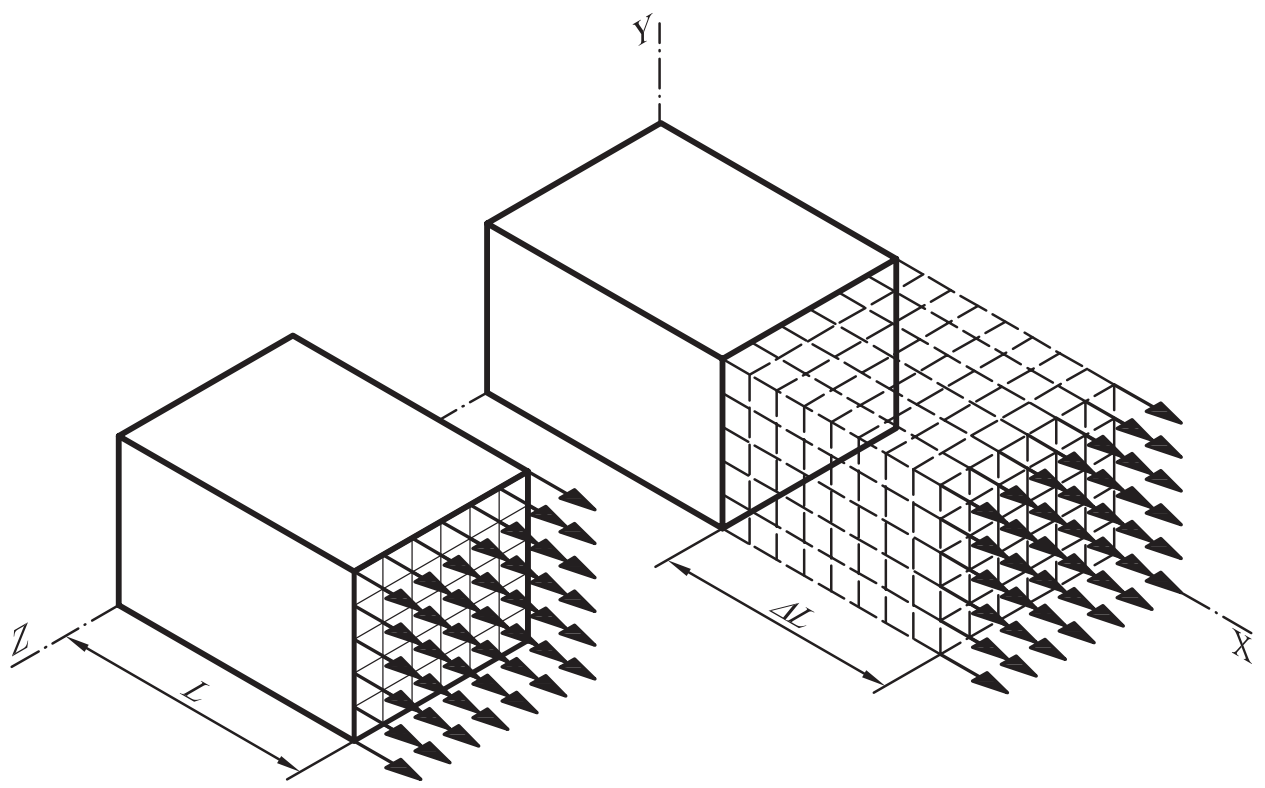

Fig. 3.9. Allargament longitudinal unitari en un paral·lelepípede elemental

Hem considerat la direcció de l'eix X, però també podríem haver considerat les altres dues, $\mathrm{i}$ en aquest cas les deformacions longitudinals unitàries es definirien de la mateixa manera:

$$
\varepsilon_{Y}=\frac{\Delta L_{Y}}{L_{Y}} \quad \varepsilon_{Z}=\frac{\Delta L_{Z}}{L_{Z}}
$$

Les deformacions longitudinals unitàries van directament relacionades amb les tensions normals, com veurem més endavant.

Les components perpendiculars (en Y i Z) són les deformacions transversals (o distorsions angulars) i es representen per $\gamma_{\mathrm{XY}} \mathrm{i} \gamma_{\mathrm{XZ}}$. Representen les variacions angulars que experimenten dues fibres del material, originàriament paral·leles als eixos X i Y (o Z, segons el cas) respectivament. Per tant, són la variació de l'angle recte que formen entre elles.

Les deformacions angulars estan directament relacionades amb les tensions tangencials, com estudiarem en el punt següent.

La distorsió angular té com a unitats els radians. Per tant, com que els radians no són cap unitat, la deformació angular també és adimensional. L'ordre de magnitud és $10^{-4}-10^{-6}$ (petita deformació). 


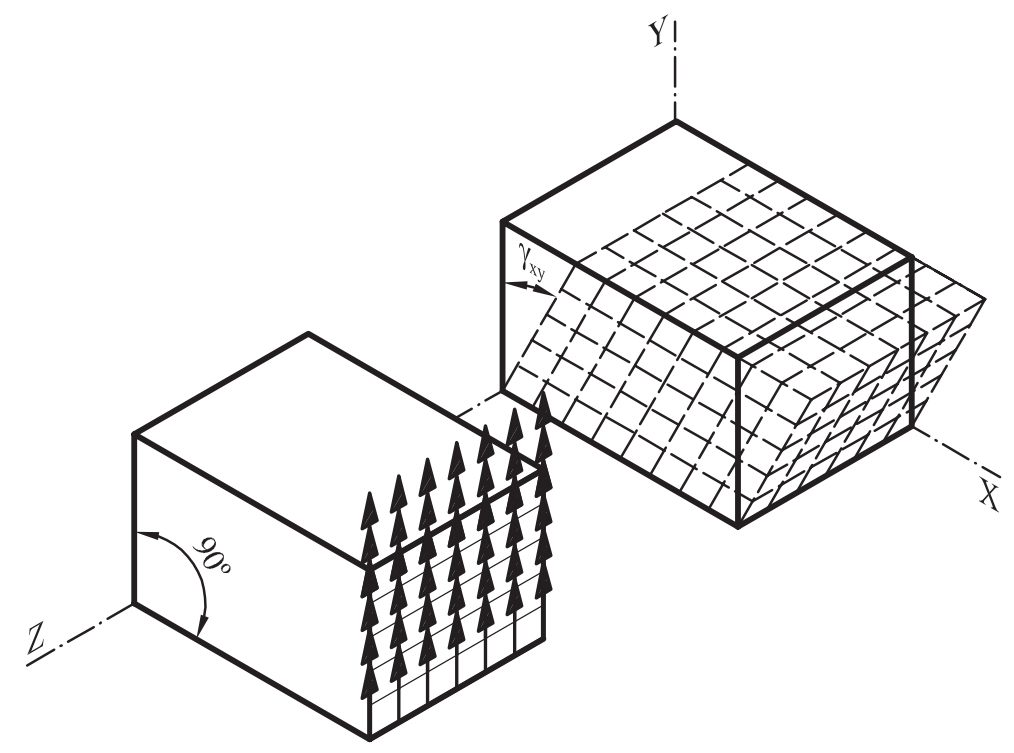

Fig. 3.10. Distorsió angular als eixos XY

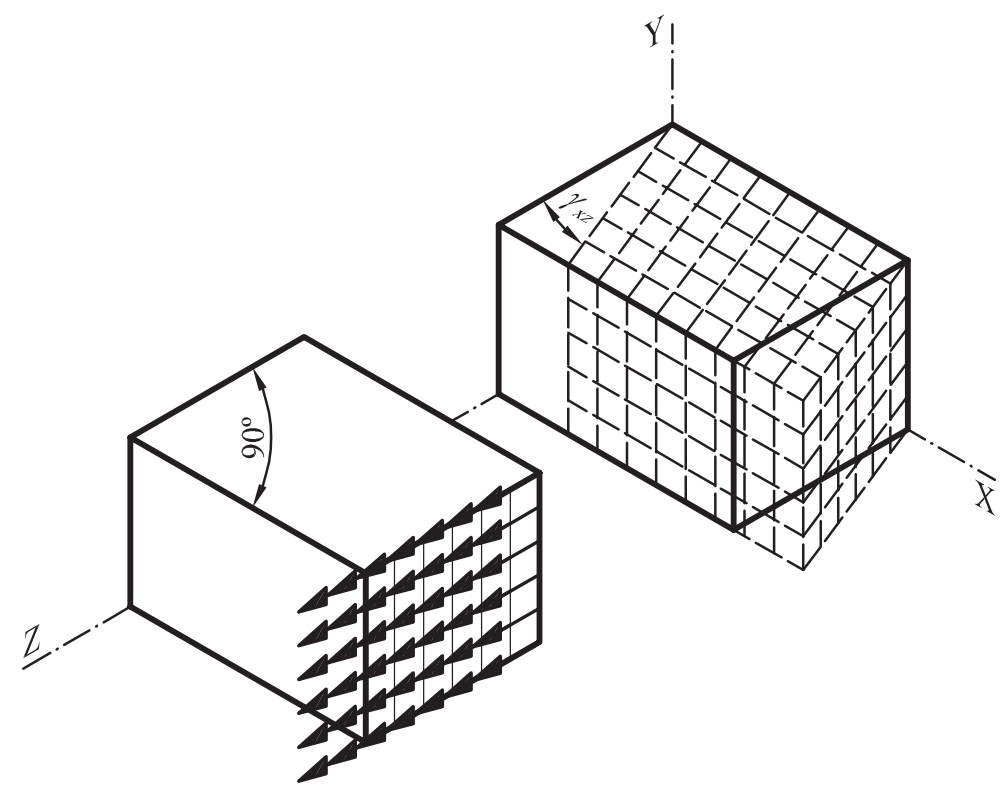

Fig. 3.11. Distorsió angular als eixos XZ

Igual que amb les tensions, pot analitzar-se l'entorn diferencial d'un punt. En un estudi detallat, faríem una anàlisi matricial de la translació de sòlid rígid, deformació longitudinal i deformació transversal (que pot descompondre's en gir i distorsió). A continuació eliminaríem la translació i el gir i ens quedaria la matriu que caracteritza l'estat de deformació en un punt. Aquesta matriu es denomina tensor de deformacions.

$$
[D]=\left[\begin{array}{ccc}
\varepsilon_{X} & \frac{\gamma_{X Y}}{2} & \frac{\gamma_{X Z}}{2} \\
\frac{\gamma_{X Y}}{2} & \varepsilon_{Y} & \frac{\gamma_{Y Z}}{2} \\
\frac{\gamma_{X Z}}{2} & \frac{\gamma_{Y Z}}{2} & \varepsilon_{Z}
\end{array}\right]
$$


Els valors de la distorsió angular apareixen dividits per dos perquè es considera que la deformació angular es produeix de manera simètrica en les dues cares contigües del prisma.
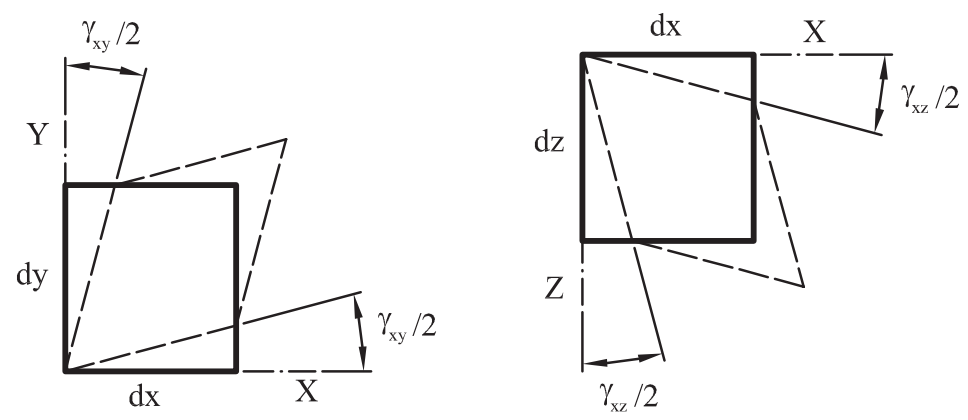

Fig. 3.12. Distorsions angulars

Encara que el càlcul exhaustiu de deformacions ha de realitzar-se mitjançant l'àlgebra matricial, en aquest curs no seguirem avançant en aquesta matèria, que queda fora de l'abast de l'assignatura.

\subsection{Relació entre tensions i deformacions}

\subsubsection{Llei de Hooke}

Al segle XVII, Robert Hooke realitzava estudis sobre el comportament de les molles, i es va adonar que existia una relació lineal entre les forces que s'apliquen i les deformacions que es produeixen; la va expressar de la manera següent:

$$
\sigma=\mathrm{E} \cdot \varepsilon
$$

Aquesta és la llei de Hooke, i és vàlida sempre que el cos es mantinga en la zona elàstica. La constant de proporcionalitat (E) s'anomena mòdul d'elasticitat o mòdul elàstic, i és una propietat intrínseca de cada material. Els materials isòtrops, com l'acer, tenen un únic mòdul d'elasticitat, però els materials ortòtrops, com ara la fusta o el formigó, tenen diferent mòdul elàstic segons la direcció, i inclús segons l'esforç aplicat. Aquesta constant també rep el nom de mòdul de Young, en homenatge a Thomas Young, que va ser el primer a estudiar-la i va fer-ne la definició precisa al segle XIX.

\subsubsection{Llei de Hooke generalitzada}

La llei de Hooke, tal com està descrita a l'apartat anterior, és vàlida si sobre la peça actua només una força que porte la direcció de l'eix X. En aquest cas, apareix una deformació longitudinal unitària en $\mathrm{X}$ que és proporcionada per l'equació esmentada. 
Per intuïció, tothom sap que quan estirem una peça (pensem, per exemple, en un tros de goma elàstica), mentre que la dimensió longitudinal augmenta, les dimensions laterals disminueixen. Aquest comportament es produeix en major o menor mesura en tots els materials. La disminució de les dimensions transversals és proporcional a l'allargament longitudinal, i la constant de proporcionalitat es denomina coeficient de Poisson $(\mu)$, que és una propietat intrínseca dels materials.

$$
\varepsilon_{Y}=\varepsilon_{Z}=-\mu \cdot \varepsilon_{X}=-\mu \cdot \frac{\sigma_{X}}{E}
$$

El coeficient $\mu$ és adimensional. El signe negatiu representa que si en X es produeixen allargaments, en $\mathrm{Y}$ i $\mathrm{Z}$ es produiran acurtaments, i viceversa.

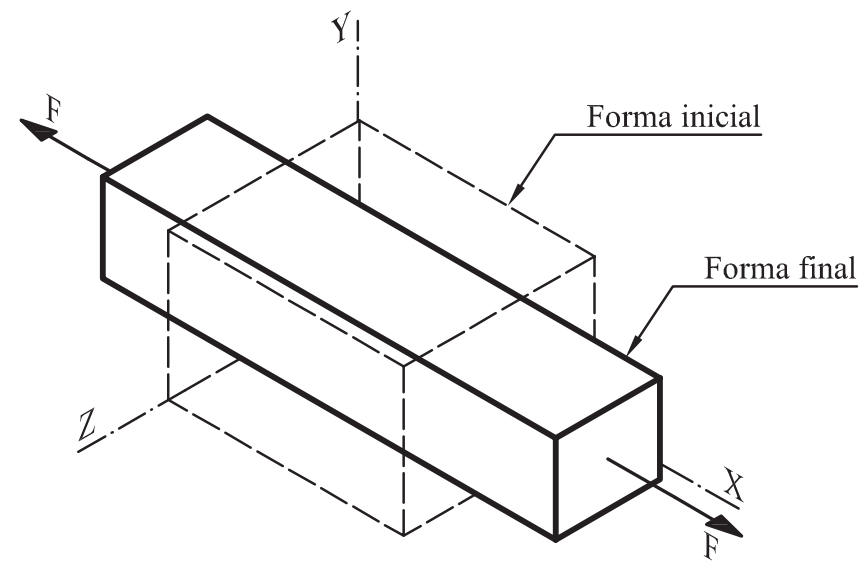

Fig. 3.13. Contracció lateral en la tracció

Coeficient de Poisson d'alguns materials:

\begin{tabular}{|l|c|}
\hline Material & Coeficient $\boldsymbol{\mu}$ \\
\hline Acer & $0,27-0,30$ \\
\hline Alumini & $0,32-0,36$ \\
\hline Formigó & $0,16-0,20$ \\
\hline Cautxú & 0.47 \\
\hline
\end{tabular}

Hi ha un límit superior del coeficient de Poisson: aquest ha de ser sempre $\mu \leq 0,5$.

Tot el que hem explicat anteriorment és d'aplicació en el cas de tensió normal uniaxial. En general, podem tindre tensions normals i tangencials als tres eixos. En el cas general, la Llei de Hooke és:

$$
\begin{array}{ll}
\varepsilon_{X}=\frac{1}{E}\left(\sigma_{X}-\mu\left(\sigma_{Y}+\sigma_{Z}\right)\right) & \gamma_{X Y}=\frac{\tau_{X Y}}{G} \\
\varepsilon_{Y}=\frac{1}{E}\left(\sigma_{Y}-\mu\left(\sigma_{X}+\sigma_{Z}\right)\right) & \gamma_{X Z}=\frac{\tau_{X Z}}{G} \\
\varepsilon_{Z}=\frac{1}{E}\left(\sigma_{Z}-\mu\left(\sigma_{X}+\sigma_{Y}\right)\right) & \gamma_{Y Z}=\frac{\tau_{Y Z}}{G}
\end{array}
$$


La constant $\mathrm{G}$ és el mòdul d'elasticitat transversal o mòdul de cisallament. També és una propietat intrínseca dels materials, $i$ està relacionada amb el mòdul elàstic $i$ el coeficient de Poisson, segons l'expressió:

$G=\frac{E}{2 \cdot(1+\mu)}$

Com que el coeficient $\mu$ és adimensional, la constant $\mathrm{G}$ tindrà les mateixes unitats que $\mathrm{E}$, és a dir, força dividida per superfície $\left(\mathrm{N} / \mathrm{m}^{2}=\mathrm{Pa}\right)$.

La constant $\mathrm{G}$ representa el canvi de forma que experimenta un material elàstic quan apliquem esforços tallants. La figura ens mostra una peça prismàtica a la qual apliquem una força $\mathrm{F}$ en la direcció $\mathrm{X}$ només en la cara superior, mantenint la inferior fixa.

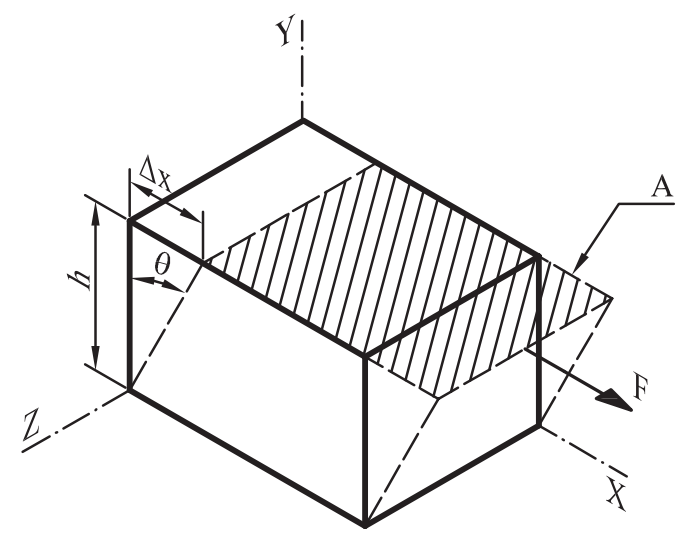

Fig. 3.14. Mòdul d'elasticitat transversal

$$
G=\frac{\tau_{m}}{\tan \theta} \simeq \frac{\tau_{m}}{\theta}=\frac{F / A}{\Delta x / h}
$$

La tensió considerada $\left(\tau_{\mathrm{m}}\right)$ és la tensió tangencial mitjana. Com que la deformació angular és tan petita, pot considerar-se que la tangent de l'angle és igual al mateix angle. La superfície A és la que correspon a la cara superior.

\subsection{Determinació de les propietats mecàniques}

\subsubsection{Elasticitat i plasticitat}

L'experiència ens mostra que qualsevol cos es deforma sota l'acció de les forces aplicades, i que quan cessen les forces, el cos té certa tendència a recuperar la seua forma primitiva; aquesta tendència que en major o menor grau tenen tots els cosos es denomina elasticitat. Si reprenem novament l'exemple de la barra sotmesa únicament a tracció, podem veure que si la força cessa, l'allargament desapareix 
completament o parcialment, és a dir, la barra tendeix a recuperar la seua longitud original. Si la barra recupera completament la seua longitud inicial, es diu que el material és perfectament elàstic.

La plasticitat és una propietat oposada; un material és perfectament plàstic quan, en deixar d'actuar la càrrega que el deforma, manté la seua configuració deformada.

En la realitat cap material resulta perfectament elàstic o perfectament plàstic. Alguns materials com l'acer, l'alumini, la goma i inclús la fusta i el formigó poden ser considerats com a perfectament elàstics dins de certs límits, és a dir, si no estan excessivament carregats.

Altres materials com l'argila i la massilla poden considerar-se com a perfectament plàstics.

De totes maneres, no seria rigorós dir que un material és dúctil o fràgil sense matisar les condicions sota les quals es fa l'afirmació. Per exemple, hi ha materials fràgils que es tornen dúctils en determinats rangs de temperatura, com ara el vidre.

Quan els materials es deformen, es modifica la distància intermolecular de la xarxa cristal-lina. Si cessa la causa de la deformació i es restitueixen les dimensions inicials, el sòlid està dins del seu període elàstic. Si se supera un límit, els enllaços cristal-lins es trenquen. Pot succeir que els enllaços tornen a formar-se substituint els primitius. Això es la plastificació del material. Aquests nous enllaços no són capaços de restituir la forma original del cos, i en ell romandrà una deformació permanent. Si el sòlid no és capaç de tornar a formar enllaços, el sòlid acabarà trencant-se.

\subsubsection{Assaig de tracció}

Per a conéixer el comportament dels sòlids i algunes de les seues propietats, és necessari fer assajos. Alguns són destructius, d'altres són no destructius. L'explicació detallada dels diversos tipus de assajos correspon a altres assignatures. Tanmateix hi ha un assaig destructiu que per la seua importància mereix ser tractat ací: l'assaig de tracció.

L'assaig de tracció és un assaig normalitzat en el qual una proveta, també normalitzada, és estirada per una màquina fins que es trenca. La proveta normalitzada és similar a la figura:

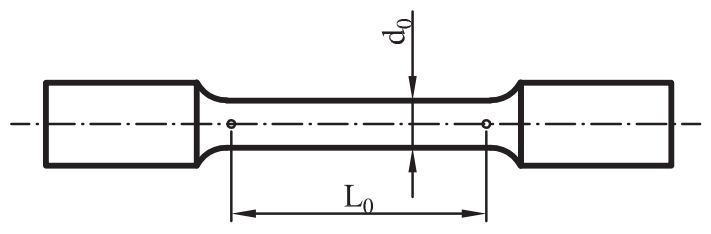

Fig. 3.15. Proveta normalitzada 
La proveta pot ser de secció rodona o rectangular. Com veiem a la figura, els extrems són més amples que la zona central, precisament perquè volem que es trenque per la zona central i no prop de la zona on agarren les mordasses. Les unions de la part central amb els extrems estan arrodonides, per tal d'evitar l'efecte de concentració de tensions.

Durant el procés d'assaig, es mesura tant la força aplicada com l'allargament produït. Com que coneixem la longitud inicial i l'àrea transversal, podem representar en un gràfic la corba tensió-deformació.

$$
\varepsilon_{X}=\frac{L_{f}-L_{0}}{L_{0}} \quad \sigma_{n X}=\frac{F}{A_{0}}
$$

És important considerar que la secció transversal de la proveta es reduirà segons ens apropem a la fractura, i si la màquina no és capaç de mesurar aquesta disminució de secció, els resultats no seran del tot correctes als trams finals del gràfic.

Una gràfica típica de l'assaig de tracció d'un acer dolç podria ser:

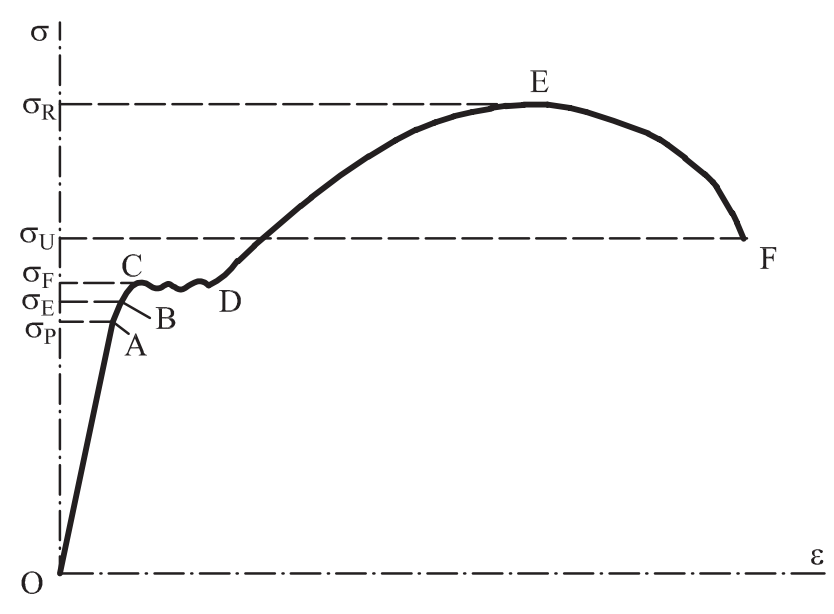

Fig. 3.16. Gràfic d'assaig de tracció

Període elàstic lineal (zona $\mathrm{OA}$ ). En un primer moment el gràfic té forma de línia recta, que representa que existeix una proporcionalitat entre tensions i deformacions. És a dir, que és vàlida la llei de Hooke. En aquesta zona, si es produeix la descàrrega de la proveta, la deformació adquirida desapareix completament. No es produeixen deformacions permanents. La tensió corresponent al punt A és el límit de proporcionalitat $\left(\sigma_{\mathrm{P}}\right)$.

Període elàstic no proporcional (zona $\mathrm{AB}$ ). Arribat a un punt $\mathrm{A}$, el gràfic deixa de ser una recta, però el comportament del sòlid és encara elàstic. Igual que en la zona proporcional, no es produeixen deformacions permanents i la deformació s'anul·la si s'elimina la càrrega. La tensió corresponent al punt B és el límit elàstic $\left(\sigma_{\mathrm{E}}\right)$. 
Quan una peça es deforma, el treball realitzat per les forces exteriors es converteix en energia de deformació. L'energia queda reflectida en el gràfic de l'assaig de tracció com a l'àrea que queda per sota de la corba. En tota la zona elàstica, l'energia elàstica es retorna al sistema un cop finalitzada la càrrega.

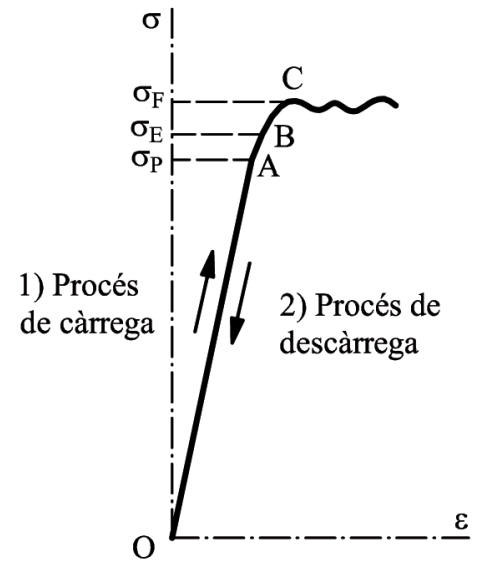

a)

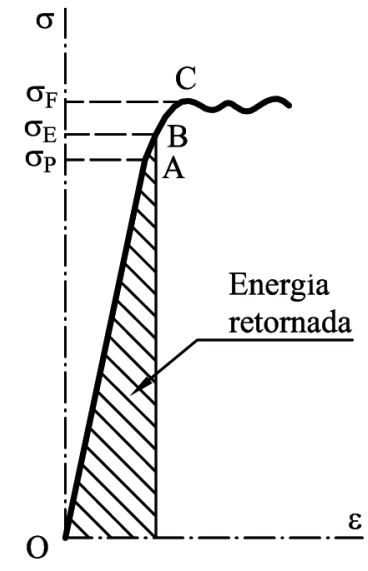

b)

Fig. 3.17. Zona elàstica: $a$ ) procés de càrrega-descàrrega; $b$ ) energia acumulada

Període elastoplàstic (zona $\mathrm{BC}$ ). Un cop superat el límit elàstic, apareixen deformacions permanents. En aquesta zona no hi ha equilibri, i en molts materials passa desapercebuda.

En moltes ocasions, els tres valors $\left(\sigma_{R}, \sigma_{E}, \sigma_{F}\right)$ estan tan prop els uns dels altres que és difícil distingir-los.

Període de fluència (zona CD). El material flueix, és a dir, es deforma sense necessitat d'augmentar la càrrega. En teoria, el gràfic hauria de ser una recta horitzontal, però en realitat el fenomen no és tan simple: la tensió oscil·la entre dos valors límits propers entre ells. La tensió corresponent al punt $\mathrm{C}$ és el límit de fluència $\left(\sigma_{\mathrm{F}}\right)$, i la tensió varia entre el límit de fluència superior i el límit de fluència inferior.

Les investigacions demostren que durant la fluència es produeixen importants lliscaments relatius entre els cristalls. Com a conseqüència d'això, en la superfície de la proveta apareixen les denominades línies de Lüders, que formen amb l'eix de la proveta un angle de $45^{\circ}$, causades per les tensions tangencials.

Si entrem en la zona de fluència, en descarregar la proveta el gràfic no retorna per la mateixa línia per la qual havia pujat, sinó per una de paral·lela a OA, indicant sobre l'eix d'abscisses que s'ha produït una deformació permanent $\left(\varepsilon_{\mathrm{p}}\right)$. En cas de tornar a carregar-se la peça, el gràfic començaria des d'aquest punt, i pujaria per la mateixa línia per on havia baixat.

Quan se supera el període elàstic, l'energia de deformació que se li entrega al sistema no és retornada completament en cas de cessar la càrrega. L'energia que no 
es retorna s'inverteix a produir deformacions permanents i a dissipar-se en forma de calor (al final de l'assaig la proveta s'ha calentat notablement).

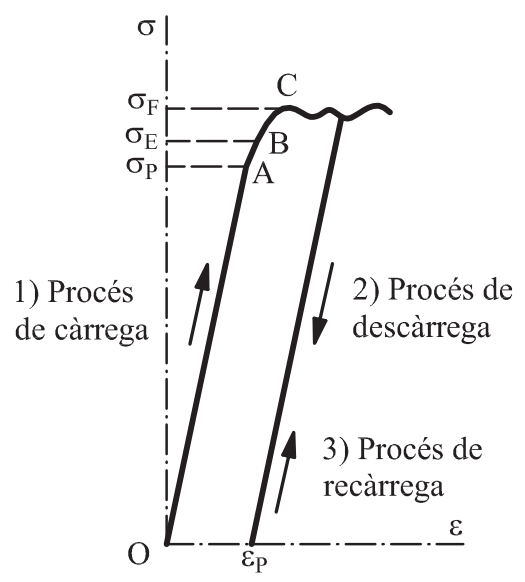

a)

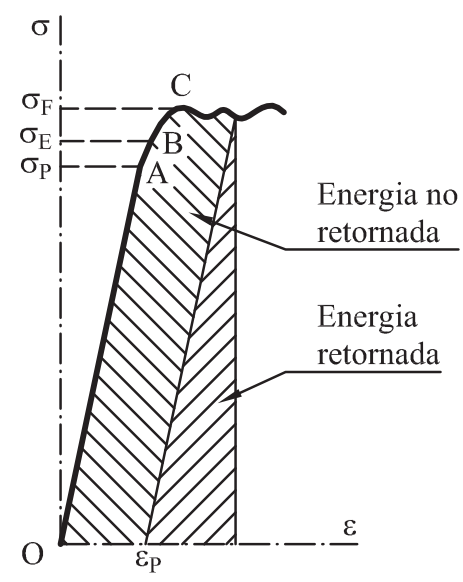

b)

Fig. 3.18. Zona plàstica: $a$ ) procés de càrrega-descàrrega; $b$ ) energia acumulada

Període d'enduriment (zona DE). Com a conseqüència d'un nou acomodament cristal-logràfic, el material experimenta un enduriment pel denominat fenomen d'acritud. La proveta té ara més resistència i augmenta la seua capacitat d'admetre càrrega. Tanmateix, les deformacions en aquest període són molt grans. La tensió augmenta fins que s'arriba a la tensió de trencament $\left(\sigma_{\mathrm{R}}\right)$.

Si durant aquest període descarreguem la peça, succeeix un fenomen similar al cas anterior. El gràfic baixa segons una recta sensiblement paral·lela a OA, i tindrem una deformació permanent $\left(\varepsilon_{\mathrm{p}}\right)$. En tornar a carregar, observem que el comportament torna a ser elàstic i lineal, però la tensió de proporcionalitat és superior a l'original i desapareix el període de fluència. Aquesta és una manera de canviar les propietats mecàniques d'un material, en aquest cas, augmentar el límit de proporcionalitat i el límit elàstic. A un material que ha experimentat aquest tractament se'l denomina estirat en fred. Tanmateix, la resistència a tracció no canvia ( $\sigma_{R}$ és la mateixa), per la qual cosa els materials estirats en fred arribaran al trencament amb una menor deformació plàstica. És a dir, el material és més fràgil.

Període de trencament (zona EF). El punt E és un punt de no-retorn: un cop superat, el trencament és inevitable. La tensió a la qual es produeix el trencament de la peça es denomina tensió última $\left(\sigma_{U}\right)$. 


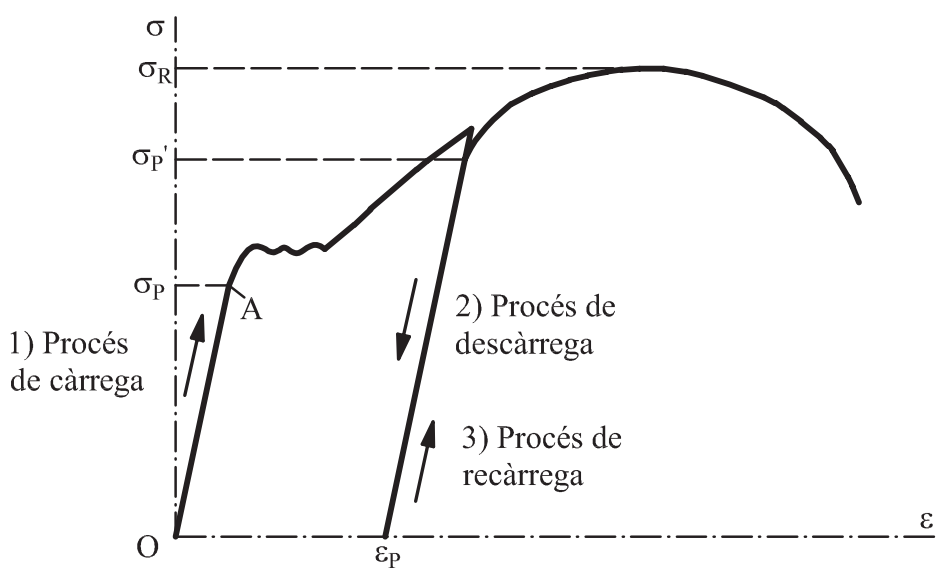

Fig. 3.19. Estirament en fred

A la figura 3.20 podem observar una seqüència del comportament d'una proveta durant l'assaig de tracció.

a)

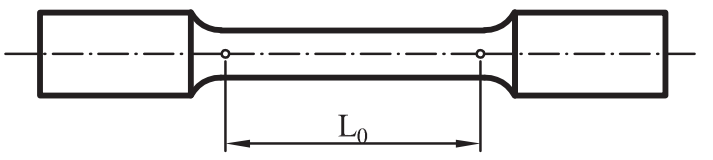

b)

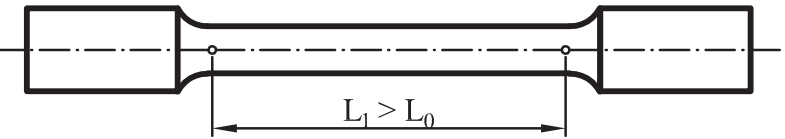

c)

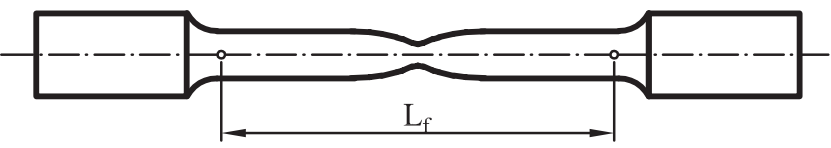

d)

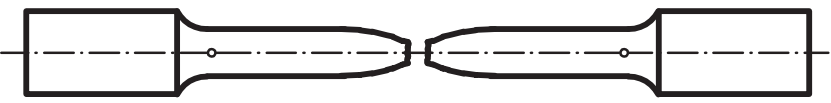

Fig. 3.20. Comportament de la proveta durant l'assaig de tracció: $a$ ) estat inicial; $b$ ) estirament en el període elàstic; $c$ ) fenomen d'estricció; $d$ ) trencament

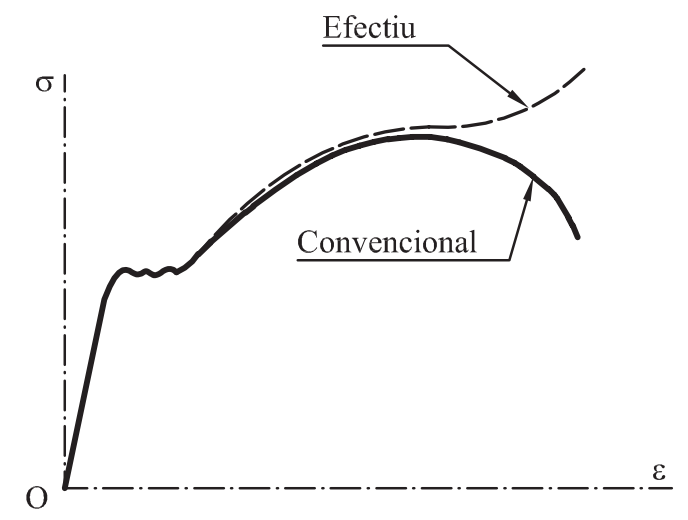

Fig. 3.21. Diagrama convencional i diagrama efectiu

Realment la tensió de trencament no és la màxima tensió a la qual s'arriba en l'assaig. Quan s'arriba a la tensió $\sigma_{\mathrm{R}}$ es desenvolupa un fenomen denominat estricció, en 
el qual es forma una espècie de coll (en anglés, necking), amb reducció de la secció. Com que la màquina no redueix la força aplicada, en reduir la secció, s'augmenta la tensió. Realment, el gràfic amb el qual s'ha fet l'explicació és un diagrama convencional. Si la màquina fóra capaç de mesurar la disminució de secció al coll d'estricció, no ens mostraria un descens de tensió, sinó un augment; tindríem un gràfic lleugerament distint a l'últim període, el diagrama efectiu.

Els resultats més immediats que podem obtindre en realitzar un assaig de tracció són el límit elàstic i el mòdul d'elasticitat. El límit elàstic s'obté directament del gràfic, encara que en la major part dels materials resulta difícil establir amb precisió on es troba aquest límit. Per aquesta raó es defineix un concepte nou: el límit elàstic convencional. El límit elàstic convencional és la tensió que produeix al material una deformació permanent del 0,2\%.

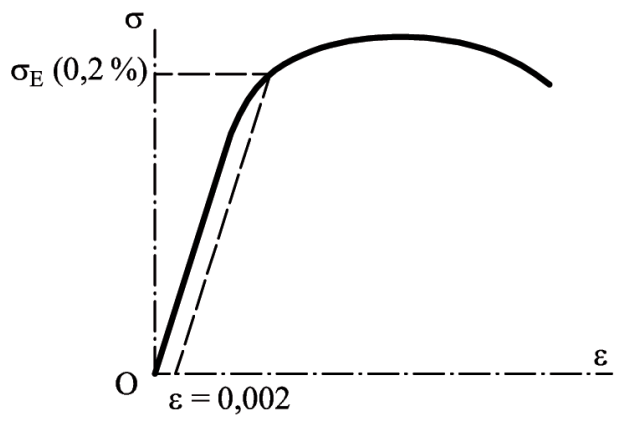

Fig. 3.22. Límit elàstic convencional

El gràfic anterior és típic de materials com el coure, l'alumini i l'acer al carboni.

La manera de trobar el límit elàstic convencional és fer una sèrie d'assajos cíclics (càrrega-descàrrega) en els quals s'augmenta lleugerament la càrrega, fins que arribem a produir una deformació permanent del $0,2 \%$.

L'altre resultat important que podem obtindre de l'assaig és el mòdul de Young (E). El mòdul d'elasticitat es defineix com el pendent del gràfic en la zona proporcional.

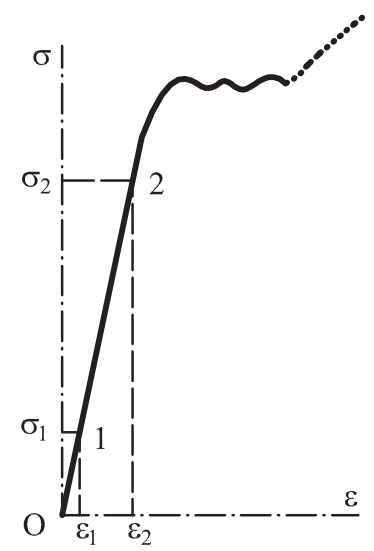

Fig. 3.23. Mòdul de Young 
Si agafem dos punts de la recta, podem obtindre el pendent:

$$
E=\frac{\sigma_{2}-\sigma_{1}}{\varepsilon_{2}-\varepsilon_{1}}
$$

Hi ha materials en els quals el període elàstic no és perfectament una recta, fet que provoca que la determinació del mòdul d'elasticitat no siga tan evident. Per a aquests casos es defineixen el mòdul tangent $\mathrm{i}$ el mòdul secant.
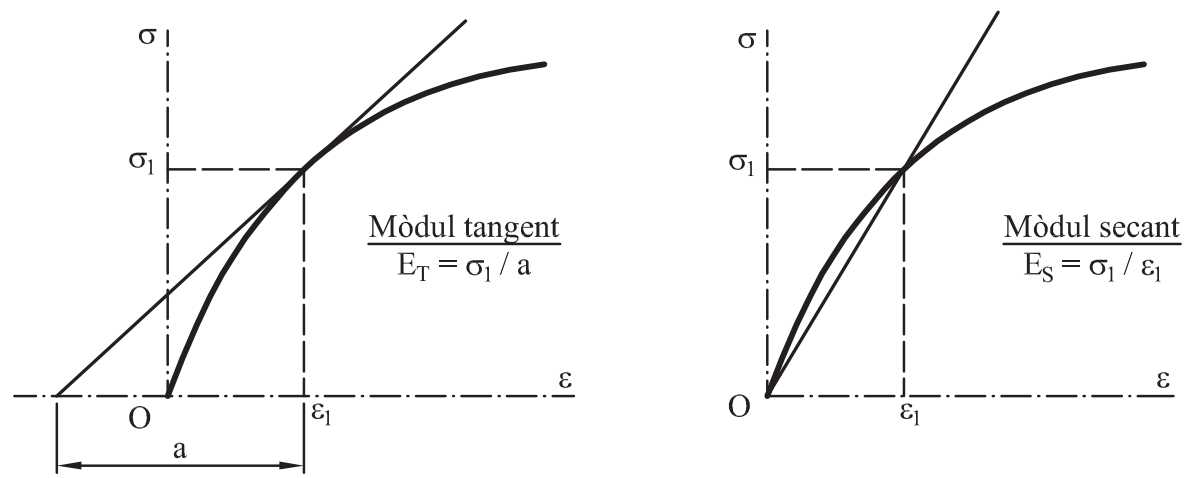

Fig. 3.24. Mòdul tangent i mòdul secant

Anteriorment hem mencionat els conceptes de ductilitat ifragilitat. Un material es considera dúctil quan es deforma molt des que es plastifica fins al trencament. La fragilitat és la propietat oposada a la ductilitat.

- Materials dúctils: alguns metalls i plàstics.

- Materials fràgils: formigó, maçoneria, ceràmics, petris, vidre.

La ductilitat permet que el trencament d'un material o el col·lapse d'una estructura «ens avise», mentre que els materials fràgils es trenquen pràcticament «sense avisar». Això pot fer que tinguem temps d'evacuar un edifici, reparar allò que estiga deteriorat, etc.

En zones sísmiques la propietat de la ductilitat és també molt important: els edificis molt rígids es trenquen i poden col·lapsar, i els dúctils es deformen i són capaços d'absorbir l'energia de les ones sísmiques sense trencar-se.

El gràfic de l'assaig per als materials fràgils ens mostra l'absència de zona de fluència (figura 3.25). El material es trenca amb molt poca deformació després de superar la zona lineal.

A la vista dels gràfics de l'assaig de diversos materials, podem deduir quins materials són més dúctils (es deformen més després de la zona de fluència), quins més rígids (tenen una $\mathrm{E}$ major) i quins més resistents (tenen una $\sigma_{\mathrm{R}}$ major). 


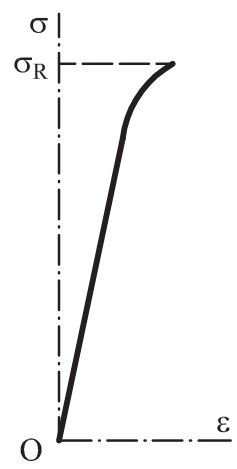

Fig. 3.25. Gràfica tensió-deformació d'un material fràgil

\section{Exemple 3.1}

A la vista dels gràfics dels assajos de tracció de tres materials diferents, ordeneu-los segons la seua ductilitat, rigidesa i resistència.

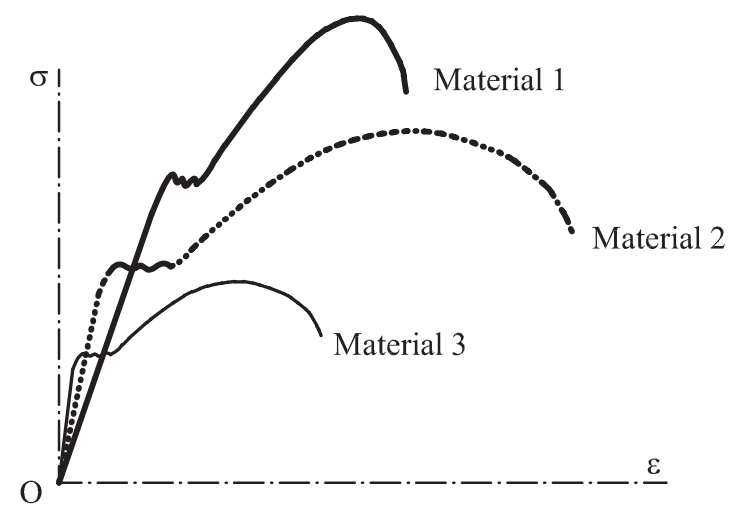

Fig. 3.26. Exemple de tipus de materials amb comportaments diferents

- L'ordre dels materials segons la seua ductilitat és: 2, 1, 3.

- L'ordenació segons el material més rígid és: 3, 2, 1.

- Segons la resistència els ordenem: $1,2,3$.

\subsubsection{Comportament a compressió}

Fins ara s'han analitzat només els assajos de tracció. Si una proveta d'un material dúctil es carregara a compressió, el gràfic tensió-deformació que obtindríem seria bàsicament el mateix en els primers trams. El comportament seria el mateix en la zona elàstica i el començament del període de fluència. El límit de proporcionalitat en metalls dúctils, com l'acer, és pràcticament igual a tracció i a compressió. Per a valors més elevats de deformació, les corbes de tracció i de compressió són més diferents, ja que a compressió no es produeix el fenomen d'estricció. Al contrari, 
en comprimir una petita proveta de material dúctil, els seus costats comencen a fer-se més amples, i pren forma de tonell. Finalment la proveta s'esclafa, oferint una resistència addicional, per la qual cosa el gràfic torna a tindre més pendent.

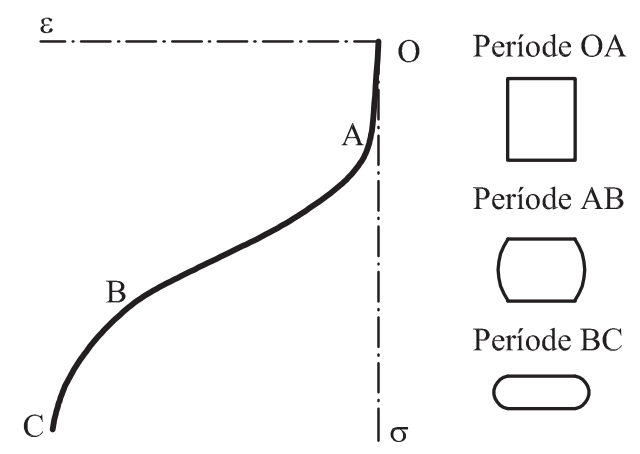

Fig. 3.27. Comportament a compressió d'un acer dúctil

Els materials fràgils a compressió també tenen una regió inicial que és lineal, seguida d'una zona on s'incrementa l'acurtament a un ritme més elevat que la càrrega. El diagrama tensió-deformació té un perfil similar al de tracció. Tanmateix, els materials fràgils solen arribar a tensions últimes més elevades a compressió que a tracció. Per exemple, el formigó té una resistència deu vegades més gran a compressió que a tracció. Una altra diferència amb els materials dúctils és que els materials fràgils es trenquen a compressió.

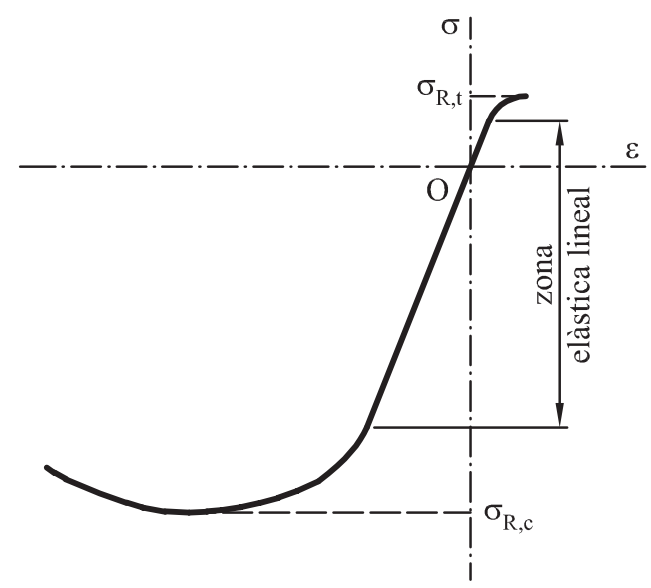

Fig. 3.28. Comportament del formigó a tracció i compressió

\subsubsection{Diagrames idealitzats}

Els diagrames que hem vist fins ara poden no ser pràctics per a treballar amb ells, per la qual cosa, en determinades circumstàncies, els reemplacem per diagrames idealitzats. El diagrama idealitzat d'un material dúctil consta de dos trams rectes, un d'ells inclinat, que correspon al període elàstic; l'altre horitzontal, el qual representa el període de fluència. L'últim període d'enduriment realment no interessa, perquè abans d'arribar-hi, considerarem que el material ha fallat. 
En els materials fràgils, com que el límit de proporcionalitat està tan pròxim al de trencament, només representem el tram recte corresponent al període lineal.

Per als materials plàstics, el diagrama és una recta horitzontal. Representa que si estan sotmesos a una càrrega, es deformen indefinidament sense necessitat d'augmentar la tensió.

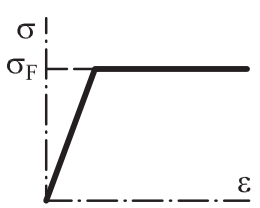

a)

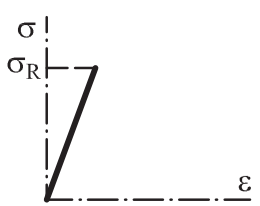

b)

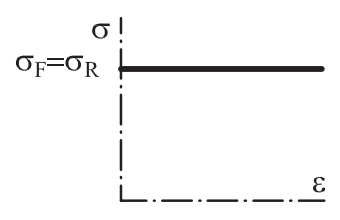

c)

Fig. 3.29. Diagrames idealitzats: $a$ ) dúctil; $b$ ) fràgil; $c$ ) plàstic

Els acers de construcció tenen un comportament paregut en tracció i en compressió (si la peça no és molt esvelta), i solen representar-se mitjançant diagrames trilineals.

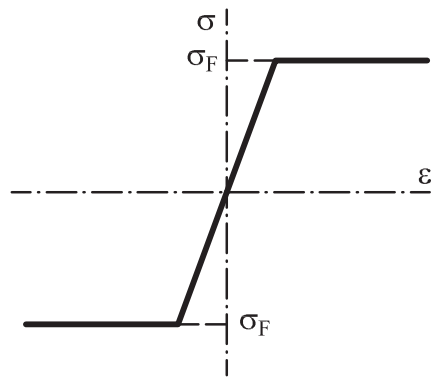

Fig. 3.30. Diagrama trilineal de l'acer de construcció

\subsection{Efecte de la temperatura}

És conegut per tothom que la major part dels cossos augmenten les seues dimensions quan augmenta la temperatura, i al contrari: si baixa la temperatura, les seues dimensions disminueixen.

Normalment, dins d'un rang de temperatura determinat, podem suposar que hi ha una relació lineal entre la variació de temperatura i la deformació que es produeix com a conseqüència.

$$
\varepsilon_{T}=\alpha \cdot \Delta T
$$

El coeficient de proporcionalitat és una constant del material, denominat coeficient de dilatació tèrmica lineal. Les seues unitats són ${ }^{\circ} \mathrm{C}^{-1}$, de manera que en multiplicar per la variació de temperatura en ${ }^{\circ} \mathrm{C}$, el resultat és adimensional (com 
han de ser les deformacions). Per exemple, el coeficient de dilatació tèrmica de l'acer és: $\alpha=1,2 \cdot 10^{-5}{ }^{\circ} \mathrm{C}^{-1}$. Els coeficients són positius, de manera que una variació de temperatura positiva (calfament) ens proporcionarà una deformació positiva (dilatació) i una variació de temperatura negativa (refredament) ens donarà una deformació negativa (contracció).

L'equació anterior és aplicable als sòlids en absència de tensions. Si existeixen tensions addicionals, la deformació que produeixen les tensions ha de sumar-se a la deformació per causa de la temperatura. Les deformacions que provoca la temperatura són sempre del tipus longitudinal, no afecten les deformacions angulars.

La llei de Hooke, si tenim en consideració la temperatura, ens queda:

$$
\begin{array}{ll}
\varepsilon_{X}=\frac{1}{E}\left(\sigma_{X}-\mu\left(\sigma_{Y}+\sigma_{Z}\right)\right)+\alpha \cdot \Delta T & \gamma_{X Y}=\frac{\tau_{X Y}}{G} \\
\varepsilon_{Y}=\frac{1}{E}\left(\sigma_{Y}-\mu\left(\sigma_{X}+\sigma_{Z}\right)\right)+\alpha \cdot \Delta T & \gamma_{X Z}=\frac{\tau_{X Z}}{G} \\
\varepsilon_{Z}=\frac{1}{E}\left(\sigma_{Z}-\mu\left(\sigma_{X}+\sigma_{Y}\right)\right)+\alpha \cdot \Delta T & \gamma_{Y Z}=\frac{\tau_{Y Z}}{G}
\end{array}
$$

Si considerem només el simplificat cas freqüent, del qual hem parlat anteriorment:

$$
\begin{array}{ll}
\varepsilon_{X}=\frac{\sigma_{X}}{E}+\alpha \cdot \Delta T & \gamma_{X Y}=\frac{\tau_{X Y}}{G} \\
\varepsilon_{Y}=-\mu \frac{\sigma_{X}}{E}+\alpha \cdot \Delta T & \gamma_{X Z}=\frac{\tau_{X Z}}{G} \\
\varepsilon_{Z}=-\mu \frac{\sigma_{X}}{E}+\alpha \cdot \Delta T & \gamma_{Y Z}=0
\end{array}
$$

La variació de dimensions d'una peça com a conseqüència de la temperatura no genera tensions addicionals, mentre la deformació no estiga impedida. En el moment en què una peça tinga impedit o limitat algun moviment, si apliquem una variació de temperatura, apareixeran tensions en la direcció corresponent. Aquesta és la raó de l'existència de les juntes de dilatació.

Un altre efecte de la temperatura el trobem en les estructures metàl-liques en les quals les unions es fan per soldadura. Com que s'aporta una gran quantitat de calor, apareixeran tensions addicionals en les juntes d'unió, que moltes vegades no són tingudes en compte.

\section{Exemple 3.2}

Tenim una biga d'acer com la de la figura, a la qual se li aplica un increment de temperatura només en una de les meitats. La secció és rectangular massissa de 4 x $6 \mathrm{~cm}$. Calculeu les tensions i les dimensions finals de la biga. No considereu el pes propi.

Dades: $\mathrm{L}=5 \mathrm{~m} ; \mathrm{E}=210 \mathrm{GPa} ; \alpha=1,2 \cdot 10^{-5}{ }^{\circ} \mathrm{C}^{-1} ; \Delta \mathrm{T}=100^{\circ} \mathrm{C} ; \mu=0,3$. 
Anomenarem peça 1 a la meitat amb l'increment de temperatura, i peça 2 a l'altra part. Com que no hi ha càrregues i la deformació no està impedida, no apareixeran tensions i la deformació serà la mateixa als tres eixos en la peça 1, i zero en la peça 2:

$\varepsilon_{X 1}=\varepsilon_{Y 1}=\varepsilon_{Z 1}=\alpha \cdot \Delta \mathrm{T}=1,2 \cdot 10^{-3}$

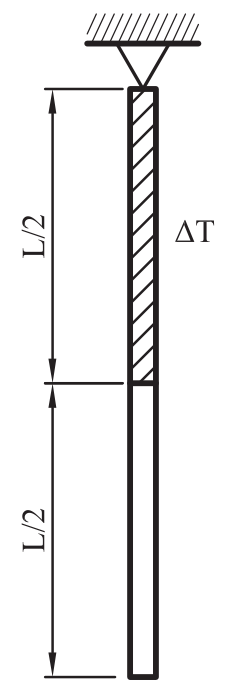

Fig. 3.31. Exemple 3.2

La variació de longitud de la peça 1: $\Delta L_{1}=\varepsilon_{X 1} \cdot \frac{L}{2}=0,003 \mathrm{~m}$.

La longitud final: $L_{f 1}=\frac{L}{2}+\Delta L_{1}=2,503 \mathrm{~m}$.

Com que la peça 2 no es deforma, la longitud final de la barra és: $\mathrm{L}_{f}=5,003 \mathrm{~m}$.

Les dimensions laterals de la peça 1 varien, però les de la peça 2 es mantenen iguals.

$a_{f 1}=a \cdot+\Delta a_{1}=a+a \cdot \varepsilon_{Y 1}=4 \cdot\left(1+1,8 \cdot 10^{-4}\right)=4,005 \mathrm{~cm}$

$b_{f 1}=b \cdot+\Delta b_{1}=b+b \cdot \varepsilon_{Z 1}=6 \cdot\left(1+1,8 \cdot 10^{-4}\right)=6,007 \mathrm{~cm}$

\section{Exemple 3.3}

Repetiu l'exercici anterior si les condicions de sustentació de la biga es canvien per les de la figura 3.32 .

En aquest cas, la longitud final de la peça ha de ser la mateixa, a causa de l'altre recolzament que apareix. Per tant, podem dir que la variació total de longitud és zero. La variació global de longitud és la suma de les variacions de longitud de cadascuna de les parts. 
La peça 1 està sotmesa a un increment de temperatura, i tractarà de dilatar-se. D'altra banda, la peça 2 no la deixa dilatar-se tant com ho faria si estiguera lliure. Per tant, la peça 1 estarà comprimida. La peça 2 serà espentada per la peça 1 , en el seu intent per dilatar-se, i també estarà comprimida.

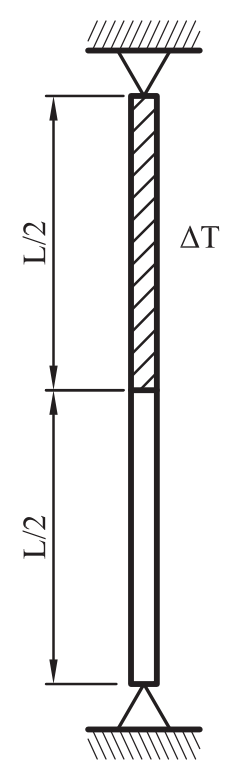

Fig. 3.32. Exemple 3.3

La força que fa una peça sobre l'altra, pel principi d'acció-reacció, serà la mateixa i de sentit oposat. La tensió és una força dividida per una superfície. En aquest cas, les superfícies són iguals en ambdues peces, i com a conseqüència, les tensions també ho són.

$\mathrm{F}_{(1-2)}=\mathrm{F}_{(2-1)} \rightarrow \sigma_{X 1} \cdot \mathrm{A}_{1}=\sigma_{X 2} \cdot \mathrm{A}_{2} \rightarrow \sigma_{X 1}=\sigma_{X 2}$

$\Delta L=0=\Delta L_{1}+\Delta L_{2} \quad \Delta L_{1}=\frac{L}{2} \varepsilon_{X 1} \quad \Delta L_{2}=\frac{L}{2} \varepsilon_{X 2}$

Com que les tensions són iguals, les anomenarem amb la mateixa lletra $(\sigma)$.

$\varepsilon_{X 1}=\frac{\sigma}{E}+\alpha \cdot \Delta T \quad \varepsilon_{X 2}=\frac{\sigma}{E} \quad\left(\frac{\sigma}{E}+\alpha \cdot \Delta T\right) \frac{L}{2}+\left(\frac{\sigma}{E}\right) \frac{L}{2}=0$

Podem aïllar la tensió:

$$
\sigma=\frac{-\alpha \cdot \Delta T \cdot E}{2}=\frac{-1,2 \cdot 10^{-5} \cdot 100 \cdot 210 \cdot 10^{9}}{2}=-1,26 \cdot 10^{9} \mathrm{~Pa}
$$

Ja podem calcular totes les variacions dimensionals:

$\begin{aligned} \varepsilon_{X 1} & =6 \cdot 10^{-4} \\ \varepsilon_{X 2} & =6 \cdot 10^{-4}\end{aligned}$

$$
\begin{array}{ll}
\Delta L_{1}=1,5 \cdot 10^{-3} m & L_{f 1}=2,5015 m \\
\Delta L_{2}=-1,5 \cdot 10^{-3} m & L_{f 1}=2,4985 m
\end{array}
$$$$
\varepsilon_{X 2}=6 \cdot 10^{-4}
$$ 


$$
\begin{array}{lll}
\varepsilon_{Y 1}=\frac{-\mu \cdot \sigma}{E}+\alpha \cdot \Delta \mathrm{T}=1,38 \cdot 10^{-3} & \Delta a_{1}=5,52 \cdot 10^{-3} \mathrm{~cm} & a_{f 1}=4,0055 \mathrm{~cm} \\
\varepsilon_{Y 2}=\frac{-\mu \cdot \sigma}{E}=1,8 \cdot 10^{-3} & \Delta a_{2}=7,2 \cdot 10^{-4} \mathrm{~cm} & a_{f 2}=4,0007 \mathrm{~cm} \\
\varepsilon_{Z 1}=\varepsilon_{Y 1} & \Delta b_{1}=8,28 \cdot 10^{-3} \mathrm{~cm} & b_{f 1}=6,0083 \mathrm{~cm} \\
\varepsilon_{Z 2}=\varepsilon_{Y 2} & \Delta b_{2}=1,08 \cdot 10^{-3} \mathrm{~cm} & b_{f 2}=6,0011 \mathrm{~cm}
\end{array}
$$

Quant a les propietats mecàniques del material, la temperatura també té la seua influència. Per exemple, en assajos fets a acers amb baix contingut de carboni (0,15\%) (Stiopin, 1968: 45-46), un increment de temperatura fa disminuir el límit elàstic i el límit de proporcionalitat. Tanmateix, la tensió de trencament és superior a la que es té en condicions normals, fins que arribem a $300^{\circ} \mathrm{C}$. A partir d'aquesta temperatura, el valor cau sobtadament. A més, la capacitat de deformació és molt variable segons la temperatura.

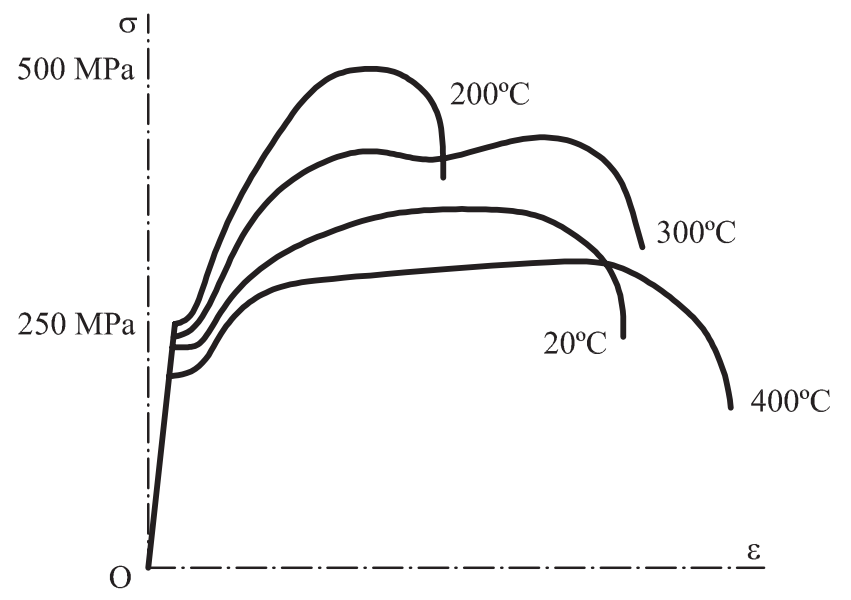

Fig. 3.33. Influència de la temperatura en un acer amb baix contingut en carboni

\subsection{Influència del temps}

Els diagrames tensió-deformació amb els quals s'ha treballat fins ara, se suposa que han sigut obtinguts d'assajos que involucren cicles estàtics de càrrega de les provetes. Per tant, en l'anàlisi no ha sigut considerada la variable temps. Tanmateix a alguns materials els afecta que les càrregues siguen mantingudes per períodes prolongats de temps. Aquest fenomen, denominat en anglés creep, pot manifestar-se de diverses maneres.

Fluència plàstica. Imaginem una barra penjada verticalment, carregada amb una força $\mathrm{P}$. Com a conseqüència de la càrrega, es produeix una deformació que podríem considerar immediata (encara que no ho és totalment, realment necessita un cert temps per a desenvolupar-se) a l'instant inicial $\left(\varepsilon_{0}\right)$. Si mantenim la càrrega constant, a causa del flux plàstic, la barra pot augmentar gradualment la seua longitud, com podem veure en el gràfic de la figura 3.34. 
Cansament o relaxació. Imaginem ara una barra que s'estira entre dos recolzaments fixos, de maenra que la longitud inicial es manté constant, i la tensió inicial és $\sigma_{0}$. Amb el temps, la tensió disminuirà gradualment, fins que al final s'arribarà a un valor constant. Aquest fenomen també és una manifestació del flux plàstic. El cansament pot produir-se en les armadures pretensades de les peces prefabricades de formigó, o en les armadures posttesades.

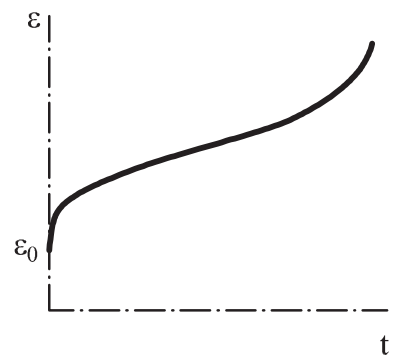

a)

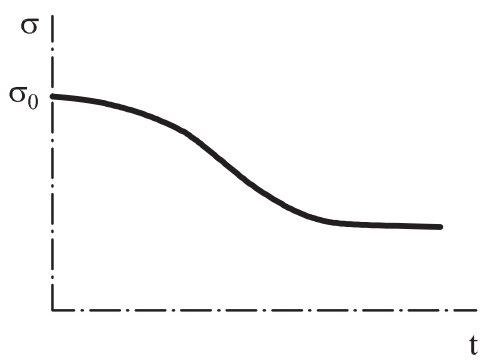

b)

Fig. 3.34. Efecte del temps: $a$ ) fluència; $b$ ) cansament

El flux plàstic és més important a temperatures elevades que en condicions normals, i per tant, és important tindre-ho present quan es fa el disseny d'estructures que han de treballar a altes temperatures durant llargs períodes de temps. L'homogeneïtat del material també té la seua influència sobre el fenomen: en els materials més heterogenis, la fluència i relaxació és major.

\subsection{Concepte de fallada i coeficient de seguretat}

\subsubsection{Concepte de fallada}

Una estructura serà tècnicament acceptable si satisfà tots els requisits de seguretat i funcionament. La seguretat exigeix que l'estructura siga capaç de suportar les càrregues a les quals estarà sotmesa, durant la seua vida projectada. Les càrregues de disseny, aquelles que suposem que actuaran sobre l'estructura, poden establir-se mitjançant codis, normatives o especificacions, o a partir de càrregues reals de servei que siguen conegudes.

La vida útil d'una estructura concreta finalitza quan les condicions de servei canvien, de tal manera que l'estructura es torna antieconòmica o insegura, o quan falla. La fallada d'una estructura no fa referència al trencament de l'element, sinó a l'incompliment dels requisits establerts per al seu ús normal. Aquests requisits poden ser: una tensió inacceptable, deformacions excessives, desplaçaments, vibracions, o qualsevol altre dany indesitjable.

En l'assignatura que ens ocupa, considerarem que els materials han de treballar en la zona elàstica lineal, i si se supera el límit elàstic, assumirem que l'estructura ha deixat de ser vàlida. En materials dúctils, aquesta tensió està molt lluny de la de trencament, però en els fràgils estan més prop l'una de l'altra. 
Existeixen mètodes de càlcul que permeten arribar fins a la plastificació de les seccions d'acer estructural, però es tracta d'un mètode avançat que queda fora dels objectius d'aquest curs. Com es veurà en assignatures posteriors, en els càlculs de formigó armat, també s'assumeix la plastificació de les armadures.

\subsubsection{Coeficients de seguretat}

En el càlcul d'estructures tenim tota una sèrie d'incerteses que hem de cobrir amb coeficients de seguretat:

- Les càrregues que actuen sobre una estructura poden ser del tipus determinista, en el qual la càrrega és perfectament coneguda i invariable. No obstant això, en la major part d'estructures d'edificació, les càrregues seran del tipus probabilista. Les càrregues de vent, neu, sisme, sobrecàrregues d'ús o accidentals, tèrmiques, etc., no són conegudes al $100 \%$. Únicament es pot fer una aproximació a partir de dades estadístiques d'ocurrència de valors màxims, o criteris pessimistes d'ús. És per això que les normatives exigeixen la utilització de coeficients de seguretat per a les càrregues. Aquests coeficients són majors que la unitat.

- Les característiques dels materials emprats no sempre són exactament les especificades, a causa, per exemple, del procés de fabricació. Això pot fer que la resistència del material siga menor que la que es pensa. Habitualment s'utilitza un coeficient de seguretat que minora la resistència del material. Segons la fiabilitat del procés de fabricació el coeficient serà major o menor i vindrà indicat en la normativa específica.

- Altres condicionants també poden fer apropiat l'ús d'un coeficient de seguretat, com ara la falta de precisió en l'execució de l'estructura, el deteriorament dels materials amb el temps, la precisió en els mètodes d'anàlisi, si la fallada és gradual o sobtada, si les conseqüències de la fallada són catastròfiques, etc.

Un coeficient de seguretat sobre la resistència és una constant que minora la tensió màxima que estem disposats a assumir. Com ja hem dit a l'apartat anterior, en materials dúctils no deixarem que el material arribe al límit elàstic, per tal d'assegurar que treballarà segons el règim elàstic.

$$
\sigma_{a d m}=\frac{\sigma_{E}}{n_{s}}
$$

En materials dúctils, com que la tensió de trencament està més prop del límit elàstic, es pot minorar $\sigma_{R}$, però a causa del risc de col-lapse, el coeficient de seguretat serà bastant més elevat. 
Un altre concepte que utilitzen les normatives és una espècie de factor d'aprofitament:

$$
\frac{E_{d}}{E_{a d m}} \leq 1
$$

És a dir, l'esforç de disseny (aquell que hem previst que tindrà una secció determinada segons el càlcul) dividit per l'esforç màxim que és capaç de suportar la secció no ha de ser superior a la unitat. Dit d'una altra manera: l'esforç de disseny no ha de superar l'admissible.

La divisió d'ambdós termes pot ser considerada un factor d'aprofitament, és a dir, un indicador de com de prop està l'estructura d'arribar al seu límit.

\subsection{Criteris de trencament i plastificació}

Els diversos materials estan caracteritzats a partir d'assajos, mitjançant els quals determinarem les tensions de límit elàstic, de trencament, etc., per a unes determinades configuracions de càrrega. Com que els tipus de càrregues i tipus de geometries són infinits, hauríem de fer un assaig per a cada cas particular. Evidentment, això és inviable.

En un cas d'una barra sotmesa a tracció, tenim només una tensió normal, que vindrà en funció de la càrrega que actue sobre ella. Per a un material determinat, tindrem les dades de l'assaig de tracció, que ens donarà el límit elàstic, tensió de trencament, etc. En aquest cas, saber si una barra supera la tensió admissible del material és tan senzill com comparar ambdós valors, la tensió calculada i la de l'assaig.

Quan tenim un cas més complex, podem tindre tensions tangencials i inclús podríem tindre altres tensions normals als altres eixos. La qüestió que se'ns presenta és com comparar aquest estat de tensions tridimensional amb les dades disponibles, que han sigut obtingudes a partir d'un estat de tensions unidimensional (assaig de tracció / compressió).

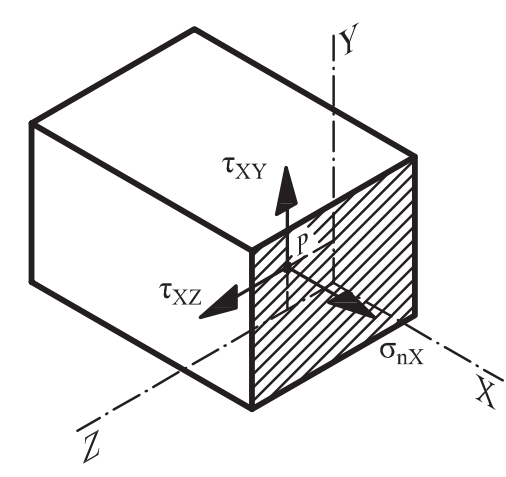

a)

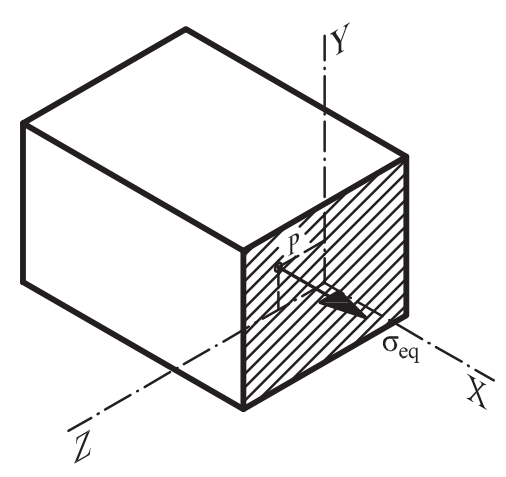

b)

Fig. 3.35. Criteris de trencament: $a$ ) estat tridimensional de tensions; $b$ ) tensió equivalent 
La solució és transformar aquest estat de tensions tridimensional en un estat unidimensional equivalent. El problema és que aquesta transformació no està basada en una teoria única: hi ha diversos autors que han desenrotllat criteris per trobar una tensió equivalent $\left(\sigma_{e q}\right)$. La tensió equivalent és una tensió teòrica que faria que la peça estiguera igual de pròxima a la fallada que quan té l'estat tridimensional real.

Descriurem ara tres dels criteris que existeixen, encara que n'hi ha més, que poden ser trobats a la bibliografia recomanada.

Com a pas previ per a aplicar els criteris, serà necessari el càlcul de les tensions principals.

\subsubsection{Criteri de Rankine o de la màxima tensió normal}

El criteri de la màxima tensió normal estableix que la fallada del material es produirà quan la màxima tensió principal (en valor absolut) siga igual o major que la tensió admissible. Per tant, la tensió equivalent, o tensió de comparació, en aquest criteri és:

$$
\sigma_{e q, R}=\operatorname{màx}\left(\left|\sigma_{1}\right|,\left|\sigma_{3}\right|\right)
$$

Suposem que les tensions principals han sigut ordenades de major a menor i com a conseqüència, la tensió $\sigma_{2}$ no pot ser mai la major en valor absolut.

La predicció de la fallada es fa quan: $\sigma_{e q, R}>\sigma_{a d m}$.

Suposem un estat pla de tensions. El criteri de Rankine és:

$$
\sigma_{e q, R}=\operatorname{màx}\left(\left|\sigma_{1}\right|,\left|\sigma_{2}\right|\right)
$$
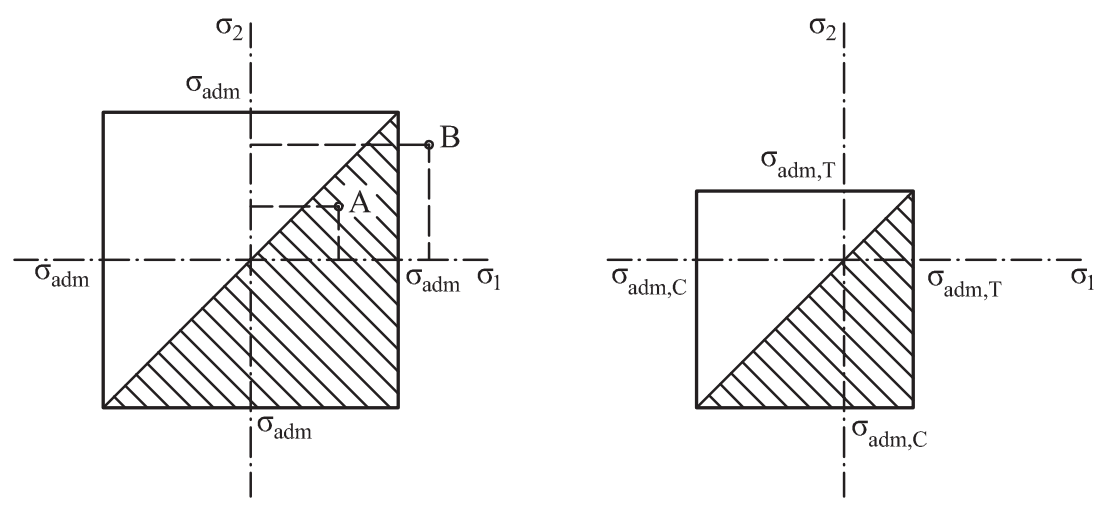

Fig. 3.36. Criteri de Rankine

Això podem representar-ho gràficament, de manera que la parella de tensions principals $\sigma_{1}, \sigma_{2}$ ens donarà un punt al gràfic. El gràfic és diferent si les tensions admissibles a tracció i a compressió són iguals o si no ho són. Si el punt queda dins 
del quadrat (com el punt A) el criteri de Rankine no prediu la fallada, i si queda fora (com el punt $\mathrm{B}$ ) el criteri ens diu que la peça fallarà. Com que les tensions han sigut ordenades de major a menor, l'única zona possible dins del quadrat és la zona ratllada $\left(\sigma_{1}>\sigma_{2}\right)$.

Els experiments ens diuen que aquest criteri no resulta vàlid per a predir la fallada de materials dúctils, però prediu raonablement bé les fallides a tracció de materials fràgils, com ara vidre i ferro colat.

\subsubsection{Criteri de Tresca o de la màxima tensió tangencial}

Aquest criteri estableix que la fallada del material per fluència succeeix, en un estat tensional determinat, quan la tensió tangencial màxima és igual o major que la màxima tensió tangencial que es produeix a l'assaig de tracció. Com que no hem entrat en profunditat en l'estudi de les tensions i com es relacionen entre elles, simplement direm que pot demostrar-se que la màxima tensió tangencial és la meitat de la diferència entre les tensions principals extremes. Així mateix, en l'assaig de tracció totes les tensions són nul·les, a excepció de $\sigma_{1}$, i en el punt on s'arriba al límit elàstic $\sigma_{1}=\sigma_{\mathrm{E}}$.

El criteri de Tresca prediu la fallada si: $\tau_{m a ́ x}=\frac{\sigma_{1}-\sigma_{3}}{2}>\frac{\sigma_{E}}{2}$.

És a dir, podem considerar com a tensió equivalent de Tresca la que podem comparar amb la tensió admissible:

En el cas tridimensional: $\sigma_{e q, T}=\sigma_{1}-\sigma_{3}$.

En tensió plana: $\sigma_{e q, T}=\sigma_{1}-\sigma_{2}$.

Si fem una representació gràfica similar a l'anterior, la predicció de la fallada es produirà si el punt representatiu de les tensions principals es troba fora del polígon de la figura.
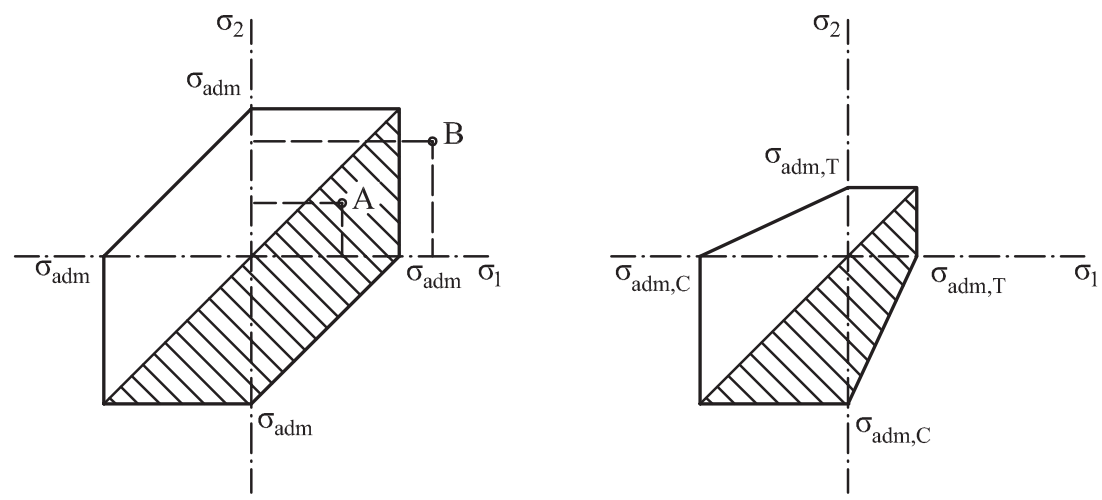

Fig. 3.37. Criteri de Tresca 
Si en el punt d'estudi només existeixen les tensions $\sigma_{X}$ i $\tau_{X Y}$ (situació relativament habitual), no fa falta calcular les tensions principals i el criteri se simplifica:

$$
\sigma_{e q, T}=\sqrt{\sigma_{X}^{2}+4 \tau_{X Y}^{2}}
$$

Els experiments indiquen que aquesta teoria és vàlida per a materials dúctils, però és lleugerament conservadora. El criteri s'utilitza amb freqüència en aplicacions de disseny pràctic per la seua senzillesa i la seua tendència conservadora.

\subsubsection{Criteri de Von Mises o de la màxima energia de distorsió}

Quan un sòlid es deforma, es desenvolupa una energia de deformació. En el parallelepípede elemental, aquesta energia pot ser descomposta en una part d'energia que s'empra per produir una dilatació del prisma i una altra part que provoca la distorsió angular del paral·lelepípede.

El criteri de Von Mises prediu la fallada quan la màxima energia de distorsió que es produeix al punt iguala o supera la màxima energia de distorsió en l'assaig de tracció. Sense entrar en desenrotllaments dels principis energètics, la tensió equivalent de Von Mises és:

Cas tridimensional: $\sigma_{e q, V M}=\sqrt{\frac{1}{2}\left[\left(\sigma_{1}-\sigma_{2}\right)^{2}+\left(\sigma_{1}-\sigma_{3}\right)^{2}+\left(\sigma_{2}-\sigma_{3}\right)^{2}\right]}$.

Cas bidimensional: $\sigma_{e q, V M}=\sqrt{\sigma_{1}^{2}+\sigma_{2}^{2}-\sigma_{1} \cdot \sigma_{2}}$.

La representació del criteri és una el·lipse, i el criteri predirà la fallada si el punt representatiu queda fora de la zona ratllada.

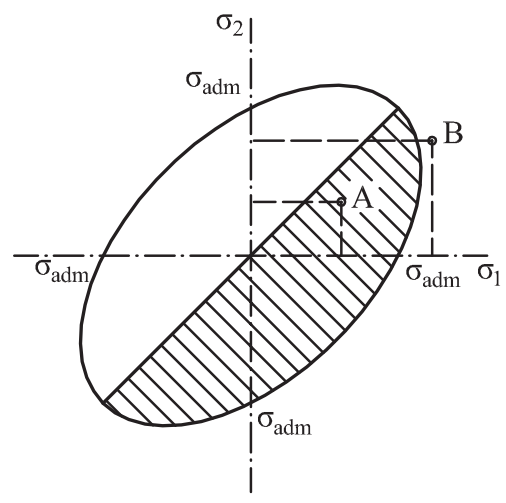

Fig. 3.38. Criteri de Von Mises

Igualment que en el criteri anterior, si en el punt d'estudi només existeixen les tensions $\sigma_{\mathrm{X}} \mathrm{i} \tau_{\mathrm{XY}}$, no fa falta calcular les tensions principals i el criteri se simplifica:

$$
\sigma_{e q, V M}=\sqrt{\sigma_{X}^{2}+3 \tau_{X Y}^{2}}
$$


Els experiments mostren una bona correlació d'aquest criteri amb el comportament dels materials dúctils sotmesos a estats generals de tensió. Aquest criteri és l'únic que es menciona en la normativa actual d'acer.

Podem fer una comparativa entre els tres criteris anteriors en un únic gràfic. Pot apreciar-se que hi ha molta zona comuna en les tres teories, però veiem que alguns punts poden quedar dins en alguna teoria i fora en una altra.

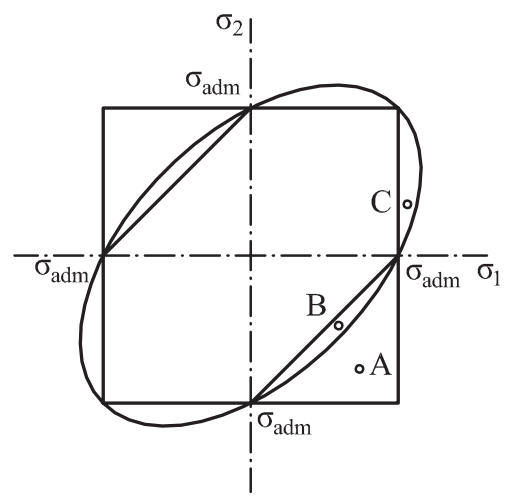

Fig. 3.39. Comparativa de criteris

Si analitzem els punts representats:

- El punt A mostra una situació en la qual el criteri de Rankine no prediu la fallada, però els altres dos criteris sí.

- El punt B és un cas que el criteri de Rankine i el de Von Mises donen per bo, però segons Tresca s'arribaria a la plastificació.

- El punt $\mathrm{C}$ seria acceptable segons Von Mises, però les teories de Rankine $\mathrm{i}$ Tresca prediuen la fallada.

\section{Exemple 3.4}

En un punt d'un element d'acer S275 d'una estructura s'ha realitzat l'estudi dels esforços i tensions, i s'han obtingut els valors següents:

- $\sigma_{\mathrm{nX}}=-90 \mathrm{MPa}$.

- $\tau_{\mathrm{XY}}=85 \mathrm{MPa}$.

- $\tau_{\mathrm{xz}}=110 \mathrm{MPa}$.

a) Obteniu les tensions principals.

b) Estudieu si els criteris de trencament i plastificació de Rankine, Tresca i Von Mises prediuen la fallada del punt. 
Dades: l'acer S275 té una tensió de límit elàstic $\sigma_{\mathrm{E}}=275 \mathrm{MPa}$ (en la normativa d'acer es denomina $f_{y}$ ). El coeficient de seguretat és $n_{s}=1,05$ (en la normativa $\gamma_{M}$ ).

La tensió admissible és:

$f_{y d}=\frac{f_{y}}{\gamma_{M}}=261,91 M P a$

Càlcul de les tensions principals:

$$
\begin{aligned}
& \lambda_{1}=\frac{1}{2}\left(\sigma_{n X}+\sqrt{4 \tau_{X Y}^{2}+4 \tau_{X Z}^{2}+\sigma_{n X}^{2}}\right)=101,12 M P a \\
& \lambda_{2}=\frac{1}{2}\left(\sigma_{n X}-\sqrt{4 \tau_{X Y}^{2}+4 \tau_{X Z}^{2}+\sigma_{n X}^{2}}\right)=-191,12 M P a \\
& \lambda_{3}=0
\end{aligned}
$$

Ordenem les tensions de major a menor.

$$
\begin{aligned}
& \sigma_{1}=101,12 \mathrm{MPa} \\
& \sigma_{2}=0 \\
& \sigma_{3}=-191,12 \mathrm{MPa}
\end{aligned}
$$

aquestes són les tensions principals en el cas tridimensional. No obstant això, podríem considerar-ho simplement com un cas pla: $\begin{gathered}\sigma_{1}=101,12 \mathrm{MPa} \\ \sigma_{2}=-191,12 \mathrm{MPa}\end{gathered}$

En qualsevol dels casos, els resultats seran els mateixos.

Criteri de Rankine: $\sigma_{e q, R}=\operatorname{màx}\left(\left|\sigma_{1}\right|,\left|\sigma_{3}\right|\right)=191,12 M P a$.

Per comparació amb la tensió admissible, veiem que la tensió equivalent és molt menor. Això significa que el criteri de Rankine ens està dient que el punt està bastant lluny de la fallada.

Criteri de Tresca: $\sigma_{e q, T}=\sigma_{1}-\sigma_{3}=292,23 M P a$.

Aquest valor està per damunt de la tensió admissible; per tant, el criteri prediu que el material arribarà a la seua plastificació.

Criteri de Von Mises:

$$
\sigma_{e q, V M}=\sqrt{\frac{1}{2}\left[\left(\sigma_{1}-\sigma_{2}\right)^{2}+\left(\sigma_{1}-\sigma_{3}\right)^{2}+\left(\sigma_{2}-\sigma_{3}\right)^{2}\right]}=257,05 M P a
$$

Segons Von Mises, el punt està prop de la tensió admissible, però no s’hi arriba.

Com que el material és acer (dúctil) sabem que el criteri de Rankine no és adequat. Això es pot veure clarament en els resultats: el criteri de Rankine és molt 
més optimista que els altres dos, que sí que són adequats per a materials dúctils. Podríem tindre el dubte de si finalment fallaria el material o no, perquè el criteri de Von Mises ens diu que el material està al límit (encara que per sota) i el de Tresca ens diu que el material es trencarà, però ja sabem que aquest criteri és lleugerament pessimista. A partir d'aquestes dades, correspon al tècnic prendre una decisió: acceptar la peça o fer variacions en el disseny perquè les tensions disminuïsquen.

\section{Exemple 3.5}

Considerem un material amb una tensió admissible, tant a tracció com a compressió de $260 \mathrm{MPa}$. Estudieu en cadascun dels casos següents si els criteris de trencament i plastificació prediuen la fallada.

a) $\sigma_{1 a}=200 \mathrm{MPa} ; \sigma_{2 a}=50 \mathrm{MPa} ; \sigma_{3 \mathrm{a}}=-150 \mathrm{MPa}$.

- Criteri de Rankine: $\sigma_{e q, R}=\operatorname{màx}\left(\left|\sigma_{1}\right|,\left|\sigma_{3}\right|\right)=200 M P a$. No prediu la fallada.

- Criteri de Tresca: $\sigma_{e q, T}=\sigma_{1}-\sigma_{3}=350 \mathrm{MPa}$. Prediu la fallada.

- Criteri de Von Mises:

$$
\sigma_{e q, V M}=\sqrt{\frac{1}{2}\left[\left(\sigma_{1}-\sigma_{2}\right)^{2}+\left(\sigma_{1}-\sigma_{3}\right)^{2}+\left(\sigma_{2}-\sigma_{3}\right)^{2}\right]}=416,83 M P a
$$

Prediu la fallada.

b) $\sigma_{1 a}=300 \mathrm{MPa} ; \sigma_{2 a}=110 \mathrm{MPa} ; \sigma_{3 a}=50 \mathrm{MPa}$.

- Criteri de Rankine: $\sigma_{e q, R}=m a ̀ x\left(\left|\sigma_{1}\right|,\left|\sigma_{3}\right|\right)=300 M P a$. Prediu la fallada.

- Criteri de Tresca: $\sigma_{e q, T}=\sigma_{1}-\sigma_{3}=250 \mathrm{MPa}$. No prediu la fallada.

- Criteri de Von Mises:

$$
\sigma_{e q, V M}=\sqrt{\frac{1}{2}\left[\left(\sigma_{1}-\sigma_{2}\right)^{2}+\left(\sigma_{1}-\sigma_{3}\right)^{2}+\left(\sigma_{2}-\sigma_{3}\right)^{2}\right]}=290,09 \mathrm{MPa}
$$

Prediu la fallada.

c) $\sigma_{1 a}=-50 \mathrm{MPa} ; \sigma_{2 a}=200 \mathrm{MPa} ; \sigma_{3 a}=-270 \mathrm{MPa}$.

- Criteri de Rankine: $\sigma_{e q, R}=\operatorname{màx}\left(\left|\sigma_{1}\right|,\left|\sigma_{3}\right|\right)=270 M P a$. Prediu la fallada.

- Criteri de Tresca: $\sigma_{e q, T}=\sigma_{1}-\sigma_{3}=220 \mathrm{MPa}$. No prediu la fallada.

- Criteri de Von Mises:

$$
\sigma_{e q, V M}=\sqrt{\frac{1}{2}\left[\left(\sigma_{1}-\sigma_{2}\right)^{2}+\left(\sigma_{1}-\sigma_{3}\right)^{2}+\left(\sigma_{2}-\sigma_{3}\right)^{2}\right]}=254,07 \mathrm{MPa}
$$

No prediu la fallada.

Conclusió: poden existir estats de tensió en els quals els tres criteris ens donen resultats diferents. Per aquesta raó, es fa necessari saber quin d'ells resulta més apropiat en cada cas concret, segons el material i el tipus de càrregues analitzades. 


\subsection{Principi de superposició}

Si el comportament del material és lineal (existeix una relació de proporcionalitat entre tensions i deformacions), pot enunciar-se el principi de superposició d'efectes: «l'efecte causat per diverses càrregues actuant simultàniament sobre un sòlid és igual a la suma d'efectes causats per cadascuna de les càrregues actuant separadament».

D'acord amb aquest principi, els efectes d'una càrrega són independents del fet que existisquen prèviament unes altres càrregues aplicades, $i$ els efectes són iguals als que produiria si el sòlid estiguera descarregat.

Aquest principi serà vàlid si assumim el principi de petita deformació, segons el qual l'efecte d'una càrrega no afecta la manera en què s'apliquen les altres càrregues.

Quan en la definició diem «efecte» ens referim tant a les reaccions com als esforços, les tensions i les deformacions.

\section{Exemple 3.6}

Comproveu el principi de superposició en la biga voladissa següent (cotes en m):

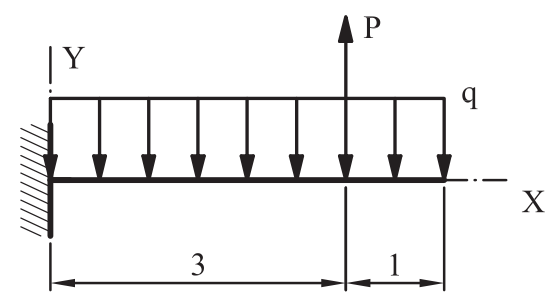

Fig. 3.40. Exemple 3.6. Enunciat

Dades: $\mathrm{P}=30 \mathrm{kN} ; \mathrm{q}=10 \mathrm{kN} / \mathrm{m} ; \mathrm{L}=4 \mathrm{~m}$.

El principi de superposició afirma que el sistema anterior pot descompondre's en dos sistemes, de manera que la suma dels efectes d'aquests dos sistemes siga igual als efectes del sistema inicial.

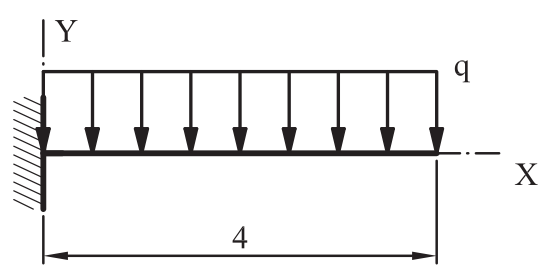

a)

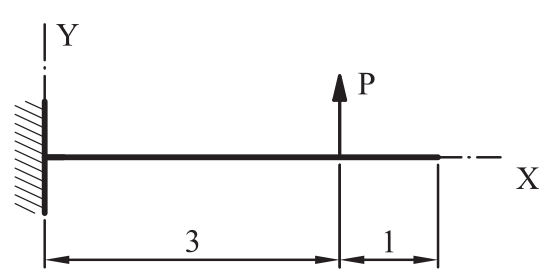

b)

Fig. 3.41. Exemple 3.6. Descomposició del sistema: $a$ ) subsistema 1; $b$ ) subsistema 2 
Calculem primer les reaccions. Subsistema 1:

$\sum \overrightarrow{F_{X}}=0 \rightarrow R_{A X 1}=0$

$\sum \overrightarrow{F_{Y}}=0 \rightarrow R_{A Y 1}=q \cdot L=10 \mathrm{kN}$

$\sum M_{Z A}=0 \rightarrow M_{A Z 1}=q \cdot L \cdot \frac{L}{2}=80 \mathrm{kN} \cdot \mathrm{m}$ (antihorari)

Subsistema 2:

$\sum F_{X}=0 \rightarrow R_{A X 2}=0$

$\sum F_{Y}=0 \rightarrow R_{A Y 2}=-P=-30 k N$

$\sum M_{Z A}=0 \rightarrow M_{A Z 2}=-P \cdot \frac{3 L}{4}=-90 \mathrm{kN} \cdot \mathrm{m}($ horari $)$

Sistema complet:

$\sum \overrightarrow{F_{X}}=0 \rightarrow R_{A X}=0$

$\sum \overrightarrow{F_{Y}}=0 \rightarrow R_{A Y}=q \cdot L-P=10 \mathrm{kN}$

$\sum \overrightarrow{M_{Z A}}=0 \rightarrow M_{A Z}=\frac{q \cdot L^{2}}{2}-P \cdot \frac{3 L}{4}=-10 \mathrm{kN} \cdot \mathrm{m}($ horari $)$

Resulta immediat adonar-se que:

$R_{A X}=R_{A X 1}+R_{A X 2}$

$R_{A Y}=R_{A Y 1}+R_{A Y 2}$

$M_{A Z}=M_{A Z 1}+M_{A Z 2}$

Representem ara les lleis d'esforços tallants i moments flectors.

Subsistema 1:

$(0 \leq \mathrm{x} \leq 4 \mathrm{~m}) \quad V_{Y 1}(x)=40-10 x$
$M_{Z 1}(x)=40 x-5 x^{2}-80$

Subsistema 2:

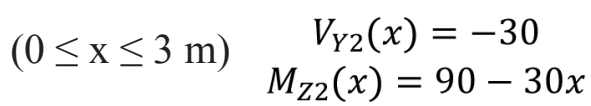

$$
\begin{aligned}
& (3 \mathrm{~m} \leq \mathrm{x} \leq 4 \mathrm{~m}) \begin{array}{c}
V_{Y 2}(x)=0 \\
M_{Z 2}(x)=0
\end{array}
\end{aligned}
$$


Sistema complet:

$V_{Y}(x)=10-10 x$
$(0 \leq \mathrm{x} \leq 3 \mathrm{~m}){ }_{M_{Z}}(x)=10 x-5 x^{2}+10$

$V_{Y}(x)=40-10 x$
$(3 \mathrm{~m} \leq \mathrm{x} \leq 4 \mathrm{~m}) M_{Z}(x)=40 x-5 x^{2}-80$

És també immediata la verificació del fet que:

$V_{Y}(x)=V_{Y 1}(x)+V_{Y 2}(x)$

$M_{Z}(x)=M_{Z 1}(x)+M_{Z 2}(x)$

(si hi haguera axial, també es verificaria).

La mateixa comprovació la podem fer de manera gràfica.
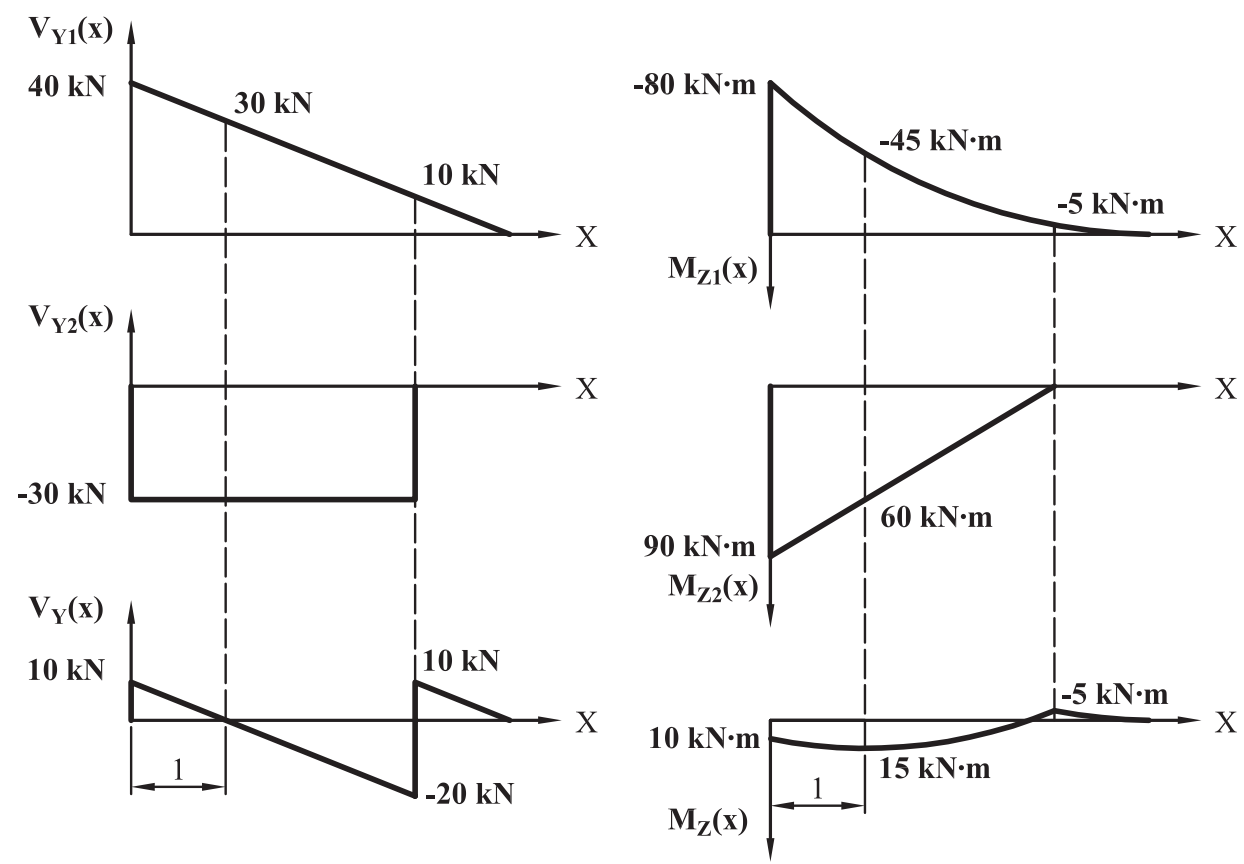

Fig. 3.42. Exemple 3.6. Diagrames d'esforços 


\section{Problemes proposats}

3.1. En un punt d'un element d'acer S275 d'una estructura s'ha realitzat l'estudi de les tensions, i s'ha obtingut el següent resultat:

- $\sigma_{\mathrm{nX}}=150 \mathrm{MPa}$.

- $\tau_{\mathrm{XY}}=50 \mathrm{MPa}$.

- $\tau_{\mathrm{xz}}=120 \mathrm{MPa}$.

a) Calculeu les tensions principals.

b) Estudieu si els criteris de trencament i plastificació de Rankine, Tresca i Von Mises prediuen la fallada del material.

Dades: per a l'acer S275, la tensió de límit elàstic és $\mathrm{f}_{\mathrm{y}}=275 \mathrm{MPa}$ i el coeficient de seguretat és $\gamma_{\mathrm{M}}=1,05$.

3.2. Tenim un cilindre d'acer $\mathrm{S} 275$ que a una temperatura de $20^{\circ} \mathrm{C}$ mesura $5 \mathrm{~cm}$ de diàmetre i $20 \mathrm{~cm}$ de llargada. Si introduïm el cilindre en un forn a $150^{\circ} \mathrm{C}$, calculeu:

a) Dimensions finals del cilindre.

b) Tensions que s'assoleixen.

c) Si es produirà la fallada del material.

Dades: $\alpha=1,2 \cdot 10^{-5}{ }^{\circ} \mathrm{C}^{-1} ; \mu=0,3 ; \mathrm{E}=210 \mathrm{GPa} ; \mathrm{f}_{\mathrm{y}}=275 \mathrm{MPa} ; \gamma_{\mathrm{M}}=1,05$.

3.3. Considerem el mateix cilindre de l'exercici anterior dins d'un marc perfectament indeformable que impedeix la deformació en l'eix X. Calculeu els mateixos punts de l'exercici anterior quan el cilindre es fica dins del forn. Les deformacions als altres dos eixos no estan impedides.

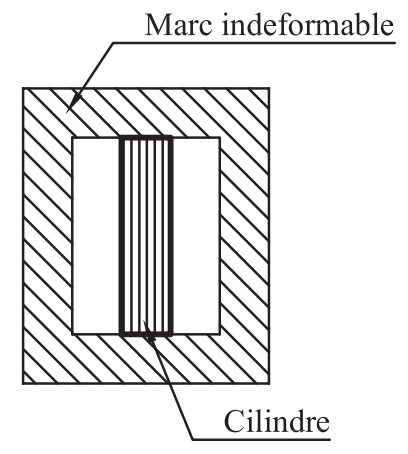

Fig. P.3.03

3.4. Tenim dos prismes rectes de dimensions idèntiques, un d'acer $i$ un altre d'alumini. Les dimensions inicials són $\mathrm{a}=12 \mathrm{~mm}, \mathrm{~b}=10 \mathrm{~mm}$ de base $\mathrm{i}$ $\mathrm{L}=20 \mathrm{~mm}$ d'alçària. Ambdós cilindres estan dins d'un marc indeformable, 
que té un joc entre la peça i la base superior de $\Delta \mathrm{L}=0,1 \mathrm{~mm}$. Les peces tenen suficient joc pels laterals per a considerar que mai es tocaran entre ells ni amb el marc.

Calculeu:

a) L'increment de temperatura necessari en cadascun dels materials perquè es tape el joc superior.

b) Dimensions finals dels prismes quan es tapa el joc.

c) L'increment de temperatura necessari en cadascun dels materials perquè s'arribe al límit elàstic del material.

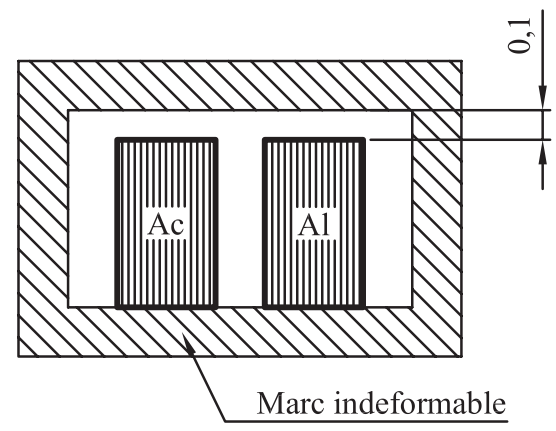

Fig. P.3.04

Dades:

- Per a l'acer, vegeu problema 3.2.

- Per a l'alumini: $\alpha_{\mathrm{al}}=2,4 \cdot 10^{-5} \mathrm{C}^{-1} ; \mu=0,33 ; \mathrm{E}=70 \mathrm{GPa} ; \mathrm{f}_{\mathrm{y}}=90 \mathrm{MPa}$. 


\section{TEMA 4}

\section{Esforç axial}

\subsection{Introducció}

En aquest tema, l'estat de tensions corresponent a un sòlid i una secció recta perpendicular al seu eix serà de tal manera que l'única component d'esforços no nulla, de les sis possibles, serà la component normal $(N)$. Si l'esforç axial és positiu, direm que la peça està treballant a tracció, i si és negatiu, a compressió.

El problema de l'esforç axial és molt important en l'àmbit de l'enginyeria d'edificació. Molts dels elements que s'hi utilitzen treballen únicament suportant aquest esforç, per exemple, cables, tirants, armadures del formigó, puntals, etc. A més, hi ha un tipus d'estructures les barres de les quals només treballen a tracció o compressió. Són les estructures articulades amb càrregues als nucs, com ara les gelosies i encavallades.

Com ja hem vist anteriorment, la relació existent entre tensió normal i esforç axial és:

$$
N=\iint_{\Omega} \sigma_{n X} d A
$$

Als següents punts plantejarem un mètode per a calcular els esforços axials en estructures articulades.

L'existència d'esforç axial provoca en la peça una variació de longitud $(\Delta L)$. Les estructures que estan formades per diverses barres unides entre elles han de moure's d'una manera compatible. En aquest tema estudiarem les deformacions que produeix l'esforç axial i analitzarem com es mouen les estructures de barres.

La compatibilitat de desplaçaments és una eina que ens ajudarà a resoldre els problemes hiperestàtics que es plantegen en la major part dels casos reals, com veurem al final del tema.

\subsection{Distribució de tensions en la secció}

\subsubsection{Hipòtesi de Bernouilli}

A priori no sabem com serà la distribució de tensions als punts d'una secció sotmesa a esforç axial. Per tal de deduir-ho, és necessari assumir una hipòtesi basada en estudis experimentals, la hipòtesi de Bernouilli: «les seccions planes perpendiculars a l'eix de la peça romandran planes i perpendiculars a l'eix de la peça 
després de produir-se la deformació». Les seccions planes es desplacen al llarg de l'eix de la peça, però no giren ni es bomben.

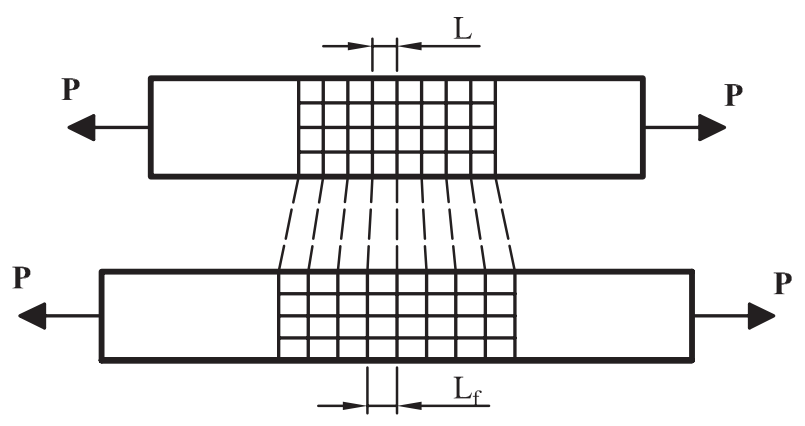

Fig. 4.1. Hipòtesi de Bernouilli

Totes les fibres que tenen una longitud L s'allarguen un mateix $\Delta \mathrm{L}$. Per tant, la deformació longitudinal unitària és la mateixa per a totes elles.

$$
\varepsilon=\frac{\Delta L}{L}
$$

Com que assumim que estem dins de la zona elàstica, es compleix la llei de Hooke:

$$
\sigma=\varepsilon \cdot E
$$

Com que E és una constant, i la deformació també ho és, podem concloure que la tensió també ha de ser una constant. Tots els punts d'una secció sotmesa a esforç axial tenen la mateixa tensió normal. Imaginem ara una barra sotmesa a una càrrega constant $N$ i de secció transversal $A$.

$$
\sigma=\frac{N}{A}
$$

La hipòtesi de Bernouilli també ens diu que les deformacions angulars són zero en les seccions rectes, per la qual cosa, segons la llei de Hooke, les tensions tangencials també ho seran.

L'equació anterior només és vàlida per a punts suficientment allunyats del punt d'aplicació de la càrrega. Prop d'eixos punts té lloc una distribució de tensions més complicada.

\subsubsection{Principi de Saint-Venant}

«El valor de la tensió en els punts d'un sòlid situats suficientment lluny dels punts d'aplicació de la càrrega depén molt poc de la forma d'aplicació de les càrregues.» 
A la figura 4.2, les tres bigues es troben sotmeses a càrregues que són estàticament equivalents. A una distància suficient, la tensió és constant i la mateixa en les tres. En les proximitats de l'extrem la càrrega distribuïda produeix una tensió uniforme, però les càrregues puntuals crearien punts de major tensió al voltant del seu punt d'aplicació i menor en punts allunyats dins de la secció. En tot cas, com a conseqüència d'aquest principi, en la major part dels casos treballarem amb una tensió mitjana dins de la secció.

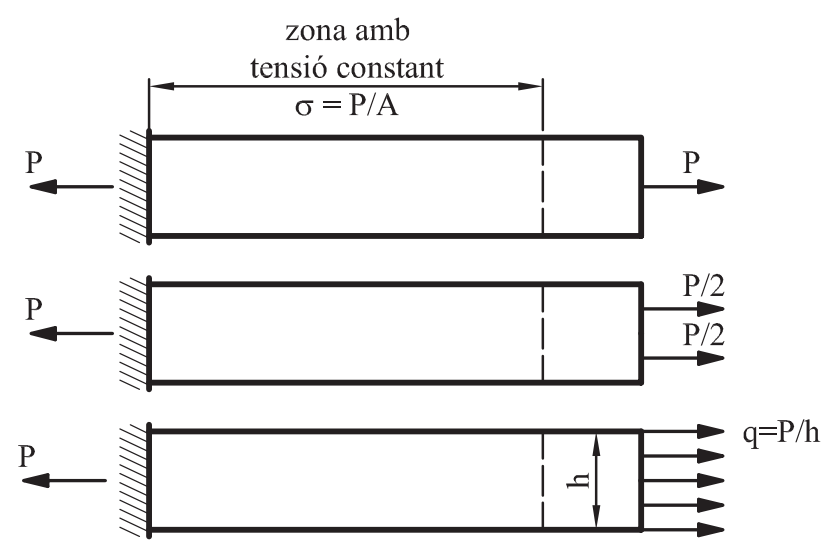

Fig. 4.2. Principi de Saint-Venant

El principi de Saint-Venant és vàlid també per a uns altres tipus d'esforç, no només per a l'axial.

El vector tensió, en absència de tensions tangencials, tindrà la direcció de l'eix X, i per tant, només existirà component normal.

\subsubsection{Efecte de concentració de tensions}

Un concentrador de tensions és una discontinuïtat geomètrica que altera la distribució de tensions en les seues immediacions. La discontinuïtat pot ser un forat, una entalla, un canvi de dimensions, etc. En les proximitats del concentrador, la tensió pot augmentar de manera significativa, inclús duplicant o triplicant la tensió mitjana.
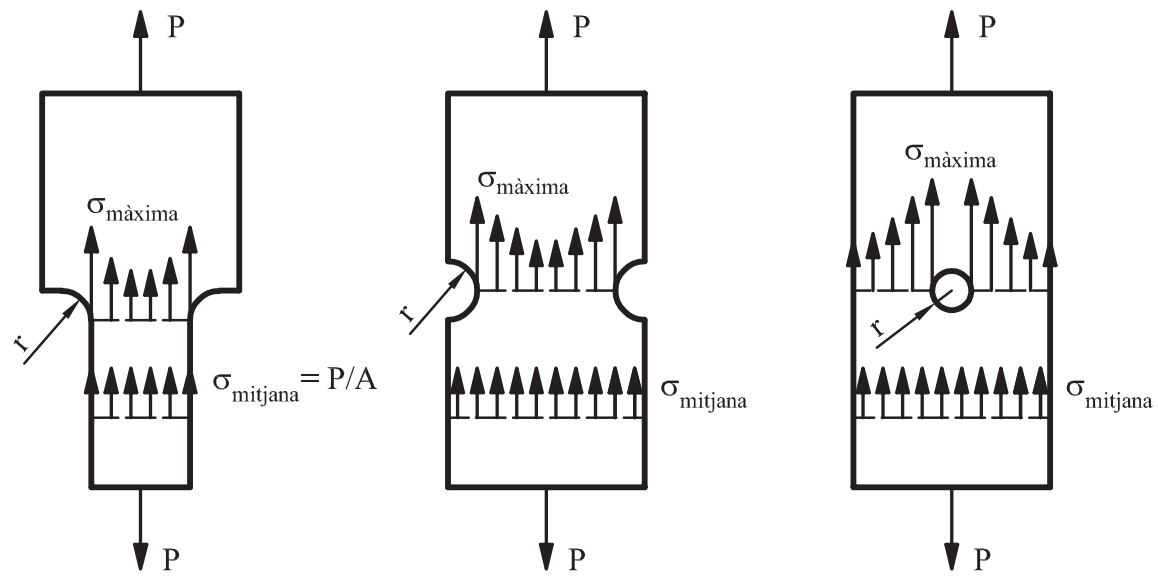

Fig. 4.3. Concentració de tensions 
En els punts de la secció pròxims a la discontinuïtat els models simplificats de resistència de materials no són vàlids per al càlcul exacte del valor real de la tensió. La tensió màxima real en les proximitats del concentrador es pot calcular com el producte de la teòrica, calculada amb el model simplificat, multiplicada per un coeficient, denominat factor teòric de concentració de tensions $\left(\mathrm{K}_{\mathrm{C}}\right)$. Aquest factor es denomina teòric pel fet que només depén de la configuració geomètrica i no del material.

$$
\sigma_{\text {màx }}=K_{C} \cdot \sigma_{\text {nom }}
$$

En l'equació, $\sigma_{\text {nom }}$ és la tensió calculada segons la resistència de materials, per a l'esforç axial, flexió, torsió, etc. En el cas d'axial, és la tensió mitjana.

El coeficient teòric de concentració de tensions s'obté amb formes empíriques o mitjançant eines computacionals, com ara els elements finits. Normalment els factors de concentració de tensions es condensen en àbacs o en programes de càlcul. El coeficient depén d'una configuració de càrregues determinada, de la geometria de l'element en estudi i del concentrador de tensions. Es representa a continuació un àbac a manera d'exemple.

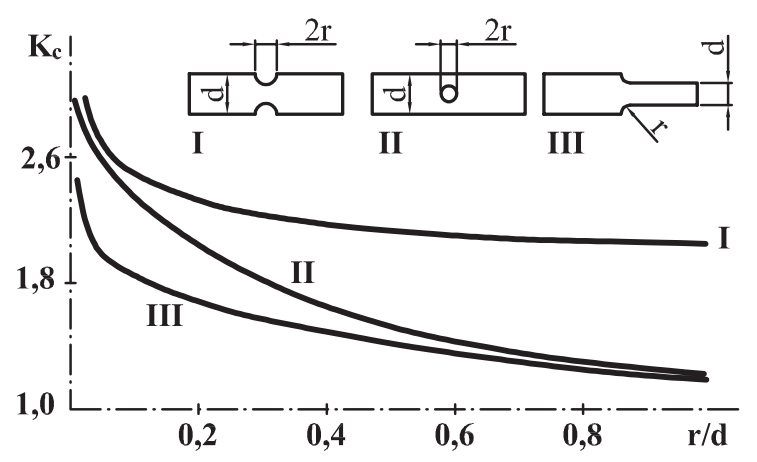

Fig. 4.4. Concentració de tensions (Pisarenko, 1979: 151)

No aprofundirem més en aquest tema, però cal remarcar que l'efecte de concentració de tensions té un major efecte quan el radi de la discontinuïtat és més menut, la qual cosa ha de ser tinguda en compte quan es fa el disseny dels elements estructurals.

Si fem una peça que canvia la seua secció en algun punt de l'eix i no rematem el salt amb un radi d'acord, això serà causa que les tensions en el punt tendisquen a infinit.

Quan un punt concret arriba a la plastificació i trencament, o simplement si existeix un defecte al material que genera un clevill, el radi del fons del clevill també està prop de zero, per la qual cosa serà un concentrador de tensions molt important, i a partir d'aquest punt és possible que el clevill seguisca avançant fins al trencament complet. 


\subsubsection{Tensions sobre una superfície obliqua}

Si sobre un element prismàtic analitzem una secció que no siga normal al seu eix longitudinal, i calculem el vector tensió en un punt, obtindrem un vector que, igual que en els casos anteriors, també porta la direcció de X. Si fem la descomposició del vector tensió per a buscar les components intrínseques respecte del pla oblic, podrem observar que hi apareixen tensions tangencials.

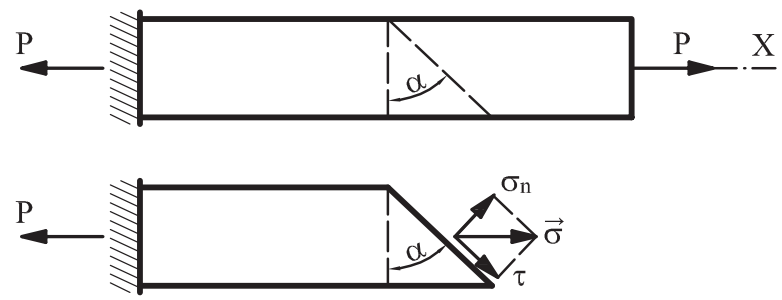

Fig. 4.5. Tensions sobre superfície obliqua

Com ja hem definit abans, la tensió és la força dividida per la superfície. Si la superfície de la secció normal és $\mathrm{A}$, la superfície de la cara obliqua serà $\mathrm{A} / \cos (\alpha)$.

Les components intrínseques seran:

$$
\sigma_{n}=\frac{P \cdot \cos (\alpha)}{A / \cos (\alpha)}=\frac{P}{A} \cos ^{2}(\alpha) \quad \tau=\frac{P \cdot \sin (\alpha)}{A / \cos (\alpha)}=\frac{P}{A} \sin (\alpha) \cos (\alpha)
$$

Això té importància en les unions amb adhesiu o soldades. Aquests elements d'unió treballen bé quan les tensions són tangencials, però no tan bé quan són normals.

\section{Exemple 4.1}

Dues peces de fusta de secció rectangular de $75 \times 150 \mathrm{~mm}$ estan unides amb adhesiu seguint la junta plana que es mostra a la figura. Determineu les tensions normals i tangencials en el pla d'unió.

Dades: $\mathrm{P}=11 \mathrm{kN}$.

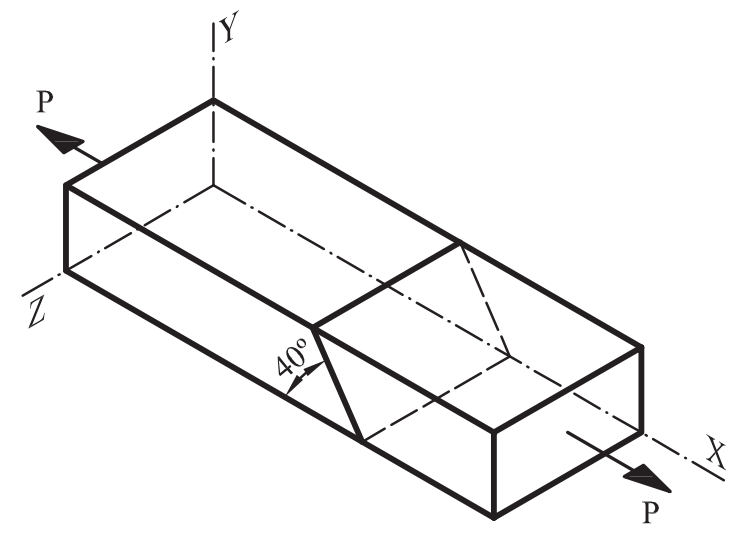

Fig. 4.6. Exemple 4.1 
L'àrea transversal és: $A=0,075 \cdot 0,15=0,011 \mathrm{~m}^{2}$.

L'angle, segons s'ha definit a la figura 4.5: $\alpha=90^{\circ}-40^{\circ}=50^{\circ}$.

Tensió normal: $\sigma_{n}=\frac{P}{A} \cos ^{2}(\alpha)=4,04 \cdot 10^{5} \mathrm{~Pa}$.

Tensió tangencial: $\tau=\frac{P}{A} \sin (\alpha) \cos (\alpha)=4,82 \cdot 10^{5} \mathrm{~Pa}$.

\section{Exemple 4.2}

Considerem la peça de l'exercici anterior. Si la màxima tensió tangencial que pot suportar l'adhesiu és $\tau_{\text {adm }}=6,21 \cdot 10^{5} \mathrm{~Pa}$, calculeu:

a) La màxima càrrega $\mathrm{P}$ que es pot aplicar sense superar la tensió admissible.

b) La tensió normal en eixe cas.

De l'equació de la tensió tangencial, podem aïllar P:

$P=\frac{A \cdot \tau_{a d m}}{\sin (\alpha) \cdot \cos (\alpha)}=14,19 \cdot 10^{3} \mathrm{~N} \quad \sigma_{n}=\frac{P}{A} \cos ^{2}(\alpha)=5,21 \cdot 10^{5} \mathrm{~Pa}$

\section{Exemple 4.3}

Arribats a l'extrem, si la junta és paral·lela a l'eix de la peça, només existiran tensions tangencials.

Si volem unir aquestes dues peces de fusta de gruix e $=22 \mathrm{~mm}$ mitjançant la unió de la figura (cotes en $\mathrm{mm}$ ), calculeu quina ha de ser la dimensió d.

Les línies més gruixudes representen les cares amb adhesiu (no es consideren les cares unides per testa).
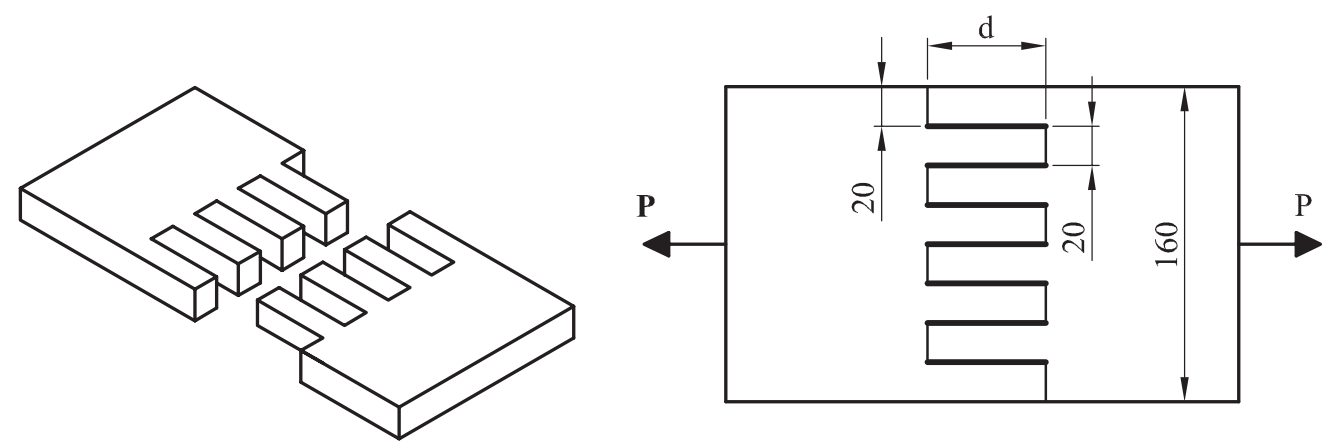

Fig. 4.7. Exemple 4.3

Dades: $\tau_{\text {adm }}=8,27 \cdot 10^{5} \mathrm{~Pa} ; \mathrm{P}=5500 \mathrm{~N}$. 
L'àrea efectiva amb adhesiu serà la de les set cares: $A=7 \cdot 0,022 d=0,154 d$.

Considerem que la càrrega es reparteix igualment en les set cares:

$\tau=\frac{P}{A} \quad 8,27 \cdot 10^{5}=\frac{5500}{0,154 d} \rightarrow d=41,91 . \mathrm{mm} \simeq 42 \mathrm{~mm}$

\subsection{Deformacions longitudinals}

\subsubsection{Variacions de longitud. Allargaments i acurtaments}

Si tenim una barra prismàtica de secció $\mathrm{A}$, sotmesa a una càrrega axial constant $\mathrm{P}$, hem vist que la tensió serà constant en tota la barra. Com que es compleix la llei de Hooke, podem escriure:

$$
\varepsilon=\frac{\sigma}{E} \quad \varepsilon=\frac{\Delta L}{L} \quad \sigma=\frac{P}{A}
$$

Si combinem les tres expressions: $\quad \Delta L=\frac{P \cdot L}{E \cdot A}$.

Si en la barra existeixen trams amb esforços axials diferents, l'allargament global serà la suma dels allargaments de cadascun dels trams.

$$
\Delta L=\sum_{i} \frac{N_{i} \cdot L_{i}}{E_{i} \cdot A_{i}}
$$

Com podem apreciar, en cada tram podem tindre axials, longituds, materials $\mathrm{i}$ àrees diferents.

\section{Exemple 4.4}

Dos cilindres massissos d'acer S275, AB i BC, estan soldats entre ells en B i carregats com mostra la figura (cotes en $\mathrm{cm}$ ). Si negligim el pes propi, determineu:

a) Mínim diàmetre admissible de cada cilindre.

b) Descens del punt C.

Dades: $\mathrm{f}_{\mathrm{y}}=275 \mathrm{MPa} ; \gamma_{\mathrm{M}}=1,05 ; \mathrm{E}=210 \mathrm{GPa} ; \mathrm{P}_{1}=55 \mathrm{kN} ; \mathrm{P}_{2}=45 \mathrm{kN}$.

La reacció en A és: $R_{A}=P 1+P 2=100 \mathrm{kN}$.

Els esforços axials són, al tram AB: $N_{1}=R_{A}=100 \mathrm{kN}$; i al tram BC: $N_{2}=P_{2}=45 \mathrm{kN}$.

La tensió admissible és: $f_{y d}=\frac{f_{y}}{\gamma_{M}}=261,9 M P a$. 


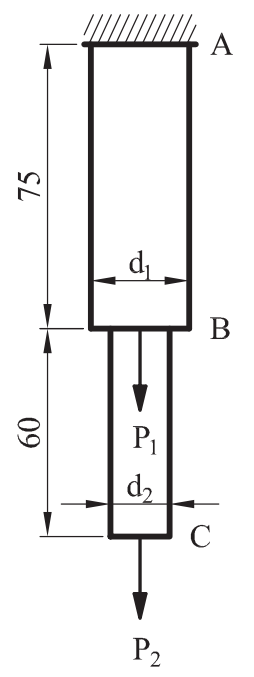

Fig. 4.8. Exemple 4.4

Com que $\sigma=\frac{N}{A} \leq f_{y d}$ i l'àrea d'un cercle és $A=\pi \frac{D^{2}}{4}$ podem aïllar el diàmetre:

$D_{i}=\sqrt{\frac{4 N_{i}}{\pi f_{y d}}}$

i amb les dades que hem obtinguts fins ara, calculem els dos diàmetres:

$D_{1}=0,022 \mathrm{~m}=22 \mathrm{~mm}$

$D_{2}=0,015 \mathrm{~m}=15 \mathrm{~mm}$

L'allargament de cadascun dels trams es calcula mitjançant:

$$
\Delta L_{i}=\frac{N_{i} \cdot L_{i}}{E \cdot A_{i}}=\frac{4 N_{i} \cdot L_{i}}{E \cdot \pi \cdot D_{i}^{2}}
$$

Els resultats obtinguts són:

$\Delta L_{1}=9,39 \cdot 10^{-4} \mathrm{~m}=0,94 \mathrm{~mm}$

$\Delta L_{2}=7,88 \cdot 10^{-4} \mathrm{~m}=0,79 \mathrm{~mm}$

$\Delta L=\Delta L_{1}+\Delta L_{2}=1,73 \cdot 10^{-3} \mathrm{~m}=1,73 \mathrm{~mm}$

El descens del punt $\mathrm{C}$ és equivalent a l'allargament total.

\subsubsection{Variació unitària de volum}

Com ja hem vist al tema 3, quan es produeixen deformacions en un eix, les dimensions als altres dos es veuen afectades també. El coeficient de Poisson ens dóna la relació entre les deformacions longitudinals i les de les dimensions transversals. A causa d'això, el volum després de la deformació no es mantindrà igual a l'inicial. 
Pensem en un prisma recte de dimensions transversals inicials $a_{0} i b_{0}$, i longitud inicial $\mathrm{L}_{0}$.

El volum inicial és: $\mathrm{V}_{0}=\mathrm{a}_{0} \cdot \mathrm{b}_{0} \cdot \mathrm{L}_{0}$.

Després de la deformació, les dimensions varien:

$$
\begin{aligned}
& \mathrm{L}=\left(1+\varepsilon_{\mathrm{X}}\right) \mathrm{L}_{0} \\
& \mathrm{a}=\left(1-\mu \varepsilon_{\mathrm{X}}\right) \mathrm{a}_{0} \\
& \mathrm{~b}=\left(1-\mu \varepsilon_{\mathrm{X}}\right) \mathrm{b}_{0}
\end{aligned}
$$

El volum final és: $\mathrm{V}=\left(1+\varepsilon_{\mathrm{X}}\right) \cdot \mathrm{a}_{0} \cdot\left(1-\mu \varepsilon_{\mathrm{X}}\right) \cdot \mathrm{b}_{0} \cdot\left(1-\mu \varepsilon_{\mathrm{X}}\right) \cdot \mathrm{L}_{0}$.

La variació unitària de volum és: $\frac{\Delta V}{V_{0}}$.

Si fem un senzill desenrotllament i negligim els productes de una deformació per una altra (el resultat del producte de dos nombres molt menuts $\left(\approx 10^{-4}\right)$ és un nombre d'un ordre de magnitud negligible):

$$
\frac{\Delta V}{V_{0}}=\left(1+\varepsilon_{X}\right) \cdot\left(1-\mu \varepsilon_{X}\right) \cdot\left(1-\mu \varepsilon_{X}\right) \simeq \varepsilon_{X}(1-2 \mu)
$$

Observem que la variació unitària de volum depén del coeficient de Poisson. Si el coeficient tendeix a zero, la variació de volum serà màxima, i si tendeix a 0,5 la variació de volum s'aproximarà a zero. Això porta a una conclusió que pot ser sorprenent a primera vista: materials com el cautxú, amb $\mu$ pròxims a 0,5 , mantenen pràcticament el seu volum encara que es deformen molt, i materials amb $\mu$ baixos, com el formigó, varien poc les seues dimensions transversals, però són els que més varien el volum respecte a l'inicial.

D'aquesta expressió sorgeix l'afirmació que s'ha fet al tema 3 sobre el límit superior del coeficient de Poisson. Si tinguérem un $\mu>0,5$, llavors la variació de volum seria negativa, la qual cosa és impossible.

\subsection{Desplaçaments de les seccions}

Les expressions anteriors de $\Delta \mathrm{L}$ són vàlides si l'axial i l'àrea transversal són uniformes a cada tram. Pot ocórrer que l'axial o l'àrea no siguen constants i que siguen una funció de $\mathrm{x}$. En aquest cas, l'equació és més general. Per a un tram determinat $\mathrm{AB}$, podem determinar l'allargament a través de la integral següent, que ens dóna el moviment relatiu entre els punts:

$$
u(A)-u(B)=\int_{A}^{B} \varepsilon(x) d x=\int_{A}^{B} \frac{N(x)}{E \cdot A(x)} d x=\Delta L
$$


En general, es pot conéixer la posició d'un punt concret de la barra, mitjançant una funció $\mathrm{u}(\mathrm{x})$, sempre que coneguem el moviment d'un dels extrems $\mathrm{u}(0)$. Si un dels extrems està fix, llavors el seu desplaçament és zero: $\mathrm{u}(0)=0$.

$$
u(x)-u(0)=\int_{0}^{x} \varepsilon(x) d x=\int_{0}^{x} \frac{N(x)}{E \cdot A(x)} d x
$$

Deduïm immediatament que si $\mathrm{N}$ i A són constants, tots els termes eixiran de la integral. Si a més, fem la integral per al punt final del tram (tota la longitud), la equació se'ns transforma en la que ja coneixíem:

$$
\Delta L=\frac{N}{E \cdot A} \int_{0}^{L} d x=\frac{N \cdot L}{E \cdot A}
$$

Igualment, si tenim diversos trams, l'allargament serà el sumatori dels allargaments parcials.

$$
\Delta L=\sum_{i} \int_{0_{0}}^{L} \frac{N_{i}(x)}{E_{i} \cdot A_{i}(x)} d x
$$

\section{Exemple 4.5}

Considerem una barra d'acer col·locada en vertical, que suporta una càrrega axial aplicada en el centre de gravetat de la secció extrema (C). La meitat inferior de la biga $(\mathrm{AB})$ està sotmesa a una variació de temperatura $\Delta \mathrm{T}$. Si considerem el pes propi de la biga:

a) Obteniu la llei d'esforços axials i dibuixeu el diagrama d'esforços convenientment acotat.

b) Calculeu el moviment vertical dels punts mitjà (B) i extrem (C) de la biga.

Dades: $\mathrm{P}=5 \mathrm{kN} ; \mathrm{E}=210 \mathrm{GPa} ; \mathrm{A}=53,8 \mathrm{~cm}^{2} ; \mathrm{L}=5 \mathrm{~m} ; \alpha=1,2 \cdot 10^{-5}{ }^{\circ} \mathrm{C}^{-1} ; \Delta \mathrm{T}=15^{\circ} \mathrm{C}$. El pes específic de l'acer és: $\gamma=7.850 \mathrm{~kg} / \mathrm{m}^{3}$.

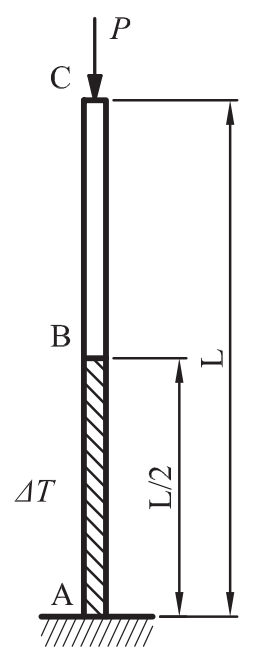

Fig. 4.9. Exemple 4.5. Enunciat 
Considerem el pes propi com una força uniformement repartida. $q(x)=\gamma \cdot g \cdot A$.

El pes propi de la biga sencera és:

$Q=\int_{0}^{L} \gamma \cdot g \cdot A d x=\gamma \cdot g \cdot A \cdot L=7850 \cdot 9,81 \cdot 53,8 \cdot 10^{-4} \cdot 5=2.071 \mathrm{~N}$

La reacció en el recolzament: $R_{A}=Q+P=7.071 \mathrm{~N}$

La llei d'esforços axials només té un tram: $N(x)=\int_{\alpha}^{x} q(x) \mathrm{d} x-R_{A}=\gamma \cdot g \cdot A \cdot(x-L)-\mathrm{P}$.

Substituint-hi els valors: $N(x)=414,16 x-7.071$. És una línia recta que varia entre:

$x=0 \rightarrow N_{A}=-7.071 \mathrm{~N}$

$x=L \rightarrow N_{B}=-5.000 \mathrm{~N}$

L'axial sempre és de compressió.

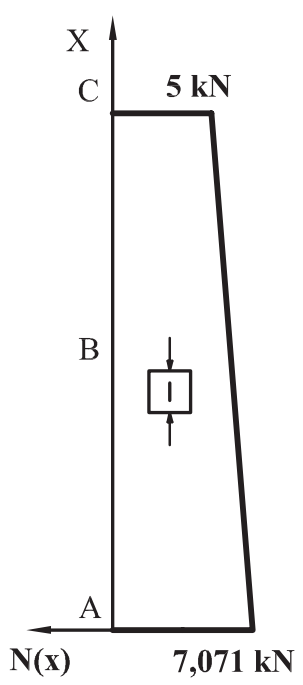

Fig. 4.10. Exemple 4.5. Diagrama d'axials

La primera meitat de la barra té un increment de temperatura, per la qual cosa la seua deformació no només estarà influenciada per la tensió en la barra, sinó, a més, per aquest increment de temperatura. La segona part només té l'esforç axial.

$\Delta L_{1}=\int_{0}^{L / 2 N(x)} \frac{L}{E \cdot A} d x+\alpha \cdot \Delta T \cdot \frac{L}{2}=\frac{1}{E \cdot A} \cdot\left(\frac{\gamma \cdot g \cdot A \cdot L^{2}}{8}-R_{A} \cdot \frac{L}{2}\right)+\alpha \cdot \Delta T \cdot \frac{L}{2}=4,35 \cdot 10^{-4} \mathrm{~m}$

$\Delta L_{2}=\int_{L / 2}^{L} \frac{N(x)}{E \cdot A} d x=\frac{1}{E \cdot A} \cdot\left(\frac{3 \cdot \gamma \cdot g \cdot A \cdot L^{2}}{8}-R_{A} \cdot \frac{L}{2}\right)=-1,22 \cdot 10^{-5} \mathrm{~m}$

Veiem que, malgrat estar a compressió, la primera part de la biga s'allarga com a conseqüència de la variació de temperatura. La segona part està a compressió i no té variació de temperatura, i com és lògic, s'acurta.

El desplaçament del punt mitjà de la barra és l'allargament del primer tram: el punt B puja: $u_{B}=0,435 \mathrm{~mm}$. El desplaçament del punt extrem és la suma de les variacions de longitud dels dos trams: $u_{C}=\Delta L_{1}+\Delta L_{2}=0,423 \mathrm{~mm}$. En ser positiu, ens diu que $\mathrm{C}$ també puja. 


\subsection{Estructures de barres}

Les estructures de barres són estructures formades per barres unides entre elles mitjançant articulacions. Si les càrregues estan aplicades exclusivament als nucs, les barres treballaran només amb esforç axial, de tracció o de compressió (negligint el pes propi de la barra, que causaria flexió).

En un recolzament articulat, si només li arriba una barra, la reacció tindrà el mateix valor que l'axial i la direcció serà la de la barra. Per tant, quan plantegem les equacions d'equilibri estàtic, com que serà coneguda la direcció de la reacció, només ens introduirà una incògnita al sistema.

Per resoldre de manera manual aquest tipus d'estructures tenim diversos mètodes. La condició és que el sistema siga isostàtic, tant externament com internament.

\subsubsection{Mètode dels nucs}

El mètode dels nucs és un procediment per resoldre estructures de barres articulades. Es pot resumir en els següents sis passos.

1. Calculem les reaccions de l'estructura.

2. Plantegem l'equilibri de cadascun dels nucs. Aïllem els nucs i considerem que els esforços axials de les barres, a efectes del nuc, són com una força. Les forces corresponents a axials eixiran del nuc, si són de tracció i entraran al nuc si són de compressió. Així mateix, considerarem les forces exteriors o reaccions sobre el nuc, si és que n'hi ha.

3. Les tres equacions d'equilibri se'ns queden en dues, si tenim en compte que l'equació de moments no aporta informació.

$$
\sum\left(\overrightarrow{F_{X}}\right)=0 \quad \sum\left(\overrightarrow{F_{Y}}\right)=0
$$

4. Com que només tenim dues equacions, hem de buscar un nuc en el qual només tinguem dues incògnites i les resoldrem.

5. Una vegada resolt un nuc, coneixerem l'axial en les barres que hi arriben. Aquest axial és el mateix que tindrà el nuc oposat de la barra, per la qual cosa ja no serà una incògnita. Buscarem un nuc contigu, que tinga dues incògnites, considerant coneguts els axials de les barres resoltes.

6. Avançarem seguint nucs contigus amb dues incògnites i resoldrem cadascun d'ells. 


\section{Exemple 4.6}

Calculeu els axials de totes les barres de l'estructura articulada de la figura (cotes en metres).

Dades: $\mathrm{P}=5 \mathrm{kN}$.

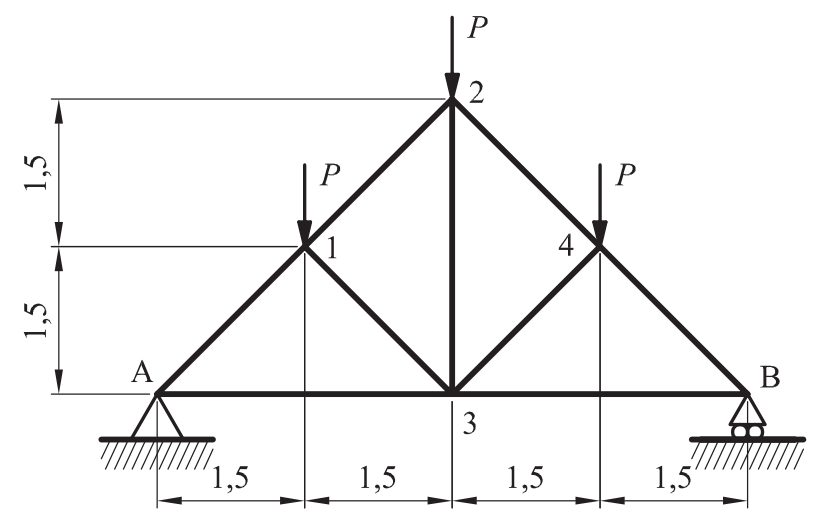

Fig. 4.11. Exemple 4.6. Enunciat

En primer lloc calcularem les reaccions. Com que existeix una simetria tan evident, podem deduir directament les reaccions: $R_{A}=R_{B}=1,5 P=7,5 \mathrm{kN}$.

Plantegem en tots els nucs les forces externes, les reaccions i els axials de les barres que arriben als nucs. De moment, els axials els considerarem tots com si foren de tracció, i si després, quan els calculem, el signe és negatiu, serà perquè realment la barra treballa a compressió.

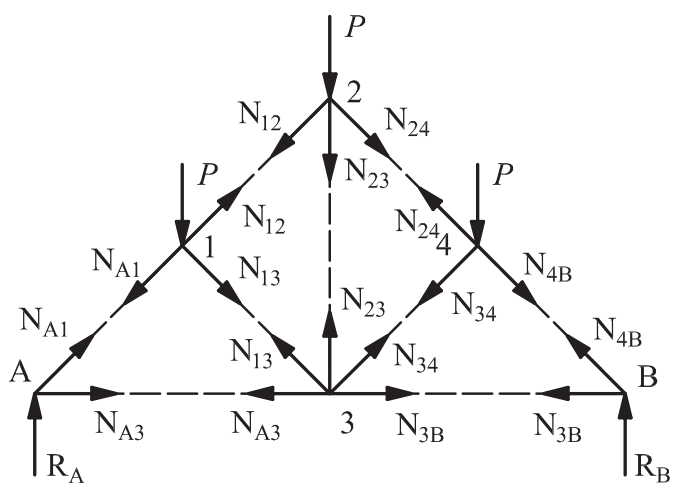

Fig. 4.12. Exemple 4.6. Plantejament inicial

Veiem que, per al nuc A, de les forces que hi concorren, no en coneixem dues. Comencem per aquest nuc i establim les equacions d'equilibri.

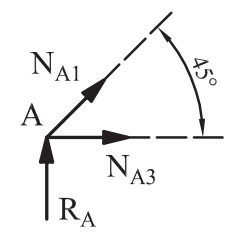

Fig. 4.13. Exemple 4.6. Equilibri nuc A 


$$
\begin{array}{ll}
\sum \overrightarrow{F_{X}}=0 \rightarrow N_{A 1} \cos \left(45^{\circ}\right)+N A_{3}=0 & N_{A 1}=-10,60 \mathrm{kN} \\
\sum \overrightarrow{F_{Y}}=0 \rightarrow R_{A}+N_{A i} \sin \left(45^{\circ}\right)=0 & N_{A 3}=7,5 \mathrm{kN}
\end{array}
$$

Com que ja coneixem $\mathrm{N}_{\mathrm{Al}}$, el nuc 1 només té dues incògnites. Encara que $\mathrm{N}_{\mathrm{A} 1}$ és negatiu i per tant el sentit suposat és el contrari, al nuc 1 seguirem mantenint la suposició de barra a tracció, i quan substituïm valors, utilitzarem el negatiu.

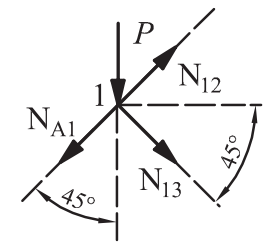

Fig. 4.14. Exemple 4.6. Equilibri nuc 1

$$
\begin{array}{ll}
\sum \overrightarrow{F_{X}}=0 \rightarrow N_{A 1} \cos \left(45^{\circ}\right)=N_{13} \cos \left(45^{\circ}\right)+N_{12} \cos \left(45^{\circ}\right) & N_{12}=-7,07 k N \\
\sum \overrightarrow{F_{Y}}=0 \rightarrow N_{12} \sin \left(45^{\circ}\right)=\mathrm{P}+N_{A 1} \sin \left(45^{\circ}\right)=N_{13} \sin \left(45^{\circ}\right) & N_{13}=-3,54 k N
\end{array}
$$

Passem al nuc 2, que només té dues incògnites, pel fet de ser $\mathrm{N}_{12}$ conegut.

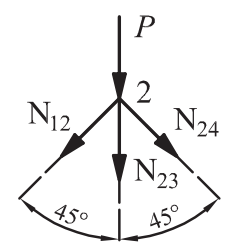

Fig. 4.15. Exemple 4.6. Equilibri nuc 2

$$
\begin{array}{ll}
\sum \overrightarrow{F_{X}}=0 \rightarrow N_{A 1} \cos \left(45^{\circ}\right)=N_{24} \cos \left(45^{\circ}\right) & N_{24}=-7,07 k N \\
\sum \overrightarrow{F_{Y}}=0 \rightarrow \mathrm{P}+N_{23} \sin \left(45^{\circ}\right)+N_{24} \sin \left(45^{\circ}\right)=0 & N_{23}=5 \mathrm{kN}
\end{array}
$$

En aquest cas, com que l'estructura és simètrica, la resta d'axials poden ser deduïts:

$N_{34}=N_{13}=-3,54 \mathrm{kN}$

$N_{4 B}=N_{A 1}=-10,61 \mathrm{kN}$

$N_{3 B}=N_{A 3}=7,5 \mathrm{kN}$

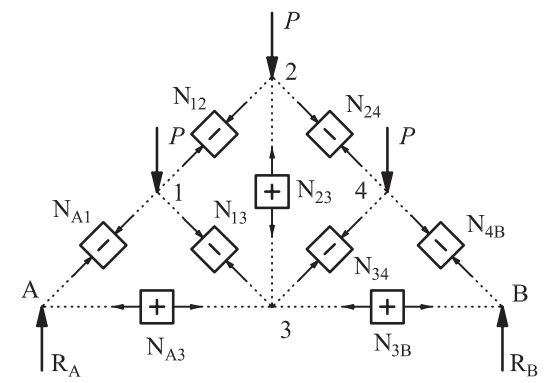

Fig. 4.16. Exemple 4.6. Solució 


\subsubsection{Mètode de les seccions}

Aquest mètode també es denomina mètode de Ritter. És més adient quan no necessitem calcular els axials de totes les barres, sinó només els d'algunes.

El procediment que s'ha de seguir és el següent:

1. Calcularem les reaccions de l'estructura completa.

2. Proposarem un tall en l'estructura, de manera que intercepte les barres a les quals ens interesse calcular l'axial. Com a màxim, aquest tall ha de interceptar tres barres.

3. Eliminarem una de les parts de l'estructura que quede a un costat del tall.

4. Col·locarem a les barres tallades unes forces, que corresponen als axials. Les forces, igual que els axials, han de portar la direcció de la barra, i per conveni, en un principi seran de tracció.

5. Establirem les condicions d'equilibri estàtic en la part de l'estructura conservada. Tindrem tres equacions amb tres incògnites i podrem resoldre el sistema.

\section{Exemple 4.7}

Per a l'estructura de l'exemple 4.6, calculeu l'esforç axial de la barra 1-3 pel mètode de les seccions.

Com que l'estructura i les càrregues són les mateixes, les reaccions no cal que les calculem una altra vegada: $R_{A}=R_{B}=7,5 \mathrm{kN}$.

Farem un tall a l'estructura, que talle la barra 1-3 i dues barres més.

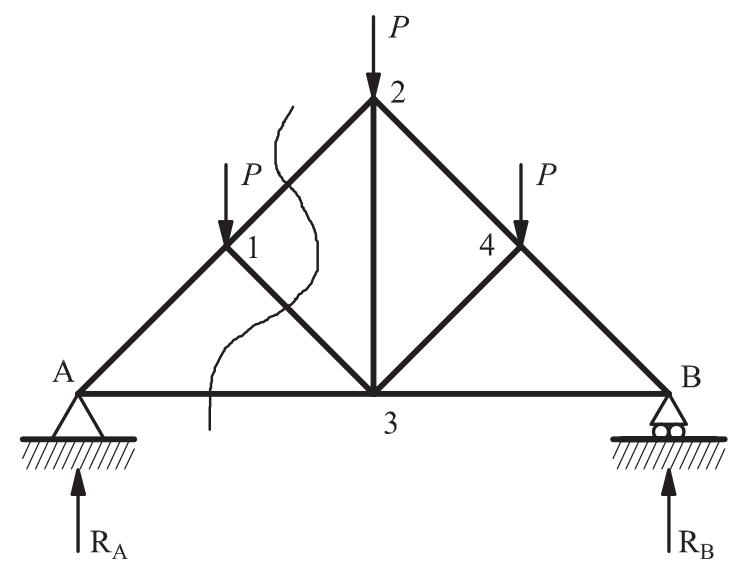

Fig. 4.17. Exemple 4.7 
Eliminem la part dreta, posem forces que representen els axials i plantegem l'equilibri.

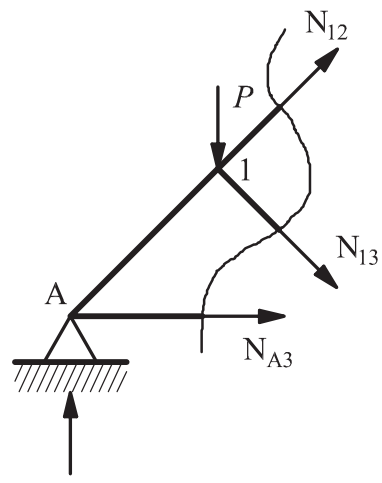

Fig. 4.18. Exemple 4.7

$\sum \overrightarrow{F_{X}}=0 \rightarrow N_{12} \cos \left(45^{\circ}\right)+N_{13} \cos \left(45^{\circ}\right)+N_{A 3}=0$

$\sum \overrightarrow{F_{Y}}=0 \rightarrow R_{A}+N_{12} \sin \left(45^{\circ}\right)=P+N_{13} \sin \left(45^{\circ}\right)$

$\sum \vec{M}_{A}=0 \rightarrow 1,5 P+1,5 \sqrt{ }(2) N_{13}=0$

De l'última equació podem aïllar: $N_{13}=3,54 \mathrm{kN}$.

No és necessari resoldre la resta del sistema, en aquest cas.

\subsubsection{Compatibilitat de desplaçaments}

Les estructures de barres treballen només amb esforç axial, i les seues barres només s'allargaran o s'acurtaran. Con que les barres estan articulades als extrems, tindran capacitar de girar al voltant de les unions. Els nucs poden estar connectats a més d'una barra. El desplaçament del nuc ha de ser compatible amb els allargaments (o acurtaments) i els girs possibles.

\section{Exemple 4.8}

Calculeu el desplaçament vertical i horitzontal del nuc C.

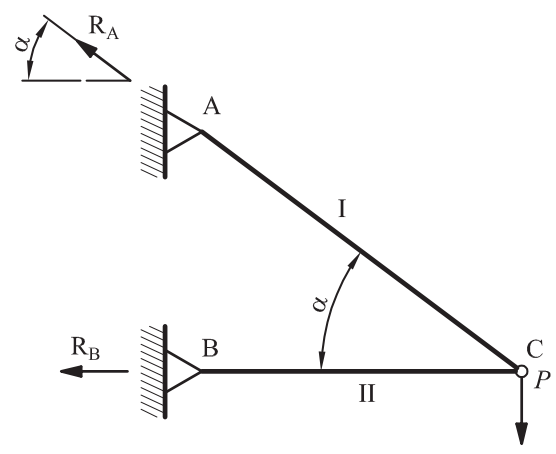

Fig. 4.19. Exemple 4.8. Enunciat 
Dades: suposem conegudes les longituds de les barres $\left(L_{1}, L_{2}\right)$, les àrees $\left(A_{1}, A_{2}\right)$, el material de les barres (E) i l'angle $(\alpha)$.

El sistema és isostàtic. Les reaccions poden ser calculades amb les equacions d'equilibri. Com que és una estructura de barres, les reaccions porten la direcció de la barra; per tant, només tenim dues incògnites. L'equació de moments, en aquest cas, no ens dóna cap resultat vàlid, perquè totes les forces del sistema passen per un punt (C).

$\sum \overrightarrow{F_{Y}}=0 \rightarrow R_{A} \sin (\alpha)=P \rightarrow R_{A}=\frac{P}{\sin (\alpha)}$

$\sum \overrightarrow{F_{X}}=0 \rightarrow R_{A} \cos (\alpha)+R_{B}=0 \rightarrow R_{B}=\frac{-P}{\tan (\alpha)}$

Els axials a les barres tenen el mateix valor que les reaccions.

$N_{1}=R_{A}($ tracció $)$

$N_{2}=R_{B}$ (compressió)

En conseqüència, la barra I s'allargarà i la barra II s'acurtarà. Podem calcular les variacions de longitud.

$\Delta_{L 1}=\frac{N_{1} \cdot L_{1}}{E \cdot A_{1}} ; \Delta_{L 2}=\frac{N_{2} \cdot L_{2}}{E \cdot A_{2}}$

Com que $\mathrm{N}_{2}<0$, llavors $\Delta \mathrm{L}_{2}<0$ (acurtament).

Les barres poden girar al voltant del seu punt de recolzament: la barra I al voltant del punt A la barra II, al voltant de B.

El nuc C s'ha de desplaçar d'una manera compatible amb les variacions de longitud calculades i amb els girs previstos. Si el problema fóra amb grans deformacions, el moviment del punt $\mathrm{C}$ seria el següent:

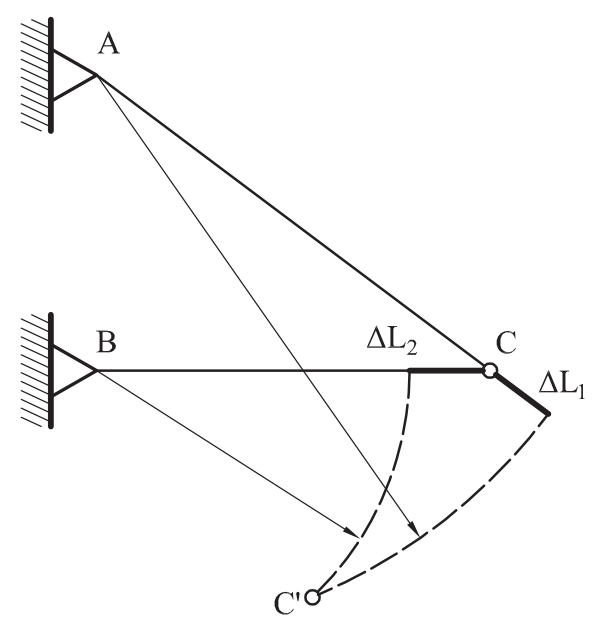

Fig. 4.20. Exemple 4.8. Moviment amb grans deformacions 
Tanmateix, des del principi estem tractant amb el supòsit que les deformacions són molt menudes. En aquests casos, pràcticament no hi ha diferència entre l'arc de circumferència i la tangent traçada pel punt (perpendicular a la barra). Veiem la figura per aclarir el concepte:

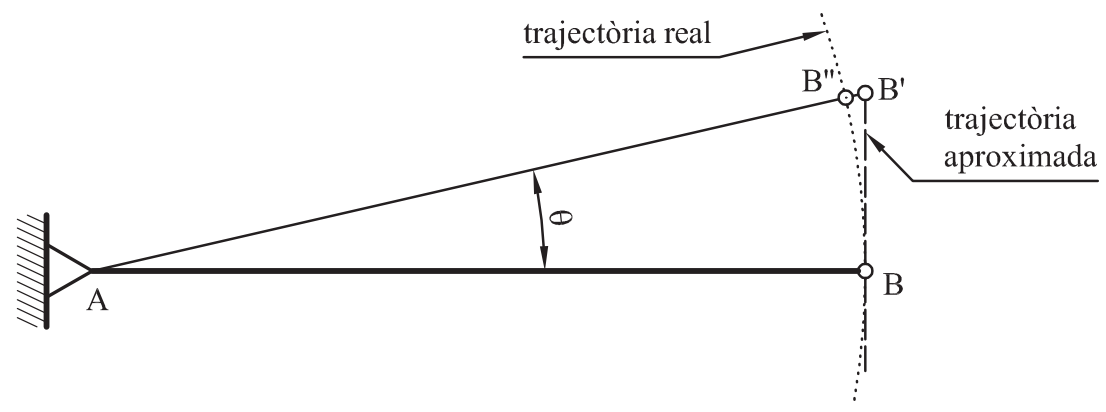

Fig. 4.21. Exemple 4.8. Aclariment sobre la petita deformació

Realment el punt B es desplaçaria fins al punt B'. Quan l'angle $\theta$ és molt menut, podem considerar que el punt B' i el B" estan tan prop l'un de l'altre que són el mateix punt.

Reprenguem ara l'exemple i observem els desplaçaments considerant la petita deformació.

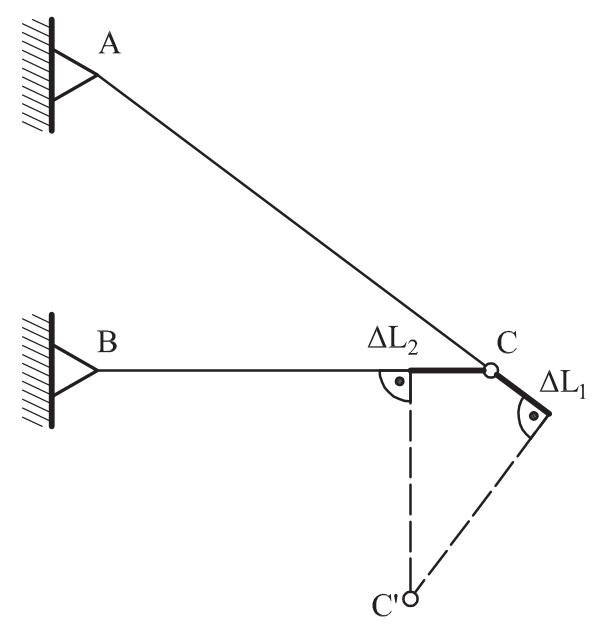

Fig. 4.22. Exemple 4.8. Moviment amb petita deformació

Ara només ens falta trobar unes relacions entre les variacions de longitud i el moviment dels punts. Per a aquest cas concret, podem veure-ho a la figura 4.23.

El desplaçament horitzontal és directament:

$u_{C}=\Delta_{L 2}=\frac{-P \cdot L_{2}}{E \cdot A_{2} \tan (\alpha)}$

Deixem el signe negatiu perquè considerem positius cap a la dreta, i el punt es mou cap a l'esquerra. 


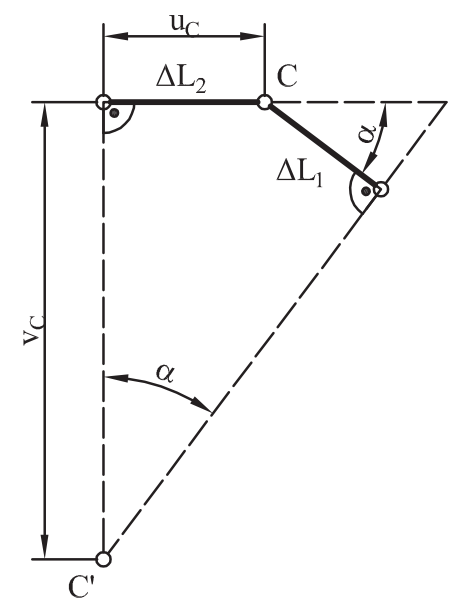

Fig. 4.23. Exemple 4.8. Relació entre les $\Delta \mathrm{L}$ i els moviments

Per al moviment vertical necessitem fer un càlcul lleugerament més complicat. Calculem la tangent de l'angle:

$\tan (\alpha)=\frac{\left|\Delta_{L 2}\right|+\frac{\left|\Delta_{L 1}\right|}{\cos (\alpha)}}{v_{c}}$

Aïllem ara $\mathrm{v}_{\mathrm{c}}$ :

$v_{c}=-\frac{\left|\Delta_{L 2}\right|+\frac{\left|\Delta_{L 1}\right|}{\cos (\alpha)}}{\tan (\alpha)}=\frac{-P}{E}\left(\frac{L_{2}}{A_{2} \tan ^{2}(\alpha)}+\frac{L_{1}}{A_{1} \sin ^{2}(\alpha)}\right)$

Les variacions de longitud les posem com a valor absolut, prescindint del signe, perquè les estem tractant com a segments, i les longituds no poden ser negatives.

\section{Exemple 4.9}

En l'estructura de la figura 4.24, el sòlid ABCD es pot considerar perfectament rígid, i per tant indeformable. La barra ED és un cable d'acer S275 i de diàmetre $1 \mathrm{~cm}$. Calculeu la tensió del cable i la posició final del punt D.

Dades: $\mathrm{P}=10 \mathrm{kN} ; \mathrm{q}=5 \mathrm{kN} ; \mathrm{a}=1 \mathrm{~m} ; \mathrm{E}=210 \mathrm{GPa} ; \phi=1 \mathrm{~cm}$.

El sistema és isostàtic. La reacció en E té la direcció coneguda (la de la barra) però la reacció en A té dues components. Disposem de tres equacions; per tant, podem resoldre.

$\sum F_{X}=0 \rightarrow R_{A X}=0$

$\sum \overrightarrow{F_{Y}}=0 \rightarrow R_{A Y}+R_{E}=P+q \cdot 2 a$

$\sum \vec{M}_{A}=0 \rightarrow P \cdot a+q \cdot 2 a \cdot 3 a=R_{E} \cdot 4 a$ 
De la tercera equació obtenim $R_{E}=10 \mathrm{kN}$ i de la segona $R_{A Y}=10 \mathrm{kN}$.

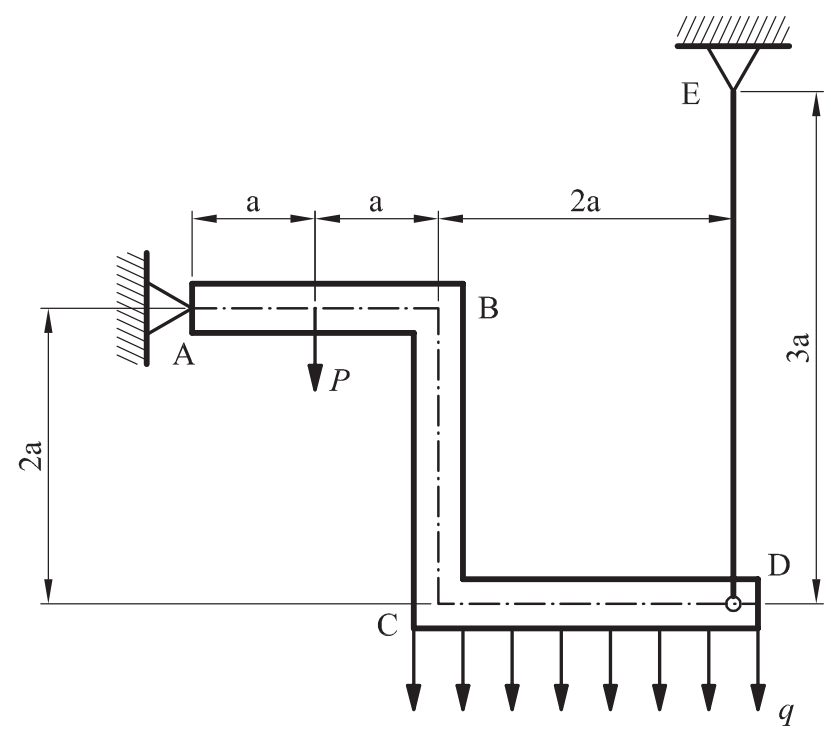

Fig. 4.24. Exemple 4.9. Enunciat

La tensió en el cable és: $\sigma=\frac{R_{E}}{A}=\frac{4 R_{E}}{\pi \phi^{2}}=127,32 \mathrm{MPa}$.

Allargament del cable: $\Delta L=\frac{R_{E} \cdot 3 a}{E \cdot A}=1,82 \cdot 10^{-3} \mathrm{~m}=1,82 \mathrm{~mm}$.

Per a calcular el desplaçament de $\mathrm{C}$, hem de plantejar la compatibilitat de desplaçaments. Sabem que el nuc C, pel fet d'estar lligat al cable ED, baixarà l'equivalent a $\Delta \mathrm{L}$ i girarà al voltant del punt $\mathrm{E}$. D'altra banda, com que també està lligat al sòlid indeformable $\mathrm{ABCD}$, girarà al voltant del punt $\mathrm{A}$. Les dues consideracions han de ser compatibilitzades.

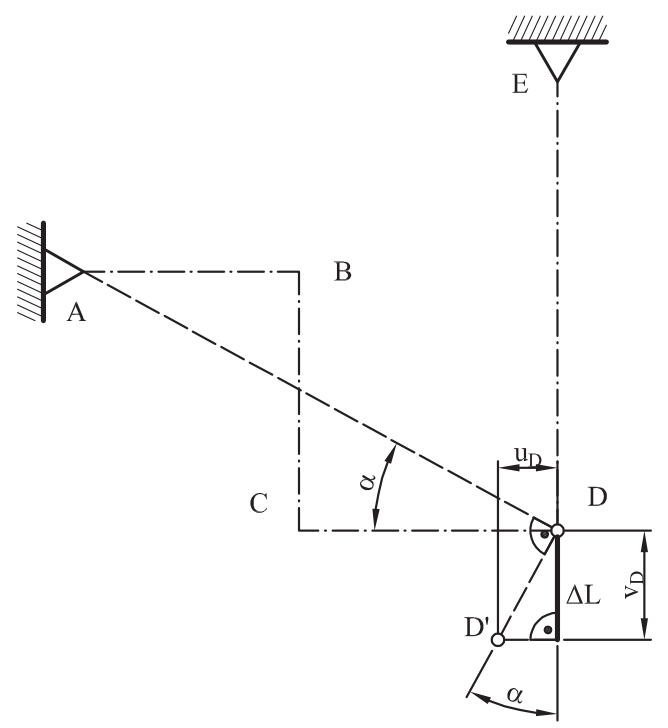

Fig. 4.25. Exemple 4.9. Compatibilitat de desplaçaments 
Seguirem la teoria de la petita deformació, i considerarem que el punt no es mou seguint un arc de circumferència, sinó segons una perpendicular a la línia que uneix el punt amb el recolzament.

D'acord amb la figura, podem dir que el desplaçament vertical del punt $\mathrm{D}$ serà equivalent a l'allargament: $v_{D}=-\Delta \mathrm{L}=-1,82 \mathrm{~mm}$.

El valor el fem negatiu perquè el punt baixa, i considerem positius els ascensos.

L'angle que es veu a la figura es pot calcular com a: $\alpha=\arctan \left(\frac{2 a}{4 a}\right)=26,56^{\circ}$.

El moviment horitzontal: $u_{D}=-\Delta \mathrm{L} \cdot \tan (\alpha)=-0,91 \mathrm{~mm}$.

És negatiu perquè es mou cap a l'esquerra.

\section{Exemple 4.10}

L'estructura de la figura (dimensions en metres) està formada per un sòlid indeformable $\mathrm{ABCD}$, que té una càrrega en cada un dels extrems, $\mathrm{P}_{1} \mathrm{i} \mathrm{P}_{2}$. El sòlid indeformable es recolza en dos pilars $\mathrm{BE}$ i $\mathrm{CF}$, les condicions de sustentació dels quals fan que ambdós puguen ser considerats com biarticulats. Calculeu el descens dels punts d'aplicació de les càrregues $(\mathrm{A}$ i D).

Dades: $\mathrm{E}=200 \mathrm{GPa} ; \mathrm{A}_{\mathrm{BE}}=125 \mathrm{~cm}^{2} ; \mathrm{A}_{\mathrm{CF}}=110 \mathrm{~cm}^{2} ; \mathrm{P}_{1}=1.000 \mathrm{kN} ; \mathrm{P}_{2}=900 \mathrm{kN}$.

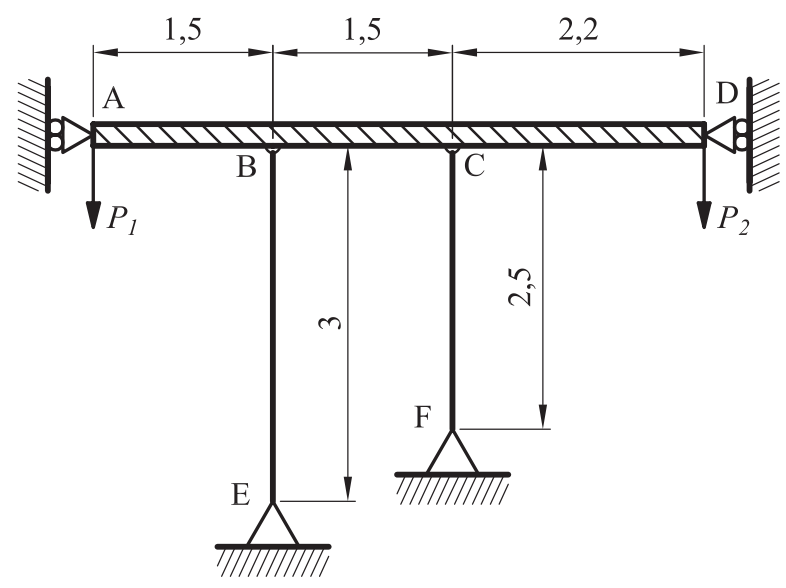

Fig. 4.26. Exemple 4.10. Enunciat

El sistema és isostàtic. Els recolzaments lliscants estan per a evitar el mecanisme, tanmateix les reaccions en ells són zero. Calculem la resta de reaccions:

$\sum \overrightarrow{F_{Y}}=0 \rightarrow P_{1}+P_{2}-R_{E}-R_{F}=0$

$\sum \overrightarrow{M_{B}}=0 \rightarrow P_{1} \cdot L_{A B}+R_{F} \cdot L_{B C}-P_{2}\left(L_{B C}+L_{C D}\right)=0$ 
De la segona equació: $R_{F}=\frac{P_{2}\left(L_{B C}+L_{C D}\right)-P_{1} \cdot L_{A B}}{L_{B C}}=1.220 \mathrm{kN}$.

De la primera: $R_{E}=P_{1}+P_{2}-R_{F}=680 k N$.

Els axials són de compressió, per tant són negatius: $\begin{gathered}N_{B E}=-680 \mathrm{kN} \\ N_{C F}=-1.220 \mathrm{kN}\end{gathered}$

Podem calcular les variacions de longitud.

$$
\begin{aligned}
\Delta L_{B E} & =\frac{N_{B E} \cdot L_{B E}}{E \cdot A_{B E}}=-8,16 \cdot 10^{-4} \mathrm{~m}=0,82 \mathrm{~mm} \\
\Delta L_{C F} & =\frac{N_{C F} \cdot L_{C F}}{E \cdot A_{C F}}=-1,39 \cdot 10^{-3} \mathrm{~m}=1,39 \mathrm{~mm}
\end{aligned}
$$

Com que la taula $\mathrm{ABCD}$ és completament rígida, la compatibilitat de desplaçaments es pot representar com a la figura.

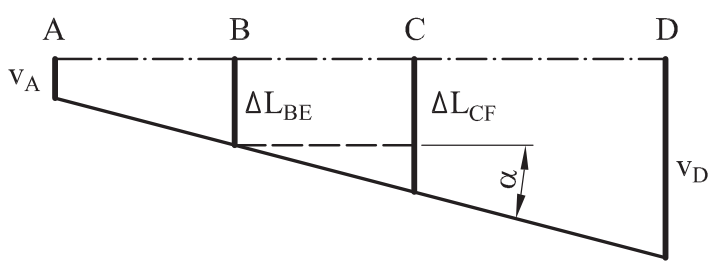

Fig. 4.27. Exemple 4.10. Compatibilitat de desplaçaments

Calculem l'angle d'inclinació de la taula respecte a l'horitzontal.

$\theta=\frac{\left|\Delta L_{C F}-\Delta L_{B E}\right|}{L_{B C}}=0,022^{\circ}$

Podem calcular l'angle de diverses maneres mitjançant la tangent, i així obtindre els desplaçaments que es demanen:

$$
\begin{aligned}
& \tan (\theta)=\frac{\left|\Delta L_{B E}\right|-\left|v_{A}\right|}{L_{A B}} \rightarrow\left|v_{A}\right|=\left|\Delta L_{B E}\right|-L_{A B} \cdot \tan (\theta)=2,46 \cdot 10^{-4} \mathrm{~m}=0,25 \mathrm{~mm} \\
& \tan (\theta)=\frac{\left|v_{D}\right|-\left|\Delta L_{B E}\right|}{L_{A B}} \rightarrow\left|v_{D}\right|=\left|\Delta L_{B E}\right|+\left(L_{B C}+L_{C D}\right) \cdot \tan (\theta)=2,22 \cdot 10^{-3} \mathrm{~m}=2,22 \mathrm{~mm}
\end{aligned}
$$




\subsection{Elements hiperestàtics}

Habitualment, les estructures d'edificació no són isostàtiques, sinó hiperestàtiques. En aquests casos, el càlcul de les reaccions no es pot fer només amb les equacions d'equilibri estàtic. Necessitem equacions addicionals, en nombre igual al grau d'hiperestatisme del sistema (GH). La compatibilitat geomètrica de les parts deformades ens proporcionarà les equacions extra que necessitem.

L'estratègia general per a resoldre les estructures hiperestàtiques és la següent:

1. Triar tantes reaccions hiperestàtiques com grau d'hiperestatisme tinga el sistema.

2. Eliminar les restriccions de moviment associades a les reaccions que hem triat.

3. Introduir forces externes corresponents a les reaccions hiperestàtiques. Com que no són conegudes, deixarem la resta de les reaccions en funció d'aquestes incògnites hiperestàtiques.

4. Afegir condicions de compatibilitat de desplaçament corresponents al punt on estaven les restriccions de moviment que hem llevat.

5. Calcular els moviments de les condicions anteriors, que quedaran en funció de les incògnites hiperestàtiques. Com que els desplaçaments són coneguts, els igualarem les equacions. Això ens permetrà aïllar les reaccions hiperestàtiques.

\section{Exemple 4.11}

Calculeu les reaccions i el diagrama d'esforços axials del sistema de la figura (cotes en $\mathrm{cm}$ ). Les barres son massissos rodons de diàmetres $\mathrm{d}_{1} \mathrm{i}_{2}$.

Dades: $\mathrm{d}_{1}=22 \mathrm{~mm} ; \mathrm{d}_{2}=15 \mathrm{~mm} ; \mathrm{P}=15 \mathrm{kN} ; \mathrm{q}=5 \mathrm{kN} / \mathrm{m} ; \mathrm{E}=210 \mathrm{GPa}$.

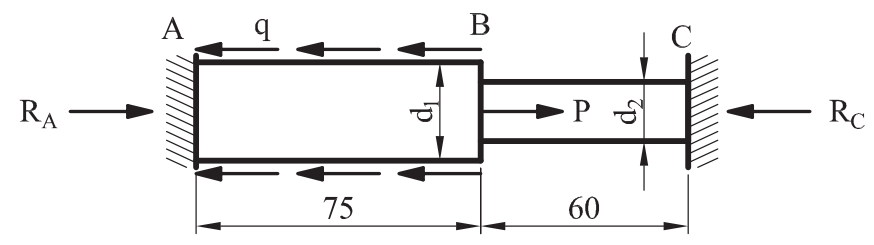

Fig. 4.28. Exemple 4.11. Enunciat

Com que tenim dues reaccions i només una equació d'equilibri estàtic $\left(\sum \overrightarrow{F_{X}}=0\right)$ el grau d'hiperestatisme és $\mathrm{GH}=1$. Escollim una de les reaccions com a incògnita hiperestàtica $\left(\mathrm{R}_{\mathrm{C}}\right)$. Llevem la restricció de moviment associada i introduïm la reacció com a força exterior. 


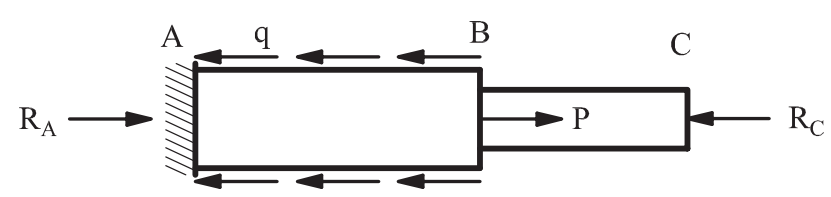

Fig. 4.29. Exemple 4.11. Eliminació de restricció de moviment

En aquesta situació, el sistema passa a ser isostàtic. Podem resoldre'1, malgrat que no coneixem la reacció en $\mathrm{C}$. Farem com si fóra coneguda i deixarem la resta de reaccions en funció d'ella.

$\sum \overrightarrow{F_{X}}=0 \rightarrow R_{A}+P-q \cdot 0,75-R_{C}=0 \rightarrow R_{A}=R_{C}+q \cdot 0,75-P=R_{C}-11,25 \mathrm{kN}$

La condició de compatibilitat associada és que el punt $\mathrm{C}$ no es mou $\left(u_{C}=0\right)$.

Establirem l'equació calculant l'allargament de les barres, que ens quedarà en funció de $\mathrm{R}_{\mathrm{C}}$, i igualant-lo a zero. Per a calcular l'allargament, necessitem calcular els axials. Tenim dos trams:

$$
\begin{aligned}
& 0<x<0,75 m \rightarrow N_{1}(x)=q \cdot x-R_{A}=5 x-R_{C}+11,25 k N \\
& 0,75 m<x<1,35 m \rightarrow N_{2}(x)=-R_{C} \\
& \Delta L=\int_{0}^{0,75} \frac{N_{1}(x)}{E \cdot A_{1}} d x+\int_{0}^{1,35} \frac{N_{2}(x)}{E \cdot A_{2}} d x=\int_{0}^{0,75} \frac{x-R_{C}+11,25}{E \cdot A_{1}} d x+\int_{0}^{1,35} \frac{R_{C}}{E \cdot A_{2}} d x \\
& \Delta L=\frac{1}{E}\left[\frac{1}{A_{1}}\left[5 \frac{x^{2}}{2}-R_{C} x+11,25 x\right]_{0}^{0,75}+\frac{1}{A_{2}}\left[-R_{C} x\right]_{0,75}^{1,35}\right] \\
& \Delta L=\frac{9,84-0,75 R_{C}}{E \cdot A_{1}}-\frac{0,6 R_{C}}{E \cdot A_{2}}
\end{aligned}
$$

Ja hem dit que aquest allargament ha de ser zero. Si l'igualem a zero, tindrem una equació amb només una incògnita. Hem de fer un càlcul previ de les àrees.

$$
A_{1}=\pi \frac{d_{1}^{2}}{4}=3,80 \cdot 10^{-4} m^{2} \quad A_{2}=\pi \frac{d_{2}^{2}}{4}=1,77 \cdot 10^{-4} \mathrm{~m}^{2}
$$

Aïllant i entrant en l'equació de l'estàtica: $R_{A}=-6,426 \mathrm{kN}$.

La reacció va al revés del sentit suposat inicialment. Les lleis d'esforços queden:

$0<x<0,75 m \rightarrow N_{1}(x)=5 x+6,426 k N$

$0,75 m<x<1,35 m \rightarrow N_{2}(x)=-4,824 k N$

Veiem que al primer tram sempre tindrem traccions, que varien linealment, $\mathrm{i}$ al segon sempre compressions. 


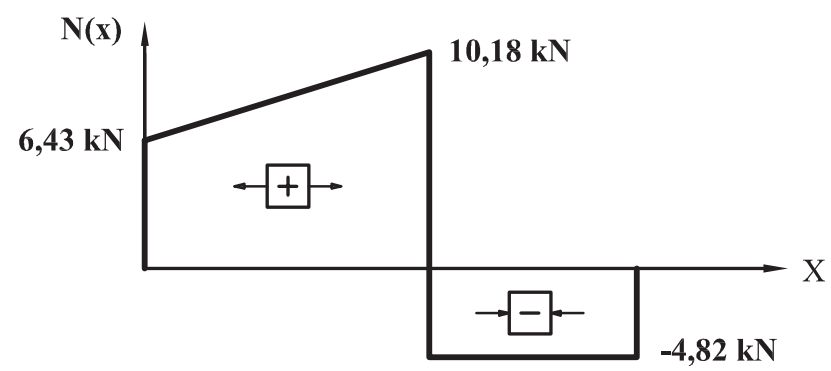

Fig. 4.30. Exemple 4.11. Diagrama d'axials

\section{Exemple 4.12}

Una barra d'un polímer amb dues seccions transversals circulars massisses distintes es sosté entre suports rígids, com es mostra a la figura. La barra sencera està sotmesa a un increment de temperatura de $30^{\circ} \mathrm{C}$. Calculeu:

a) Esforços axials en la barra.

b) Màxima tensió normal al pla de la secció recta.

c) Desplaçament horitzontal de la secció B.

Dades: $\mathrm{d}_{1}=50 \mathrm{~mm} ; \mathrm{d}_{2}=75 \mathrm{~mm} ; \mathrm{L}_{1}=225 \mathrm{~mm} ; \mathrm{L}_{2}=300 \mathrm{~mm} ; \mathrm{E}=6 \mathrm{GPa} ; \alpha=10^{-4} \mathrm{C}^{-1}$.

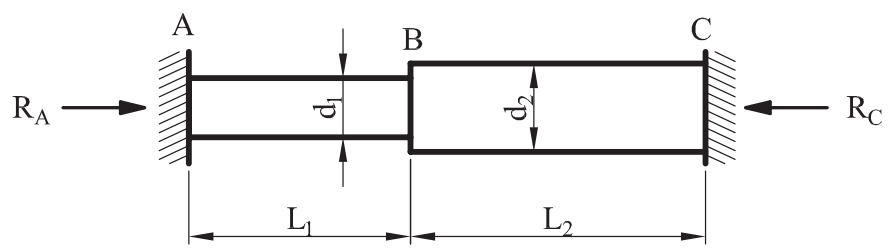

Fig. 4.31. Exemple 4.12. Enunciat

Aquest cas és molt similar al de l'exemple anterior. La diferència és que en aquest cas no hi ha cap càrrega aplicada, només un increment de temperatura. El procediment és anàleg a l'anterior.

Escollim $\mathrm{R}_{\mathrm{C}}$ com a incògnita hiperestàtica, llevem el recolzament, apliquem $\mathrm{R}_{\mathrm{C}}$ com si fóra una força exterior i establim la condició de compatibilitat de desplaçament.

$R_{A}=R_{C}$. L'esforç axial serà, per tant, constant en tota la barra, i de valor $N(x)=-R_{C}$.

Tal com hem dibuixat les reaccions, l'esforç ha de ser de compressió. Si finalment no ho fóra, ens eixirà un valor amb el signe canviat.

$A_{1}=\pi \frac{d_{1}^{2}}{4}=19,64 \cdot 10^{-4} \mathrm{~m}^{2} \quad A_{2}=\pi \frac{d_{2}^{2}}{4}=44,18 \cdot 10^{-4} \mathrm{~m}^{2}$ 


$$
\Delta L=\int_{0}^{L_{1}}\left(\frac{-R_{C}}{E \cdot A_{1}}+\alpha \Delta T\right) d x+\int_{0}^{L_{1}+L_{2}}\left(\frac{-R_{C}}{E \cdot A_{2}}+\alpha \Delta T\right) d x=0
$$

Podem resoldre l'equació, i obtenim el resultat: $R_{C}=51,78 \mathrm{kN} ; N(x)=51,78 \mathrm{kN}$.

Com que l'axial és el mateix en tota la barra, la tensió serà màxima quan l'àrea siga mínima. Això es, al primer tram.

$$
\sigma=\frac{N}{A_{1}}=-26,372 \cdot 10^{6} \mathrm{~Pa}=-26,372 \mathrm{MPa}
$$

El desplaçament del punt B és la primera part de la integral anterior:

$u_{B}=\int_{0}^{L_{4}}\left(\frac{-R_{C}}{E \cdot A_{1}}+\alpha \Delta T\right) d x=-3,14 \cdot 10^{-4} m=-0,314 \mathrm{~mm}$

\section{Exemple 4.13}

A la mateixa estructura de l'exemple 4.9 li col-loquen un nou cable (II) vertical entre els punts $\mathrm{B} i \mathrm{~F}$. L'àrea transversal del cable és $\mathrm{A}_{2}$.

Plantegeu de manera indicada les equacions que resoldrien el problema.

Dades: $E_{1}, A_{1}, E_{2}, A_{2}$, a, P, q.

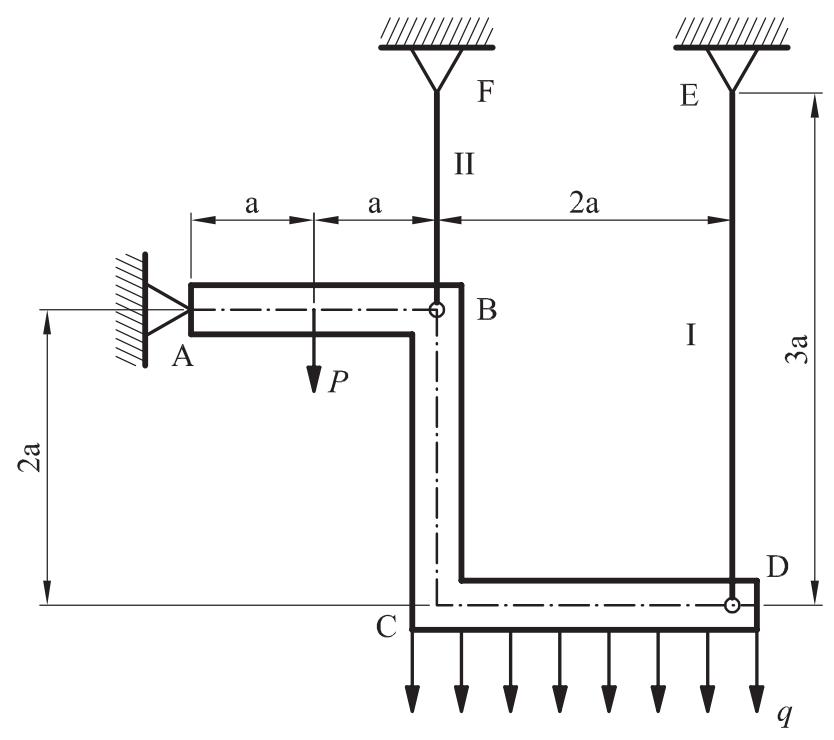

Fig. 4.32. Exemple 4.13. Enunciat

Ara és un cas hiperestàtic. No podem resoldre el sistema només amb les equacions d'equilibri.

$\sum F_{X}=0 \rightarrow R_{A X}=0$ 
$\sum \overrightarrow{F_{Y}}=0 \rightarrow R_{A Y}+R_{E}+R_{F}=P+q \cdot 2 a$

$\sum \vec{M}_{A}=0 \rightarrow P \cdot a+q \cdot 2 a \cdot 3 a=R_{\mathrm{F}} \cdot 2 a+R_{E} \cdot 4 a$

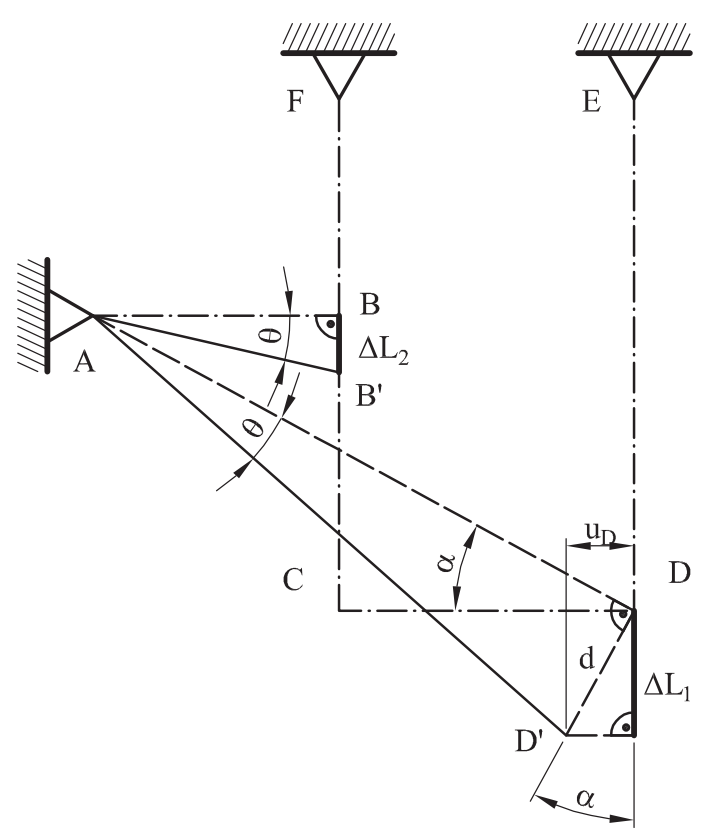

Fig. 4.33. Exemple 4.13. Compatibilitat de desplaçaments

Tenim quatre incògnites i només tres equacions: $\mathrm{GH}=1$. Necessitem una equació addicional.

Podem plantejar una relació entre l'allargament dels cables BF i DE, basada en el fet que ambdós estan units al sòlid indeformable $A B C D$. La rigidesa infinita del sòlid fa que tots els seus punts giren el mateix angle $(\theta)$, i és precisament a partir d'aquest angle com relacionarem els allargaments. Això ho veiem a la figura 4.33.

El desplaçament del punt D ja va ser explicat a l'exemple 4.9. El punt B, com que està lligat al cable BF, experimentarà un descens a causa d'allargament del cable, i un gir al voltant de $\mathrm{F}$, que es materialitzarà mitjançant un desplaçament sobre la línia perpendicular a BF. Així mateix, $\mathrm{B}$ està lligat al sòlid indeformable, per la qual cosa girarà al voltant del punt $\mathrm{A}$. Això serà un desplaçament sobre la línia perpendicular a $\mathrm{AB}$. La unió de les dues condicions anteriors ens dóna la posició del punt B (B').

Necessitem calcular algunes dades auxiliars:

$L_{A D}=\sqrt{(2 a)^{2}+(4 a)^{2}}=a \sqrt{20}$

En l'entorn del punt D, podem calcular:

$$
d=\frac{\Delta L_{1}}{\cos (\alpha)}
$$


L'angle girat pels punts B i D ha de ser el mateix $(\theta)$.

$$
\tan (\theta)=\frac{\Delta L_{2}}{2 a}=\frac{d}{L_{A D}}=\frac{\Delta L_{1}}{\cos (\alpha) \cdot a \sqrt{20}} \rightarrow \frac{R_{F} \cdot a}{2 \cdot E_{2} \cdot A_{2}}=\frac{R_{E} \cdot 3 a}{E_{2} \cdot A_{2} \cdot \cos (\alpha) \cdot a \sqrt{20}}
$$

Aquesta és l'equació addicional que ens permet resoldre el problema.

\section{Exemple 4.14}

Establiu les equacions necessàries per resoldre el problema de la figura 4.34, en el qual el sòlid ACDE es pot considerar perfectament rígid.

Dades: $\mathrm{E}_{1}, \mathrm{~A}_{1}, \mathrm{E}_{2}, \mathrm{~A}_{2}, \mathrm{a}, \mathrm{P}$.

Les reaccions no tenen la direcció coneguda, perquè arriben dos cables al punt $\mathrm{B}$. Com que tenim quatre incògnites i només tres equacions, és un cas hiperestàtic de grau $1(\mathrm{GH}=1)$. Hem de plantejar les equacions d'equilibri estàtic i una equació de compatibilitat addicional.

L'equació de compatibilitat de desplaçaments ens donarà una relació entre els axials. En aquest cas, els axials no són directament les reaccions. Hem d'establir una relació entre els axials i les reaccions (figura 4.35).

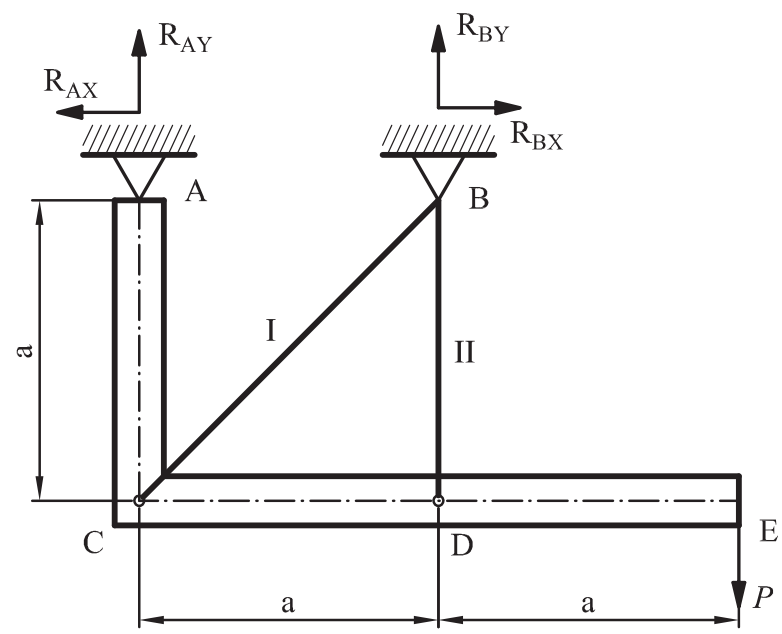

Fig. 4.34. Exemple 4.14. Enunciat

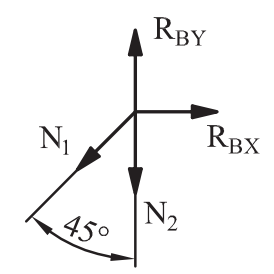

Fig. 4.35. Exemple 4.14. Relació entre axials i reaccions al punt B 
$R_{B X}=N_{1} \sin \left(45^{\circ}\right)$

$R_{B Y}=N_{2}+N_{1} \cdot \cos \left(45^{\circ}\right)$

$\sum \overrightarrow{F_{X}}=0 \rightarrow R_{A X}=N_{1} \cdot \sin \left(45^{\circ}\right)$

$\sum \overrightarrow{F_{Y}}=0 \rightarrow R_{A Y}+N_{2}+N_{1} \cos \left(45^{\circ}\right)=P$

$\sum \vec{M}_{A}=0 \rightarrow\left(N_{2}+N_{1} \cos \left(45^{\circ}\right)\right) \cdot a=P \cdot 2 a$

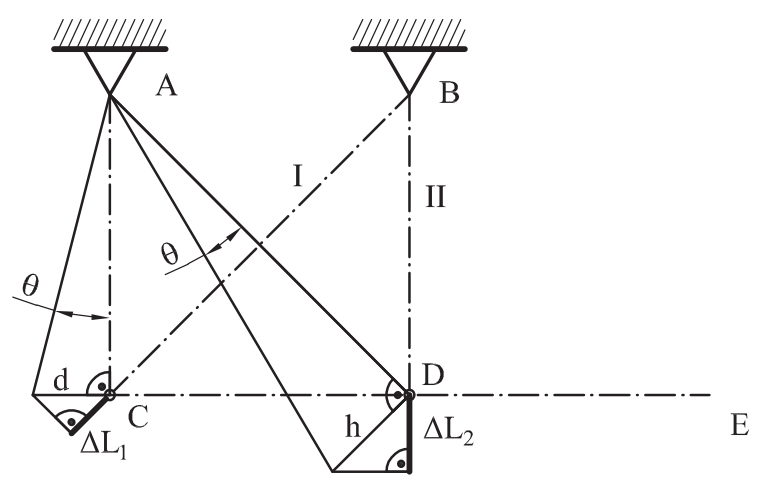

Fig. 4.36. Exemple 4.14. Compatibilitat de desplaçaments

$$
\begin{aligned}
& L_{A D}=a \sqrt{2} \quad d=\frac{\Delta L_{1}}{\cos \left(45^{\circ}\right)} \quad h=\frac{\Delta L_{2}}{\cos \left(45^{\circ}\right)} \\
& \tan (\theta)=\frac{d}{a}=\frac{h}{L_{A D}} \rightarrow \frac{\Delta L_{1}}{a \cdot \cos \left(45^{\circ}\right)}=\frac{\Delta L_{2}}{a \sqrt{2} \cdot \cos \left(45^{\circ}\right)} \rightarrow \\
& \frac{N_{1} \cdot a \sqrt{2}}{E_{1} \cdot A_{1} \cdot a \cdot \cos \left(45^{\circ}\right)}=\frac{N_{2} \cdot a}{E_{2} \cdot A_{2} \cdot a \sqrt{2} \cdot \cos \left(45^{\circ}\right)} \rightarrow \frac{2 N_{1}}{E_{1} \cdot A_{1}}=\frac{N_{2}}{E_{2} \cdot A_{2}}
\end{aligned}
$$

\section{Exemple 4.15}

Considereu una grua lleugera com la que s'esquematitza a la figura, composta per un perfil d'acer BCD articulat a la paret (BCD pot girar lliurement en el pla del paper al voltant de B) i suportat inicialment per un únic tirant $\mathrm{AD}$ de secció circular. La biga BCD suporta el seu propi pes de $61,3 \mathrm{~kg} / \mathrm{m}$ i el pes d'un motor que, en el cas més desfavorable, es considerarà com una càrrega puntual aplicada en l'extrem D de $500 \mathrm{~kg}$. Les deformacions de qualsevol tipus en la biga BCD es poden negligir. 


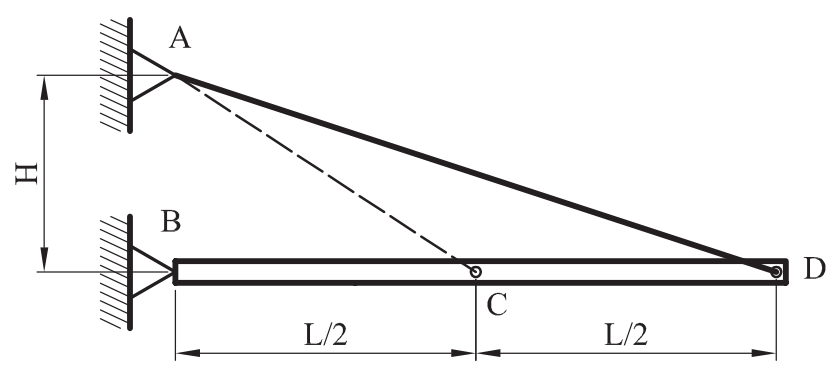

Fig. 4.37. Exemple 4.15. Enunciat

a) Calculeu el descens vertical de l'extrem D.

Amb l'activitat que es realitza en el recinte en què es troba instal-lada la grua, la temperatura augmenta $30^{\circ} \mathrm{C}$. Aquest fet afecta la deformació en el cable AD i conseqüentment, augmenta el desplaçament vertical de l'extrem D. A fi de compensar aquest increment, s'introdueix un segon cable AC.

b) Calculeu el diàmetre que ha de tindre el cable $\mathrm{AC}$ per aconseguir que el descens de D siga igual al calculat en l'apartat $a$.

Dades:

$\begin{array}{llll}\mathrm{q}=61,3 \mathrm{~kg} / \mathrm{m} & \mathrm{L}=3 \mathrm{~m} & \mathrm{H}=1 \mathrm{~m} & \mathrm{P}=500 \mathrm{~kg} \\ \phi_{\mathrm{AD}}=2 \mathrm{~cm} & \mathrm{E}_{\mathrm{AD}}=210 \mathrm{GPa} & \alpha_{\mathrm{AD}}=1,2 \cdot 10^{-5}{ }^{\circ} \mathrm{C}^{-1} & \Delta \mathrm{T}_{\mathrm{AD}}=30^{\circ} \mathrm{C} \\ \phi_{\mathrm{AC}}=? ? & \mathrm{E}_{\mathrm{AC}}=80 \mathrm{GPa} & \alpha_{\mathrm{AC}}=1 \cdot 10^{-5}{ }^{\circ} \mathrm{C}^{-1} & \Delta \mathrm{T}_{\mathrm{AC}}=30^{\circ} \mathrm{C}\end{array}$

En aquest problema no podem utilitzar les dades de massa, hem de transformar les masses de barra i motor $(\mathrm{kg})$ a pesos $(\mathrm{N})$, multiplicant els dos valors per 9,81.

A més, necessitem fer uns càlculs previs.

$$
\begin{array}{ll}
A_{A D}=\pi \frac{\phi_{A D}^{2}}{4}=3,14 \cdot 10^{-4} \mathrm{~m}^{2} & \\
\alpha=\arctan \left(\frac{H}{L}\right)=18,44^{\mathrm{o}} & L_{A D}=\sqrt{L^{2}+H^{2}}=3,162 \mathrm{~m} \\
\beta=\arctan \left(\frac{2 H}{L}\right)=33,69^{\mathrm{o}} & L_{A C}=\sqrt{\left(\frac{L}{2}\right)^{2}+H^{2}}=1,803 \mathrm{~m}
\end{array}
$$

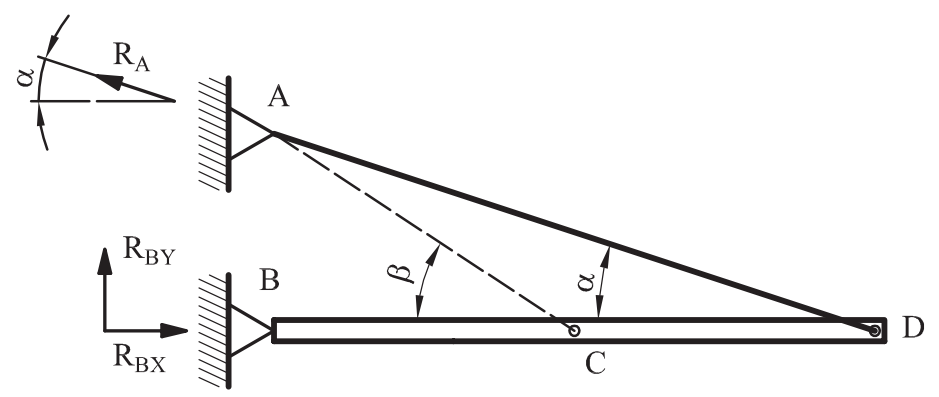

Fig. 4.38. Exemple 4.15 
És un cas isostàtic, podem resoldre'l amb les equacions d'equilibri.

$\sum \overrightarrow{F_{X}}=0 \rightarrow R_{B X}=R_{A} \cos (\alpha)$

$\sum \overrightarrow{F_{Y}}=0 \rightarrow R_{B Y}-q \cdot L-P+R_{A} \sin (\alpha)=0$

$\sum \vec{M}_{B}=0 \rightarrow q \frac{L^{2}}{2}+P \cdot L-R_{A} \cos (\alpha) \cdot H=0$

De la tercera equació calculem $\mathrm{R}_{\mathrm{A}}$ :

$R_{A}=\frac{\frac{q \cdot L^{2}}{2}+P \cdot L}{H \cos (\alpha)}=\frac{\frac{61,3 \cdot 9,81 \cdot 3^{2}}{2}+500 \cdot 9,81 \cdot 3}{1 \cos \left(18,44^{\circ}\right)}=18.357 \mathrm{~N}=18,357 \mathrm{kN}$

De la primera equació: $R_{B X}=R_{A} \cos (\alpha)=17,415 \mathrm{kN}$.

I de la segona: $R_{B Y}=q \cdot L-P+R_{A} \sin (\alpha)=0,902 \mathrm{kN}$.

L'axial al cable té el mateix valor que la reacció, i com que és de tracció, el seu valor serà positiu: $N_{A D}=R_{A}=18,357 \mathrm{kN}$.

Podem calcular l'allargament: $\Delta L_{A D}=\frac{N_{A D} \cdot L_{A D}}{E_{A D} \cdot A_{A D}}=8,79 \cdot 10^{-4} \mathrm{~m}=0,88 \mathrm{~mm}$.

Per a calcular el descens del punt $\mathrm{D}$, hem de fer una relació de compatibilitat de desplaçaments entre el moviment associat al cable i el moviment associat a la barra BCD.

La barra BCD és perfectament rígida, i l'únic moviment que permet és el gir al voltant de $\mathrm{B}$. Això significa que el punt $\mathrm{D}$ es mourà segons una perpendicular a BCD, és a dir, verticalment.

El cable AD s'allarga, i també gira al voltant del punt $\mathrm{A}$. El punt $\mathrm{D}$ podrà moure's segons una perpendicular a la línia $\mathrm{AD}$, que traçarem després de representar l'allargament.

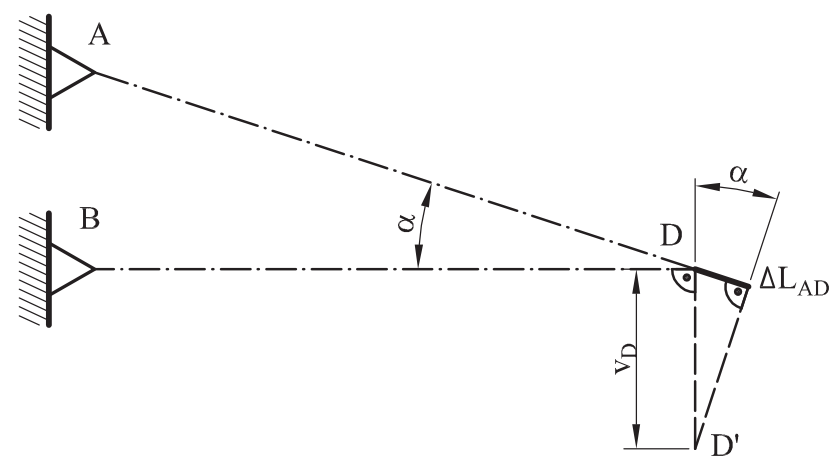

Fig. 4.39. Exemple 4.15. Compatibilitat de desplaçaments 
Un cop fetes aquestes consideracions, les relacions que establim entre l'allargament del cable i el moviment del punt $\mathrm{D}$ són:

$u_{D}=0 v_{D}=\frac{\Delta L_{A D}}{\sin (\alpha)}=2,783 \mathrm{~mm}$

Segona part. Ara tenim un increment de temperatura. El cable s'allargarà més que en condicions normals. Podríem calcular quin seria el descens del punt D abans de col·locar el segon cable. Les reaccions, i per tant, l'axial són iguals fins que no collloquem el cable AC.

$$
\begin{aligned}
& \Delta L_{A D}{ }^{\prime}=\frac{N_{A D} \cdot L_{A D}}{E_{A D} \cdot A_{A D}}+\alpha_{A D} \cdot \Delta T \cdot L_{A D}=2,02 \cdot 10^{-3} \mathrm{~m}=2,02 \mathrm{~mm} \\
& v_{D}{ }^{\prime}=\frac{\Delta L_{A D^{\prime}}}{\sin (\alpha)}=6,383 \mathrm{~mm}
\end{aligned}
$$

Comprovem que és més del doble de descens. L’hem de limitar mitjançant un segon cable que anirà de $\mathrm{A} \mathrm{a} \mathrm{C}$. El cas passa a ser hiperestàtic. Ara ja no coneixem la direcció de la reacció en $\mathrm{A}$, perquè hi concorren dues barres.

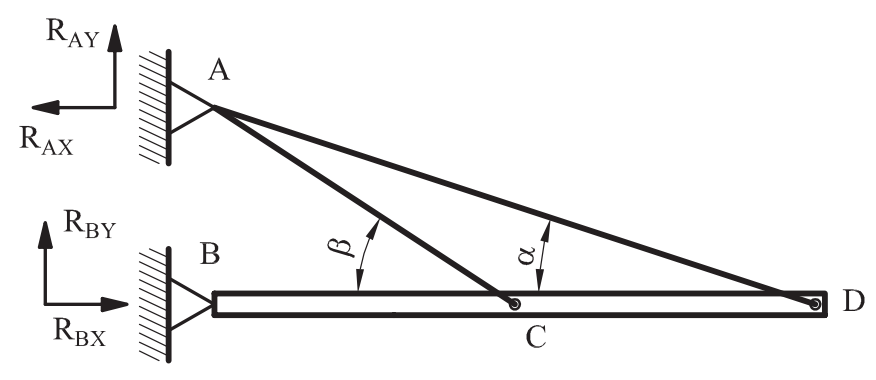

Fig. 4.40. Exemple 4.15. Reaccions amb el segon cable

Les equacions d'equilibri estàtic no són suficients per a calcular les reaccions.

$\sum \overrightarrow{F_{X}}=0 \rightarrow R_{B X}=R_{A X}$

$\sum \overrightarrow{F_{Y}}=0 \rightarrow R_{B Y}-q \cdot L-P+R_{A Y}=0$

$\sum \vec{M}_{B}=0 \rightarrow q \frac{L^{2}}{2}+P \cdot L-R_{A X} \cdot H=0$

Farem la compatibilitat de desplaçaments que ens relacionarà els allargaments dels cables entre ells. Una relació entre allargaments és equivalent a una reacció entre axials. En aquest cas, com que les reaccions no són iguals als axials, hem de fer també una relació entre reaccions i axials.

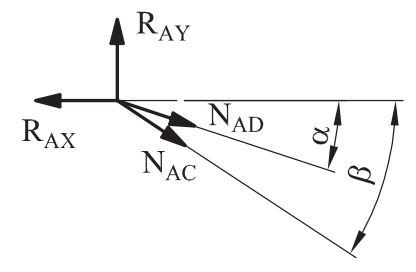

Fig. 4.41. Exemple 4.15. Relació entre axials i reaccions 
$R_{A X}=N_{A D} \cos (\alpha)+N_{A C} \cos (\beta)$

$R_{A Y}=N_{A D} \sin (\alpha)+N_{A C} \sin (\beta)$

Aquests valors els podem substituir en les equacions d'equilibri, de manera que després ho tindrem tot en funció dels axials.

$\sum \overrightarrow{F_{X}}=0 \rightarrow R_{B X}=N_{A D} \cos (\alpha)+N_{A C} \cos (\beta)$

$\sum \overrightarrow{F_{Y}}=0 \rightarrow R_{B Y}-q \cdot L-P+N_{A D} \sin (\alpha)+N_{A C} \sin (\beta)=0$

$\sum \vec{M}_{B}=0 \rightarrow q \frac{L^{2}}{2}+P \cdot L-\left(N_{A D} \cos (\alpha)+N_{A C} \cos (\beta)\right) \cdot H=0$

La compatibilitat de desplaçaments es basa en la rigidesa de la barra BCD. Com que la barra no es deforma, tots els seus punts giraran el mateix angle $(\theta)$ :

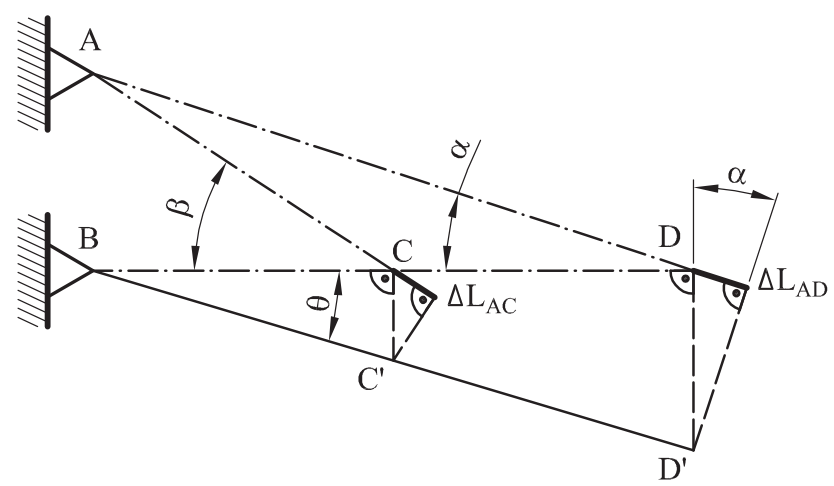

Fig. 4.42. Exemple 4.15. Compatibilitat de desplaçaments

La condició de compatibilitat és: $\tan (\theta)=\frac{v_{C}}{L / 2}=\frac{v_{D}}{L} \rightarrow v_{D}=2 v_{C}$.

Els desplaçaments estan relacionats amb els allargaments i els allargaments amb els axials:

$$
\begin{gathered}
\quad \Delta L_{A C}=\frac{N_{A C} \cdot L_{A C}}{E_{A C} \cdot A_{A C}}+\alpha_{A C} \cdot \Delta T \cdot L_{A C} \\
\frac{2 \Delta L_{A C}}{\sin \beta}=\frac{\Delta L_{A D}}{\sin (\alpha)} \quad \Delta L_{A D}=\frac{N_{A D} \cdot L_{A D}}{E_{A D} \cdot A_{A D}}+\alpha_{A D} \cdot \Delta T \cdot L_{A D} \\
\frac{2}{\sin (\beta)}\left(\frac{N_{A C} \cdot L_{A C}}{E_{A C} \cdot A_{A C}}+\alpha_{A C} \cdot \Delta T \cdot L_{A C}\right)=\frac{1}{\sin (\alpha)}\left(\Delta L_{A D}=\frac{N_{A D} \cdot L_{A D}}{E_{A D} \cdot A_{A D}}+\alpha_{A D} \cdot \Delta T \cdot L_{A D}\right)
\end{gathered}
$$

Aquesta seria l'equació de compatibilitat de desplaçaments, que unida a les d'equilibri ens permet resoldre el sistema. Tanmateix, no caldrà utilitzar aquesta equació tan complexa, en primer lloc perquè desconeixem el diàmetre de la barra $\mathrm{AC}$, i en segon lloc, perquè segons les dades del problema, coneixem el màxim desplaçament admissible per al punt $\mathrm{D}$. 
$\mathrm{v}_{\mathrm{D}}=2,783 \mathrm{~mm} \rightarrow \Delta L_{A D}=0,88 \mathrm{~mm}$

Podem calcular l'axial en la barra AD:

$N_{A D}=\frac{A_{A D} \cdot E_{A D} \cdot\left(\Delta L_{A D}-\alpha_{A D} \cdot \Delta T \cdot L_{A D}\right)}{L_{A D}}=-5,39 \cdot 10^{3} \mathrm{~N}=-5,39 \mathrm{kN}$

Amb l'equació d'equilibri corresponent a la suma de moments, podem calcular l'axial a l'altre cable:

$N_{A C}=\frac{q \frac{L^{2}}{2}+P \cdot L-H \cdot N_{A D} \cdot \cos (\alpha)}{H \cdot \cos (\beta)}=2,71 \cdot 10^{4} N=27,08 \mathrm{kN}$

També podem calcular l'allargament:

$$
v_{C}=\frac{v_{D}}{2}=1,391 \mathrm{~mm} \rightarrow \Delta L_{A C}=v_{C} \cdot \sin (\beta)=0,772 \mathrm{~mm}
$$

Amb aquests resultats, podem calcular l'àrea necessària del cable AC i el seu diàmetre:

$$
\begin{aligned}
& A_{A C}=\frac{N_{A C} \cdot L_{A C}}{E_{A C}\left(\Delta L_{A C}-\alpha_{A C} \cdot \Delta T \cdot L_{A C}\right)}=8,503 \cdot 10^{-5} \mathrm{~m}^{2} \\
& \phi_{A C}=\sqrt{\frac{4 \cdot A_{A C}}{\pi}}=0,0104 \mathrm{~m}=10,4 \mathrm{~mm}
\end{aligned}
$$




\section{Problemes proposats}

4.1. Dues peces de fusta de secció transversal 75 x $125 \mathrm{~mm}$ estan apegades mitjançant la unió obliqua que es mostra a la figura.

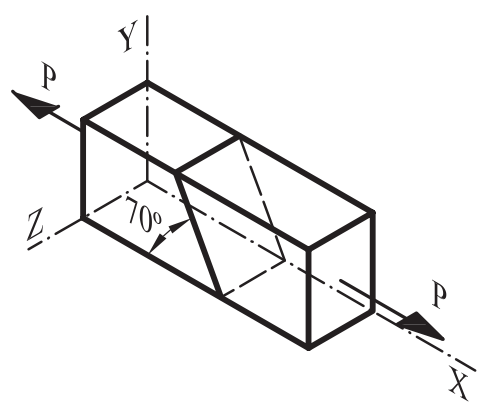

Fig. P.4.01

Si coneixem que la màxima tensió normal que suporta la cola és $0,5 \mathrm{MPa}$, calculeu:

a) La màxima càrrega $\mathrm{P}$ que pot ser aplicada perquè la unió no falle a tensió normal.

b) La corresponent tensió tangencial en la cola.

4.2. Les dues parts del sòlid prismàtic de la figura estan apegades formant un angle $\theta$ amb l'horitzontal. Sabem que els límits de trencament per a la unió són: $17 \mathrm{MPa}$ per a la tensió normal i $9 \mathrm{MPa}$ per a la tensió tangencial. Determineu els valors de l'angle $\theta$ per als quals el coeficient de seguretat és almenys de 3 .

Dades: dimensió transversal del sòlid, 30 x $50 \mathrm{~mm}$.

Definició de coeficient de seguretat $\mathrm{n}=\mathrm{P}_{\text {trencament }} / \mathrm{P}_{\text {aplicada }}$.

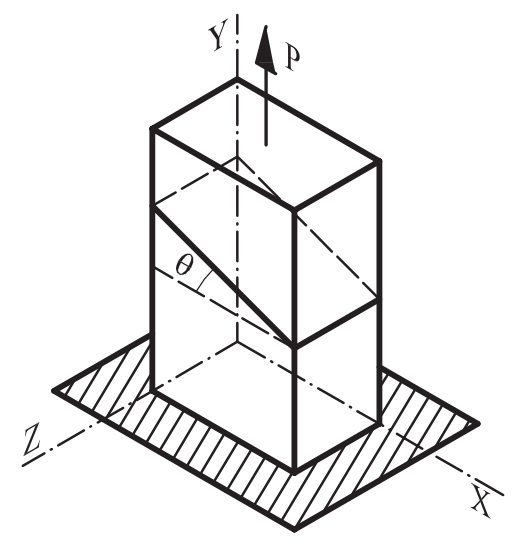

Fig. P.4.02 
4.3. La peça de la figura està feta d'alumini. Calculeu la màxima força $\mathrm{P}$ que pot exercir-se perquè no s'arribe a la tensió admissible i la deformació axial no supere els $4 \mathrm{~mm}$.

El punt A és un encast.

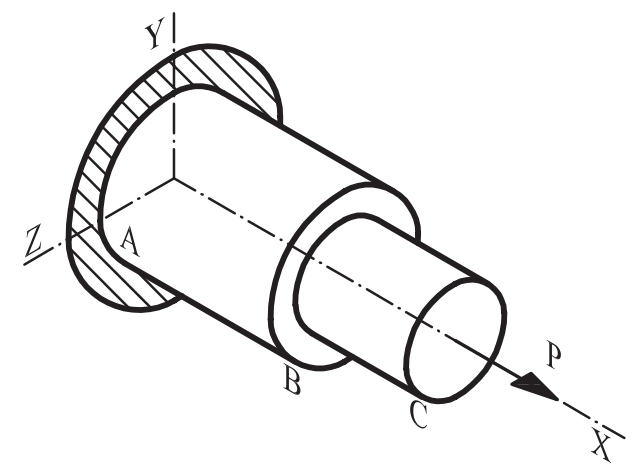

Fig. P.4.03

Dades: $\mathrm{E}=73 \mathrm{GPa} ; \sigma_{\mathrm{adm}}=160 \mathrm{MPa} ; \mathrm{L}_{\mathrm{AB}}=1,2 \mathrm{~m} ; \mathrm{L}_{\mathrm{BC}}=0,8 \mathrm{~m} ; \mathrm{D}_{\mathrm{AB}}=30 \mathrm{~mm}$; $\mathrm{D}_{\mathrm{BC}}=20 \mathrm{~mm}$.

4.4. La peça de la figura està feta d'alumini i el punt A és un encast.

a) Calculeu el valor de la força $\mathrm{Q}$, aplicada en $\mathrm{B}$, que fa que el punt $\mathrm{C}$ no es desplace.

b) Calculeu el desplaçament del punt B.

Dades: $\mathrm{E}=73 \mathrm{GPa} ; \mathrm{P}=4 \mathrm{kN} ; \mathrm{L}_{\mathrm{AB}}=0,5 \mathrm{~m} ; \mathrm{L}_{\mathrm{BC}}=0,4 \mathrm{~m} ; \mathrm{D}_{\mathrm{AB}}=60 \mathrm{~mm} ; \mathrm{D}_{\mathrm{BC}}=20 \mathrm{~mm}$.

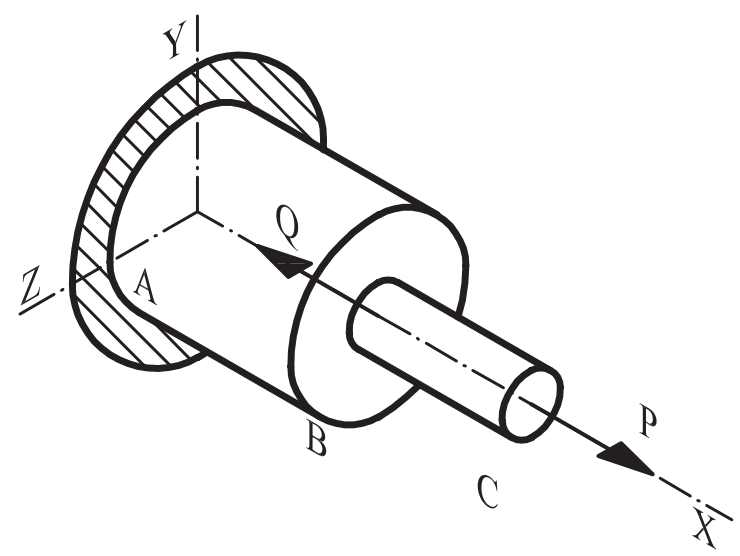

Fig. P.4.04

4.5. Calculeu tots els esforços axials de l'estructura de barres de la figura (cotes en metres). Totes les unions són articulades. 


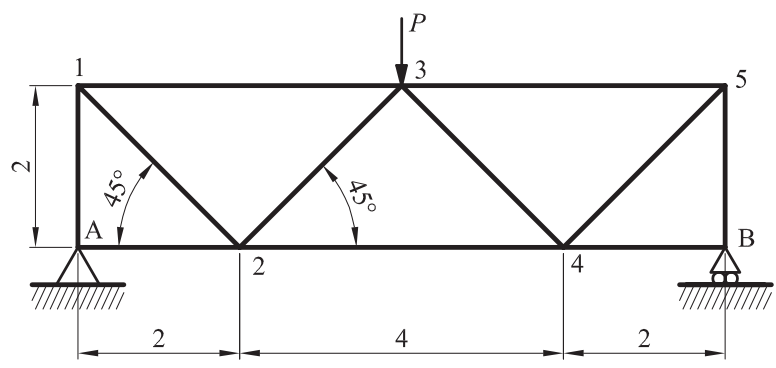

Fig. P.4.05

Dades: $\mathrm{P}=50 \mathrm{kN}$.

4.6. En la figura següent, el sòlid $A B C$ és indeformable i el cable $C D$ és d'acer S275 de diàmetre $1 \mathrm{~cm}$. Calculeu la tensió del cable i la posició del punt C.

Dades: $\mathrm{P}=6 \mathrm{kN} ; \mathrm{a}=1 \mathrm{~m} ; \mathrm{E}=210 \mathrm{GPa}$.

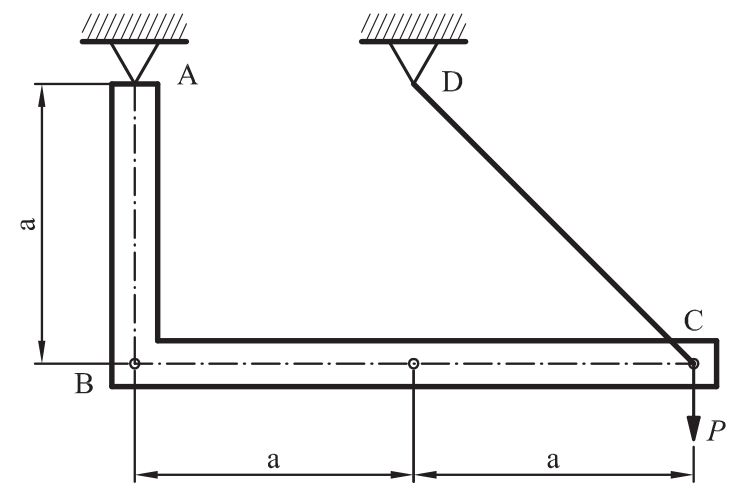

Fig. P.4.06

4.7. En la figura, el sòlid ABCD és indeformable i el cable DE és d'acer S275 i de diàmetre $1 \mathrm{~cm}$. Calculeu la tensió del cable i la posició del punt $\mathrm{D}$.

Dades: $\mathrm{P}=35 \mathrm{kN} ; \mathrm{a}=1 \mathrm{~m} ; \mathrm{E}=210 \mathrm{GPa}$.

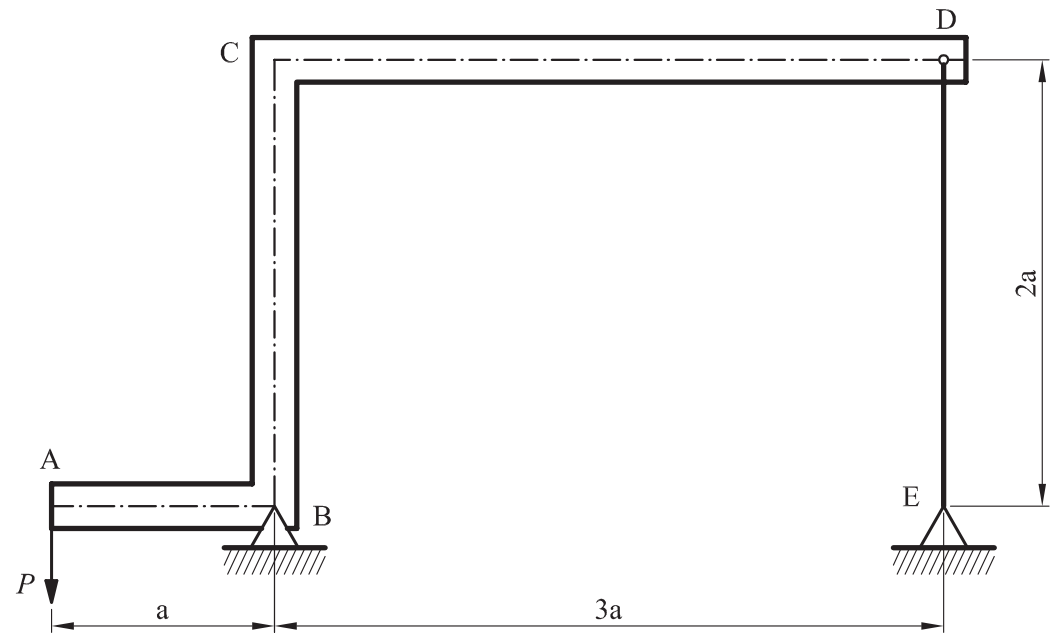

Fig. P.4.07 
4.8. Calculeu l'esforç axial en cadascuna de les barres de l'estructura de barres següent. Totes les unions són articulades.

Deixeu els resultats en funció de P.

Dades: P; per a totes les barres, E, A.

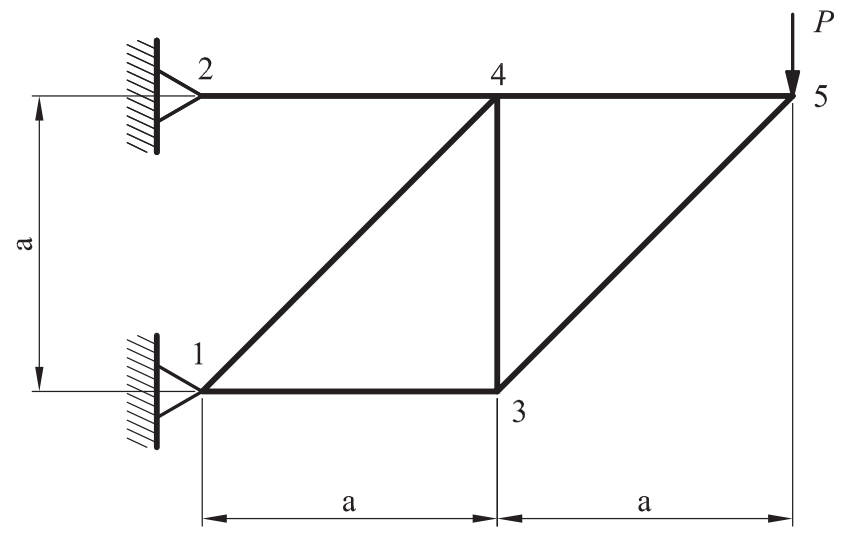

Fig. P.4.08

4.9. Les dues barres de la figura estan articulades als seus extrems. El material d'ambdues és acer, el diàmetre $2 \mathrm{~cm}$ i la longitud $3,5 \mathrm{~m}$.

Calculeu el desplaçament horitzontal i vertical del punt C.

Dades: $\mathrm{P}=5 \mathrm{kN} ; \mathrm{E}=210 \mathrm{GPa}$.

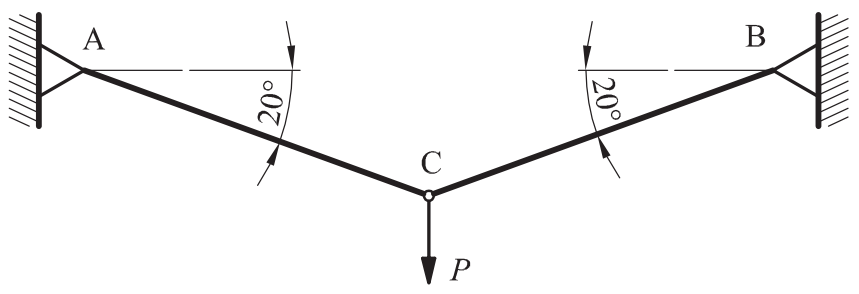

Fig. P.4.09

4.10. La barra d'acer de la figura és de secció circular de $25 \mathrm{~mm}$ de diàmetre. La seua densitat és $\delta=7.850 \mathrm{~kg} / \mathrm{m}^{3}$.

a) Determineu la tensió màxima que es produeix a la peça i si se supera la tensió admissible.

b) Calculeu el desplaçament dels punts B i C.

Dades: $\mathrm{L}=25 \mathrm{~m} ; \mathrm{P}_{1}=65 \mathrm{kN} ; \mathrm{P}_{2}=75 \mathrm{kN} ; \mathrm{E}=210 \mathrm{GPa} ; \sigma_{\mathrm{adm}}=235 \mathrm{MPa}$. 


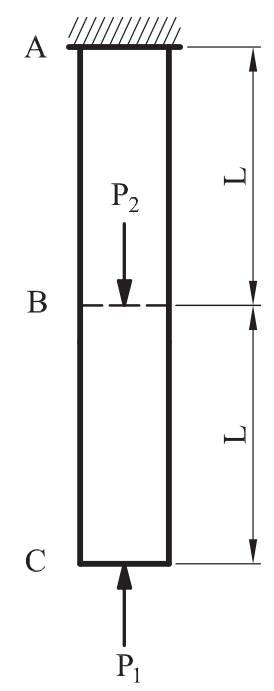

Fig. P.4.10

4.11. L'estructura de la figura representa una passarel-la (considerada infinitament rígida) per a creuar un barranc. S'estima que les accions que suportarà es poden reduir a una càrrega uniformement repartida de valor $\mathrm{q}=50 \mathrm{kN} / \mathrm{m}$ en tota la seua longitud. El disseny inicial inclou pilars biarticulats de perfil IPE 200 (S275). Com a condició per a la seua unió amb els camins adjacents, s'exigeix que el màxim descens de qualsevol dels extrems siga d'1 mm. Comproveu si el disseny és correcte.

Dades: $\mathrm{L}_{\mathrm{AB}}=\mathrm{L}_{\mathrm{BC}}=4 \mathrm{~m} ; \mathrm{L}_{\mathrm{AD}}=2 \mathrm{~m} ; \mathrm{L}_{\mathrm{BE}}=4 \mathrm{~m} ; \mathrm{L}_{\mathrm{CF}}=3 \mathrm{~m}$.

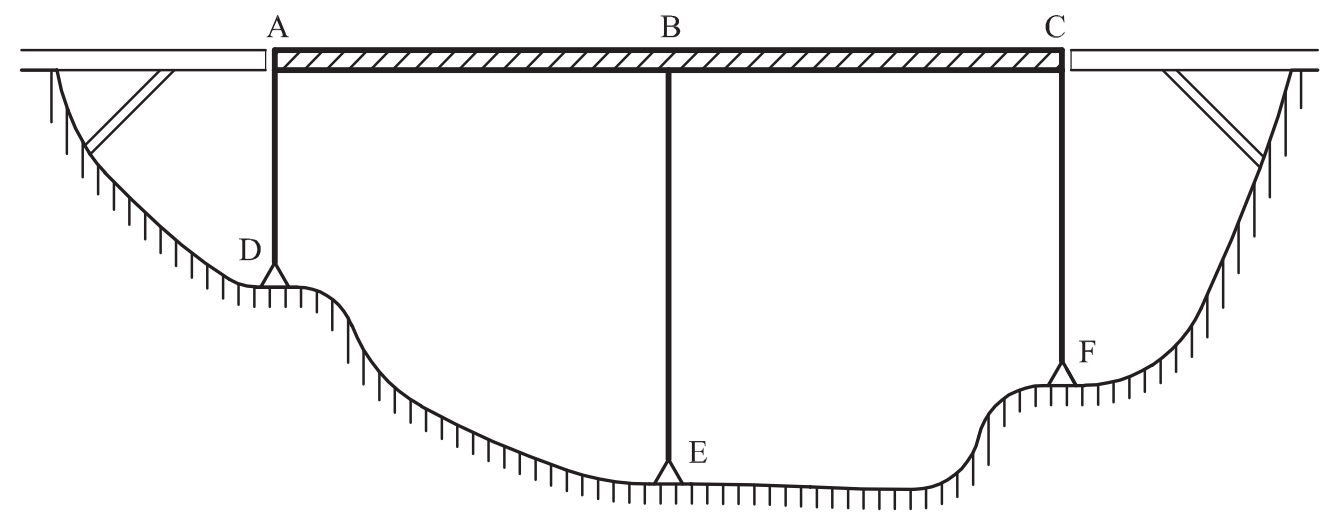

Fig. P.4.11

Nota: considereu que els punts A i C tenen el desplaçament horitzontal impedit, i per tant, existeix l'equivalent a un recolzament lliscant en eixos punts, de manera que el sistema no siga un mecanisme. 
4.12. En la següent figura, el marc $A B C D$ és un quadrat de costat $1,5 \mathrm{~m}$, perfectament rígid. Els dos cables són rodons d'acer S275JR, de diàmetre $25 \mathrm{~mm}$ i de longitud 2,0 $\mathrm{m}$, i estan biarticulats.

a) Estudieu el màxim valor de la càrrega $\mathrm{P}$ aplicada en el punt $\mathrm{B}$, de manera que el descens del punt siga menor que $1,5 \mathrm{~mm}$.

b) Calculeu totes les reaccions.

c) Verifiqueu que en els cables no se supera la tensió admissible del material.

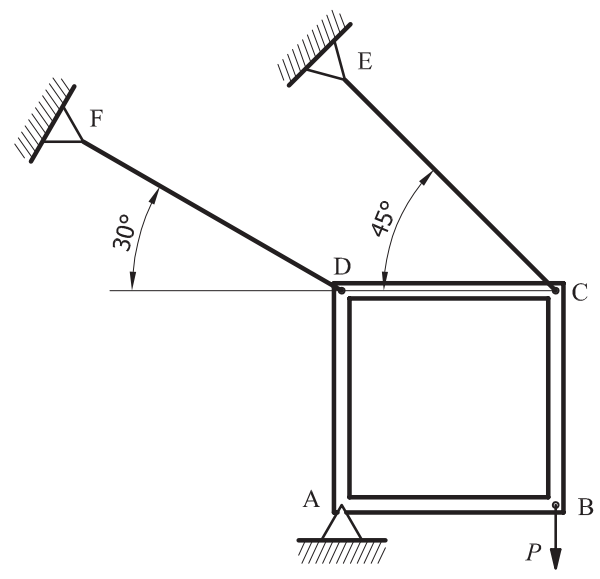

Fig. P.4.12

4.13. El sistema estructural de la figura està compost per un element triangular equilàter $\mathrm{BCD}$ que es pot considerar infinitament rígid, articulat a una referència fixa en $\mathrm{C} i$ unit a dues referències fixes més a través de les barres $\mathrm{AB} i$ $\mathrm{EF}$, ambdues biarticulades. Sobre la base del triangle actua la càrrega distribuïda de valor constant q. Calculeu el màxim valor de la càrrega distribuïda $\mathrm{q}$ perquè es complisquen els tres requisits de disseny següents:

a) Que cap de les barres supere la tensió admissible (no feu cap consideració sobre el vinclament).

b) Que l'elongació de la barra AB siga inferior a $1 \mathrm{~mm}$.

c) Que la rotació de l'element triangular respecte de $\mathrm{C}$ siga inferior a 0,001 radians.

Dades: $\varphi_{1}=1 \mathrm{~cm} ; \varphi_{2}=2 \mathrm{~cm} ; \mathrm{L}_{2}=3 \mathrm{~m} ; \mathrm{d}=1,5 \mathrm{~m}$ (costat del triangle); $\sigma_{\mathrm{adm}}=175 \mathrm{MPa}$.

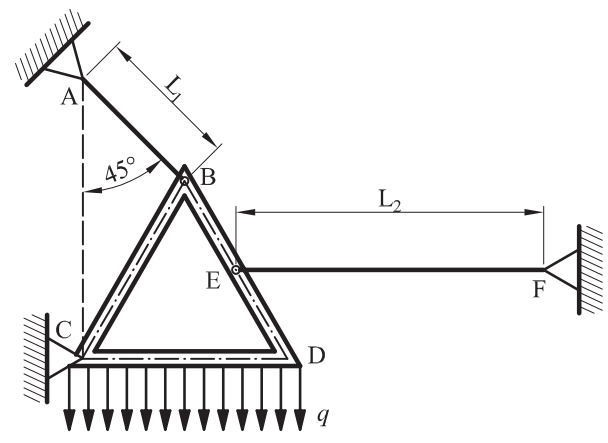

Fig. P.4.13 


\section{TEMA 5}

\section{Flexió - tensions}

\subsection{Introducció}

Considerarem en aquest tema els prismes mecànics a les seccions dels quals apareixen una o les dues components de moments flectors $\left(M_{Y} ; M_{Z}\right)$.

Quan un element relativament esvelt suporta càrregues que estan aplicades perpendicularment al seu eix longitudinal, o moments externs, l'element es denomina biga. Qualsevol element d'una estructura, siga d'una màquina o d'un pont, que es flexiona sota l'acció de les càrregues, es denomina biga.

Això resulta bastant freqüent en els casos típics en edificació. A més, les tensions i les deflexions que es produeixen degudes a la flexió solen ser més elevades que les que produeixen uns altres tipus d'esforços. Per tot això, considerem aquest tema com un dels més importants del curs.

L'objecte principal de l'estudi de bigues és la determinació dels esforços interns, de les tensions i de les deflexions causades per les càrregues aplicades. En aquest tema ens centrarem en l'estudi de les tensions que apareixen com a conseqüència de la flexió, i en el tema següent tractarem les deformacions. Veurem que existeix una relació directa entre els esforços en una secció i les tensions que apareixen en els seus punts. En bigues isostàtiques ja sabem com calcular els esforços, per tant el càlcul de les tensions el farem de manera quasi immediata. En bigues hiperestàtiques, utilitzarem l'estudi de les deflexions que veurem al tema 6 per resoldre l'hiperestatisme i obtindre les lleis d'esforços.

\subsection{Tipus de flexió}

Quan en tota secció recta d'un prisma mecànic, la resultant de les forces situades a un costat d'ella és nul·la i el vector moment resultant està contingut en el pla de la secció, direm que el prisma està sotmés a flexió pura. Si el vector moment porta la direcció d'un dels eixos principals d'inèrcia de la secció, s'anomena flexió simètri$c a$. Si, per contra, el vector no porta la direcció de cap dels eixos, llavors podrem fer una descomposició vectorial, i direm que apareixen moments flectors als dos eixos principals. Aquest cas és una flexió asimètrica o esbiaixada.

Si el vector tensió no és l'única resultant dels esforços, sinó que, a més, apareixen esforços tallants, la flexió s'anomena flexió simple (que també pot ser simètrica o asimètrica). 
En el cas que els moments flectors vagen acompanyats d'esforç axial, direm que tenim flexió composta. En aquest cas, també pot ser simple i simètrica o asimètrica.
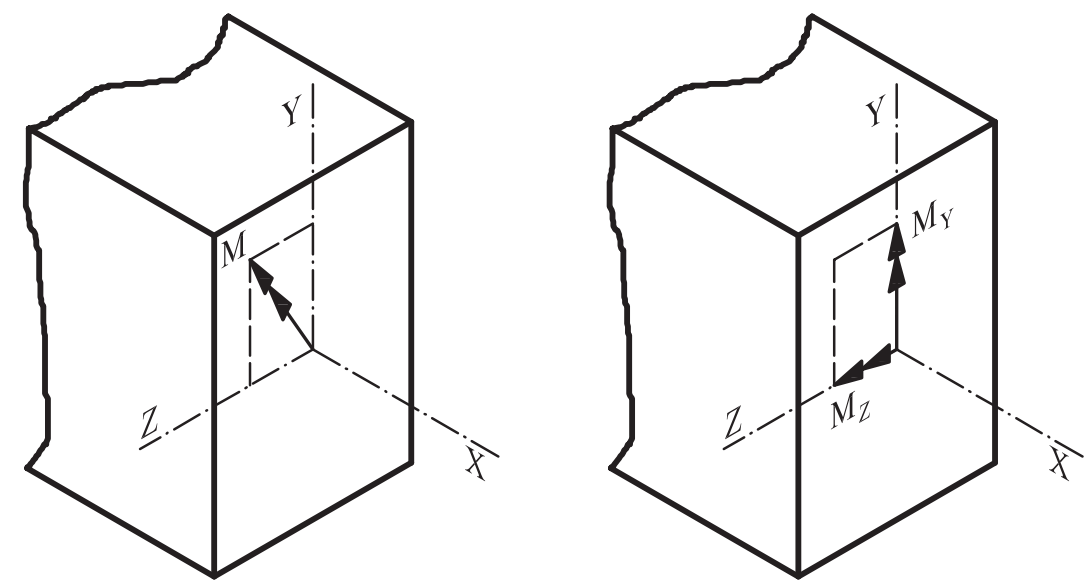

Fig. 5.1. El moment resultant pot descompondre's segons els eixos principals. Les dues figures són equivalents

Quan tenim un cas pla (bidimensional), com que només tenim un únic moment flector $\left(M_{Z}\right)$, normalment utilitzem com a representació dels moments flectors una fletxa corbada, com hem fet fins ara. Si el cas es tridimensional, les fletxes corbes poden induir a error, a causa de la perspectiva. Per aquesta raó és freqüent l'ús de fletxes rectes que, per a diferenciar-se de les forces, tindran dues puntes. En aquest cas resulta més fàcil apreciar si el moment és positiu o negatiu. Serà positiu si el vector porta la direcció de l'eix corresponent. La direcció del vector ha de deduir-se seguint la regla del cargol o del llevataps.

Farem ara una representació dels diversos casos de flexió.

Flexió pura: $N=V_{Y}=V_{Z}=M_{T}=0$. Podem tindre un únic moment flector o els dos.

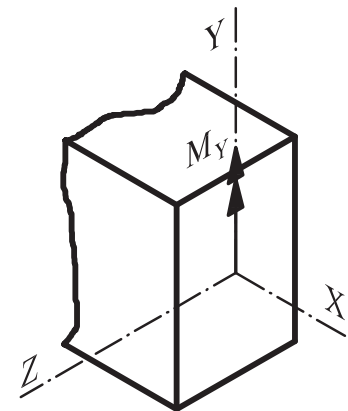

a)

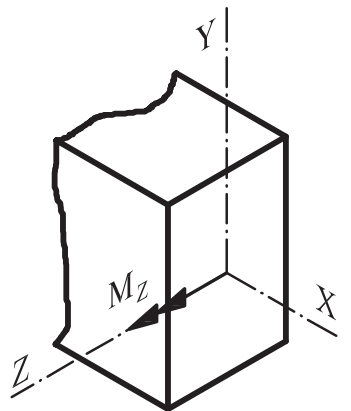

b)

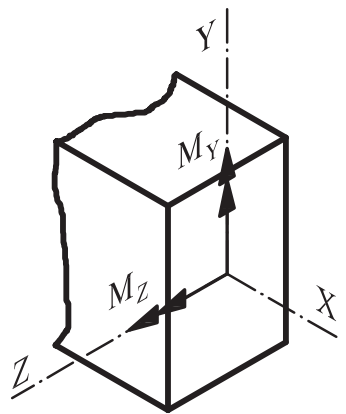

c)

Fig. 5.2. Flexió pura: a) i b) simètrica; $c$ ) asimètrica

Flexió simple: $N=M_{T}=0$. Ha d'existir un esforç tallant. Normalment, un esforç tallant en $\mathrm{Y}$ implica un moment flector en $\mathrm{Z}$, i viceversa. Pot existir un tallant o els dos, i un moment o els dos. 

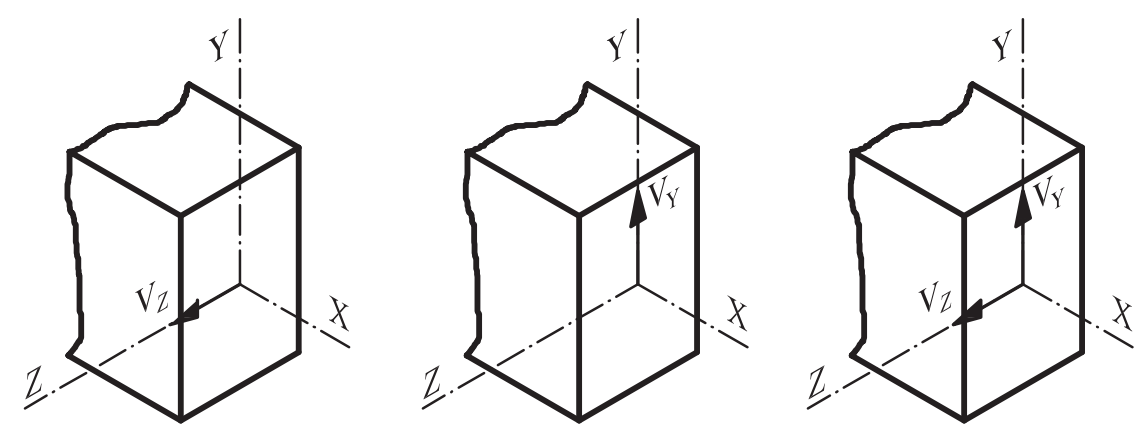

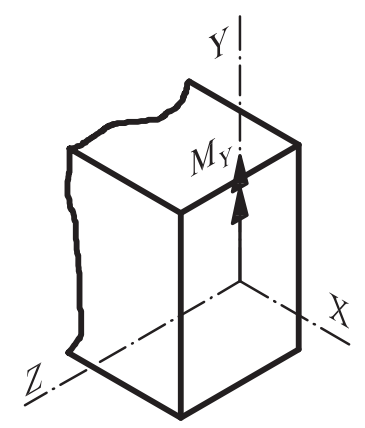

a)

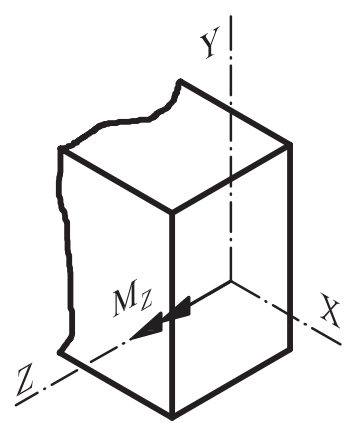

b)

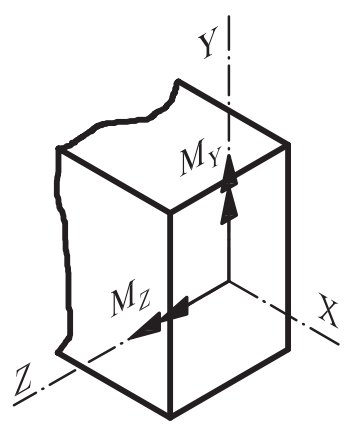

c)

Fig. 5.3. Flexió simple: $a$ ) i $b$ ) simètrica; $c$ ) asimètrica.

Es representen per separat els moments i els tallants

Flexió composta: $M_{T}=0$. Ha d'existir esforç axial. Els tallants poden estar o no, i pot existir un tallant o els dos, i un moment o els dos.

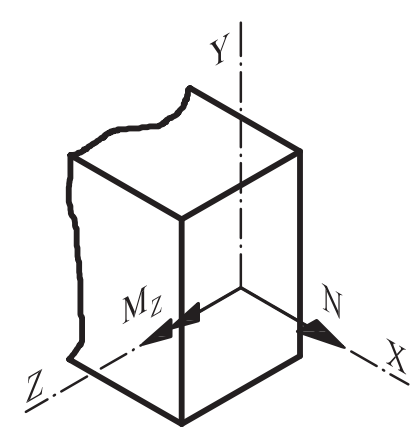

a)

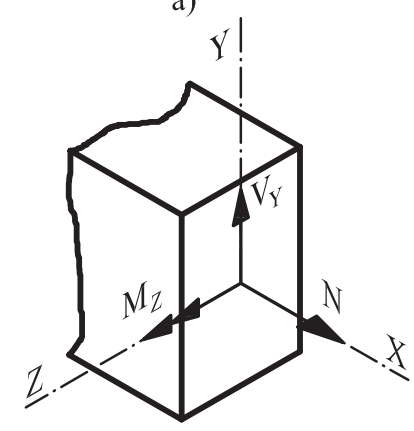

c)

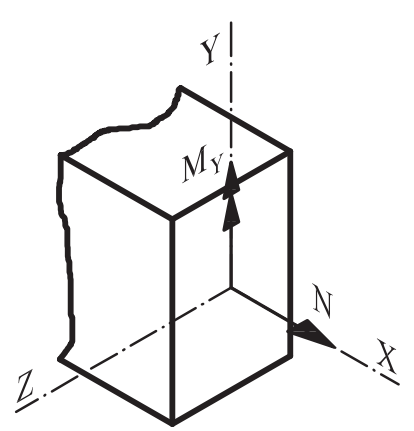

b)

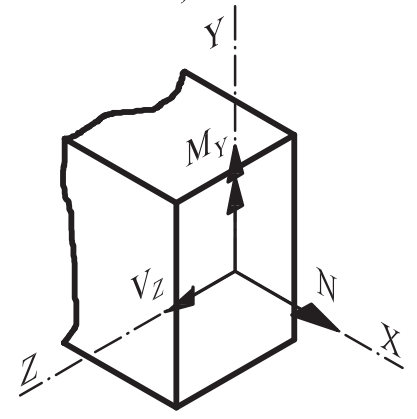

d)

Fig. 5.4. Flexió composta: $a$ ) i $b$ ) pures; $c$ ) i $d$ ) simples. Només es representen les flexions simètriques. Per a les flexions esbiaixades hauríem de representar els dos moments en cada cas 
En un mateix element pot donar-se el cas que tinguem tipus diferents de tensió en segons quines seccions.

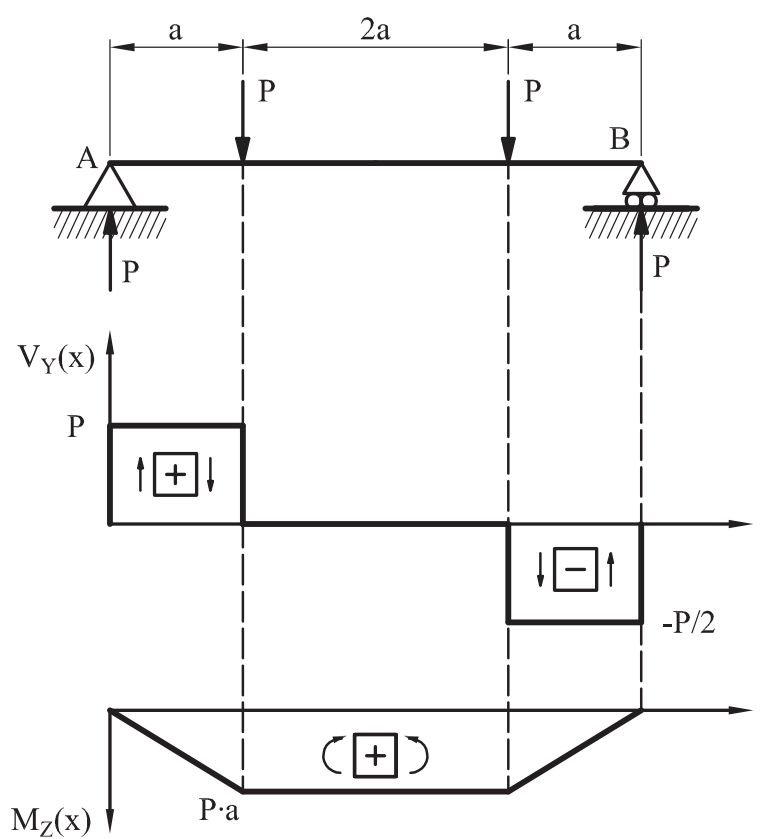

Fig. 5.5. Diferents tipus de flexió en la mateixa peça. En les zones prop dels recolzaments tenim flexió simple i en la zona central, flexió pura

\subsection{Relació entre esforços i distribució de càrrega}

En una biga sotmesa a una distribució qualsevol de forces, existeix una relació entre els esforços que es generen i les forces aplicades. Representem aquesta distribució de forces qualsevol, en aquest cas en la direcció Y, de la manera següent.

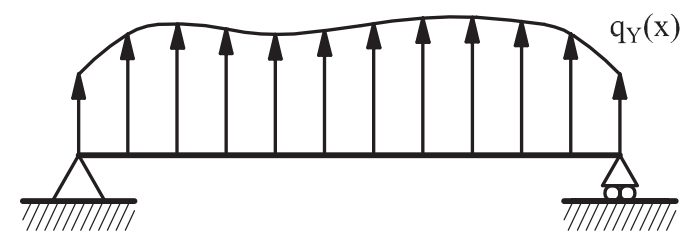

Fig. 5.6. Distribució qualsevol de forces

Si ara prenem una llesca diferencial de la barra, com que la càrrega varia de manera contínua, podem assumir que existirà una variació diferencial tant de la càrrega com dels esforços a un costat i l'altre de la llesca.

Podem plantejar l'equilibri de la llesca diferencial:

$$
\begin{aligned}
& \sum \overrightarrow{F_{X}}=0 \rightarrow V_{Y}-\left(V_{Y}+d V_{Y}\right)+q_{Y}(x) \cdot d x=0 \\
& \left.\sum \overrightarrow{F_{Y}}=0 \rightarrow M_{Z}+d M_{Z}\right)-M_{Z}+q_{Y}(\mathrm{x}) \frac{d x^{2}}{2}-\left(V_{Y}+d V_{Y}\right)=0
\end{aligned}
$$




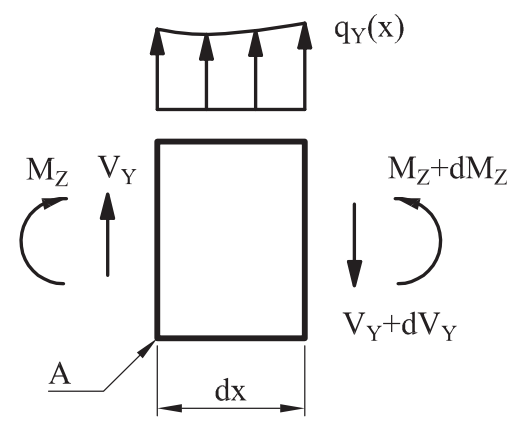

Fig. 5.7. Esforços sobre una llesca diferencial

Si en aquestes equacions negligim els diferencials de segon ordre i reorganitzem els elements:

$$
q_{Y}(x)=\frac{d V_{Y}(x)}{d x} \quad V_{Y}(x)=\frac{d M_{Z}(x)}{d x}
$$

Podríem haver obtingut un resultat anàleg en fer les suposicions amb la càrrega en la direcció $\mathrm{Z}$.

$$
q_{Z}(x)=\frac{d V_{Z}(x)}{d x} \quad V_{Z}(x)=\frac{d M_{Y}(x)}{d x}
$$

Això ja ho havíem tractat, encara que de manera més intuïtiva, quan vam veure els diagrames d'esforços. En aquell punt déiem que el moment era màxim quan s'anul-lava el tallant, perquè la derivada del moment era el tallant, i això és el típic càlcul matemàtic de màxims i mínims.

\subsection{Distribució de tensions normals. Llei de Navier}

Si pensem en un prisma mecànic sotmés a flexió pura, podem adonar-nos que es produeix un corbament de la línia mitjana. La conseqüència és que les fibres que es troben a un costat de la fibra mitjana s'allarguen i les de l'altre costat s'acurten. Necessàriament, les fibres que s'allarguen han d'estar sotmeses a esforços de tracció, i les que s'acurten a compressions. La fibra mitjana no experimentarà ni allargaments ni acurtaments, per la qual cosa es denomina fibra neutra. Com a conseqüència, els centres de gravetat de les seccions només es mouen verticalment.

Per al desenrotllament de l'explicació considerarem flexió pura. Posteriorment farem consideracions sobre si els resultats obtinguts són vàlids per a la resta de tipus de flexió.

Necessitem fer algunes hipòtesis prèvies:

1. El sòlid en flexió es manté dins de la zona elàstica proporcional.

2. S'admet la hipòtesi de Bernouilli: les seccions planes abans de la deformació segueixen sent-ho després d'ella. Aquesta hipòtesi es vàlida si l'esforç 
tallant és zero. Si no ho és, es comet un error proporcional a l'altura de la peça dividida per la seua longitud $(\mathrm{h} / \mathrm{L})$. En bigues, normalment la longitud és molt més gran que l'altura, i l'error que es comet és suficientment menut. En bigues que són molt altes en relació amb la longitud (bigues de gran cantell), o en les mènsules curtes, l'error no és negligible.

3. Les deformacions són suficientment menudes perquè l'acció de les forces exteriors no siga modificada per la deformació (petita deformació).

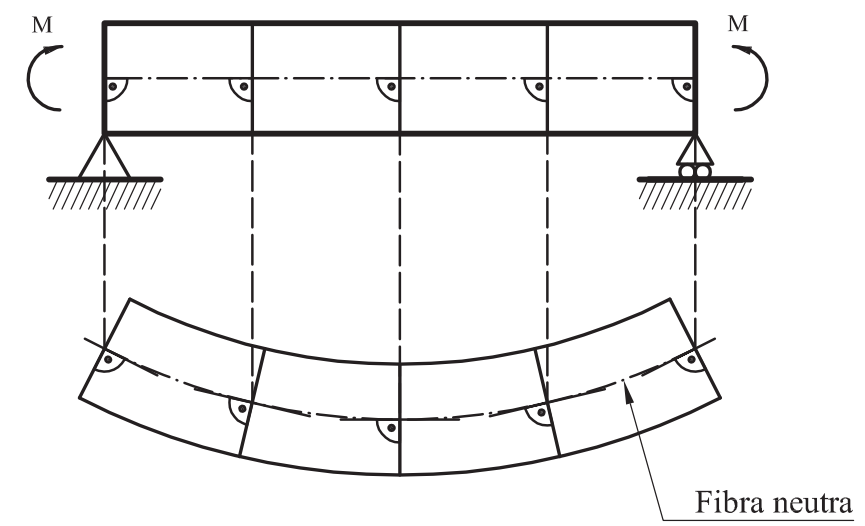

Fig. 5.8. Hipòtesi de Bernouilli

Si recordem les equacions que relacionaven els esforços amb les tensions, que ja vam veure al tema 3:

$$
\begin{array}{ll}
N=\iint_{\Omega} \sigma_{n X} d A & M_{T}=\iint_{\Omega}\left(\tau_{X Z} \cdot y-\tau_{X Y} \cdot z\right) d A \\
V_{Y}=\iint_{\Omega} \tau_{X Y} d A & M_{Y}=\iint_{\Omega} \sigma_{n X} \cdot z d A \\
V_{Z}=\iint_{\Omega} \tau_{X Z} d A & M_{Z}=-\iint_{\Omega} \sigma_{n X} \cdot y d A
\end{array}
$$

És evident que existeix una relació directa entre l'esforç axial, els moments flectors i la tensió normal. Així mateix, estan relacionats els esforços tallants i el moment torçor amb les tensions tangencials. Com que hem dit que farem l'estudi per a flexió pura, no tindrem ni tallants ni torçor, per la qual cosa podem deduir que les tensions tangencials són nul·les. A més, la hipòtesi de Bernouilli ens diu que les seccions planes han de seguir sent planes, i per tant, no poden existir tensions tangencials que puguen bombar la secció.

D'aquesta manera, en aplicar només un moment flector $M_{z}$, com que la secció només gira al voltant de l'eix Z (figura 5.9. a), el desplaçament horitzontal d'un punt de la secció només depén de la posició vertical del punt dins de la secció (de la coordenada y). Si b" és una constant de proporcionalitat: $\Delta x=b$ ”. $y$.

De manera similar, si apliquem un moment $M_{Y}$, els desplaçaments horitzontals dels punts dependran directament de la seua coordenada z (figura 5.9. $b$ ): $\Delta x=c " \cdot z$. 
Si apliquem només un esforç axial $N$, com ja hem vist al tema anterior, tots els punts de la secció es desplacen la mateixa distància (figura 5.9. c): $\Delta x=a$ ".

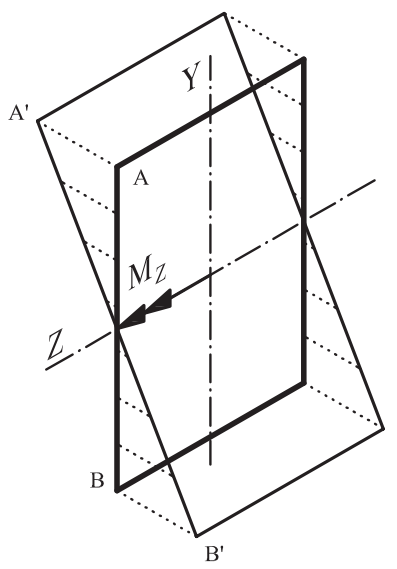

a)

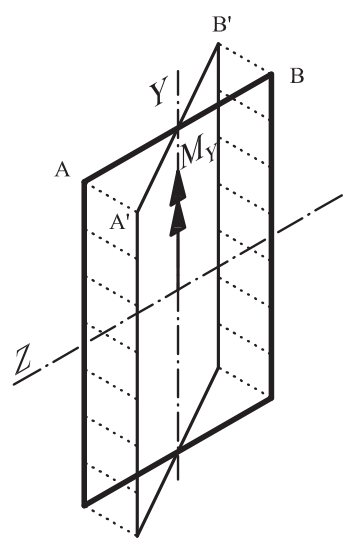

b)

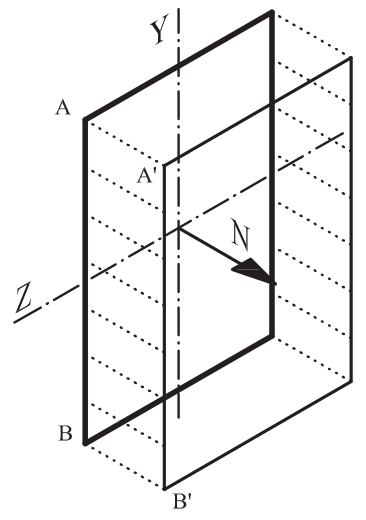

c)

Fig. 5.9. Desplaçaments deguts a moments flectors i axial

En el cas que actuen els tres esforços alhora, el desplaçament dels punts serà una combinació dels tres anteriors, però la secció romandrà plana.

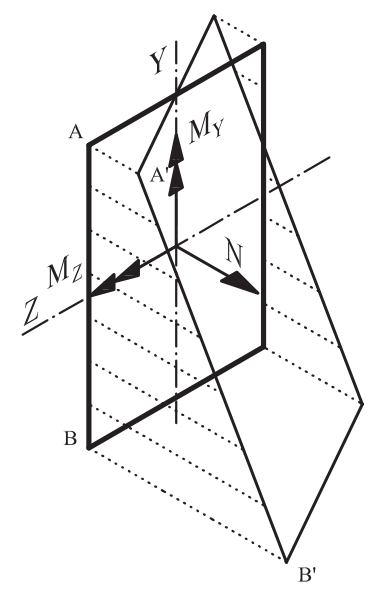

Fig. 5.10. Desplaçaments deguts a la combinació dels esforços

$$
\Delta x=a{ }^{\prime \prime}+b^{\prime \prime} \cdot y+c c^{\prime} \cdot z
$$

L'anterior equació és l'equació d'un pla. Com que la deformació és proporcional al desplaçament dels punts, la llei de deformacions també serà l'equació d'un pla:

$$
\varepsilon(x)=a^{\prime}+b^{\prime} \cdot y+c^{\prime} \cdot z
$$

Estem considerant que no abandonem el règim elàstic i la llei de Hooke és vàlida. Les tensions són proporcionals a les deformacions. La llei de tensions també tindrà la forma d'equació d'un pla:

$$
\sigma(x)=a+b \cdot y+c \cdot z
$$


El que hem d'aconseguir ara és trobar el valor de les constants, a, b i c. Desenrotllem les equacions considerant aquesta forma per a la tensió normal.

$$
\begin{aligned}
& N=\iint_{\Omega} \sigma_{n X} d A=\iint(a+b \cdot y+c \cdot z) d A=a \iint d A+b \iint y d A+c \iint z d A \\
& M_{Z}=-\iint_{\Omega} \sigma_{n X} \cdot y d A=-\iint(a+b \cdot y+c \cdot z) y d A=-a \iint y d A-b \iint y^{2} d A-c \iint y \cdot z d A \\
& M_{Y}=\iint_{\Omega} \sigma_{n X} \cdot z d A=\iint(a+b \cdot y+c \cdot z) z d A=a \iint z d A+b \iint y \cdot z d A+c \iint z^{2} d A
\end{aligned}
$$

Els termes de les expressions poden ser calculats:

$$
\iint d A=A
$$

Els moments estàtics i els productes d'inèrcia respecte als eixos principals d'inèrcia són zero.

$$
\iint y d A=0 \quad \iint z d A=0 \quad \iint y \cdot z d A=0
$$

La definició de moments d'inèrcia és:

$$
I_{Z}=\iint y^{2} d A \quad I_{Y}=\iint z^{2} d A
$$

Per tant, les expressions anteriors ens queden com a:

$$
\begin{gathered}
N=a \cdot A \\
M_{Z}=-b \cdot I_{Z} \\
M_{Y}=c \cdot I_{Y}
\end{gathered}
$$

Aïllem les constants i substituïm en l'equació del pla:

$$
\sigma(x)=\frac{N}{A}-\frac{M_{Z}}{I_{Z}} y+\frac{M_{Y}}{I_{Y}} z
$$

Aquesta expressió, que relaciona les tensions normals amb els esforços que les produeixen, s'anomena llei de Navier.

Habitualment no tindrem flexió pura: és molt més freqüent tindre flexió simple. L'esforç tallant produeix tensions tangencials, bomba la secció i produeix deformacions addicionals. Tanmateix, pot demostrar-se que, llevat d'alguns casos concrets, les tensions i les deformacions degudes al tallant poden negligir-se. Els casos en els quals tenen una gran importància relativa són les bigues de gran cantell i mènsules curtes. Per tant, considerarem que la llei de Navier continua sent vàlida en presència d'esforços tallants. 


\subsection{Flexió simètrica}

La major part dels casos de bigues que hem vist fins ara són casos de flexió simètrica, perquè només hi ha un moment flector (habitualment $M_{Z}$ ). En aquests casos, l'eix deformat de la biga està contingut en el pla perpendicular a l'eix de la flexió. Per exemple, en el cas més senzill: una biga voladissa.
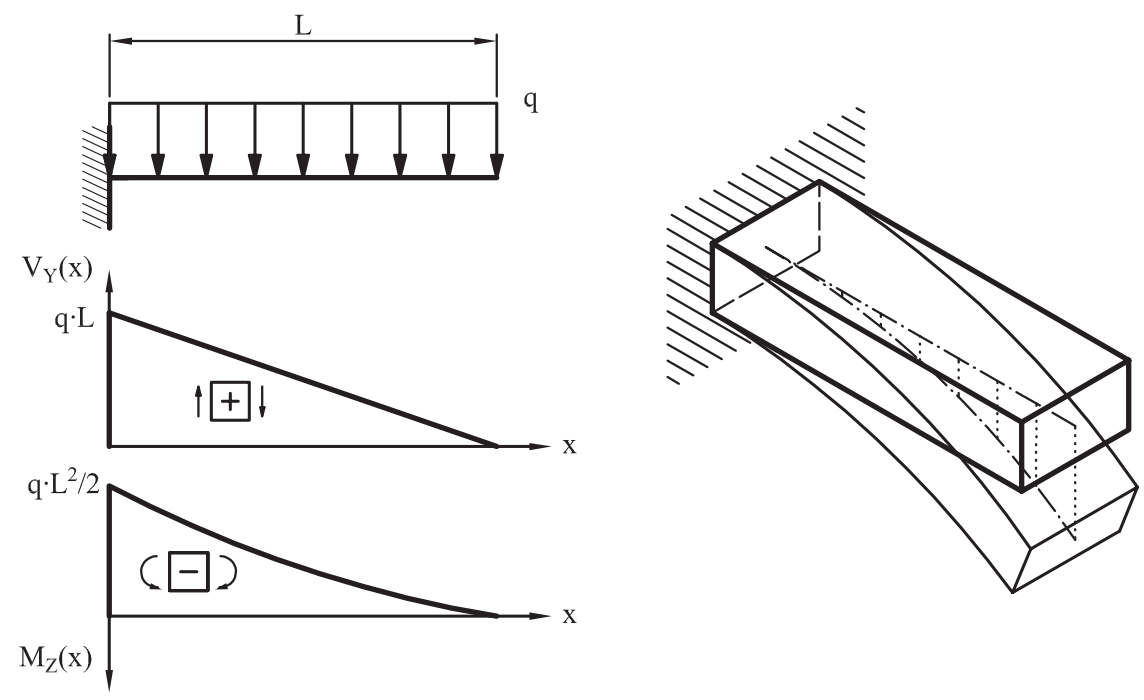

Fig. 5.11. Flexió simètrica

La llei de Navier queda més simplificada en $\operatorname{ser} N=M_{Y}=0$ :

$$
\sigma(x)=\frac{-M_{Z}}{I_{z}} y
$$

En aquest exemple, el moment flector és negatiu en tota la barra $\left(M_{Z}<0\right)$. El moment d'inèrcia és sempre positiu. Per a valors de la coordenada y positius, la tensió serà positiva, és a dir, de tracció. Al contrari, si els valors de y són negatius, la tensió també ho serà (compressió). Aquest resultat és coherent amb el que podem apreciar a la figura anterior, en la perspectiva de la deformació. Es veu clarament com les fibres superiors s'allarguen, per tant estan sotmeses a tracció, i les fibres inferiors s'acurten, estan sotmeses a compressió.

Podem representar els valors de les deformacions i les tensions d'una secció determinada en un diagrama (figura 5.12). En l'exemple, qualsevol secció de la biga tindrà uns diagrames similars, perquè totes tenen moments flectors negatius. En la figura podem observar com els punts superiors tenen una deformació longitudinal màxima de tracció $\left(\varepsilon_{\text {t,màx }}\right)$, en els punts més allunyats de l'eix Z. Els punts inferiors tenen una deformació longitudinal màxima de compressió $\left(\varepsilon_{\mathrm{t} \text {,max }}\right)$, també en els punts més allunyats de l'eix. La variació entre ambdós valors és lineal.

Així mateix, als punts més allunyats de l'eix $\mathrm{Z}$ trobem la màxima tensió normal de tracció $\left(\sigma_{t, \text { màx }}\right)$ i de compressió $\left(\sigma_{c, \text { màx }}\right)$. La variació entre els valors extrems també és lineal. 


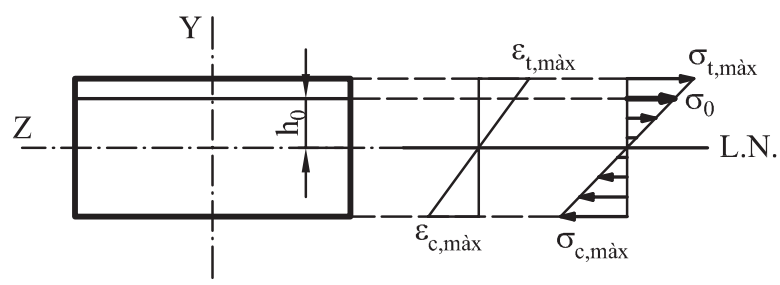

Fig. 5.12. Distribució de deformacions i tensions en una secció amb flexió simple simètrica

Com es desprén de la llei de Navier, tots els punts que comparteixen la mateixa coordenada y tindran la mateixa tensió normal. Per exemple, per a tots els punts de la línia horitzontal amb coordenada $\mathrm{y}=\mathrm{h}_{0}$, la tensió normal serà:

$$
\sigma_{0}=\frac{-M_{Z}}{I_{Z}} h_{0}
$$

Com que la distribució de tensions al llarg de la secció varia de manera lineal, des d'un valor positiu a un costat fins a un valor negatiu a l'altre, és evident que hi haurà uns punts als quals la tensió normal serà zero. Aquest conjunt de punts es denomina línia neutra (LN). La unió de totes les línies neutres de totes les seccions forma una superfície, que pot ser plana o bombada, i que anomenem fibra neutra.

Per a trobar l'equació de la LN, igualarem a zero la llei de Navier (són els punts amb tensió nul·la). En aquest cas és prou senzill deduir que la LN tindrà com a equació: $y=0$.

Tots els punts que estan a la mateixa distància de la LN tindran la mateixa tensió.

En general, els casos que se'ns poden donar en flexió simètrica són:
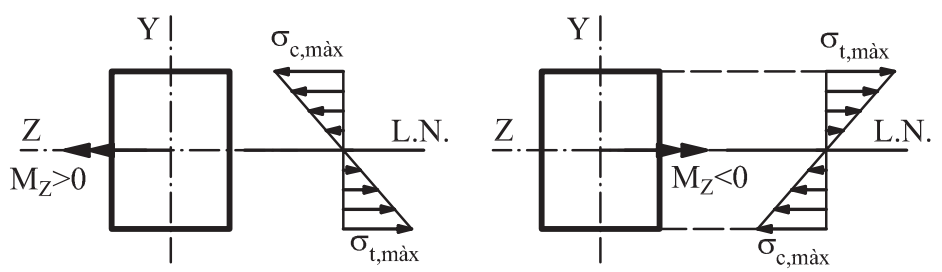

Fig. 5.13. Distribució de tensions amb moments flectors en Z, positius i negatius
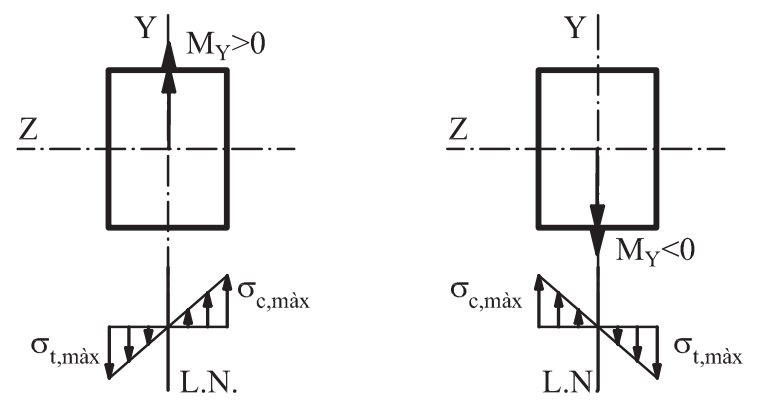

Fig. 5.14. Distribució de tensions amb moments flectors en Y, positius i negatius 


\section{Exemple 5.1}

La biga de la figura 5.15 té la secció indicada.

1. Trobeu la secció més desfavorable i obteniu la distribució de tensions normals en ella.

2. Verifiqueu si se supera la tensió admissible al punt més desfavorable.

No considereu les tensions tangencials degudes a tallant.

Dades: $\mathrm{E}=210 \mathrm{GPa} ; \mathrm{P}=6 \mathrm{kN} ; \mathrm{f}_{\mathrm{y}}=275 \mathrm{MPa} ; \gamma_{\mathrm{M}}=1,05$.
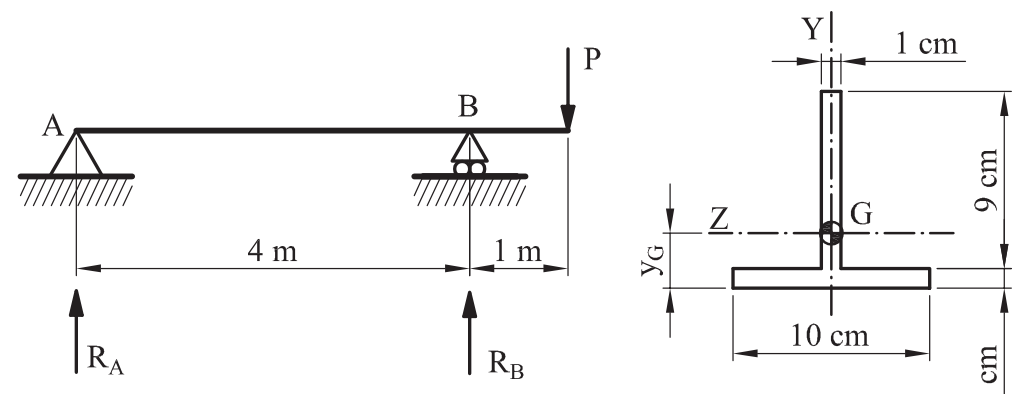

Fig. 5.15. Exemple 5.1. Enunciat

En primer lloc, obtindrem les reaccions i les lleis d'esforços. Com que l'objecte del tema no és aprofundir en aquest tipus de càlcul, anirem directament fins a la solució, assumint que l'alumne ha de ser capaç, en aquest punt, d'arribar a les mateixes conclusions de manera autònoma.

$R_{A}=-1,5 \mathrm{kN} \quad R_{B}=7,5 \mathrm{kN}$

$0 \leq x \leq 4 m \quad V_{Y}(x)=R_{A}=-1,5 k N \quad M_{Z}(x)=R_{A} \cdot x=-1,5 x$

$4 m \leq \mathrm{x} \leq 5 m \quad V_{Y}(x)=P=6 k N \quad M_{Z}(x)=P \cdot(x-5)=6 x-30$

La secció més desfavorable és $x=4 m$, en la qual el moment flector màxim és $M_{\text {màx }}=-6 \mathrm{kN} \cdot \mathrm{m}$. La secció està sotmesa a flexió simple simètrica. Per a calcular la tensió normal produïda pel moment flector, aplicarem la llei de Navier.

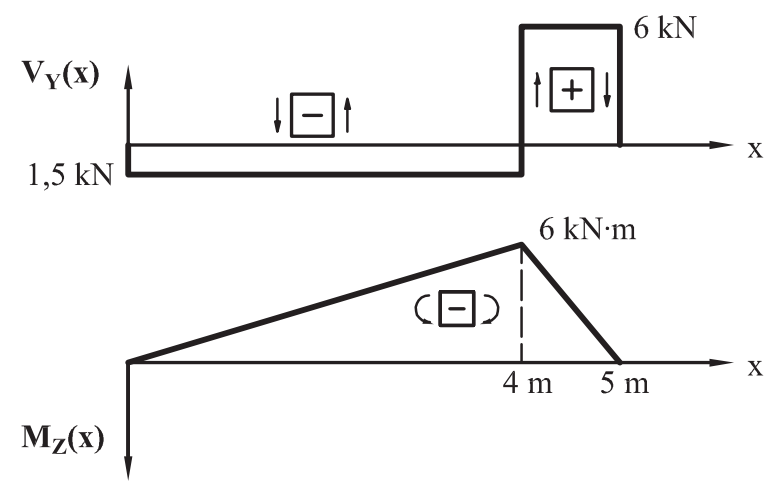

Fig. 5.16. Exemple 5.1. Diagrames d'esforços 
És necessari determinar quins són els eixos principals d'inèrcia. Com que la secció té un eix de simetria, aquest eix serà principal d'inèrcia. L'altre eix principal serà perpendicular a l'anterior, i passarà pel centre de gravetat.

El càlcul de centres de gravetat i moments d'inèrcia és una eina essencial en aquesta assignatura, raó per la qual l'alumne ha de tindre ben interioritzada la mecànica d'aquest càlcul. L'explicació del càlcul no entra dins del temari de l'assignatura, és objecte d'assignatures anteriors. Tanmateix, hem inclòs una explicació succinta (vegeu annexos) amb exemples, perquè l'alumne que no tinga l'habilitat necessària, la prenga abans d'abordar l'assignatura. Per aquesta raó, ni en aquest problema ni en els posteriors (llevat que siga convenient) es desenrotllarà el càlcul dels centres de gravetat i dels moments d'inèrcia.

Considerem que ha sigut previament calculada la posició del centre de gravetat des de la base de la secció: $y_{G}=2,87 \mathrm{~cm}$.

En aquest cas només és necessari el càlcul del moment d'inèrcia de la secció respecte de l'eix $Z$, perquè només tenim moment flector en $Z: I_{Z}=1,8 \cdot 10^{-6} \mathrm{~m}^{4}$.

La distribució de tensions normals en la secció respondrà a la llei de Navier, i varia linealment des d'un valor màxim en la part superior fins a un altre valor màxim en la part inferior. Els punts més allunyats de la LN per la part superior tenen una coordenada $y_{A}=10-y_{G}=7,13 \mathrm{~cm}$ i per la part inferior $y_{B}=-y_{G}=-2,87 \mathrm{~cm}$.

Les tensions als punts anteriors són:

$$
\begin{aligned}
& \sigma_{A}=\frac{-M_{Z}}{I_{Z}} \cdot y_{A}=\frac{6 \cdot 10^{3}}{1,8 \cdot 10^{-6}} \cdot 7,13 \cdot 10^{-2}=2,38 \cdot 10^{8} \mathrm{~Pa}=237,73 \mathrm{MPa} \\
& \sigma_{B}=\frac{-M_{Z}}{I_{Z}} \cdot y_{A}=\frac{6 \cdot 10^{3}}{1,8 \cdot 10^{-6}} \cdot\left(-2,87 \cdot 10^{-2}\right)=-9,56 \cdot 10^{7} \mathrm{~Pa}=-95,60 \mathrm{MPa}
\end{aligned}
$$

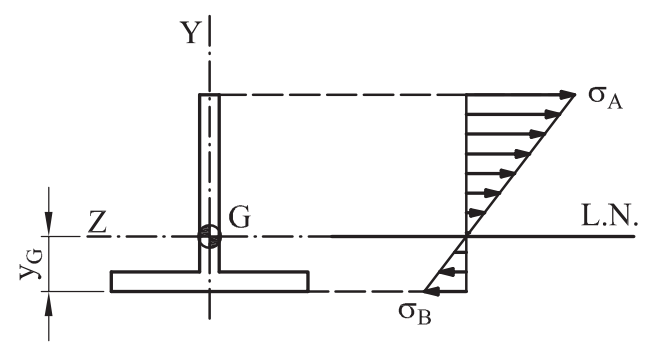

Fig. 5.17. Exemple 5.1. Distribució de tensions normals a la secció més desfavorable

La tensió màxima admissible és: $f_{y d}=\frac{f_{y}}{\gamma_{M}}=261,9 M P a$.

Com que en cap punt de la secció més desfavorable se supera la tensió admissible, podrem dir que el disseny és correcte quant a resistència. 
Un dels aspectes sobre els quals podem treballar en resistència de materials és la comprovació de seccions, com en l'exemple anterior. En aquests casos la secció ja està definida $\mathrm{i}$ hem de comprovar si se supera la tensió admissible o no.

Un altre problema que ens pot sorgir és el dimensionament de les seccions. És a dir, si coneixem les lleis d'esforços en una biga, $i$ hem decidit el material (coneixem la tensió admissible), el dimensionament consisteix a dissenyar la secció, quant a dimensions i/o forma perquè resistisca les tensions.

\section{Exemple 5.2}

Redissenyar la biga de l'exemple 5.1 amb secció rectangular. La relació entre l'ample (b) i el cantell $(h)$ de la biga ha de ser $b=h / 3$.

En aquest cas, pel fet de tindre doble simetria, el centre de gravetat passa pel punt mitjà.

El moment d'inèrcia que ens interessa és el de Z. Per a un rectangle, respecte al centre de gravetat:

$$
I_{Z}=\frac{1}{12} b \cdot h^{3}=\frac{1}{12} \frac{h}{3} h^{3}=\frac{h^{4}}{36}
$$

El màxim moment flector és el mateix que a l'exemple anterior (és independent de la secció).

Segons la llei de Navier, per a flexió simple simètrica, la LN passa pel centre de gravetat. Els punts que tenen més tensió seran els més allunyats de la LN, per tant, aquells que es troben a una distància igual a mig cantell, tant per un costat com per un altre.

$\sigma_{m a ̀ x}=\frac{-M_{Z}}{I_{Z}} y_{m a ̀ x}=\frac{6 \cdot 10^{3}}{\frac{h^{4}}{36}} \cdot \frac{h}{2}=6 \cdot 10^{3} \cdot \frac{18}{h^{3}}=\frac{1,08 \cdot 10^{5}}{h^{3}}$

Aquesta tensió no ha de superar l'admissible: $\frac{1,08 \cdot 10^{5}}{h^{3}} \leq f_{y d}=\frac{f_{y}}{\gamma_{m}}$.

D'aquesta desigualtat podem deduir que $h \geq 0,0744 \mathrm{~m}$. Normalment no podem mantindre la dimensió que obtenim del càlcul exactament. Hem d'arrodonir el resultat, bé a perfils comercials de dimensió immediatament superior, bé a una modulació coherent si el perfil ha de ser fabricat. En aquest cas, com que no tenim més dades, triem com a dimensió $h=7,5 \mathrm{~cm}$. Per tant, segons la relació de l'enunciat: $b=2,5 \mathrm{~cm}$. 
De la fórmula de Navier pot deduir-se la forma de la secció recta ideal d'una biga sotmesa a flexió simple, en el cas de ser iguals en valor absolut les tensions admissibles a tracció i compressió. La condició que hem d'aplicar és la d'utilitzar la menor quantitat possible de material. Una secció serà més resistent com més gran siga el moment d'inèrcia. En efecte, com que el moment d'inèrcia està dividint en l'equació de Navier, per a un mateix moment flector, com major siga el moment d'inèrcia, la secció suportarà una tensió menor. Aquesta condició es verifica quan la superfície de la secció es troba tan lluny com és possible de l'eix Z. Això es podria assolir amb una secció ideal formada per dues xapes separades una certa distància entre elles. Òbviament, açò és impossible des del punt de vista constructiu: cal unir les dues xapes per fer un únic perfil. La solució són els perfils que tenen forma de I, com els IPE o els IPN.

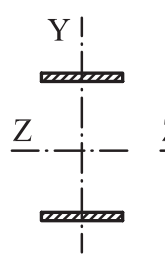

a)

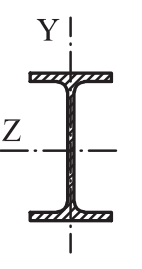

b)

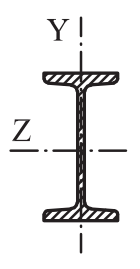

c)

Fig. 5.18. a) secció ideal; b) IPE; c) IPN

Actualment són més emprats els perfils IPE, pels seus avantatges. Encara que a igualtat de cantell, l'IPN té una inèrcia lleugerament més gran, habitualment el pes també és major i les estructures a base d'IPN solen resultar més pesades. A més, la cara interior de l'IPE és paral·lela a l'ala i la de l'IPN té una inclinació, que dificulta el muntatge posterior d'estructures que s'hagen de recolzar en aquesta superfície. La manca de paral·lelisme també dificulta el cargolament.

També existeixen uns altres tipus de perfils comercials, com ara les sèries de perfils en $\mathrm{H}$ o en U. Pràcticament a tot Europa s'empren els mateixos tipus de perfils, però a la resta del món s'utilitzen sèries de perfils similars en forma, però amb variacions en les dimensions.

Les característiques geomètriques i els valors estàtics dels perfils els trobem tabulats, no cal calcular-los cada cop. Les taules de perfils, que fa un temps venien recollides en les normatives, ara són publicades pels fabricants.

Si hem de dimensionar seccions comercials en flexió simple simètrica, el procediment, seguint la llei de Navier, seria un procés iteratiu:

1. Calcular el màxim moment flector actuant.

2. Triar un perfil pel qual començar.

3. Buscar el moment d'inèrcia i el cantell en les taules. 
4. Calcular la tensió normal màxima i comparar-la amb l'admissible. Els punts més separats de la LN estan a una distància que és la meitat del cantell.

5. Si la tensió és més gran que l'admissible, la secció no és capaç de suportar l'esforç: hem de triar un perfil superior de la sèrie. Si és menor que l'admissible, la secció és vàlida. No obstant això, seguint un criteri econòmic (mínim ús de material) haurem de verificar si algun perfil inferior fóra també vàlid.

6. Tornar al punt 3 fins a la convergència del resultat.

Aquest procediment pot evitar-se, en aquest tipus de flexió, recorrent al concepte de mòdul resistent. Aquest nou concepte es defineix com el moment d'inèrcia dividit per la màxima distància de qualsevol punt a la LN.

$$
W_{Z}=\frac{I_{Z}}{y_{\operatorname{mà} x}} \quad W_{Y}=\frac{I_{Y}}{z_{m \text { à }}}
$$

I la llei de Navier ens queda:

$$
\sigma=\frac{-M_{Z}}{W_{z}}
$$

En cas de flexió simple simètrica, $y_{\max }=h / 2$ ( $h$ és el cantell). Com que el mòdul resistent és un paràmetre que només depén de la geometria, també el trobem recollit en les taules de perfils.

El procés de dimensionament és ara:

1. Calcular el màxim moment flector actuant.

2. Calcular el moment resistent necessari, mitjançant:

$$
W_{\text {Zneces }}=\frac{\left|M_{Z}\right|}{\sigma_{a d m}}
$$

El sentit de considerar el valor absolut del moment és que el mòdul resistent és sempre positiu. Realment, en aquest moment, no ens interessa saber si les tensions de tracció estan en la part superior o la inferior, només volem triar un perfil.

3. Buscar en les taules un perfil que tinga un mòdul resistent immediatament superior al necessari.

S'ha de tindre cura amb els eixos quan busquem els valors estàtics en les taules. Malgrat que en tota aquesta obra s'utilitzen els mateixos noms per als eixos longitudinals i per als principals d'inèrcia (excepte al tema 8 ), les taules de perfils poden canviar aquesta nomenclatura (normalment inclouen una figura aclaridora). Hem de tindre present amb quin eix estem treballant, independentment de si l'anomenem Z, Y o X, i buscar en les taules el valor corresponent, deixant de costat el nom que s'haja emprat. 
Per aquesta raó, moltes vegades anomenarem eix fort l'eix que té una inèrcia major, i eix feble el que té una menor inèrcia.

\section{Exemple 5.3}

En una secció determinada d'una biga d'acer S275 tenim un moment flector $M_{Z}=45 \mathrm{kN} \cdot \mathrm{m}$. Dimensioneu la secció utilitzant els perfils comercials: IPE, IPN, HEB, UPN, i identifiqueu quin perfil és el més econòmic en aquest cas.

L'acer S2575 té un límit elàstic $f_{y}=275 M P a$, i hem d'aplicar un coeficient de seguretat $\gamma_{M}=1,05$, per la qual cosa la tensió admissible és $f_{y d}=261,9 \mathrm{MPa}$.

El mòdul resistent necessari és:

$W_{\text {Zneces }}=\frac{\left|M_{Z}\right|}{f_{y d}}=\frac{45 \cdot 10^{3}}{261,9 \cdot 10^{6}}=1,718 \cdot 10^{-4} \mathrm{~m}^{3}=171,8 \mathrm{~cm}^{3}$

Acudim a les taules i triem un perfil que tinga el mòdul resistent immediatament superior en cadascuna de les tipologies demanades.

\begin{tabular}{|c|c|c|}
\hline Perfil & $\left.\mathbf{W}_{\mathbf{Z}} \mathbf{( c m}^{\mathbf{3}}\right)$ & $\mathbf{p}(\mathbf{k g} / \mathbf{m})$ \\
\hline IPE 200 & 194 & 22.4 \\
\hline IPN 200 & 214 & 26.3 \\
\hline HEB 140 & 216 & 33.7 \\
\hline UPN 200 & 191 & 25.3 \\
\hline
\end{tabular}

Com podem apreciar, el més lleuger dels perfils vàlids és l'IPE.

Després de fer un dimensionament amb un perfil comercial, és pràcticament impossible que el perfil que hem escollit tinga el mateix mòdul resistent que el necessari. Com a conseqüència, la secció no treballarà al $100 \%$ de la seua capacitat. Definirem la ràtio d'aprofitament (a) com la relació entre la tensió que realment tenim en la secció i la tensió màxima que és capaç de suportar la secció.

$$
a=\frac{\sigma_{\text {màx }}}{\sigma_{a d m}}=\frac{\frac{N}{A}+\frac{\left|M_{Z}\right|}{W_{Z}}+\frac{\left|M_{Y}\right|}{W_{Y}}}{f_{y d}}=\frac{N}{A \cdot f_{y d}}+\frac{\left|M_{Z}\right|}{W_{Z} \cdot f_{y d}}+\frac{\left|M_{Y}\right|}{W_{Y} \cdot f_{y d}}
$$

Evidentment, la ràtio ha de ser inferior a la unitat per tal que no es supere la tensió admissible; per tant, podem utilitzar l'expressió anterior com a fórmula de comprovació. L'equació anterior està completa, però si algun dels termes és nul, com en el cas de flexió simple simètrica, també és vàlida. 


\section{Exemple 5.4}

Calculeu la ràtio d'aprofitament dels perfils calculats a l'exemple 5.3.

\begin{tabular}{|c|c|}
\hline Perfil & a \\
\hline IPE 200 & 0,886 \\
\hline IPN 200 & 0,803 \\
\hline HEB 140 & 0,795 \\
\hline UPN 200 & 0.9 \\
\hline
\end{tabular}

El perfil que havíem triat per criteri econòmic està treballant al 88,6 \% de la seua capacitat. El perfil UPN estaria treballant més, però també és més pesat. Els altres dos estarien més desaprofitats.

\section{Exemple 5.5}

En la biga de la figura:

1. Dimensioneu la secció mitjançant un perfil IPE (acer S275) i calculeu la ràtio d'aprofitament.

2. Investigueu si té influència la consideració de pes propi com a càrrega distribuïda.

Dades: $\mathrm{P}=15 \mathrm{kN} ; \mathrm{q}=15 \mathrm{kN} / \mathrm{m}$.

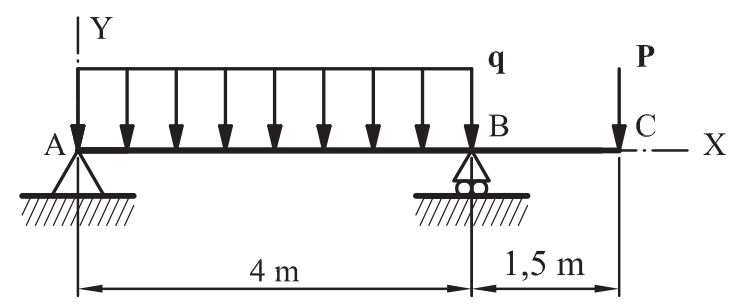

Fig. 5.19. Exemple 5.5. Enunciat

Les reaccions són: $R_{A}=24,375 \mathrm{kN} ; R_{B}=50,625 \mathrm{kN}$.

La llei d'esforços tallants:

$0 \leq x \leq 4 m$

$4 m \leq x \leq 5,5 m$

$$
\begin{aligned}
& V_{Y}(x)=R_{A}-q \cdot x=24,375-15 \mathrm{x} k \\
& V_{Y}(\mathrm{x})=P=15 k N
\end{aligned}
$$

I la de moments flectors:

$0 \leq x \leq 4 m$

$4 m \leq \mathrm{x} \leq 5,5 m$

$$
\begin{aligned}
& M_{Z}(x)=R_{A} \cdot x-q \cdot 0,5 x^{2}=24,375 x-7,5 x^{2} k N \cdot m \\
& M_{Z}(x)=P \cdot(x-5,5)=15 x-82,5 k N \cdot m
\end{aligned}
$$




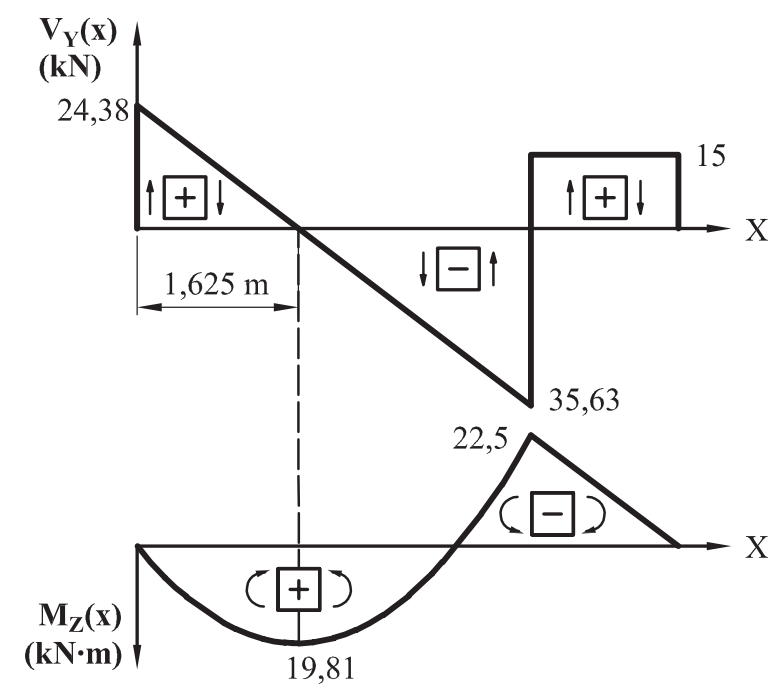

Fig. 5.20. Exemple 5.5. Diagrames

Observem que hi ha un pas per zero del diagrama de tallants, on hi haurà un màxim relatiu del diagrama de moments.

$x_{1}=\frac{R_{A}}{q}=1,625 \mathrm{~m} \quad M_{Z}\left(x_{1}\right)=19,805 \mathrm{kN} \cdot \mathrm{m}$

L'altre possible màxim es troba en $\mathrm{B}: M_{Z}(4 \mathrm{~m})=-22,5 \mathrm{kN} \cdot \mathrm{m}$.

El segon valor és més gran: dimensionarem amb aquest moment. El mòdul resistent necessari és, doncs:

$W_{\text {Zneces }}=\frac{M_{\text {màx }}}{f_{y d}}=\frac{22,5 \cdot 10^{3}}{261,9 \cdot 10^{6}}=8,591 \cdot 10^{-5} \mathrm{~m}^{3}=85,91 \mathrm{~cm}^{3}$

Busquem en la taula de perfils i el primer que supera aquest valor és l'IPE $160 \mathrm{amb}$ $W_{Z}=109 \mathrm{~cm}^{3}$.

La ràtio d'aprofitament és: $a=\frac{M_{m a ̀ x}}{W_{z} \cdot f_{y d}}=0,788$.

Això significa que la secció treballa al 78,8 \% al seu punt més desfavorable.

El pes d'aquest perfil és: $p=15,8 \mathrm{~kg} / \mathrm{m}$.

Per a valorar si és important la seua consideració o podem negligir-la, farem els mateixos càlculs aplicant una càrrega distribuïda en tota la longitud de la biga, amb un valor $q_{P P}=p \cdot g=155 \mathrm{~N} / \mathrm{m}=0,155 \mathrm{kN} / \mathrm{m}$ ( $g$ és l'acceleració de la gravetat). Ja veiem des d'un principi que el valor corresponent és molt inferior l'ordre de magnitud de les càrregues que tenim. No obstant això, calcularem el moment màxim.

Com que ja tenim calculades les lleis d'esforços anteriors, podem afegir les que produeix aquesta càrrega, segons el principi de superposició, o bé podem calcular 
les noves reaccions i tornar a calcular les lleis. Si només considerem la càrrega distribuïda, les reaccions són:

$R_{A P P}=0,266 k N \quad R_{B P P}=0,586 k N$

Les reaccions amb totes les càrregues:

$R_{A T}=R_{A}+R_{A P P}=24,641 \mathrm{kN} \quad R_{B T}=R_{B}+R_{B P P}=51,211 \mathrm{kN}$

La llei d'esforços tallants:

$0 \leq x \leq 4 m$

$$
\begin{aligned}
& V_{Y}(x)=R_{A T}-\left(q+q_{P P}\right) \cdot x=24,641-15,155 x k N \\
& V_{Y}(x)=R_{A T}-\left(q+q_{P P}\right) \cdot x+R_{B T}=75,852-15,155 x k N
\end{aligned}
$$

$4 m \leq \mathrm{x} \leq 5,5 m$

I la de moments flectors:

$0 \leq x \leq 4 m$

$$
\begin{array}{ll}
0 \leq x \leq 4 m & M_{Z}(x)=R_{A T} \cdot x-\left(q+q_{P P}\right) \cdot 0,5 x^{2}=24,375 x-7,5 x^{2} k N \cdot m \\
4 m \leq \mathrm{x} \leq 5,5 m & M_{Z}(x)=R_{A T} \cdot x-q \cdot 4(x-2)-q_{P P} \cdot 0,5 x^{2}+R_{B T} \cdot(x-4)= \\
& =15,266 x-0,077 x^{2}-84,844 \mathrm{kN} \cdot \mathrm{m}
\end{array}
$$

Observem que hi ha un pas per zero del diagrama de tallants, on hi haurà un màxim relatiu del diagrama de moments.

$x_{2}=\frac{R_{A T}}{q+q_{P P}}=1,626 \mathrm{~m} \quad M_{Z}\left(x_{2}\right)=20,033 \mathrm{kN} \cdot \mathrm{m}$

L'altre possible màxim es troba en B: $M_{z}(4 m)=-22,674 \mathrm{kN} \cdot \mathrm{m}$.

El segon valor segueix sent més gran: dimensionarem amb aquest moment. El mòdul resistent necessari és, doncs:

$W_{\text {Zneces }}=\frac{M_{\text {màx }}}{f_{y d}}=\frac{22,674 \cdot 10^{3}}{261,9 \cdot 10^{6}}=8,658 \cdot 10^{-5} \mathrm{~m}^{3}=86,575 \mathrm{~cm}^{3}$

Comprovem que el perfil triat abans (IPE 160) segueix sent vàlid.

La ràtio d'aprofitament, considerant el pes propi, és:

$a=\frac{M_{m a ̀ x}}{W_{Z} \cdot f_{y d}}=0,794$

Això significa que la secció treballa al 79,4 \% al seu punt més desfavorable.

Conclusió: la diferència entre considerar el pes propi o no és normalment insignificant, pel que fa a les tensions. Si tenim en compte que si el considerem, el problema passa 
a ser iteratiu (fins que no triem perfil no coneixem el seu pes) i que introdueix la dificultat afegida d'haver de calcular amb una càrrega distribuïda addicional, habitualment no tindrem el pes propi en consideració. Si en algun cas estimem que el pes propi pot tindre una certa importància relativa, en primer lloc dimensionarem sense tindre'l en compte, i a posteriori avaluarem si l'efecte és significatiu o no, tal com hem fet en aquest exemple.

\section{Exemple 5.6}

Es disposa d'una biga recolzada en els extrems, de 3 metres de longitud i de perfil IPE 120 (S275). La biga està sotmesa a una càrrega uniformement distribuïda $\mathrm{q}=20 \mathrm{kN} / \mathrm{m}$. Comproveu si el disseny de la biga és adequat, $\mathrm{i}$ en cas negatiu estudieu com podria donar-se una solució al problema mitjançant l'addició de xapes de $\mathrm{e}=3 \mathrm{~mm}$ de gruix i $\mathrm{b}=60 \mathrm{~mm}$ d'amplària. Ha d'optimitzar-se el pes d'acer, disposant la xapa o xapes necessàries només en els trams en què siga imprescindible.

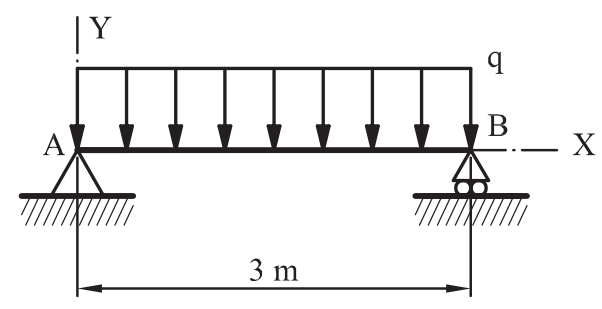

Fig. 5.21. Exemple 5.6. Enunciat

Les reaccions són: $R_{A}=R_{B}=30 \mathrm{kN}$.

La llei de flectors és: $M(x)=R_{A} \cdot x-q \cdot 0,5 x^{2}$ amb un màxim al punt mitjà de la biga, de valor: $M_{\text {màx }}=M(1,5 \mathrm{~m})=22,5 \mathrm{kN} \cdot \mathrm{m}$.

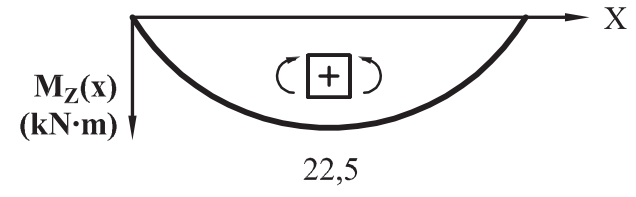

Fig.5.22. Exemple 5.6. Diagrama de moments flectors

El mòdul resistent necessari és:

$W_{\text {Zneces }}=\frac{M_{\text {màx }}}{f_{y d}}=85,91 \mathrm{~cm}^{3}$

El mòdul resistent de l'IPE 120 és $W_{Z 120}=52,96 \mathrm{~cm}^{3}$; per tant, no és suficient per a suportar les tensions que es produeixen en les seccions més desfavorables. 
El perfil IPE 120 és capaç de suportar, com a màxim, un moment flector de valor

$$
M_{Z 120}=W_{Z 120} \cdot f_{y d}=13,87 \mathrm{kN} \cdot \mathrm{m}
$$

Calcularem els trams de la biga en els quals el moment flector és menor que aquest valor i que, per tant, no necessiten reforç. Igualem la llei de moments al moment que hem calculat: $R_{A} \cdot x-q \cdot 0,5 x^{2}=13,87$. Això és una equació de segon grau amb dues solucions: $x_{1}=0,57 m ; x_{2}=2,43 m$. La conclusió és que en el tram $x_{1}<x<x_{2}$ la biga no suporta l'esforç i hem d'afegir les xapes.

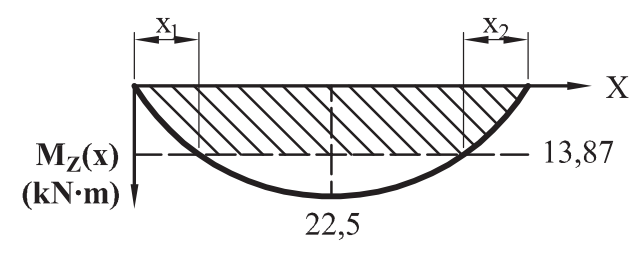

Fig. 5.23. Exemple 5.6. Trams coberts per l'IPE 120

Posarem una xapa soldada a l'ala superior i una altra a l'ala inferior. Ara, el moment d'inèrcia i el mòdul resistent han canviat, ja no els podem trobar a les taules i els hem de calcular. El moment d'inèrcia de l'IPE 120 sense xapes és: $I_{Z 120}=317,8 \mathrm{~cm}^{3}$. El cantell és $h=12 \mathrm{~cm}$.

$$
\begin{aligned}
& I_{Z 1}=I_{Z 120}+2 \cdot\left[\frac{1}{12} b \cdot e^{3}+b \cdot e \cdot\left(\frac{h}{2}+\frac{e}{2}\right)^{2}\right]=453,99 \mathrm{~cm}^{4} \\
& y_{m \text { àx } 1}=\frac{h}{2}+e=6,3 \mathrm{~cm} \quad W_{Z 1}=\frac{I_{Z 1}}{y_{\text {mà } x 1}}=72,06 \mathrm{~cm}^{3}
\end{aligned}
$$

Aquesta secció reforçada amb dues xapes pot suportar un moment màxim: $M_{Z 1}=W_{Z 1} \cdot f_{y d}=18,87 \mathrm{kN} \cdot m$ que tampoc és suficient. Igual que abans, hem de calcular el tram que queda cobert per aquesta secció i el tram que necessita un nou reforç.

$R_{A} \cdot x-q \cdot 0,5 x^{2}=18,87$. Ens dóna dues solucions: $x_{3}=0,90 m ; x_{4}=2,10 \mathrm{~m}$.

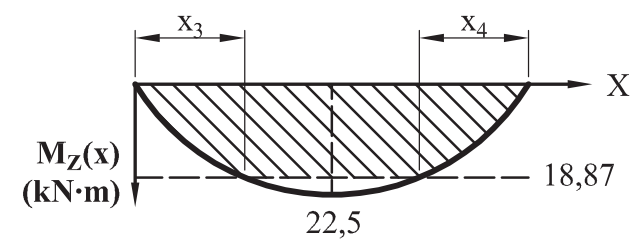

Fig. 5.24. Exemple 5.6. Trams coberts per l'IPE 120 reforçat amb una xapa

Al tram que ens queda, li soldarem una segona xapa en cada costat. Calculem els valors estàtics una altra vegada:

$$
\begin{aligned}
& I_{Z 2}=I_{Z 1}+2 \cdot\left[\frac{1}{12} b \cdot e^{3}+b \cdot e \cdot\left(\frac{h}{2}+e+\frac{e}{2}\right)^{2}\right]=603,78 \mathrm{~cm}^{4} \\
& y_{\text {màx } 2}=\frac{h}{2}+2 e=6,6 \mathrm{~cm} W_{Z 2}=\frac{I_{Z 2}}{y_{\text {mà } x 2}}=91,48 \mathrm{~cm}^{3} M_{Z 2}=W_{Z 2} \cdot f_{y d}=23,96 \mathrm{kN} \cdot \mathrm{m}
\end{aligned}
$$


Ara sí que se supera el moment màxim, i per tant, la biga no plastificarà en cap punt.

En resum, la biga ens quedaria com es mostra a la figura 5.25. Aquesta disposició és la mínima teòrica, tot $\mathrm{i}$ que normalment s'allargarien les xapes una distància de seguretat per cada costat.

La manera de procedir d'aquest exemple és la base del mètode que s'utilitza en els càlculs de formigó armat, quan es calcula un armament per tandes: es disposa més armadura on es necessita, i menys on hi ha un moment menor. En formigó, la distància que s'han de prolongar les armadures ens ve indicada en la normativa corresponent. Hi ha altres característiques específics del formigó que condicionen la disposició d'armadures, però tot això es desenrotllarà en assignatures posteriors.

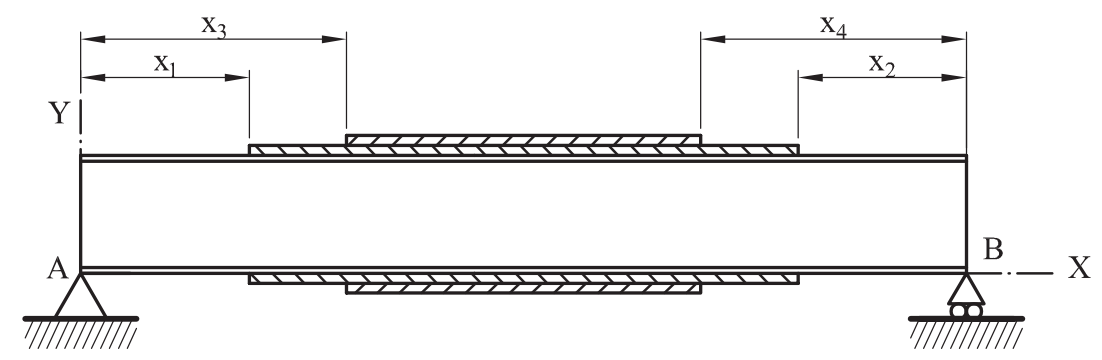

Fig. 5.25. Exemple 5.6. Solució. Fora d'escala

\subsection{Flexió asimètrica}

La flexió asimètrica o esbiaixada es produeix quan tenim moments flectors segons els dos eixos principals d'inèrcia. Recordem que això representa realment que el moment flector resultant no porta la direcció de cap dels eixos principals d'inèrcia, per la qual cosa podem fer la descomposició vectorial segons els dos eixos.

La flexió esbiaixada pot produir-se quan sobre una biga actuen càrregues en la direcció Y i en la direcció Z. Equivalent a l'anterior és quan sobre una biga actuen càrregues en una direcció, però la secció de la biga està inclinada respecte del pla horitzontal, com per exemple a les corretges de les cobertes inclinades.

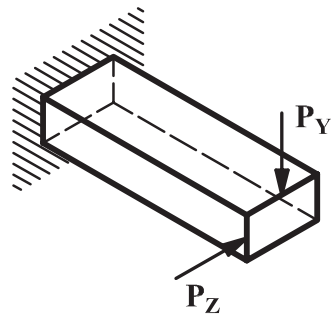

a)

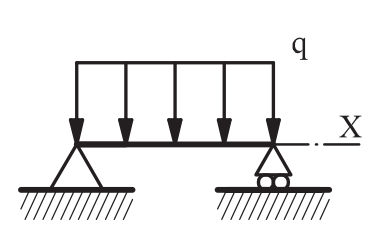

b)

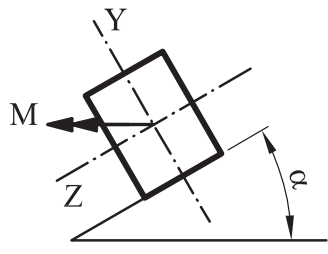

Fig. 5.26. Flexió esbiaixada: $a$ ) càrregues en Y i Z; b) secció inclinada 
En el cas de la figura 5.26 , en la secció de l'encast, tenim uns moments flectors:

$$
M_{Z}=P_{Y} \cdot L \quad M_{Y}=P_{Z} \cdot L
$$

En el cas de la figura 5.26 , el moment flector màxim (en la secció mitjana de la biga) és:

$M=\frac{q \cdot L^{2}}{8}$

que pot descompondre's en: $M_{Z}=\operatorname{Mcos}(\alpha), M_{Y}=M \sin (\alpha)$.

Les tensions que es desenrotllen en flexió asimètrica són una superposició de les que es produirien si actuaren els dos moments flectors per separat. Pensem en aquesta última possibilitat: les tensions que són conseqüència dels dos moments flectors, podem veure-les a la figura següent:

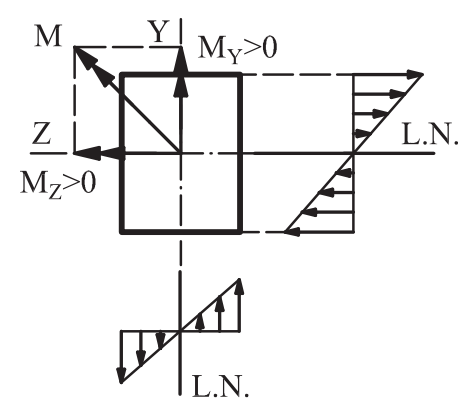

Fig. 5.27. Flexió esbiaixada. Superposició de tensions

La distribució de tensions de la dreta representa l'expressió de la llei de Navier per a flexió simple simètrica quan només actua $\mathrm{M}_{\mathrm{Z}}$ :

$$
\sigma=\frac{-M_{Z}}{I_{Z}} y
$$

La distribució de tensions representada sota la secció és l'equivalent a l'anterior però quan actua només el moment $\mathrm{M}_{\mathrm{Y}}$ :

$$
\sigma=\frac{M_{Y}}{I_{Y}} Z
$$

Realment, quan actuen tots dos alhora, la llei de Navier ens queda:

$$
\sigma=\frac{-M_{Z}}{I_{Z}} y+\frac{M_{Y}}{I_{Y}} z
$$


Podem obtindre l'equació de la LN $(\sigma=0)$ per a flexió esbiaixada:

$$
y_{L N}=\frac{M_{Y} \cdot I_{Z}}{M_{Z} \cdot I_{Y}} z_{L N}
$$

Evidentment, aquesta és l'equació d'una recta inclinada respecte als eixos Y i Z. En flexió simple simètrica, la LN era paral·lela a un dels eixos, i els punts amb més tensió eren els que tenien una coordenada y o z més gran. En flexió asimètrica, no és evident a primera vista quins seran els punts amb més tensió. Necessitem esbrinar quins són els punts més allunyats de la LN. La millor cosa que podem fer és una representació gràfica de la LN sobre la secció; encara que no siga molt exacta, almenys la farem de manera qualitativa.

Un punt pel qual passa la LN que sí que es dedueix a primera vista és el punt: $\mathrm{y}=0 ; \mathrm{z}=0$.

Suposem, com a exemple, que els moments flectors que obtenim en una secció per als eixos $\mathrm{Y}$ i Z són ambdós positius. Com que els moments d'inèrcia són sempre positius, podem deduir que per a valors de $\mathrm{z}>0$, obtindrem valors de $\mathrm{y}>0$. I al revés, per a valors de $\mathrm{z}<0$, obtindrem valors de $\mathrm{y}<0$. Llavors, la $\mathrm{LN}$ podríem representar-la com a la figura.

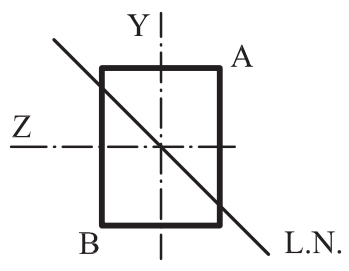

Fig. 5.28. Línia neutra en flexió esbiaixada

Els punts més allunyats de la LN són el A i el B, i seran els que més tensió tindran de tota la secció, encara que en aquest moment, no sabem encara si són de tracció o de compressió. Per a calcular les tensions en aquests punts, substituirem les coordenades d'ambdós en la llei de Navier. Suposem que les dimensions de la secció són b (ample) i h (cantell). Les coordenades dels punts són:

$$
\begin{array}{ll}
y_{A}=h / 2 & z_{A}=-b / 2 \\
y_{B}=-h / 2 & z_{B}=b / 2
\end{array}
$$

Si observem la llei de Navier:

$$
\sigma=\frac{-M_{Z}}{I_{Z}} y+\frac{M_{Y}}{I_{Y}}
$$

podrem deduir que les tensions per al punt A seran sempre negatives (els dos termes són negatius) i les tensions al punt B seran sempre positives (els dos termes són positius). Ara podem fer la representació de les tensions sobre la secció, de manera similar als casos de flexió simètrica. 
Tots els punts que estan a la mateixa distància de la LN tindran la mateixa tensió. Els punts que estan a la mateixa distància són els que estan sobre una paral·lela a la LN. En la figura, tots els punts que pertanyen a la recta M-N tenen la mateixa tensió $\left(\sigma_{0}\right)$. Encara que les coordenades de cadascun dels punts d'aquesta recta són diferents entre elles, si fem la substitució en la llei de Navier de qualsevol parell de coordenades, el resultat seria el mateix.

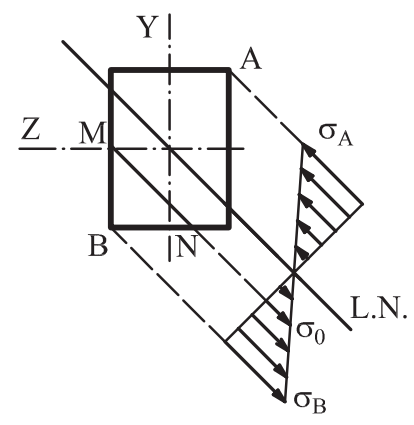

Fig. 5.29. Distribució de tensions en flexió esbiaixada

\section{Exemple 5.7}

La següent biga encastada està sotmesa a un moment $M_{0}$ en la secció del seu extrem, en la direcció indicada en la figura. Dimensioneu la biga (trobeu el valor de t), de manera que no se supere la tensió admissible.

Dades: $\mathrm{M}_{0}=20 \mathrm{kN} \cdot \mathrm{m} ; \sigma_{\text {adm }}=120 \mathrm{MPa}$.

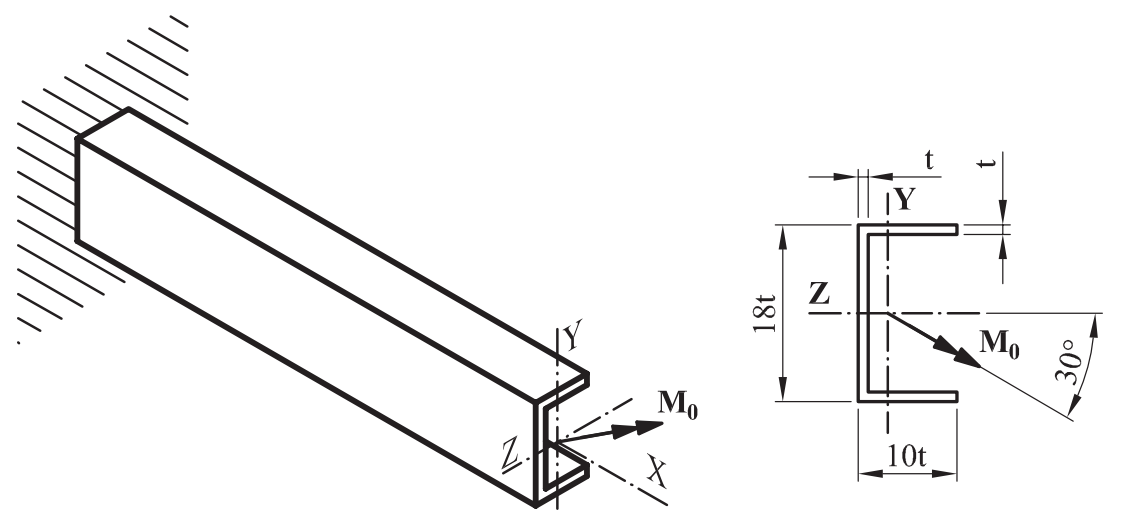

Fig. 5.30. Exemple 5.7. Enunciat

Com que la biga només té aplicat un moment en l'extrem, la llei de moments flectors serà constant per a totes les seccions de la biga i igual al moment aplicat en cada eix. En conclusió, és indiferent la secció que analitzem en l'estudi de les tensions, totes tenen la mateixa distribució de tensions.

Hem de trobar la posició dels eixos principals d'inèrcia. Sabem la posició de l'eix Z, atenent a raons de simetria. L'eix $\mathrm{Y}$ és perpendicular al $\mathrm{Z}$ i passa pel centre de gravetat de la secció. 
Calculem el centre de gravetat de la secció. Dividim la secció en tres rectangles.

\begin{tabular}{|l|c|c|c|}
\hline Rectangle & Àrea $\left(\mathbf{A}_{\mathbf{i}}\right)$ & Posició $\mathbf{Z}_{\mathrm{Gi}} \mathbf{( c m )}$ & $\mathbf{A}_{\mathbf{i}} \cdot \mathbf{Z}_{\mathbf{G i}}$ \\
\hline Ala superior & $10 \mathrm{t}^{2}$ & $5 \mathrm{t}$ & $50 \mathrm{t}^{3}$ \\
\hline Ànima & $16 \mathrm{t}^{2}$ & $\mathrm{t} / 2$ & $8 \mathrm{t}^{3}$ \\
\hline Ala inferior & $10 \mathrm{t}^{2}$ & $5 \mathrm{t}$ & $50 \mathrm{t}^{3}$ \\
\hline Suma & $36 \mathrm{t}^{2}$ & & $108 \mathrm{t}^{3}$ \\
\hline
\end{tabular}

$Z_{G}=\frac{\sum A_{i} \cdot Z_{G i}}{\sum A_{i}}=\frac{108 t^{3}}{36 t^{2}}=3 t$

Hem de calcular també el moment d'inèrcia en ambdós eixos. Per a l'eix Z és més senzill si al moment d'inèrcia del rectangle massís de secció $10 \mathrm{t} \cdot 18 \mathrm{t}$ li restem el moment d'inèrcia de l'aire que té al seu interior (rectangle de $9 \mathrm{t} \cdot 16 \mathrm{t}$ ).

$I_{Z}=\frac{1}{12} \cdot 10 t \cdot(18 t)^{3}-\frac{1}{12} \cdot 9 t \cdot(16 t)^{3}=1.788 t^{4}$

Per a l'eix Y dividirem en els mateixos tres rectangles que abans i haurem d'aplicar el teorema de Steiner.

$I_{Y}=2\left[\frac{1}{12} \cdot t \cdot(10 t)^{3}+t \cdot 10 t \cdot(2 t)^{2}\right]+\frac{1}{12} \cdot 16 t \cdot t^{3}+16 t \cdot t \cdot(2,5 t)^{2}=348 t^{4}$

El moment aplicat el podem descompondre segons els dos eixos principals d'inèrcia.

$M_{Y}=-M_{0} \cdot \sin \left(30^{\circ}\right)=\frac{-M_{0}}{2}=-10 \mathrm{kN} \cdot \mathrm{m}$

$M_{Z}=-M_{0} \cdot \cos \left(30^{\circ}\right)=\frac{-\sqrt{3}}{2} M_{0}=-17,32 \mathrm{kN} \cdot \mathrm{m}$

Per a conéixer la distribució de tensions en la secció, hem d'utilitzar la llei de Navier.

$\sigma=\frac{-M_{Z}}{I_{Z}} y+\frac{M_{Y}}{I_{Y}} Z=\frac{\sqrt{3} M_{0}}{2 \cdot 1.788 t^{4}} y-\frac{M_{0}}{2 \cdot 384 t^{4}} Z$

Per a calcular l'equació de la LN igualem a zero la tensió $(\sigma=0)$ i aïllem una de les variables en funció de l'altra: $y=2,966 z$.

Podem fer-ne una representació gràfica de manera qualitativa: 


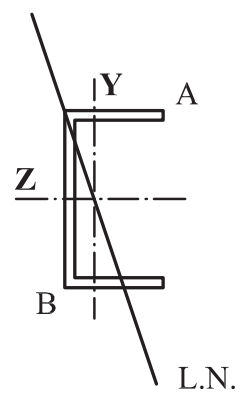

Fig. 5.31. Exemple 5.7. Representació de la LN

Evidentment, els punts més allunyats de la LN són el A i el B, les coordenades dels quals són:

$$
\begin{array}{ll}
y_{A}=9 t & z_{A}=-7 t \\
y_{B}=-9 t & z_{B}=7 t
\end{array}
$$

Com que l'enunciat no ens demana la distribució de tensions en la secció, sinó dimensionar-la, només necessitem el punt més allunyat de tots dos, que resulta A.

$\sigma_{A}=\frac{\sqrt{3} M_{0}}{2 \cdot 1.788 t^{4}} 9 t-\frac{M_{0}}{2 \cdot 384 t^{4}}(-7 t) \leq \sigma_{a d m}$

D'aquesta desigualtat podem aïllar la nostra incògnita: $t=0,0134 \mathrm{~m}$.

Conclusió: el mínim valor del gruix t necessari perquè la tensió en la biga no supere l'admissible en cap punt és de 13,4 $\mathrm{mm}$.

\subsection{Flexió composta}

La flexió composta és aquella en la qual intervé l'esforç axial, siga de tracció o de compressió. Pot existir un moment flector o tots dos. En aquest últim cas, la llei de Navier té tots els seus termes. Si només tenim un moment flector, per exemple $M_{Z}$, la fórmula de Navier queda:

$$
\sigma=\frac{N}{A}-\frac{M_{Z}}{I_{Z}} y
$$

L'equació de la $\mathrm{LN}$ en aquest cas ens dóna una recta paral·lela a l'eix $\mathrm{Z}$ però desplaçada cap a la zona de compressions, si l'axial és de tracció, o cap a la zona de traccions, si l'axial és de compressió. La LN ja no passa pel centre de gravetat de la secció.

$$
y=\frac{N \cdot I_{Z}}{A \cdot M_{Z}}
$$


Pensem, per exemple, en un axial i un moment positius. L'equació de la LN serà: $y=K$ ( $K$ és una constant major que zero).

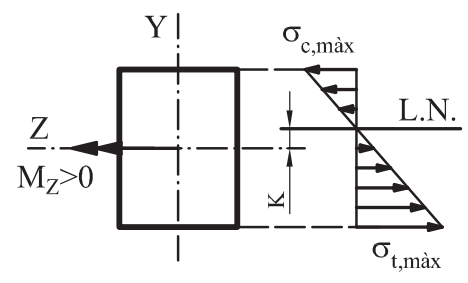

Fig. 5.32. Flexió composta amb només un moment

Com veiem, la zona de traccions augmenta (hi ha més percentatge de la secció treballant a tracció). Pot ocórrer que inclús la LN estiga fora de la secció, per damunt o per sota, si l'axial és molt gran. Això farà que la peça només tinga traccions o compressions. Aquesta circumstància pot ser aprofitada per fer treballar la secció d'una manera convenient als nostres interessos. Per exemple, amb les bigues prefabricades de formigó pretensat, el que es fa és aplicar un axial de compressió inicial, abans d'entrar la biga en càrrega, per a disminuir la zona de traccions (ja sabem que el formigó es comporta bastant malament a tracció).

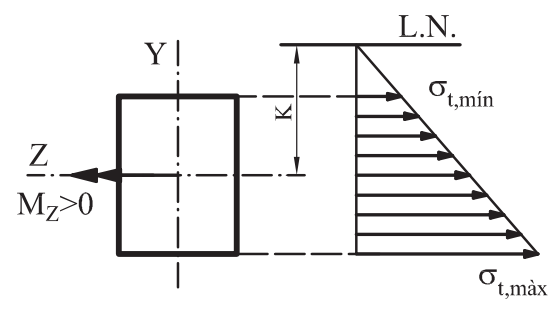

Fig. 5.33. Flexió composta amb només un moment si $\mathrm{N}$ és molt gran i positiu

\section{Exemple 5.8}

Una biga de secció rectangular està sotmesa a una càrrega $\mathrm{P}$, que està continguda dins del pla XY i inclinada de la manera que es mostra a la figura. Calculeu la màxima tensió normal a la secció més desfavorable.
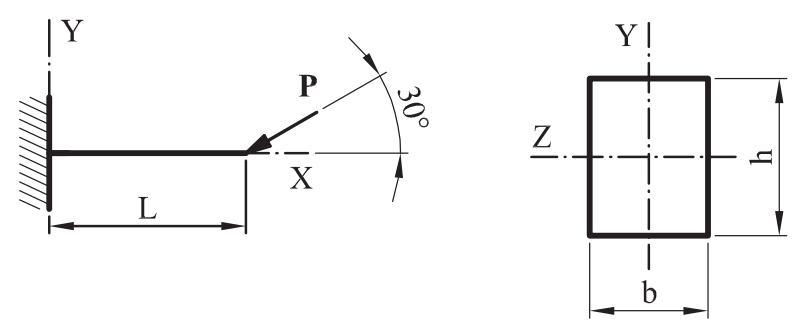

Fig. 5.34. Exemple 5.8. Enunciat

Dades: $\mathrm{P}=400 \mathrm{kN} ; \mathrm{L}=3 \mathrm{~m} ; \mathrm{h}=40 \mathrm{~cm} ; \mathrm{b}=20 \mathrm{~cm}$. 
Si fem una descomposició vectorial de la força $\mathrm{P}$, ens adonem que el problema és de flexió composta, perquè la component horitzontal de $\mathrm{P}$ és un axial de compressió.

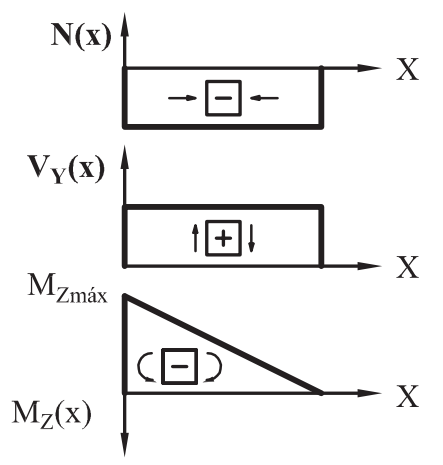

Fig. 5.35. Exemple 5.8. Diagrames

Hem de buscar, en primer lloc, la secció més desfavorable. Calculem i representem les lleis d'esforços.

$N(x)=-P \cdot \cos (30)$

$V(x)=P \cdot \sin \left(30^{\circ}\right)$

$M(x)=P \cdot \sin \left(30^{\circ}\right) \cdot(x-L)$

La secció més desfavorable és clarament la de l'encast, perquè té el moment flector més gran, a igualtat d'axials.

L'àrea i el moment d'inèrcia són: $A=0,08 \mathrm{~m}^{2} ; I_{Z}=1,067 \cdot 10^{-3} \mathrm{~m}^{4}$.

L'axial és $N=-346,41 \mathrm{kN}$ i el moment flector $M_{Z}=-600 \mathrm{kN} \cdot \mathrm{m}$.

L'equació de la LN és:

$y=\frac{N \cdot I_{Z}}{A \cdot M_{Z}}=7,698 \cdot 10^{-3} \mathrm{~m}=0,77 \mathrm{~cm}$

Podem apreciar que l'efecte de l'axial no és massa important, perquè no desplaça en gran mesura la LN dins de la secció. El diagrama de tensions ens queda:

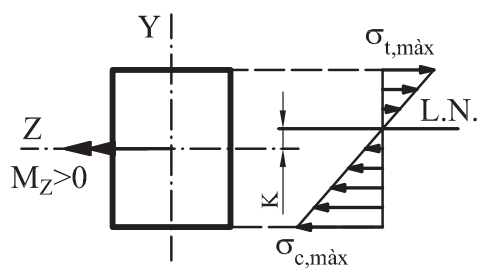

Fig. 5.36. Exemple 5.8. Tensions normals en la secció de l'encast. Fora d'escala

Com que creix la zona de compressions, els pitjors punts seran els que estan més allunyats de l'eix Z per la part de baix $(y=-h / 2)$. La tensió en aquests punts és: 
$\sigma_{c, m a ̀ x}=\frac{N}{A}-\frac{M_{Z}}{I_{Z}} y=\frac{-P \cdot \cos \left(30^{\circ}\right)}{A}-\frac{-P \cdot \sin \left(30^{\circ}\right) \cdot L}{I_{Z}} \cdot \frac{-h}{2}=-1,168 \cdot 10^{8} \mathrm{~Pa}=-116,8 \mathrm{MPa}$

A l'altre extrem tindrem la màxima tracció, però podem demostrar que el seu valor serà més menut que la compressió:

$\sigma_{c, m a ̀ x}=\frac{N}{A}-\frac{M_{Z}}{I_{Z}} y=\frac{-P \cdot \cos \left(30^{\circ}\right)}{A}-\frac{-P \cdot \sin \left(30^{\circ}\right) \cdot L}{I_{Z}} \cdot \frac{h}{2}=1,082 \cdot 10^{8} \mathrm{~Pa}=108,2 \mathrm{MPa}$

Si tenim una flexió composta esbiaixada, la LN no només no passa pel centre de gravetat, sinó que a més no és paral·lela a cap dels eixos. D'igual manera que abans, l'axial influeix en les tensions, augmentant la zona de traccions, si és positiu, i la zona de compressions, si és negatiu.

L'equació de la LN en aquest cas tindrà la forma següent:

$$
y=\frac{N \cdot I_{Z}}{A \cdot M_{Z}}+\frac{I_{Z} \cdot M_{Y}}{I_{Y} \cdot M_{Z}} Z
$$

La LN es desplaça paral·lelament a la que tindria en el cas de flexió simple esbiaixada.

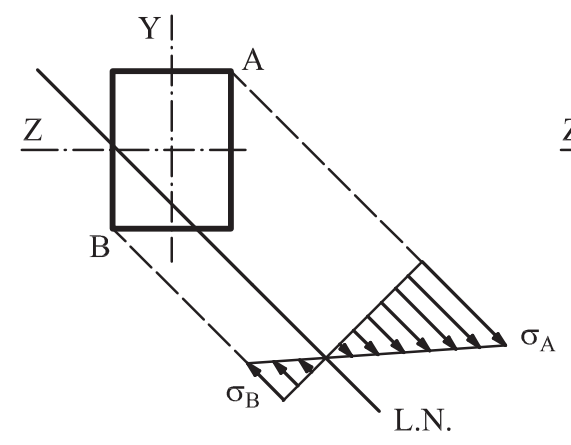

a)

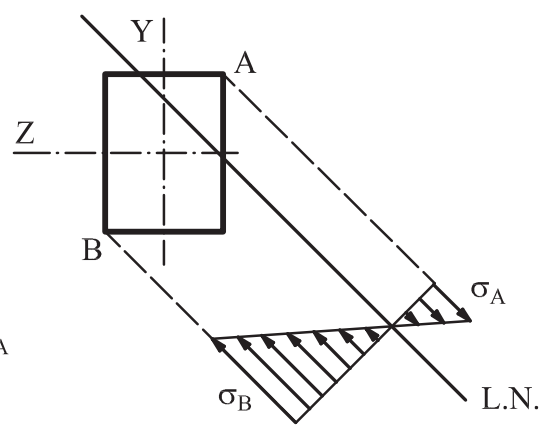

b)

Fig. 5.37. Flexió composta esbiaixada: $a$ ) axial positiu; $b$ ) axial negatiu

També podem tindre una flexió composta esbiaixada si sobre una biga actua una força excèntrica, com a la figura següent:

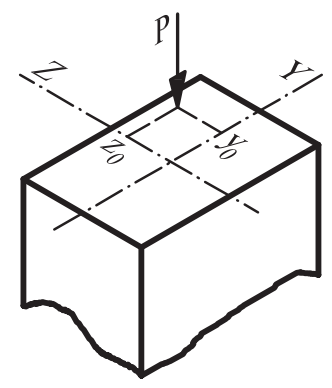

Fig. 5.38. Flexió composta esbiaixada causada per una força axial excèntrica 
Si desplacem la càrrega $\mathrm{P}$ al centre de gravetat obtenim un axial i dos moments:

$$
\begin{gathered}
N=-P \\
M_{Z}=P \cdot y_{0} \\
M_{Y}=-P \cdot z_{0}
\end{gathered}
$$

i les tensions en la secció, segons Navier:

$$
\sigma=\frac{-P}{A}-\frac{P \cdot y_{0}}{I_{Z}} y-\frac{P \cdot z_{0}}{I_{Y}} Z
$$

\section{Exemple 5.9}

Un pilar de formigó d'una nau industrial té la secció que s'indica a la figura 5.39. El pilar suporta en la secció $\mathrm{B}$ les càrregues següents (vegeu dibuix):

1. Actuant excèntricament, en el punt $\mathrm{P}$ de la secció $\mathrm{B}$, un esforç axial $\mathrm{N}$ de compressió.

2. En la direcció de l'eix $\mathrm{Z}$ i sentit negatiu, un esforç tallant $\mathrm{V}$.

Calculeu, per a la secció A de l'encast, l'equació i representació de la línia neutra i el diagrama acotat de tensions normals.

Dades: $\mathrm{N}=1.000 \mathrm{kN} ; \mathrm{V}=500 \mathrm{kN}$.
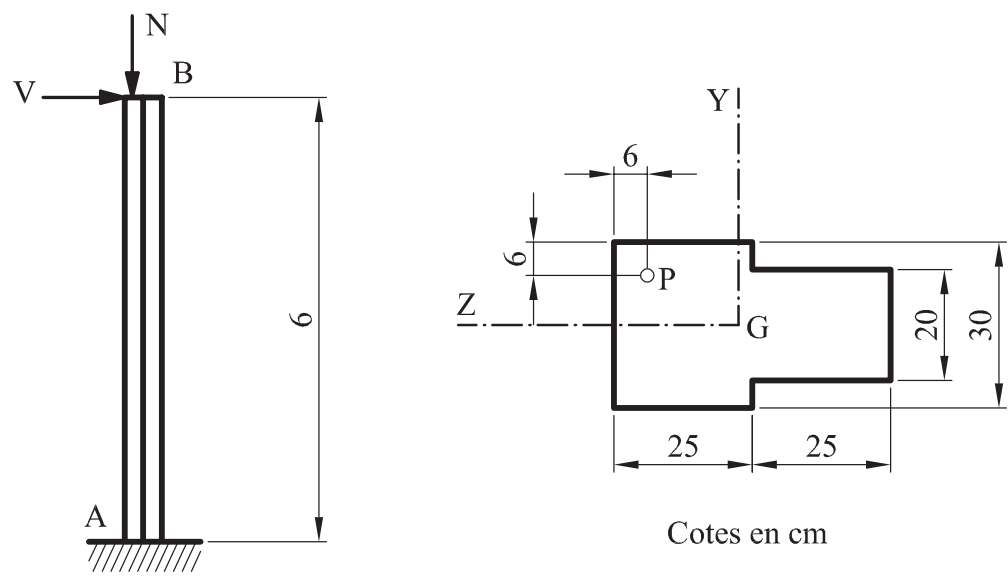

Cotes en $\mathrm{m}$

Fig. 5.39. Exemple 5.9. Enunciat

El centre de gravetat de la secció es troba sobre l'eix de simetria i a una distància de $22,5 \mathrm{~cm}$ del costat esquerre de la secció. L'àrea és $A=0,125 \mathrm{~m}^{2}$ i els moments d'inèrcia $I_{Z}=7,292 \cdot 10^{-4} \mathrm{~m}^{4} ; I_{Y}=2,526 \cdot 10^{-3} \mathrm{~m}^{4}$ (s'omet el càlcul).

En la secció $\mathrm{B}$ tenim les forces $\mathrm{N}$ i V, però a més, apareixen dos moments com a conseqüència de l'excentricitat de la càrrega $\mathrm{N}$. 
El moment al voltant de Z és positiu, segons la regla del llevataps. L'excentricitat de la càrrega és en aquest cas: $15-6=9 \mathrm{~cm}$. El moment és, per tant: $M_{Z B}=0,09$. $1.000=90 \mathrm{kN} \cdot \mathrm{m}$.

El moment al voltant de $\mathrm{Y}$ és negatiu. L'excentricitat és $22,5-6=16,5 \mathrm{~cm}$. El moment té un valor de: $M_{Y B}=0,165 \cdot 1.000=-165 \mathrm{kN} \cdot \mathrm{m}$.

En la secció A tenim els mateixos esforços que en la secció B, afegint-hi el moment causat per la força $\mathrm{V}$. Aquest moment és al voltant de l'eix Y i és positiu. L'hem de sumar al que prové de l'excentricitat.

En resum, en la secció A tenim:

$$
\begin{gathered}
N_{A}=-N=-1.000 \mathrm{kN} \\
M_{Z A}=M_{Z B}=90 \mathrm{kN} \cdot \mathrm{m} \\
M_{Y A}=M_{Y B}+\mathrm{V} \cdot \mathrm{h}=2.835 \mathrm{kN} \cdot \mathrm{m}
\end{gathered}
$$

La distribució de tensions normals segueix la llei de Navier.

$\sigma_{A}=\frac{-1000 \cdot 10^{3}}{0,125}-\frac{90 \cdot 10^{3}}{7,292 \cdot 10^{-4}} y+\frac{2835 \cdot 10^{3}}{2,526 \cdot 10^{-3}} z$

Per a deduir quins són els punts amb més tensió, hem de representar la LN. Igualem a zero l'expressió anterior. El més fàcil és buscar la intersecció de la LN amb els eixos. Per a l'eix Z, substituïm el valor $y=0$ i obtenim un valor de $z=0,713 \mathrm{~cm}$. Si prenem $z=0$, el valor que s'obté és $y=-6,481 \mathrm{~cm}$. Això ens permet dibuixar la LN i adonar-nos que els punts més allunyats són el M i el N. Les coordenades d'aquests punts són:

$$
\begin{array}{ll}
y_{M}=0,1 m & z_{M}=-0,275 m \\
y_{N}=-0,15 m & z_{N}=0,225 m
\end{array}
$$

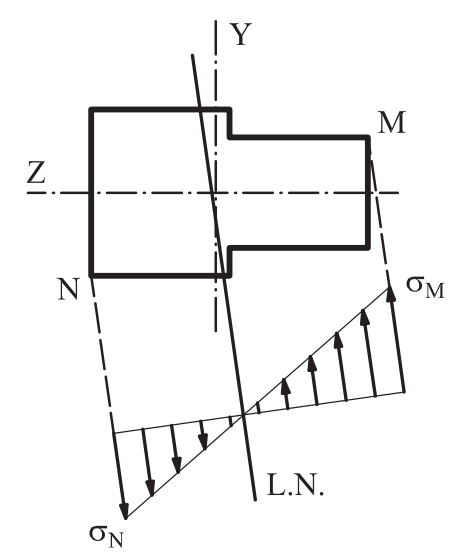

Fig. 5.40. Exemple 5.9. Posició de la LN i distribució de tensions en la secció A

Si substituïm les coordenades en la llei de Navier obtenim les tensions dels dos punts: 
$\sigma_{A}\left(y_{M} Z_{M}\right)=-3,29 \cdot 10^{8} \mathrm{~Pa}=-328,98 \mathrm{MPa}$. Com que és negatiu, la tensió és de compressió.

$\sigma_{A}\left(y_{N} Z_{N}\right)=2,63 \cdot 10^{8} P a=263,03 M P a$. Aquesta tensió es de tracció.

\section{Exemple 5.10}

Dimensioneu una biga mitjançant un perfil format per dues UPN en caixó soldat, d'acer S275, que suporta uns esforços en la secció més desfavorable: $N=200 \mathrm{kN}$; $M_{Z}=40 \mathrm{kN} \cdot \mathrm{m} ; M_{Y}=20 \mathrm{kN} \cdot \mathrm{m}$. Dibuixeu el diagrama de tensions normals i calculeu els valors als punts de màxima tensió.

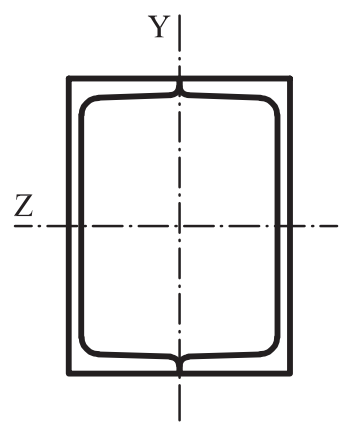

a)

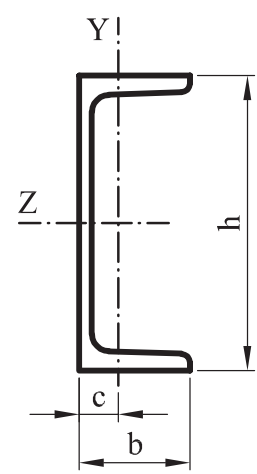

b)

Fig. 5.41. Exemple 5.10.a) Secció UPN en caixó; b) paràmetres geomètrics de la secció

Quan parlem d'una secció formada per UPN en caixó ens referim a seccions com la de la figura, amb un cordó de soldadura en la unió dels dos perfils.

Les seccions del tipus UPN tenen simetria només en un eix. La posició del centre de gravetat de la secció ens la donen les taules (paràmetre c). L'àrea, els moments d'inèrcia $\mathrm{i}$ els mòduls resistents s'han de calcular de la següent manera (si $\mathrm{A}_{\mathrm{UPN}}$, $\mathrm{I}_{\text {ZUPN }}$ i $_{\text {YUPN }}$ són els valors d'un UPN senzill).
$A=2 A_{U P N}$
$I_{Z}=2 I_{Z U P N}$
$I_{Y}=2\left[I_{Y U P N}+A_{U P N}(b-c)^{2}\right]$
$W_{Z}=\frac{I_{Z}}{h / 2}$
$W_{Y}=\frac{I_{Y}}{b}$

La primera cosa que hem de fer és estudiar quina és la col·locació idònia per a la secció. Tenim un moment més gran en un eix que en l'altre, però no sabem, a priori, quin dels dos eixos tindrà un moment d'inèrcia més gran. Agafem un perfil qualsevol i fem la prova, per exemple l'UPN 200, que té uns valors estàtics segons les taules: $A_{U P N}=32,2 \mathrm{~cm}^{2} ; I_{Z U P N}=1.910 \mathrm{~cm}^{4} ; I_{Y U P N}=148 \mathrm{~cm}^{4}$. Els valors de la secció composta, segons les fórmules anteriors, són: $A=64,4 \mathrm{~cm}^{2} ; I_{Z}=3.820 \mathrm{~cm}^{4}$; $I_{Y}=2.237 \mathrm{~cm}^{4}$. Comprovem que té més moment d'inèrcia l'eix Z. Per aquesta raó, la col·locació ha de ser tal que l'eix Z suporte el moment flector més gran. Aquesta col·locació és la que es representa a la figura 5.41.a. 
El dimensionament és un procés iteratiu. Per a evitar començar pel primer perfil de la sèrie, farem un predimensionament considerant només el moment més gran $\left(\mathrm{M}_{7}\right)$. La llei de Navier ens queda:

$\sigma_{\text {màx }}=\frac{\left|M_{Z}\right|}{W_{Z}}=\frac{\left|M_{Z}\right|}{2 W_{Z U P N}} \leq f_{y d}$

i el mòdul resistent d'un perfil simple haurà de ser més gran que:

$W_{Z U P N} \geq \frac{\left|M_{Z}\right|}{2 f_{y d}}=76,36 \cdot 10^{-6} \mathrm{~m}^{3}=76,36 \mathrm{~cm}^{3}$

El perfil escollit és l'UPN 140. Els valors geomètrics i estàtics d'aquest perfil són: $b=60 \mathrm{~mm} ; h=140 \mathrm{~mm} ; c=17,5 \mathrm{~mm} ; A_{U P N}=20,4 \mathrm{~cm}^{2} ; I_{Z U P N}=605 \mathrm{~cm}^{4} ; I_{Y U P N}=62,7 \mathrm{~cm}^{4}$. Els valors de la secció composta, segons les fórmules anteriors, ens queden: $A=40,8 \mathrm{~cm}^{2} ; I_{Z}=1210 \mathrm{~cm}^{4} ; I_{Y}=862,35 \mathrm{~cm}^{4} ; W_{Z}=172,86 \mathrm{~cm}^{3} ; W_{Y}=143,73 \mathrm{~cm}^{3}$.

La comprovació que no superem la tensió admissible la farem mitjançant el concepte de ràtio d'aprofitament, segons l'expressió:

$$
a=\frac{|N|}{A \cdot f_{y d}}+\frac{\left|M_{Z}\right|}{W_{z} \cdot f_{y d}}+\frac{\left|M_{Y}\right|}{W_{Y} \cdot f_{y d}}
$$

Si substituïm els valors que tenim, obtenim una ràtio $a=1,602$; per tant, superem la tensió admissible. Hem de provar un perfil més gran. Com que la ràtio és bastant més gran que la unitat, saltarem el perfil UPN 160 i agafarem directament l'UPN 180. Els valors geomètrics i estàtics d'aquest perfil són: $b=70 \mathrm{~mm} ; h=180 \mathrm{~mm}$; $c=19,2 \mathrm{~mm} ; A_{U P N}=28 \mathrm{~cm}^{2} ; I_{Z U P N}=1.350 \mathrm{~cm}^{4} ; I_{Y U P N}=114 \mathrm{~cm}^{4}$. Els valors de la secció composta, segons les fórmules anteriors, queden: $A=56 \mathrm{~cm}^{2} ; I_{Z}=2.700 \mathrm{~cm}^{4}$; $I_{Y}=1.673 \mathrm{~cm}^{4} ; W_{Z}=300 \mathrm{~cm}^{3} ; W_{Y}=293,02 \mathrm{~cm}^{3}$.

La ràtio d'aprofitament en aquest cas és: $a=0,965$. No se supera la tensió admissible. Com que és un valor que està bastant prop de la unitat, podem pensar que si haguérem fet la prova pel perfil UPN 160 , hauríem obtingut una ràtio $a>1$. La solució del dimensionament és 2 UPN 180.

L'equació de la LN és: $y=\frac{N \cdot I_{Z}}{A \cdot M_{Z}}+\frac{I_{Z} \cdot M_{Y}}{I_{Y} \cdot M_{Z}} z=0,024+0,807 z$ en unitats del SI.

Obtenim el tall amb els eixos:

$\mathrm{z}=0 \rightarrow \mathrm{y}=0,024 \mathrm{~m}$

$\mathrm{y}=0 \rightarrow \mathrm{z}=-0,030 \mathrm{~m}$

Representem la LN i observem que els punts més allunyats són A i B (vegeu figura 5.42). Les coordenades dels punts són: 


$$
\begin{aligned}
& y_{A}=0,09 m \quad z_{A}=-0,07 m \\
& y_{B}=-0,09 \mathrm{~m} \quad z_{B}=0,07 \mathrm{~m}
\end{aligned}
$$

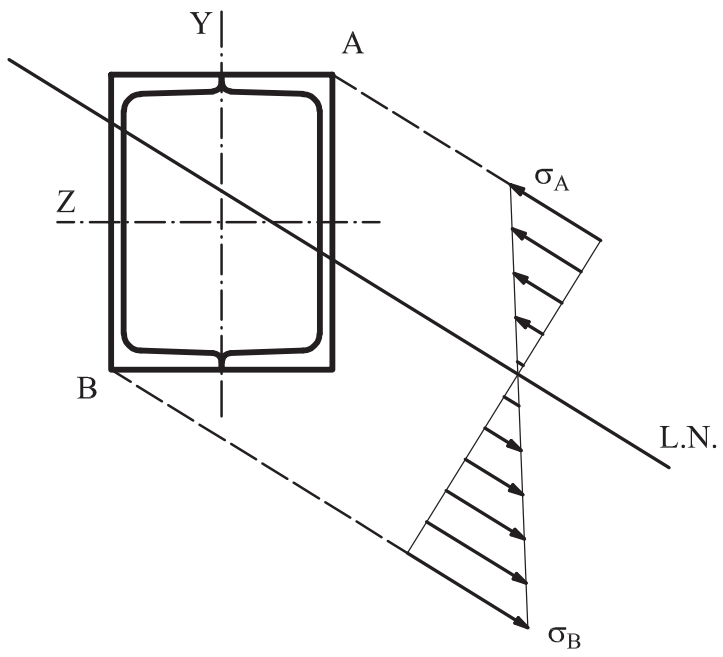

Fig. 5.42. Exemple 5.10. Posició de la LN i distribució de tensions en la secció

I les tensions normals en els punts A i B són:

$\sigma\left(y_{A}, Z_{A}\right)=-181,29 \cdot 10^{6} \mathrm{~Pa}=-181,29 \mathrm{MPa}$. El punt A està comprimit.

$\sigma\left(y_{B}, Z_{B}\right)=252,72 \cdot 10^{6} \mathrm{~Pa}=252,72 \mathrm{MPa}$. El punt B està a tracció i la seua tensió és més gran que la corresponent al punt A: com que tenim un axial de tracció, la LN es desplaça del centre de gravetat, i deixa més percentatge de la secció a tracció. Com a conseqüència, es redueix el valor de les tensions de compressió i s'augmenta el valor de les tensions de tracció.

\subsection{Bigues compostes o mixtes}

Amb certa freqüència, les bigues es fabriquen amb diferents materials. En aquest punt només estudiarem les bigues fetes amb dos materials. Com a exemples podem esmentar les bigues de fusta reforçades amb plaques d'acer, bigues sandvitx, bigues bimetàl-liques, tubs d'acer recoberts de plàstic, bigues de formigó armat, etc.

Analitzarem el comportament resistent (distribució de tensions normals) de bigues compostes de dos materials amb comportament elàstic lineal, sotmeses a flexió simètrica.

S'admet la hipòtesi de Bernouilli (les seccions planes i perpendiculars a l'eix longitudinal romanen planes).

Considerem una biga rectangular que consta de dos materials (1 i 2), adherits l'un a l'altre. La hipòtesi de Bernouilli implica que les deformacions unitàries 
varien linealment a partir de la LN. Als punts d'unió d'ambdós materials, les deformacions han de ser iguals.

Si els materials tenen diferents mòduls d'elasticitat podem definir una raó modular com:

$$
n=\frac{E_{2}}{E_{1}}
$$

Si els materials són elàstics i lineals, el fet que a la superfície d'unió la deformació siga la mateixa als dos materials representa:

$$
\varepsilon_{1}=\varepsilon_{2} \rightarrow \frac{\sigma_{1}}{E_{1}}=\frac{\sigma_{2}}{E_{2}} \rightarrow \sigma_{2}=n \sigma_{1}
$$

Les tensions en un dels materials no seran les mateixes que en l'altre, estaran modificades per la raó modular n. A la figura 5.43 es mostra la distribució de tensions si $n>1$.

El que farem per a determinar els esforços és variar la geometria de la secció de manera que, si la biga fóra d'un únic material, la rigidesa a flexió $\left(E \cdot I_{Z}\right)$ de la secció modificada siga la mateixa que la de la secció real. Aquesta nova secció serà la secció transformada o secció homogeneïtzada, i el procés el denominarem homogeneïtzar la secció.

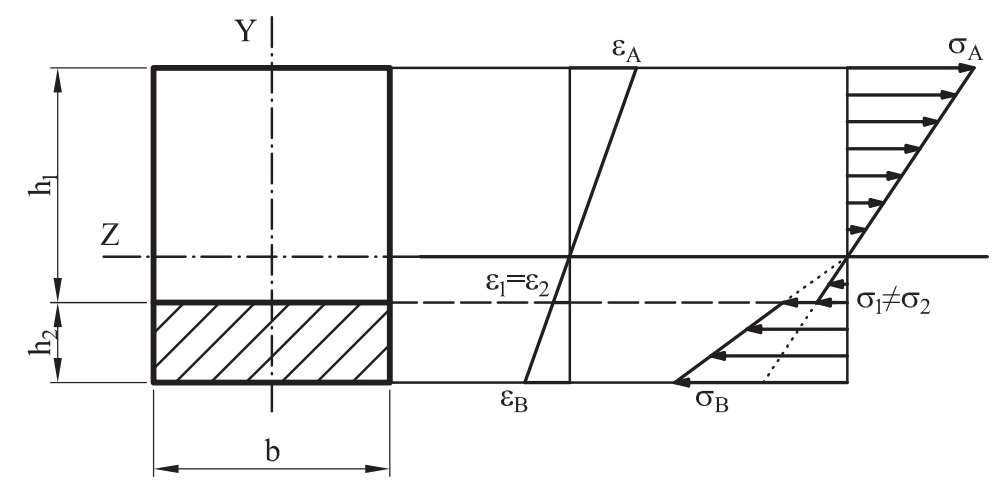

Fig. 5.43. Bigues de dos materials: deformacions i tensions als punts de la secció

Per a homogeneïtzar la secció el que farem serà multiplicar l'ample de la secció al material 2 per la raó modular o dividir l'ample de la secció al material 1 per n. Podríem haver definit la raó modular a la inversa; $n=\frac{E_{1}}{E_{2}}$, i llavors tots els càlculs de seccions transformades serien equivalents, amb la diferència que quan abans multiplicàvem, ara dividiríem, i viceversa. 


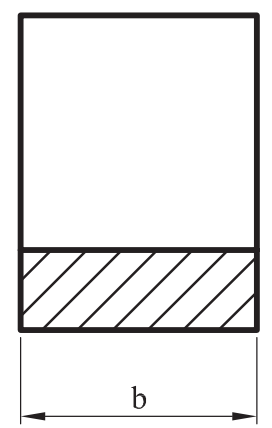

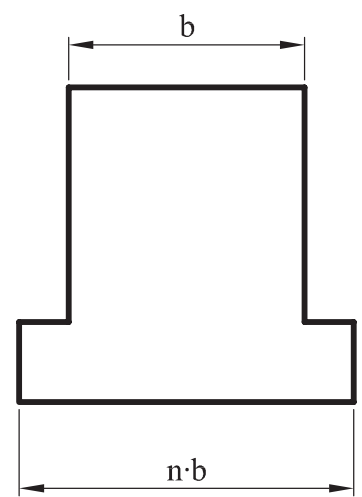

a)

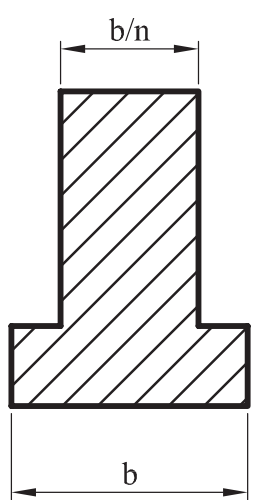

b)

Fig. 5.44. Homogeneïtzació. $a$ ) respecte al material $1 ; b$ ) respecte al material 2

S'ha de tindre en consideració que perquè la LN romanga en la seua posició, només podem modificar la dimensió paral·lela a l'eix de la flexió. Aquesta LN no passa pel centre de gravetat de la secció composta, sinó pel centre de gravetat de la secció homogeneïtzada.

Un cop homogeneïtzada la secció, calcularem el seu centre de gravetat, per on passarà la LN, i el seu moment d'inèrcia respecte a la LN $\left(I_{Z T}\right)$. La distribució de tensions normals en la secció, per a cadascun dels materials, és:

$$
n=\frac{E_{2}}{E_{1}} \quad \sigma_{1}=-\frac{M_{Z}}{I_{Z T}} y \quad \sigma_{2}=-n \frac{M_{Z}}{I_{Z T}} y
$$

La distribució de tensions és la que hem representat a la figura 5.43.

Si haguérem pres la raó modular respecte al material 2:

$$
n=\frac{E_{1}}{E_{2}} \quad \sigma_{1}=-n \frac{M_{Z}}{I_{Z T}} y \quad \sigma_{2}=-\frac{M_{Z}}{I_{Z T}} y
$$

Però el resultat quant a tensions seria el mateix.

La rigidesa a flexió respecte a l'eix que passa pel centre de gravetat serà (homogeneïtzant respecte al material 1):

$$
E_{1} \cdot I_{Z T}=E_{1} \cdot I_{Z 1}+E_{2} \cdot I_{Z 2}
$$

Els moments d'inèrcia dels dos materials $\left(I_{Z 1}\right.$ i $\left.I_{Z 2}\right)$ són respecte al mateix eix que passa pel centre de gravetat de la secció homogeneïtzada. 


\section{Exemple 5.11}

Una biga composta està formada per una biga de fusta de dimensions $b_{1} \mathrm{x} h_{1} \mathrm{i}$ una placa d'acer de reforç, del mateix ample que la fusta $\left(b_{2}=b_{1}\right)$ i de gruix $h_{2}$. La secció més desfavorable de la biga està sotmesa a un moment flector positiu conegut. Calculeu les tensions màximes i mínimes dins de cadascun dels materials, utilitzant el mètode de la secció transformada.

Dades: $\mathrm{E}_{1}=10,5 \mathrm{GPa} ; \mathrm{E}_{2}=210 \mathrm{GPa} ; \mathrm{b}_{1}=\mathrm{b}_{2}=10 \mathrm{~cm} ; \mathrm{h}_{1}=15 \mathrm{~cm} ; \mathrm{h}_{2}=12 \mathrm{~mm}$.

Aquest problema pot ser resolt de dues maneres, homogeneïtzant respecte al material 1 o respecte al material 2. Com a exemple, ho resoldrem d'ambdues maneres, $i$ mostrarem que el resultat és el mateix. En primer lloc, homogeneïtzarem respecte al material 1.

La raó modular és:

$n=\frac{210}{10,5}=20$

Variarem l'ample del material $2: \mathrm{b}_{2}{ }^{\prime}=\mathrm{n} \cdot \mathrm{b}_{2}=2 \mathrm{~m}$.
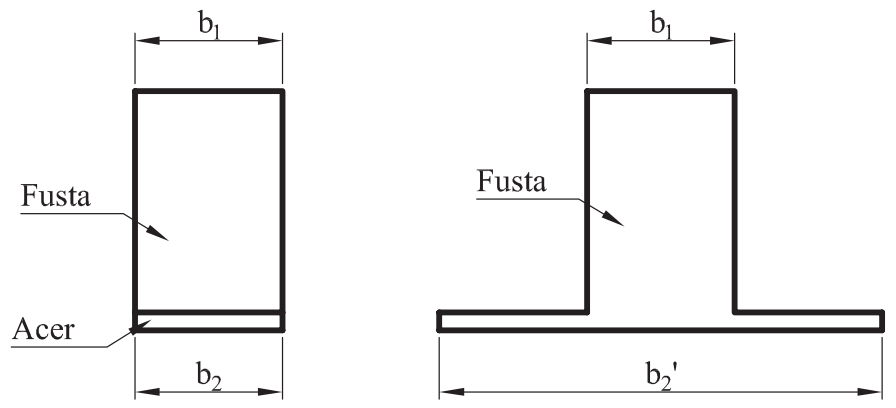

Fig. 5.45. Homogeneïtzació respecte al material 1. Fora d'escala

En aquest cas hipotètic, la biga està composta per un únic material (fusta).

La LN en flexió simètrica travessarà el centre de gravetat geomètric de l'àrea homogeneïtzada. Calculem la posició vertical del centre de gravetat. Prenem com a referència la part baixa de la secció homogeneïtzada.

$Y_{G}=\frac{h_{1} \cdot b_{1} \cdot\left(h_{2}+\frac{h_{1}}{2}\right)+h_{2} \cdot b_{2} \cdot \frac{h_{2}}{2}}{h_{1} \cdot b_{1}+h_{2} \cdot b_{2^{\prime}}}=3,715 \mathrm{~cm}$ 


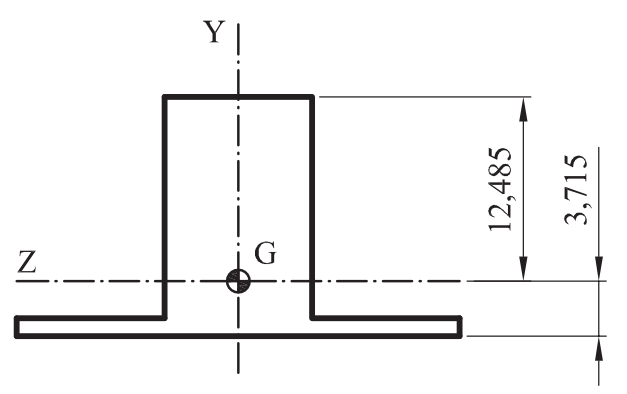

Fig. 5.46. Posició dels eixos principals de la secció transformada

Un cop calculada la posició del centre de gravetat, calcularem el moment d'inèrcia de la secció transformada respecte a l'eix que passa pel centre de gravetat.

$I_{Z T}=\frac{1}{12} \cdot b_{1} \cdot h_{1}^{3}+b_{1} \cdot h_{1} \cdot\left(h_{2}+\frac{h_{1}}{2}-Y_{G}\right)^{2}+\frac{1}{12} \cdot b_{2}{ }^{\prime} \cdot h_{2}^{3}+b_{2}{ }^{\prime} \cdot h_{2} \cdot\left(Y_{G}-\frac{h_{2}}{2}\right)^{2}$

$I_{Z T}=8,9 \cdot 10^{-5} \mathrm{~m}^{4}$

La distribució de tensions normals és: $\sigma_{1}=\frac{-M_{Z}}{I_{Z}} y$ i en el material $2 \sigma_{2}=-n \cdot \frac{M_{Z}}{I_{Z}} y$

Utilitzant les equacions anteriors podem calcular les tensions màximes i mínimes en la fusta $i$ en l'acer:

$\sigma_{1}\left(h_{1}+h_{2}-Y_{G}\right)=-9,82 \cdot 10^{6} \mathrm{~Pa} \quad \sigma_{2}\left(-Y_{G}+h_{2}\right)=39,58 \cdot 10^{6} \mathrm{~Pa}$

$\sigma_{1}\left(-Y_{G}+h_{2}\right)=1,98 \cdot 10^{6} \mathrm{~Pa} \quad \sigma_{2}\left(-Y_{G}\right)=58,46 \cdot 10^{6} \mathrm{~Pa}$

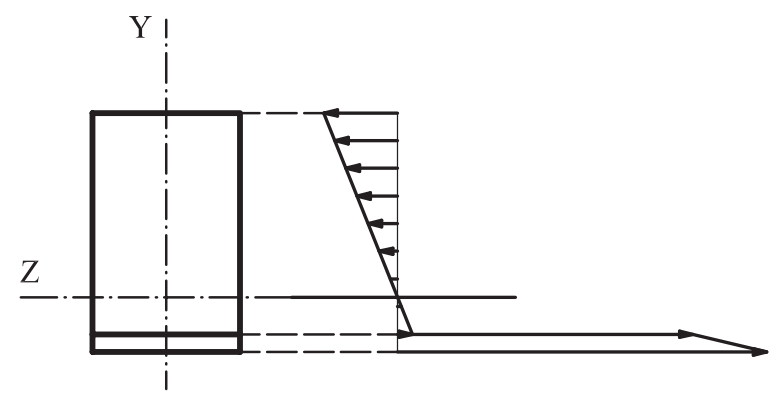

Fig. 5.47. Exemple 5.11. Distribució de tensions normals

Com a segona opció de resolució del problema, podríem haver optat per homogeneïtzar respecte al material 2 (acer). La raó modular és ara:

$n=\frac{E_{1}}{E_{2}}=0,05$

Modificarem l'ample de la fusta: $\mathrm{b}_{1}{ }^{\prime}=\mathrm{n} \cdot \mathrm{b}_{1}=0,5 \mathrm{~cm}$. 

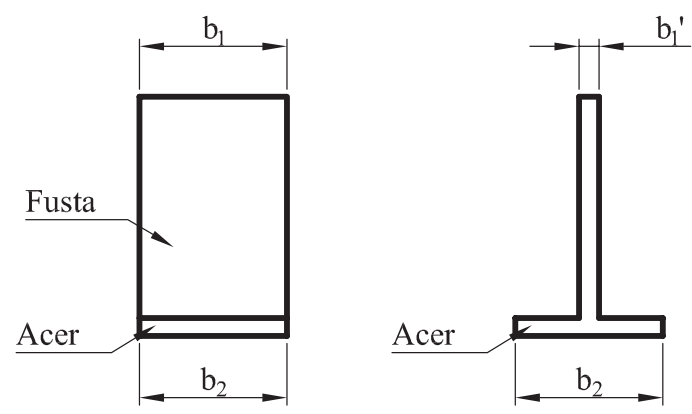

Fig. 5.48. Homogeneïtzació respecte al material 2. Fora d'escala

Farem tota la sèrie de càlculs equivalents al cas anterior però amb la nova geometria.

$Y_{G}=\frac{h_{1} \cdot b_{1}{ }^{\prime} \cdot\left(h_{2}+\frac{h_{1}}{2}\right)+h_{2} \cdot b_{2} \cdot \frac{h_{2}}{2}}{h_{1} \cdot b_{1}{ }^{\prime}+h_{2} \cdot b_{2}}=3,715 \mathrm{~cm} \quad$ (és la mateixa posició)

$I_{Z T}=\frac{1}{12} \cdot b_{1}{ }^{\prime} \cdot h_{1}^{3}+b_{1}{ }^{\prime} \cdot h_{1} \cdot\left(h_{2}+\frac{h_{1}}{2}-Y_{G}\right)^{2}+\frac{1}{12} \cdot b_{2} \cdot h_{2}^{3}+b_{2} \cdot h_{2} \cdot\left(Y_{G}-\frac{h_{2}}{2}\right)^{2}$

$=444,88 \mathrm{~cm}^{4}$

$\sigma_{1}=-n \frac{M_{Z}}{I_{Z}} y \quad \sigma_{2}=-\frac{M_{Z}}{I_{Z}} y$

$\sigma_{1}\left(h_{1}+h_{2}-Y_{G}\right)=-9,822 \cdot 10^{6} P a \quad \sigma_{2}\left(-Y_{G}+h_{2}\right)=39,578 \cdot 10^{6} P a$

$\sigma_{1}\left(-Y_{G}+h_{2}\right)=1,979 \cdot 10^{6} P a \quad \sigma_{2}\left(-Y_{G}\right)=58,46 \cdot 10^{6} P a$

Comprovem que les tensions són les mateixes que abans.

\section{Exemple 5.12}

Siga la biga composta de la figura (cotes en $\mathrm{cm}$ ) sotmesa a un moment flector conegut $\left(M_{Z}\right)$.

a) Calculeu la posició de la LN en la secció.

b) Representeu la distribució de tensions normals en ambdós materials, assenyalant les màximes tensions de tracció i compressió que experimenten.

c) Determineu la rigidesa a flexió $\left(E \cdot I_{Z}\right)$ de la biga.

Dades: $\mathrm{E}_{1}=2,88 \cdot 10^{10} \mathrm{~Pa} ; \mathrm{E}_{2}=3,6 \cdot 10^{10} \mathrm{~Pa} ; \mathrm{M}_{\mathrm{Z}}=30 \mathrm{kN} \cdot \mathrm{m}$. 


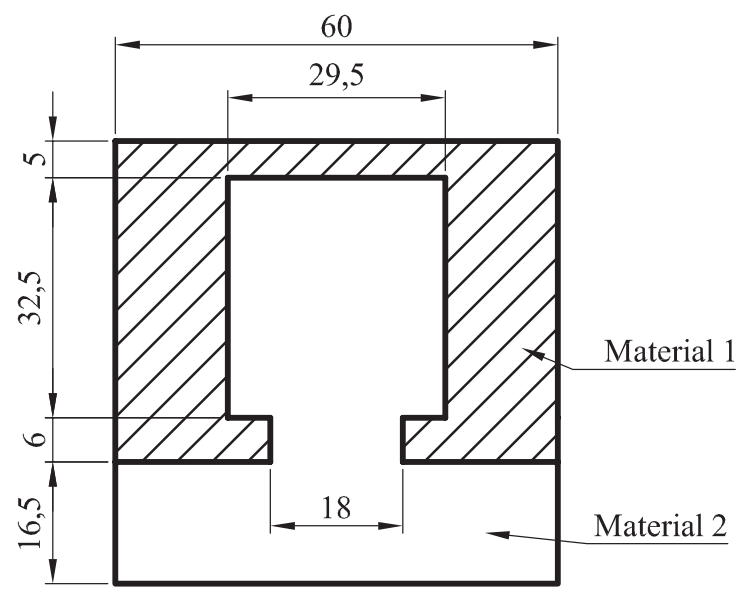

Fig. 5.49. Exemple 5.12. Enunciat

Hem d'homogeneïtzar la secció. Seleccionarem com a material de referència el material 2. La raó modular és:

$n=\frac{E_{1}}{E_{2}}=0,8$

Dividirem la secció en franges i multiplicarem l'ample del material 1 per la raó modular.

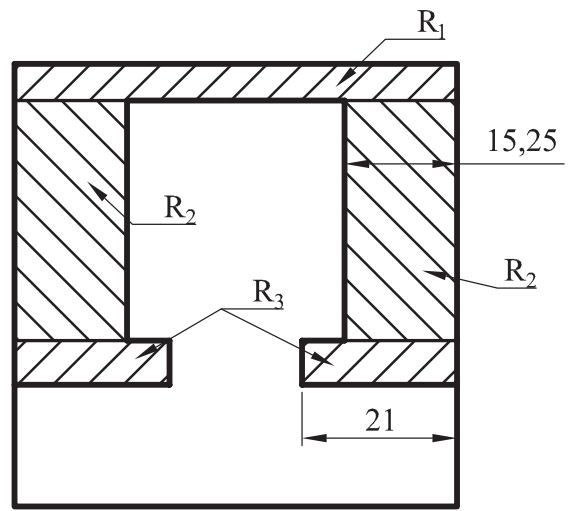

Fig. 5.50. Exemple 5.12. Divisió en franges

$R_{1}{ }^{\prime}=R_{1} \cdot n=60 \cdot 0,8=48 \mathrm{~cm}$

$R_{2}^{\prime}=R_{2} \cdot n=15,25 \cdot 0,8=12,2 \mathrm{~cm}$

$R_{3}{ }^{\prime}=R_{3} \cdot n=21 \cdot 0,8=16,8 \mathrm{~cm}$

Així doncs, com que hem fet una secció equivalent d'un sol material, tractarem les parts homogeneïtzades i les originals del material 2 com un únic material.

La secció resultant també la dividirem en franges, als efectes de càlcul de centre de gravetat i moments d'inèrcia. 

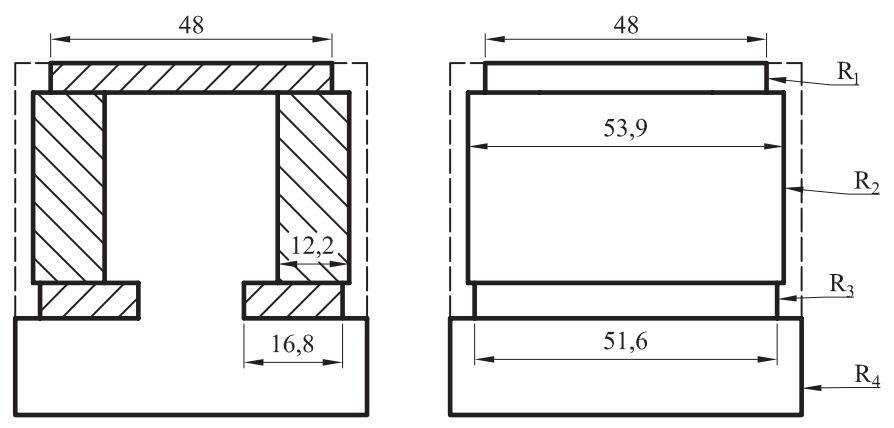

Fig. 5.51. Exemple 5.12. Secció homogeneïtzada

Càlcul de la posició del centre de gravetat de la secció homogeneïtzada (respecte al punt més baix de la secció).

$R_{1} \rightarrow A_{1}=48 \cdot 5=240 \mathrm{~cm}^{2} \quad Y_{G 1}=57,5 \mathrm{~cm}$

$R_{2} \rightarrow A_{2}=53,9 \cdot 32,5=1751,75 \mathrm{~cm}^{2} Y_{G 2}=38,75 \mathrm{~cm}$

$R_{3} \rightarrow A_{3}=51,6 \cdot 6=309,6 \mathrm{~cm}^{2} \quad Y_{G 3}=19,5 \mathrm{~cm}$

$R_{4} \rightarrow A_{4}=60 \cdot 16,5=990 \mathrm{~cm}^{2} \quad Y_{G 4}=8,25 \mathrm{~cm}$

$Y_{G}=\frac{\sum A_{i} \cdot Y_{G i}}{\sum A_{i}}=29,13 \mathrm{~cm} . \mathrm{La} \mathrm{LN}$ passa per aquesta posició.

Per a representar la distribució de tensions normals utilitzarem la llei de Navier. Necessitem calcular el moment d'inèrcia de la secció homogeneïtzada respecte a Z. Amb els rectangles de la figura, i aplicant el teorema de Steiner, el càlcul és senzill $\left(b_{i} \mathrm{i} h_{i}\right.$ són les dimensions dels rectangles i $d_{i}$ és la distància del centre de gravetat del rectangle al centre de gravetat de la secció):

$I_{Z T}=\sum I_{Z i}=\sum\left(\frac{1}{12} b_{i} \cdot h_{i}^{3}+b_{i} \cdot h_{i} \cdot d_{i}^{2}\right)=993.686,21 \mathrm{~cm}^{4}$

La distribució de tensions per al material 1: $\sigma_{1}=-n \frac{M_{Z}}{I_{Z}} y$

i per al material 2: $\sigma_{2}=\frac{-M_{Z}}{I_{Z}} y$.

Els punts més allunyats de la LN en els materials i les tensions associades són:

Material 1

$$
\begin{array}{ll}
y_{\text {màx }}=60-Y_{G}=30,87 \mathrm{~cm} & \sigma\left(y_{\text {màx }}\right)=-0,745 \mathrm{MPa} \\
y_{\text {min }}=-\left(Y_{G}-16,5\right)=-12,63 \mathrm{~cm} & \sigma\left(y_{\text {min }}\right)=0,305 \mathrm{MPa}
\end{array}
$$


Material 2

$$
\begin{array}{ll}
y_{\text {max }}=55-Y_{G}=25,87 \mathrm{~cm} & \sigma\left(y_{\text {max }}\right)=-0,781 \mathrm{MPa} \\
y_{\text {min }}=-Y_{G}=-29,13 \mathrm{~cm} & \sigma\left(y_{\text {min }}\right)=0,880 \mathrm{MPa}
\end{array}
$$

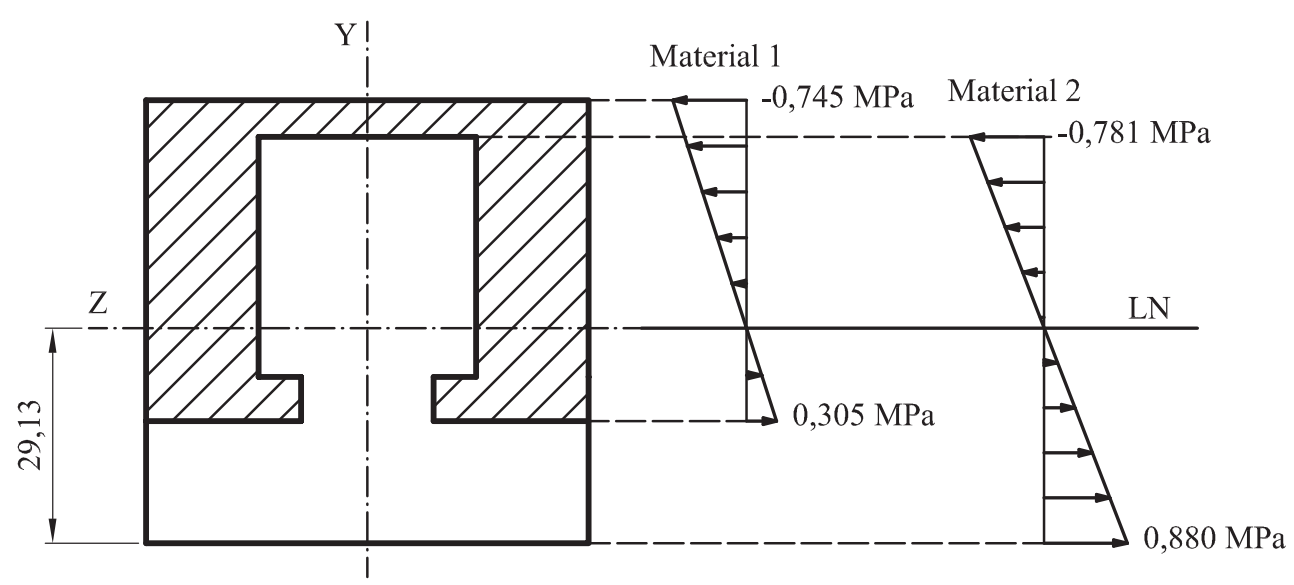

Fig. 5.52. Exemple 5.12. Distribució de tensions

La rigidesa a flexió de la biga relaciona el moment flector amb la curvatura i és el producte del mòdul d'elasticitat del material respecte al qual hem homogeneïtzat pel moment d'inèrcia de la secció homogeneïtzada.

En aquest cas:

Rigidesa de flexió $=E_{2} \cdot I_{Z T}=3,6 \cdot 10^{10} \cdot 9,937 \cdot 10^{-3}=357.728 .400 \mathrm{~N} \cdot \mathrm{m}^{2}$.

\subsection{Distribució de tensions tangencials en flexió}

La major part dels casos de flexió estan relacionats amb l'existència de esforços tallants, és a dir, són casos de flexió simple. Ja hem vist que els esforços axials i els moments flectors impliquen l'aparició de tensions normals. En aquest capítol estudiarem les tensions tangencials (o de cisallament) que apareixen com a conseqüència dels esforços tallants. El criteri determinant en el disseny d'una biga per resistència sol ser el màxim valor de l'esforç normal en la secció; les tensions de cisallament són, normalment, d'un ordre de magnitud inferior. Les tensions tangencials seran importants relativament, quan les bigues siguen curtes i gruixudes o quan tinguen un cantell molt gran. 


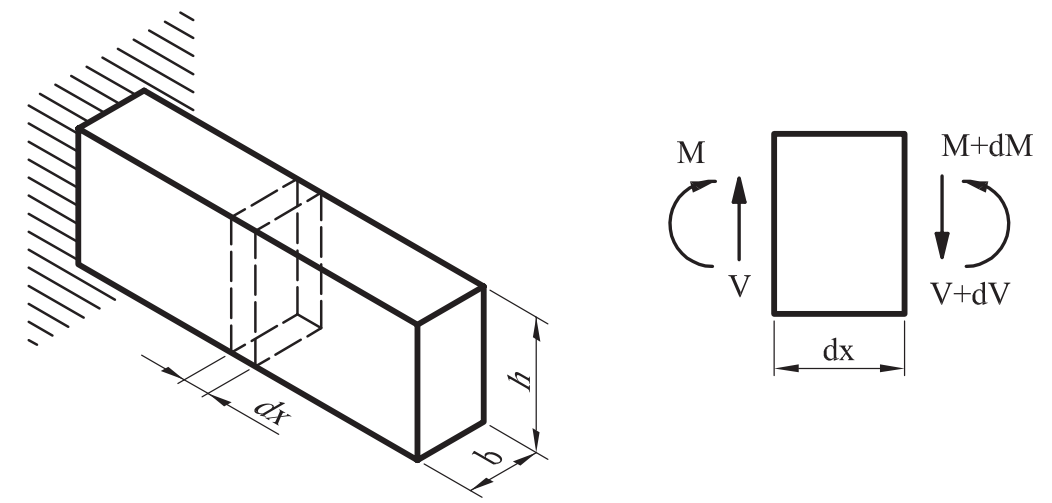

Fig. 5.53. Llesca diferencial en biga sotmesa a flexió simple

Imaginem una biga sotmesa a flexió simple, que tindrà una distribució de esforços tallants $V_{Y}(x)$ i moments flectors $M_{Z}(x)$ com la de la figura 5.53. Prenguem una llesca diferencial. Com que la distribució de tallants i flectors és contínua, existirà una variació diferencial en els esforços a un costat i altre de la llesca.

Hem estudiat als apartats anteriors quina és la distribució de tensions normals, que seran diferents a un costat i l'altre de la biga.

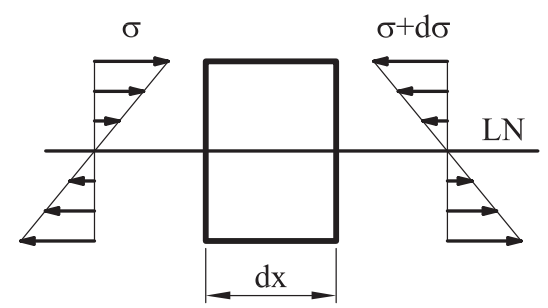

Fig. 5.54. Distribució de tensions normals en la llesca diferencial

Com ja sabem, si la biga està en equilibri, les seues parts també ho estaran. En concret, la llesca diferencial ha d'estar en equilibri. Si ara dividim en dues parts la llesca, totes dues han d'estar en equilibri.

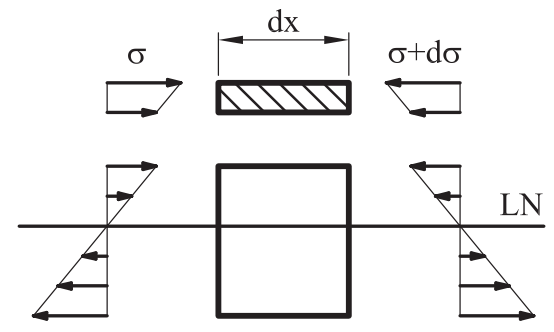

Fig. 5.55. Distribució de tensions normals en les dues parts de la llesca diferencial

Considerem la part superior. La resultant de les tensions normals en una cara lateral ens donarà un esforç axial, i en l'altra part, el mateix esforç, però amb una petita variació diferencial. 
L'axial serà $N^{*}=\int_{A^{*}} \sigma d A$ i la variació diferencial $d N^{*}=\int_{A^{*}} d \sigma d A$

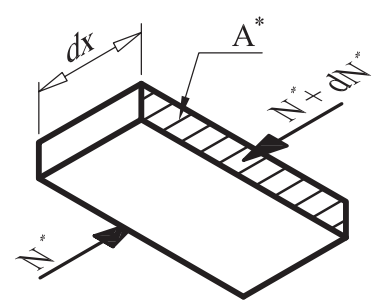

Fig. 5.56. Resultant de forces sobre la part superior de la llesca diferencial vista des de baix.

D'aquesta manera la peça no està en equilibri (el sumatori de forces no és zero)

Podem desenrotllar aquesta última expressió aplicant la llei de Navier per a flexió simple simètrica:

$$
d N^{*}=\int_{A^{*}} d \sigma d A=\int_{*^{*}} \frac{d M_{Z}}{I_{Z}} y d A=\frac{d M_{Z}}{I_{Z}} \int_{\mu^{*}} y d A=\frac{d M_{Z}}{I_{Z}} S_{Z}^{*}
$$

$\mathrm{S}_{\mathrm{Z}}{ }^{*}$ és el moment estàtic de la superfície de la secció que queda per damunt de la coordenada y considerada.

La part superior de la llesca diferencial ha d'estar també en equilibri, i amb la resultant dels esforços axials, si atenem a la figura 5.56, no ho està. Ha d'aparèixer alguna força (com a resultant d'una tensió) en alguna de les cares restants per tal de restituir l'equilibri. Com que a la cara superior de la llesca i als seus laterals no pot haver-hi tensió, perquè són parts exteriors de la peça, podem deduir que ha d'aparèixer una tensió a la cara inferior. La tensió serà tangencial, i la resultant d'aquesta tensió sobre la cara ha de ser igual a la variació d'esforç axial que teníem abans.

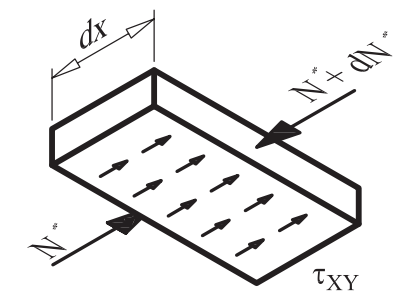

Fig. 5.57. Part superior de la llesca diferencial vista des de baix.

Tensions tangencials que hi apareixen

$$
d N^{*}=\tau_{X Y} \cdot b \cdot d x
$$

Segons el teorema de reciprocitat de les tensions tangencials, com ja vam explicar al tema 3, les tensions tangencials que apareixen en la superfície inferior són iguals a les que apareixen en la superfície de la secció. 


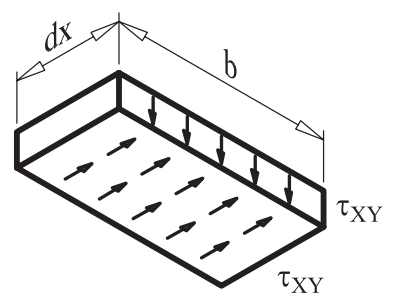

Fig. 5.58. Reciprocitat de les tensions tangencials

Si ara igualem les dues expressions que ens donen aquesta variació d'axial:

$$
\tau_{X Y} \cdot b \cdot d x=\frac{d M_{Z}}{I_{Z}} S_{Z}^{*}
$$

També sabem que hi ha una relació entre el moment flector i l'esforç tallant:

$$
V_{Y}=\frac{d M_{Z}}{d x}
$$

Introduïm aquesta expressió en l'anterior i podem aïllar $\tau_{\mathrm{XY}}$. D'aquesta manera tindrem la distribució de tensions tangencials en la secció:

$$
\tau_{X Y}=\frac{V_{Y} \cdot S_{Z}^{*}}{b \cdot I_{Z}}
$$

Aquesta és la fórmula de Collignon-Jourawski que ens relaciona l'esforç tallant amb les tensions tangencials que es produeixen a la secció.

Per a una determinada secció, l'esforç tallant és únic. El valor del moment d'inèrcia és el de la secció completa. El valor del moment estàtic depén de la coordenada y. A més, l'ample de la secció no sempre serà constant, pot dependre també de $\mathrm{y}$.

Si fem les mateixes consideracions però amb un esforç tallant en l'altra direcció $\left(\mathrm{V}_{\mathrm{z}}\right)$ obtindrem un resultat equivalent, canviant la variable y per la z i l'ample pel cantell.

Així doncs, podem enunciar la fórmula de Collignon per a les dues tensions tangencials que poden aparéixer com a:

$$
\tau_{X Y}(y)=\frac{V_{Y} \cdot S_{Z}^{*}(y)}{b(y) \cdot I_{Z}} \quad \tau_{X Z}(z)=\frac{V_{Z} \cdot S_{Y}^{*}(z)}{h(z) \cdot I_{Y}}
$$

Les tensions tangencials portaran la mateixa direcció i sentit que el tallant associat. 


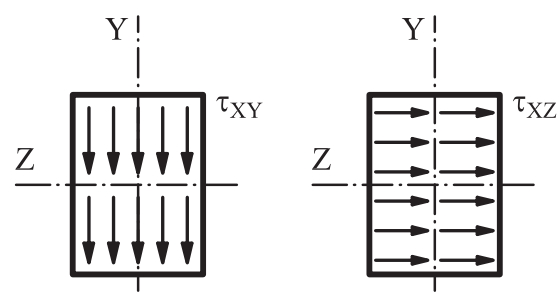

Fig. 5.59. Direccions que porten les tensions tangencials

El càlcul dels moments estàtics es realitza amb la resolució de les següents integrals.
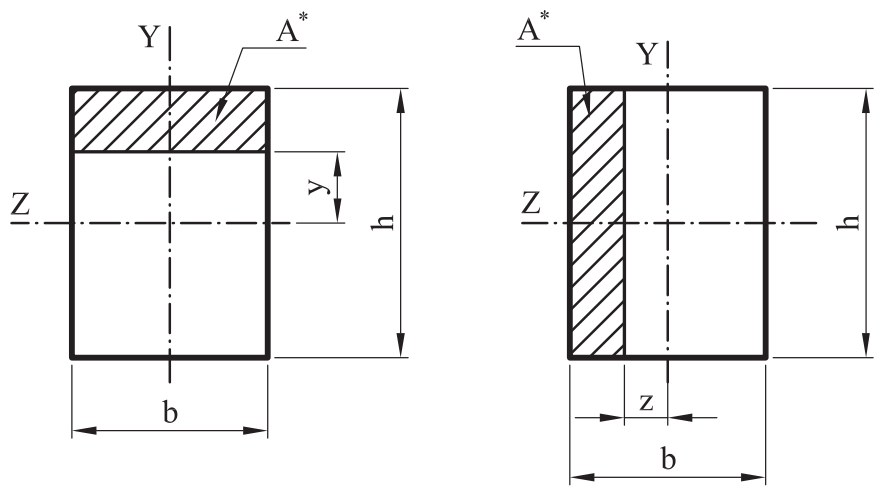

Fig. 5.60. Càlcul dels moments estàtics

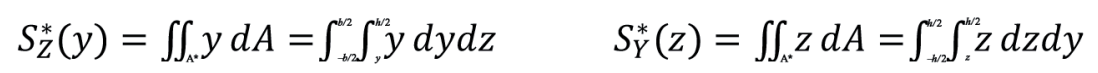

La integral representa el producte de l'àrea $\mathrm{A}^{*}$ per la distància des del centre de gravetat d'aquesta àrea a l'eix considerat. Això fa que, si l'àrea és senzilla de calcular, com ara un rectangle, pot resultar més fàcil el càlcul següent:

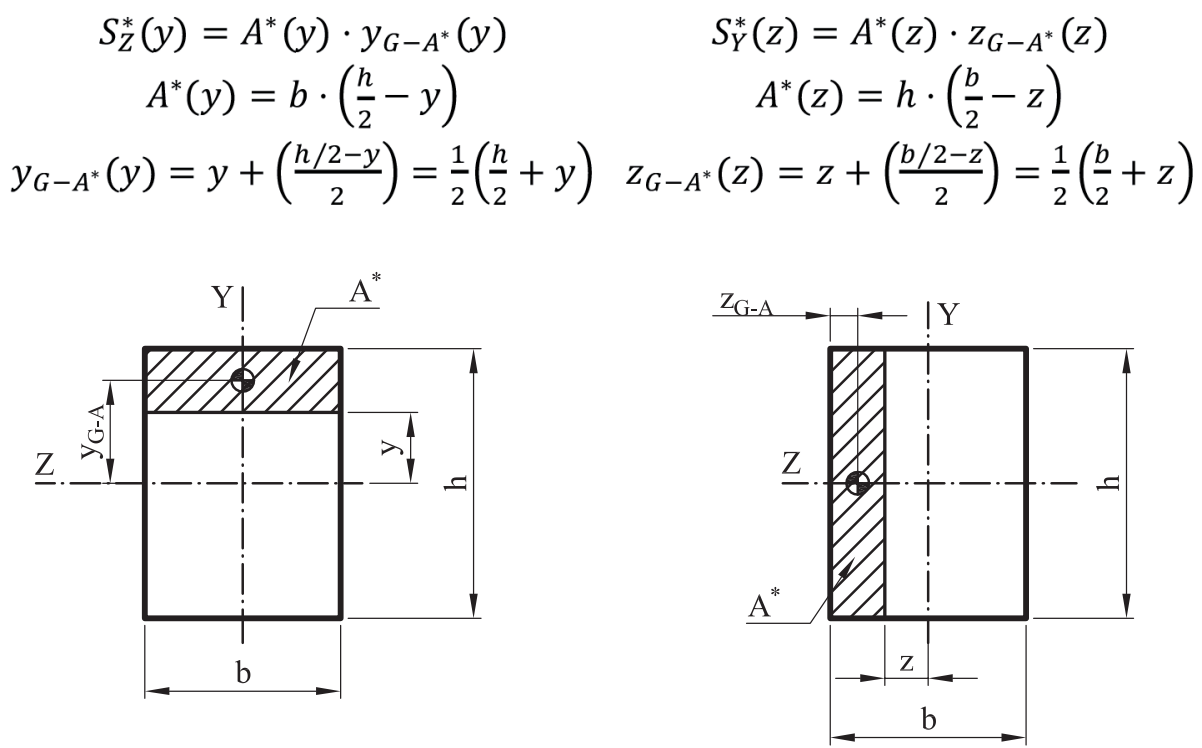

Fig. 5.61. Càlcul alternatiu dels moments estàtics 
Igual que féiem amb les tensions normals, podem fer una representació gràfica de les tensions tangencials. Aquest gràfic representarà la magnitud de la tensió, però no ens donarà informació sobre el sentit de la tensió. Sempre considerarem, com hem dit adés, que el sentit serà el mateix que el que porta l'esforç associat.

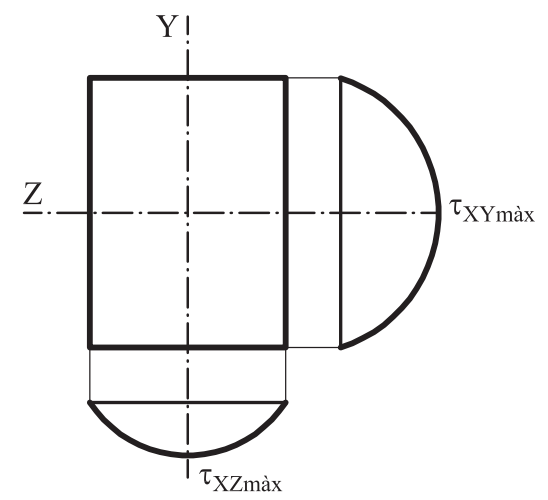

Fig. 5.62. Representació gràfica de les tensions tangencials

Com podem observar, la distribució de tensions tangencials a partir de la fórmula de Collignon és parabòlica i la tensió tangencial és zero en els exteriors de la peça. En aquest cas particular de secció simètrica, el valor màxim s'obté al punt mitjà.

\section{Exemple 5.13}

En el problema de l'exemple 5.9, calculeu les lleis de tensions tangencials en la secció A degudes a l'esforç tallant, i representeu-les gràficament, acotant els valors més significatius.

Recordem la geometria de la secció:

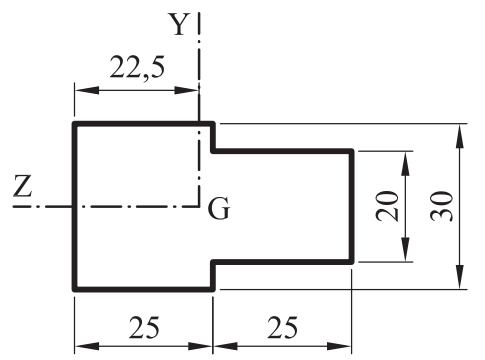

Cotes en $\mathrm{cm}$

Fig. 5.63. Exemple 5.13. Geometria de la secció

En la secció A només tenim esforç tallant segons la direcció z: $V_{Z}=500 \mathrm{kN}$.

El moment d'inèrcia que ens farà falta, ja l'havíem calculat anteriorment: $I_{Y}=2,526 \cdot 10^{-3} \mathrm{~m}^{4}$. 
Calcularem el moment estàtic. Com que la secció té dos amples diferents, serà necessari calcular els moments estàtics dels dos trams. Com a conseqüència, també obtindrem dues distribucions de tensions tangencials diferents.

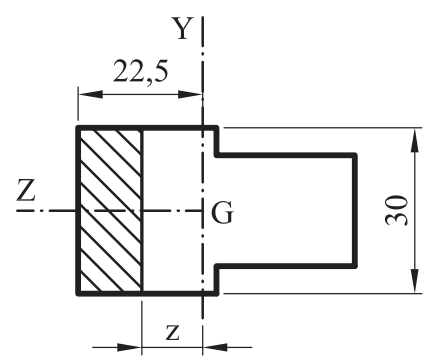

a)

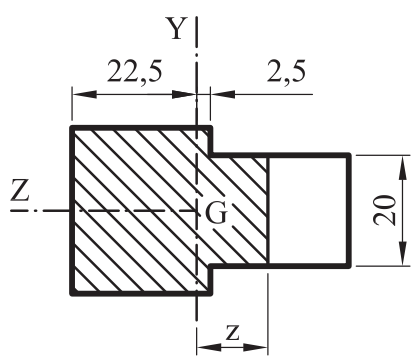

b)

Fig. 5.64. Exemple 5.13. Càlcul dels moments estàtics: $a$ ) primer tram; $b$ ) segon tram

$S_{Y 1}^{*}(z)=\int_{-a 15}^{0,5} \int_{z}^{0,25} z d z d y=7,59 \cdot 10^{-3}-0,15 z^{2}$

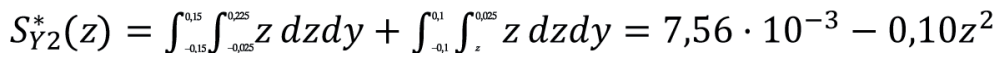

Com podem veure, la primera integral del segon tram correspon al moment estàtic del primer tram quan estem en el punt $\mathrm{z}=-0,025 \mathrm{~m}$. Per tant, no seria necessari fer-la: obtindríem el mateix resultat calculant:

$S_{Z 1}^{*}(-0,025)=7,5 \cdot 10^{-3} \mathrm{~m}^{3}$

Si apliquem la fórmula de Collignon, obtindrem les distribucions de tensions tangencials en els dos trams:

$\tau_{X Z 1}(z)=\frac{V_{Z} \cdot S_{Y 1}^{*}(z)}{h(z) \cdot I_{Y}}=\frac{500 \cdot 10^{3} \cdot\left(7,59 \cdot 10^{-3}-0,15 z^{2}\right)}{0,3 \cdot 2,526 \cdot 10^{-3}}=5007917,6-98970704,7 z^{2}(P a)$

$\tau_{X Z 2}(z)=\frac{V_{Z} \cdot S_{Y 2}^{*}(z)}{h(z) \cdot I_{Y}}=\frac{500 \cdot 10^{3} \cdot\left(7,56 \cdot 10^{-3}-0,10 z^{2}\right)}{0,2 \cdot 2,526 \cdot 10^{-3}}=7482185,2-98970704,7 z^{2}(P a)$

Les hem calculades segons el SI, però resulten més còmodes si les expressem en MPa:

$\tau_{X Z 1}(z)=5,01-98,97 z^{2}(M P a)$

$\tau_{X Z 2}(z)=7,48-98,97 z^{2}(M P a)$

Donem valors als punts extrems de cada tram. Si obtenim en les cares exteriors un valor diferent de zero, serà senyal que hem comés un error. Si no ens dóna exactament zero però es un valor molt menut, es tracta d'un error d'arrodoniment.

$\tau_{X Z 1}(0,225)=0$

$\tau_{X Z 1}(-0,025)=4,95 \mathrm{MPa}$
$\tau_{X Z 2}(-0,025)=7,42 \mathrm{MPa}$

$\tau_{X Z 2}(-0,275)=0$ 
La representació gràfica de les tensions tangencials, de manera qualitativa és:

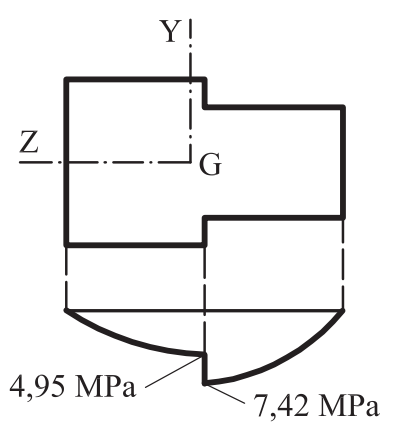

Fig. 5.65. Exemple 5.13. Representació de les tensions tangencials

\section{Exemple 5.14}

Determineu i dibuixeu la distribució de tensions tangencials i normals de la secció de l'encast d'una biga voladissa de $10 \mathrm{~m}$ de longitud amb una càrrega de $1 \mathrm{kN}$ aplicada al seu extrem. La biga té una secció rectangular de dimensions $b=10 \mathrm{~cm}$, $h=20 \mathrm{~cm}$.

Els diagrames d'esforços en la biga són immediats.

L'esforç tallant és constant en tota la biga, i té un valor $V_{Y}=1 \mathrm{kN}$. Per al càlcul de la distribució de tensions tangencials en la secció de l'encast, utilitzarem la fórmula de Collignon. Hem de calcular primer els moments estàtics en funció de la coordenada y. En aquest exercici ho calcularem mitjançant el segon mètode explicat anteriorment.

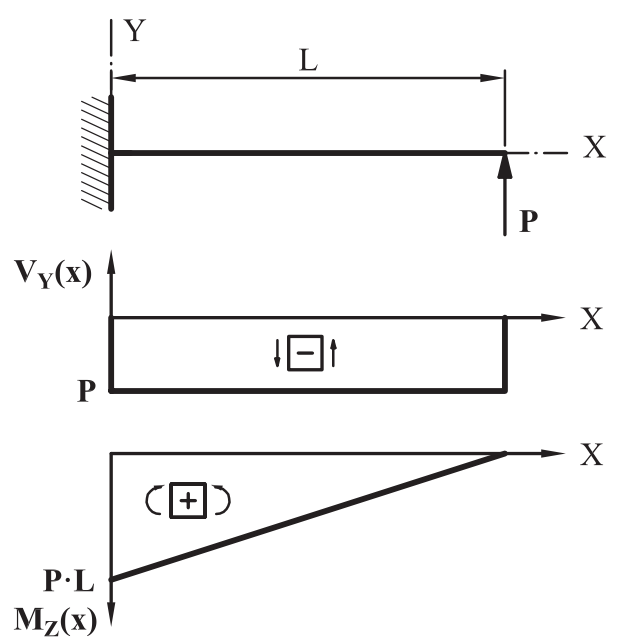

Fig. 5.66. Exemple 5.14. Diagrames d'esforços

Com que es tracta de una secció rectangular, l'esquema utilitzat per al càlcul és el de la figura 5.61, i les expressions que utilitzarem són: 


$$
\begin{aligned}
& A^{*}(y)=b \cdot\left(\frac{h}{2}-y\right) \\
& y_{G-A^{*}}(y)=y+\left(\frac{h / 2-y}{2}\right)=\frac{1}{2}\left(\frac{h}{2}+y\right) \\
& S_{Z}^{*}(y)=A^{*}(y) \cdot y_{G-A^{*}}(y)=\frac{b \cdot h^{2}}{8}-\frac{b}{2} y^{2}
\end{aligned}
$$

Les tensions tangencials vindran representades per:

$\tau_{X Y}(y)=V_{Y} \frac{\frac{b \cdot h^{2}}{8} \frac{b}{2} y^{2}}{b \cdot \frac{1}{12} \cdot b \cdot h^{3}}=\frac{3}{2} \cdot \frac{V_{Y}}{b} \cdot \frac{\left(h^{2}-4 y^{2}\right)}{h^{3}}$

Això és una distribució parabòlica amb uns valors representatius:

$$
\tau_{X Y}\left(\frac{h}{2}\right)=\tau_{X Y}\left(\frac{-h}{2}\right)=0 \quad \tau_{X Y}(0)=\frac{3}{2} \cdot \frac{V_{Y}}{b \cdot h}=7,5 \cdot 10^{4} \mathrm{~Pa}
$$

Les tensions normals ens les dóna la llei de Navier:

$\sigma(y)=\frac{-M_{Z}}{I_{Z}} y=\frac{-12 M_{Z}}{b \cdot h^{3}} y$

que és una distribució lineal de tensions, que varia entre els valors extrems:

$\sigma\left(\frac{h}{2}\right)=-1,5 \cdot 10^{7} \mathrm{~Pa} \quad \sigma\left(\frac{-h}{2}\right)=1,5 \cdot 10^{7} \mathrm{~Pa}$

Com podem observar a la figura, en els punts en els quals la tensió tangencial és màxima, la tensió normal és zero, i viceversa. La tensió normal màxima dins de la secció és 200 vegades més gran que la màxima tensió tangencial.

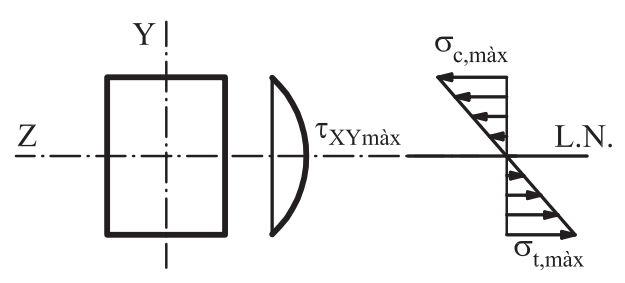

Fig. 5.67. Exemple 5.14. Diagrames de tensions

Podem obtindre unes conclusions interessants si fem la comparació entre la màxima tensió normal i tangencial a cadascuna de les seccions de la biga. Evidentment, com que l'esforç tallant és constant en tota la biga, la tensió tangencial màxima també ho serà. Tanmateix, la tensió normal disminueix segons avancem cap a l'extrem de la biga.

$$
\sigma_{m a ̀ x}(x)=\frac{-M_{Z}(x)}{I_{Z}} y_{m \grave{x} x}=\frac{-12 M_{Z}(x)}{b \cdot h^{3}} \cdot \frac{h}{2}=\frac{-6}{b \cdot h^{2}} \cdot P(L-x)
$$


Com que és flexió simètrica, la màxima tensió en la part inferior serà la mateixa però positiva. Representarem les dues funcions de tensió màxima (normal positiva i tangencial).

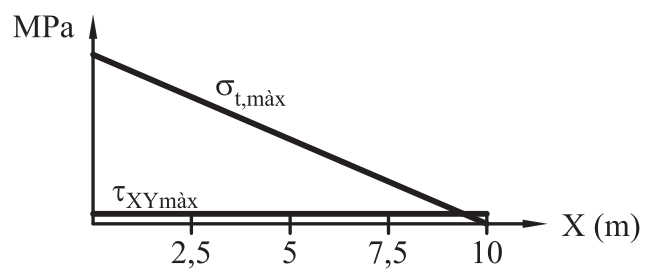

Fig. 5.68. Exemple 5.14. Tensions màximes

Veiem que les tensions normals màximes predominen àmpliament sobre les tangencials en bona part de la biga. Només s'apropen en el tram final. Fem una vista ampliada d'aquest últim tram:

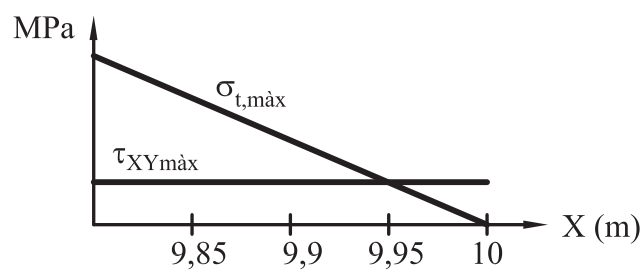

Fig. 5.69. Exemple 5.14. Tensions màximes. Vista ampliada de l'extrem de la biga

La tensió tangencial màxima és més gran que la màxima tensió normal només als últims cinc centímetres de la biga.

Aquest resultat confirma el que havíem comentat durant el tema sobre el fet que les tensions tangencials només tenen una importància relativa significativa en mènsules curtes, però si la biga té una certa longitud, les tensions tangencials passen a ser negligibles.

Per a seccions circulars, l'expressió de Collignon és també vàlida, però les tensions tangencials no poden portar la direcció de l'esforç tallant.

Això suposaria que existeixen tensions perpendiculars a la cara exterior, la qual cosa no pot ocórrer si no és perquè hi ha càrregues exteriors justament en eixe punt.

Es produeix una redistribució de les tensions tangencials, que conflueixen en un punt $\mathrm{M}$.

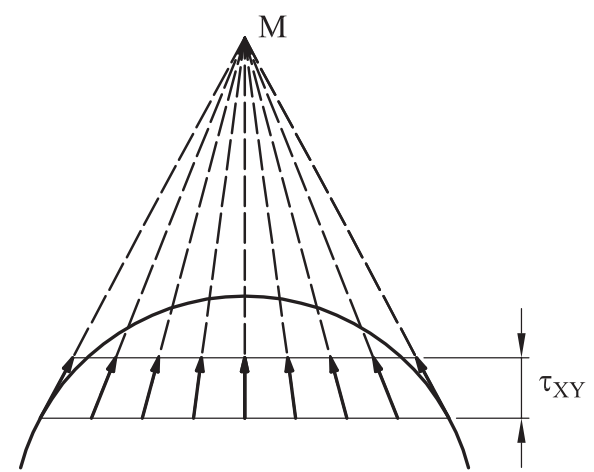

Fig. 5.70. Tensions tangencials en seccions circulars 
Si considerem una secció de paret estreta, com ara un perfil IPE, el càlcul dels moments estàtics, de la manera com l'hem fet fins ara, ens donaria una distribució de tensions tangencials com la de la figura.

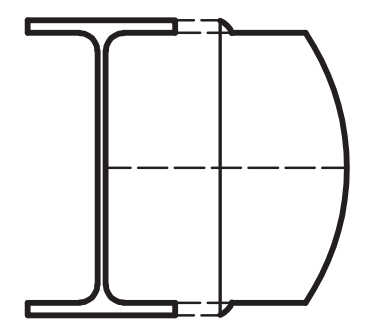

Fig. 5.71. Tensions tangencials en secció IPE

Però el comportament en les ales no és eixe. Es produeix una redistribució de les tensions tangencials, que no segueixen la direcció del tallant, sinó que adopten la direcció de l'ala.

Les tensions tangencials són funcions lineals, no parabòliques, amb un valor nul en l'extrem i màxim al punt mitjà de l'ala.

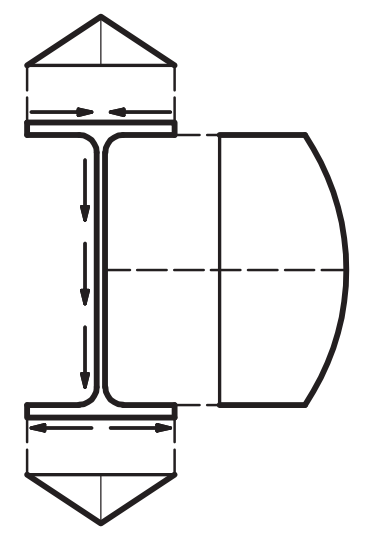

Fig. 5.72. Tensions tangencials en secció IPE

Per al càlcul del moment estàtic no hem de considerar l'ala tallada per una línia horitzontal, sinó per una de vertical, a una distància $s$.

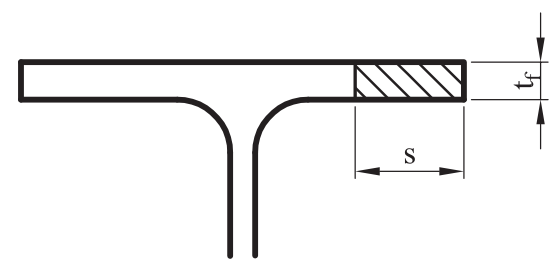

Fig 5.73. Càlcul del moment estàtic en ala de secció IPE

El moment estàtic és el producte de l'àrea ratllada de la figura anterior, per la distància des del centre de gravetat fins a l'eix Z . 


$$
\begin{gathered}
A^{*}(s)=t_{f} \cdot s \\
y_{G-A^{*}}=\frac{h}{2}-\frac{t_{f}}{2} \\
S_{Z, a l a}^{*}(s)=\frac{t_{f}}{2} \cdot\left(h-t_{f}\right) \cdot s
\end{gathered}
$$

El moment estàtic és una funció lineal amb màxim quan $\mathrm{s}=\mathrm{b} / 2$. La tensió tangencial en l'ala serà també una funció lineal:

$$
\tau_{a l a}=\frac{V_{Y} \cdot S_{Z, a l a}^{*}(s)}{t_{f} \cdot I_{Z}}
$$

El càlcul del moment estàtic en l'ànima sí que el farem de la mateixa manera que fins ara, i la tensió tangencial serà una funció parabòlica.

$$
\tau_{\text {ànima }}=\frac{V_{Y} \cdot S_{Z, \text { ànima }}^{*}(s)}{t_{w} \cdot I_{Z}}
$$

Els valors dels gruixos d'ala $\mathrm{i}$ ànima venen donats per $t_{f} \mathrm{i} t_{w}$ respectivament. La lletra i el subíndex venen de l'anglés thickness (gruix), flange (ala) i web (ànima).

En un perfil tipus UPE, la redistribució de tensions tangencials seria:

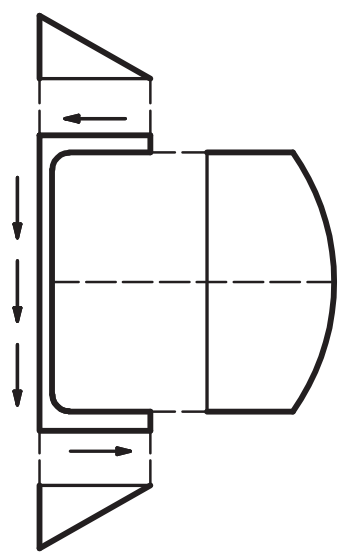

Fig. 5.74. Tensions tangencials en secció UPE 


\section{Problemes proposats}

5.1. En la següent secció, sotmesa a una càrrega axial de compressió de $100 \mathrm{kN}$, aplicada al punt $\mathrm{M}$, localitzeu el punt de màxima tensió i calculeu el seu valor. Cotes en $\mathrm{cm}$.

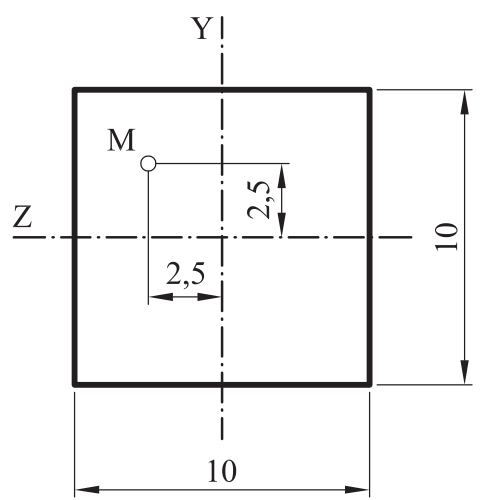

Fig. P.5.01

5.2. Dimensioneu un element d'acer S275, la secció més desfavorable del qual té un esforç axial de $200 \mathrm{kN}$ i un moment flector de $41,1 \mathrm{kN} \cdot \mathrm{m}$. Trieu la tipologia de perfil que resulte més econòmica (IPE, UPN, HEB).

5.3. Per a la següent barra, dimensioneu-la amb perfil IPE $\mathrm{i}$ amb HEB.

Dades: $\mathrm{P}_{1}=200 \mathrm{kN} ; \mathrm{P}_{2}=20 \mathrm{kN} ; \mathrm{P}_{3}=40 \mathrm{kN} ; \mathrm{h}=3 \mathrm{~m}$.

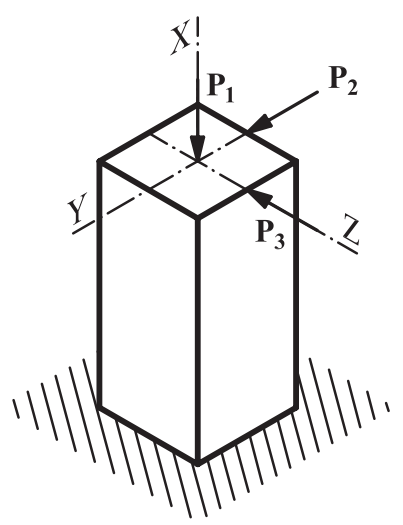

Fig. P.5.03

5.4. Per a una nau industrial es pretenen dimensionar les corretges de coberta. Les corretges es consideren com a bigues recolzades amb una càrrega uniformement distribuïda de valor q i una llum L igual a la separació entre pòrtics. Es volen usar perfils conformats en fred de la sèrie CF. Escolliu el perfil adient de la sèrie, atenent només a criteris de resistència. 
Dades: acer S235; $\mathrm{q}=2 \mathrm{kN} / \mathrm{m} ; \mathrm{L}=5 \mathrm{~m}$; el pendent de la nau és del $15 \%$.
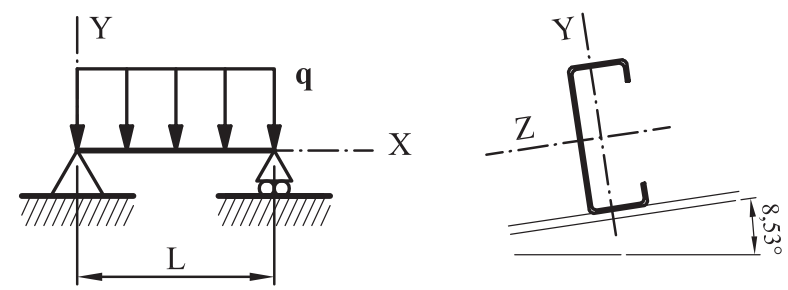

Fig. P.5.04

5.5. Per a la següent biga recolzada:

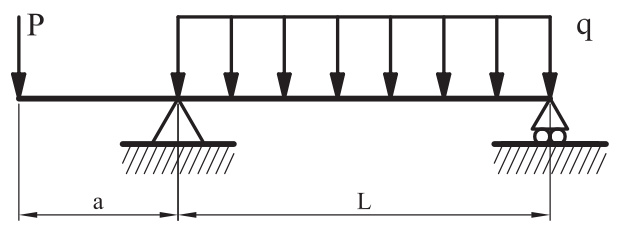

Fig. P.5.05

a) Dimensioneu el perfil IPE.

b) Calculeu els diagrames de tensió normal i tensió tangencial en la secció del suport fix.

c) Comproveu que aquesta secció compleix amb els criteris de resistència de Rankine, Tresca i Von Mises.

Dades: $\mathrm{P}=40 \mathrm{kN} ; \mathrm{q}=30 \mathrm{kN} / \mathrm{m} ; \mathrm{a}=0,8 \mathrm{~m} ; \mathrm{L}=4 \mathrm{~m}$; acer $\mathrm{S} 275$.

5.6. Considerem la següent biga, de 5 metres de longitud, sotmesa a una càrrega axial de compressió excèntrica $\mathrm{P}_{1}=100 \mathrm{kN}$, situada al punt $\mathrm{M}$ de la secció extrema, $\mathrm{i}$ a les càrregues $\mathrm{P}_{2}=25 \mathrm{kN}$ i $\mathrm{P}_{3}=10 \mathrm{kN}$. Calculeu, per a la secció més desfavorable:

a) Equació de la LN i representació gràfica.

b) Màxima tensió de tracció i de compressió i punts on es produeixen.
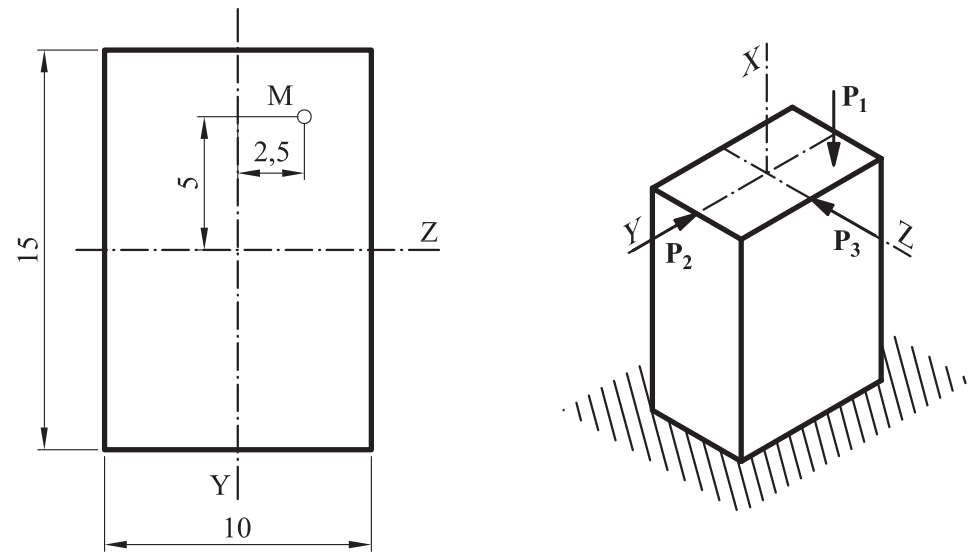

Fig. P.5.06 
5.7. Tenim la biga IPE de la figura recolzada sobre tres suports, amb càrrega uniformement repartida $\mathrm{q}=12 \mathrm{kN} / \mathrm{m}$. La longitud és $\mathrm{L}=3 \mathrm{~m}$.

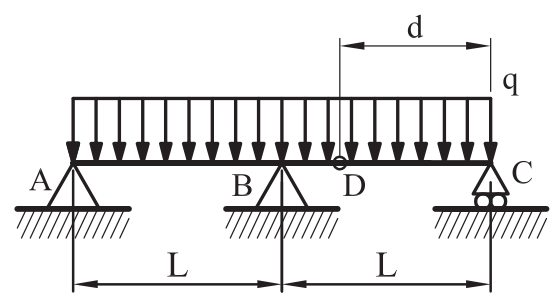

Fig. P.5.07

a) Establiu la posició de l'articulació D, de manera que s'iguale el moment màxim en els trams amb el moment en la secció del suport central.

b) Dibuixeu els diagrames d'esforços.

c) Dimensioneu el perfil en acer S275 i calculeu la ràtio d'aprofitament del material.

5.8. Per a la biga composta de la figura (cotes en $\mathrm{mm}$ ), dibuixeu el diagrama de tensions normals per a ambdós materials en la secció més desfavorable.

Dades: $\mathrm{L}=5 \mathrm{~m} ; \mathrm{E}_{1}=210 \mathrm{GPa} ; \mathrm{E}_{2}=70 \mathrm{GPa} ; \mathrm{P}=15 \mathrm{kN} ; \mathrm{q}=5 \mathrm{kN} / \mathrm{m}$.
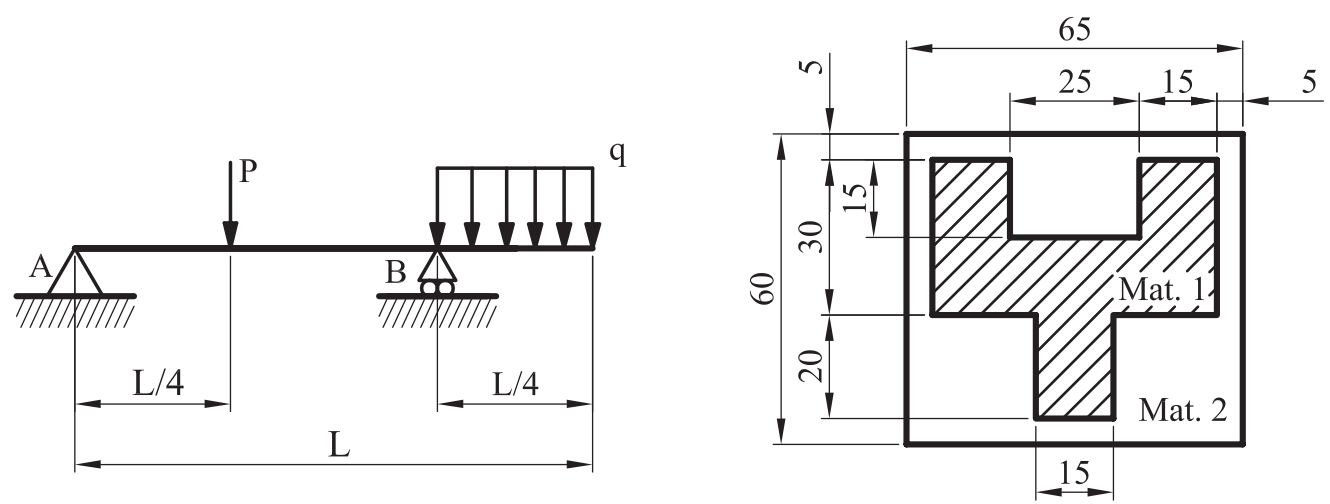

Fig. P.5.08

5.9. Considerem la biga voladissa encastada de la figura sotmesa a quatre càrregues $\mathrm{P}_{1}, \mathrm{P}_{2}, \mathrm{P}_{3}$ i $\mathrm{P}_{4}$ disposades tal com es mostra. La biga presenta una secció en forma de creu massissa, doblement simètrica, les dimensions de la qual es representen a la figura.

a) Determineu la distribució de tensions tangencials $\tau_{\mathrm{XY}}$ i $\tau_{\mathrm{XZ}}$ en la secció de l'encast (expressió matemàtica i diagrama aproximat de cadascuna d'elles).

b) Determineu la distribució de tensions normals $\sigma_{\mathrm{X}}$ en la secció de l'encast (expressió matemàtica).

c) Calculeu l'equació de la línia neutra en la secció de l'encast i representeu-la gràficament. 
d) Determineu les coordenades del punt de la secció de l'encast sotmés a la màxima tensió normal positiva i les del punt sotmés a la màxima tensió normal negativa.

e) Calculeu les tensions principals en el punt de la secció de l'encast, de coordenades $\mathrm{y}=2 \mathrm{~cm}, \mathrm{z}=2 \mathrm{~cm}$, i calculeu la tensió equivalent de Von Mises en eixe mateix punt.

Dades: $\mathrm{P}_{1}=\mathrm{P}_{2}=\mathrm{P}_{3}=1 \mathrm{kN} ; \mathrm{P}_{4}=2 \mathrm{kN}$.

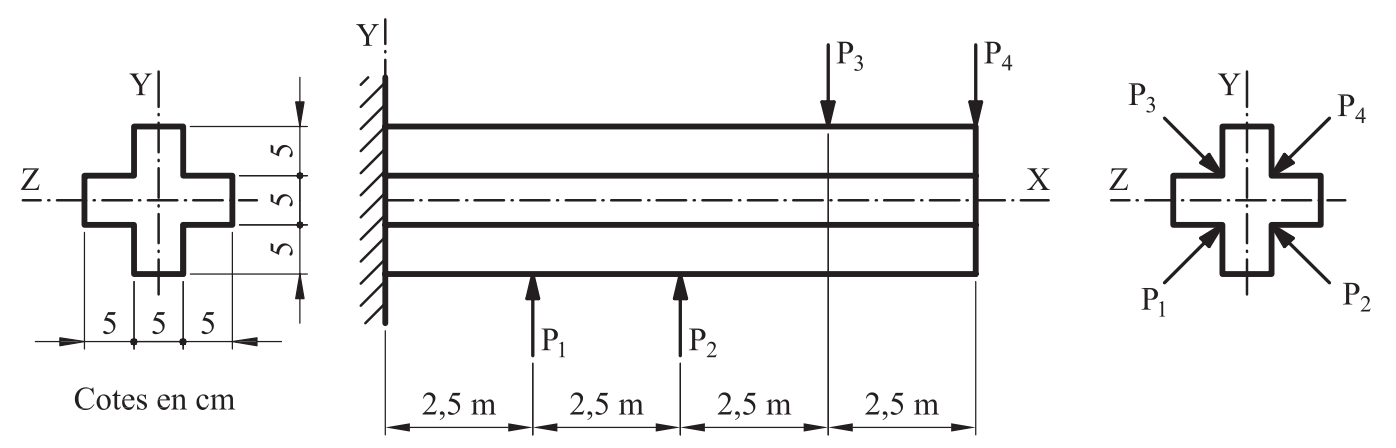

Fig. P.5.09 


\section{TEMA 6}

\section{Flexió - deformacions}

\subsection{Introducció}

Al tema 5 hem estudiat les distribucions de tensions que apareixen en les seccions rectes, quan una peça està sotmesa a flexió pura, simple o composta. En aquest tema analitzarem les deformacions que es produeixen en ella, quan les sollicitacions són d'aquest mateix tipus.

Els elements estructurals sotmesos a flexió han d'acomplir uns requisits de rigidesa, és a dir, no han de deformar-se més enllà d'un límit, normalment marcat per normatives. En moltes ocasions, el disseny d'un element estructural ve determinat més per les condicions de rigidesa que per les de resistència. Freqüentment, determinats elements de les estructures es calculen obligant que les deformacions màximes siguen iguals a les admissibles, $\mathrm{i}$ després comprovant que no se supera la tensió admissible.

En aquest tema estudiarem, de manera eminentment pràctica, alguns mètodes per a calcular les deformacions d'una biga, en tots els seus punts (equació de l'elàstica) o en alguns dels seus punts concrets (mètode de Maxwell-Mohr).

Al final del tema, utilitzarem el càlcul de les deformacions com a eina per a resoldre els sistemes hiperestàtics: les condicions de compatibilitat de desplaçament les utilitzarem com a equacions addicionals, que sumades a les equacions d'equilibri estàtic, ens permetran resoldre les incògnites.

\subsection{Equació general de l'elàstica}

Els desplaçaments deguts a la flexió s'obtenen de les deformacions que tenen lloc al llarg de l'element. Aquestes deformacions es basen en la hipòtesi cinemàtica (Bernouilli) que les seccions planes i perpendiculars a l'eix en les bigues abans de la deformació romandran planes i perpendiculars a l'eix després de la deformació. La hipòtesi de Bernouilli ja va ser comentada quan estudiàrem el tema de tensions, i la figura que la il·lustra és la 5.8.

Farem una sèrie de consideracions, per a flexió pura:

- L'eix longitudinal adopta una forma corbada, però es manté dins del pla perpendicular a l'eix de la flexió. Per exemple, si la flexió és conseqüència d'un moment $\mathrm{M}_{\mathrm{Z}}$, l'eix deformat romandrà dins del pla XY. 
- Com que les deformacions seran molt menudes, els centres de gravetat de les seccions es mouran perpendicularment a l'eix no deformat (negligirem els desplaçaments axials).

- La longitud de l'eix longitudinal, que està contingut en la fibra neutra, no canvia després de la deformació. Les fibres superiors s'acurten i les inferiors s'allarguen (o viceversa).

- Les seccions roden respecte a l'eix deformat, per a mantindre la perpendicularitat amb ell, i romanen planes.

En flexió simple, l'esforç tallant afegeix una deformació addicional, però serà negligible en la major part dels casos.

Les noves posicions dels centres de gravetat de totes les seccions ens donen la posició de la LN. Aquestes posicions dels centres de gravetat poden ser expressades en forma d'una equació $y(x)$ anomenada equació de l'elàstica o de la deformada, que per a cada valor de $\mathrm{x}$, ens dóna el moviment vertical del centre de gravetat. El valor del descens habitualment s'anomena fletxa.

Suposem una biga $\mathrm{AB}$ que està sotmesa a un estat qualsevol de forces que li provoca una flexió. La deformació d'un punt qualsevol $\mathrm{C}$ estarà definida per dues magnituds:

- La fletxa, o desplaçament vertical del punt $\left(y_{C}\right)$.

- L'angle de flexió, o angle de gir $\left(\theta_{C}\right)$. És l'angle que forma la tangent a la corba en el punt $\mathrm{C}$.

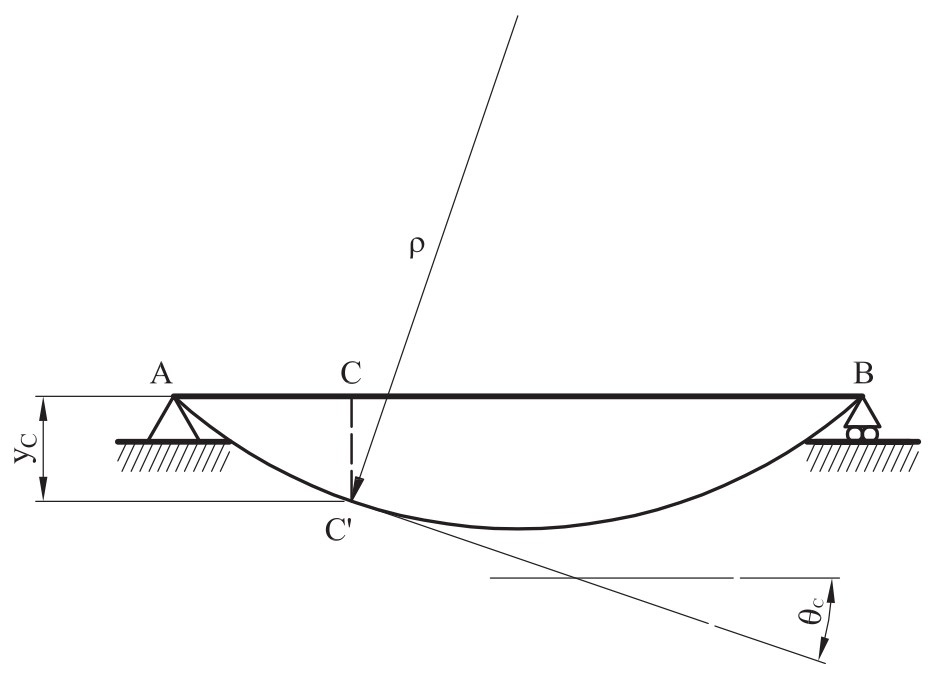

Fig. 6.1

Cada punt de la biga té una rotació i una fletxa, per la qual cosa hi existiran dues funcions $\theta(x)$ i $y(x)$ que definiran ambdues magnituds. Però la rotació de la secció $\mathrm{i}$ la deformada no són funcions independents, entre elles guarden la següent relació: 


$$
\tan [\theta(x)]=\frac{d y(x)}{d x}
$$

Quan parlem de deformacions molt menudes, l'angle de gir també és molt menut, i si l'expressem en radians, podem considerar que la tangent de l'angle és igual al mateix angle.

$$
\tan [\theta(x)] \approx \theta(x)
$$

En aquest cas:

$$
\theta(x)=\frac{d y(x)}{d x}
$$

Necessitem fer un parell de definicions més:

- El radi de curvatura ( $\rho$ ) en un punt és el radi de la circumferència que passa pel punt i per dos més infinitament pròxims (per tres punts només passa una circumferència).

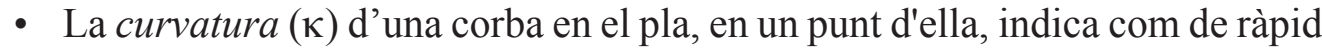
la corba abandona la tangent en eixe punt. La curvatura és l'invers del radi de curvatura.

$$
\kappa(x)=\frac{1}{\rho(x)}=\frac{d^{2} y(x)}{d x^{2}}
$$

No és l'objectiu d'aquest text fer la demostració matemàtica de per què la curvatura és la segona derivada de l'equació de l'elàstica, com tampoc ho és demostrar la següent expressió. El lector podrà trobar-la en la bibliografia recomanada si té interés a aprofundir-hi. Per tant, només direm que després d'un desenrotllament relativament senzill, podrem relacionar la curvatura amb el moment flector:

$$
M_{Z}(x)=E I_{Z} \kappa(x)
$$

I llavors podrem obtindre una expressió que és l'equació diferencial del problema de flexió en petits desplaçaments per a bigues elàstiques.

$$
\frac{d^{2} y(x)}{d x^{2}}=\frac{M_{Z}}{E I_{Z}}
$$

Aquesta equació ens permet obtindre l'equació de l'elàstica per doble integració de la llei de moments flectors dividida per la rigidesa a flexió $\left(E \cdot I_{Z}\right)$.

$$
y(x)=\iint \frac{M_{Z}}{E I_{Z}} d x d x
$$


Cal dir que aquesta integral és indefinida, raó per la qual apareixen dues constants d'integració que hauran de ser calculades per les condicions de contorn. Aquestes condicions poden ser, com a exemple:

- En un recolzament o en un encast, el moviment vertical del punt és zero $(y(x)=0)$.

- En un encast, el gir del punt és zero $\left(\theta(x)=y^{\prime}(x)=0\right)$.

En un punt on canvia la llei de moments flectors ha d'haver-hi continuïtat en la fletxa $\left(y_{1}(x)=y_{2}(x)\right)$.

En un punt on canvia la llei de moments flectors, si no és una ròtula, ha d'haver-hi continuïtat en el pendent $\left(\theta_{1}(x)=\theta_{2}(x)\right.$, o dit d'una altra manera $\left.y_{1}^{\prime}(x)=y_{2}^{\prime}(x)\right)$.

\section{Exemple 6.1}

Determineu l'equació de l'elàstica d'una biga recolzada als seus extrems, sotmesa a una càrrega uniformement repartida.

Dades: L, q, E, I .

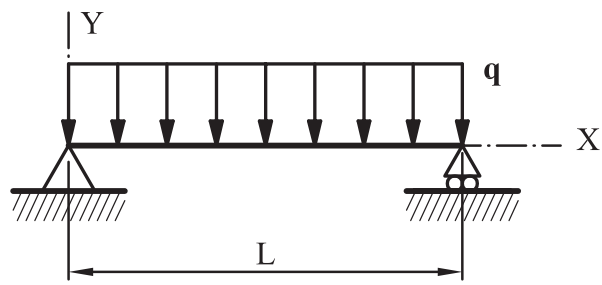

Fig. 6.2. Exemple 6.1. Enunciat

Donem per conegut el càlcul de la llei de moments flectors:

$M_{Z}(x)=\frac{q \cdot L}{2} x-\frac{q}{2} x^{2}=E \cdot I_{Z} \cdot y^{\prime \prime}(x)$

Si integrem dues vegades:

$E \cdot I_{Z} \cdot y^{\prime}(x)=\frac{q \cdot L}{4} x^{2}-\frac{q}{6} x^{3}+C_{1}$

$E \cdot I_{Z} \cdot y(x)=\frac{q \cdot L}{12} x^{3}-\frac{q}{24} x^{4}+C_{1} \cdot x+C_{2}$

Les constants d'integració s'obtenen de les condicions de contorn; en aquest cas, el desplaçament en els extrems és zero.

$$
\begin{aligned}
& y(0)=0 \rightarrow C_{2}=0 \\
& y(L)=0 \rightarrow C_{1}=\frac{-q \cdot L^{3}}{24} \rightarrow y(x)=\frac{1}{E \cdot I_{z}}\left(\frac{q \cdot L}{12} x^{3}-\frac{q}{24} x^{4}-\frac{q \cdot L^{3}}{24} x\right)
\end{aligned}
$$


Per a calcular la màxima fletxa, igualarem a zero la derivada, $y^{\prime}(x)=0$. És fàcil veure que això es produeix en $x=L / 2$, i en aquest punt:

$y_{m a ̀ x}=\frac{-5}{384} \frac{q \cdot L^{4}}{E \cdot I_{Z}}$

\section{Exemple 6.2}

Calculeu l'equació de la deformada de la biga voladissa de la figura.

Dades: L, P, E, I ${ }_{Z}$.

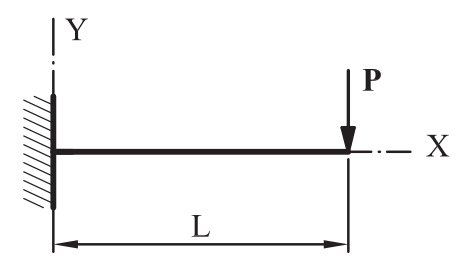

Fig. 6.3. Exemple 6.2. Enunciat

La llei de moments flectors és M_Z $(\mathrm{x})=\mathrm{P} \cdot(\mathrm{x}-\mathrm{L})$, per tant:

$E \cdot I_{Z} \cdot y^{\prime}(x)=\frac{P \cdot x^{2}}{2}-P L x+C_{1}$

$E \cdot I_{Z} \cdot y(x)=\frac{P \cdot x^{3}}{6}-\frac{P \cdot L \cdot x^{2}}{2}+C_{1} \cdot x+C_{2}$

Les constants d'integració s'obtenen de les condicions de contorn referents al fet que el desplaçament $\mathrm{i}$ el gir al punt de l'encast és zero.

$\begin{aligned} & y^{\prime}(0)=0 \rightarrow C_{1}=0 \\ & y(0)=0 \rightarrow C_{2}=0\end{aligned} \rightarrow y(x)=\frac{1}{E \cdot I_{Z}}\left(\frac{P \cdot x^{3}}{6}-\frac{P \cdot L \cdot x^{2}}{2}\right)$

Aquesta funció té un màxim en $x=L: y_{\text {màx }}=\frac{-P \cdot L^{3}}{3 \cdot E \cdot I_{Z}} ;$ el signe és negatiu perquè el punt descendeix.

Aquests dos exemples tenien la mateixa llei de moments flectors per a tota la barra, però aquest no és el cas més freqüent.

Quan la llei de moments flectors és una funció a trams, l'equació de l'elàstica també ho serà. En aquests casos, haurem de fer tantes dobles integracions com trams hi haja. Això suposa tindre tantes condicions de contorn com constants d'integració, és a dir, dues per cada tram. Les condicions a aplicar en aquests casos són la continuïtat de la fletxa i del gir, en els punts en els quals la llei canvia. Evidentment, quan la llei canvia, el descens d'un punt ha de ser el mateix si el calculem amb l'equació d'un tram o amb la de l'altre. El mateix passa amb els girs. 


\section{Exemple 6.3}

En la biga recolzada als seus extrems representada en la figura 6.4, que està sotmesa a una càrrega puntual, calculeu l'equació de l'elàstica en funció de $\mathrm{E}, \mathrm{I}_{\mathrm{Z}}, \mathrm{P}$, L, a, b.

Donarem per sabut el càlcul de reaccions i l'obtenció de les lleis d'esforços. La llei de moments flectors és una funció en dos trams:

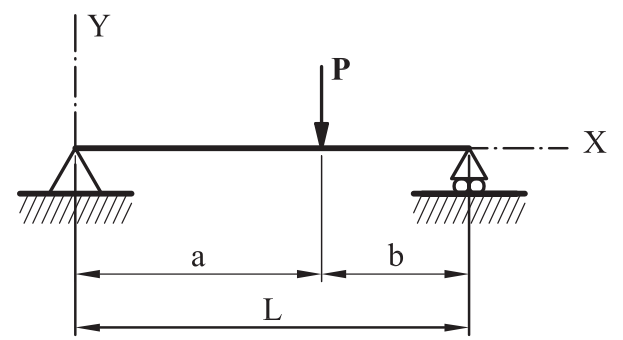

Fig. 6.4. Exemple 6.3. Enunciat

$0 \leq x \leq a \rightarrow M_{Z 1}(x)=\frac{P \cdot b}{L} x$

$a \leq x \leq L \rightarrow M_{Z 2}(x)=\frac{P \cdot b}{L} x-P \cdot(x-a)$

Calcularem l'equació de l'elàstica per doble integració de la llei de flectors; per tant, també tindrà dos trams. $\mathrm{Al}$ primer tram:

$E \cdot I_{Z} \cdot y_{1}^{\prime}(x)=\frac{P \cdot b}{L} \frac{x^{2}}{2}+C_{1}$

$E \cdot I_{Z} \cdot y_{1}(x)=\frac{P \cdot b}{L} \cdot \frac{x^{3}}{6}+C_{1} \cdot x+C_{2}$

I al segon tram:

$E \cdot I_{Z} \cdot y_{2}{ }^{\prime}(x)=\frac{P \cdot b}{L} \cdot \frac{x^{2}}{2}-P \cdot \frac{(x-a)^{2}}{2}+D_{1}$

$E \cdot I_{Z} \cdot y_{2}(x)=\frac{P \cdot b}{L} \cdot \frac{x^{3}}{6}-P \cdot \frac{(x-a)^{3}}{6}+D_{1} \cdot x+D_{2}$

Condicions de contorn:

1. El recolzament de l'esquerra no descendeix: $y_{1}(0)=0$.

2. El recolzament de la dreta no descendeix: $y_{2}(L)=0$.

3. Continuïtat de la fletxa: $y_{1}(a)=y_{2}(a)$.

4. Continuitat del gir: $y_{1}{ }^{\prime}(a)=y_{2}{ }^{\prime}(a)$.

De la condició 1 obtenim ràpidament la solució: $C_{2}=0$. 
De la condició $4, \frac{P \cdot b}{L} \frac{a^{2}}{2}+C_{1}=\frac{P \cdot b}{L} \cdot \frac{a^{2}}{2}-P \cdot \frac{(a-a)^{2}}{2}+D_{1}$, obtenim: $C_{1}=D_{1}$.

Substituint l'anterior resultat en la condició 3:

$$
\frac{P \cdot b}{L} \cdot \frac{a^{3}}{6}+C_{1} \cdot a+0=\frac{P \cdot b}{L} \cdot \frac{a^{3}}{6}-P \cdot \frac{(a-a)^{3}}{6}+D_{1} \cdot a+D_{2}, \text { obtenim: } D_{2}=0 .
$$

Entrant amb tots aquests resultats en la condició 2:

$$
\begin{aligned}
& \frac{P \cdot b}{L} \cdot \frac{L^{3}}{6}-P \cdot \frac{(L-a)^{3}}{6}+D_{1} \cdot L+0=0, \text { podem aïllar } D_{l} . \\
& D_{1}=\frac{-P \cdot b \cdot L^{2}}{6 \cdot L}+P \cdot \frac{(L-a)^{3}}{6 \cdot L}=\frac{P \cdot b}{6 \cdot L}\left(b^{2}-L^{2}\right)=C_{1}
\end{aligned}
$$

Finalment, l'equació de l'elàstica als dos trams:

$$
\begin{aligned}
& 0 \leq x \leq a \rightarrow y_{1}(x)=\frac{1}{E \cdot I_{Z}}\left(\frac{P \cdot b}{L} \cdot \frac{x^{3}}{6}+\frac{P \cdot b}{6 \cdot L}\left(b^{2}-L^{2}\right) \cdot x\right) \\
& a \leq x \leq L \rightarrow y_{2}(x)=\frac{1}{E \cdot I_{Z}}\left(\frac{P \cdot b}{L} \cdot \frac{x^{3}}{6}-P \cdot \frac{(x-a)^{3}}{6}+\frac{P \cdot b}{6 \cdot L}\left(b^{2}-L^{2}\right) \cdot x\right)
\end{aligned}
$$

Aquest últim exercici té només dos trams, i ens han aparegut quatre constants d'integració, que hem hagut de resoldre amb quatre equacions. Normalment tindrem més de dos trams. Quan tenim $n$ trams, el nombre de constants d'integració serà $2 n$. Com a conseqüència, el plantejament del problema comença a tindre una complexitat elevada, perquè és necessari un nombre igual d'equacions al sistema $(2 n)$ per a resoldre-les. En aquests casos podem acudir al mètode universal, en el qual només ens quedaran dues constants d'integració. El mètode es basa en la utilització de les funcions de discontinuïtat, que són del tipus:

$$
K \cdot\langle x-a\rangle^{n}=\left\{\begin{array}{c}
0 \text { si } x \leq a \\
K \cdot(x-a)^{n} \text { si } x>a
\end{array}\right\}
$$

Explicarem la manera de procedir a través d'un exemple pràctic.

\section{Exemple 6.4}

Obtenim l'equació de l'elàstica per a la biga de la figura.

Dades: a, M, q, P, E, I I $_{\text {. }}$ 


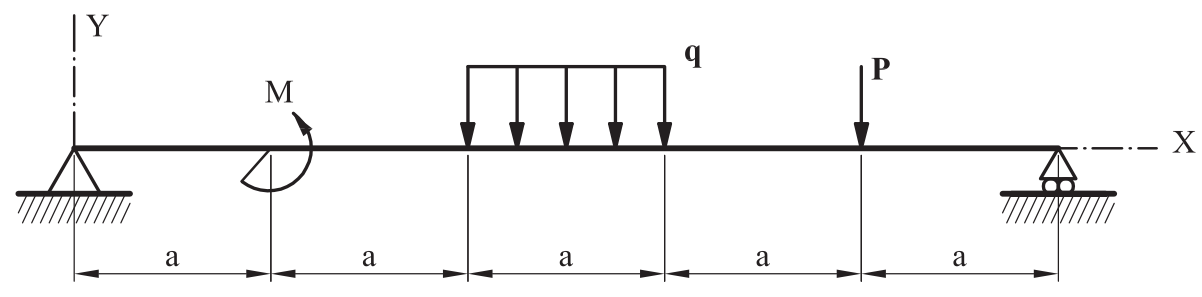

Fig. 6.5. Exemple 6.4. Enunciat

En aquest cas tenim cinc trams en la llei de moments flectors. Açò implica deu constants d'integració, que s'han de resoldre amb un sistema del mateix nombre d'equacions. Per tal d'evitar-ho, utilitzarem el mètode universal.

El primer que hem de fer és calcular les reaccions.

$R_{A}=\frac{1}{5} P+\frac{1}{2} q \cdot a+\frac{M}{5 \cdot a}$

$R_{B}=\frac{4}{5} P+\frac{1}{2} q \cdot a-\frac{M}{5 \cdot a}$

Ara calcularem la llei de moments flectors com si estiguérem considerant l'últim tram de la biga, però hem de fer un parell d'artificis:

- Si tenim una càrrega distribuïda que comença i acaba abans del final de la biga, la prolongarem fins al final i la compensarem amb una càrrega en sentit contrari de la mateixa magnitud.

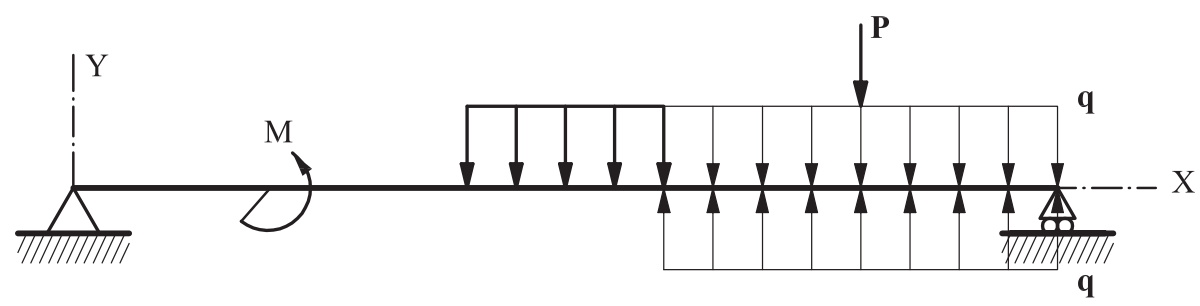

Fig. 6.6. Exemple 6.4. Primer artifici

- Si tenim un moment M aplicat, en la llei de moments considerarem $M \cdot(x-a)^{0}$.

La llei de moments flectors a l'últim tram serà:

$M_{Z}(x)=R_{A} x-M\langle x-a\rangle^{0}-q \frac{\langle x-2 a\rangle^{2}}{2}+q \frac{\langle x-3 a\rangle^{2}}{2}-P\langle x-4 a\rangle$ 


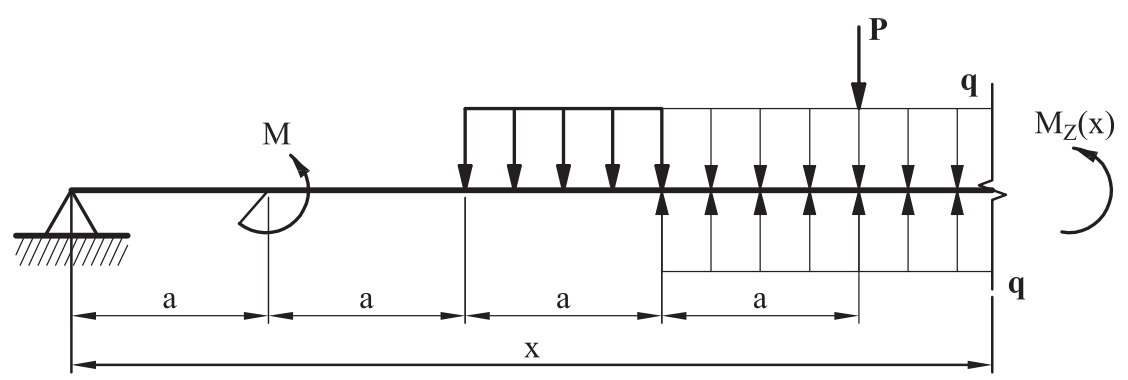

Fig. 6.7. Exemple 6.4. Moments flectors a l'últim tram

$E I_{Z} y^{\prime \prime}(x)=M_{Z}(x)$

$E I_{Z} y^{\prime}(x)=R_{A} \frac{x^{2}}{2}-M\langle x-a\rangle-q \frac{\langle x-2 a\rangle^{3}}{6}+q \frac{\langle x-3 a\rangle^{3}}{6}-P \frac{\langle x-4 a\rangle^{2}}{2}+C_{1}$

$E I_{Z} y(x)=R_{A} \frac{x^{3}}{6}-M \frac{\langle x-a\rangle^{2}}{2}-q \frac{\langle x-2 a\rangle^{4}}{24}+q \frac{\langle x-3 a\rangle^{4}}{24}-P \frac{\langle x-4 a\rangle^{3}}{6}+C_{1} x+C_{2}$

Les constants d'integració s'obtenen de les condicions de contorn:

1. El recolzament de l'esquerra no es mou: $y(0)=0$.

2. El recolzament de la dreta no es mou: $y(5 a)=0$.

En la condició 1, tots els termes que estan entre parèntesis, com que són negatius, tindran un valor de zero, perquè són funcions de discontinuïtat. Els altres termes també són zero, a causa de la coordenada $\mathrm{x}=0$. Directament obtenim, doncs: $C_{2}=0$.

De la segona condició:

$E I_{Z} y(5 a)=R_{A} \frac{(5 a)^{3}}{6}-M \frac{(4 a)^{2}}{2}-q \frac{(3 a)^{4}}{24}+q \frac{(2 a)^{4}}{24}-P \frac{a^{3}}{6}+C_{1} 5 a=0$

Podem aïllar $\mathrm{C}_{1}$ :

$C_{1}=\frac{23}{30} M \cdot a-\frac{37}{24} q \cdot a^{3}-\frac{4}{5} P \cdot a^{2}$

La solució obtinguda és vàlida per a tots els trams; només hem d'eliminar, en cada tram, els termes en els quals el valor de dins dels parèntesis siga negatiu. Per exemple, als dos primers trams:

$0 \leq x \leq a \rightarrow y_{1}(x)=\frac{1}{E I_{Z}}\left[R_{A} \frac{x^{3}}{6}+\left(\frac{23}{30} M a-\frac{37}{24} q a^{3}-\frac{4}{5} P a^{2}\right) x\right]$

$a \leq x \leq 2 a \rightarrow y_{2}(x)=\frac{1}{E I_{Z}}\left[R_{A} \frac{x^{3}}{6}-M \frac{(x-a)^{2}}{2}+\left(\frac{23}{30} M a-\frac{37}{24} q a^{3}-\frac{4}{5} P a^{2}\right) x\right]$

D'aquesta manera podríem obtindre la resta de trams. Comprovem que, malgrat que també és relativament laboriós, és significativament més senzill que plantejar i resoldre un sistema de deu equacions amb deu incògnites. 


\subsection{Rigidesa a flexió. Bigues simples i mixtes}

Com ja hem vist anteriorment, hi ha una relació entre el moment flector i la curvatura que adopta un tram de biga.

$$
M_{Z}=E I_{Z} \kappa
$$

El producte $E \cdot I_{Z}$ s'anomena rigidesa a flexió, i representa l'oposició a flexionar-se que presenta una biga sotmesa a un moment flector.

En el cas de bigues mixtes de dos materials amb mòduls d'elasticitat $E_{1}$ i $E_{2}$, homogeneïtzarem la secció respecte a un dels materials, com ja hem fet anteriorment. La rigidesa a flexió es defineix com a: $E_{r e f} \cdot I_{T}$

En aquest cas:

- $E_{r e f}$ és el mòdul de Young del material respecte al qual hem homogeneïtzat.

- $I_{T}$ és el moment d'inèrcia de la secció homogeneïtzada respecte a la LN.

Podem afirmar també que:

$$
E_{r e f} \cdot I_{T}=E_{1} \cdot I_{Z 1}+E_{2} \cdot I_{Z 2}
$$

$I_{Z 1}$ i $I_{Z 2}$ són els moments d'inèrcia de cada material (considerant la secció real) respecte a la LN.

\section{Exemple 6.5}

Calculeu la rigidesa flexional de la biga composta de l'exemple 5.11.

En aquell exemple vam fer, en primer lloc, l'homogeneïtzació respecte del material 1, vam trobar el centre de gravetat i vam calcular el moment d'inèrcia de la secció homogeneïtzada.

$Y_{G}=3,715 \mathrm{~cm} ; I_{Z T}=8,9 \cdot 10^{-5} \mathrm{~m}^{4}$

La rigidesa a flexió de la biga homogeneïtzada és, doncs:

$E_{\text {ref }} \cdot \mathrm{I}_{\text {homog }}=E_{1} \cdot I_{Z T}=9,2 \cdot 10^{5} \mathrm{~N} \cdot \mathrm{m}^{2}$

Comprovarem ara que les rigideses a flexió de la biga homogeneïtzada i de la biga original coincideixen. Hem de calcular els moments d'inèrcia de les àrees originals respecte a l'eix Z:

$I_{1}=\frac{1}{12} \cdot b_{1} \cdot h_{1}^{3}+b_{1} \cdot h_{1} \cdot\left(h_{2}+\frac{h_{1}}{2}-Y_{G}\right)^{2}=7,19 \cdot 10^{-5} \mathrm{~m}^{4}$ 


$$
\begin{aligned}
& I_{2}=\frac{1}{12} \cdot b_{2} \cdot h_{2}^{3}+b_{2} \cdot h_{2} \cdot\left(Y_{G}-\frac{h_{2}}{2}\right)^{2}=1,25 \cdot 10^{-6} \mathrm{~m}^{4} \\
& E \cdot I_{\text {orig }}=E_{1} \cdot I_{1}+E_{2} \cdot I_{2}=9,2 \cdot 10^{5} \mathrm{~N} \cdot \mathrm{m}^{2}
\end{aligned}
$$

Comprovem doncs que: $E_{\text {ref }} \cdot \mathrm{I}_{\text {homog }}=E_{l} \cdot I_{\text {orig }}$.

En la segona part del problema, ho resolguérem tot un altre cop, però homogeneïtzant respecte del material 2. També podem comprovar que les rigideses a flexió són les mateixes. La posició del centre de gravetat era la mateixa que anteriorment. El moment d'inèrcia de la secció homogeneïtzada és $I_{Z T}=444,88 \mathrm{~cm}^{4}$; per tant, la rigidesa flexional de la secció homogeneïtzada respecte del material 2:

$E \cdot \mathrm{I}_{\text {homog }}=E_{2} \cdot I_{Z T}=9,2 \cdot 10^{5} \mathrm{~N} \cdot \mathrm{m}^{2}$.

Els moments d'inèrcia $I_{1}$ i $I_{2}$ són els mateixos que abans, pel fet d'estar el centre de gravetat a la mateixa posició. Per aquesta raó, la rigidesa original i la resta dels valors són els mateixos. Comprovem que tornen a coincidir ambdues rigideses.

\section{Exemple 6.6}

Calculeu els diagrames d'esforços de la biga de la figura. Les cotes estan en metres i suposem coneguda la secció de la biga $\mathrm{i}$ el material. Calculeu la fletxa en $\mathrm{x}=3 \mathrm{~m}$ i en $\mathrm{x}=18 \mathrm{~m}$ i el gir en $\mathrm{x}=12 \mathrm{~m}$.

Dades: $\mathrm{I}_{\mathrm{Z}}, \mathrm{E}, \mathrm{P}_{1}=6 \mathrm{kN} ; \mathrm{P}_{2}=7 \mathrm{kN} ; \mathrm{q}=8 \mathrm{kN} / \mathrm{m}$.

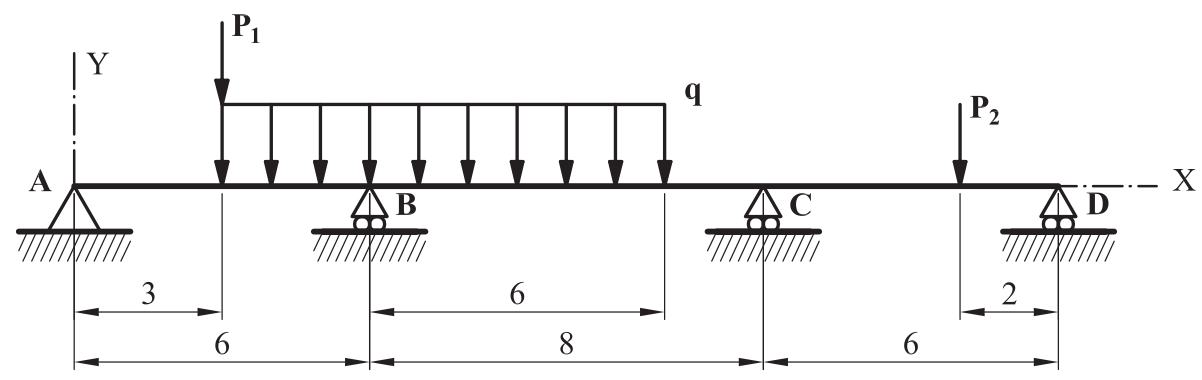

Fig. 6.8. Exemple 6.6. Enunciat

Aquest és un cas clarament hiperestàtic. Tenim dues equacions de l'estàtica i quatre reaccions desconegudes, per tant $\mathrm{GH}=2$. Per a calcular els casos hiperestàtics utilitzarem equacions addicionals que sorgeixen del càlcul de moviments coneguts en l'estructura. Són les que anomenem equacions de compatibilitat de desplaçament. Per a casos com aquest, en els quals la biga és completament recta, podem utilitzar el mètode de la doble integració. Més endavant estudiarem uns altres mètodes. Tanmateix, en aquest problema en particular, és més adient el mètode de la doble integració perquè a més de resoldre l'hiperestatisme, hem de calcular la fletxa en dos punts i el gir en un altre. Amb els mètodes que veurem després, el problema s'allargaria molt més que amb la doble integració. 
Per a fer el mètode de la doble integració, necessitem fer l'artifici de prolongar la càrrega distribuïda $\mathrm{i}$ compensar-la amb una de sentit contrari.

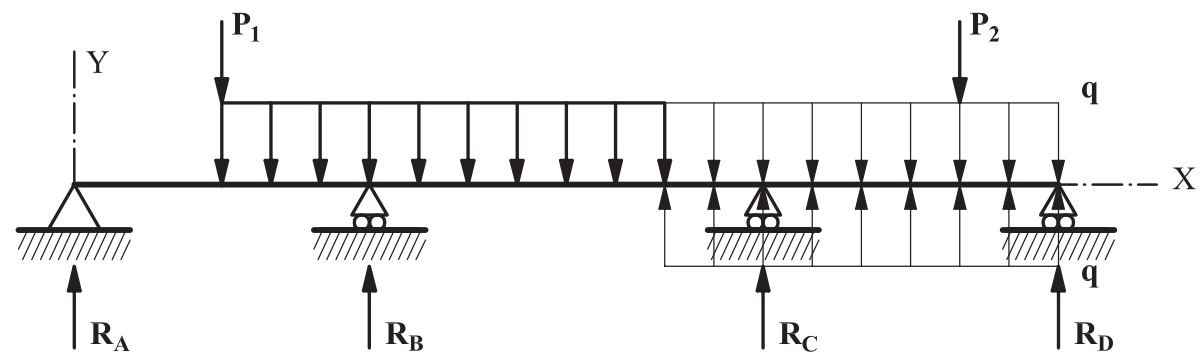

Fig. 6.9. Exemple 6.6. Artifici amb la càrrega distribuïda

Com podem observar a la figura, tindríem sis trams en la llei de moments flectors. En aquest mètode, calcularem el moment flector a l'últim tram, utilitzant les funcions de discontinuïtat abans explicades.

Sabem que $M_{Z}(x)=E I_{Z} \frac{d^{2} y}{d x^{2}}$.

$$
\begin{aligned}
& M_{Z}(x)=R_{A} x+R_{B}\langle x-6\rangle+R_{C}\langle x-14\rangle-P_{1}\langle x-3\rangle-P_{2}\langle x-18\rangle-q \frac{\langle x-3\rangle^{2}}{2}+q \frac{\langle x-12\rangle^{2}}{2} \\
& E I_{Z} y^{\prime}(x)=R_{A} \cdot \frac{x^{2}}{2}+R_{B} \frac{\langle x-6\rangle^{2}}{2}+R_{C} \frac{\langle x-14\rangle^{2}}{2}-P_{1} \frac{\langle x-3\rangle^{2}}{2}-P_{2} \frac{\langle x-18\rangle^{2}}{2}-q \frac{\langle x-3\rangle^{3}}{6} \\
& +q \frac{\langle x-12\rangle^{3}}{6}+C_{1} \\
& E I_{Z} y(x)=R_{A} \frac{x^{3}}{6}+R_{B} \frac{\langle x-6\rangle^{3}}{6}+R_{C} \frac{\langle x-14\rangle^{3}}{6}-P_{1} \frac{\langle x-3\rangle^{3}}{6}-P_{2} \frac{\langle x-18\rangle^{3}}{6}-q \frac{\langle x-3\rangle^{4}}{24} \\
& +q \frac{\langle x-12\rangle^{4}}{24}+C_{1} x+C_{2}
\end{aligned}
$$

Apliquem condicions de contorn per a resoldre les incògnites que tenim, que en són sis (les quatre reaccions i les dues constants d'integració). Recordem que els termes dins dels parèntesis que siguen negatius, els eliminarem.

1) $x=0 \rightarrow y(x)=0 \rightarrow C_{2}=0$.

2) $x=6 m \rightarrow y(x)=0$.

$$
\begin{aligned}
& R_{A} \frac{6^{3}}{6}-P_{1} \frac{(6-3)^{3}}{6}-q \frac{(6-3)^{4}}{6}+C_{1} \cdot 6=0 \\
& \rightarrow 36 R_{A}-54+6 C_{1}=0
\end{aligned}
$$

3) $\underline{\mathrm{x}}=14 m \rightarrow y(x)=0$.

$$
\begin{aligned}
& R_{A} \frac{14^{3}}{6}+R_{B} \frac{(14-6)^{3}}{6}-P_{1} \frac{(14-3)^{3}}{6}-q \frac{(14-3)^{4}}{24}+q \frac{(14-12)^{4}}{24}+C_{1} \cdot 14=0 \\
& \rightarrow 457,33 R_{A}+85,33 R_{B}-6206+14 C_{1}=0
\end{aligned}
$$


4) $x=20 \rightarrow y(x)=0$.

$$
\begin{aligned}
& R_{A} \frac{20^{3}}{6}+R_{B} \frac{(20-6)^{3}}{6}+R_{C} \frac{(20-14)^{3}}{6}-P_{1} \frac{(20-3)^{3}}{6}-P_{2} \frac{(20-18)^{3}}{6}-q \frac{(20-3)^{4}}{24} \\
& +q \frac{(20-12)^{4}}{24}+C_{1} \cdot 20=0 \\
& \rightarrow 1333,33 R_{A}+457,33 R_{B}+36 R_{C}-31397,33+20 C_{1}=0
\end{aligned}
$$

Equacions d'equilibri estàtic:

$\Sigma F_{Y}=0 \rightarrow R_{A}+R_{B}+R_{C}+R_{D}-P_{1}-P_{2}-q \cdot 9=0$

$\Sigma M_{D}=0 \rightarrow R_{A} \cdot 20+R_{B} \cdot 14+R_{C} \cdot 6-P_{I} \cdot 17-P_{2} \cdot 2-q \cdot 9 \cdot 12,5=0$

Tenim sis equacions amb sis incògnites. Realment, ja sabem que només ens queden cinc equacions i cinc incògnites. Fem la resolució del sistema:

$R_{A}=2,74 k N ; R_{B}=59,27 k N ; R_{C}=21,79 k N ; R_{D}=1,08 k N ; C_{l}=-7,44 k N$

Malgrat l'inconvenient que suposa resoldre un sistema de cinc equacions amb cinc incògnites, pensem què haguera passat si haguérem plantejat el problema mitjançant el mètode general, amb la llei de moments flectors tram a tram, i integrant en cadascun d'ells. Tindríem dues constants d'integració per cada tram, en total dotze constants, més les quatre reaccions, un total de setze incògnites. Hauríem de resoldre el sistema de setze equacions amb setze incògnites. Evidentment, el mètode universal és més eficaç en eixe sentit.

Un cop resolt l'hiperestatisme, el càlcul de les fletxes i el gir ja és immediat:

$$
\begin{aligned}
& y(3)=\frac{1}{E I_{Z}}\left[R_{A} \frac{3^{3}}{6}+3 C_{1}\right]=\frac{-10}{E I_{Z}} \\
& y(18)=\frac{1}{E I_{Z}}\left[R_{A} \frac{18^{3}}{6}+R_{B} \frac{(18-6)^{3}}{6}+R_{C} \frac{(18-14)^{3}}{6}-P_{1} \frac{(18-3)^{3}}{6}-q \frac{(18-3)^{4}}{24}+q \frac{(18-12)^{4}}{24}+18 C_{1}\right] \\
& y(18)=\frac{14,83}{E I_{Z}} \\
& \theta(12)=y^{\prime}(12)=\frac{1}{E I_{Z}}\left[R_{A} \frac{12^{2}}{2}+R_{B} \frac{(12-6)^{2}}{2}-P_{1} \frac{(12-3)^{2}}{2}-q \frac{(12-3)^{3}}{6}+C_{1}\right] \\
& \theta(12)=\frac{41,70}{E I_{Z}}
\end{aligned}
$$




\subsection{Mètode de Maxwell-Mohr}

$\mathrm{Al}$ punt anterior hem vist com calcular l'equació de l'elàstica, la qual ens dóna la posició de totes les seccions d'una biga (del centre de gravetat). Hi ha vegades en què no ens interessa tant conéixer la posició de totes les seccions com la d'una en concret. Per a aquests casos existeix un mètode que ens permet calcular desplaçaments o girs de seccions determinades en bigues rectes sotmeses a flexió plana.

El mètode es basa en els teoremes energètics, que formen part de la teoria de l'elasticitat, però que no hem estudiat en aquest curs. En concret, el mètode de Maxwell-Mohr es basa en el teorema de Castigliano. Com que no hem treballat sobre aquest últim, no podrem fer la demostració teòrica del mètode, que l'alumne interessat podrà trobar fàcilment a la bibliografia recomanada.

Imaginem una biga carregada amb una distribució qualsevol de forces, com la de la figura (farem l'explicació amb la biga recolzada als extrems de la figura, però pot tindre qualsevol geometria). Volem trobar la posició final del centre de gravetat de la secció $\mathrm{C}$.

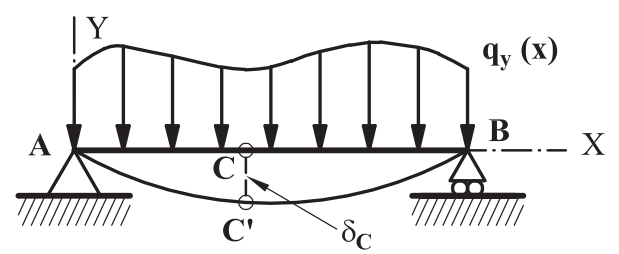

Fig. 6.10. Mètode de Maxwell-Mohr

El procediment és el següent:

1) Introduïm una força fictícia unitària $(\Phi)$ en el punt $C$, en la direcció en la qual volem calcular el desplaçament. En aquest cas, com que volem calcular el descens, la força serà vertical.

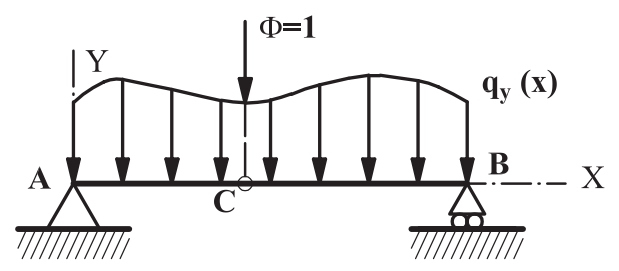

Fig. 6.11. Mètode de Maxwell-Mohr. Força fictícia

2) Aplicarem el teorema de superposició, i separarem les forces reals de la força fictícia. Calcularem per separat els diagrames de moments «reals», $M_{Z}(x)$, i els diagrames de moments «ficticis», $M_{\Phi}(x)$. Evidentment, com que la càrrega fictícia és puntual, el diagrama $M_{\Phi}(x)$ sempre serà lineal. 

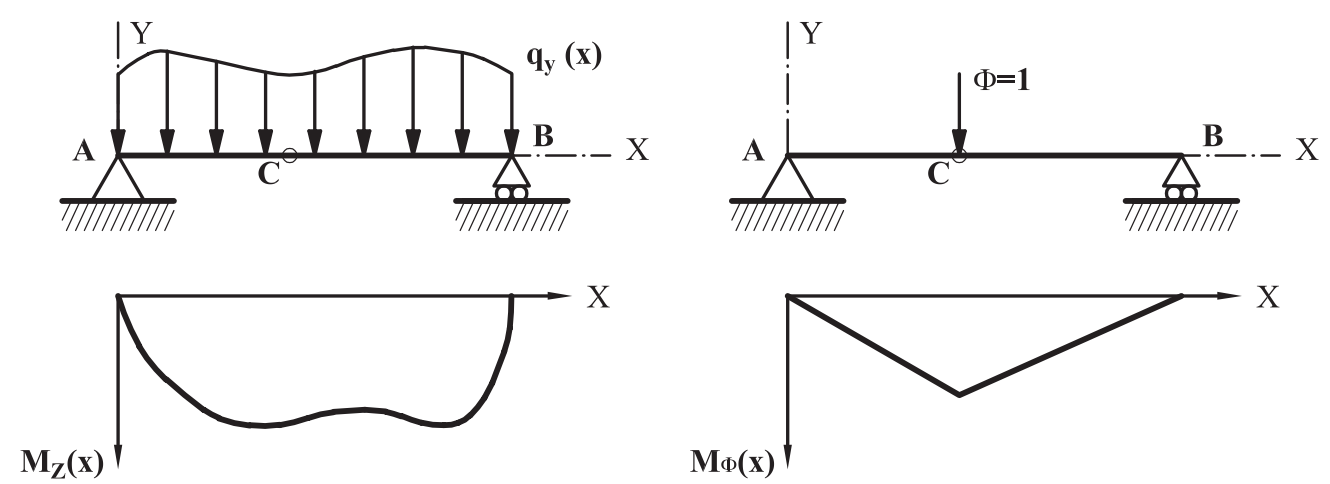

Fig. 6.12. Mètode de Maxwell-Mohr. Separació per superposició

3) Pot demostrar-se que el desplaçament del punt d'aplicació de la força $\Phi$, en la direcció de la força, és:

$$
\delta_{C}=\int \frac{M_{Z}(x) \cdot M_{\Phi}(x)}{E I_{Z}} d x
$$

És a dir, hem de calcular les lleis de moments reals i ficticis, multiplicar els dos polinomis i integrar el resultat en tota la longitud de la biga. Aquest resultat, dividit per la rigidesa, és el desplaçament.

Consideracions addicionals:

a) Si les lleis de moments són a trams, hem de fer una integral per a cada tram i sumar-les. Realment el que hem de tindre són funcions contínues per a les dues lleis de moments. Encara que la llei de moments reals siga contínua en un tram, si la de moments ficticis té la discontinuïtat en eixe tram, haurem de dividir-lo en dos. Per exemple, a la figura 6.12, podem veure que $M_{z}(x)$ és contínua en tota la longitud de la biga, però $M_{\Phi}(x)$ té una discontinuïtat en $\mathrm{C}$. Això ens obliga a fer dues integrals, una de $\mathrm{A}$ a $\mathrm{C}$ i una altra de $\mathrm{C}$ a $\mathrm{B}$.

b) El desplaçament serà positiu si el punt es mou en la direcció de la força fictícia que hem introduït.

c) El mètode és vàlid per a estructures de més d'una biga ( $n$ elements). En aquest cas és necessari fer les integrals en cadascun dels elements i sumar-les. Quan l'estructura està composta de més d'un element, hem d'aplicar el mètode obligatòriament a tota l'estructura, independentment de la secció en la qual volem obtindre el desplaçament.

$$
\delta_{C}=\sum_{i=1}^{n} \int \frac{M_{Z i}(x) \cdot M_{\Phi i}(x)}{E_{i} I_{Z i}} d x
$$

d) Si el que volem és trobar el gir d'una secció, en lloc de introduir una força fictícia puntual unitària, introduirem un moment puntual unitari. La resta del 
mètode és exactament igual. El gir obtingut serà positiu si la secció gira en el mateix sentit que el moment aplicat.

\section{Exemple 6.7}

Calculeu el desplaçament del punt extrem de la biga voladissa següent, sense calcular l'equació de l'elàstica.

Dades: $\mathrm{q}=5 \mathrm{kN} / \mathrm{m} ; \mathrm{L}=3 \mathrm{~m} ; \mathrm{E}=210 \mathrm{GPa} ; \mathrm{I}_{\mathrm{Z}}=11.770 \mathrm{~cm}^{4}$.

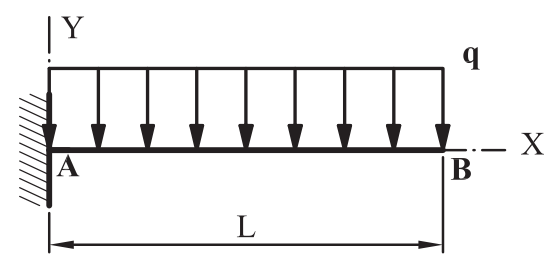

Fig. 6.13. Exemple 6.7. Enunciat

Les reaccions són:

$R_{A}=q L=15 \mathrm{kN} ; M_{A}=-q \frac{L^{2}}{2}=-22,5 \mathrm{kN} \cdot \mathrm{m}$

La llei de moments flectors és:

$M_{Z}(x)=-q \frac{L^{2}}{2}+q L x-q \frac{x^{2}}{2}$

Per a calcular el desplaçament del punt extrem de la biga, apliquem una càrrega fictícia unitària vertical en el punt $\mathrm{B}$.

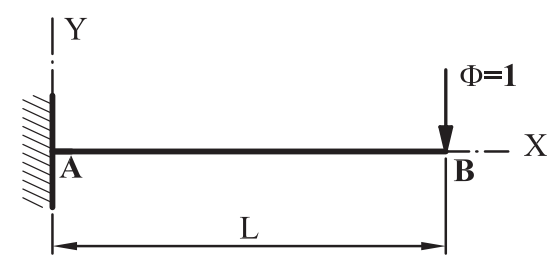

Fig. 6.14. Exemple 6.7. Càrrega fictícia

La llei de moments «ficticis» amb la càrrega $\Phi=1$ és: $\mathrm{M}_{\Phi}(x)=x-L$.

Ambdues lleis són contínues en la barra sencera. Només caldrà fer una integral. Fem primer el producte de les dues lleis:

$M_{Z}(x) \cdot M_{\Phi}(x)=-q \frac{L^{2}}{2} x+q L x^{2}-q \frac{x^{3}}{2}+q \frac{L^{3}}{2}-q L^{2} x+q L \frac{x^{2}}{2}$

i ara, fem la integral. 
$\delta_{B}=\frac{1}{E I_{Z}} \int_{0}^{L}\left(-q \frac{L^{2}}{2} x+q L x^{2}-q \frac{x^{3}}{2}+q \frac{L^{3}}{2}-q L^{2} x+q L \frac{x^{2}}{2}\right) d x$

$\delta_{B}=\frac{1}{E I_{Z}}\left[-q \frac{L^{2}}{2} \frac{x^{2}}{2}+q L \frac{x^{3}}{3}-q \frac{x^{4}}{8}+q \frac{L^{3}}{2} x-q L^{2} \frac{x^{2}}{2}+q L \frac{x^{3}}{6}\right]_{0}^{L}$

$\delta_{B}=\frac{1}{E I_{Z}}\left[-q \frac{L^{4}}{4}+q \frac{L^{4}}{3}-q \frac{L^{4}}{8}+q \frac{L^{4}}{2}-q \frac{L^{4}}{2}+q \frac{L^{4}}{6}\right]=\frac{q L^{4}}{8 E I_{Z}}=2,05 \cdot 10^{-3} \mathrm{~m}$

El valor del desplaçament és positiu, la qual cosa representa que el punt baixarà, és a dir, es desplaçarà en la mateixa direcció i sentit que la força fictícia.

\section{Exemple 6.8}

Calculeu el desplaçament del punt mitjà de la biga recolzada als extrems de la figura.

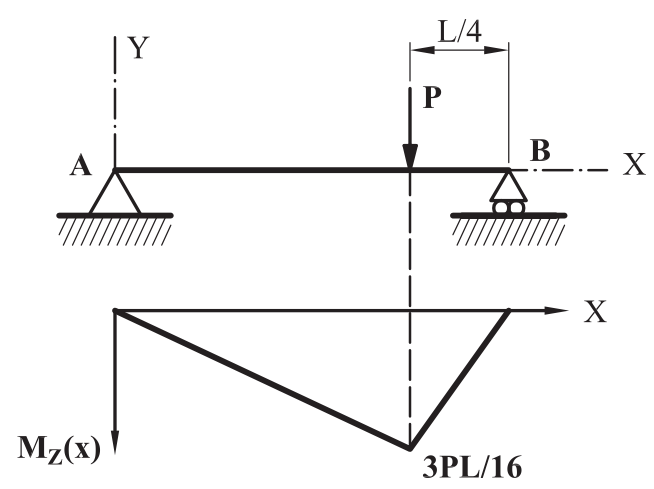

Fig. 6.15. Exemple 6.8. Enunciat i diagrama de moments «reals»

Dades: $\mathrm{P}=10 \mathrm{kN} ; \mathrm{L}=5 \mathrm{kN}: \mathrm{E}=210 \mathrm{GPa} ; \mathrm{I}_{\mathrm{Z}}=11.770 \mathrm{~cm}^{4}$.

Les reaccions són:

$R_{A}=P / 4=2,5 k N ; R_{B}=3 P / 4=7,5 k N$

La llei de moments flectors és en dos trams:

$0 \leq x \leq \frac{3}{4} L \rightarrow M_{Z 1}(x)=\frac{P}{4} x$

$\frac{3}{4} L \leq x \leq L \rightarrow M_{Z 2}(x)=\frac{3}{4} P(L-x)$

Com que volem calcular el desplaçament del punt mitjà, hi apliquem una força unitària. 


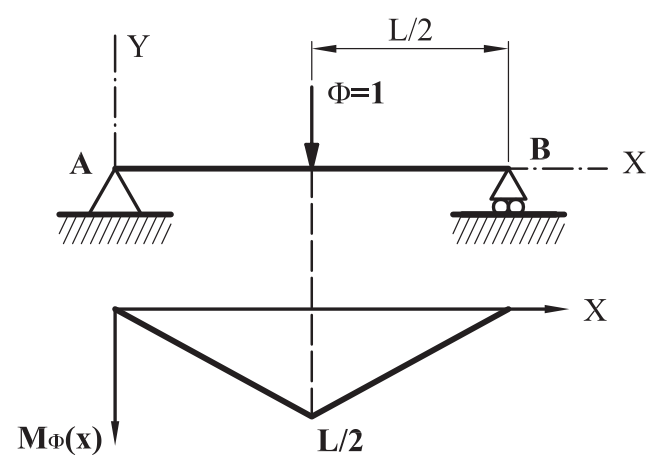

Fig. 6.16. Exemple 6.8. Força fictícia i diagrama de moments «ficticis»

La llei de moments ficticis també és en dos trams, però no són els mateixos que abans:

$$
\begin{gathered}
0 \leq x \leq \frac{L}{2} \rightarrow M_{\Phi 1}(x)=\frac{x}{2} \\
\frac{L}{2} \leq x \leq L \rightarrow M_{\Phi 2}(x)=\frac{L-x}{2}
\end{gathered}
$$

Com que els diagrames reals tenen una discontinuïtat en 3L/4 i els ficticis la tenen en $\mathrm{L} / 2$, haurem de considerar tres trams per tal de tindre funcions contínues en ambdues lleis, dins de cada tram. El desplaçament serà el resultat de la suma de les integrals:

$$
\delta=\frac{1}{E I_{Z}}\left[\int M_{Z 1}(x) \cdot M_{\Phi 1}(x) d x+\int M_{Z 1}(x) \cdot M_{\Phi 2}(x) d x+\int M_{Z 2}(x) \cdot M_{\Phi 2}(x) d x\right]
$$

Si fem tots els productes i les integrals, finalment obtindrem:

$\delta=\frac{11 L^{3} P}{768 E I_{Z}}=7,24 \cdot 10^{-4} \mathrm{~m}$

\subsection{Interpretació gràfica del mètode de Maxwell-Mohr}

Com hem vist, el mètode implica fer el producte de dos polinomis i després integrar el resultat. Si tenim lleis de moments complexes i molts trams, la resolució pot esdevindre molt laboriosa. Per a aquests casos hi ha una interpretació gràfica del mètode de Maxwell-Mohr.

Sabem que la llei de moments ficticis serà lineal, perquè la càrrega fictícia és puntual. Per tant, adoptarà la forma genèrica de l'equació d'una recta: $M_{\Phi}(x)=a+b x$.

El desplaçament serà, doncs:

$$
\delta_{C}=\sum_{d e m} \int \frac{M_{Z}(x) \cdot(a+b x)}{E I_{Z}} d x=\sum_{d e m} \int \frac{a \cdot M_{Z}(x)}{E I_{Z}} d x+\sum_{d e m} \int \frac{b x M_{Z}(x)}{E I_{Z}} d x
$$


En el primer terme, la integral $\int M_{Z}(x) d x$ representa l'àrea del diagrama de moments flectors al tram considerat. La resta són constants que ixen de la integral.

En el segon terme, la integral $\int x M_{Z}(x) d x$ és el numerador de la coordenada del centre de gravetat de l'àrea del diagrama de moments flectors.

$X_{G M}=\frac{\int x M_{Z}(x) d x}{\int M_{Z}(x) d x}=\frac{\int x M_{Z}(x) d x}{A_{M}}$

Reescrivim l'expressió del desplaçament:

$\delta=\sum \frac{1}{E I_{Z}}\left(a A_{M}+b A_{M} X_{G M}\right)=\sum \frac{A_{M}}{E I_{Z}}\left(a+b X_{G M}\right)$

Si ens hi fixem, ens adonarem que el parèntesi és el moment fictici, calculat en la coordenada del centre de gravetat de l'àrea del diagrama de moments flectors.

El mètode s'anomena també en alguns textos mètode de Veresxaquin o de multiplicació dels gràfics.

A primera ullada pot semblar més complicat que l'anterior, però realment el mètode es limita al càlcul d'àrees conegudes, normalment rectangles i triangles, $i$ dels seus centres de gravetat.

Farem un resum operatiu del mètode, encara que els tres primers passos són els mateixos.

Considerem una biga sotmesa a una distribució genèrica de càrregues transversals i el diagrama de moments flectors associat, com els de la figura 6.12. Volem obtindre el desplaçament d'un punt qualsevol (C).

1) Obtenim el diagrama de moments flectors «reals». Moltes vegades no és necessari tindre la funció $M_{z}(x)$ si podem definir el diagrama de manera senzilla.

2) Eliminem les càrregues exteriors $\mathrm{i}$ apliquem una força fictícia en el punt $\mathrm{C}$.

3) Representarem el diagrama de moments flectors «ficticis», que sempre seran lineals (figura 6.12).

4) Descomponem els diagrames en seccions longitudinals, de manera que en cada tram les dues funcions siguen contínues.

5) Calculem les àrees del diagrama de moments «reals» per a cada tram i la posició del centre de gravetat d'aquestes àrees.

6) Calculem el moment fictici en les coordenades dels centres de gravetat anteriorment calculats. 


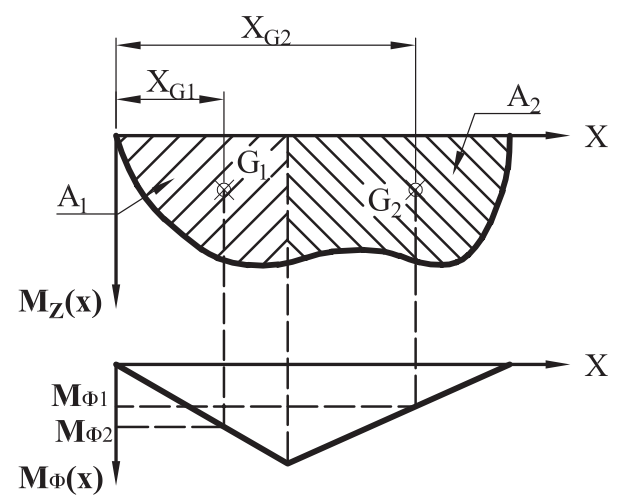

Fig. 6.17. Interpretació gràfica del mètode de Maxwell-Mohr

7) Aplicarem la fórmula:

$$
\delta=\frac{1}{E I_{Z}} \sum A_{M i}^{r e a l} \cdot M_{\Phi i}\left(X_{G i}^{r e a l}\right)=\frac{1}{E I_{Z}}\left[A_{1} \cdot M_{\Phi 1}\left(X_{G 1}\right)+A_{2} \cdot M_{\Phi 2}\left(X_{G 2}\right)\right]
$$

Important: les àrees dels diagrames de moments flectors han d'anar amb el seu signe. És a dir, si el moment és positiu, l'àrea serà positiva, i si el moment és negatiu, l'àrea serà negativa.

Comprovarem a continuació, a través d'uns exemples, que el mètode resulta senzill d'aplicar.

\section{Exemple 6.9}

Determineu el desplaçament del punt extrem del voladís (A) de la biga de la figura, sense calcular l'equació de l'elàstica.

Dades: P, L, E, I

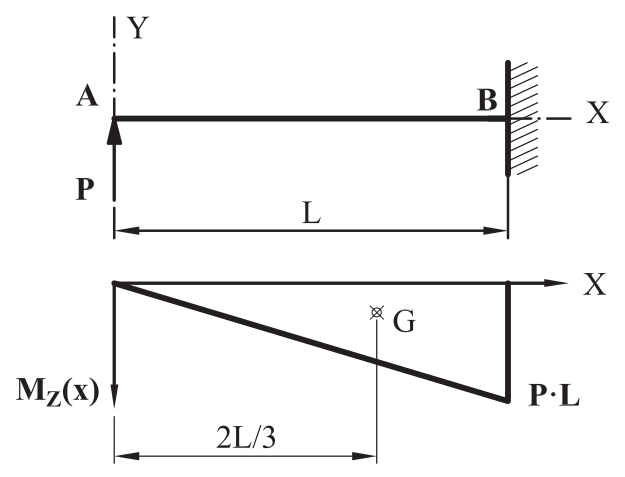

Fig. 6.18. Exemple 6.9. Enunciat i diagrama de moments

Aquest és un dels casos senzills en els quals, amb un mínim d'experiència en la resolució de diagrames d'esforços (que en aquest punt del curs, ja hauria de tindre 
l'alumne), no és necessari el càlcul de la llei d'esforços de manera matemàtica. Només adonar-nos que serà un triangle, amb valor zero en $\mathrm{A}$ i valor $P \cdot L$ en $\mathrm{B}$. La posició del centre de gravetat també és coneguda: en un triangle rectangle està a $2 / 3$ del vèrtex o a $1 / 3$ de la base.

Llevem la càrrega $\mathrm{P} i$ apliquem una força fictícia unitària al punt $\mathrm{A}$. La llei de moments ficticis té la mateixa forma que la de moments reals, però amb un màxim de valor $L$.

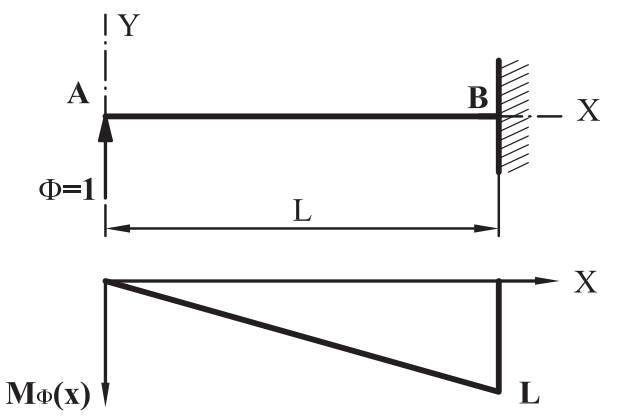

Fig. 6.19. Exemple 6.9. Força fictícia. Diagrama

$\delta=\frac{1}{E I_{Z}} A_{M}^{r e a l} \cdot M_{\Phi}\left(X_{G}^{r e a l}\right)$

L'àrea d'un triangle de base L i altura P · L és:

$A_{M}^{\text {real }}=\frac{1}{2} L P L=\frac{P L^{2}}{2}$

En la coordenada del centre de gravetat de l'àrea anterior $\left(X_{G}=2 L / 3\right)$ calculem quant val el moment fictici. En aquest cas, tampoc és necessari el càlcul de la llei matemàtica de moments ficticis. Podem fer una senzilla semblança de triangles $\mathrm{i}$ veure que:

$x=L \rightarrow M_{\Phi}(x)=L$

$x=2 L / 3 \rightarrow M_{\Phi}(x)=2 L / 3$

Això ho podem fer si estem segurs de la forma dels diagrames; en cas contrari, calcularem la senzilla expressió, $i$ substituirem la coordenada $X_{G}$.

$\delta=\frac{1}{E I_{Z}} \frac{P L^{2}}{2} \frac{2 L}{3}=\frac{P L^{3}}{3 E I_{Z}}$

El valor és positiu perquè el punt es mou cap a dalt, que és el mateix sentit que duu la força fictícia. 


\section{Exemple 6.10}

Determineu el desplaçament del punt $\mathrm{C}$ de la biga recolzada de la figura, en la qual s'aplica la càrrega $P$.

Dades: $\mathrm{P}=10 \mathrm{kN} ; \mathrm{L}=2 \mathrm{~m} ; \mathrm{E}=210 \mathrm{GPa} ; \mathrm{I}_{\mathrm{Z}}=11.770 \mathrm{~cm}^{4}$.
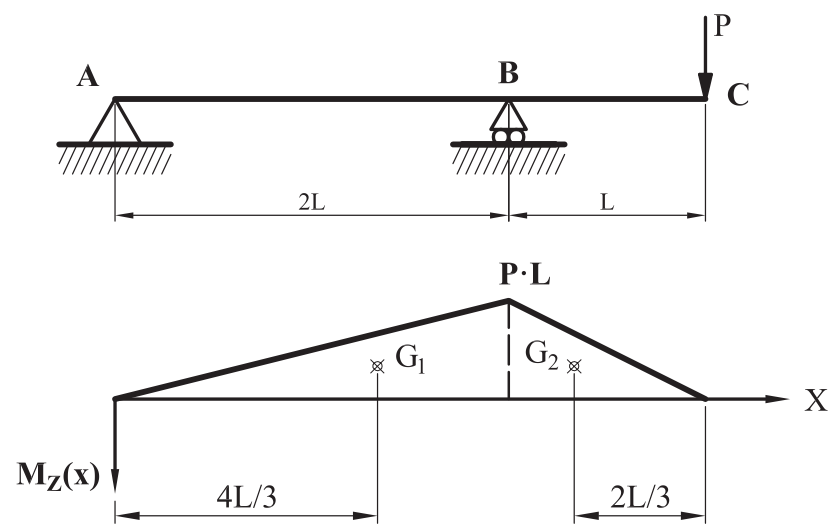

Fig. 6.20. Exemple 6.10. Enunciat i diagrama de moments

Les reaccions són: $R_{A}=\frac{-P}{2} ; R_{B}=\frac{3}{2} P$.

Apliquem la càrrega fictícia en $\mathrm{C}$ i calculem el diagrama.
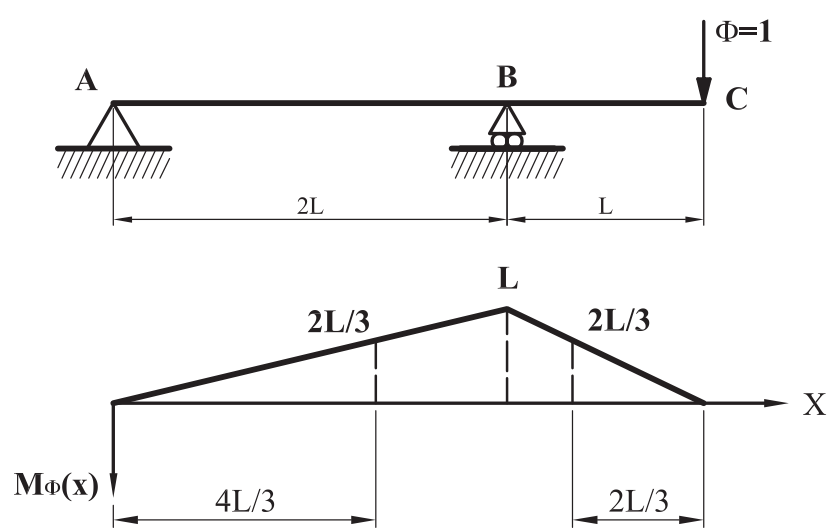

Fig. 6.21. Exemple 6.10. Força fictícia. Diagrama

Ara tenim dues àrees, que són dos triangles. Els moments ficticis en les coordenades dels centres de gravetat també podem calcular-los per semblança de triangles.

$A_{1}=\frac{1}{2} 2 L P L=P L^{2} \rightarrow X_{G 1}=\frac{2}{3} 2 L=\frac{4}{3} L \rightarrow M_{\Phi 1}\left(X_{G 1}\right)=\frac{2}{3} L$

$A_{2}=\frac{1}{2} L P L=P \frac{L^{2}}{2} \rightarrow X_{G 2}=2 L+\frac{L}{3}=\frac{7}{3} L \rightarrow M_{\Phi 2}\left(X_{G 2}\right)=\frac{2}{3} L$

$\delta=\frac{1}{E I_{Z}}\left[A_{1} M_{\Phi 1}\left(X_{G 1}\right)+A_{2} M_{\Phi 2}\left(X_{G 2}\right)\right]=\frac{P L^{3}}{E I_{Z}}=3,24 \cdot 10^{-3} \mathrm{~m}$ 
Com ja hem comentat, els diagrames de moments flectors seran àrees conegudes, normalment triangles o rectangles. Quan la càrrega és distribuïda, el moment resultant és una paràbola.

En aquest curs, per a aquest tipus de problemes només treballarem amb càrregues uniformement distribuïdes, de manera que la llei de moments serà una paràbola quadràtica. L'àrea sota la corba és coneguda, així com la posició del centre de gravetat.

En general l'àrea sota una paràbola de grau $n$ és: $A=\frac{1}{n+1} L H$

i la posició del centre de gravetat respecte del vèrtex: $X_{G}=\frac{n+1}{n+2} L$.

En el cas de paràbola quadràtica $($ grau $\mathrm{n}=2): A=\frac{1}{3} L H ; X_{G}=\frac{3}{4} L$.

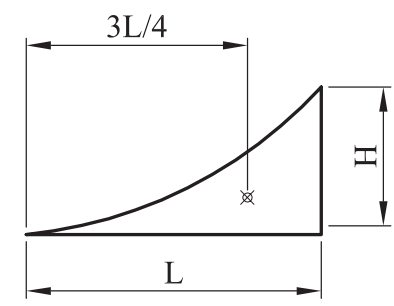

Fig. 6.22. Àrea i centre de gravetat d'una paràbola quadràtica

$\mathrm{Si}$, com a conseqüència de l'existència de diverses càrregues, els diagrames de moments no són figures senzilles conegudes, el que farem serà aplicar el teorema de superposició. Separarem les càrregues individualment, de manera que les àrees siguen senzilles, i després farem el sumatori, considerant totes aquestes àrees.

En el següent exemple podem veure l'aplicació dels dos conceptes anteriorment explicats.

\section{Exemple 6.11}

En la biga de la figura, calculeu el desplaçament del punt C.

Dades: P, q, L, E, I ${ }_{Z}$. 


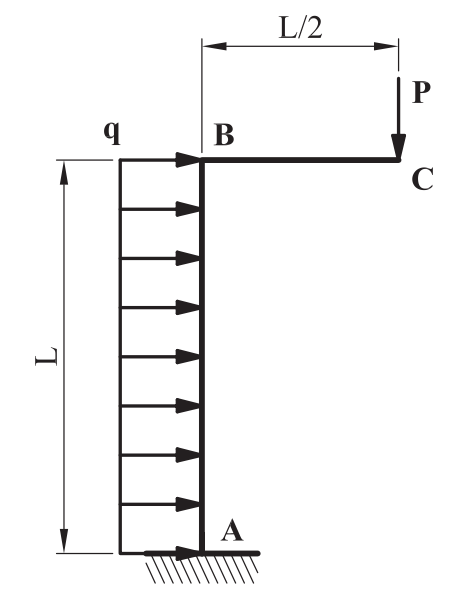

Fig. 6.23. Exemple 6.11. Enunciat

El problema el resoldrem pel mètode d'interpretació gràfica. Es proposa que l'alumne intente resoldre'l pel mètode de Maxwell-Mohr i que comprove que el resultat és el mateix.

El sistema és isostàtic. Podríem calcular les reaccions en A amb les equacions d'equilibri, però no és necessari en aquest problema (si fem el càlcul per MaxwellMohr sí que hauríem de calcular-les). Les àrees que s'obtenen del càlcul global amb totes les càrregues no són conegudes. És per això que aplicarem el teorema de superposició.

Si considerem l'estructura només amb la càrrega $\mathrm{q}$, sabem que la distribució serà parabòlica, amb un màxim en $\mathrm{A}$ i valor zero en $\mathrm{B}$. Aquest màxim serà el valor del moment de reacció en A.

$R_{A q}=\frac{q L^{2}}{2}$. En la barra BC no hi ha moment flector.

Si considerem només la càrrega $\mathrm{P}$, en la barra $\mathrm{BC}$ ha d'haver-hi una distribució lineal de moment flector, amb un valor nul en $\mathrm{C}$ i un màxim en $\mathrm{B}$ igual a la força per la distància $(P \cdot L / 2)$. Al punt $\mathrm{B}$ ha de verificar-se l'equilibri estàtic $\mathrm{i}$, com que no hi ha cap moment aplicat, en eixe punt el moment flector ha de ser igual en la barra $\mathrm{BC}$ que en la $\mathrm{AB}$. En la barra $\mathrm{AB}$ no hi ha cap càrrega aplicada, per la qual cosa el moment flector serà constant en tota ella. Es verifica que el valor del moment flector és igual al moment de reacció en A.

$M_{A P}=P \frac{L}{2}$ 


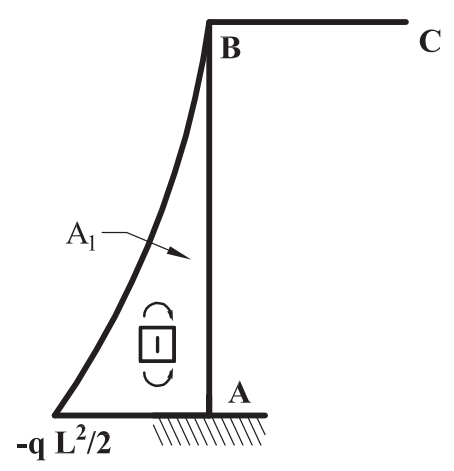

a)

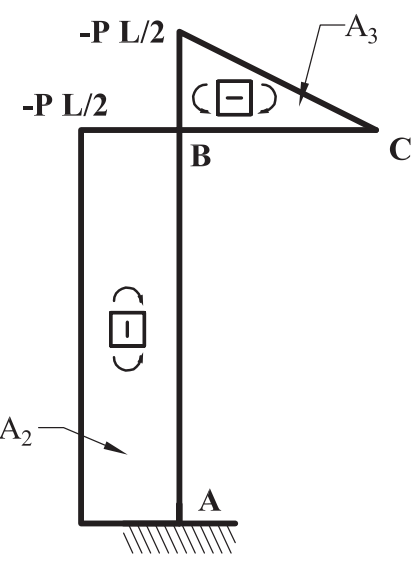

b)

Fig. 6.24. Exemple 6.11. Diagrames de moments «reals»: $a$ ) força distribuïda q; $b$ ) força puntual P

Volem conéixer el desplaçament vertical del punt C. Apliquem una força fictícia en el punt i calculem els diagrames de moments «ficticis». Tenen la mateixa forma que els que genera $\mathrm{P}$.

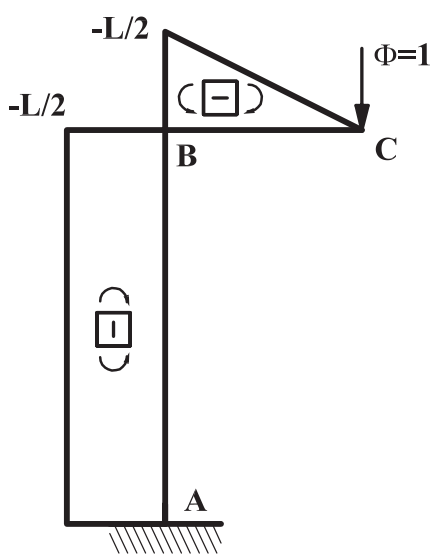

Fig. 6.25. Exemple 6.11. Força fictícia i diagrames

Calculem ara les àrees i els centres de gravetat.

$A_{1}=\frac{-1}{3} L\left(P \frac{L^{2}}{2}\right)=\frac{-P L^{3}}{6} \quad X_{G 1}=\frac{L}{4}$

$A_{2}=-L\left(P \frac{L}{2}\right)=\frac{-P L^{2}}{2} \quad X_{G 2}=\frac{L}{2}$

$A_{3}=\frac{-1}{2} \frac{L}{2}\left(P \frac{L}{2}\right)=\frac{-P L^{2}}{8} \quad X_{G 3}=\frac{1}{3} \frac{L}{2}=\frac{L}{6}$

La variable $\mathrm{x}$ es refereix als eixos locals de les barres.

Com que el diagrama de moments «ficticis» és constant en la barra $\mathrm{AB}$, podem dir que:

$M_{\Phi 1}=M_{\Phi 2}=\frac{-L}{2}$ 
Per a la barra $\mathrm{BC}$, farem una semblança de triangles. Si la base del diagrama és $\mathrm{L} / 2$ i l'altura és $-\mathrm{L} / 2$, quan la base siga L/3, l'altura serà també -L/3.

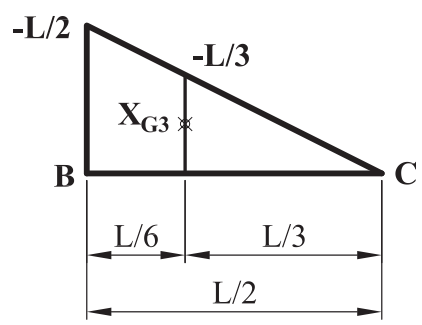

Fig. 6.26. Exemple 6.11. Semblança de triangles

$M_{\Phi 3}=\frac{-L}{3}$

El desplaçament del punt C serà: $\delta_{C}=\frac{1}{E I_{Z}}\left[A_{1} \cdot M_{\Phi 1}+A_{2} \cdot M_{\Phi 2}+A_{3} \cdot M_{\Phi 3}\right]$.

$\delta_{C}=\frac{1}{E I_{Z}}\left[\left(\frac{-P L^{3}}{6}\right)\left(\frac{-L}{2}\right)+\left(\frac{-P L^{2}}{2}\right)\left(\frac{-L}{2}\right)+\left(\frac{-P L^{2}}{8}\right)\left(\frac{-L}{3}\right)\right]=\frac{1}{E I_{Z}}\left[\frac{q L^{4}}{12}+\frac{5 P L^{3}}{16}\right]$

\subsection{Sistemes hiperestàtics}

Els sistemes hiperestàtics són aquells que tenen un grau d'hiperestatisme més gran que zero, és a dir, els sistemes en els quals tenim més incògnites que equacions de l'estàtica disponibles.

Per a resoldre aquest tipus de sistemes, hem de buscar tantes equacions addicionals com grau d'hiperestatisme tinguem. La qüestió és decidir quines seran aquestes equacions addicionals.

Existeix una metodologia general per resoldre els sistemes hiperestàtics, malgrat que en alguns casos procedirem de manera diferent, si trobem equacions d'una altra forma.

Procediment general. L'explicarem acompanyats d'una estructura d'exemple.

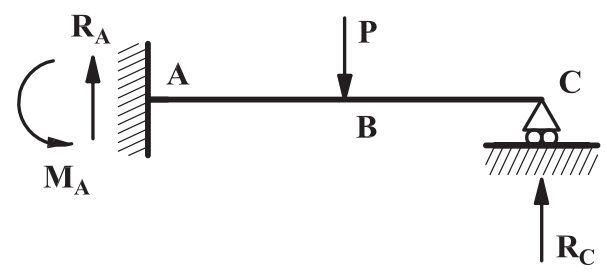

Fig. 6.27. Sistema hiperestàtic exemple 
1) Calcularem el GH. En el cas de l'exemple GH $=1$.

2) Seleccionarem tantes incògnites hiperestàtiques com GH. A l'exemple, com que $\mathrm{GH}=1$, hem de triar només una incògnita. Pot ser qualsevol de les tres reaccions que tenim $\left(R_{A}, M_{A}, R_{C}\right)$.

3) Eliminem la restricció de moviment associada amb la incògnita hiperestàtica triada, i substituïm la reacció per una força exterior. La força serà desconeguda, però actuarem fins al final com si la coneguérem. D'aquesta manera, el sistema es torna isostàtic, encara que tenim una força no coneguda. No és normal en un encast triar la força vertical i mantindre el moment, perquè obtindríem un encast lliscant, que no resulta molt intuïtiu per a l'alumne. Per tant, només considerarem les reaccions $\mathrm{M}_{\mathrm{A}} \mathrm{i} \mathrm{R}_{\mathrm{C}}$.
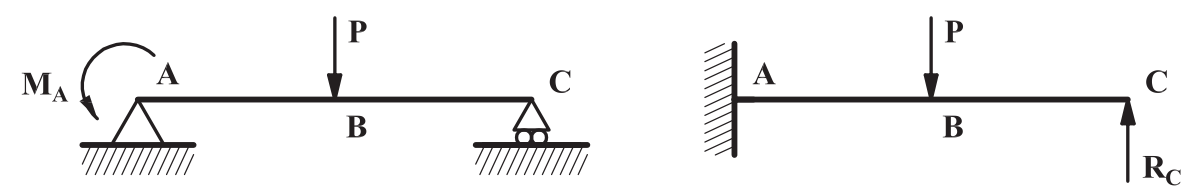

Fig. 6.28. Sistemes isostàtics estàticament equivalents. Triem una de les dues opcions

4) Introduirem equacions de compatibilitat de moviments relacionades amb les restriccions eliminades, per tal que el sistema siga equivalent a l'inicial. A l'exemple, les condicions són:

4.1) Si eliminem la restricció del gir, hem de dir que el punt A realment no girarà. L'equació serà $\theta_{\mathrm{A}}=0$.

4.2) Si eliminem el recolzament lliscant, hem de dir que el punt $\mathrm{C}$ realment no es mourà verticalment. L'equació serà $\mathrm{v}_{\mathrm{C}}=0$.

5) Calcularem el desplaçament conegut per les condicions anteriors, amb el mètode de Maxwell-Mohr o la seua interpretació gràfica. Com que les forces exteriors que hem introduït són desconegudes, en les equacions anteriors ens quedarà una única incògnita, que podrem aïllar.

\section{Exemple 6.12}

Determineu el desplaçament del punt $\mathrm{C}$ de la biga de la figura, en la qual s'aplica la càrrega $P$.

Dades: $\mathrm{P}=10 \mathrm{kN} ; \mathrm{L}=2 \mathrm{~m} ; \mathrm{E}=210 \mathrm{GPa} ; \mathrm{I}_{\mathrm{Z}}=11.770 \mathrm{~cm}^{4}$. 


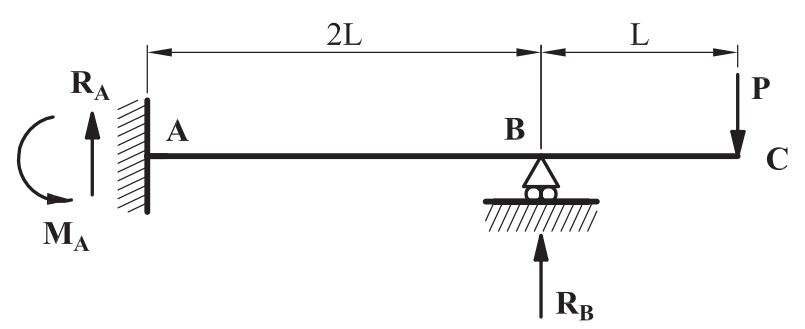

Fig. 6.29. Exemple 6.12. Enunciat

Com que el sistema és hiperestàtic, triarem una incògnita hiperestàtica i eliminarem la restricció de moviment associada. Si triem $\mathrm{M}_{\mathrm{A}}$, el sistema resultant ens quedarà pràcticament igual que el de l'exemple 6.10, però amb el moment aplicat en $\mathrm{A}$. Si triem $R_{B}$, el sistema serà una biga voladissa amb les càrregues $P \mathrm{i}_{\mathrm{B}}$. En aquesta ocasió resoldrem el problema amb el segon supòsit.

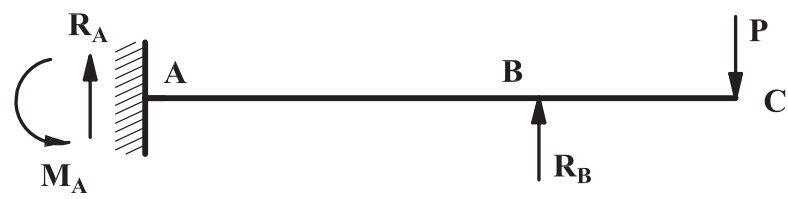

Fig. 6.30. Exemple 6.12. Sistema isostàtic estàticament equivalent

La condició de compatibilitat de desplaçament és: $\mathrm{v}_{\mathrm{B}}=0$.

Si ho plantegem pel mètode de Maxwell-Mohr, hem de calcular les reaccions a l'encast, que ens quedaran en funció de $\mathrm{R}_{\mathrm{B}}$ :

$R_{A}=P-R_{B}$

$M_{A}=3 L P-2 L R_{B}$

La llei de moments flectors és en dos trams:

$0 \leq x \leq 2 L \rightarrow M_{1}(x)=R_{A} x-M_{A}=\left(P-R_{B}\right) x+2 L R_{B}-3 L P$

$2 L \leq x \leq 3 L \rightarrow M_{2}(x)=R_{A} x-M_{A}+R_{B}(x-2 L)=\left(P-R_{B}\right) x+2 L R_{B}-3 L P+R_{B}(X-2 L)$

Apliquem una força fictícia unitària en $\mathrm{B}$, i calculem els diagrames de moments.

La llei de moments ficticis també és en dos trams.

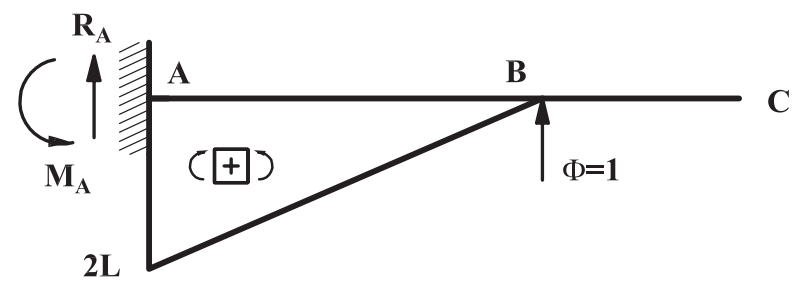

Fig. 6.31. Exemple 6.12. Força fictícia i diagrama 
$0 \leq x \leq 2 L \rightarrow M_{\Phi 1}(x)=2 L-x$

$2 L \leq x \leq 3 L \rightarrow M_{\Phi 2}(x)=0$

Apliquem la condició de compatibilitat:

$v_{B}=\frac{1}{E I_{Z}}\left[\int_{0}^{2 \mathrm{~L}} M_{1}(x) \cdot M_{\Phi 1}(x) d x+\int_{2 \mathrm{~L}}^{3 \mathrm{~L}} M_{2}(x) \cdot M_{\Phi 2}(x) d x\right]=0$

$v_{B}=\frac{1}{E I_{Z}}\left[\int_{0}^{2 \mathrm{~L}}\left(\left(P-R_{B}\right) x+2 L R_{B}-3 L P\right) \cdot(2 L-x) d x\right]=0$

Hem de fer el producte dels dos polinomis, integrar i aïllar $\mathrm{R}_{\mathrm{B}}$. El resultat és:

$R_{B}=17,5 \mathrm{kN}$

Mitjançant les equacions d'equilibri estàtic, obtenim les altres dues reaccions:

$R_{A}=-7,5 \mathrm{kN} ; M_{A}=10 \mathrm{kN}$

Ara que ja està resolt l'hiperestatisme, hem de calcular el desplaçament en C. Apliquem una força fictícia en $\mathrm{C}$, sobre l'estructura equivalent anterior.

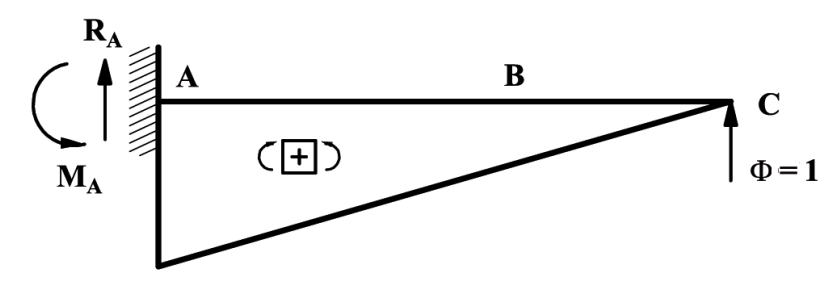

Fig. 6.32. Exemple 6.12. Força fictícia i diagrama

La llei de moments reals és la mateixa que abans. La llei de moments «ficticis» és en un tram.

$\mathrm{M}_{\Phi}(x)=3 L-x$

$v_{C}=\frac{1}{E I_{Z}}\left[\int_{0}^{\mathrm{2L}} M_{1}(x) \cdot M_{\Phi} d x+\int_{2 \mathrm{~L}}^{3 \mathrm{~L}} M_{2}(x) \cdot M_{\Phi}(x) d x\right]=2,7 \cdot 10^{-3} m$

El problema podria haver sigut resolt pel mètode d'interpretació gràfica, i probablement resultarà més fàcil el càlcul d'àrees senzilles que fer el producte dels polinomis i després integrar i aïllar les solucions (a menys que es dispose d'una eina informàtica). Es deixa proposada per a l'alumne la resolució mitjançant el mètode gràfic. Tanmateix farem un recordatori: les funcions de les lleis de moments reals i les lleis de moments ficticis han de ser contínues en cada tram. Quan estem resolent l'hiperestatisme, les àrees que ens apareixen són les de la figura: 


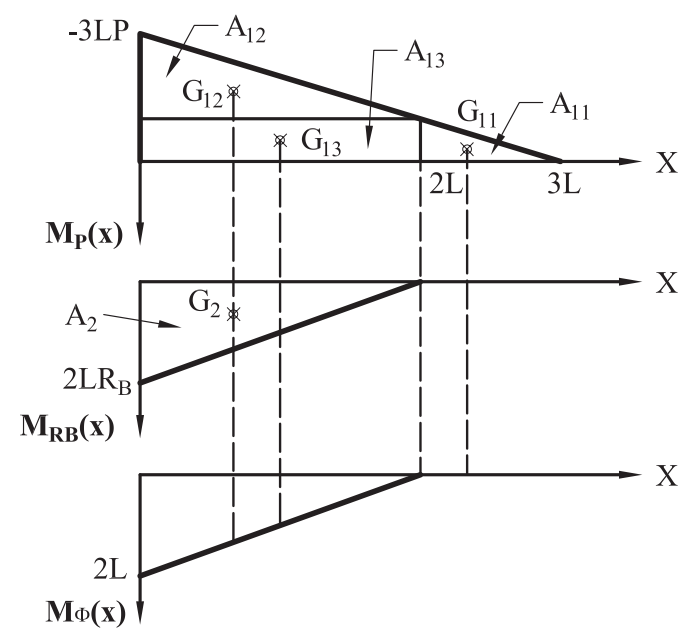

Fig. 6.33. Exemple 6.12. Mètode gràfic

L'àrea 1 cal dividir-la en dues parts, de 0 a $2 L$ i de $2 L$ a $3 L$. La part de la dreta és un triangle $\left(\mathrm{A}_{11}\right)$, però la de l'esquerra és un trapezi. L'àrea del trapezi i la posició del seu centre de gravetat no és una cosa que normalment tinguem a la memòria, per la qual cosa podem dividir el trapezi en un triangle $\left(A_{12}\right)$ i un rectangle $\left(A_{13}\right)$. A partir d'això, el mètode és equivalent a l'anterior: plantegem el moviment vertical de $B$, que és zero, $i$ aillem $R_{B}$.

$v_{B}=\frac{1}{E I_{Z}}\left[A_{11} \cdot M_{\Phi}\left(X_{G 11}\right)+A_{12} \cdot M_{\Phi}\left(X_{G 12}\right) A_{13} \cdot M_{\Phi}\left(X_{G 13}\right)+A_{2} \cdot M_{\Phi}\left(X_{G 2}\right)\right]$

\section{Exemple 6.13}

Per a la biga amb tres recolzaments de la figura:

a) Calculeu les reaccions i els diagrames d'esforços.

b) Calculeu el mínim perfil necessari de la secció tubular quadrada per a que no se supere la tensió admissible.

c) Calculeu el valor de la fletxa màxima i el lloc on es produeix.

d) Estimeu la deformada.

Dades: $\mathrm{E}=210 \mathrm{GPa} ; \mathrm{q}=125 \mathrm{kN} / \mathrm{m} ; \mathrm{L}=3 \mathrm{~m} ; \sigma_{\text {adm }}=142 \mathrm{MPa}$.

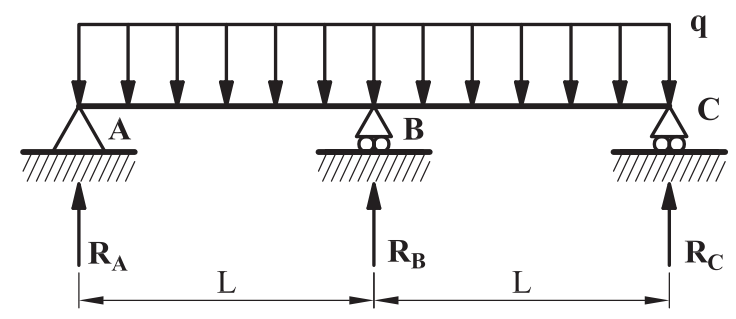

Fig. 6.34. Exemple 6.13. Enunciat 
És un problema hiperestàtic, tenim més incògnites que equacions disponibles. Per a resoldre'l escollirem una incògnita com a hiperestàtica, en aquest cas, $R_{B}$, llevarem el recolzament lliscant $\mathrm{i}$ introduirem una força exterior. La condició de compatibilitat de desplaçament és que el punt B no es desplaça.

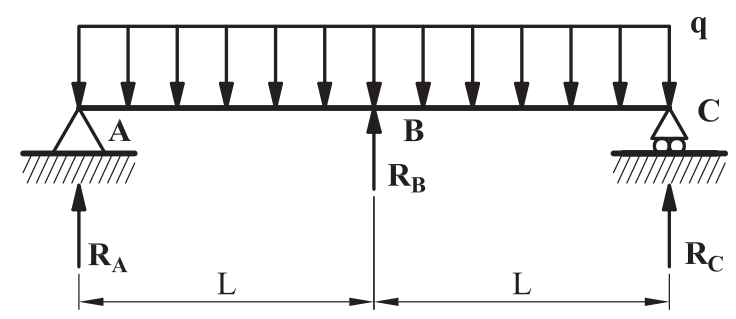

Fig. 6.35. Exemple 6.13. Sistema isostàtic estàticament equivalent

Aquest problema el resoldrem pel mètode gràfic. Com que el diagrama de moments flectors no ens dóna figures conegudes, apliquem el principi de superposició per a tindre àrees senzilles.

Si considerem només q, les reaccions són: $R_{A q}=R_{C q}=q L=375 \mathrm{kN}$.

La llei de moments flectors: $M_{q}(x)=R_{A q} x-q \frac{x^{2}}{2}$.

Aquesta funció és una paràbola amb un màxim en: $\mathrm{x}=\mathrm{L}: M_{q m a ̀ x}=562,5 \mathrm{kN} \cdot \mathrm{m}$.

Si considerem només $\mathrm{R}_{\mathrm{B}}$, les reaccions són: $R_{A R b}=R_{C R b}=\frac{-R_{B}}{2}$.

La llei de moments és en dos trams:

$$
\begin{gathered}
0 \leq x \leq L \rightarrow M_{1}(x)=\frac{-R_{B}}{2} x \\
L \leq x \leq 2 L \rightarrow M_{2}(x)=\frac{-R_{B}}{2} x+R_{B}(x-L)=R_{B}\left(\frac{x}{2}-L\right)
\end{gathered}
$$

Aquesta funció és lineal, forma dos triangles, amb un màxim: $M_{R 1 m a ̀ x}=-R_{B} \frac{L}{2}$.

Apliquem una força puntual unitària (fictícia) en B. Els diagrames de moments «ficticis» són similars als anteriors, amb un màxim en $x=L$ de $M_{\text {Фmàx }}=L / 2$.

Podem escriure la llei de moments ficticis en dos trams:

$0 \leq x \leq L \rightarrow M_{1}(x)=\frac{-x}{2}$

$L \leq x \leq 2 L \rightarrow M_{2}(x)=\frac{x}{2}-L$ 


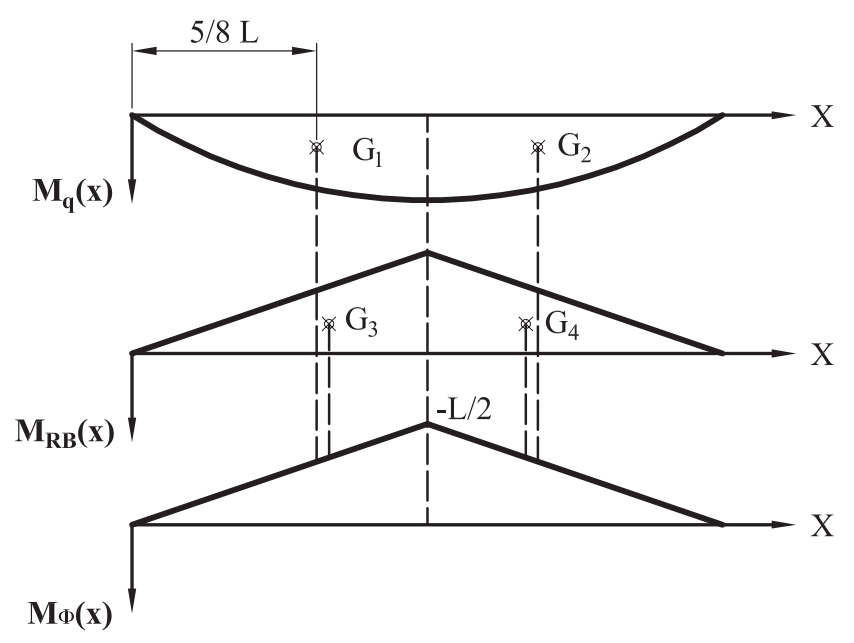

Fig. 6.36. Exemple 6.13. Diagrames d'esforços

Tenim quatre àrees:

$A_{1}=A_{2}=\frac{2}{3} L M_{q m a ̀ x}=1125 \mathrm{kN} \cdot \mathrm{m}^{2}$

$X_{G 1}=\frac{5}{8} L=1,875 m ; M_{\Phi}\left(X_{G 1}\right)=\frac{-X_{G 1}}{2}=-0,938 m$

$X_{G 2}=2 L-\frac{5}{8} L=4,125 m ; M_{\Phi}\left(X_{G 2}\right)=\frac{X_{G 2}}{2}-L=-0,938 m$

$A_{3}=A_{4}=\frac{1}{2} L \frac{-R_{B} L}{2}=\frac{-R_{B} L^{2}}{4}=-2,25 R_{B}$

$X_{G 3}=\frac{2}{3} L=2 m ; M_{\Phi}\left(X_{G 3}\right)=\frac{-X_{G 3}}{2}=-1 m$

$X_{G 4}=2 L-\frac{2}{3} L=4 m ; M_{\Phi}\left(X_{G 4}\right)=\frac{X_{G 4}}{2}-L=-1 m$

$v_{B}=\frac{1}{E I_{Z}} \sum_{i} A_{i} \cdot M_{\Phi}\left(X_{G i}\right)=0$

$1125 \cdot(-0,938)+1125 \cdot(-0,938)-2,25 R_{B} \cdot(-1)-2,25 R_{B} \cdot(-1)=0$

$R_{B}=468,75 \mathrm{kN}$

Les altres reaccions es calculen amb les equacions d'equilibri:

$R_{A}+R_{B}+R_{C}=q \cdot 2 L$

$R_{B} L+R_{C} 2 L-q 2 L^{2}=0$

$R_{A}=R_{C}=140,625 \mathrm{kN}$ 


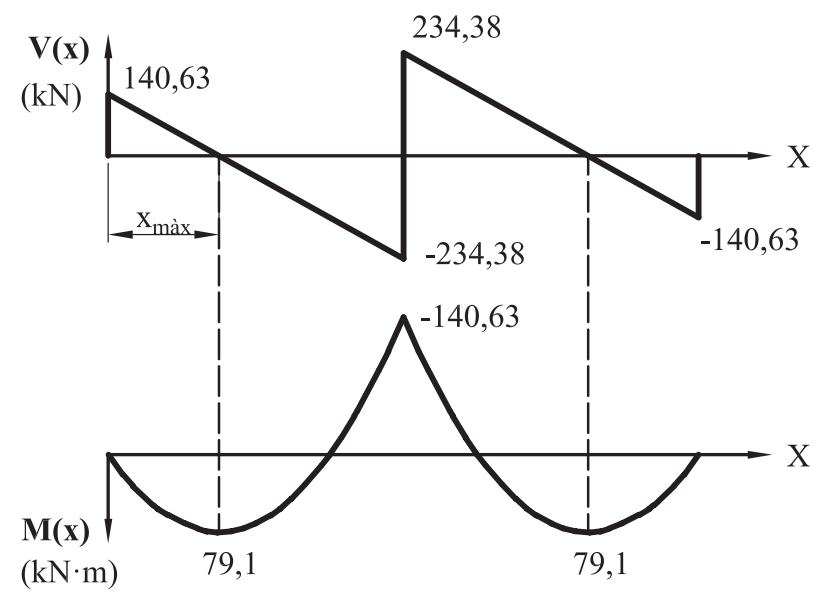

Fig. 6.37. Exemple 6.13. Diagrames d'esforços

Lleis d'esforços tallants:

$0 \leq x \leq L \rightarrow V_{1}(x)=R_{A}-q x$

$L \leq x \leq 2 L \rightarrow V_{2}(x)=R_{A}+R_{B}-q x$

Lleis de moments flectors:

$0 \leq x \leq L \rightarrow M_{1}(x)=R_{A} x-q \frac{x^{2}}{2}$

$L \leq x \leq 2 L \rightarrow V_{2}(x)=R_{A} x+R_{B}(x-L)-q \frac{x^{2}}{2}$

Es produeix un màxim relatiu en els moments flectors quan el tallant s'anul·la.

$x_{\text {màx }}=\frac{R_{A}}{q}=1,125 \mathrm{~m} ; M_{1}\left(x_{\text {màx }}\right)=79,1 \mathrm{kN} \cdot \mathrm{m}$

D'una altra banda, existeix un màxim en el punt $\mathrm{B}$, que veiem que és més desfavorable.

Dimensionarem la secció amb aquest moment:

$W_{\text {Zneces }}=\frac{\left|M_{1}(L)\right|}{\sigma_{\text {adm }}}=9,9 \cdot 10^{-4} \mathrm{~m}^{3}=990 \mathrm{~cm}^{3}$

Busquem en una taula de perfils comercials i el primer perfil que té més inèrcia que la necessària és el perfil de $25 \mathrm{~cm}$ de costat i $16 \mathrm{~mm}$ de gruix.

Càlcul de la fletxa màxima. A causa de la simetria, només calcularem el primer tram.

$\theta_{1}(x)=\int \frac{M_{1}(x)}{E I_{Z}} d x=\frac{1}{E I_{Z}}\left[R_{A} \frac{x^{2}}{2}-q \frac{x^{3}}{6}+C_{1}\right]$ 
$y_{1}(x)=\iint \frac{M_{1}(x)}{E I_{Z}} d x d x=\frac{1}{E I_{Z}}\left[R_{A} \frac{x^{3}}{6}-q \frac{x^{4}}{24}+C_{1} x+C_{2}\right]$

Condicions de contorn:

$x=0 \rightarrow y_{1}(x)=0 \rightarrow C_{2}=0$

$x=L \rightarrow y_{1}(x)=0 \rightarrow C_{1}=-70,31 \mathrm{kN} \cdot \mathrm{m}^{2}$

La màxima fletxa es produeix quan la derivada s'anul·la.

$\theta_{1}(x)=0 \rightarrow R_{A} \frac{x^{2}}{2}-q \frac{x^{3}}{6}+C_{1}=0$

Tenim una equació de tercer grau, amb tres solucions. L'única que es troba dins del tram considerat és: $x_{f m}=1,265 \mathrm{~m}$.

$y_{1}\left(x_{f m}\right)=-2,17 \cdot 10^{-3} \mathrm{~m}=-2,17 \mathrm{~mm}$. És negatiu perquè el punt baixa.

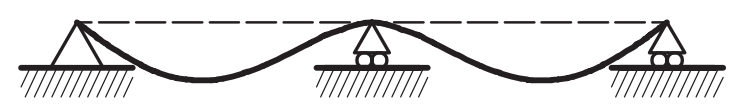

Fig. 6.38. Exemple 6.13. Deformada

\section{Exemple 6.14.}

Les bigues de la figura són de la mateixa longitud i estan en contacte al seu punt mitjà. Abans d'aplicar les càrregues, les bigues no tenen cap deformació i no exerceixen cap força l'una sobre l'altra. Calculeu, quan les càrregues s'apliquen, les reaccions $i$ el descens del punt mitjà $(\mathrm{E})$.

Dades: $\mathrm{P}=50 \mathrm{kN} ; \mathrm{L}=4 \mathrm{~m} ; \mathrm{E}=210 \mathrm{GPa} ; \mathrm{I}_{\mathrm{z}}=11.770 \mathrm{~cm}^{4}$.

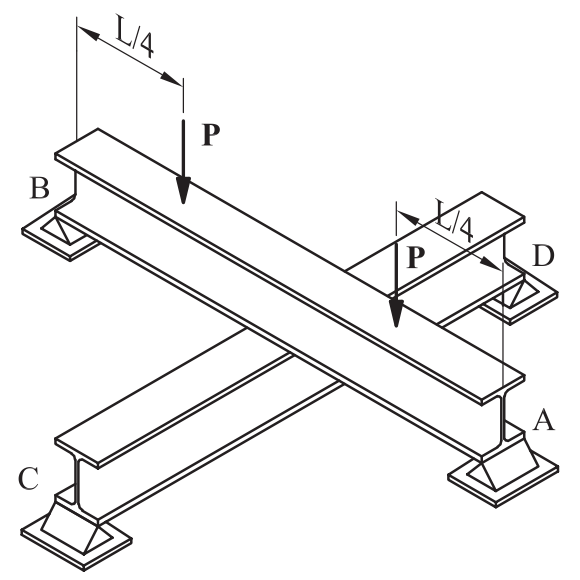

Fig. 6.39. Exemple 6.14. Enunciat 
El sistema és hiperestàtic $(\mathrm{GH}=1)$. El que farem en aquests casos d'estructures que interactuen entre elles serà separar-les, considerar la força mútua com a força exterior i plantejar una compatibilitat de desplaçament entre els punts d'unió. La incògnita en aquest cas serà la força mútua.
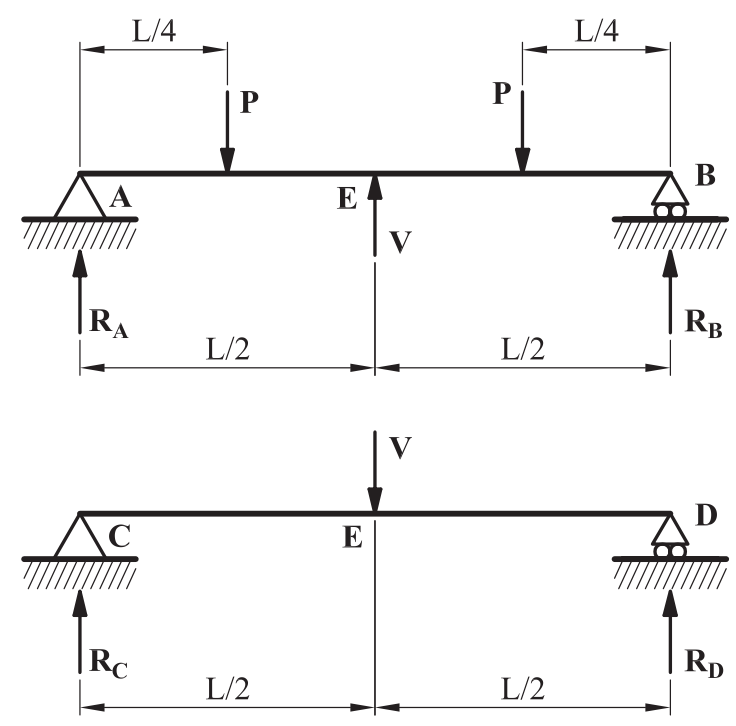

Fig. 6.40. Exemple 6.14. Separació en dos subsistemes

En el primer subsistema, aplicarem superposició, i separarem les càrregues conegudes $(\mathrm{P})$ i les desconegudes $(\mathrm{V})$.

Considerem només les càrregues $\mathrm{P}$, les reaccions són: $R_{A P}=R_{B P}=P$ i el diagrama de moments:

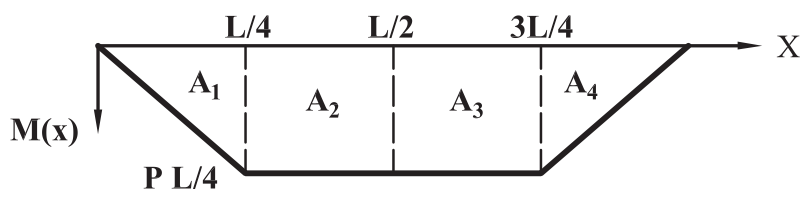

Fig. 6.41. Exemple 6.14. Subsistema 1. Diagrama de moments només amb les càrregues $\mathrm{P}$

Si considerem la càrrega $\mathrm{V}$, les reaccions són: $R_{A V}=R_{B V}=-V / 2$ i el diagrama de moments:

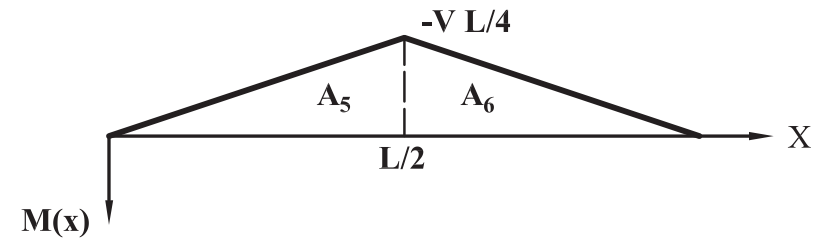

Fig. 6.42. Exemple 6.14. Subsistema 1. Diagrama de moments només amb la càrrega V

Per a calcular el desplaçament del punt E, hi apliquem una força fictícia unitària en direcció vertical i calculem els seus diagrames. 


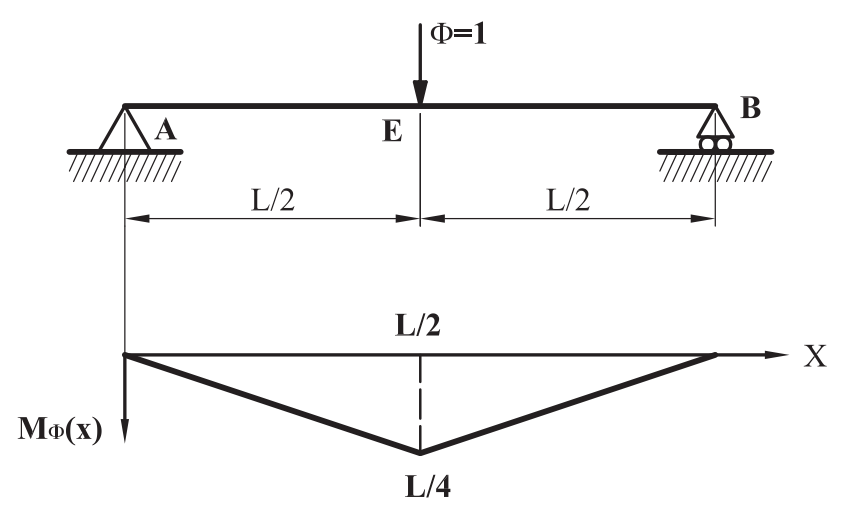

Fig. 6.43. Exemple 6.14. Subsistema 1. Força fictícia i diagrama de moments

Ho resoldrem amb el mètode gràfic. Com que el diagrama de moments «ficticis» té una discontinuiitat en $\mathrm{L} / 2$, hem de dividir el rectangle central de la figura 6.41 en $\operatorname{dos}\left(\mathrm{A}_{2} \mathrm{i} \mathrm{A}_{3}\right)$.

$A_{1}=A_{4}=\frac{1}{2} \frac{L}{4} \frac{P L}{4}=\frac{P L^{2}}{32}=25 \mathrm{kN} \cdot \mathrm{m}^{2} ; X_{G 1}=\frac{2}{3} \frac{L}{4}=\frac{L}{6} ; M_{\Phi}\left(X_{G 1}\right)=\frac{L}{12}=0,33 \mathrm{~m}$

A causa de la simetria, podem deduir que:

$A_{2}=A_{3}=\frac{L}{4} \frac{P L}{4}=\frac{P L^{2}}{16}=50 \mathrm{kN} \cdot \mathrm{m}^{2} ; X_{G 2}=\frac{L}{4}+\frac{1}{2} \frac{L}{4}=1,5 \mathrm{~m} ; M_{\Phi}\left(X_{G 2}\right)=\frac{L}{16}=0,25 \mathrm{~m}$

A causa de la simetria, podem deduir que:

$A_{5}=A_{6}=\frac{1}{2} \frac{L}{2} \frac{(-V L)}{4}=\frac{-V L^{2}}{16} ; X_{G 5}=\frac{2}{3} \frac{L}{2}=1,33 \mathrm{~m} ; M_{\Phi}\left(X_{G 5}\right)=\frac{L}{6}=0,67 \mathrm{~m}$

A causa de la simetria, podem deduir que: $M_{\Phi}\left(X_{G 6}\right)=M_{\Phi}\left(X_{G 5}\right)$.

El desplaçament vertical del punt E és:

$v_{E 1}=\frac{1}{E I_{Z}}\left[\sum_{i=1}^{6} A_{i} \cdot M_{\Phi}\left(X_{G i}\right)\right]=\frac{1}{E I_{Z}}\left[\frac{5 P L^{3}}{384}-\frac{V L^{3}}{48}\right]$

Al segon subsistema, la cosa és molt pareguda.

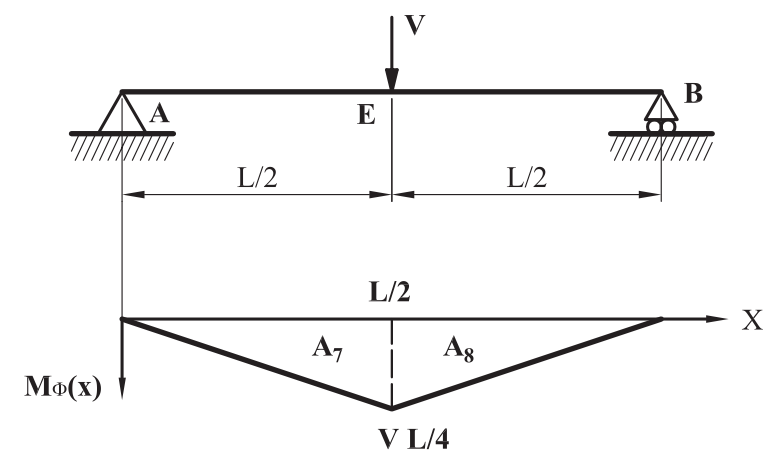

Fig. 6.44. Exemple 6.14. Subsistema 2 
La força fictícia i els diagrames d'esforços són completament equivalents als de la figura 6.43 .

$A_{7}=A_{8}=\frac{1}{2} \frac{L}{2} \frac{V L}{4}=\frac{V L^{2}}{16} ; X_{G 7}=\frac{2}{3} \frac{L}{2}=1,33 \mathrm{~m} ; M_{\Phi}\left(X_{G 7}\right)=\frac{L}{6}=0,67 \mathrm{~m}$

A causa de la simetria, podem deduir que: $M_{\Phi}\left(X_{G 8}\right)=M_{\Phi}\left(X_{G 7}\right)$.

$v_{E 2}=\frac{1}{E I_{Z}}\left[\sum_{i=7}^{8} A_{i} \cdot M_{\Phi}\left(X_{G i}\right)\right]=\frac{1}{E I_{Z}}\left[\frac{V L^{3}}{48}\right]$

La condició de compatibilitat de desplaçaments és que $v_{E 1}=v_{E 2}$.

Com que només tenim una incògnita, podem aïllar-la: $V=15,63 \mathrm{kN}$.

Les reaccions es calculen amb les equacions d'equilibri.

$$
R_{A}=R_{B}=\frac{(2 P-V)}{2}=42,19 \mathrm{kN} ; R_{C}=R_{D}=\frac{V}{2}=7,81 \mathrm{kN}
$$

Podem calcular el descens del punt E amb qualsevol de les dues expressions anteriors.

$v_{E}=8,23 \cdot 10^{-4} \mathrm{~m}=0,823 \mathrm{~mm}$ 


\section{Problemes proposats}

6.1. Calculeu l'equació de la deformada de la següent biga voladissa.

Dades: a, L, P, E, I

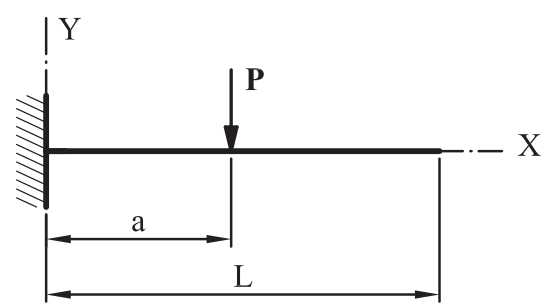

Fig. P.6.01

6.2. Siga la següent biga voladissa amb una càrrega distribuïda que actua al seu extrem final.

a) Calculeu l'equació de l'elàstica en funció de $q, E, I_{Z}, L$.

b) Particularitzant per a un IPE 330 d'acer S275, i els valors $L=4 m ; q=5 \mathrm{kN} / \mathrm{m}$, calculeu la fletxa i el gir a l'extrem del voladís.

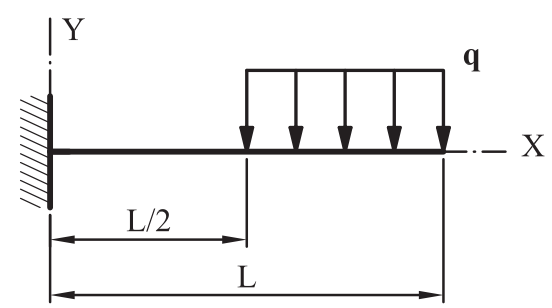

Fig. P.6.02

6.3. En la mateixa biga de l'exemple 6.3 per a la qual hem calculat l'equació de l'elàstica, considerem que la secció està composta per dos materials, fusta $\mathrm{i}$ acer. La part de fusta té de dimensions $20 \times 30 \mathrm{~cm}$ i se li ha adossat una platina de $20 \mathrm{~mm}$ de gruix d'acer a la part inferior, com es mostra a la figura. Calculeu el desplaçament del punt mitjà de la biga si la càrrega s'aplica en $\mathrm{a}=3 \mathrm{~m}$.

Dades: $\mathrm{E}_{1}=20 \mathrm{GPa} ; \mathrm{E}_{2}=210 \mathrm{GPa} ; \mathrm{L}=4 \mathrm{~m} ; \mathrm{a}=3 \mathrm{~m} ; \mathrm{P}=10 \mathrm{kN}$.

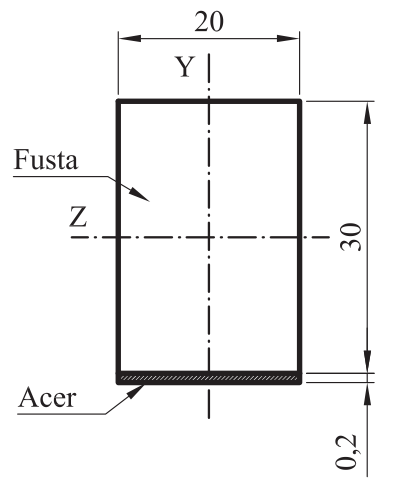

Fig. P.6.03 
6.4. Calculeu l'equació de l'elàstica en la biga de la figura, en la qual el punt B és una articulació. Calculeu el descens dels punts B i D.

Dades: $\mathrm{M}=20 \mathrm{kN} \cdot \mathrm{m} ; \mathrm{q}=10 \mathrm{kN} / \mathrm{m} ; \mathrm{P}=10 \mathrm{kN} ; \mathrm{E}=210 \mathrm{GPa} ; \mathrm{I}_{\mathrm{Z}}=2,772 \cdot 10^{-5} \mathrm{~m}^{4}$.

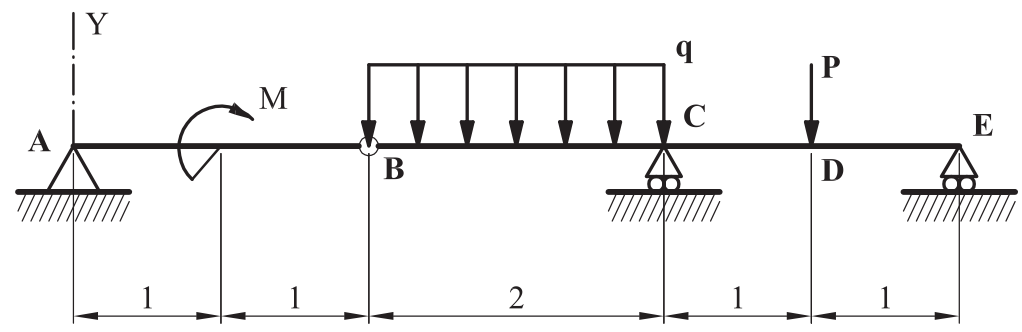

Fig. P.6.04

Nota: aquest exercici és isostàtic. Com que tenim una ròtula, es recomana calcular les lleis de moments a les dues parts de manera separada, desarticulant per la unió i calculant el resultat de la reacció dins del passador (V). S'utilitza la variable x per al primer tram, i a partir de B es canvia a la variable $\mathrm{w}($ al punt $\mathrm{B}$ tindrem $\mathrm{w}=0$ ).

6.5. Calculeu l'equació de l'elàstica en la biga de la figura. Calculeu el descens dels punts B i D.

Dades: $\mathrm{M}=20 \mathrm{kN} \cdot \mathrm{m} ; \mathrm{q}=10 \mathrm{kN} / \mathrm{m} ; \mathrm{P}=10 \mathrm{kN} ; \mathrm{E}=210 \mathrm{GPa} ; \mathrm{I}_{\mathrm{Z}}=2,772 \cdot 10^{-5} \mathrm{~m}^{4}$.

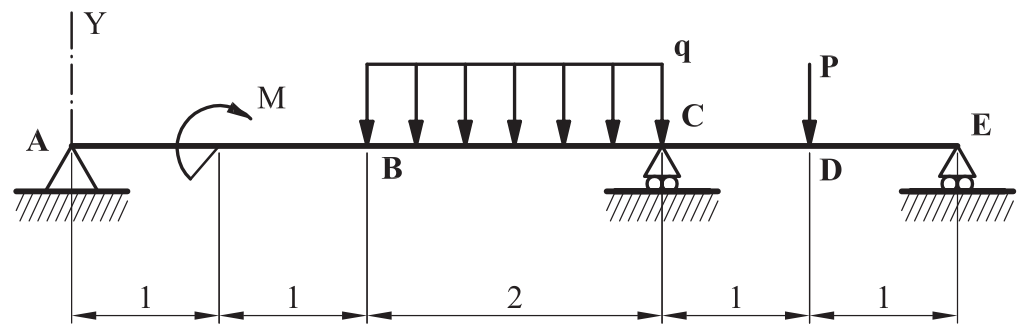

Fig. P.6.05

Nota: aquest exercici és hiperestàtic. Calcularem la llei de moments flectors a l'últim tram. Amb els desplaçaments coneguts dels punts A, C, E i les dues equacions de l'estàtica, podem resoldre el sistema.

6.6. Calculeu les reaccions de la biga doblement encastada de la figura. Utilitzeu el mètode universal per al càlcul de l'equació de l'elàstica, sense fer simplificacions per simetria.

Dades: a, M, q.

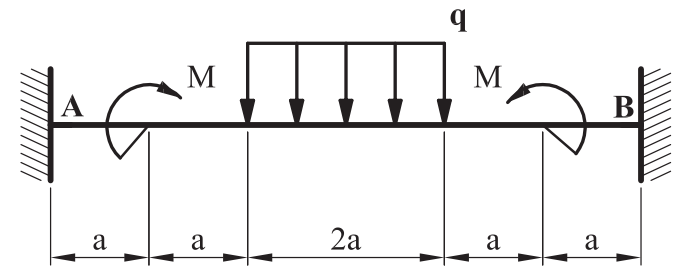

Fig. P.6.06 
Nota: aquest cas és hiperestàtic de grau 2. Als encastos tindrem dues condicions de contorn: el desplaçament i el gir són zero.

6.7. Torneu a resoldre els exemples 6.7 i 6.8 pel mètode de la interpretació gràfica.

6.8. Torneu a resoldre els exemples 6.9 i 6.10 pel mètode de Maxwell-Mohr.

6.9. Calculeu el desplaçament del punt B.

Dades: q, L, E, I .

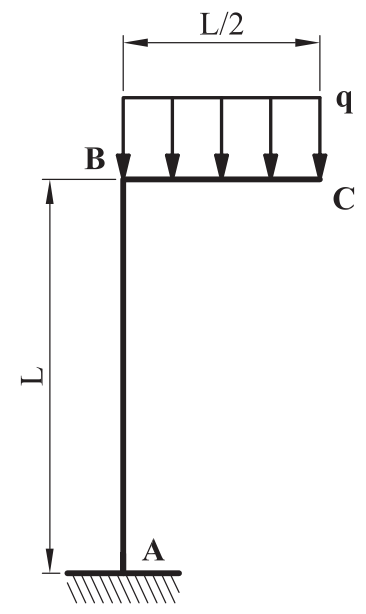

Fig. P.6.09

6.10. Calculeu el desplaçament del punt mitjà del següent sistema.

Dades: P, a, E, I

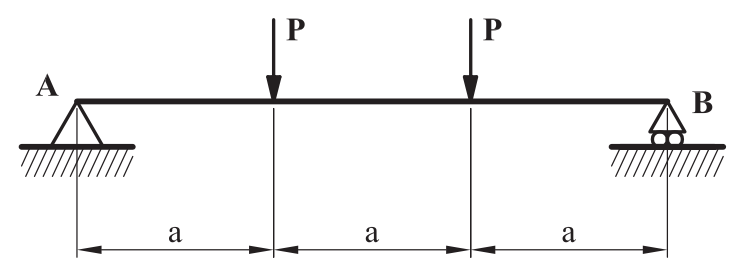

Fig. P.6.10

6.11. Es desitja construir una biga de fusta amb els tres recolzaments de la figura $(\mathrm{A}, \mathrm{B}, \mathrm{D}) \mathrm{i}$ una ròtula intermèdia $(\mathrm{C})$ perquè suporte les càrregues que es mostren.

a) Dimensioneu la biga emprant una secció rectangular de fusta amb una relació ample/cantell: $\frac{b}{h}=\frac{2}{3}$ (negligiu l'efecte de les tensions tangencials degudes a l'esforç tallant). 
b) Calculeu el gir del punt E, extrem del voladís.

Dades: $\mathrm{P}=5 \mathrm{kN} ; \mathrm{q}=7 \mathrm{kN} / \mathrm{m} ; \mathrm{L}=1 \mathrm{~m} ; \mathrm{E}=10 \mathrm{GPa} ; \sigma_{\text {adm }}=5 \mathrm{MPa}$.

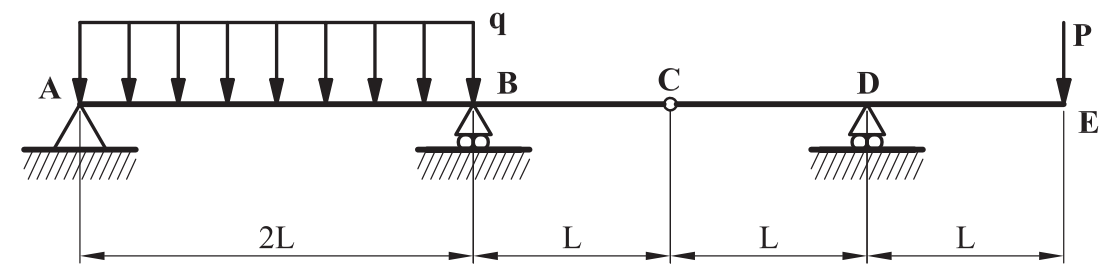

Fig. P.6.11

6.12. Calculeu la fletxa en el punt d'aplicació de la càrrega.

Dades: P, a, E, $\mathrm{I}_{\mathrm{Z}}$.

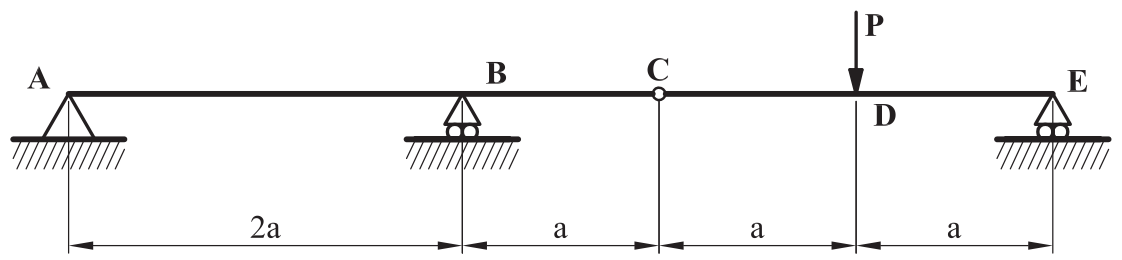

Fig. P.6.12

6.13. Calculeu el màxim moment flector en el sistema de la figura.

Dades: P, a, E, I .

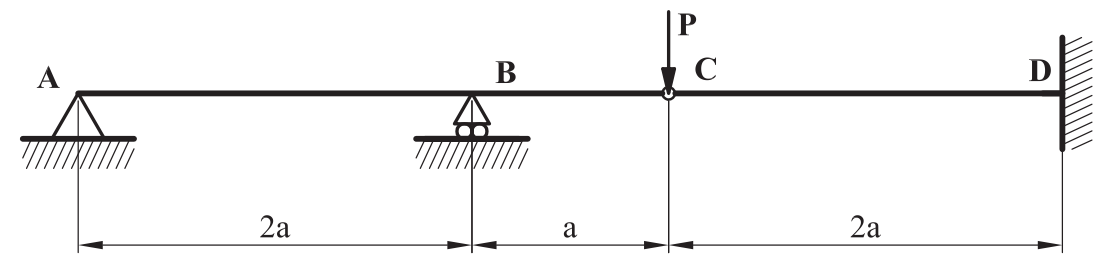

Fig. P.6.13

6.14. Per a l'estructura de la figura:

a) Calculeu les reaccions.

b) Representeu els diagrames d'esforços.

c) Estimeu la deformada.

d) Calculeu la fletxa al punt B.

e) Calculeu el gir al punt C.

Dades: $\mathrm{P}=4 \mathrm{kN} ; \mathrm{L}=4 \mathrm{~m} ; \mathrm{E}=210 \mathrm{GPa}$; secció IPN -100 . 


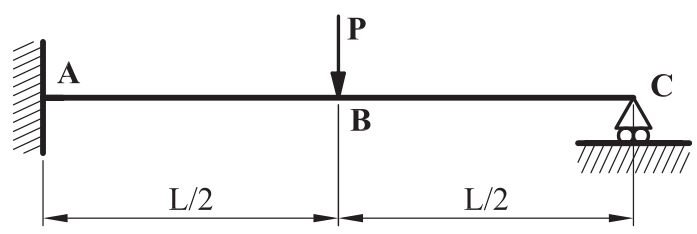

Fig. P.6.14

6.15. Calculeu les reaccions als encastos.

Dades: q, a, E, I .

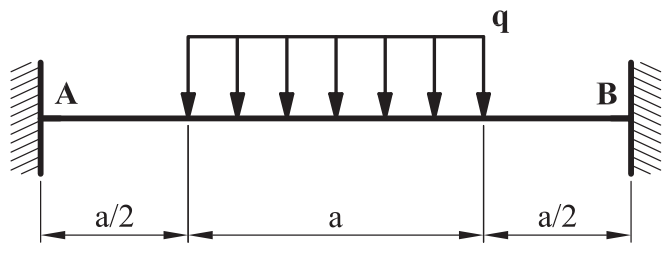

Fig. P.6.15

Nota: aquest problema és hiperestàtic de grau $2(\mathrm{GH}=2)$. Hem d'alliberar dues restriccions de moviment, per exemple les limitacions al gir, i introduir dos moments exteriors. D'aquesta manera obtenim dues condicions de compatibilitat de desplaçament: el gir en A i el gir en B són zero. A partir d'elles, tindrem dues equacions amb dues incògnites, que podrem resoldre.

6.16. Calculeu les reaccions i representeu els diagrames d'esforços.

Dades: q, P, a, E, I

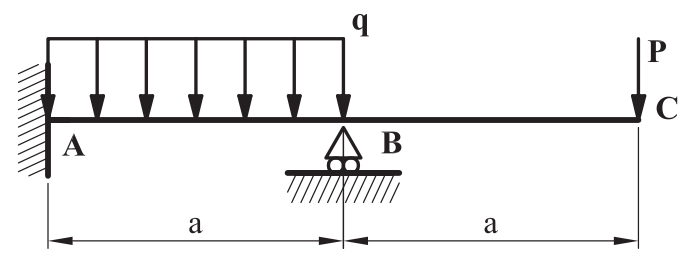

Fig. P.6.16

6.17. Considerant la biga de secció constant de la figura, es demana:

a) Diagrama d'esforços tallants i moments flectors.

b) Desplaçament vertical de la secció $\mathrm{D}$, on es troba l'articulació.

c) Gir de la secció $C$, on apliquem la càrrega $P$.

d) Estimeu la deformada.

Dades: P, a, E, I . 


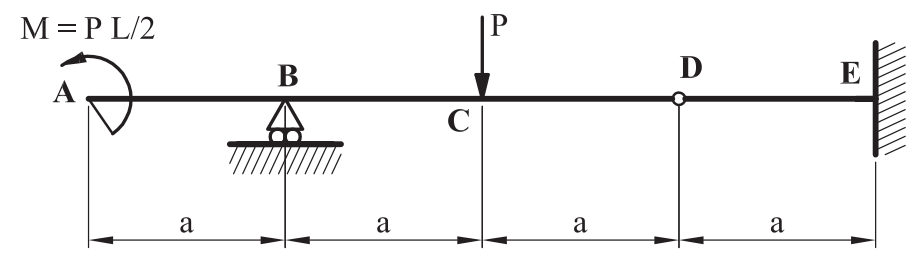

Fig. P.6.17

6.18. En la biga de la figura, determineu:

a) Reaccions i diagrama d'esforços tallants i moments flectors.

b) Perfil IPE necessari.

c) Fletxa al punt mitjà.

d) Variació dels diagrames i de la fletxa si el punt B descendeix $1 \mathrm{~cm}$.

e) Validesa del dimensionament en el cas del descens imposat.

Dades: $\mathrm{P}=140 \mathrm{kN} ; \mathrm{L}=2 \mathrm{~m}$; acer S275.

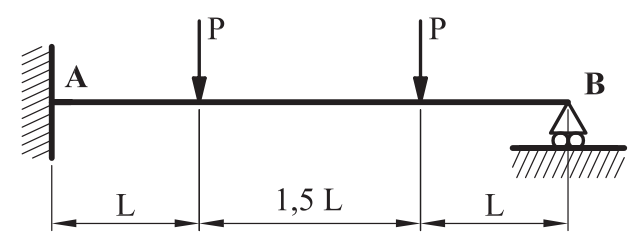

Fig. P.6.18

Nota: el punt $d$ és un desplaçament imposat. Representa, per exemple, el que passaria si una sabata de cimentació s'afonara un centímetre. El problema es resol de la mateixa manera que habitualment, però aquest cop, la condició de compatibilitat no és que el punt B no descendeix, sinó que descendeix el valor marcat a l'enunciat.

6.19. La biga $A B C$ que es mostra a la figura es troba encastada en $\mathrm{C}$ i es recolza en $\mathrm{B}$, punt mitjà de la biga transversal EF. Quan no s'aplica càrrega, ambdues bigues estan en contacte sense transmetre's cap càrrega. Calculeu quina és la càrrega que es transmet a la biga $\mathrm{EF} i$ quant descendix el punt $\mathrm{B}$.

Dades: $\mathrm{P}=1 \mathrm{kN} ; \mathrm{L}_{\mathrm{CB}}=3 \mathrm{~m} ; \mathrm{L}_{\mathrm{BA}}=2 \mathrm{~m} ; \mathrm{L}_{\mathrm{DB}}=\mathrm{L}_{\mathrm{BE}}=2,5 \mathrm{~m}$; ambdues bigues: perfil buit rectangular $120 \times 60 \times 6(\mathrm{~S} 275), \mathrm{I}_{\mathrm{Z}}=317 \mathrm{~cm}^{4}$.

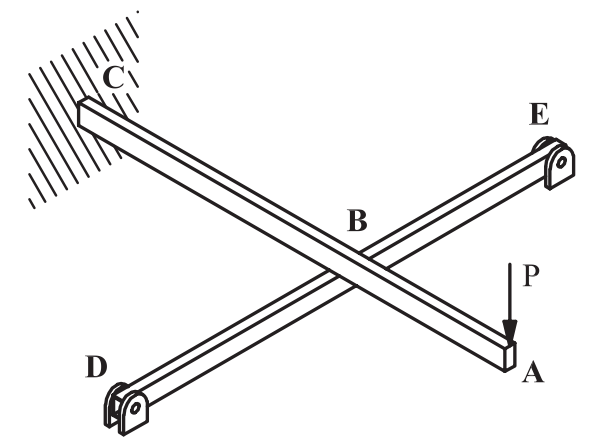

Fig. P.6.19 
6.20. En el sistema de la figura, determineu l'esforç axial al tirant CD i el descens del punt $\mathrm{C}$. El punt $\mathrm{C}$ permet el gir del tirant, però no és una articulació per a la barra $\mathrm{AB}$.

Dades:

- Tirant: $\mathrm{E}=200 \mathrm{GPa} ; \mathrm{A}=1 \mathrm{~cm}^{2}$.

- Bigues: $\mathrm{E}=40 \mathrm{GPa}$; secció 20 × $20 \mathrm{~cm}$.

- $\mathrm{P}=30 \mathrm{kN} ; \mathrm{a}=1 \mathrm{~m}$.

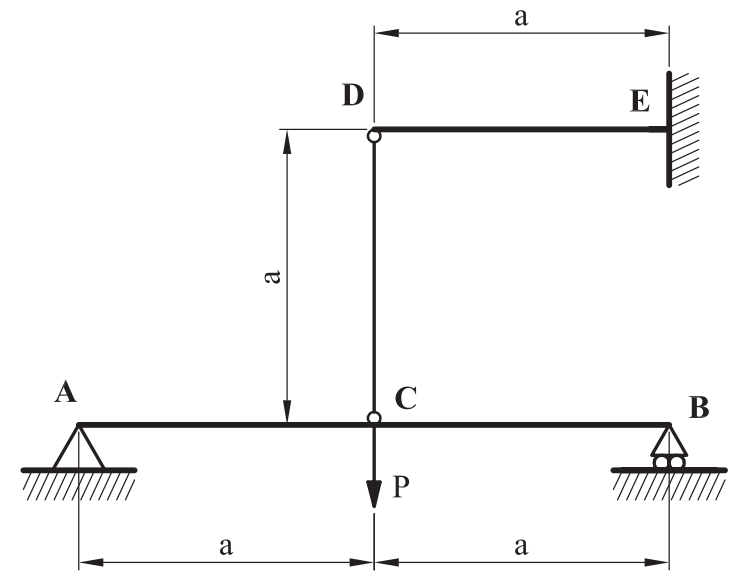

Fig. P.6.20

Nota: Aquest és un cas hiperestàtic que combina la teoria de flexió i la d'axial. El tirant $\mathrm{CD}$ està biarticulat i només té càrregues als extrems, per la qual cosa només treballa a axial. Per a resoldre'l, separarem els tres elements, considerant l'axial al cable $(\mathrm{Q})$ com a càrrega exterior, que serà la incògnita que haurem de calcular. En la condició de compatibilitat de desplaçaments hem de considerar l'allargament del cable. Per tant, la condició serà: el punt $\mathrm{C}$ descendirà el mateix que $\mathrm{D}$, més l'allargament del tirant $\left(v_{C}=v_{D}+\Delta L\right)$. 


\section{TEMA 7}

\section{Torsió}

\subsection{Introducció}

Una estructura està sotmesa a torsió quan en les seues seccions transversals actuen moments en la direcció de l'eix X. Aquests moments s'anomenen moments torçors $\left(M_{T}\right)$ i produeixen un retorciment de la secció al voltant de l'eix longitudinal. Exemples de peces que treballen a torsió són: eixos de transmissió, impulsors $\mathrm{d}$ 'hèlices, elements amb càrregues aplicades de manera excèntrica, etc. Normalment, els elements que han de treballar a torsió es dissenyen amb seccions rodones, massisses o buides, que són les que tenen un comportament millor quan han de resistir la torsió. El comportament de la resta de seccions és molt diferent i no sol ser adequat.

En general, en edificació, el moment torçor resulta indesitjable, i encara que és inevitable en alguns casos, un adequat disseny de l'estructura pot minimitzar els efectes no desitjats. Un cas molt típic d'element treballant amb moment torçor són les bigues que suporten un forjat només en un dels seus costats.

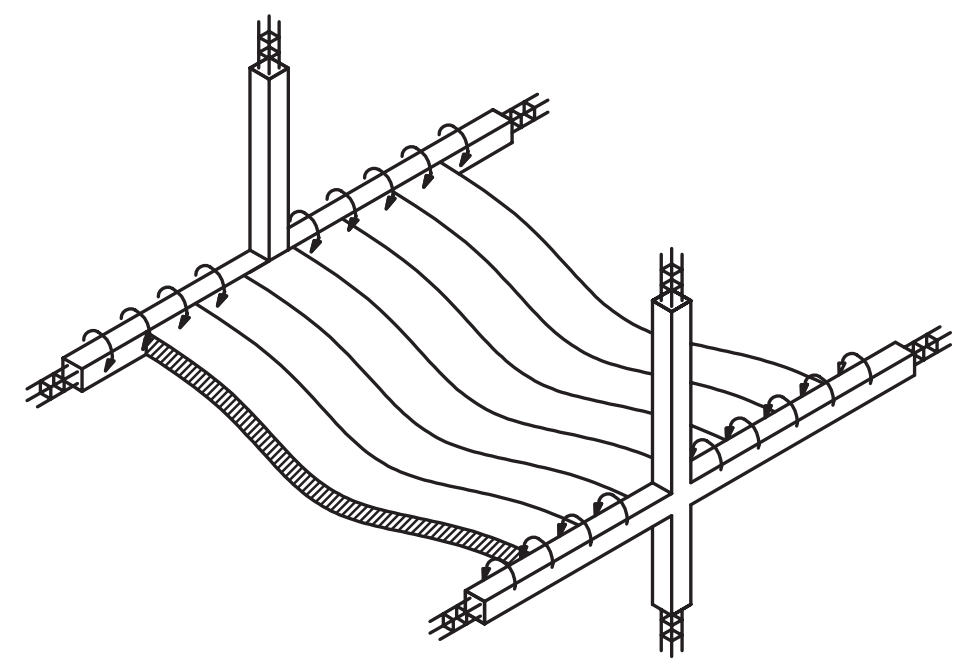

Fig. 7.1. Exemple de biga d'edificació sotmesa a torsió

En aquest tema estudiarem de manera molt sumària el comportament de bigues de secció circular, i en menor mesura, de bigues de seccions amb unes altres geometries. Per a un estudi en més profunditat, l'alumne interessat haurà de consultar la bibliografia recomanada. 


\subsection{Tensions degudes a torsió}

Considerem una biga que treballa a torsió pura. De totes les equacions que relacionen les tensions amb els esforços, l'única que no és nul·la és:

$$
M_{T}=\iint_{A}\left(\tau_{X Z} y-\tau_{X Y} z\right) d A
$$

Aquesta equació per si mateixa no permet determinar les tensions que el moment torçor origina en la secció. És necessari recórrer a la hipòtesi de Coulomb: «les seccions transversals circulars de la biga romanen planes durant la torsió, girant com un tot rígid al voltant de l'eix normal de la secció $(\mathrm{X}) »$.

En conseqüència, els radis de les seccions transversals giren i romanen rectes, mentre que les generatrius de la superfície lateral es transformen en hèlices. Com a conseqüència d'això, l'angle girat per les seccions (angle de torsió) és diferent en cadascuna d'elles, és a dir, és una funció que depén de $\mathrm{x}: \varphi=\varphi(\mathrm{x})$.

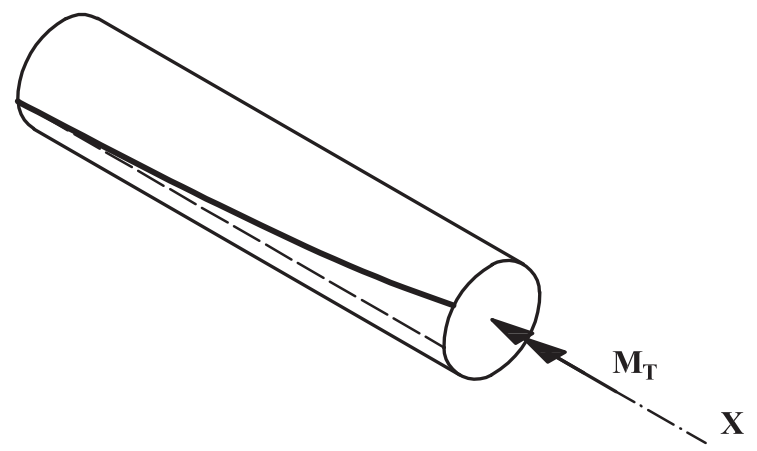

Fig. 7.2. Transformació d'una generatriu en hèlice en torsió (moment torçor negatiu)

També s'admet el règim elàstic i per tant, que es compleix la llei de Hooke.

Per totes aquestes raons, es pot demostrar que en tot punt de la secció les tensions normals són nul·les i només hi ha tensions tangencials.

La següent figura representa que agafem una llesca diferencial en una biga de secció circular sotmesa a un moment torçor positiu.

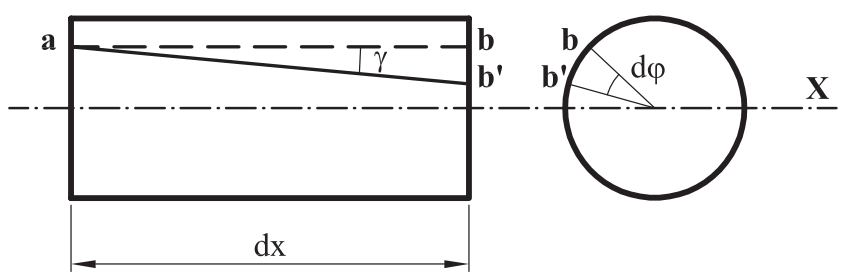

Fig. 7.3. Llesca diferencial de biga treballant a torsió

Com que estem en una llesca diferencial, l'angle girat per la secció és també diferencial $(\mathrm{d} \varphi)$. Podem considerar que l'hèlice és una línia recta i dir que la distorsió o deformació angular és: 


$$
\gamma \approx \tan \gamma=\frac{b b^{\prime}}{a b}=\frac{r d \varphi}{d x}
$$

Notes: quan un angle és molt menut, el valor de la seua tangent és pràcticament igual a l'angle en radians. La línia bb', que havíem considerat com a recta, en realitat és un arc de circumferència, per tant, és igual al radi multiplicat per l'angle.

Definirem l'angle de torsió per unitat de longitud com:

$$
\theta=\frac{d \varphi}{d x}
$$

i llavors:

$$
\gamma=r \frac{d \varphi}{d x}=r \theta
$$

Segons la llei de Hooke: $\tau=\mathrm{G} \gamma=\mathrm{Gr} \theta$.

En l'expressió anterior, $\mathrm{r}$ representa la distància de cada punt al centre del cercle. Les equacions anteriors estableixen que la deformació angular i la tensió tangencial varien linealment amb la distància radial des del centre. Ens falta deduir quina direcció portaran aquestes tensions tangencials. Si la tensió tangencial que actua en la secció transversal de la biga tinguera component radial, aquesta produiria el guerxament de la secció, la qual cosa està en contra de la hipòtesi de Coulomb. Per tant, l'esforç tallant en una secció transversal està dirigit segons una perpendicular al radi que passa per ell.

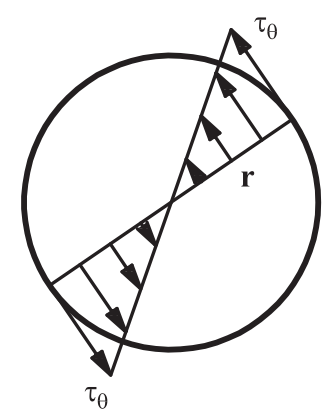

Fig. 7.4. Tensions tangencials degudes a torsió en secció circular massissa

Com que la tensió varia amb la distància al centre, no pareix que l'expressió en coordenades cartesianes siga la més adient.

Si l'equació $M_{T}=\iint_{A}\left(\tau_{X Z} y-\tau_{X Y} z\right) d A$ la transformem a coordenades polars, obtenim $M_{T}=\iint_{A} \tau_{\theta} r d A$ i com que $\tau=G r \theta$ obtenim: $M_{T}=G \theta \iint_{A} \mathrm{r}^{2} d A=G \theta I_{P}$.

Definirem moment d'inèrcia polar con: $I_{P}=\iint_{a} r^{2} d A$. 
De totes aquestes deduccions arribem a: $\theta=\frac{M_{T}}{G I_{P}}$ i llavors: $\tau=\frac{M_{T}}{I_{P}} r$.

La tensió tangencial varia entre un valor zero al centre de la secció $(r=0)$ i un valor màxim en el cantell $(r=R)$. Com podem apreciar, és una expressió francament semblant a la de la llei de Navier per a flexió, si assimilem els termes als de la torsió. Igual que en el cas de flexió, podem definir el moment resistent a torsió.

$W_{P}=\frac{I_{P}}{r_{m a ̀ x}}$ i la tensió ens queda: $\tau_{m a ̀ x}=\frac{M_{T}}{W_{P}}$.

Per a secció circular de diàmetre D:

$I_{P}=\iint_{a} r^{2} d A=\int_{0}^{D r^{2}} r^{2} 2 \pi r d r=\frac{\pi D^{4}}{32} \quad W_{P}=\frac{I_{P}}{D / 2}=\frac{\pi D^{3}}{16}$

Per a secció circular buida de diàmetres $\mathrm{D}$ i d:

$I_{P}=\iint_{a} r^{2} d A=\int_{\alpha_{2}}^{02} r^{2} 2 \pi r d r=\frac{\pi D^{4}}{32}\left(1-\frac{d^{4}}{D^{4}}\right) \quad W_{P}=\frac{I_{P}}{D / 2}=\frac{\pi D^{3}}{16}\left(1-\frac{d^{3}}{D^{3}}\right)$

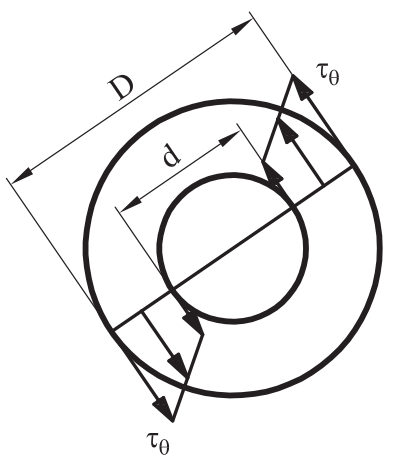

Fig. 7.5. Tensions tangencials degudes a torsió en secció circular buida

Moltes vegades s'utilitzen les seccions buides en lloc de les massisses. La raó és que al centre de la secció les tensions són molt més menudes que al cantell, i a més, el braç de palanca també és més menut. Per aquesta raó, el material que es troba a la part central està bastant desaprofitat. Podem eliminar-lo i fer un estalvi de material. Si el forat central es fa per mecanització, realment no estalviarem material i el treball de torn pot encarir la peça. Si el preu no és determinant, però el pes sí que ho és, si més no, aconseguirem tindre una peça més lleugera. 


\subsection{Gir de les seccions}

Tornem a l'expressió anterior:

$\theta=\frac{d \varphi}{d x}=\frac{M_{T}}{G I_{P}} \rightarrow d \varphi=\frac{M_{T}}{G I_{P}} d x$

El gir relatiu entre dues seccions A i B s'obté mitjançant la integral:

$$
\varphi_{A B}=\varphi_{B}-\varphi_{A}=\int_{A}^{B} \frac{M_{T}}{G I_{P}} d x
$$

Si el material i la secció són constants:

$\varphi_{A B}=\varphi_{B}-\varphi_{A}=\frac{1}{G I_{P}} \int_{A}^{B} M_{T} d x=\frac{A_{T}}{G I_{P}}$

$\mathrm{A}_{\mathrm{T}}$ és l'àrea del diagrama de moments torçors entre A i B.

Si, a més, el moment torçor també és constant: $\varphi_{A B}=\frac{M_{T} L}{G I_{P}}$.

\subsection{Perfils massissos no circulars}

Les equacions per a la torsió de barres circulars no poden usar-se per a les barres d'altres geometries. Les barres no circulars, com les rectangulars o les de forma en I, es comporten de manera diferentment de les barres circulars: les seues seccions transversals no romanen planes.

Les tensions màximes no es localitzen a les majors distàncies del punt mitjà de la secció.

Aquestes barres necessiten mètodes més avançats d'anàlisi, basats en la teoria de l'elasticitat, com la desenrotllada per Saint-Venant, o la de Prandtl, «analogia de la membrana».

Generalment farem un estudi simplificat, en el qual assumirem que, per exemple, per a una secció rectangular $(b \cdot h)$ :

$$
\tau_{\text {màx }}=\frac{M_{T}}{\alpha h b^{2}} \quad \theta=\frac{M_{T}}{\beta G b h^{3}}
$$


En la qual els coeficients $\alpha$ i $\beta$ estan tabulats:

\begin{tabular}{|c|c|c|c|c|}
\hline $\mathrm{h} / \mathrm{b}$ & 1 & 1.5 & 1.75 & 2 \\
\hline$\alpha$ & 0.208 & 0.231 & 0.239 & 0.246 \\
\hline$\beta$ & 0.141 & 0.196 & 0.212 & 0.229 \\
\hline
\end{tabular}

En aquests casos, la distribució de tensions no és com la que tenim en seccions circulars: en produir-se el guerxament, les tensions màximes no sempre les trobem als cantells. El guerxament de les seccions es pot comprovar fàcilment si sobre un tros de cautxú dibuixem una retícula i retorcem la peça.
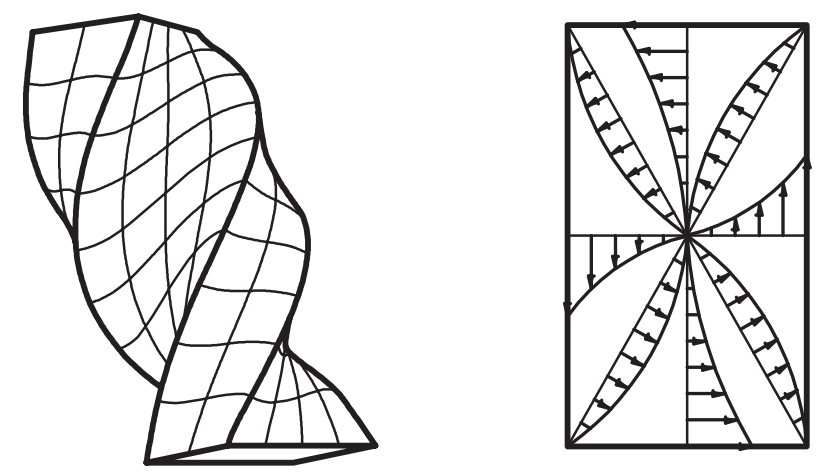

Fig. 7.6. Guerxament de les seccions i distribució de tensions en una peça de secció rectangular

En el cas de perfil circular, el moment d'inèrcia polar multiplicat per G representa una rigidesa. Per als perfils gruixut no circulars, es defineix un concepte nou, la rigidesa a torsió $(\mathrm{J})$, que s'obté de taules i amb el qual podem obtindre l'angle de torsió per unitat de longitud en una secció determinada quan s'aplica un moment torçor.

$$
J=\frac{M_{T}}{G \theta}
$$

\section{Exemple 7.1}

Una biga mènsula $\mathrm{AB}$ de secció circular de diàmetre $\mathrm{D}$ està sotmesa a dos moments torçors $\left(M_{1}\right.$ i $\left.M_{2}\right)$. Determineu:

a) La tensió tangencial màxima.

b) El diagrama d'angles de torsió.

Dades: $\mathrm{M}_{1}=8 \mathrm{kN} \cdot \mathrm{m} ; \mathrm{M}_{2}=4 \mathrm{kN} \cdot \mathrm{m} ; \mathrm{L}=1 \mathrm{~m} ; \mathrm{D}=10 \mathrm{~cm} ; \mathrm{G}=80 \mathrm{GPa}$. 


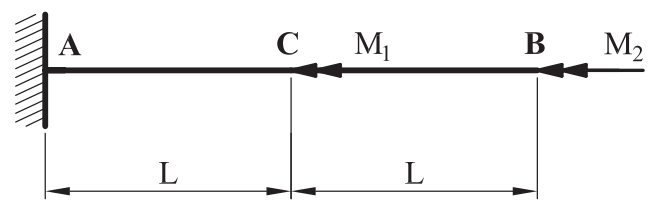

Fig. 7.7. Exemple 7.1. Enunciat

En primer lloc, calcularem la reacció en el punt A (encast): $M_{A}=\mathrm{M}_{1}+\mathrm{M}_{2}=12 \mathrm{kN} \cdot \mathrm{m}$.

El moment torçor tindrà signe negatiu en tota la barra. Podem fer una representació gràfica en forma de diagrama:

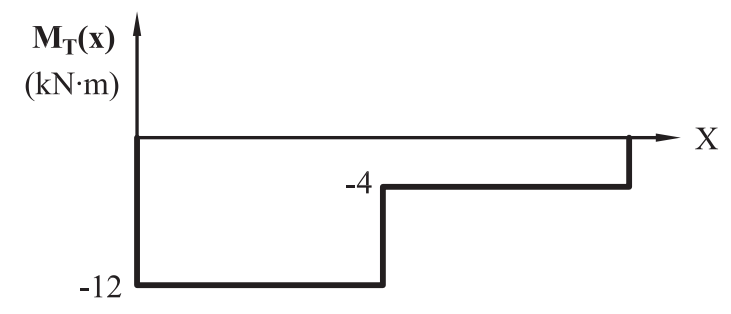

Fig. 7.8. Exemple 7.1. Diagrama de moments torçors

La tensió tangencial màxima s'obté de la fórmula:

$$
\tau_{m a ̀ x}=\frac{M_{T m a ̀ x}}{I_{P}} r_{m a ̀ x}
$$

El moment torçor màxim es $\mathrm{M}_{\mathrm{A}}$. El moment d'inèrcia polar es calcula de la següent manera:

$I_{P}=\frac{\pi D^{4}}{32}=9,82 \cdot 10^{-6} \mathrm{~m}^{4}$

La màxima distància del centre de la secció és $\mathrm{r}_{m a x}=\mathrm{D} / 2$.

Apliquem l'expressió anterior i obtenim: $\tau_{\text {màx }}=6,11 \cdot 10^{7} \mathrm{~Pa}=61,1 \mathrm{MPa}$.

Per al càlcul dels angles de torsió, hem de fer dues integrals, una per a cada tram de moment.

$$
\varphi_{C}-\varphi_{A}=\int \frac{M_{A}}{G I_{P}} d x=\frac{M_{A} L}{G I_{P}}
$$

Com que sabem que la secció A no pot girar $\phi_{\Delta}=0$ :

$\varphi_{C}=-0,015 \mathrm{rad}$

$$
\varphi_{B}-\varphi_{C}=\int \frac{M_{1}}{G I_{P}} d x=\frac{M_{1} L}{G I_{P}}
$$


Com que l'angle girat en $\mathrm{C}$ és ja conegut:

$\varphi_{B}=\frac{M_{1} L}{G I_{P}}+\varphi_{C}=-0,025 \mathrm{rad}$

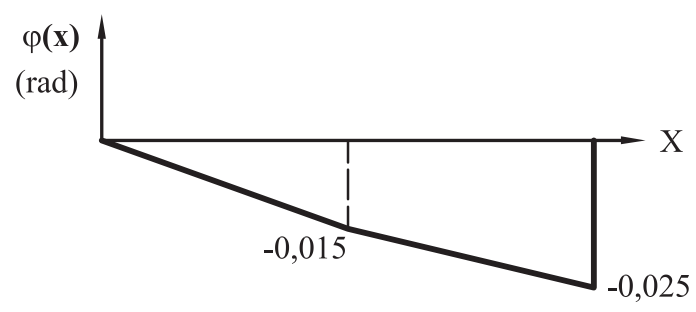

Fig. 7.9. Exemple 7.1. Diagrama d'angles de torsió

\section{Exemple 7.2}

Un eix d'una màquina gira a 120 revolucions per minut, i està recolzat en dos coixinets. L'eix transmet des de la politja 1 a la politja 2 una potència de $100 \mathrm{CV}$, que es tradueix en un moment torçor de $\mathrm{M}_{\mathrm{T}}=5.848,94 \mathrm{~N} \cdot \mathrm{m}$. Determineu:

a) El diagrama d'esforços de l'eix.

b) El diàmetre $\mathrm{D}$ de la secció transversal de l'eix, en els casos de secció circular massissa i secció circular buida ( $\mathrm{s}^{\prime}$ ha de respectar la relació $\mathrm{d} / \mathrm{D}=0,85$ ).

c) Gir relatiu de les seccions extremes de l'eix en ambdós casos.

Dades: $\tau_{\text {adm }}=40 \mathrm{MPa} ; \mathrm{G}=80 \mathrm{GPa} ; \mathrm{L}=2 \mathrm{~m}$.

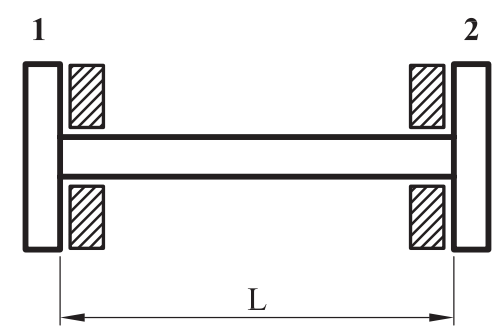

Fig. 7.10. Exemple 7.2. Enunciat

El moment torçor és constant en tota la barra i de valor igual a $\mathrm{M}_{\mathrm{T}}$.

Secció massissa: $\tau_{m a ̀ x}=\frac{M_{T}}{W_{P}}=\frac{M_{T}}{\frac{\pi D^{3}}{16}}<\tau_{a d m}$

i aïllem: $D=\left(\frac{16 M_{T}}{\pi \tau_{a d m}}\right)^{\frac{1}{3}}=0,091 \mathrm{~m}$. 


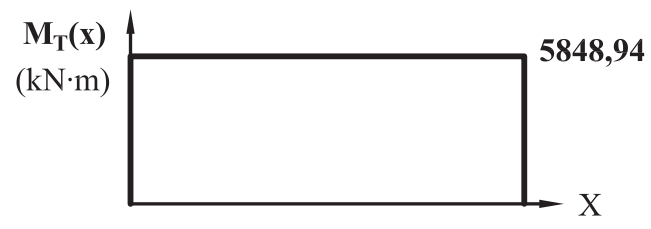

Fig. 7.11. Exemple 7.2. Diagrama de moments torçors

Secció buida: $\tau_{m a ̀ x}=\frac{M_{T}}{W_{P}}=\frac{M_{T}}{\frac{\pi D^{3}}{16}\left(1-0,85^{4}\right)}<\tau_{a d m}$ també podem aillar el diàmetre

$D=\left(\frac{16 M_{T}}{\pi \tau_{\text {adm }}\left(1-0,85^{4}\right)}\right)^{\frac{1}{3}}=0,116 m$

$d=0,85 D=0,099 m$

Podem calcular l'àrea de material en ambdós casos:

Massissa: $A_{m}=\pi \frac{D^{2}}{4}=65,52 \mathrm{~cm}^{2}$.

Buida: $A_{b}=\pi \frac{\left(D^{2}-d^{2}\right)}{4}=29,29 \mathrm{~cm}^{2}$.

Com veiem, la secció buida té menys de la meitat d'àrea que la massissa.

El gir relatiu el calcularem mitjançant l'expressió: $\varphi_{B}-\varphi_{A}=\frac{M_{T} L}{G I_{P}}$.

Massissa: $I_{P m}=\pi \frac{D^{4}}{32}=6,63 \cdot 10^{-6} \mathrm{~m}^{4} \quad \varphi_{B}-\varphi_{A}=0,022 \mathrm{rad}$.

Buida: $I_{P b}=\pi \frac{D^{4}-d^{4}}{32}=8,67 \cdot 10^{-6} \mathrm{~m}^{4} \quad \varphi_{B}-\varphi_{A}=0,017 \mathrm{rad}$.

A més de ser més lleugera, la secció buida té més rigidesa en el gir.

\subsection{Torsió per a perfils de paret prima}

El que segueix a continuació és un càlcul simplificat.

Per a perfils de paret prima, de gruix t $\mathrm{i}$ longitud $\mathrm{b}$, definim la rigidesa com a:

$$
J=\frac{1}{3} b t^{3}
$$

La tensió tangencial és: $\tau=\frac{2 M_{T}}{J} z$. 
La màxima tensió tangencial es donarà en $z=\frac{t}{2}$ i per tant: $\tau_{m a ̀ x}=\frac{M_{T}}{J} t$.

Inclús si la peça està formada per alguns perfils de paret prima units entre ells, l'expressió de la tensió és la mateixa, però la rigidesa és la suma de les rigideses parcials:

$J=\frac{1}{3} \sum_{i} b_{i} t_{i}^{3}$

Si tenim perfils tipus IPE o UPN, podem assimilar-los a la unió de perfils que hem mencionat abans.
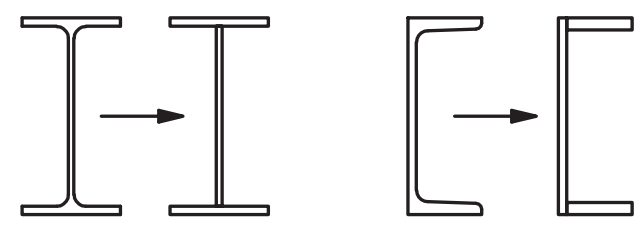

Fig. 7.12

La rigidesa és la mateixa per a tota la peça. $\mathrm{Si}$ ens fixem en la fórmula de la tensió tangencial, veurem que en una peça composta de més d'un element, la tensió tangencial màxima es donarà al tram que tinga un gruix més gran. A partir d'això, és previsible que si augmentem el moment torçor, el tram que tendirà a trencar-se serà el de major gruix, i no el més estret, com en principi ens diria la intuïció.

De l'expressió de la tensió tangencial anterior, podem deduir que la tensió tangencial canvia de sentit a l'interior del perfil (figura 7.13) perquè la coordenada $\mathrm{z}$ varia en l'interval:

$$
\frac{-t}{2} \leq z \leq \frac{t}{2}
$$

Les distribucions tangencials tenen una distribució del tipus que veiem a la figura 7.14.

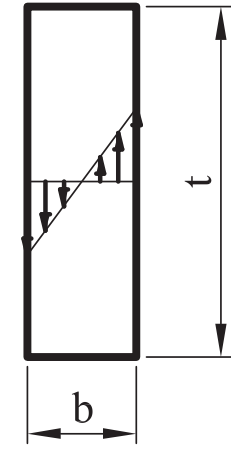

Fig. 7.13

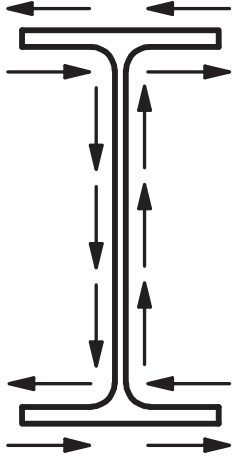

Fig. 7.14 
La qual cosa genera guerxament en les ales del perfil. Als extrems de la biga, el guerxament és lliure, no està restringit (figura 7.15). Al centre de la peça, però, les seccions contigües coarten en certa mesura el moviment, la qual cosa genera zones comprimides. Com que aquestes zones són esveltes, pot produir-se el vinclament localitzat en les ales del perfil (figura 7.16).

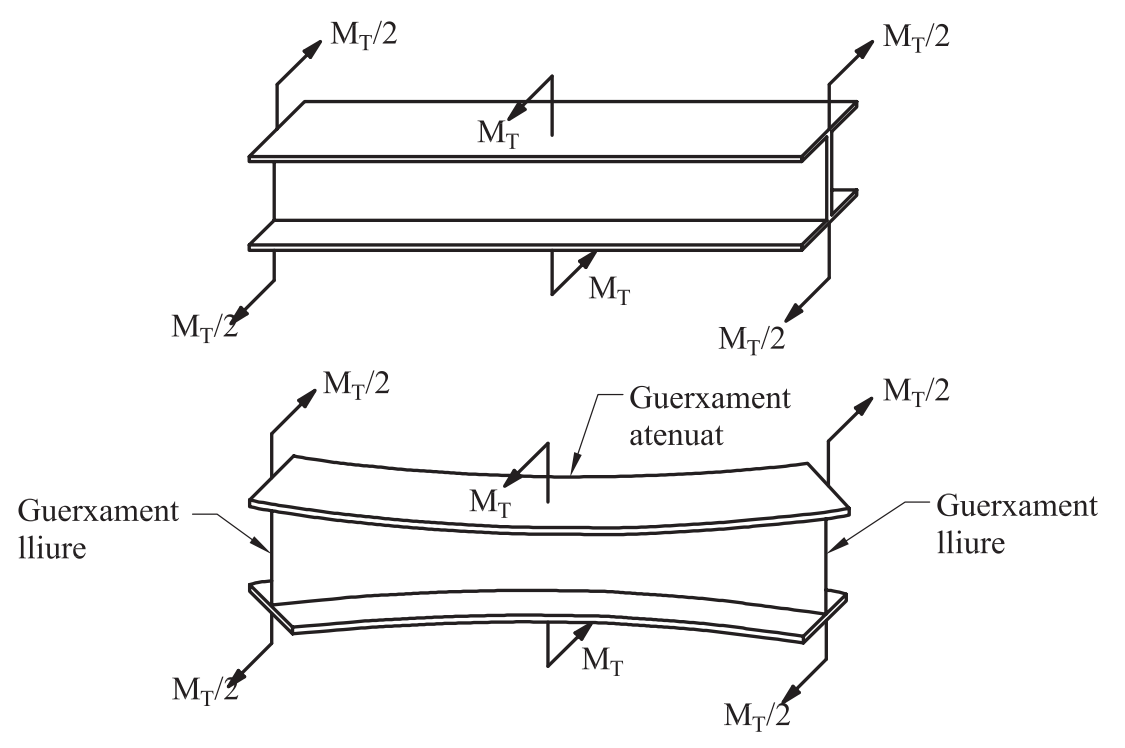

Fig. 7.15. Guerxament de les seccions degut a torsió

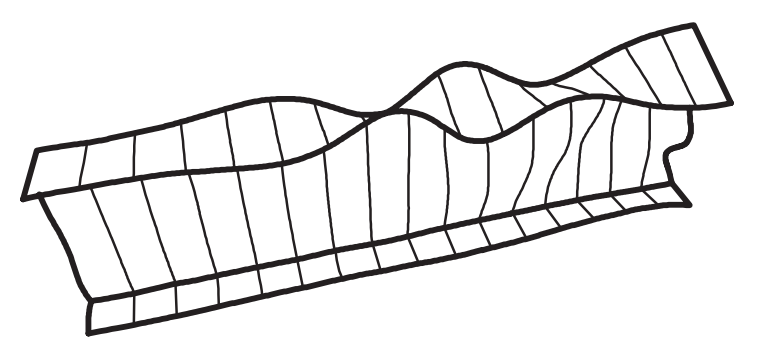

Fig. 7.16. Vinclament localitzat d'ales i ànima en una biga en I

\subsection{Perfils tubulars}

En perfils tancats de paret prima la tensió no canvia de signe dins la secció. La tensió manté el sentit i es considera constant en tot el gruix.

Si t és el gruix i $\mathrm{A}_{0}$ l'àrea continguda dins de la línia mitjana del perfil:
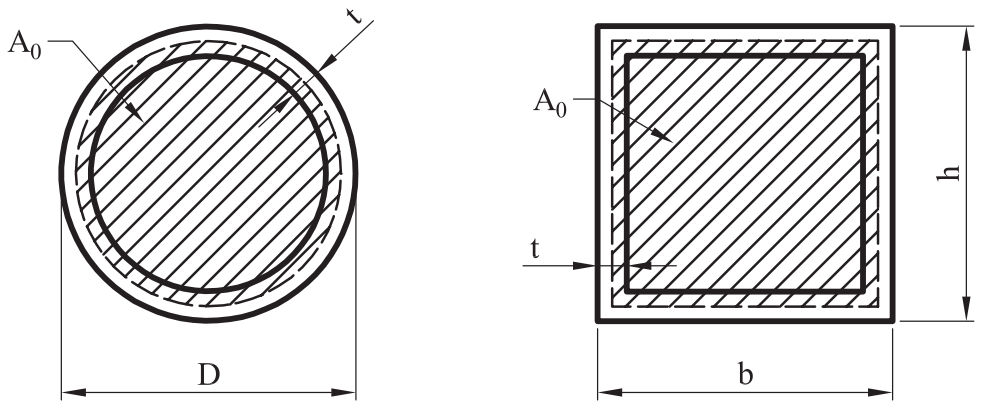

Fig. 7.17 


$$
\tau_{m a ̀ x}=\frac{M_{T}}{2 t A_{0}}
$$

Per a secció rectangular:

$$
A_{0}=(b-t) \cdot(h-t)
$$

Per a secció circular:

$$
A_{0}=\frac{\pi(D-t)^{2}}{4}
$$

En aquest cas, el gruix està en el denominador de l'expressió. Això vol dir que si tenim un perfil en el qual el gruix no siga constant, la màxima tensió tangencial es produirà on el gruix siga mínim.

En general, els perfils tancats es comporten millor que els oberts.

\section{Exemple 7.3}

Compareu el comportament a torsió d'un perfil tubular quadrat enfront del mateix perfil però obert. Cotes en $\mathrm{cm}$.
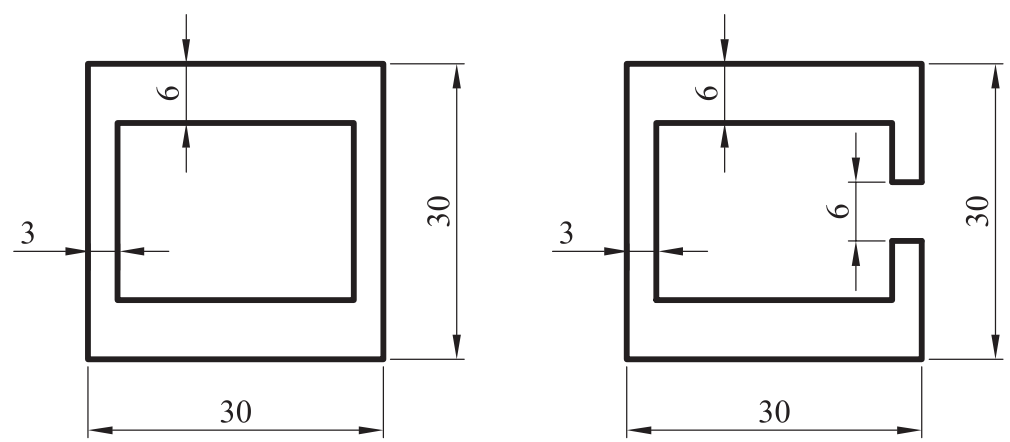

Fig. 7.18. Exemple 7.3. Enunciat

Considerem primer la secció tancada:

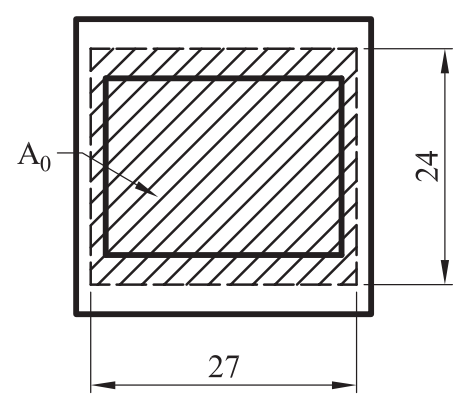

Fig. 7.19. Exemple 7.3. Secció tancada 
$\mathrm{A}_{0}=24 \cdot 27=648 \mathrm{~cm}^{2}$. La màxima tensió tangencial es produirà en els costats on el gruix és mínim: $(t=3 \mathrm{~mm}) \tau=\frac{M_{T}}{2 t A_{0}}=\frac{M_{T}}{3.888}$.

Analitzem ara la secció oberta. Com que és un perfil obert de paret prima, dividirem la secció en rectangles:

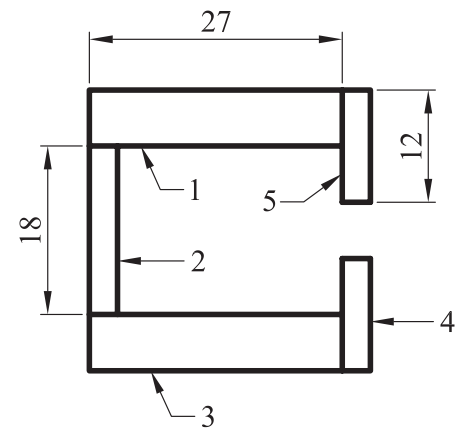

Fig. 7.20. Exemple 7.3. Secció oberta

La rigidesa a torsió del conjunt de la peça és la suma de les rigideses dels rectangles.

$J=\sum_{i=1}^{5} J_{i}=\frac{1}{3}\left(27 \cdot 6^{3}+18 \cdot 3^{3}+27 \cdot 6^{3}+12 \cdot 3^{3}+12 \cdot 3^{3}\right)=4.266 \mathrm{~cm}^{4}$

$\tau=\frac{M_{T}}{J}$. El màxim valor per a la tensió es donarà on el gruix siga més gran.

En aquest cas $\mathrm{t}=6 \mathrm{~cm}: \tau=\frac{M_{T}}{4.266} 12=\frac{M_{T}}{355,5}$.

Veiem que, en aquest problema, la tensió que es produeix en el cas del perfil obert és unes deu vegades més gran que en el cas de perfil tancat. Que el comportament de les seccions tancades és millor en front de torsió és una circumstància que es repeteix habitualment, i que ha de ser tinguda en consideració quan dissenyem un element que haja de treballar a torsió.

\section{Exemple 7.4}

Calculeu la màxima força $\mathrm{P}$ que pot aplicar-se en una biga $\mathrm{ABC}$ com la de la figura abans que arribe el trencament. La biga simula el pany d'una porta i és d'un perfil circular massís de $3 \mathrm{~cm}$ de diàmetre.

Dades: $\mathrm{L}_{\mathrm{AB}}=2 \mathrm{a} ; \mathrm{L}_{\mathrm{BC}}=\mathrm{a}=10 \mathrm{~cm} ; \sigma_{\mathrm{u}}=410 \mathrm{MPa}$.

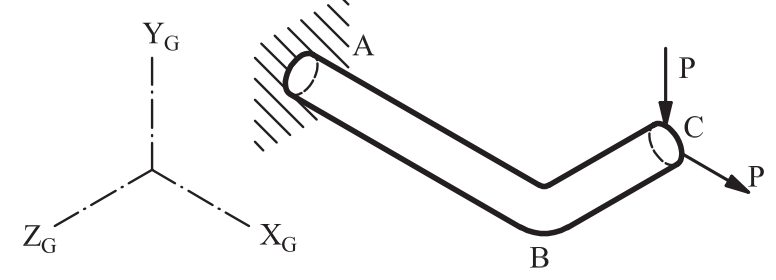

Fig. 7.21. Exemple 7.4. Enunciat 
El problema és una combinació dels temes de flexió i de torsió. La biga tindrà tensions normals degudes al moment flector i tensions tangencials degudes a tallant i al moment torçor. Haurem de calcular-les, establir l'estat tensional al punt més desfavorable i calcular la tensió equivalent de Von Mises, per tal de comparar-la amb la tensió de trencament.

Es tracta d'un cas isostàtic. Podem calcular les reaccions amb les equacions d'equilibri. Cal diferenciar entre els eixos globals de l'estructura i els eixos locals de cada barra.

Al punt A tenim pràcticament totes les reaccions possibles.

$$
\begin{array}{ll}
R_{A X}=P & M_{A X}=-P \cdot a \\
R_{A Y}=P & M_{A Y}=-P \cdot a \\
R_{A Z}=0 & M_{A Z}=-P \cdot 2 a
\end{array}
$$

Els eixos locals de la barra $\mathrm{AB}$ porten la mateixa direcció que els globals, però en la barra $\mathrm{BC}$ estan girats $90^{\circ}$.

Els diagrames d'esforços són els de la figura 7.22:

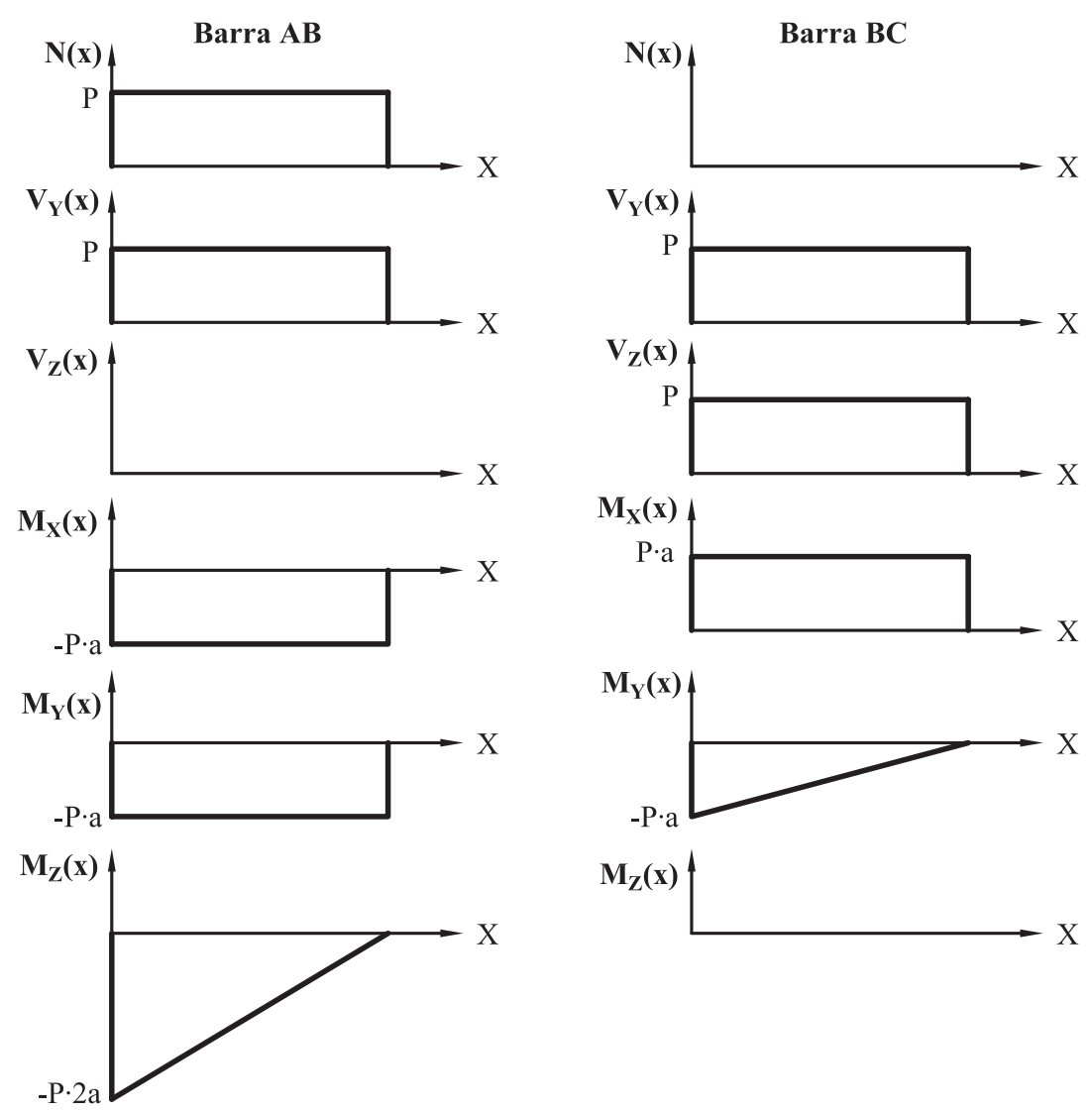

Fig. 7.22. Exemple 7.4. Diagrames d'esforços

Podem apreciar que, com que els eixos locals de la barra BC estan girats, els moments al voltant dels eixos no representen els mateixos tipus de moment. Així tenim: 
- En la barra $\mathrm{AB}$, el moment $\mathrm{M}_{\mathrm{X}}$ representa un torçor, mentre que en $\mathrm{BC}$ és un flector.

- Tant en la barra $\mathrm{AB}$ com en la $\mathrm{BC}, \mathrm{M}_{\mathrm{Y}}$ és un moment flector.

- En la barra $\mathrm{AB}$, el moment $\mathrm{M}_{\mathrm{Z}}$ és un flector, $\mathrm{i}$ en $\mathrm{BC}$ seria un torçor (encara que és nul en aquest cas).

La secció més desfavorable serà clarament la secció de l'encast.

Calculem les tensions normals degudes a flexió. Tenim una flexió composta esbiaixada. La llei de Navier tindrà tots els seus termes.

$\sigma=\frac{N}{A}-\frac{M_{Z}}{I_{Z}} y+\frac{M_{Y}}{I_{Y}} Z$

Calculem els paràmetres geomètrics:

$A=\frac{\pi D^{2}}{4}=7,07 \cdot 10^{-4} \mathrm{~m}^{2} ; I_{Y}=I_{Z}=\frac{\pi D^{4}}{64}=3,98 \cdot 10^{-8} \mathrm{~m}^{4}$

Els valors dels esforços estan en funció de $\mathrm{P}$, la tensió també serà una funció de $\mathrm{P}$.

$\sigma=1414,71 P+5,03 \cdot 10^{6} P y-2,51 \cdot 10^{6} P z$

Hem de buscar quina serà la secció més desfavorable, és a dir, la que té una tensió més gran. Calcularem l'equació de la $\mathrm{LN}$ fent $\sigma=0$.

Podem simplificar-la dividint tots els termes per $\mathrm{P}$, i veiem que la posició de la LNno depén de la càrrega: $1414,71+5,03 \cdot 10^{6} \mathrm{y}-2,51 \cdot 10^{6} \mathrm{z}=0$. Si busquem dos punts de la recta, per exemple els talls amb els eixos, podrem representar-la (figura 7.23).

$\mathrm{z}=0 \rightarrow \mathrm{y}=-2,81 \cdot 10^{-4} \mathrm{~m}$

$\mathrm{y}=0 \rightarrow \mathrm{z}=5,63 \cdot 10^{-4} \mathrm{~m}$

Com veiem, la LN està molt pròxima al centre de la secció. Això vol dir que l'esforç axial té poca importància relativa.

El punt més allunyat de la LN serà el de màxima tensió normal. El punt es troba sobre el radi perpendicular a la LN. Per trobar la seua posició necessitem calcular l'angle que forma la LN amb l'eix X.

$$
\tan (\alpha)=\frac{2,81}{5,63} \rightarrow \alpha=26,56^{\circ}
$$

El radi del cercle és: $R=\frac{D}{2}=0,015 \mathrm{~m}$. 


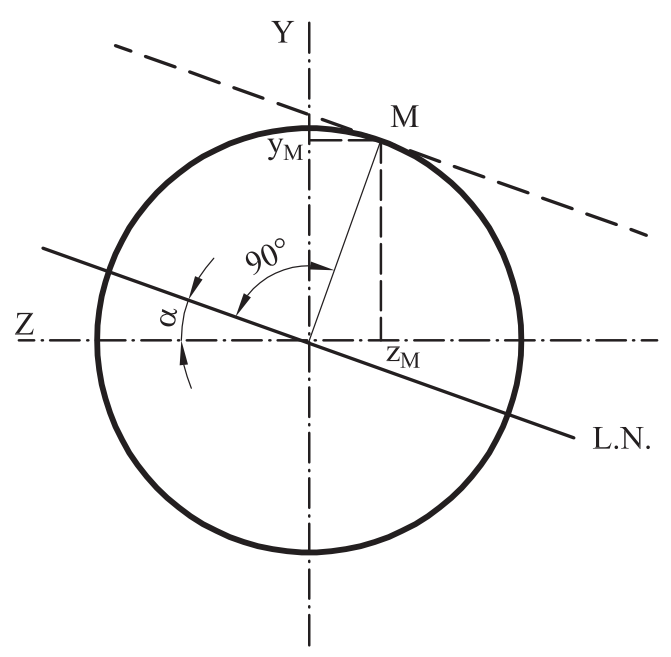

Fig. 7.23. Exemple 7.4. Posició de la LN i del punt més allunyat (M)

Les coordenades del punt M són:

$\mathrm{y}_{\mathrm{M}}=\mathrm{R} \cos (\alpha)=0,0134 \mathrm{~m}$

$\mathrm{z}_{\mathrm{M}}=-\mathrm{R} \sin (\alpha)=-0,0067 \mathrm{~m}$

Substituint en la llei de Navier les coordenades, obtenim: $\sigma_{M}=8,58 \cdot 10^{4} P$ (totes les tensions que calcularem a l'exercici estan expressades en $\mathrm{Pa}$, si la càrrega s'expressa en $\mathrm{N}$ ).

Calculem ara les tensions degudes a l'esforç tallant. Normalment les tensions normals predominaran sobre les tensions tangencials, per la qual cosa analitzarem el mateix punt $\mathrm{M}$ de la secció $\mathrm{A}$.

Es pot demostrar que l'expressió de Collignon per a seccions circulars de radi R és:

$\tau_{X Y}=\frac{4}{3} \frac{V_{Y}}{\pi R^{4}}\left(R^{2}-y^{2}\right)$

En la secció A tenim un esforç tallant igual a P. Substituint els valors i les coordenades del punt M, obtenim: $\tau_{X Y M}=377,25 P$. Comprovem que, efectivament, és molt inferior a la tensió normal. Encara que ja vam explicar que aquesta tensió no portaria realment la direcció del tallant, sinó que seria tangent, farem la simplificació de Collignon i la considerarem vertical.

Tensions tangencials degudes al moment torçor: $\tau_{\theta}=\frac{M_{T}}{I_{P}} r$.

Moment d'inèrcia polar: $I_{P}=\frac{\pi D^{4}}{32}=7,95 \cdot 10^{-8} \mathrm{~m}^{4}$.

En el punt M la distància al centre és el radi: $r_{M}=R$.

$\tau_{\theta M}=\frac{M_{T}}{I_{P}} r=\frac{-P \cdot a}{I_{P}} R=-1,89 \cdot 10^{4} P$ 


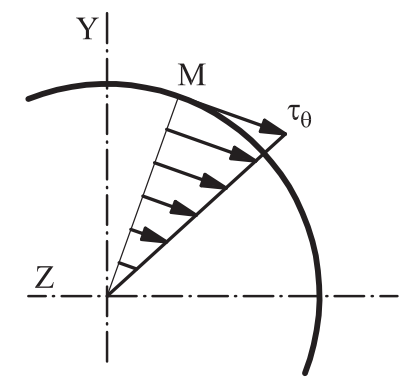

Fig. 7.24. Exemple 7.4. Tensions tangencials degudes a torçor en M

La tensió tangencial deguda a torsió és més menuda que la tensió normal, però està dins del mateix ordre de magnitud, per la qual cosa tindrà certa influència sobre la tensió equivalent.

El càlcul de la tensió equivalent de Von Mises el farem a partir de les tensions principal al punt M. Hem de descompondre la tensió $\tau_{\theta}$ sobre els eixos Y i Z. La tensió sobre l'eix Y s'haurà de sumar a la tensió tangencial deguda a tallant $\left(\tau_{\mathrm{XY}}\right)$.

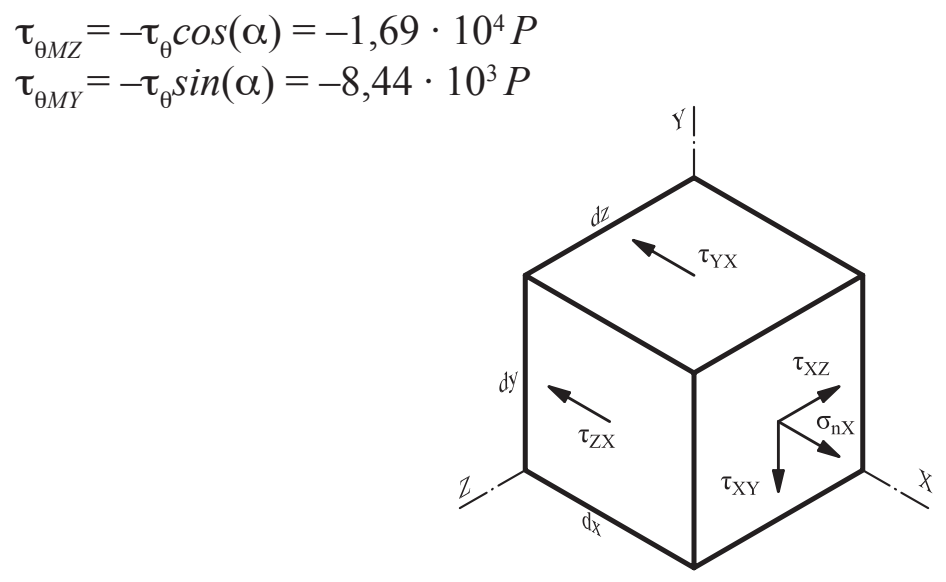

Fig. 7.25. Exemple 7.4. Tensions en l'entorn diferencial del punt M

$$
\begin{aligned}
& \sigma_{X}=\sigma_{M}=8,58 \cdot 10^{4} P \\
& \tau_{X Y}=-\tau_{X Y M}-\tau_{\theta M Z}=-8,81 \cdot 10^{3} P \\
& \tau_{X Z}=-\tau_{\theta M Y}=-1,69 \cdot 10^{4} P
\end{aligned}
$$

Les tensions principals les calcularem amb:

$\lambda_{1}=\frac{1}{2}\left(\sigma_{X}+\sqrt{4 \tau_{X Y}^{2}+4 \tau_{X Z}^{2}+\sigma_{X}^{2}}\right)=1,51 \cdot 10^{5} P$

$\lambda_{2}=\frac{1}{2}\left(\sigma_{X}-\sqrt{4 \tau_{X Y}^{2}+4 \tau_{X Z}^{2}+\sigma_{X}^{2}}\right)=-1,01 \cdot 10^{5} P$

$\lambda_{3}=0$

$\sigma_{e q, V M}=\sqrt{\frac{1}{2}\left[\left(\lambda_{1}-\lambda_{2}\right)^{2}+\left(\lambda_{1}-\lambda_{3}\right)^{2}+\left(\lambda_{2}-\lambda_{3}\right)^{2}\right]}=2,2 \cdot 10^{5} P$

Aquesta tensió ha de ser menor que la tensió última: $\sigma_{e q, V M}<\sigma_{u}$.

Podem aillar la càrrega: $P=4,46 \cdot 10^{3} \mathrm{~N}=4,46 \mathrm{kN}$. 


\section{Problemes proposats}

7.1. Una barra de secció circular buida, de diàmetre $\mathrm{D}$ i gruix e, està encastada en un extrem. En l'altre extrem s'ha soldat una barreta vertical, que considerarem infinitament rígida, de $20 \mathrm{~cm}$ de longitud, de manera que cadascun dels extrems de la barreta està a $10 \mathrm{~cm}$ del centre de la secció. A cada extrem se li apliquen dues càrregues $\mathrm{P}$ de sentit contrari. Calculeu:

a) Tensió màxima que es produeix en la secció si la considerem com de paret gruixuda.

b) Tensió màxima que es produeix en la secció si es considera de paret prima.

c) Gir relatiu entre els extrems de la barra.

Dades: $\mathrm{E}=200 \mathrm{GPa} ; \mu=0,25 ; \mathrm{D}=30 \mathrm{~mm} ; \mathrm{e}=3 \mathrm{~mm} ; \mathrm{L}_{\mathrm{AB}}=1,5 \mathrm{~m} ; \mathrm{s}=10 \mathrm{~cm}$; $\mathrm{P}=3 \mathrm{kN}$.

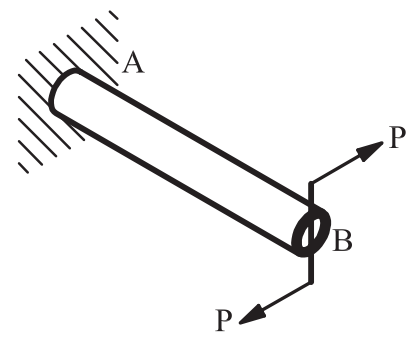

Fig. P.7.01 


\section{TEMA 8}

\section{Vinclament}

\subsection{Introducció}

Els materials que pertanyen a les estructures han de verificar uns requisits que fan referència a la resistència del material, a la rigidesa de les peces (límits de deformació) i també a l'estabilitat. Una estructura que té un equilibri entre les forces exteriors i interiors pot ser estable o inestable. L'equilibri estàtic és estable si el cos que s'ha deformat durant qualsevol desviació de l'estat d'equilibri té tendència a tornar a l'estat inicial, un cop cessa la causa de la desviació. Serà inestable si, per contra, segueix deformant-se en la direcció de la desviació provocada i després de cessar la causa no torna a l'estat original.

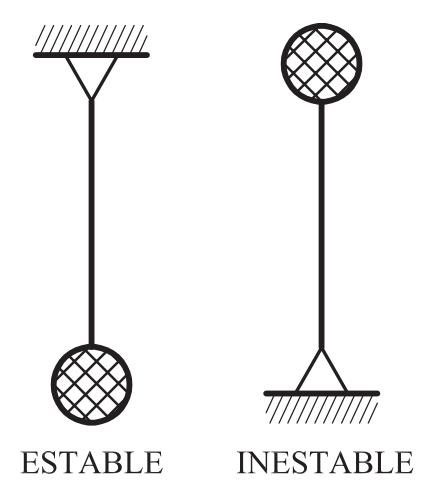

Fig. 8.1. Equilibri estable i inestable

El vinclament és un fenomen d'inestabilitat de les peces esveltes comprimides. El concepte d'esveltesa fa referència a la dimensió transversal de la secció respecte a la seua longitud. Una peça serà més esvelta com menor siguen les dimensions de la secció transversal respecte a la longitud.

Típicament, un material elàstic com l'acer té la mateixa tensió admissible a tracció i a compressió. Tanmateix, el comportament d'una barra esvelta sotmesa a un esforç axial de tracció no és el mateix que si l'esforç és de compressió. Per exemple, una vareta d'acer $\mathrm{S} 275$ d' $1 \mathrm{~cm}$ de diàmetre pot suportar a tracció un pes d'aproximadament dues tones $(20 \mathrm{kN})$ sense plastificar. Imaginem una vareta com l'anterior, de $3 \mathrm{~m}$ de longitud. Podríem mantindre un cotxe damunt d'aquesta vareta sense que la vareta es plegara?

Entre l'estat estable i l'inestable, podem trobar un estat transitori anomenat estat crític. L'estabilitat de la posició d'equilibri del cos deformat depén de la càrrega que se li aplica. S'anomena càrrega crítica $\left(P_{c r}\right)$ la càrrega que origina que el cos 
arribe a l'estat crític; en cas de superar-se, es perd l'estabilitat de la forma original del cos.

- Si tenim una peça esvelta, apliquem una càrrega menuda $\left(P<P_{c r}\right)$ i introduïm una petita pertorbació en el sistema, la peça tornarà a la seua posició d'equilibri.

- Si la càrrega és $P=P_{c r}$, la barra es trobarà en l'estat crític. Qualsevol petita pertorbació causarà que la peça abandone la posició d'equilibri. La barra es deforma, adoptant una forma flexionada, i es trenca sobtadament. Aquest és el fenomen del vinclament.

- Si la càrrega es $\mathrm{P}>\mathrm{P}_{\mathrm{cr}}$ es produeix el vinclament.

Analitzarem ara què entenem per petita pertorbació. Les petites pertorbacions són aquelles causes de la pèrdua de les condicions ideals que assumim en aquesta assignatura. Aquestes condicions ideals són: que el sòlid es isòtrop, homogeni i continu, que la càrrega s'aplica en el centre de gravetat de la secció i que l'eix longitudinal de la barra és perfectament rectilini. Per tant, les petites deformacions no han de ser obligatòriament forces actuant en direcció perpendicular a la biga. També poden ser excentricitats en el punt d'aplicació de la càrrega, deformacions prèvies de la biga (en el proces de fabricació, en el transport i manipulació, etc.) o defectes de fabricació que provoquen que el sòlid no siga perfectament elàstic. Les petites pertorbacions sempre estaran presents, perquè el procés de fabricació no és perfecte.

\subsection{Càrrega crítica d'Euler}

Euler va estudiar la màxima càrrega axial centrada que un pilar biarticulat podia suportar. Aquesta càrrega es va anomenar càrrega crítica d'Euler $\left(N_{c r}\right)$.

Si introduïm una petita deformació en una biga recta sotmesa a compressió, s'hi generarà una petita fletxa $(\mathrm{v})$.

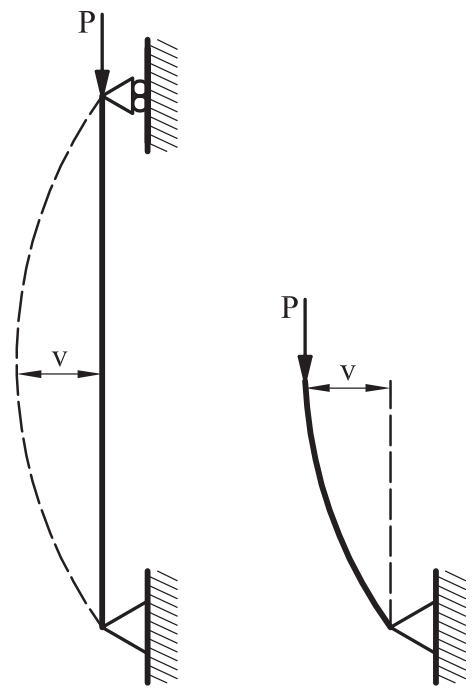

Fig. 8.2. Moments estabilitzador i desestabilitzador 
Si analitzem una secció de la biga, podem veure que, d'una banda, tenim que la força $\mathrm{P}$ està desplaçada i, per tant, genera un moment desestabilitzador. D'altra banda, a causa de la curvatura produïda, segons la teoria de la flexió, es produeix un moment que intenta tornar la peça a la seua posició inicial és un moment estabilitzador.

$$
\begin{aligned}
& M_{\text {estab }}=\kappa E I_{Z} \\
& M_{\text {desest }}=-P \cdot v
\end{aligned}
$$

Poden ocórrer tres situacions:

1. $M_{\text {estab }}>M_{\text {desest }}$ : es restablirà l'equilibri.

2. $M_{\text {estab }}=M_{\text {desest }}$ : tenim un equilibri inestable.

3. $M_{\text {estab }}<M_{\text {desest }}$ : es produeix el col·lapse.

El vinclament és un fenomen de collapse sobtat i irreversible. En el moment que el moment desestabilitzador supere l'estabilitzador, la fletxa augmentarà. Això fa augmentar el moment desestabilitzador i el cicle es repetirà fins al colllapse.

Com que estem buscant la càrrega que provoca l'estat crític, ens situarem en el moment en què els dos moments són iguals.

$$
M_{\text {estab }}=M_{\text {desest }}=-N c r \cdot v
$$

Considerem l'equació diferencial del problema de flexió:

$$
\kappa=\frac{M_{e s t a b}}{E I_{Z}}=\frac{d^{2} v(x)}{d x^{2}} \rightarrow \frac{d^{2} v(x)}{d x^{2}}-\frac{M_{e s t a b}}{E I}=0
$$

Com veiem, no hem indicat amb un subíndex a quin moment d'inèrcia ens estem referint. Com que el vinclament pot produir-se en els dos eixos, les expressions subsegüents seran vàlides per a ambdós eixos. Substituïm la igualtat anterior:

$$
\frac{d^{2} v}{d x^{2}}+\frac{N_{c r}}{E I} v=0
$$

si anomenem $k^{2}=\frac{N_{c r}}{E I_{Z}}$, l'equació diferencial ens queda:

$$
\frac{d^{2} v}{d x^{2}}+k^{2} v=0
$$

La solució de l'equació diferencial d'equilibri és:

$$
v=A \sin (k x)+B \cos (k x)
$$

On A i B són constants que s'obtenen de les condicions d'equilibri: 


$$
\begin{gathered}
v(x=0)=0 \rightarrow B=0 \\
v(x=L)=0 \rightarrow \sin (k \cdot L)=0
\end{gathered}
$$

Com que A no pot ser zero, ha de ser zero el sinus. Perquè això ocórrega, el terme $(k \cdot L)$ ha de ser múltiple de $\pi \cdot k \cdot L=n \cdot \pi ; n=1,2,3 \ldots$

L'equilibri s'assoleix quan $k=\frac{n \pi}{L} \rightarrow k^{2}=\left(\frac{n \pi}{L}\right)^{2}=\frac{N_{c r}}{E I}$.

La càrrega crítica d'Euler és: $N_{c r}=\left(\frac{n \pi}{L}\right)^{2} E I$.

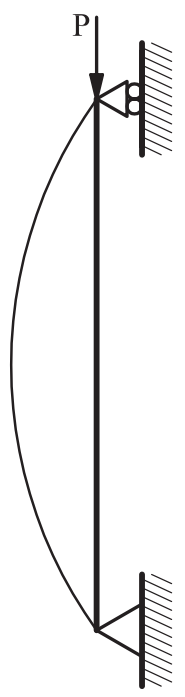

a)

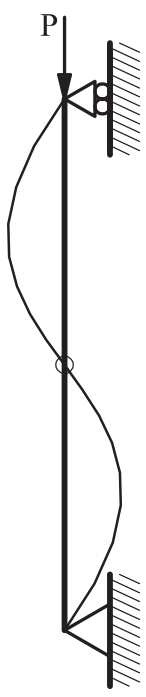

b)

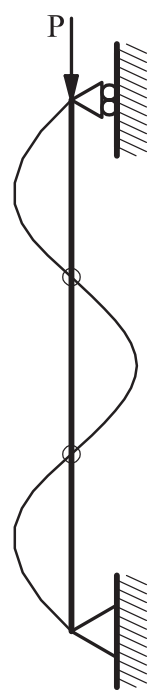

c)

Fig. 8.3. $a)$ primer mode de vinclament $(\mathrm{n}=1) ; b)$ segon mode de vinclament $(\mathrm{n}=2)$;

$c$ ) tercer mode de vinclament $(\mathrm{n}=3)$. Els punts marcats per als modes segon i tercer mode han de ser fixats perquè aquests modes puguen donar-se

L'únic mode de vinclament que es dóna de manera natural és el primer $(\mathrm{n}=1)$. La resta es donen si els nodes tenen el moviment restringit. Per al primer mode de vinclament:

$$
N_{c r}=\left(\frac{\pi}{L}\right)^{2} E I
$$

Tot aquest estudi ha estat desenrotllat per a bigues biarticulades, però no sempre tindrem aquestes condicions als extrems. Hauríem d'aplicar el mateix procediment si els pilars tenen diferents tipus de recolzaments: encasts, extrems lliures, etc.

Tanmateix, és més fàcil comparar la deformada de l'element en estudi amb la del cas biarticulat, i buscar una longitud equivalent de vinclament $\left(L_{K}\right)$. És a dir, una longitud teòrica que hauria de tindre l'element amb les condicions biarticulades perquè la forma del vinclament fóra la mateixa. En aquest curs només estudiarem els quatre casos de la figura 8.4, que anomenarem formes canòniques. 


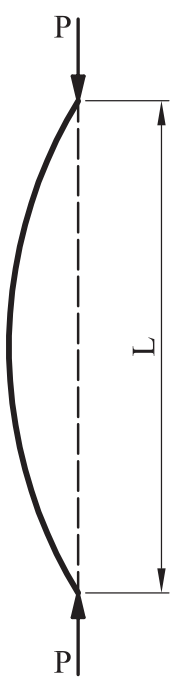

a)

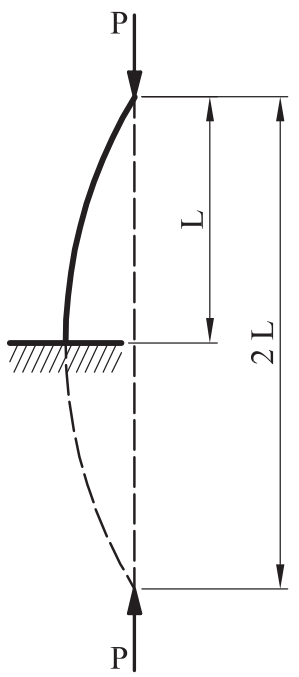

b)

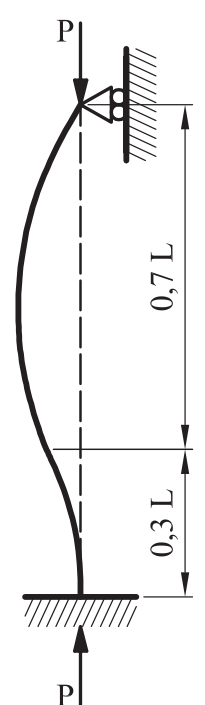

c)

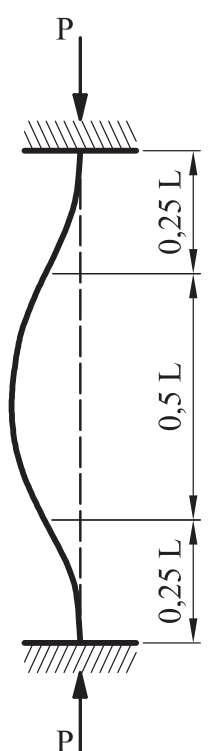

d)

Fig. 8.4. Formes canòniques: $a$ ) articulat-articulat; $b$ ) encastat-lliure; $c$ ) encastat-articulat; d) encastat-encastat

Considerem com a base el cas articulat-articulat, en el qual $L_{K}=L$. Com veiem a la figura, per a la biga encastada-lliure de longitud L, la biga hauria de ser el doble de llarga perquè la forma deformada fóra igual al cas biarticulat. En aquest cas tenim $L_{K}=2 L$. Si fem el mateix raonament, podem obtindre els valors per al cas encastatarticulat $\left(L_{K}=0,7 L\right)$ i per al cas encastat-encastat $\left(L_{K}=0,5 L\right)$.

En general, per a les diverses possibilitats de vinclament que es poden donar, degudes a les condicions de recolzament i d'unió amb la resta de l'estructura, podem dir que la longitud equivalent serà igual a la longitud L multiplicada per un coeficient $\beta$.

$$
L_{K}=\beta L
$$

Per als casos canònics, els valors estan clars:

- Articulat-articulat: $\beta=1$.

- Encastat-1liure: $\beta=2$.

- Encastat-articulat: $\beta=0,7$.

- Encastat-encastat: $\beta=0,5$.

Per a la resta de casos, les normatives ens donen fórmules per a calcular el coeficient $\beta$, però això excedeix els objectius d'aquest curs, i forma part de cursos posteriors. 


\subsection{Esveltesa}

Quan tenim una biga comprimida, sotmesa a la tensió crítica $N_{c r}$, la tensió que tindrà la peça s'anomena tensió crítica.

$$
\sigma_{c r}=\frac{N_{c r}}{A}=\frac{\pi^{2} E I}{L_{K}^{2} A}=\frac{\pi^{2} E i^{2}}{L_{K}^{2}}
$$

En la fórmula anterior hem utilitzat el concepte de radi de gir:

$$
i=\sqrt{\frac{I}{A}}
$$

Com que tenim dos moments d'inèrcia, un per a cada eix, també existiran dos radis de gir.

L'equació només serà aplicable si el material roman en el rang elàstic. Això significa que la tensió crítica ha de ser menor que el límit elàstic.

Podem definir l'esveltesa mecànica:

$$
\lambda=\frac{L_{K}}{i}
$$

I l'equació de la tensió crítica:

$$
\sigma_{c r}=\frac{\pi^{2} E}{\lambda^{2}}
$$

Aquesta equació depén de l'esveltesa, però no del límit elàstic. Representarem en un gràfic la tensió crítica en funció de l'esveltesa.

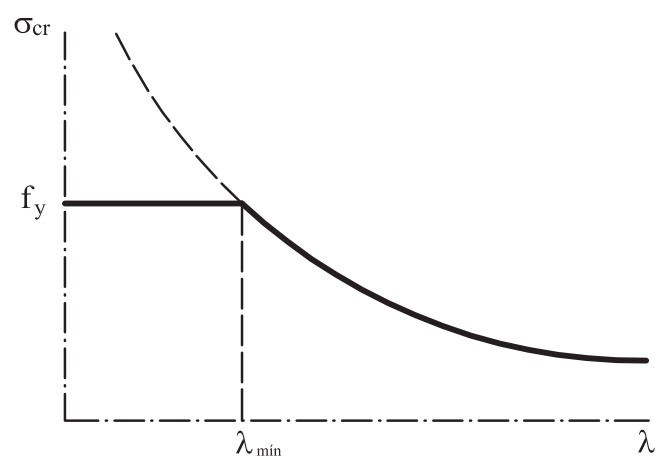

Fig. 8.5. Tensió crítica de vinclament

Si prenem la tensió de límit elàstic, i l'esveltesa a la qual es produeix, obtenim un límit inferior de la fórmula de vinclament, una esveltesa mínima. Per a esvelteses superiors a la mínima, la fallada es produirà per vinclament, però per a esvelteses més menudes, s'arribarà primer al límit elàstic, és a dir, la peça fallarà per resistència. 
L’esveltesa mínima és:

$$
\lambda_{\min }=\sqrt{\frac{\pi^{2} E}{f_{y}}}
$$

Per tant, l'esveltesa mínima només depén del material, del mòdul d'elasticitat i del límit elàstic. Per exemple, per a l'acer S275: $\lambda_{\min }=84,72$.

\subsection{Disseny d'elements}

Els elements comprimits podran vinclar-se en dues direccions. Hi ha dues maneres de veure-ho, que varien segons publicacions i segons normatives, per la qual cosa és necessari tindre clar a quina s'està fent referència quan ens trobem amb la diversa documentació.
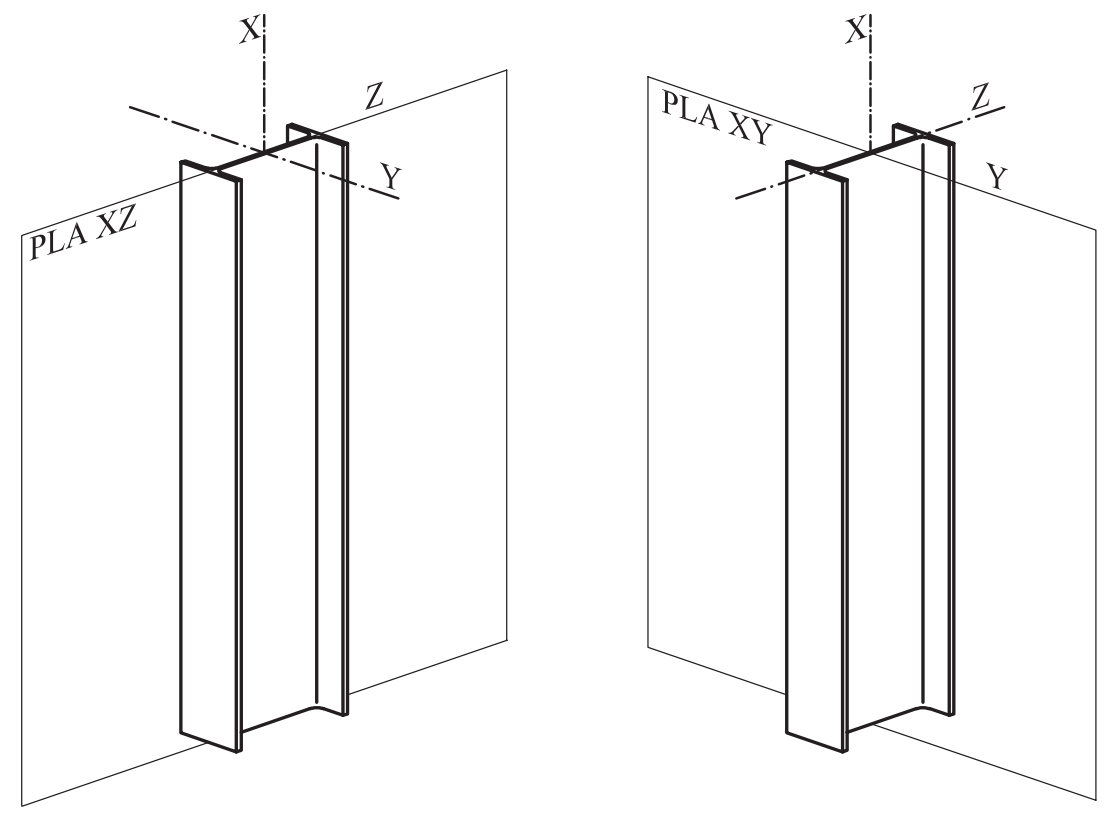

Fig. 8.6. Eixos i plans de vinclament

El vinclament no deixa de ser una flexió causada per la compressió. Quan estudiàrem el tema de flexió, vérem que la flexió podia donar-se al voltant dels dos eixos de la secció (normalment Y i Z). Si parlem d'eixos de vinclament, el sentit és el de l'eix al voltant del qual la barra girarà. Si parlem de plans de vinclament, el sentit és el d'un pla en el qual la barra deformada es mourà. En tot cas, és equivalent parlar d'eixos o de plans de vinclament, sempre que la correspondència siga correcta. Així doncs, referint-nos a la figura 8.6:

- Pla fort = pla de vinclament XZ = eix de vinclament Y.

- $\quad$ Pla feble = pla de vinclament $X Y=$ eix de vinclament $\mathrm{Z}$. 
Com ja ha pogut notar el lector, els noms dels eixos de la secció han sigut intercanviats. La raó és que les actuals normatives nacionals fan referència als eixos d'aquesta manera, i mantindre la mateixa nomenclatura que hem utilitzat en la resta del llibre, pot induir a error, si no es treballa amb molta cura. Per tant, en allò que fa referència a aquest tema, anomenarem $\mathrm{Y}$ a l'eix fort i $\mathrm{Z}$ a l'eix feble.

Tornem a l'expressió de la càrrega crítica d'Euler:

$$
N_{c r}=\frac{\pi^{2}}{(\beta L)^{2}} E I
$$

La càrrega serà diferent per a cada un dels eixos d'inèrcia. Evidentment, si el coeficient $\beta$ és igual en tots dos, el vinclament arribarà abans segons l'eix més feble. Tanmateix, les condicions de sustentació no són sempre les mateixes en els dos plans de vinclament. Aquestes poden ser diferents en cada cas concret; per tant, també ho serà el coeficient $\beta$. La conseqüència és que no sabem quin dels dos eixos es vinclarà primer, perquè amb un coeficient $\beta$ més gran, pot ser que l'eix fort tinga menys capacitat enfront del vinclament (menor $N_{c r}$ ) que el feble.

Realment les peces comprimides es vinclen abans d'arribar a la càrrega crítica d'Euler, perquè no es compleixen les condicions ideals (falta de rectitud inicial, tensions residuals, excentricitat de les càrregues, enduriment per deformació, etc.). Aquesta circumstància ha sigut confirmada per assajos experimentals. Per tant, la teoria d'Euler en els casos reals ens pot quedar del costat de la inseguretat.

Les normatives referents a cadascun dels materials han trobat maneres de dissenyar elements, basades en la teoria d'Euler, però modificades perquè siguen segures, de manera que es puga tindre confiança en l'estructura dissenyada.

En aquest curs, analitzarem la manera de dissenyar de les normatives d'acer, ja que l'acer és el material típicament elàstic més utilitzat en edificació. El formigó, que és l'altre material més emprat, no té les característiques de sòlid elàstic, i el seu càlcul és més complicat. A Europa, les normatives d'aquesta matèria s'anomenen eurocodis. Els eurocodis han de ser transposats als diferents països membres. A Espanya, la transposició de l'Eurocodi 3 (EC3: Projecte d'estructures d'acer) ha sigut feta al Codi Tècnic de l'Edificació (CTE Document Bàsic - Seguretat Estructural - Estructures d'Acer) per a estructures d'edificació i a la Instrucció d'Acer Estructural $(E A E)$ per a estructures d'altres tipus.

Els assajos fets per les normatives van trobar que es produeix la fallada per sota de la corba de la tensió crítica, per a cada esveltesa analitzada. Per tal d'eliminar la dependència del material, es van modificar els eixos del gràfic. L'eix d'abscisses es va modificar dividint l'esveltesa mecànica per l'esveltesa mínima. El valor resultant es va anomenar esveltesa adimensional o esveltesa reduïda. $\lambda=\lambda \lambda_{\text {min }}$. A l'eix d'ordenades, es va dividir la tensió crítica pel límit elàstic $\sigma_{c r} / f_{y}$. 


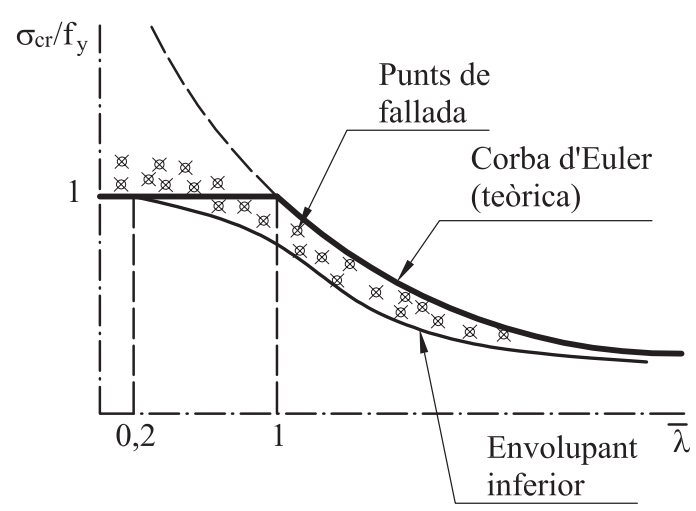

Fig. 8.7. Gràfic d'assajos adimensionalitzat

Per sota de l'esveltesa reduïda igual a 0,2 , la fallada no es produeix per vinclament sinó per resistència.

El disseny d'elements segons l'eurocodi per a vinclament per compressió es basa en el compliment de:

$$
\frac{N_{e d}}{N_{b, R d}} \leq 1
$$

- $\mathrm{N}_{\text {ed }}$ és l'esforç axial que hem calculat que ha de suportar la peça (axial de disseny).

- $\mathrm{N}_{\mathrm{b}, \mathrm{Rd}}$ és la resistència última de la barra a vinclament.

El límit elàstic del material ha de ser minorat per un coeficient de seguretat:

$$
f_{y d}=\frac{f_{y}}{\gamma_{M}}
$$

Com ja sabem, per a una peça sotmesa a un esforç axial, la resistència seria $N=A \cdot f_{y d}$.

Però això només serà vàlid per a les peces que estan a tracció. Les peces comprimides tenen una resistència menor. Per a quantificar-la, multiplicarem el valor anterior per un coeficient de reducció per vinclament $\chi \leq 1$, de manera que la resistència última de la barra a vinclament ens queda: $N_{b, R d}=\chi \cdot A \cdot f_{y d}$.

El coeficient $\chi$ depén de l'esveltesa reduïda:

$$
\bar{\lambda}=\sqrt{\frac{A \cdot f_{y}}{N_{c r}}}
$$

L'esveltesa reduïda per a peces comprimides té un límit màxim que no pot ser superat per disseny, per a elements principal $\lambda \leq 2$ si per a elements de trava $\lambda \leq 2,7$.

Els assajos van mostrar que cada tipus de secció tenia un comportament diferent, i es podia traçar una envolupant diferent. 
En total es va dividir el conjunt de tipologies en cinc corbes diferents $\left(a_{0}, a, b, d i d\right)$.

Totes aquestes corbes s'anomenen corbes europees de vinclament.

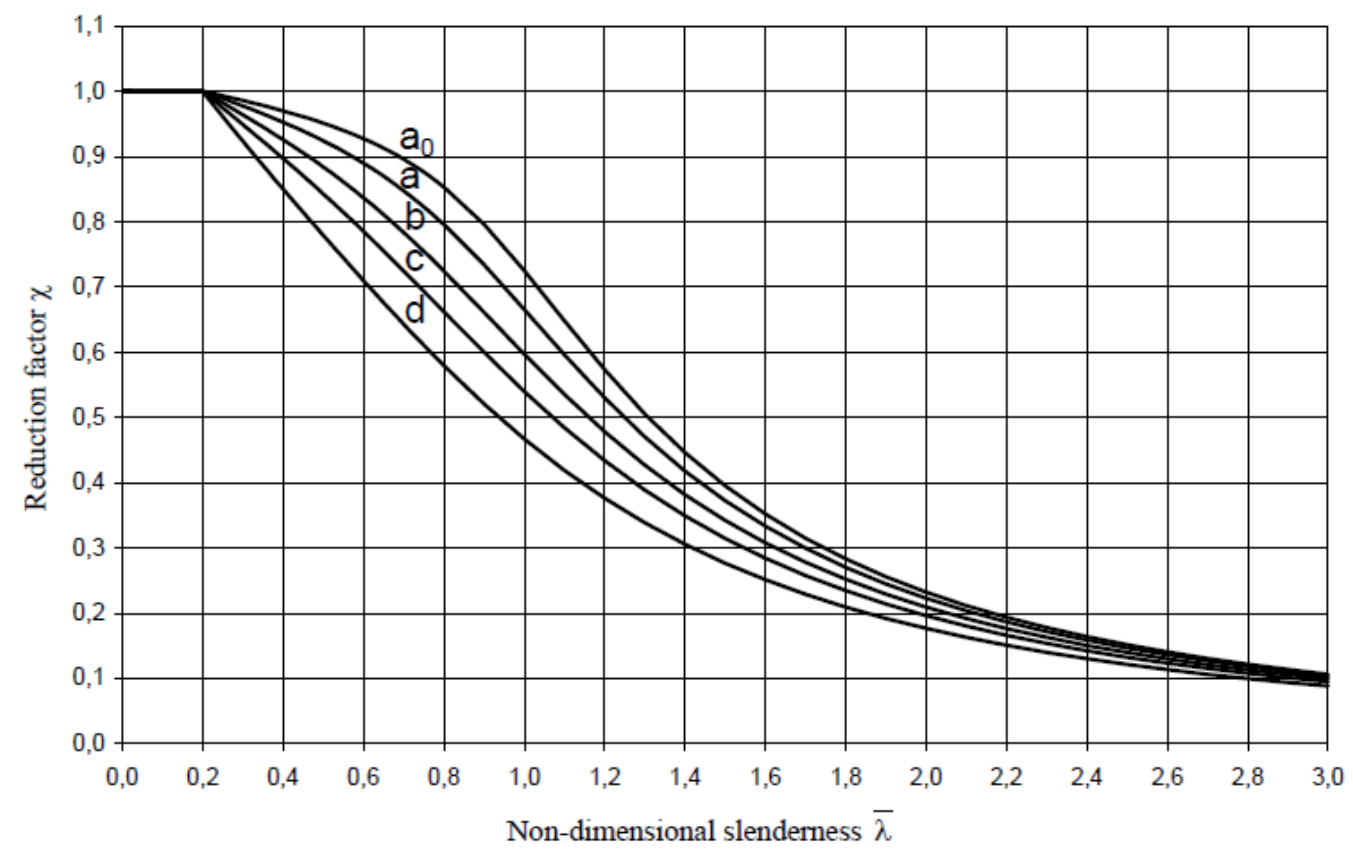

Fig. 8.8. Corbes europees de vinclament. Extret de l'Eurocodi 3

Les corbes de vinclament del gràfic poden expressar-se en forma de funció:

$\chi=\frac{1}{\Phi+\sqrt{\Phi^{2}-\bar{\lambda}^{2}}}$ on $\Phi=0,5\left[1+\alpha(\bar{\lambda}-0,2)+\bar{\lambda}^{2}\right]$

El coeficient $\alpha$ és un factor d'imperfecció que depén del tipus de corba.

El tipus de corba que hem d'utilitzar per a cada cas s'obté d'una altra taula. A causa de la seua extensió, només representarem ací la part corresponent als perfils laminats en I.

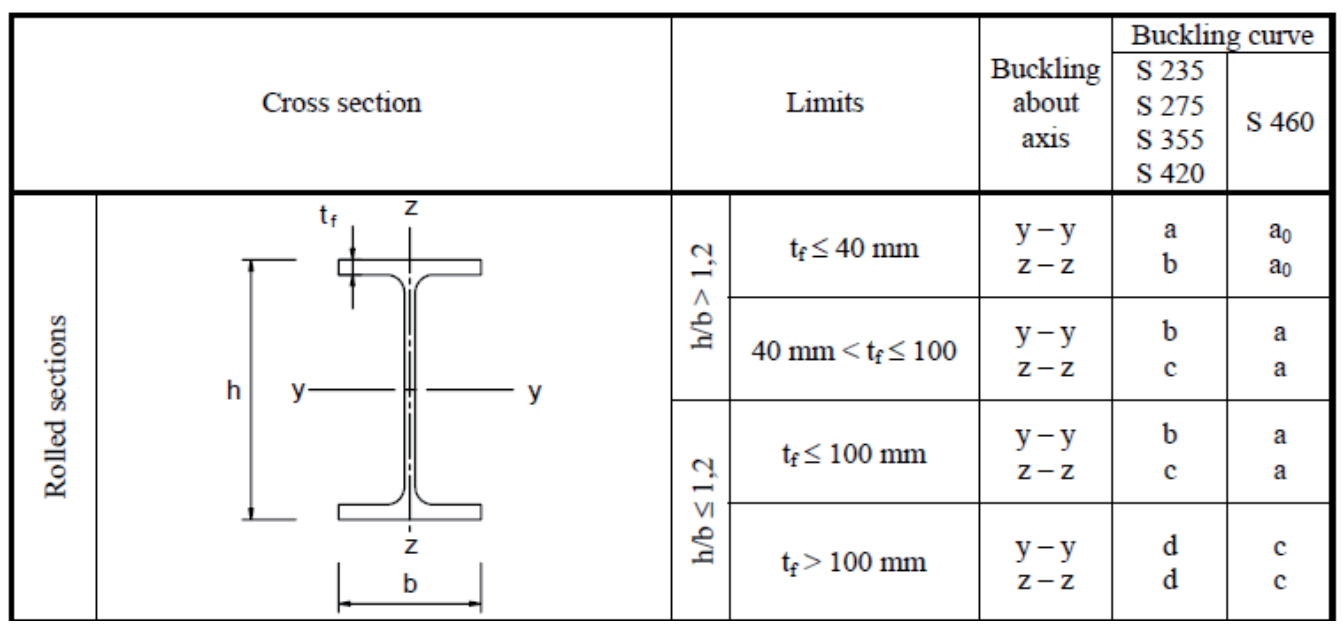

Fig. 8.10. Selecció de les corbes de vinclament en funció de la secció transversal. Extret de l'Eurocodi 3 
El tipus de corba depén de la resistència de l'acer, del gruix de les ales i de la relació cantell/ample de l'ala. El tipus de corba serà també diferent segons que considerem l'eix fort o el feble. Per exemple, per a un perfil IPE 300 d'acer S275, tenim $\mathrm{t}_{\mathrm{f}}<40 \mathrm{~mm} \mathrm{i} \mathrm{h/b}>1,2$; per tant, la corba a utilitzar en l'eix fort (Y) és la corba a, $\mathrm{i}$ en l'eix feble $(Z)$ és la corba $b$.

Els valors del coeficient de reducció per vinclament els tenim tabulats, de manera que ens podem evitar el càlcul. Els valors intermedis han de ser obtinguts per interpolació lineal.

\begin{tabular}{|c|c|c|c|c|c|}
\hline \multirow[b]{2}{*}{ Esbeltez reducida } & \multicolumn{5}{|c|}{ Curva de pandeo } \\
\hline & $\mathbf{a}_{0}$ & $\mathbf{a}$ & b & c & d \\
\hline $\begin{array}{r}\text { Coeficiente }(\alpha) \\
\text { de imperfección }\end{array}$ & 0,13 & 0,21 & 0,34 & 0,49 & 0,76 \\
\hline$\leq 0,20$ & 1,00 & 1,00 & 1,00 & 1,00 & 1,00 \\
\hline 0,30 & 0,99 & 0,98 & 0,96 & 0,95 & 0,92 \\
\hline 0,40 & 0,97 & 0,95 & 0,93 & 0,90 & 0,85 \\
\hline 0,50 & 0,95 & 0,92 & 0,88 & 0,84 & 0,78 \\
\hline 0,60 & 0,93 & 0,89 & 0,84 & 0,79 & 0,71 \\
\hline 0,70 & 0,90 & 0,85 & 0,78 & 0,72 & 0,64 \\
\hline 0,80 & 0,85 & 0,80 & 0,72 & 0,66 & 0,58 \\
\hline 0,90 & 0,80 & 0,73 & 0,66 & 0,60 & 0,52 \\
\hline 1,00 & 0,73 & 0,67 & 0,60 & 0,54 & 0,47 \\
\hline 1,10 & 0,65 & 0,60 & 0,54 & 0,48 & 0,42 \\
\hline 1,20 & 0,57 & 0,53 & 0,48 & 0,43 & 0,38 \\
\hline 1,30 & 0,51 & 0,47 & 0,43 & 0,39 & 0,34 \\
\hline 1,40 & 0,45 & 0,42 & 0,38 & 0,35 & 0,31 \\
\hline 1,50 & 0,40 & 0,37 & 0,34 & 0,31 & 0,28 \\
\hline 1,60 & 0,35 & 0,32 & 0,31 & 0,28 & 0,25 \\
\hline 1,80 & 0,28 & 0,27 & 0,25 & 0,23 & 0,21 \\
\hline $2,00^{(1)}$ & 0,23 & 0,22 & 0,21 & 0,20 & 0,18 \\
\hline $2,20^{(1)}$ & 0,19 & 0,19 & 0,18 & 0,17 & 0,15 \\
\hline $2,40^{(1)}$ & 0,16 & 0,16 & 0,15 & 0,14 & 0,13 \\
\hline $2,70^{(2)}$ & 0,13 & 0,13 & 0,12 & 0,12 & 0,11 \\
\hline $3,00^{(2)}$ & 0,11 & 0,10 & 0,10 & 0,10 & 0,09 \\
\hline
\end{tabular}

Fig. 8.9. Coeficient de reducció per vinclament. Extret del CTE-DB-SE-AE

La figura 8.11 representa un arbre de decisió per al disseny en vinclament. Si el problema a resoldre està basat en un únic perfil comercial, podem realitzar el predimensionament assegurant l'exigència que l'esveltesa reduïda no ha de superar un valor determinat.

$$
\bar{\lambda}=\sqrt{\frac{A \cdot f_{y}}{N_{c r}}}=\sqrt{\frac{A \cdot f_{y}}{\frac{\pi^{2}}{L_{K}^{2}} E I}}<\bar{\lambda}_{m a ̀ x}
$$

Podem reorganitzar els termes d'aquesta desigualtat per a trobar un resultat interessant:

$\frac{I}{A}>\frac{f_{y}}{\bar{\lambda}^{2} \frac{\pi^{2}}{L_{K}^{2}} E}$ i aprofitant la definició de radi de gir $i=\sqrt{\frac{I}{A}}$. 


$$
i_{\text {mín }}=\sqrt{\frac{f_{y}}{\bar{\lambda}_{m \grave{a} x}^{2} \frac{\pi^{2}}{L_{K}^{2}} E}}
$$

Calcularem el radi de gir necessari en cadascun dels eixos i buscarem un perfil a les taules que tinga els dos radis de gir superiors als mínims.

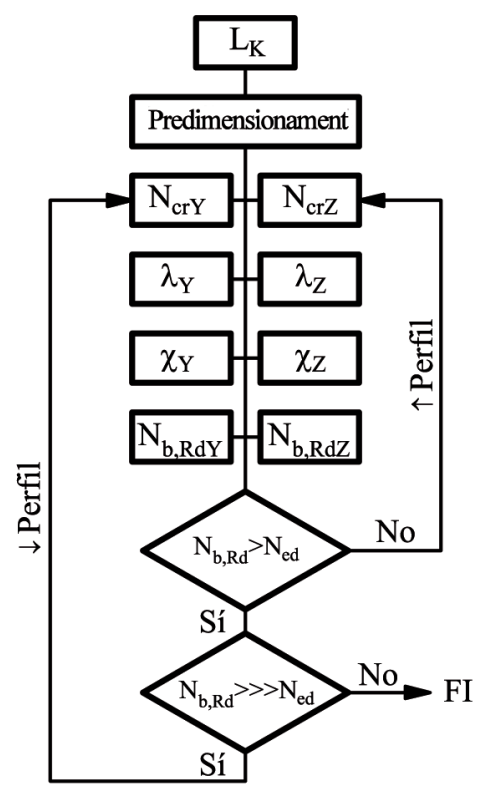

Fig. 8.11. Arbre de decisió per al disseny en vinclament

Si el problema és d'un altre tipus, aquesta fórmula no serà d'aplicació i el predimensionament l'haurem de fer un poc més intuïtivament. Una manera podria ser calcular l'àrea necessària si el perfil estiguera treballant a tracció $\left(A=N_{e d} / f_{y d}\right)$ i començar la iteració amb un perfil que tinga una àrea tres, quatre o cinc vegades superior.

\section{Exemple 8.1}

Calculeu la màxima càrrega axial de compressió admissible per a un pilar IPE 500 d'acer S275, de 10 m de longitud, sotmés exclusivament a esforç axial. Les condicions de sustentació són:

- Encastat-1liure al pla XZ.

- Encastat-articulat al pla XY.

Nota: l'eix fort del perfil és el Y i el feble el Z.

Dades: $\mathrm{h}=500 \mathrm{~mm} ; \mathrm{b}=200 \mathrm{~mm} ; \mathrm{A}=115 \mathrm{~cm}^{2} ; \mathrm{I}_{\mathrm{Y}}=48.200 \mathrm{~cm}^{4} ; \mathrm{I}_{\mathrm{Z}}=2.142 \mathrm{~cm}^{4}$. Hem de fer la comprovació als dos eixos de vinclament. 
$\beta_{Y}=2$

$L_{K Y}=\beta_{Y} \cdot L=20 \mathrm{~m}$

$N_{c r Y}=\frac{\pi^{2}}{L_{K Y}^{2}} E I_{Y}=2,50 \cdot 10^{6} \mathrm{~N}$

$\bar{\lambda}_{Y}=\sqrt{\frac{A \cdot f_{y}}{N_{c r Y}}}=1,125$
$\beta_{Z}=0,7$

$$
L_{K Z}=\beta_{Z} \cdot L=7 \mathrm{~m}
$$

$N_{c r Z}=\frac{\pi^{2}}{L_{K Z}^{2}} E I_{Z}=9,06 \cdot 10^{5} \mathrm{~N}$

$\bar{\lambda}_{Z}=\sqrt{\frac{A \cdot f_{y}}{N_{c r Z}}}=1,868$

Les esvelteses són menors que la màxima

Corba a

Corba $b$

Calculem mitjançant la fórmula, o entrant en la taula.

$\chi_{Y}=0,579$

$N_{b, R d Y}=\chi_{Y} \cdot A \cdot f_{y d}=1,74 \cdot 106 N$

$$
\begin{aligned}
& \chi_{Z}=0,236 \\
& N_{b, R d Z}=\chi_{Z} \cdot A \cdot f_{y d}=7,11 \cdot 105 N
\end{aligned}
$$

La conclusió és que l'eix Z (o el pla XY) es vinclarà abans, perquè la seua capacitat és menor.

\section{Exemple 8.2}

Dimensioneu el perfil IPE d'acer S275 necessari per a suportar una càrrega axial centrada de $500 \mathrm{kN}$. La longitud del pilar és de $7 \mathrm{~m}$.

- Encastat-1liure al pla XZ.

- Encastat-articulat al pla XY.

$$
\begin{array}{ll}
\beta_{Y}=2 & \beta_{Z}=0,7 \\
L_{K Y}=\beta_{Y} \cdot L=14 \mathrm{~m} & L_{K Z}=\beta_{Z} \cdot L=4,9 \mathrm{~m} \\
\bar{\lambda}_{\text {màx }}=2 & \\
\sigma=\frac{-M_{Z}}{I_{Z}} y+\frac{M_{Y}}{I_{Y}} z=\frac{\sqrt{3} M_{0}}{2 \cdot 1 \cdot 788 t^{4}} y-\frac{M_{0}}{2 \cdot 384 t^{4}} z &
\end{array}
$$

Anem a les taules de perfils comercials i busquem en la columna del radi de gir el primer que supera el necessari. A l'eix Y el primer és l'IPE 200 i a l'eix Z és l'IPE 270. Triem l'IPE 270 i verifiquem si compleix amb la càrrega admissible.

Dades del perfil: $\mathrm{h}=270 \mathrm{~mm} ; \mathrm{b}=135 \mathrm{~mm} ; \mathrm{A}=45,94 \mathrm{~cm}^{2} ; \mathrm{I}_{\mathrm{Y}}=5.790 \mathrm{~cm}^{4}$; $\mathrm{I}_{\mathrm{z}}=419,9 \mathrm{~cm}^{4}$.

$$
N_{c r Y}=\frac{\pi^{2}}{L_{K Y}^{2}} E I_{Y}=612,27 k N \quad N_{c r Z}=\frac{\pi^{2}}{L_{K Z}^{2}} E I_{Z}=362,47 k N
$$


$\bar{\lambda}_{Y}=\sqrt{\frac{A \cdot f_{y}}{N_{c r Y}}}=1,436$

Corba a

$\chi_{Y}=0,401$

$N_{b, R d Y}=\chi_{Y} \cdot A \cdot f_{y d}=481,94 \mathrm{kN}$
$\bar{\lambda}_{Z}=\sqrt{\frac{A \cdot f_{y}}{N_{c r Z}}}=1,867$

Corba b

$\chi_{z}=0,237$

$N_{b, R d Z}=\chi_{Z} \cdot A \cdot f_{v d}=284,59 \mathrm{kN}$

El perfil no és vàlid, perquè tenim un axial més gran que el màxim que pot suportar. Hem d'augmentar el perfil. Com que la capacitat a l'eix Z està molt lluny de l'axial que tenim, augmentarem dos perfils de cop, pujarem fins a l'IPE 330 .

Dades del perfil: $\mathrm{h}=330 \mathrm{~mm} ; \mathrm{b}=160 \mathrm{~mm} ; \mathrm{A}=62,61 \mathrm{~cm}^{2} ; \mathrm{I}_{\mathrm{Y}}=11.770 \mathrm{~cm}^{4}$; $\mathrm{I}_{\mathrm{Z}}=788,1 \mathrm{~cm}^{4}$.

$$
\begin{array}{ll}
N_{c r Y}=\frac{\pi^{2}}{L_{K Y}^{2}} E I_{Y}=1.245 \mathrm{kN} & N_{c r Z}=\frac{\pi^{2}}{L_{K Z}^{2}} E I_{Z}=680,31 \mathrm{kN} \\
\bar{\lambda}_{Y}=\sqrt{\frac{A \cdot f_{y}}{N_{c r Y}}}=1,176 & \bar{\lambda}_{Z}=\sqrt{\frac{A \cdot f_{y}}{N_{c r Z}}}=1,591
\end{array}
$$

Corba a

Corba $b$

$\chi_{Y}=0,545$

$$
\chi_{Z}=0,311
$$

$N_{b, R d Y}=\chi_{Y} \cdot A \cdot f_{y d}=894,04 \mathrm{kN}$

$$
N_{b, R d Z}=\chi_{Z} \cdot A \cdot f_{y d}=509,71 \mathrm{kN}
$$

Amb aquest perfil sí que es compleix la condició $\frac{N_{e d}}{N_{b, R d}} \leq 1$.

\section{Exemple 8.3}

Volem dissenyar un pilar de longitud $\mathrm{L}=10 \mathrm{~m}$ d'una nau industrial, a base de dos perfils IPE, iguals, d'acer S355 col·locats tal com indica la figura.

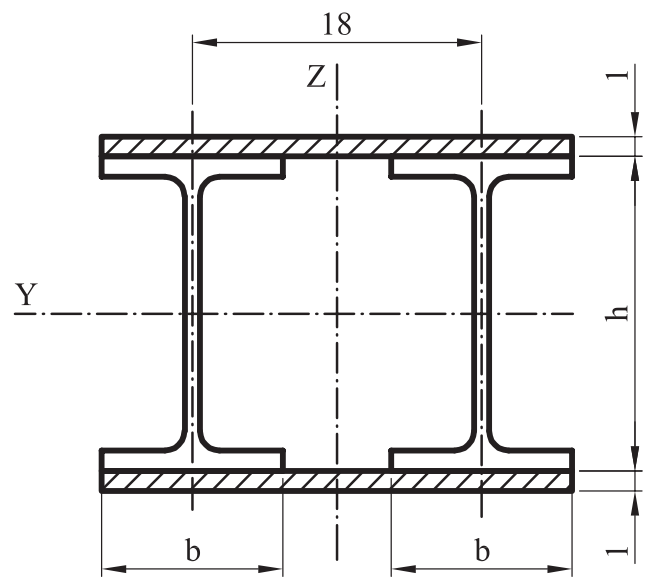

Fig. 8.12. Exemple 8.3. Enunciat. Cotes en cm 
Els perfils estaran units per les ales mitjançant unes platines de $1 \mathrm{~cm}$ de gruix. Trobeu la secció de l'IPE necessària per a suportar l'axial de disseny $\mathrm{N}_{\mathrm{ed}}=750 \mathrm{kN}$. Anomenarem la separació entre les ànimes $\mathrm{s}=18 \mathrm{~cm}$ i el gruix de les platines $\mathrm{t}=1 \mathrm{~cm}$.

En aquest cas no podem calcular un radi de gir per al predimensionament de la secció. No ens queda més remei que acudir al càlcul iteratiu. Buscarem l'àrea necessària a tracció.

$A_{t r}=\frac{N_{e d}}{f_{y d}}=\frac{1,05 \cdot 750 \cdot 10^{3}}{355 \cdot 10^{6}}=2,22 \cdot 10^{-3} \mathrm{~m}^{2}$

L'expressió per a l'àrea de la secció composta és:

$A=2[t \cdot(s+b)]+2 A_{I P E}$

Si provem amb un IPE $200\left(\mathrm{~b}=100 \mathrm{~mm}, \mathrm{~A}_{\mathrm{IPE}}=28,75 \mathrm{~cm}^{2}\right)$, obtenim una àrea $\mathrm{A}$ $=0,011 \mathrm{~m}^{2}$, que és unes cinc vegades més que la necessària a tracció. Començarem per aquest perfil.

Les expressions dels moments d'inèrcia de la secció composta són:

$$
\begin{aligned}
& I_{Y}=2\left[\frac{1}{12}(s+b) \cdot t^{3}+(s+b) \cdot t \cdot\left(\frac{h}{2}+\frac{t}{2}\right)^{2}\right]+2 I_{I P E . Y} \\
& I_{Z}=2\left[\frac{1}{12} t \cdot(s+b)^{3}\right]+2\left[I_{I P E . Z}+A_{I P E} \cdot\left(\frac{s}{2}\right)^{2}\right]
\end{aligned}
$$

Dades del perfil: $\mathrm{h}=200 \mathrm{~mm} ; \mathrm{b}=100 \mathrm{~mm} ; \mathrm{A}_{\mathrm{IPE}}=28,75 \mathrm{~cm}^{2} ; \mathrm{I}_{\text {IPE.Y }}=1940 \mathrm{~cm}^{4}$; $\mathrm{I}_{\text {IPE.Z }}=142 \mathrm{~cm}^{4}$.

$$
\begin{array}{ll}
\beta_{Y}=2 & \beta_{Z}=0,7 \\
L_{K Y}=\beta_{Y} \cdot L=20 \mathrm{~m} & L_{K Z}=\beta_{Z} \cdot L=7 \mathrm{~m} \\
N_{c r Y}=\frac{\pi^{2}}{L_{K Y}^{2}} E I_{Y}=521,19 \mathrm{kN} & N_{c r Z}=\frac{\pi^{2}}{L_{K Z}^{2}} E I_{Z}=3.638 \mathrm{kN} \\
\bar{\lambda}_{Y}=\sqrt{\frac{A \cdot f_{y}}{N_{c r Y}}}=2,78 & \bar{\lambda}_{Z}=\sqrt{\frac{A \cdot f_{y}}{N_{c r Z}}}=1,052
\end{array}
$$

En aquest punt hem de rebutjar el perfil, perquè l'esveltesa és superior al límit. Es pot demostrar que els perfils IPE 220, IPE 240 i IPE 270 tampoc tindran una esveltesa admissible. Anem directament al perfil IPE 300.

Dades del perfil: $\mathrm{h}=300 \mathrm{~mm} ; \mathrm{b}=150 \mathrm{~mm} ; \mathrm{A}_{\mathrm{IPE}}=53,8 \mathrm{~cm}^{2} ; \mathrm{I}_{\mathrm{IPE} . \mathrm{Y}}=8356 \mathrm{~cm}^{4}$; $\mathrm{I}_{\text {IPE.Z }}=603,8 \mathrm{~cm}^{4}$. 
$N_{c r Y}=\frac{\pi^{2}}{L_{K Y}^{2}} E I_{Y}=1.688 \mathrm{kN}$

$\bar{\lambda}_{Y}=\sqrt{\frac{A \cdot f_{y}}{N_{c r Y}}}=1,911$

Corba a

$\chi_{Y}=0,212$

$N_{b, R d Y}=\chi_{Y} \cdot A \cdot f_{v d}=1.245 \mathrm{kN}$
$N_{c r Z}=\frac{\pi^{2}}{L_{K Z}^{2}} E I_{Z}=6.731 \mathrm{kN}$

$\bar{\lambda}_{Z}=\sqrt{\frac{A \cdot f_{y}}{N_{c r Z}}}=0,957$

Corba b

$\chi_{Z}=0,565$

$N_{b, R d Z}=\chi_{Z} \cdot A \cdot f_{y d}=3.318 \mathrm{kN}$

Podem comprovar que el perfil escollit compleix sense problemes la condició de resistència:

$\frac{N_{e d}}{N_{b, R d Y}}=0,603 \leq 1$

La condició pot ser considerada com una ràtio d'aprofitament, que ens diu que el perfil compost està treballant al 60,3\% de la seua capacitat. Tanmateix, no podem considerar un perfil IPE més menut, perquè deixaria de complir la condició d'esveltesa.

\section{Exemple 8.4}

Considerem el sistema de la figura, en el qual les barres AB i AC són barres biarticulades de secció circular buida de diàmetre $\mathrm{D}$, gruix e i longitud L. La biga $\mathrm{DE}$ està formada per un únic tram recte de perfil IPE 270 encastat en D. Les tres barres són d'acer S275.

Determineu:

1. La màxima càrrega $\mathrm{P}$ que pot ser aplicada en $\mathrm{E}$ perquè no es produïsca la inestabilitat per vinclament de les barres.

2. La ràtio d'aprofitament de la barra $\mathrm{DE}$.

Dades: $\mathrm{L}=5 \mathrm{~m} ; \mathrm{D}=65 \mathrm{~mm}$; $\mathrm{e}=4 \mathrm{~mm}$.

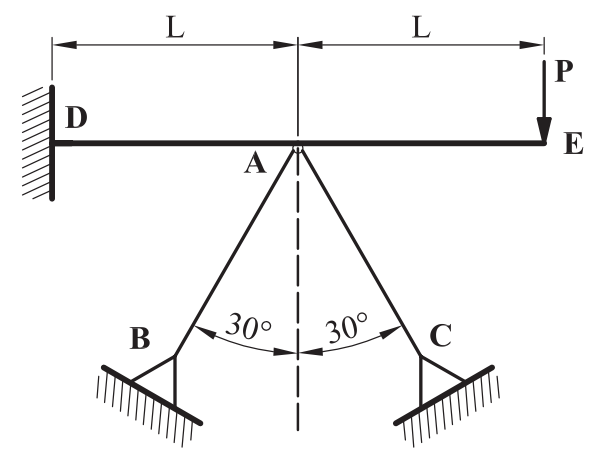

Fig. 8.13. Exemple 8.4. Enunciat 
Aquest és un problema que combina tres temes: el d'esforç axial, perquè es necessari fer una compatibilitat de desplaçaments en el punt A, el de flexió de la barra DE i el de vinclament per a les barres $\mathrm{AB}$ i AC.

El sistema és hiperestàtic. La condició de compatibilitat de desplaçaments s'obté a partir del moviment del punt A.

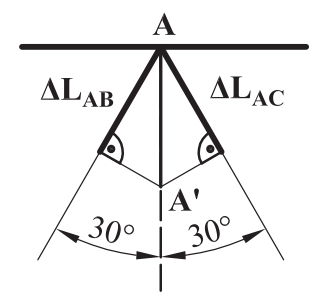

Fig. 8.14. Exemple 8.4. Compatibilitat de desplaçaments

Per tant, tenim que el descens del punt $\mathrm{A}$ està relacionat amb l'acurtament de les barres $\mathrm{AB}$ i AC, segons l'expressió:

$v_{A}=\frac{\Delta L}{\cos \left(30^{\circ}\right)}$

El màxim axial que poden suportar les barres $\mathrm{AB}$ i $\mathrm{AC}$ ve condicionat per la teoria del vinclament. Com que les barres són biarticulades, $\beta=1$ i $L_{K}=L$.

Moment d'inèrcia de la secció. Com que té doble simetria, els dos moments són iguals. Com que les condicions de sustentació son les mateixes en els dos eixos, només haurem de calcular una vegada.

$I_{Z}=\frac{\pi D^{4}}{64}-\frac{\pi(D-2 e)^{4}}{64}=3,58 \cdot 10^{-7} \mathrm{~m}^{4}$ i l'àrea $A=\frac{\pi D^{2}}{4}-\frac{\pi(D-2 e)^{2}}{4}=3,96 \cdot 10^{-4} \mathrm{~m}^{2}$

$N_{c r}=\frac{\pi^{2}}{L^{2}} \cdot E \cdot I_{Z}=29,87 k N$

$\bar{\lambda}=\sqrt{\frac{A \cdot f_{y}}{N_{c r}}}=1,915$. Com que és menor que 2, és admissible.

Per a perfils rodons conformats en calent, s'ha d'utilitzar la corba a. $\alpha=0,21$.

$\Phi=0,5\left[1+\alpha(\bar{\lambda}-0,2)+\bar{\lambda}^{2}\right]=2,54$

$\chi=\frac{1}{\Phi+\sqrt{\Phi^{2}-\bar{\lambda}^{2}}}=0,241$

$N_{b, R d}=\chi \cdot A \cdot f_{y d}=25,03 k N$ 
Si alguna de les barres supera aquest axial, es vinclarà. En el límit, l'acurtament de les barres serà:

$L=\frac{N_{b, R d} \cdot L}{E \cdot A}=1,51 \cdot 10^{-3} \mathrm{~m}$ i el descens del punt A: $v_{A}=\frac{\Delta L}{\cos \left(30^{\circ}\right)}=1,74 \cdot 10^{-3} \mathrm{~m}$

Ara calcularem el mateix descens del punt A però per a la barra DE, mitjançant la teoria de la flexió. Deixarem el descens en funció de P, l'igualarem al valor obtingut de $v_{A}$ i aïllarem $\mathrm{P}$.

Si considerem la biga DE, a més de la força $\mathrm{P}$ tenim les forces que li transmeten les dues barres comprimides. En el límit són $\mathrm{N}_{\mathrm{b}, \mathrm{Rd}}$. Les components horitzontals s'anul·len i les verticals se sumen. Per a simplificar, anomenarem

$$
Q=2 N_{b, R d} \cos \left(30^{\circ}\right)=201,32 k N
$$

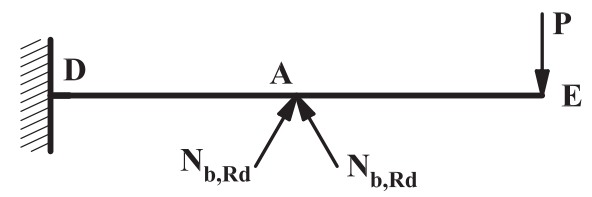

Fig. 8.15. Exemple 8.4. Barra DE

Per a calcular el descens del punt A utilitzarem el mètode d'interpretació gràfica. Apliquem una força puntual unitària en A. Separarem per superposició les forces reals.

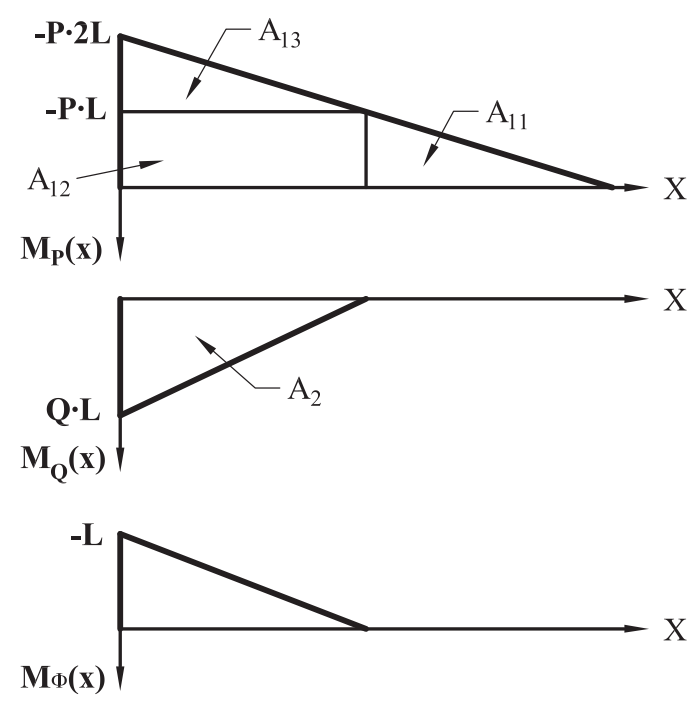

Fig. 8.16. Exemple 8.4. Barra DE. Diagrames d'esforços «reals» i «ficticis»

$$
\begin{array}{ll}
A_{11}=\frac{1}{2} L(-P \cdot L)=\frac{-P \cdot L^{2}}{2} & M_{\Phi 11}=0 \\
A_{12}=L(-P \cdot L)=-P \cdot L^{2} & M_{\Phi 12}=\frac{-L}{2}
\end{array}
$$


$A_{13}=\frac{1}{2} L(-P \cdot L)=\frac{-P \cdot L^{2}}{2} \quad M_{\Phi 13}=\frac{-2}{3} L$

$A_{2}=\frac{1}{2} L \cdot Q \cdot L=\frac{Q \cdot L^{2}}{2} \quad M_{\Phi 2}=\frac{-2}{3} L$

$v_{A}=\frac{1}{E I_{Z}}\left[A_{11} M_{\Phi 11}+A_{12} M_{\Phi 12}+A_{13} M_{\Phi 13}+A_{2} M_{\Phi 2}\right]=\frac{1}{E \cdot I_{Z}}\left[\frac{5 P L^{3}}{6}-\frac{Q L^{3}}{3}\right]=1,74 \cdot 10^{-3} \mathrm{~m}$

Aïllem $P=17,55 \cdot 10^{3} N=17,55 k N$.

Podem calcular les reaccions en l'encast:

$R_{D}=Q-P=25,81 \mathrm{kN} ; M_{D}=Q L-P 2 L=41,33 \mathrm{kN} \cdot \mathrm{m}$

La llei de moments flectors:

$0 \leq x \leq L \rightarrow M(x)=M_{D}-R_{D} x$

$L \leq x \leq 2 L \rightarrow M(x)=M_{D}-R_{D} x+Q(x-L)$

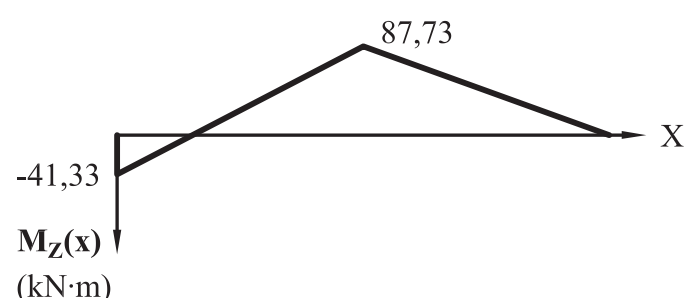

Fig. 8.17. Exemple 8.4. Barra DE. Diagrama de flectors

El màxim moment flector es produeix en $x=L \rightarrow M(L)=-87,73 \mathrm{kN} \cdot \mathrm{m}$.

La ràtio d'aprofitament serà, doncs: $a=\frac{|M(L)|}{W_{Z} \cdot f_{y d}}=0,781$. 


\section{Problemes proposats}

8.1. Es té un pilar format per un IPE 500, que ha de suportar l'esforç axial P que s'indica. Un cop realitzat el càlcul a vinclament, es conclou que encara que l'eix fort sí que resisteix, el perfil no resisteix l'esforç en l'eix dèbil, per la qual cosa es proposa com a solució soldar a l'ànima dos xicotets IPE, de la manera que es representa en la figura.

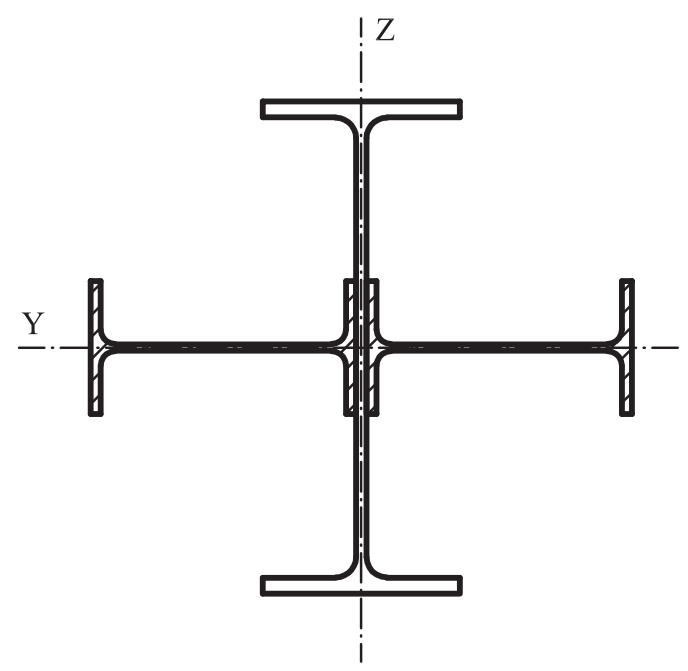

Fig. P.8.1

Dimensioneu els dos IPE, coneixent que les condicions de sustentació en relació amb la resta de l'estructura són, per a ambdós plans de vinclament:

- Base del pilar - encastada.

- Cap del pilar - lliure.

NotA: com es diu a l'enunciat, està assegurada la resistència a l'eix fort, per la qual cosa no cal comprovar-la.

Dades:

- Material: acer S275.

- Longitud del pilar: $\mathrm{L}=10 \mathrm{~m}$.

- Càrrega axial aplicada en el CDG del pilar: $\mathrm{P}=850 \mathrm{kN}$.

8.2. La biga biarticulada de la figura, de secció rectangular 10 x $20 \mathrm{~cm}$ i longitud $\mathrm{L}=10 \mathrm{~m}$, té impedit el desplaçament del seu punt mitjà en una direcció, tal com indica la figura. Determineu la càrrega de vinclament. 

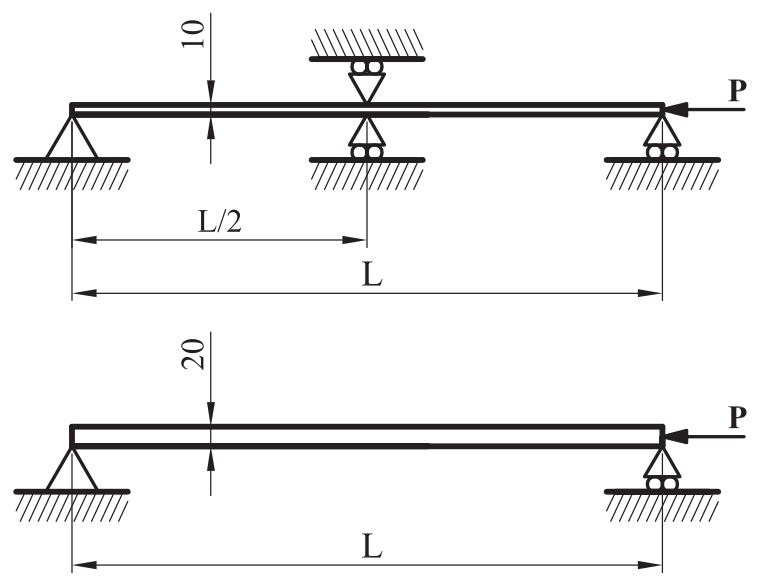

Fig. P.8.2

8.3. Els suports verticals d'una nau industrial estan encastats en la base $\mathrm{i}$ articulats al punt superior. Les condicions de trava en la nau fan que puga considerar-se que en el pla del pòrtic no hi haja cap impediment al desplaçament horitzontal i que el desplaçament estiga impedit en el pla perpendicular al pòrtic. Determineu el perfil HEB capaç de suportar, d'acord amb l'Eurocodi 3, una càrrega vertical de $100 \mathrm{kN}$. Els suports tenen una longitud de $10 \mathrm{~m}$.

8.4. L'estructura de la figura (cotes en $\mathrm{m}$ ) està constituïda pels següents elements estructurals:

- Biga AB: Perfil IPE 200.

- Suport BC: Perfil heB 100.

La biga $\mathrm{AB}$ està encastada en $\mathrm{A} i$ articulada en $\mathrm{B}$ al suport biarticulat $\mathrm{BC}$. Determineu la màxima càrrega q que pot suportar el sistema estructural, si:

a) No s'ha de superar la resistència a flexió de la biga.

b) El suport no ha de vinclar-se.

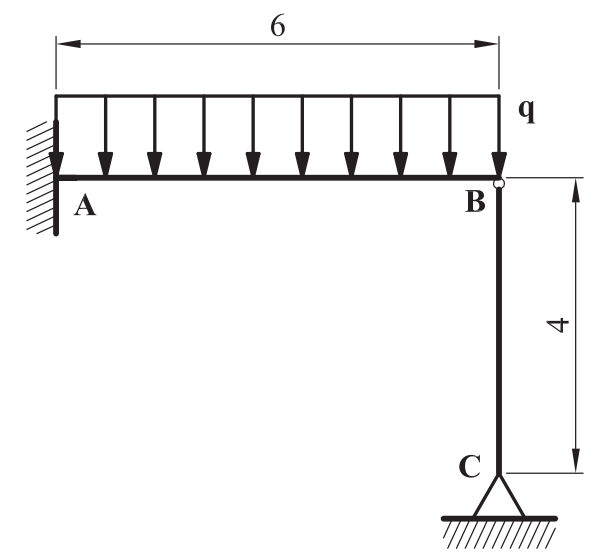

Fig. P.8.4 
8.5. Un pilar de $3 \mathrm{~m}$ de longitud es troba sotmés a una càrrega $\mathrm{P}$ de compressió centrada. Calculeu el valor de la càrrega màxima que podrà suportar per als supòsits següents:

a) El pilar té impedit completament el vinclament.

b) El pilar té impedit el vinclament en el pla XY.

c) El pilar té impedit el vinclament en el pla XZ.

d) El pilar pot vinclar-se lliurement.

Dades: S275. Perfil HEB 160. Considereu condicions de sustentació recolzat-encastat en els casos en què el vinclament no estiga impedit.

8.6. Un pilar de $6 \mathrm{~m}$ de longitud, articulat en els seus extrems, es troba sotmés a una càrrega de compressió de $1.100 \mathrm{kN}$. La secció del perfil és 2 UPN en caixó. Es demana:

a) Dimensioneu la secció del pilar a resistència.

b) Redimensioneu el pilar a vinclament, utilitzant la normativa europea.

c) Repetiu els apartats anteriors, si el pilar tinguera $8 \mathrm{~m}$ de longitud.

Dades: S275.

8.7. En el sistema de la figura, en el qual l'element BE és un puntal biarticulat:

a) Determineu el valor màxim al qual pot arribar la càrrega q sense que es produïsca el vinclament del puntal BE.

b) Representeu els diagrames d'esforços de tots els elements estructurals del sistema acotant els valors més significatius.

c) Determineu la tensió equivalent de Von Mises en el punt de coordenades $y=10 \mathrm{~cm}, z=5 \mathrm{~cm}$ de la secció D.

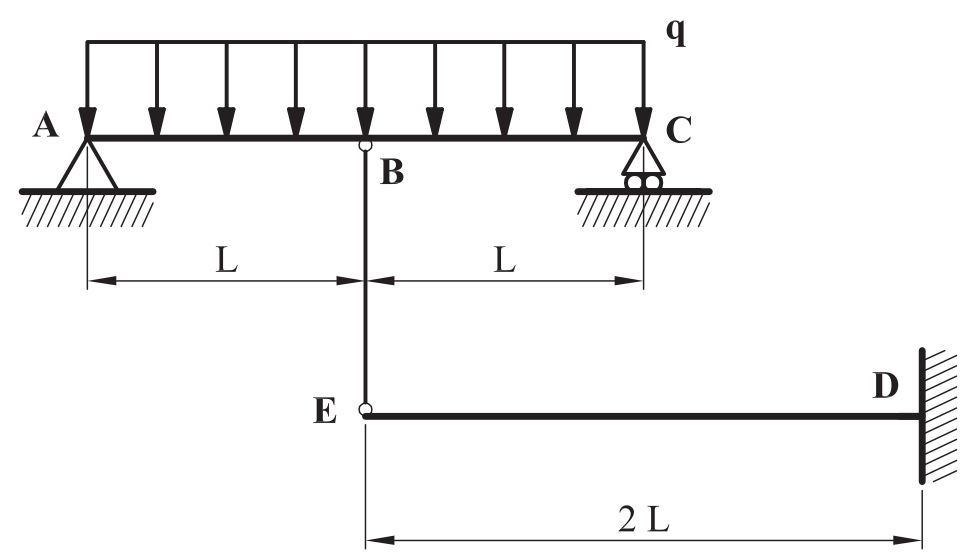

Fig. P.8.7 
Dades:

Puntal:

- Longitud: $\mathrm{L}=1 \mathrm{~m}$.

- $\mathrm{E}=200 \mathrm{GPa}$.

- Secció circular massissa de diàmetre $\mathrm{D}=2.5 \mathrm{~cm}$.

Bigues:

- $\mathrm{L}=1 \mathrm{~m}$.

- $\mathrm{E}=30 \mathrm{GPa}$.

- Secció quadrada de 20 × $20 \mathrm{~cm}$.

8.8. Vol dissenyar-se un pilar per a una nau industrial utilitzant dos perfils UPN units mitjançant dues planxes d'acer de $2 \mathrm{~cm}$ de gruix com mostra la figura. Determineu el perfil UPN (S275) mínim a utilitzar perquè el pilar suporte una càrrega axial centrada en el centre de gravetat de la secció $\mathrm{P}=1.000 \mathrm{kN}$.

Dades:

- Condicions de sustentació:

- Pla XY (eix Z): encastat-lliure.

- Pla XZ (eix Y): encastat-articulat.

- Altura del pilar: $\mathrm{L}=10 \mathrm{~m}$.

- Separació entre els centres de gravetat dels perfils: $\mathrm{s}=20 \mathrm{~cm}$.

- Gruix de les plaques d'acer: $\mathrm{t}=2 \mathrm{~cm}$.

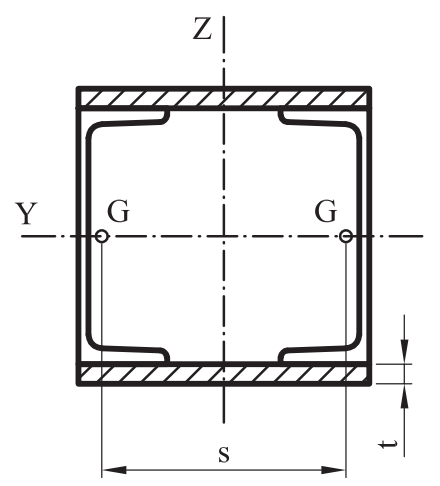

Fig. P.8.8 


\section{ANNEX A}

\section{Mètodes d'unió}

\section{A.1. Introducció}

Moltes vegades, tant en construcció de màquines com en edificació, és necessari unir adequadament les peces que constitueixen el sistema corresponent, perquè puguen exercir correctament les funcions per a les quals han sigut projectades.

Si es tracta de peces metàl-liques, els procediments més emprats són la unió cargolada i la unió per soldadura. També es pot donar el cas de tindre una unió articulada mitjançant un boló o passador que permeta el gir.

Les diverses normatives expliquen el procediment de verificació de les unions. No obstant això, en aquest annex no es vol fer un recull de les especificacions de la normativa, ni de les seues fórmules de comprovació. El món normatiu està en canvi continu, i les normes que avui estan en vigor, poden ser modificades o substituïdes en un període relativament curt de temps. Per tant, en un text com aquest, no té sentit analitzar una normativa en concret. El que es pretén ací és que l'alumne comprenga els mecanismes de treball d'aquests elements d'unió, per tal que siga capaç d'analitzar la normativa actual (o les que estiguen per vindre) de manera autònoma.

\section{A.2. Unions cargolades}

En les primeres estructures metàl-liques modernes (segle XIX) que es van construir, era freqüent l'us de reblons, com per exemple a la Torre Eiffel, on hi ha aproximadament dos milions i mig de reblons. Un exemple més proper el tenim a l'Estació del Nord de València. Els reblons s'utilitzaven per a l'acoblament de peces d'estructures metàl-liques i estaven composts per una espiga de forma cilíndrica, amb un extrem (cap) en forma de casquet esfèric que s'introduïa en forats practicats en les peces a unir (de forma pareguda als cargols). El rebló era calfat a una temperatura entre $950{ }^{\circ} \mathrm{C}$ (roig cirera) i $1050{ }^{\circ} \mathrm{C}$ (roig taronja). Quan el rebló estava introduït als forats, es formava un altre cap a la part oposada, pel mètode d'estampació, amb un motlle denominat boterola. En estructures, els reblons han caigut en desús, encara que es manté la seua utilització en algunes màquines i dipòsits. El procés de deformació del cap no sempre és amb deformació a altes temperatures, els reblons més habituals s'instal·len mitjançant una simple deformació mecànica.

Avui en dia, en estructures, els reblons han sigut substituïts pels cargols. Un cargol és una peça similar al rebló, que té una rosca tallada en tota la seua longitud, o en una part de l'espiga, i que per tal d'impedir-se l'eixida del forat, s'immobilitza mitjançant una peça amb un forat interior amb la rosca tallada de forma negativa (femella). 


\section{A.2.1. Disposicions constructives}

La situació dels cargols en la unió ha de contribuir a reduir la possibilitat de corrosió i vinclament local de les xapes, i tindre en compte les necessitats de muntatge $\mathrm{i}$ inspeccions futures.

Els cargols poden disposar-se de manera alineada o a portell.

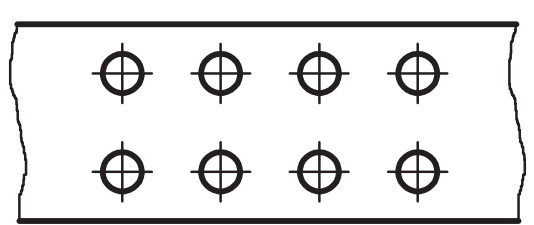

a)

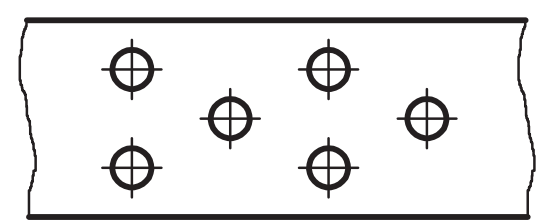

b)

Fig. A.01. a) disposició alineada; $b$ ) disposició a portell

La normativa ens marca unes distàncies mínimes i màximes entre l'eix del forat i el cantell de la peça $\mathrm{i}$ entre eixos dels forats, que depenen del diàmetre del forat $\mathrm{i}$ del gruix de les peces.

Les maneres d'unió de les peces poden dividir-se en unions per solapament o unions a topall.
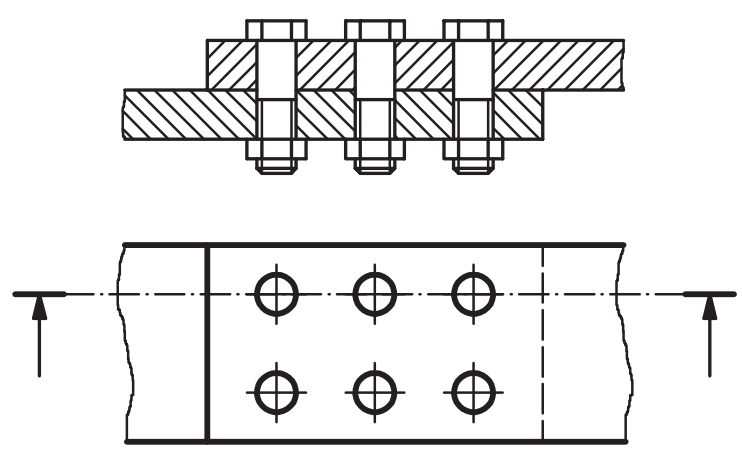

Fig. A.02. Unió per solapament

La unió per solapament té l'inconvenient que els esforços a transmetre no són coplanars, i per tant, apareix un moment flector que tendeix a corbar les xapes, com es mostra a la figura.

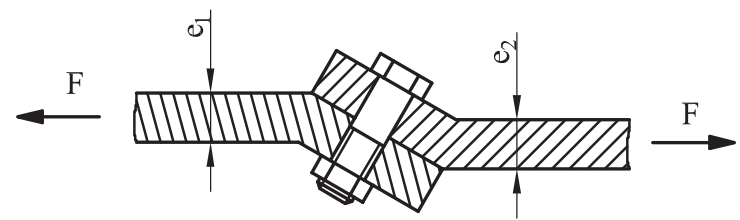

Fig. A.03. Corbament que es produeix com a conseqüència del desalineament de forces

$$
M=F \frac{e_{1}+e_{2}}{2}
$$


Per tal d'evitar aquest efecte es recorre a la utilització de dos tapajunts sobre les xapes col-locades a topall.
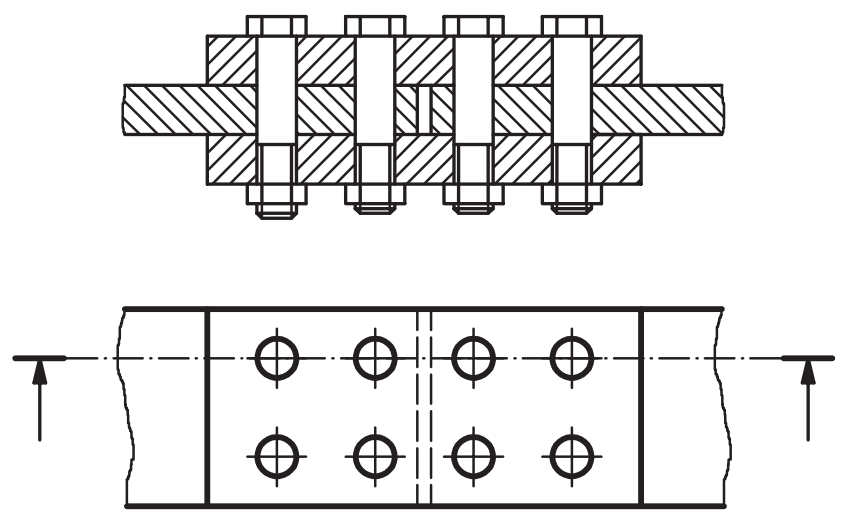

Fig. A.04. Unió a topall amb tapajunts (separació entre xapes exagerada)

La distància de centre a centre entre forats d'una mateixa fila es denomina pas. El pas pot variar d'una fila a una altra dins de la mateixa unió. La distància entre els eixos de dues files en les disposicions alineades es diu pas entre files.

Mòdul repetitiu és un conjunt de cargols que es repeteix al llarg de la unió. Generalment convé basar els càlculs en la resistència d'un d'aquests grups en lloc de considerar tota la longitud de la unió. Freqüentment se'l denomina només mòdul.

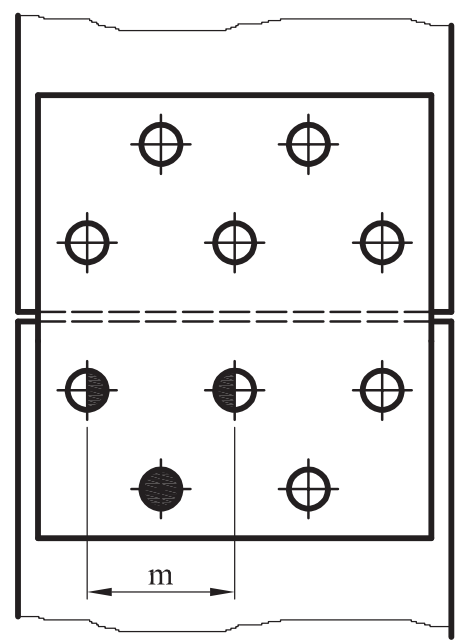

Fig. A.05. Mòdul repetitiu (m)

\section{A.2.2. Formes de trencament de les unions cargolades}

a) Cisallament de l'espiga per tallant simple o doble. Encara que hem vist al tema de flexió que les tensions tangencials no es distribueixen de manera uniforme per tota la secció, de manera aproximada farem la suposició que tenim una uniformitat de tensions en la secció. 
Els assajos mostren que per a un material com l'acer normal, el punt de fluència per cisallament és aproximadament entre $0,5-0,6$ vegades el valor de la tensió normal de fluència.

$$
\tau_{F}=0,5 \sim 0,6 \sigma_{F}
$$

En cisallament per tallant simple, considerem que la força que suporta el cargol es reparteix per tota la secció transversal de l'espiga de diàmetre $\mathrm{d}$. Per tant, la tensió tangencial serà:

$$
\tau_{C}=\frac{4 F}{\pi d^{2}}
$$

Si tenim un cas de doble tall, hem de considerar el doble d'àrea.

\section{Exemple A.1}

Dues plaques d'acer de $15 \mathrm{~mm}$ estan unides amb una unió per solapament d'una fila de cargols com es mostra a la figura. El pas és de $6 \mathrm{~cm}$ i el diàmetre dels cargols de $22 \mathrm{~mm}$. La càrrega que suporten les plaques és de $800 \mathrm{kN}$ per metre d'amplària. Determineu les tensions màximes de tall als cargols.

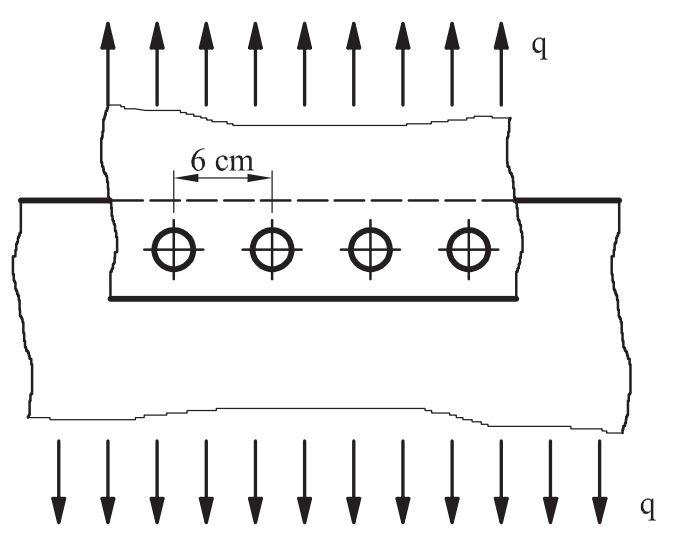

Fig. A.06. Exemple A.1

Açí tindríem una costura de longitud indeterminada, per la qual cosa calcularem el mòdul repetitiu per a calcular la tensió tangencial. En aquest cas és molt simple, perquè suposa un únic cargol i la seua separació són $6 \mathrm{~cm}$.

Cada mòdul suportarà una càrrega de: $F=q \cdot m=800 \cdot 0,06=48 \mathrm{kN}$.

L'àrea transversal del cargol és: $A_{C}=\pi \frac{d^{2}}{4}=3,8 \cdot 10^{-4} \mathrm{~m}^{2}$.

La tensió tangencial mitjana serà: $\tau_{C}=\frac{F}{A_{C}}=1,26 \cdot 10^{8} \mathrm{~Pa}=126,27 \mathrm{MPa}$. 


\section{Exemple A.2}

Considereu la unió per solapament de doble fila de cargols representada en la figura adjunta, en la qual el pas en ambdues files és de $7 \mathrm{~cm}$. Els cargols estan distribuïts a portell i mesuren $25 \mathrm{~mm}$ de diàmetre. Cada placa té $15 \mathrm{~mm}$ de gruix. La força que actua sobre cada xapa és de $1.200 \mathrm{kN} / \mathrm{m}$. Trobeu les tensions tallants en la unió.

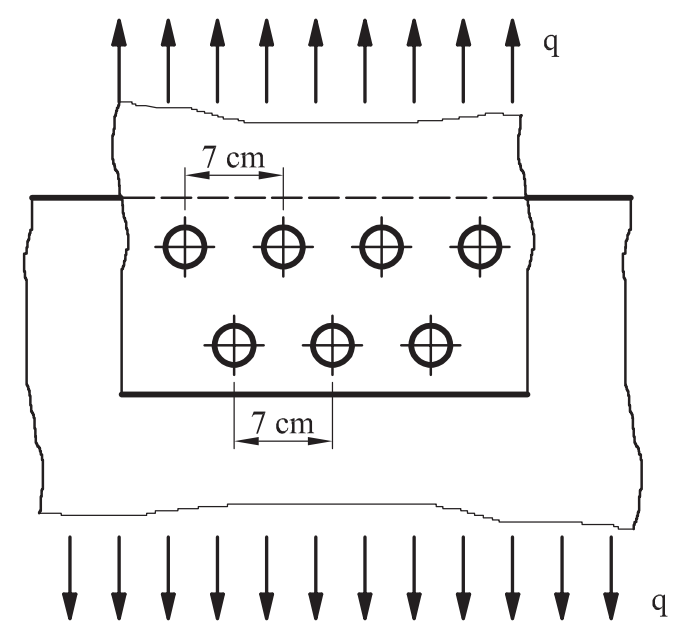

Fig. A.07. Exemple A.2

Cada mòdul repetitiu mesura $7 \mathrm{~cm}$. Com veiem a la figura, cada mòdul comprén un cargol i dues meitats, per tant és l'equivalent a dos cargols.

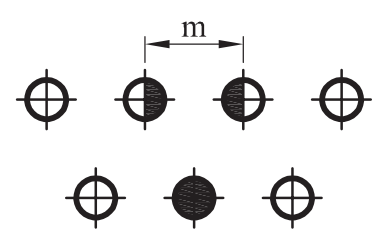

Fig. A.08. Exemple A.2

La força que actua sobre cada mòdul és: $F=q \cdot m=1.200 \cdot 0,07=84 k N$.

L'àrea transversal del mòdul és: $A_{C}=2 \pi \frac{d^{2}}{4}=9,82 \cdot 10^{-4} \mathrm{~m}^{2}$.

La tensió tangencial mitjana serà: $\tau_{C}=\frac{F}{A_{C}}=8,56 \cdot 10^{7} \mathrm{~Pa}=85,52 \mathrm{MPa}$.

b) Xafada de la xapa o el cargol produïda per la pressió entre les superfícies cilíndriques del cargol i el forat, com es veu a la següent figura. Per a calcular la resistència a la xafada sol usar-se el producte de la projecció de l'àrea del forat cilíndric, açò és, el diàmetre del forat pel gruix de la xapa i de la resistència a ruptura per compressió del material. 
La tensió normal de compressió que hem de comprovar és: $\sigma_{X}=\frac{P}{t \cdot d}<\sigma_{a d m, C}$ (t és el gruix de la xapa i d el diàmetre del forat).
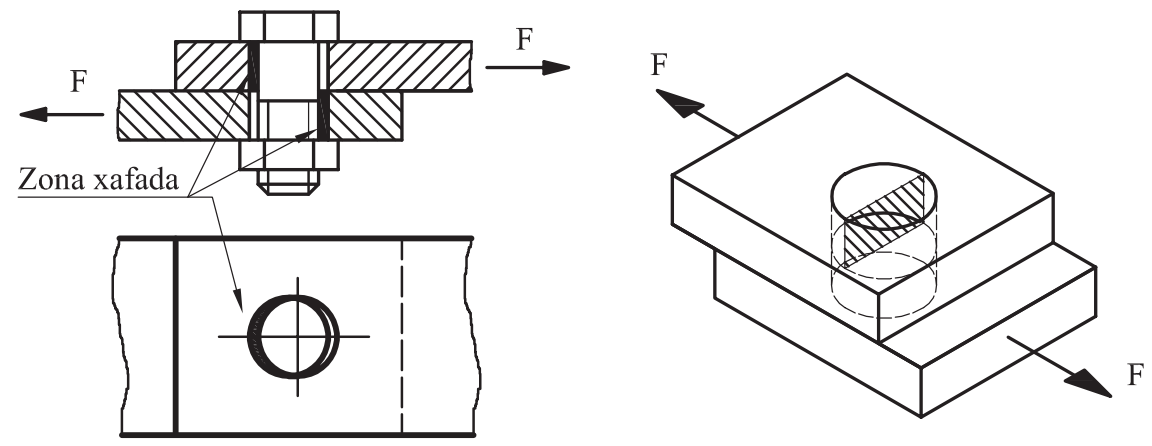

Fig. A.09. Xafada de la xapa. En la perspectiva només es representa l'àrea projectada de la xapa superior

\section{Exemple A.3}

En la unió de l'exemple A.1, calculeu la tensió de xafada.

Com que el mòdul repetitiu implica només un diàmetre, la secció serà:

$$
A_{X}=t \cdot d=3,3 \cdot 10^{-4} \mathrm{~m}^{2}
$$

i la tensió normal de xafada:

$$
\sigma_{X}=\frac{F}{A_{X}}=1,45 \cdot 10^{8} \mathrm{~Pa}=145,45 \mathrm{MPa}
$$

\section{Exemple A.4}

En la unió de l'exemple A.2., calculeu la tensió de xafada.

Com que el mòdul repetitiu implica dos diàmetres, la secció serà:

$$
A_{X}=2 t \cdot d=7,5 \cdot 10^{-4} \mathrm{~m}^{2}
$$

i la tensió normal de xafada:

$$
\sigma_{X}=\frac{F}{A_{X}}=1,12 \cdot 10^{8} \mathrm{~Pa}=120 \mathrm{MPa}
$$

c) Esquinçament de la xapa entre els forats a causa de la falta de resistència a tracció en la secció al llarg d'una fila de cargols. La tensió normal de tracció no ha de superar la tensió admissible de tracció del material. La tensió es calcula dividint la força que actua sobre el mòdul repetitiu entre la superfície lateral de l'espai entre forats. 


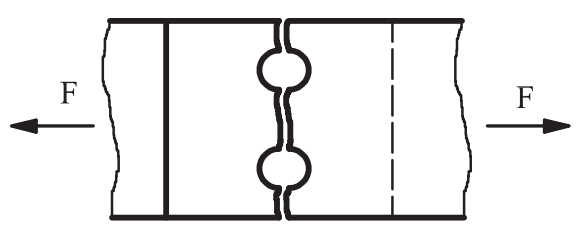

Fig. A.10. Esquinçament de la xapa

\section{Exemple A.5}

Calculeu la tensió de tracció en la unió de l'exemple A.1.

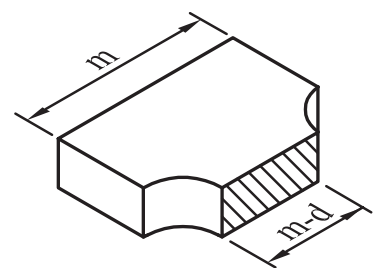

Fig. A.11. Exemple A.5. Calculem el mínim espai entre forats dins d'un mòdul repetitiu

Àrea d'esquinçament: $A_{E}=t \cdot(m-d)=5,7 \cdot 10^{-4} \mathrm{~m}^{2}$.

Tensió de tracció: $\sigma_{E}=\frac{F}{A_{E}}=8,42 \cdot 10^{7} \mathrm{~Pa}=84,21 \mathrm{MPa}$.

\section{Exemple A.6}

Calculeu la tensió de tracció en la unió de l'exemple A.2.

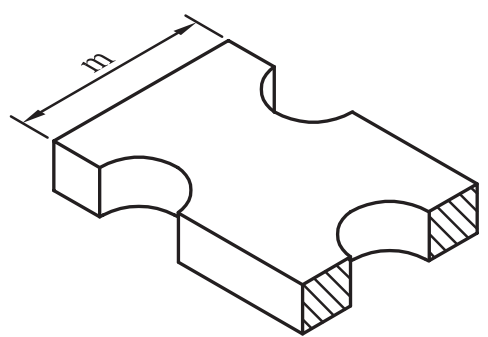

Fig. A.12. Exemple A.6

Tenim dues àrees possibles: una equivalent a la de la figura A.11 i una altra com la que es mostra a la figura A.12.

Àrea d'esquinçament: $A_{E}=t \cdot(m-d)=6,75 \cdot 10^{-4} \mathrm{~m}^{2}$.

Tensió de tracció: $\sigma_{E}=\frac{F}{A_{E}}=1,24 \cdot 10^{8} \mathrm{~Pa}=124,44 \mathrm{MPa}$. 
d) Esquinçament segons una diagonal. Està indicat a la figura A.13. Aquest tipus de ruptura no sol ocórrer si el pas entre files és almenys 1,5 vegades el diàmetre del forat. En els exercicis que resoldrem, suposarem que el pas té almenys aquesta proporció amb el diàmetre de les reblades, per la qual cosa no estudiarem aquest tipus de trencament.

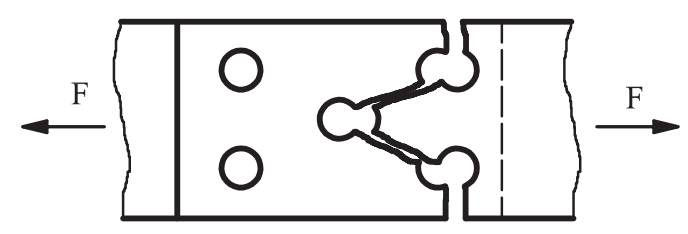

Fig. A.13. Esquinçament segons una diagonal

e) Tall de la xapa o, possiblement, esquinçament de la xapa entre un forat de reblada i el cantell de la placa, com es veu en la següent figura. Aquests tipus de ruptura no solen ocórrer si la distància del centre del forat al cantell és aproximadament el doble del diàmetre del cargol. Suposarem que respectem aquest condicionant de forma i tampoc considerarem aquest tipus de trencament.

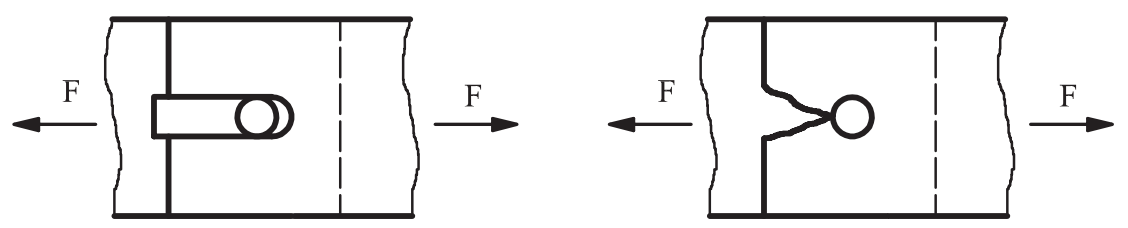

Fig. A.14. Tall de la xapa o esquinçament cap al cantell

\section{Exemple A.7}

Considerant la unió per solapament de doble fila de cargols de la figura adjunta, en la qual el pas és de $7 \mathrm{~cm}$, el gruix de la placa $15 \mathrm{~mm}$ i els cargols tenen $20 \mathrm{~mm}$ de diàmetre, calculeu la càrrega màxima admissible.

Les tensions de ruptura recomanades són: tracció $\sigma_{\mathrm{E}}=355 \mathrm{MPa}$, tallant $\tau_{\mathrm{C}}=300 \mathrm{MPa}$ i compressió $\sigma_{\mathrm{X}}=650 \mathrm{MPa}$.

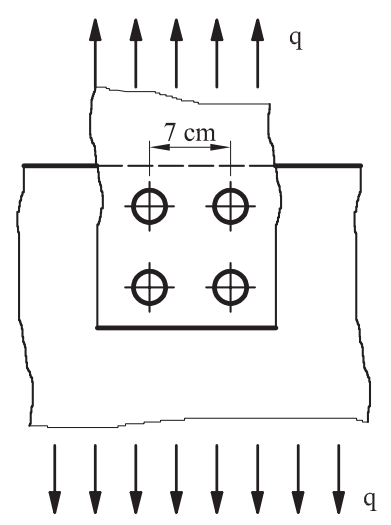

Fig. A.15. Exemple A.7. Enunciat 
El mòdul repetitiu podem veure'l a la figura. Tenim l'equivalent a dos cargols per mòdul.

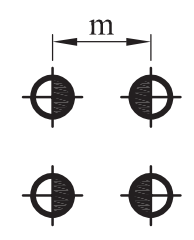

Fig. A.16. Exemple A.7. Mòdul repetitiu

Estudi de les tensions de cisallament:

$A_{C}=2 \pi \frac{d^{2}}{4}=6,28 \cdot 10^{-4} \mathrm{~m}^{2}$

$P_{C}=A_{C} \cdot \tau_{C}=1,88 \cdot 10^{5} \mathrm{~N}$

$q_{C}=\frac{P_{C}}{m}=2,69 \cdot 10^{6} \mathrm{~N} / \mathrm{m}$

Estudi de la xafada a compressió:

$A_{X}=2 \cdot t \cdot d=6 \cdot 10^{-4} \mathrm{~m}^{2}$ Poden xafar-se dos cargols per mòdul.

$P_{X}=A_{X} \cdot \sigma_{X}=3,9 \cdot 10^{5} \mathrm{~N}$

$q_{X}=\frac{P_{X}}{m}=5,57 \cdot 10^{6} \mathrm{~N} / \mathrm{m}$

Estudi de l'esquinçament a tracció:

$A_{E}=t \cdot(m-d)=7,5 \cdot 10^{-4} \mathrm{~m}^{2}$

$P_{E}=A_{E} \cdot \sigma_{E}=2,66 \cdot 10^{5} \mathrm{~N}$

$q_{E}=\frac{P_{E}}{m}=3,8 \cdot 10^{6} \mathrm{~N} / \mathrm{m}$

\section{A.2.3. Cargols d'alta resistència}

La resistència de les unions en què s'empren cargols d'alta resistència es deu a l'aprofitament de les forces de fregament desenrotllades en estrényer fortament els cargols. Aquestes contraresten l'acció de les forces exteriors que tendeixen a fer lliscar les peces entre elles.

La força d'estrenyiment origina en l'espiga del caragol un esforç de tracció molt elevat, el qual comprimeix les peces a unir, donant lloc a forces de fregament que s'oposen al lliscament d'ambdues superfícies. 
Els cargols d'alta resistència provoquen, al llarg de les seccions que uneixen, una distribució de tensions més favorable que uns altres mitjans d'unió. En concret, es redueixen els efectes de concentració de tensions als voltants del forat.

La magnitud de les forces que es poden transmetre depenen fonamentalment de:

1. La intensitat de la força de tracció en el cos del cargol.

2. El coeficient de fregament que s'haja aconseguit.

És important destacar que en aquest tipus d'unions, si estan ben realitzades, els cargols no treballen a tall, per la qual cosa no cal calcular-los per a aquesta sol-licitació.

Aquest comportament requereix un procediment de càlcul específic, que excedeix els àmbits d'aquesta assignatura, encara que pot ser estudiat per l'alumne que hi tinga interés seguint la bibliografia adequada.

\section{A.3. Unions soldades}

En les estructures es troben dos tipus ordinaris d'unions soldades de xapes. Es coneixen per soldadures a topall i soldadures en angle. A la figura següent estan representats ambdós tipus. Les soldadures a topall poden actuar només en tracció i en compressió, mentre que les soldadures en angle poden suportar tallant, tracció i compressió i, a vegades, a més, flexió. La soldadura s'executa o per l'arc elèctric o amb gas.

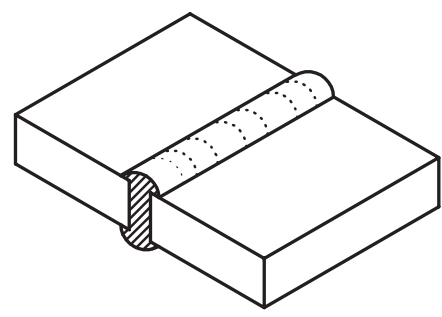

a)

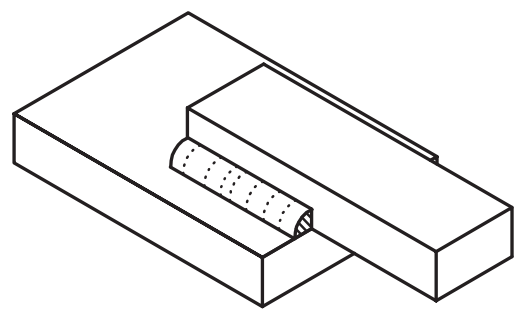

b)

Fig. A.17. Unions soldades: $a$ ) a topall; $b$ ) en angle

\section{A.3.1. Resistència de les soldadures a topall}

Suposem que la resistència de la soldadura a topall representada a la figura anterior és igual a la secció total de la soldadura multiplicada per la tensió de treball admissible en tracció o compressió del material soldat $\left(\sigma_{\text {sol }}\right)$. Es pren com a àrea total el producte de la longitud de la soldadura (b) pel gruix de la xapa més prima (t) de les que s'uneixen.

$$
P=\sigma_{\text {sol }} \cdot b \cdot t
$$




\section{A.3.2. Resistència de les soldadures en angle}

Abans de calcular la resistència de la soldadura en angle representada a la figura anterior, és necessari definir diverses de les seues dimensions característiques. A la secció de la figura A.18, la soldadura té amplàries de cordó (o catets) iguals. La dimensió mínima de la seua secció s'anomena gola (a). Evidentment, en aquest cas amb els catets iguals, la gola és igual al producte de l'amplària del cordó per $\sin \left(45^{\circ}\right)$.

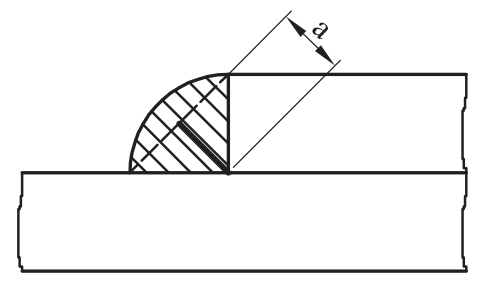

Fig. A.18. Definició de gola $(a)$ de la soldadura

És costum suposar que només cal considerar la resistència al tallant d'aquestes soldadures, perquè la fallada se sol produir per tallant a $45^{\circ}$ en la gola. Per això, es pren la resistència de la soldadura igual al producte de l'àrea total en la gola per la tensió de treball admissible a tallant en el material.

\section{Exemple A.8}

Calculeu la màxima càrrega de tracció $\mathrm{P}$ que pot aplicar-se en una soldadura $\mathrm{a}$ topall de dues xapes de $20 \mathrm{~cm}$ d'ample i $12 \mathrm{~mm}$ de gruix. La tensió admissible de treball és $\tau_{\text {adm }}=90 \mathrm{MPa}$.

Solució: $\mathrm{P}=\tau_{a d m} \cdot t \cdot b=2,16 \cdot 10^{5} \mathrm{~N}$.

\section{Exemple A.9}

En la soldadura en angle de la figura, es coneix el gruix de les xapes (12 mm). Tenim una soldadura a cada costat, cadascuna de $18 \mathrm{~cm}$. La tensió de treball admissible és $\tau_{\text {adm }}=80 \mathrm{MPa}$.

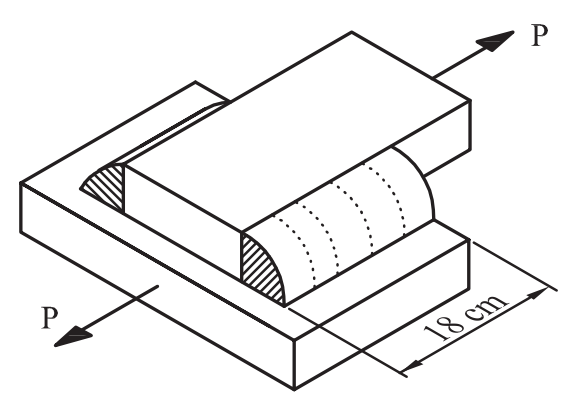

Fig. A.19. Exemple A.9 
Es considera que la càrrega està centrada entre les soldadures. Determineu la màxima càrrega $\mathrm{P}$ que es pot aplicar a les xapes.

Suposem els dos catets iguals, de $12 \mathrm{~mm}$. L'ample de la gola serà:

$$
a=12 \cdot \sin \left(45^{\circ}\right)=8,42 \mathrm{~mm}
$$

L'àrea eficaç de la soldadura (considerant els dos cordons de soldadura) és:

$$
A_{S}=21 \cdot \mathrm{a}=2 \cdot 0,18 \cdot 8,42 \cdot 10^{-3}=3,06 \cdot 10-4 \mathrm{~m}^{2}
$$

La càrrega admissible: $P=\tau_{a d m} \cdot A_{S}=2,44 \cdot 105 N$. 


\section{Problemes proposats}

A.1. Considereu la unió per solapes d'una sola fila de cargols representada a la figura A.06. El pas és de $6 \mathrm{~cm}$, l'espessor de les xapes $12 \mathrm{~mm}$ i els cargols tenen $20 \mathrm{~mm}$ de diàmetre. Les tensions de trencament recomanades són: tracció $\sigma_{\mathrm{E}}=355 \mathrm{MPa}$, tallant $310 \mathrm{MPa}$, compressió $\sigma_{\mathrm{X}}=650 \mathrm{MPa}$. Determineu la càrrega admissible.

A.2. Considereu la unió a topall de doble fila de cargols de la figura, on el pas és de $7,5 \mathrm{~cm}$, les plaques principals tenen $12 \mathrm{~mm}$ de gruix i el tapajunts, $10 \mathrm{~mm}$. El diàmetre dels cargols és de $20 \mathrm{~mm}$. Les tensions admissibles són: tracció $\sigma_{\mathrm{E}}=140 \mathrm{MPa}$, tallant $\tau_{\mathrm{C}}=100 \mathrm{MPa}$ i compressió $\sigma_{\mathrm{X}}=280 \mathrm{MPa}$. Determineu la càrrega admissible.

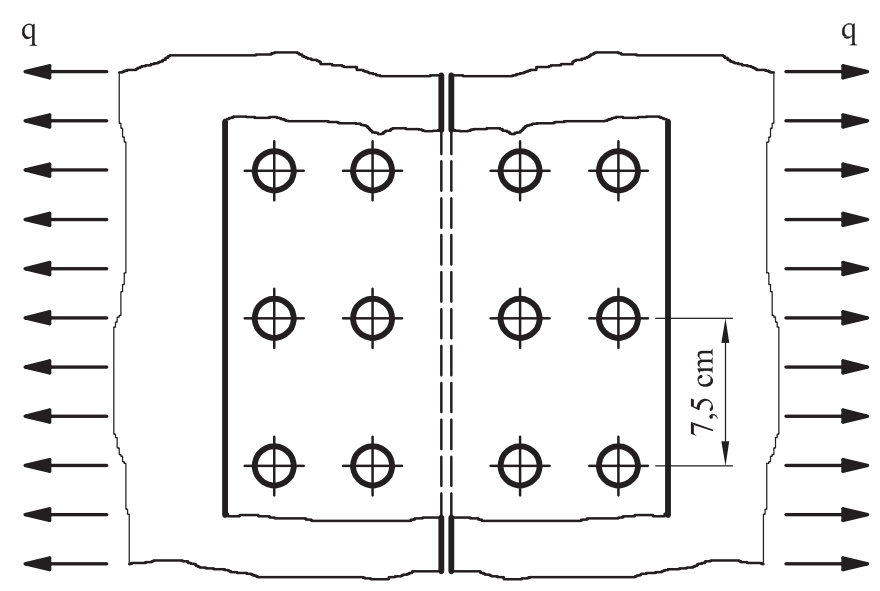

Fig. P.A.2 


\section{ANNEX B}

\section{Coneixements previs - sistemes d'unitats}

\section{B.1. Introducció}

Fins al segle Xvi existia una llarga confusió sobre les diferents unitats de pesos i mesures, i com un intent d'aclarir-la va sorgir el sistema decimal d'unitats. No obstant això, fins a l'any 1791, després de la Revolució Francesa, no es van assentar les bases d'un sistema d'unitats adequat per a ser adoptat per tot el món. Aquest sistema, establit per l'Acadèmia de Ciències Franceses, es va basar en el metre com a unitat de longitud, i el gram com a unitat de massa. Un segle després d'aquella data, en una reunió a la qual van assistir quinze països, celebrada a París l'any 1875 , es va estandarditzar internacionalment el sistema mètric decimal, i es va crear l'Oficina Internacional de Pesos i Mesures. Al seu voltant es va constituir, una Conferència General de Pesos i Mesures (CGPM) capaç de tractar tots els assumptes internacionals relacionats amb aquest tema.

El sistema mètric original proporcionava un conjunt d'unitats per a la mesura de longitud, àrea, volum i massa, basat en dues unitats fonamentals: el metre i el kilogram; la mesura de quantitats addicionals requerides per la ciència i el comerç van impulsar el desenrotllament d'unitats derivades.

L'any 1881 es va afegir, com a fonamental, la unitat de temps i va aparéixer el sistema cegesimal (centímetre-gram-segon, CGS). Posteriorment, al voltant de 1900, es va establir el sistema MKS (metre-kilogram-segon), que adoptava com a unitats fonamentals el metre i el quilogram. A aquest sistema es va afegir l'ampere com una nova unitat fonamental de corrent elèctric, i es va denominar, des d'aquell moment, sistema MKSA.

En la desena Conferència General de Pesos i Mesures celebrada en 1954, es va adoptar el sistema MKSA. Es va afegir el kelvin com la unitat de temperatura, i la candela com la unitat d'intensitat lumínica.

El nom formal de sistema internacional d'unitats (SI) va ser atorgat en l'onzena CGPM, celebrada en 1960. A aquesta reunió van assistir un total de 36 països.

Posteriorment, es va afegir el $\mathrm{mol}$ com una sèptima unitat bàsica en la catorzena CGPM, celebrada en 1971, i es van aprovar noms específics per a algunes de les unitats derivades, com per exemple, la unitat de pressió $\left(\mathrm{N} / \mathrm{m}^{2}\right)$ que es va denominar $\operatorname{pascal}(\mathrm{Pa})$. 


\section{B.2. Sistema internacional (sI)}

El si és una selecció racionalitzada i coherent d'unitats del sistema mètric, que inclou set unitats bàsiques o fonamentals i que n'estableix amb precisió el nom, el símbol i la definició.

El gran avantatge del si és que hi ha una unitat, i només una, per a cada quantitat física (com ara, el metre per a longitud, el kilogram per a massa, etc.). A partir d'aquestes unitats fonamentals s'han deduït les unitats derivades, que es defineixen per equacions molt simples, com per exemple:

$$
\begin{array}{ccccc}
\text { velocitat } & \text { acceleració } & \text { força } & \text { treball o energia } & \text { potència } \\
v=\frac{d l}{d t} & a=\frac{d v}{d t} & F=m a & W=F l & P=\frac{W}{t}
\end{array}
$$

Algunes d'aquestes unitats derivades tenen noms genèrics, com per exemple, metre per segon $(\mathrm{m} / \mathrm{s})$ per a velocitat; d'altres tenen noms especials, com newton $(\mathrm{N})$ per a força, joule $(\mathrm{J})$ per a treball o energia, i watt $(\mathrm{W})$ per a potència.

Un avantatge addicional que presenta aquest sistema es deriva de l'ús d'un conjunt de símbols únic i ben definit.

\section{B.2.1. Unitats i símbols}

Les unitats del sI es dividixen en tres categories:

- Unitats fonamentals.

- Unitats suplementàries.

- Unitats derivades.

Unitats fonamentals del SI

\begin{tabular}{|l|l|l|}
\hline Magnitud & Nom de la unitat & Símbol \\
\hline Longitud & metre & $\mathrm{m}$ \\
Massa & kilogram & $\mathrm{kg}$ \\
Temps & segon & $\mathrm{S}$ \\
Intensitat de corrent elèctric & ampere & $\mathrm{A}$ \\
Temperatura & kelvin & $\mathrm{K}$ \\
Intensitat lluminosa & candela & $\mathrm{cd}$ \\
Quantitat de substància & mol & $\mathrm{mol}$ \\
\hline
\end{tabular}

Unitats suplementàries del sI

\begin{tabular}{|l|l|l|}
\hline Magnitud & Nom de la unitat & Símbol \\
\hline Angle pla & radiant & rad \\
Angle sòlid & estereoradiant & sr (str) \\
\hline
\end{tabular}


Algunes unitats derivades del SI

\begin{tabular}{|c|c|c|c|}
\hline Magnitud & Nom de la unitat & Símbol & Expressió \\
\hline $\begin{array}{l}\text { Superfície } \\
\text { Volum } \\
\text { Freqüència } \\
\text { Nombre d'ona } \\
\text { Densitat } \\
\text { Velocitat } \\
\text { Velocitat angular } \\
\text { Acceleració } \\
\text { Acceleració angular } \\
\text { Força } \\
\text { Pressió (tensió mecànica) } \\
\text { Viscositat cinemàtica } \\
\text { Viscositat dinàmica } \\
\text { Treball, energia, quantitat } \\
\quad \text { de calor } \\
\text { Entropia } \\
\text { Potència } \\
\text { Conductivitat tèrmica } \\
\text { Intensitat energètica } \\
\text { Quantitat d'electricitat } \\
\text { Tensió elèctrica, diferència } \\
\quad \text { de potencial, força } \\
\quad \text { electromotriu } \\
\text { Intensitat de camp elèctric } \\
\text { Resistència elèctrica } \\
\text { Capacitat elèctrica } \\
\text { Flux d'inducció magnètica } \\
\text { Inductància } \\
\text { Inducció magnètica } \\
\text { Intensitat de camp magnètic } \\
\text { Força magnetomotriu } \\
\text { Flux lluminós } \\
\text { Luminància } \\
\text { Il·luminància } \\
\text { Activitat (d'un brollador } \\
\quad \text { radioactiu) }\end{array}$ & $\begin{array}{l}\text { metre quadrat } \\
\text { metre cúbic } \\
\text { Hertz } \\
1 \text { per metre } \\
\text { kilogram per metre cúbic } \\
\text { metre per segon } \\
\text { radiant per segon } \\
\text { metre per segon per segon } \\
\text { radiant per segon per segon } \\
\text { newton } \\
\text { newton per metre quadrat } \\
\text { (pascal) } \\
\text { metre quadrat per segon } \\
\text { kilogram per metre per segon } \\
\text { joule } \\
\text { joule per kelvin } \\
\text { joule per kilogram per kelvin } \\
\text { watt per metre per kelvin } \\
\text { watt per estereoradiant } \\
\text { coulomb } \\
\text { volt }\end{array}$ & $\begin{array}{l}\mathrm{m}^{2} \\
\mathrm{~m}^{3} \\
\mathrm{~Hz} \\
\mathrm{~m}^{-1} \\
\mathrm{~kg} / \mathrm{m}^{3} \\
\mathrm{~m} / \mathrm{s} \\
\mathrm{rad} / \mathrm{s} \\
\mathrm{m} / \mathrm{s}^{2} \\
\mathrm{rad} / \mathrm{s}^{2} \\
\mathrm{~N} \\
\mathrm{~N} / \mathrm{m}^{2} \\
\mathrm{~Pa} \\
\mathrm{~m}^{2} / \mathrm{s} \\
\mathrm{kg} / \mathrm{m} \cdot \mathrm{s} \\
\mathrm{J} \\
\mathrm{J} / \mathrm{K} \\
\mathrm{J} / \mathrm{kg} \cdot \mathrm{K}) \\
\mathrm{W} /(\mathrm{m} \cdot \mathrm{K}) \\
\mathrm{W} / \mathrm{sr} \\
\mathrm{C} \\
\mathrm{V} \\
\mathrm{V} / \mathrm{m} \\
\Omega \\
\mathrm{F} \\
\mathrm{Wb} \\
\mathrm{H} \\
\mathrm{T} \\
\mathrm{A} / \mathrm{m} \\
\mathrm{A} \\
\mathrm{lm} \\
\mathrm{cd} / \mathrm{m}^{2} \\
\mathrm{~lx} \\
\mathrm{~s}-1\end{array}$ & $\begin{array}{l}(=\mathrm{V} / \mathrm{A}) \\
(=\mathrm{A} \cdot \mathrm{s} / \mathrm{V}) \\
(=\mathrm{V} \cdot \mathrm{s}) \\
(=\mathrm{V} \cdot \mathrm{s} / \mathrm{A}) \\
\left(=\mathrm{Wb} / \mathrm{m}^{2}\right)\end{array}$ \\
\hline
\end{tabular}

Nota: la quarta columna és l'expressió en funció de les unitats fonamentals o derivades.

Podem observar que els símbols de les unitats s'escriuen amb minúscula, excepte els procedents d'un nom propi, que sempre s'escriuen amb majúscula. 


\section{B.2.2. Prefixos}

Els prefixos i símbols que apareixen a la taula anterior s'utilitzen per a formar noms i símbols dels múltiples i submúltiples decimals de les unitats del sI, excepte per al kilogram.

Múltiples i submúltiples decimals

\begin{tabular}{|c|c|c|}
\hline $1000000000000000000=10^{18}$ & exa & $\mathrm{E}$ \\
\hline $1000000000000000=10^{15}$ & peta & $\mathrm{P}$ \\
\hline $1000000000000=10^{12}$ & tera & $\mathrm{T}$ \\
\hline $1000000000=10^{9}$ & giga & G \\
\hline $1000000=10^{6}$ & mega & M \\
\hline $1000=10^{3}$ & kilo & $\mathrm{k}$ \\
\hline $100=10^{2}$ & hecto & $\mathrm{h}$ \\
\hline $10=10^{1}$ & deca & $\mathrm{da}$ \\
\hline $0,1=10^{-1}$ & deci & $\mathrm{d}$ \\
\hline $0,01=10^{-2}$ & centi & $\mathrm{c}$ \\
\hline $0,001=10^{-3}$ & mil·li & $\mathrm{m}$ \\
\hline $0,000001=10^{-6}$ & micro & $\mu$ \\
\hline $0,000000001=10^{-9}$ & nano & $\mathrm{n}$ \\
\hline $0,000000000001=10^{-12}$ & pico & $\mathrm{p}$ \\
\hline $0,000000000000001=10^{-15}$ & femto & $\mathrm{f}$ \\
\hline $0,000000000000000001=10^{-18}$ & atto & $\mathrm{a}$ \\
\hline
\end{tabular}

\section{B.3. Altres sistemes d'unitats}

Com ja hem indicat, en l'actualitat es tendeix a l'ús exclusiu d'un sistema d'unitats (el sistema internacional). Els tres únics països del món que no han adoptat, avui dia, el sistema internacional com a prioritari o únic són Libèria, Myanmar i els Estats Units d'Amèrica. No obstant això, encara hi ha moltes publicacions i gran quantitat de dades que es troben en altres sistemes d'unitats, per la qual cosa el seu coneixement resulta convenient.

Per a establir qualsevol sistema d'unitats serà suficient triar certes magnituds com a fonamentals, i deduir totes les altres a partir d'aquelles. Encara que l'elecció d'aquestes magnituds és arbitrària, en els sistemes habituals en figuren sempre dues: longitud i temps. Per a fixar la quantitat de matèria dels cossos es requereix una tercera magnitud fonamental, que pot ser la seua massa o el seu pes, és a dir, la força d'atracció que la Terra exerceix sobre els cossos. 
Fins ara, en el terreny científic s'ha triat sempre la massa com a tercera magnitud fonamental, fet que ha donat lloc als sistemes de magnituds absoluts (L.M.t). A la taula següent es resumeixen les unitats fonamentals d'aquests sistemes.

Sistemes d'unitats absolutes

\begin{tabular}{|l|l|l|l|}
\hline $\begin{array}{l}\text { Magnituds } \\
\text { fonamentals }\end{array}$ & $\begin{array}{l}\text { Cegesimal } \\
\text { (CGS) }\end{array}$ & $\begin{array}{l}\text { Pràctic o de Giorgi } \\
\text { (MKS) }\end{array}$ & $\begin{array}{l}\text { Anglés } \\
\text { (FPS) }\end{array}$ \\
\hline Longitud, $\mathrm{L}$ & 1 centímetre $(\mathrm{cm})$ & 1 metre $(\mathrm{m})$ & 1 peu $(\mathrm{ft})$ \\
Massa, M & 1 gram massa $(\mathrm{g})$ & 1 kilogram massa $(\mathrm{kg})$ & 1 lliura $(\mathrm{lb})$ \\
Temps, t & 1 segon $(\mathrm{s})$ & 1 segon $(\mathrm{s}), 1$ hora $(\mathrm{h})$ & 1 segon $(\mathrm{s}), 1$ hora $(\mathrm{h})$ \\
Temperatura, $\mathrm{T}$ & $1{ }^{\circ} \mathrm{C}$ & $1{ }^{\circ} \mathrm{C}$ & $1{ }^{\circ} \mathrm{F}$ \\
\hline
\end{tabular}

En canvi, en el terreny tècnic, es va triar sempre la força com a tercera magnitud fonamental, fet que ha donat lloc als sistemes tècnics (L.F.t). A la taula es donen les magnituds d'aquests sistemes.

Sistemes d'unitats tècniques

\begin{tabular}{|l|l|l|}
\hline Magnituds fonamentals & Mètric & Anglés \\
\hline Longitud, L & 1 metre $(\mathrm{m})$ & 1 peu $(\mathrm{ft})$ \\
Força, F & 1 kilogram força $(\mathrm{kgf})$ & 1 lliura força $(\mathrm{lbf})$ \\
Temps, $\mathrm{t}$ & 1 segon $(\mathrm{s}), 1$ hora $(\mathrm{h})$ & 1 segon $(\mathrm{s}), 1$ hora $(\mathrm{h})$ \\
Temperatura, $\mathrm{T}$ & $1^{\circ} \mathrm{C}$ & $1{ }^{\circ} \mathrm{F}$ \\
\hline
\end{tabular}

En la bibliografia tècnica s'utilitzen, encara que cada vegada menys, els denominats sistemes de magnituds d'enginyeria (L.M.F.t), als quals se'ls considera com a magnituds fonamentals independents, a més de la longitud i el temps, la massa i la força, relacionades pel principi fonamental de la dinàmica. A fi de fer compatible aquesta elecció arbitrària, com a magnituds fonamentals, de dues que estan relacionades entre si, és necessari introduir un factor de correcció, $\mathrm{g}_{\mathrm{c}}$, en l'expressió de l'esmentada llei:

$$
\left(\mathrm{g}_{\mathrm{c}}\right) \cdot(\text { Força })=(\text { Massa }) \cdot(\text { Acceleració })
$$

on el factor $\mathrm{g}_{\mathrm{c}}$ té les dimensions $\left(\mathrm{F}^{-1} \cdot \mathrm{M} \cdot \mathrm{L} \cdot \mathrm{t}^{-2}\right)$ i un valor numèric igual a l'acceleració de la gravetat, g. Les unitats fonamentals dels sistemes d'enginyeria que es consideren es resumeixen, juntament amb els valors de $g_{c}$, a la taula següent.

Sistema d'unitats d'enginyeria

\begin{tabular}{|l|l|l|}
\hline Magnituds fonamentals & Mètric & Anglés \\
\hline Longitud, $\mathrm{L}$ & 1 metre $(\mathrm{m})$ & 1 peu $(\mathrm{ft})$ \\
Massa, $\mathrm{M}$ & 1 kilogram massa $(\mathrm{kg})$ & 1 lliura massa $(\mathrm{lb})$ \\
Força, $\mathrm{F}$ & 1 kilogram força $(\mathrm{kgf})$ & 1 lliura força $(\mathrm{lbf})$ \\
Temps, $\mathrm{t}$ & 1 segon $(\mathrm{s}), 1$ hora $(\mathrm{h})$ & 1 segon $(\mathrm{s}), 1$ hora $(\mathrm{h})$ \\
Temperatura, $\mathrm{T}$ & $1^{\circ} \mathrm{C}$ & $1^{\circ} \mathrm{F}$ \\
\hline Factor de correcció & Mètric & Anglés \\
\hline $\mathrm{g}_{\mathrm{c}}$ & $9,81\left(\mathrm{~kg} \cdot \mathrm{kgf}^{-1} \cdot \mathrm{m} \cdot \mathrm{s}^{-2}\right)$ & $32,17\left(\mathrm{lb} \cdot 1 \mathrm{bf} \mathrm{f}^{-1} \cdot \mathrm{ft} \cdot \mathrm{s}^{-2}\right)$ \\
\hline
\end{tabular}




\section{B.4. Factors de conversió}

L'alumne pot adonar-se que les dades que utilitza estan expressades en una gran varietat d'unitats diferents, de manera que tindrà necessitat de convertir els valors numèrics a un sistema comú (SI), abans d'efectuar els càlculs. Per a fer això, haurà d'usar els factors de conversió, que es defineixen com el nombre d'unitats d'una magnitud d'un sistema contingudes en una unitat de la mateixa magnitud d'un altre sistema.

Els factors de conversió de les unitats de les magnituds derivades dels diferents sistemes es calculen a partir dels factors de conversió de les unitats de les magnituds fonamentals.

Aplicacions dels factors de conversió

Sovint es presenten dues situacions en els càlculs tècnics:

a) Conversió de valors numèrics.

\section{Exemple B.1}

Convertir el valor del mòdul d'elasticitat de l'acer $\mathrm{E}=210 \mathrm{GPa}$ al sistema tècnic $\left(\mathrm{kgf} / \mathrm{cm}^{2}\right)$.

$E=210 G P a \frac{10^{9} \mathrm{~Pa}}{1 \mathrm{GPa}} \frac{1 \mathrm{~N} / \mathrm{m}^{2}}{1 \mathrm{~Pa}} \frac{1 \mathrm{~m}^{2}}{10^{4} \mathrm{~cm}} \frac{1 \mathrm{kgf}}{9,81 \mathrm{~N}}=2,14 \cdot 10^{6} \frac{\mathrm{kgf}}{\mathrm{cm}^{2}}$

b) Conversió d'unitats en una fórmula.

\section{Exemple B.2}

La pèrdua de calor per conducció i convecció des d'una paret de més de tres peus d'altura cap a l'aire circumdant, a pressió i temperatures ordinàries, pot calcular-se mitjançant l'expressió:

en la qual:

$$
\mathrm{Q}=0,27(\Delta \mathrm{T})^{1,25}
$$

- $Q$ : pèrdua de calor en BTU/h $\cdot f t^{2}$ (British Thermal Unit).

- $\Delta T$ : diferència de temperatures entre la paret i l'aire, en ${ }^{\circ} \mathrm{F}$.

Transformeu l'equació anterior en una altra que permeta utilitzar les unitats següents:

- $Q$ en $\mathrm{Kcal} / \mathrm{h} \cdot \mathrm{m}^{2}$.

- $\Delta T$ en ${ }^{\circ} C$. 
Quan una equació expressada en unitats angleses s'empra per a un sol cas concret, el més còmode és fer el càlcul en aquelles unitats, $i$ una vegada resolt el problema, passar a la unitat mètrica corresponent. Si per contra, l'equació ha de ser emprada nombroses vegades, és preferible transformar-la. S'aconsella utilitzar el següent procediment.

Observem que el coeficient 0,27 té les dimensions següents: $\quad 0,27 \frac{B T U}{h f t^{20} F^{1,25}}$

i que aquesta constant numèrica es pot convertir a les unitats mètriques:

$\frac{\mathrm{Kcal}}{\mathrm{hm}^{20} \mathrm{C}^{1,25}}$

pel procediment indicat en l'apartat anterior. Els factors de conversió necessaris seran, en aquest cas:

$0,252 \frac{\mathrm{Kcal}}{\mathrm{BTU}} \quad 1,8 \frac{{ }^{\circ} \mathrm{F}}{{ }^{\circ} \mathrm{C}} \quad 0,3048 \frac{\mathrm{m}}{\mathrm{ft}}$

El nou coeficient, en unitats mètriques, l'obtindrem fent el producte:

$0,27 \frac{B T U}{h f t^{20} F^{1,25}} 0,252 \frac{\mathrm{Kcal}}{B T U}\left(0,3048 \frac{\mathrm{m}}{\mathrm{ft}}\right)^{2}\left(1,8 \frac{{ }^{\circ} \mathrm{F}}{{ }^{\circ} \mathrm{C}}\right)^{1,25}=1,527 \frac{\mathrm{Kcal}}{\mathrm{hm}^{20} \mathrm{C}^{1,25}}$

\section{Exemple B.3}

La següent funció representa l'evolució del moment flector en una biga en $\mathrm{kg} f \cdot \mathrm{cm}$ (si $x$ s'expressa en metres).

$$
M_{Z}(\mathrm{x})=25 \mathrm{x}^{2}+5 \mathrm{x}+6
$$

Responeu a les següents preguntes relatives a la seua transformació a altres unitats:

1. En quines unitats estan expressades les constants 25,5 i 6 ?

Anomenem K la unitat buscada. Els tres sumands de l'expressió, en substituir el valor de $x$ en metres, proporcionen una quantitat en $\mathrm{kg} \cdot \mathrm{cm}$. En el primer sumand, en multiplicar la unitat $K$ pels metres quadrats que ens dóna $x^{2}$, hem d'obtindre $\mathrm{kgf} \cdot \mathrm{cm}$.

$25 K_{1} \cdot \mathrm{m}^{2}=25 \mathrm{kgf} \cdot \mathrm{cm}$, per tant, la unitat ha de ser: $K_{1}=\frac{\mathrm{kgf} \cdot \mathrm{cm}}{\mathrm{m}^{2}}$.

En el segon sumand, en multiplicar $K$ pels metres que ens dóna $x$, hem d'obtindre també $\mathrm{kgf} \cdot \mathrm{cm}$.

$5 K_{1} \cdot \mathrm{m}^{2}=5 \mathrm{kgf} \cdot \mathrm{cm}$, per tant, la unitat ha de ser: $K_{2}=\frac{\mathrm{kgf} \cdot \mathrm{cm}}{\mathrm{m}}$. 
En el tercer sumand és immediat que la unitat ha de ser $K_{3}=\mathrm{kgf} \cdot \mathrm{m}$.

2. Quina expressió adoptaria la funció si volem substituir $x$ en metres i obtindre un valor de $\mathrm{M}_{\mathrm{Z}}$ en $N \cdot m$ ?

És necessari canviar les constants 25, 5 i 6 d'unitats.

Per al $K_{1}$, hem de canviar les unitats anteriorment calculades per: $\frac{N \cdot m}{m^{2}}$.

Aplicarem factors de correcció successius.

$$
25 \frac{\mathrm{kgf} \cdot \mathrm{cm}}{\mathrm{m}^{2}} \frac{9,81 \mathrm{~N}}{1 \mathrm{kgf}} \frac{1 \mathrm{~m}}{100 \mathrm{~cm}}=2,452 \frac{\mathrm{N} \cdot \mathrm{m}}{\mathrm{m}^{2}}
$$

Per al $K$, el procediment és paregut:

$$
5 \frac{\mathrm{kgf} \cdot \mathrm{cm}}{\mathrm{m}} \frac{9,81 \mathrm{~N}}{1 \mathrm{kgf}} \frac{1 \mathrm{~m}}{100 \mathrm{~cm}}=0,49 \frac{\mathrm{N} \cdot \mathrm{m}}{\mathrm{m}}
$$

I finalment, per a $K_{3}$ :

$$
6 \mathrm{kgf} \cdot \mathrm{cm} \frac{9,81 \mathrm{~N}}{1 \mathrm{kgf}} \frac{1 \mathrm{~m}}{100 \mathrm{~cm}}=0,588 \mathrm{~N} \cdot \mathrm{m}
$$

La funció tindria la forma: $M_{Z}(x)=2,425 x^{2}+0,49 x+0,588$. 


\section{Problemes proposats}

B.1. Expresseu les magnituds següents en les unitats que s'indiquen.

\begin{tabular}{|l|l|l|}
\hline $\mathrm{a}=5 \mu \mathrm{m} \rightarrow \mathrm{m}$ & $\mathrm{E}=210 \mathrm{GPa} \rightarrow \mathrm{N} / \mathrm{mm}^{2}$ & $\mu=0,05 \mathrm{~g} / \mathrm{cm} / \mathrm{s} \rightarrow \mathrm{kg} / \mathrm{m} / \mathrm{s}$ \\
\hline $\mathrm{b}=9,5 \mathrm{~nm} \rightarrow \mathrm{km}$ & $\rho=4000 \mathrm{mg} / \mathrm{cm}^{3} \rightarrow \mathrm{kg} / \mathrm{m}^{3}$ & $\mathrm{Q}=50 \mathrm{l} / \mathrm{s} \rightarrow \mathrm{m} / \mathrm{h}$ \\
\hline $\mathrm{A}_{1}=12 \mathrm{~mm}^{2} \rightarrow \mathrm{m}^{2}$ & $\theta=25^{\circ} \rightarrow \mathrm{rad}$ & $\mathrm{C}=2 \mu \mathrm{g} / \mathrm{l} \rightarrow \mathrm{kg} / \mathrm{m}^{3}$ \\
\hline $\mathrm{A}_{2}=30,3 \mathrm{~km}^{2} \rightarrow \mathrm{hm}^{2}$ & $\mathrm{t}_{1}=2 \mathrm{~h} 50^{\prime} 10^{\prime} \rightarrow \mathrm{h}$ & $\sigma=28 \mathrm{kgf} / \mathrm{pm}^{2} \rightarrow \mathrm{Pa}$ \\
\hline $\mathrm{V}=27 \mathrm{hm}^{3} \rightarrow \mathrm{ml}$ & $\mathrm{t}_{2}=5 \mathrm{~h} 25^{\prime} 53^{\prime \prime} \rightarrow \mathrm{min}$ & $\mathrm{c}_{0}=299792456 \mathrm{~m} / \mathrm{s} \rightarrow \mathrm{Em} / \mathrm{h}$ \\
\hline $\mathrm{P}=15 \mathrm{kgf} / \mathrm{cm}^{2} \rightarrow \mathrm{kN} / \mathrm{m}^{2}$ & $\omega=1,2 \mathrm{rev} / \mathrm{min} \rightarrow \mathrm{rad} / \mathrm{s}$ & $\mathrm{G}=9,807 \mathrm{~m} / \mathrm{s}^{2} \rightarrow \mathrm{km} / \mathrm{h}^{2}$ \\
\hline
\end{tabular}

B.2. Expresseu les següents magnituds en unitats del sistema internacional.

Equivalències:

- $1 \mathrm{ft}=0,305 \mathrm{~m}(\mathrm{peu})$.

- 1 in $=2,54 \mathrm{~cm}$ (polzada).

- $1 \mathrm{lb}=0,454 \mathrm{~kg}$ (lliura).

- $1 \mathrm{mi}=1,609 \mathrm{~km}$ (milla).

\begin{tabular}{|l|l|l|}
\hline $\mathrm{h}_{1}=3 \mathrm{ft}$ & $\mathrm{M}=100 \mathrm{lb}$ & $\rho=250 \mathrm{lb} / \mathrm{in}^{3}$ \\
\hline $\mathrm{A}=2 \mathrm{in}^{2}$ & $\mathrm{P}=5 \mathrm{lbf} / \mathrm{in}^{2}$ & $\mathrm{~V}_{1}=25 \mathrm{ft} / \mathrm{s}$ \\
\hline $\mathrm{V}=30,6 \mathrm{ft}^{3}$ & $\mathrm{a}=15 \mathrm{ft} / \mathrm{s}^{2}$ & $\mathrm{~V}_{2}=70 \mathrm{mph}$ \\
\hline
\end{tabular}




\section{ANNEX C}

\section{Coneixements previs - àrees i centres de gravetat}

\section{C.1. Introducció}

Habitualment treballarem amb elements tipus biga, en els quals la secció transversal serà coneguda, i haurem de ser capaços de calcular tant la seua àrea com el seu centre de gravetat, o bé serà una secció comercial i aquestes dades ens les donaran les taules.

D'altra banda, durant l'assignatura hi ha mètodes gràfics de càlcul que requereixen que calculem l'àrea i el centre de gravetat de funcions polinòmiques.

Per tant, per al treball en l'assignatura, és imprescindible conéixer el càlcul d'àrees i centres de gravetat de figures planes.

\section{C.2. Àrees}

L'àrea és una mesura de l'extensió d'una superfície, expressada en unitats de mesura denominades superficials. Per a superfícies planes el concepte és més intuïtiu. Qualsevol superfície plana de costats rectes pot triangular-se i es pot calcular la seua àrea com a suma de les àrees dels triangles formats. Ocasionalment s'utilitza el terme àrea com a sinònim de superfície, quan no hi ha confusió entre el concepte geomètric en si mateix (superfície) i la magnitud mètrica associada al concepte geomètric (àrea).

No obstant això, per a calcular l'àrea de superfícies corbes es requereix introduir mètodes de geometria diferencial.

En principi, per als casos habituals que tractarem en l'assignatura només serà necessari conéixer les fórmules més bàsiques per a les àrees de:

- un rectangle de base b i altura h: $A=b \cdot h$.

- un triangle de base b i altura h: $A=\frac{1}{2} b \cdot h$.

- un cercle de radi R: $A=\pi R^{2}$.

Pràcticament totes les seccions planes podran ser calculades dividint-les en un nombre $n$ de parts, de manera que l'àrea total siga: 


$$
A_{T}=\sum_{i=1}^{n} A_{i}
$$

En el cas que tinguem una funció $f(x)$ i hàgem de calcular la seua àrea, en un interval $(a, b)$ el procediment és realitzar la integral:

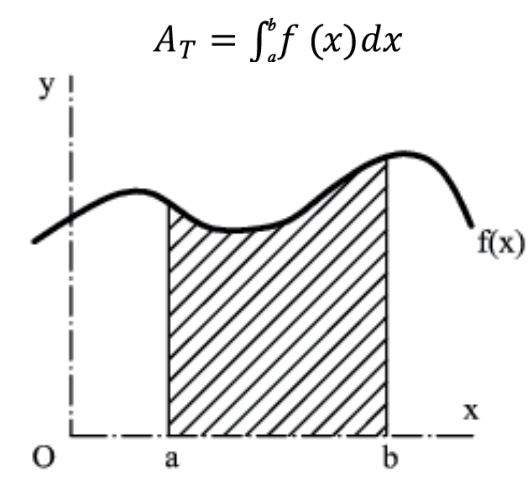

Fig. C.1. Àrea sota una funció $\mathrm{f}(\mathrm{x})$ en un interval $(\mathrm{a}, \mathrm{b})$

Si es tracta de l'àrea compresa entre dues funcions $\mathrm{f}(\mathrm{x}) \mathrm{i} \mathrm{g}(\mathrm{x})$, l'àrea es calcularà com a:

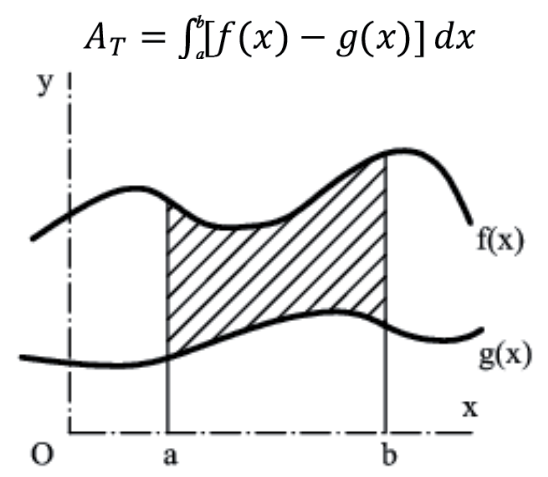

Fig. C.2. Àrea entre dues funcions $\mathrm{f}(\mathrm{x})$ i $\mathrm{g}(\mathrm{x})$ en un interval $(\mathrm{a}, \mathrm{b})$

\section{Exemple C.1}

Calculeu l'àrea de la secció de la figura.
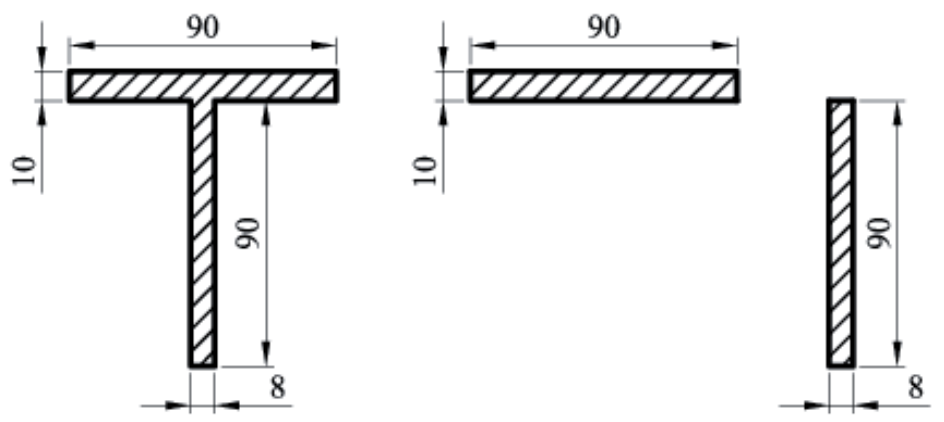

Fig. C.3. Exemple C.1

$A_{T}=[(90 \cdot 10)+(8 \cdot 90)]=1.620 \mathrm{~mm}^{2}$ 


\section{Exemple C.2}

Calculeu l'àrea de la secció de la figura.
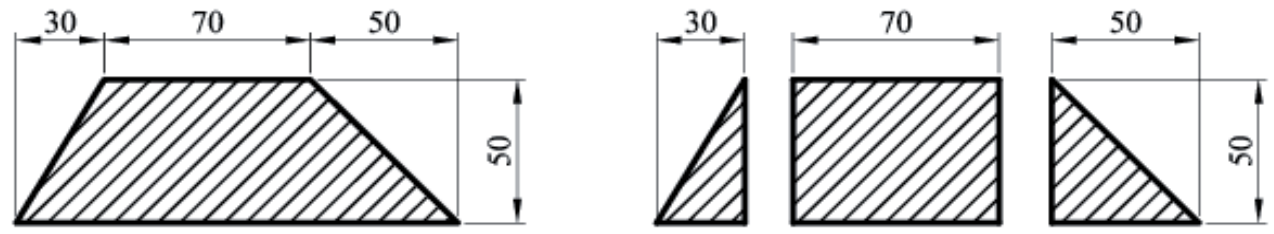

Fig. C.4. Exemple C.2

$A_{T}=\left[\left(\frac{1}{2} 30 \cdot 50\right)+(70 \cdot 50)+\left(\frac{1}{2} 50 \cdot 50\right)\right]=5.500 \mathrm{~mm}^{2}$

Quan tinguem figures amb zones buides procedirem de la manera següent:

1. Calcularem l'àrea de la figura com si fóra completament massissa.

2. Calcularem l'àrea del buit.

3. Restarem ambdues àrees.

\section{Exemple C.3}

Calculeu l'àrea de la secció de la figura.
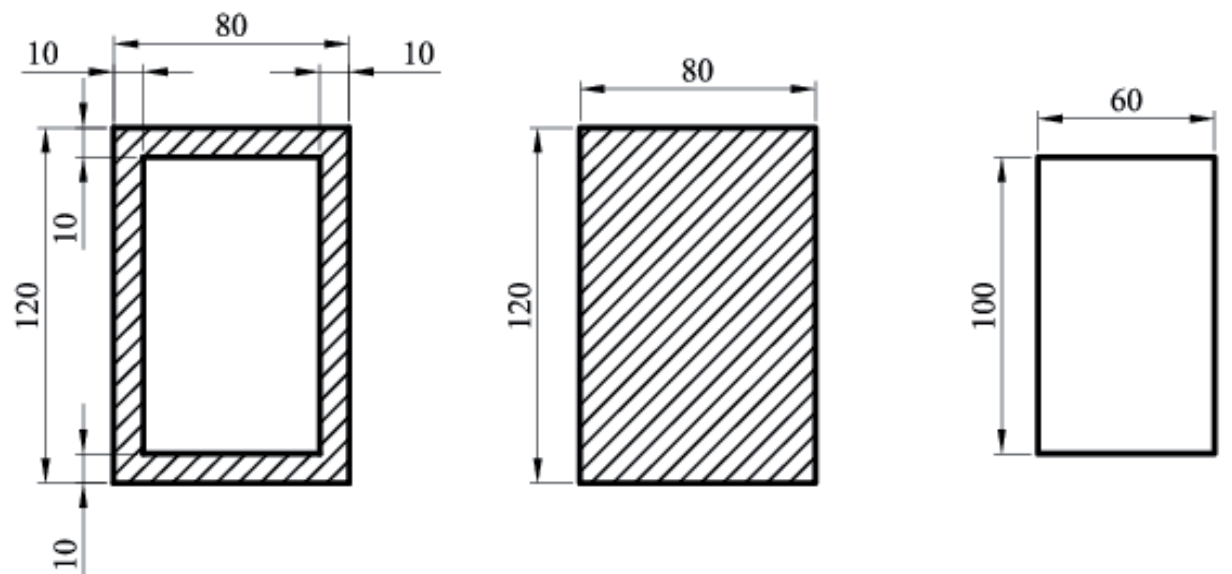

Fig. C.5. Exemple C.3

$A_{T}=[(80 \cdot 120)-(60 \cdot 100)]=3.600 \mathrm{~mm}^{2}$ 


\section{Exemple C.4}

Calculeu l'àrea de la secció de la figura.

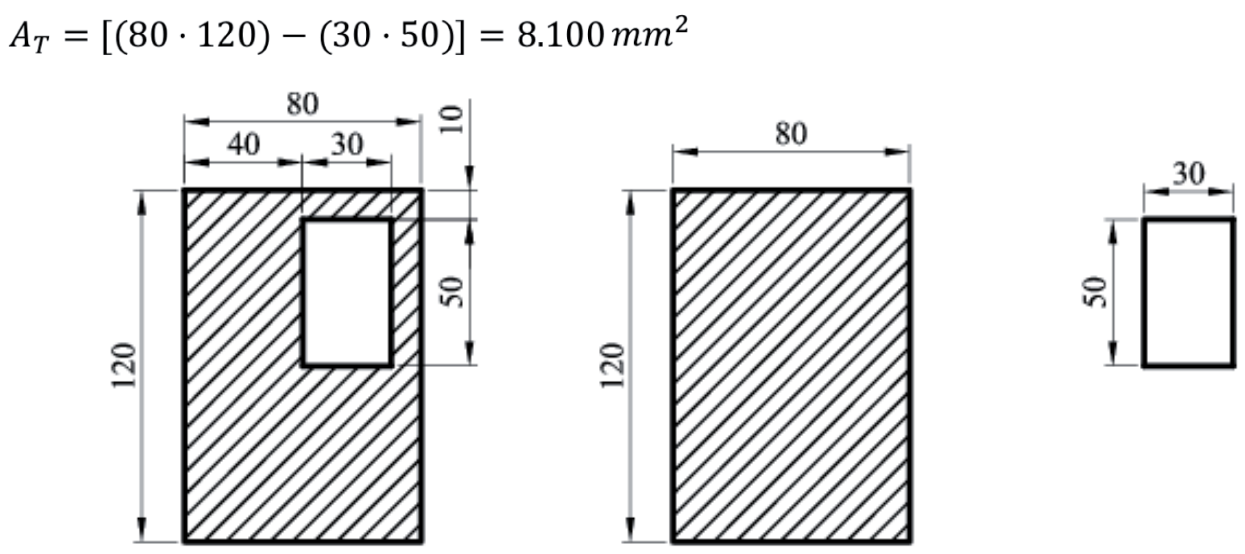

Fig. C.6. Exemple C.4

\section{Exemple C.5}

Calculeu l'àrea de la secció de la figura.
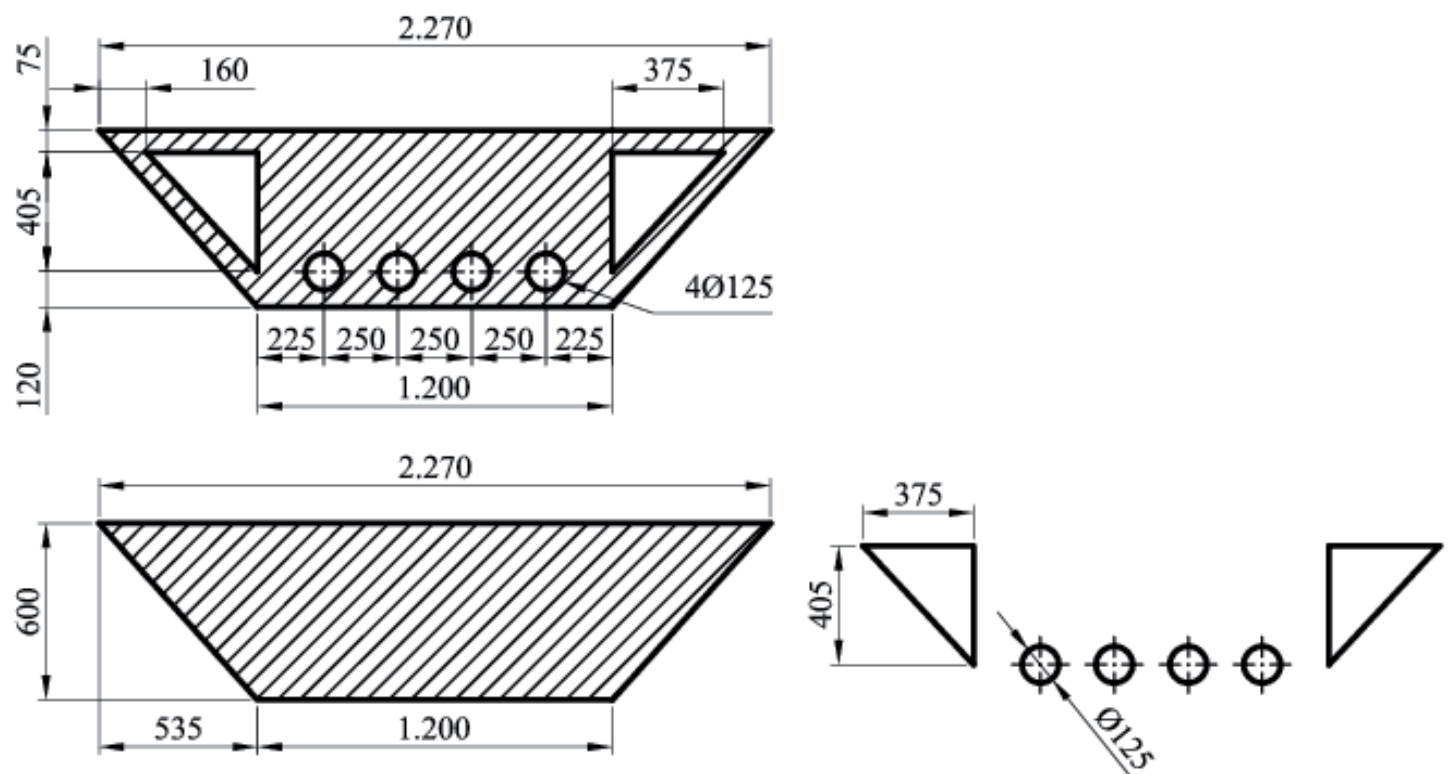

Fig. C.7. Exemple C.5

$$
A_{T}=\left[2\left(\frac{535 \cdot 600}{2}\right)+(1200 \cdot 600)-2\left(\frac{375 \cdot 405}{2}\right)-4\left(\frac{\pi 125^{2}}{4}\right)\right]=840.037,61 \mathrm{~mm}^{2}
$$




\section{Exemple C.6}

Una biga voladissa té una llei de moments flectors que és una funció per trams. Calculeu l'àrea del diagrama de moments entre 0 i $L$.

$$
\begin{aligned}
& 0 \leq x \leq L / 2 \rightarrow M(x)=(P+q L) x-P \frac{L}{2}-q \frac{x^{2}}{2} \\
& L / 2 \leq x \leq L \rightarrow M(x)=q L x-q \frac{x^{2}}{2} \\
& A_{T}=\int\left[(P+q L) x-P \frac{L}{2}-q \frac{x^{2}}{2}\right] d x+\int\left[q L x-q \frac{x^{2}}{2}\right] d x \\
& A_{T}=\left[(P+q L) \frac{x^{2}}{2}-P \frac{L}{2} x-q \frac{x^{3}}{6}\right]_{0}^{L / 2}+\left[q L \frac{x^{2}}{2}-q \frac{x^{3}}{6}\right]_{L / 2}^{L} \\
& A_{T}=\left[(P+q L) \frac{L^{2}}{8}-P \frac{L^{2}}{2}-q \frac{L^{3}}{24}\right]+\left[q \frac{L^{3}}{2}-q \frac{L^{3}}{6}\right]-\left[q \frac{L^{3}}{8}-q \frac{L^{3}}{24}\right]=q \frac{L^{3}}{3}-P \frac{L^{2}}{8}
\end{aligned}
$$

\section{C.3. Centre de gravetat, centre de masses i centroide}

El centre de gravetat ( $\mathrm{CDG}$ ) és el punt d'aplicació de la resultant de totes les forces de gravetat que actuen sobre les diferents porcions materials d'un cos, de tal manera que el moment respecte a qualsevol punt d'aquesta resultant, aplicada en el centre de gravetat, és el mateix que el produït pels pesos de totes les masses materials que constitueixen el cos.

En altres paraules, el centre de gravetat d'un cos és el punt respecte al qual les forces que la gravetat exerceix sobre els diferents punts materials, que constitueixen el cos, produeixen un moment resultant nul.

El CDG d'un cos no correspon necessàriament a un punt material del cos. Així, el CDG d'una esfera buida està situat en el centre de l'esfera que, òbviament, no pertany al cos.

El centre de masses d'un sistema discret o continu és el punt geomètric que dinàmicament es comporta com si hi estiguera aplicada la resultant de les forces externes al sistema. De manera anàloga, es pot dir que el sistema format per tota la massa concentrada en el centre de masses és un sistema equivalent a l'original. Normalment s'abrevia com a c. m.

En geometria, el centroide o baricentre d'un objecte X pertanyent a un espai $\mathrm{n}$-dimensional és la intersecció de tots els hiperplans que divideixen $\mathrm{X}$ en dues parts del mateix n-volum respecte a l'hiperplà. Informalment, és la mitjana de tots els punts de $\mathrm{X}$. 
En la física, el centroide, el centre de gravetat i el centre de masses poden, sota certes circumstàncies, coincidir entre si. En aquests casos solen utilitzar-se els termes de manera intercanviable, encara que designen conceptes diferents. El centroide és un concepte purament geomètric que depén de la forma del sistema; el centre de masses depén de la distribució de matèria, mentre que el centre de gravetat depén també del camp gravitatori. Així tindrem que:

- El centre de masses coincideix amb el centroide quan la densitat és uniforme o quan la distribució de matèria en el sistema té certes propietats, com ara simetria.

- El centre de masses coincideix amb el centre de gravetat, quan el sistema es troba en un camp gravitatori uniforme (el mòdul i la direcció de la força de gravetat són constants).

Càlcul del centre de gravetat. En un cas genèric, considerem la següent figura plana, que podem dividir en infinites porcions diferencials, en la qual tenim:

- $\mathrm{A}_{\mathrm{T}}$ (àrea total de la figura plana).

- $\mathrm{X}_{\mathrm{G}}$ (coordenada $\mathrm{X}$ del CDG de la figura plana).

- $\mathrm{Y}_{\mathrm{G}}$ (coordenada y del CDG de la figura plana).

- dA (element diferencial d'àrea).

- x,y (posició de l'element diferencial d'àrea).

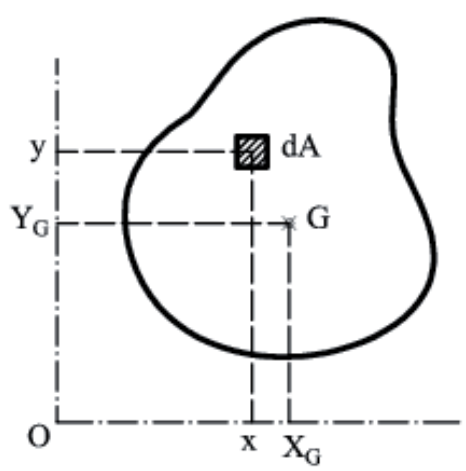

Fig. C.8. Càlcul del centre de gravetat

Per definició, els moments de primer ordre han de ser iguals, tant si considerem l'àrea total respecte a qualsevol eix com si considerem la suma de moments de tots els elements diferencials.

$$
\begin{array}{ll}
A_{T} \cdot X_{G}=\sum d A \cdot x & X_{G}=\frac{\sum d A \cdot x}{A_{T}} \\
A_{T} \cdot Y_{G}=\sum d A \cdot y & Y_{G}=\frac{\sum d A \cdot y}{A_{T}}
\end{array}
$$

Sent precisos, els sumatoris anteriors serien integrals en tota l'àrea considerada. 
De totes maneres, en la majoria de casos pràctics, les àrees poden ser subdividides en un nombre discret d'àrees simples, els centres de gravetat individuals del qual són coneguts, com ara triangles, rectangles, cercles, etc.
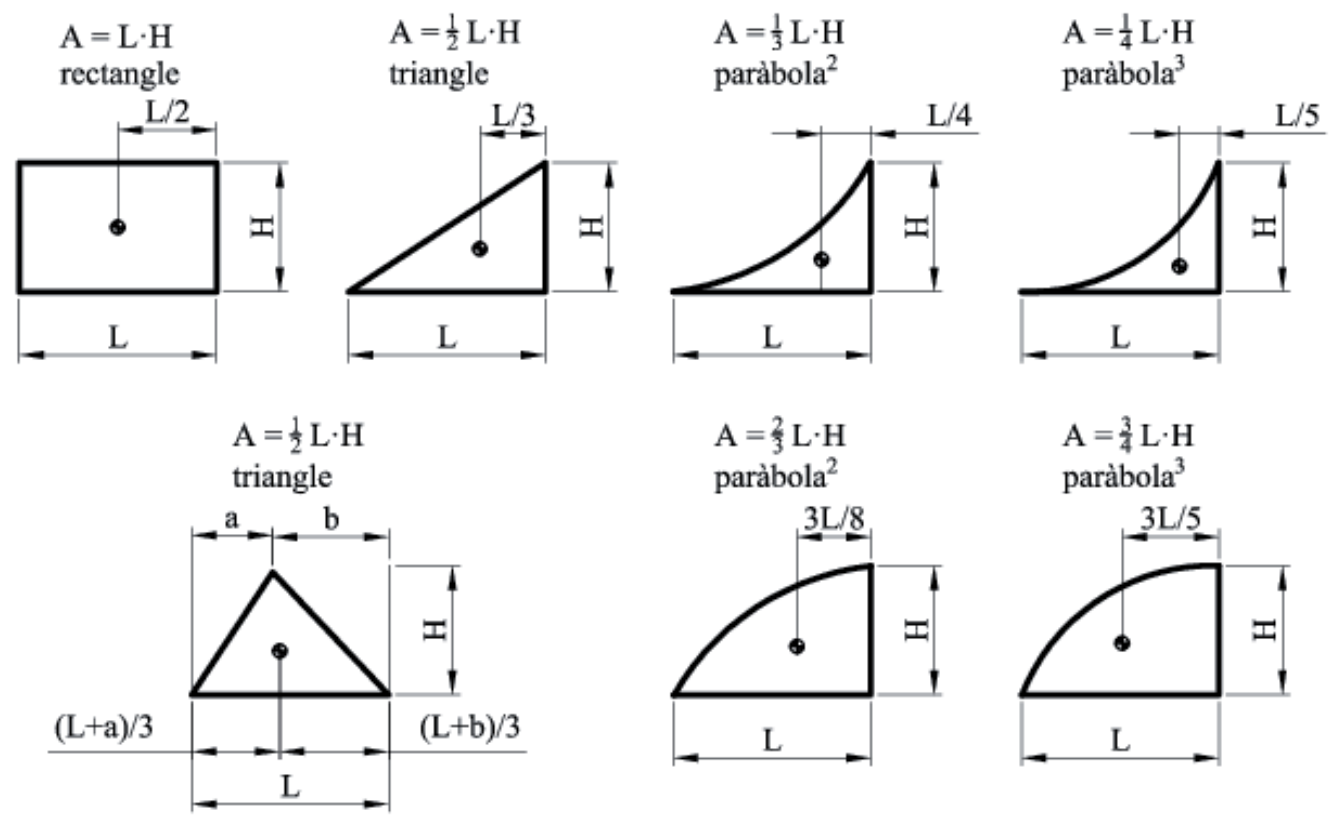

Fig. C.9. Àrees i centres de gravetat d'algunes figures planes

Si una figura és simètrica respecte a un eix, el CDG es trobarà en ell. Si és simètrica respecte a dos eixos, el CDG estarà en la intersecció d'ambdós.

Com a exemple, calcularem els centres de gravetat de les figures dels exemples anteriors.

\section{Exemple C.7}

Calculeu la posició del centre de gravetat de la figura de l'exemple C.1.

En aquest cas, com que hi ha simetria respecte a l'eix Y, podem dir que $X_{G}=45 \mathrm{~mm}$.

D'altra banda, per a calcular $\mathrm{Y}_{\mathrm{G}}$ situarem una referència en la base de la figura. La distància de la referència al CDG de la subàrea superior és $95 \mathrm{~mm}$ i la distància al CDG de l'altra subàrea és $45 \mathrm{~mm}$.

Ja coneixem de l'exemple C.1: $\mathrm{A}_{\mathrm{T}}=1.620 \mathrm{~mm}^{2}$. 


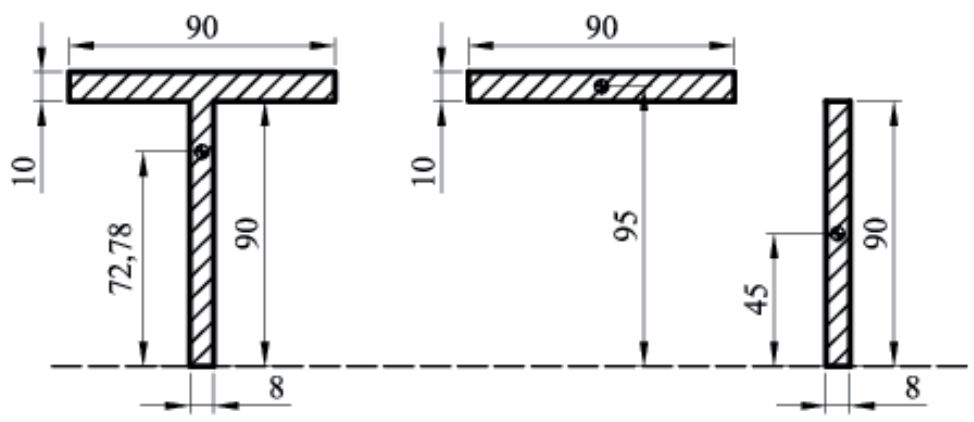

Fig. C.10. Exemple C.7

$Y_{G}=\frac{A_{1} \cdot Y_{G 1}+A_{2} \cdot Y_{G 2}}{A_{T}}=\frac{(90 \cdot 10) \cdot 95+(8 \cdot 90) \cdot 45}{1620}=72,78 \mathrm{~mm}$

\section{Exemple C.8}

Calculeu la posició del centre de gravetat de la figura de l'exemple C.2.

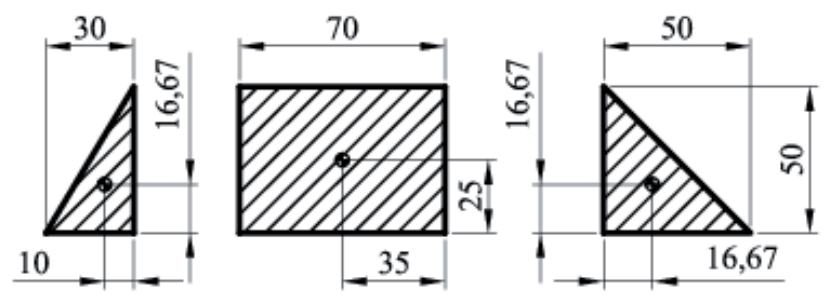

Fig. C.11. Exemple C.8

En aquest cas no hi ha simetria, per la qual cosa hem de calcular en ambdós eixos. Prendrem com a referència el cantó inferior esquerre de la figura.

$$
\begin{aligned}
& X_{G}=\frac{\sum_{i=1}^{3} A_{i} \cdot X_{G i}}{A_{T}}=\frac{\left(\frac{1}{2} 30 \cdot 50\right) \cdot 20+(70 \cdot 50) \cdot 65+\left(\frac{1}{2} 50 \cdot 50\right) \cdot 116,67}{5.500}=70,60 \mathrm{~mm} \\
& Y_{G}=\frac{\sum_{i=1}^{3} A_{i} \cdot Y_{G i}}{A_{T}}=\frac{\left(\frac{1}{2} 30 \cdot 50\right) \cdot 16,67+(70 \cdot 50) \cdot 25+\left(\frac{1}{2} 50 \cdot 50\right) \cdot 16,67}{5.500}=21,97 \mathrm{~mm}
\end{aligned}
$$

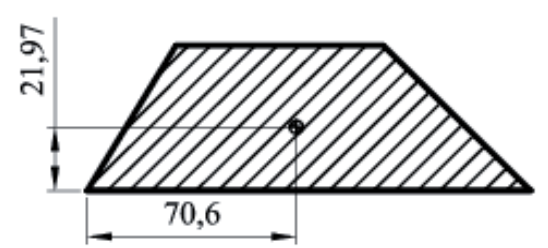

Fig. C.12. Exemple C.8 


\section{Exemple C.9}

Calculeu la posició del centre de gravetat de la figura de l'exemple C.3.

En aquest cas tenim una doble simetria en la figura, per la qual cosa és immediat concloure que: $X_{G}=40 \mathrm{~mm} ; Y_{G}=60 \mathrm{~mm}$.

\section{Exemple C.10}

Calculeu la posició del centre de gravetat de la figura de l'exemple C.4.

En aquest cas tenim buits, hem de tractar les àrees buides com si foren negatives.
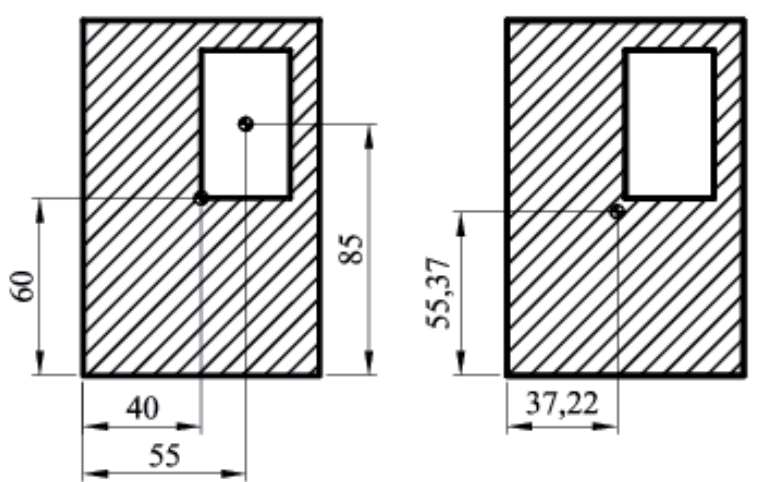

Fig. C.13. Exemple C.10

$X_{G}=\frac{A_{1} \cdot X_{G 1}-A_{2} \cdot X_{G 2}}{A_{T}}=\frac{(80 \cdot 120) \cdot 40-(30 \cdot 50) \cdot 55}{8.100}=37,22 \mathrm{~mm}$

$Y_{G}=\frac{A_{1} \cdot Y_{G 1}-A_{2} \cdot Y_{G 2}}{A_{T}}=\frac{(80 \cdot 120) \cdot 60-(30 \cdot 50) \cdot 85}{8.100}=55,37 \mathrm{~mm}$

\section{Exemple C.11}

Calculeu la posició del centre de gravetat de la figura de l'exemple C.5.

Veiem que hi ha simetria respecte a l'eix vertical, i per això, el CDG es trobarà en ell. Prenem com a referència el cantó superior esquerre: $X_{G}=1.135 \mathrm{~mm}$.

Per a l'altre eix procedim com en el cas anterior. 

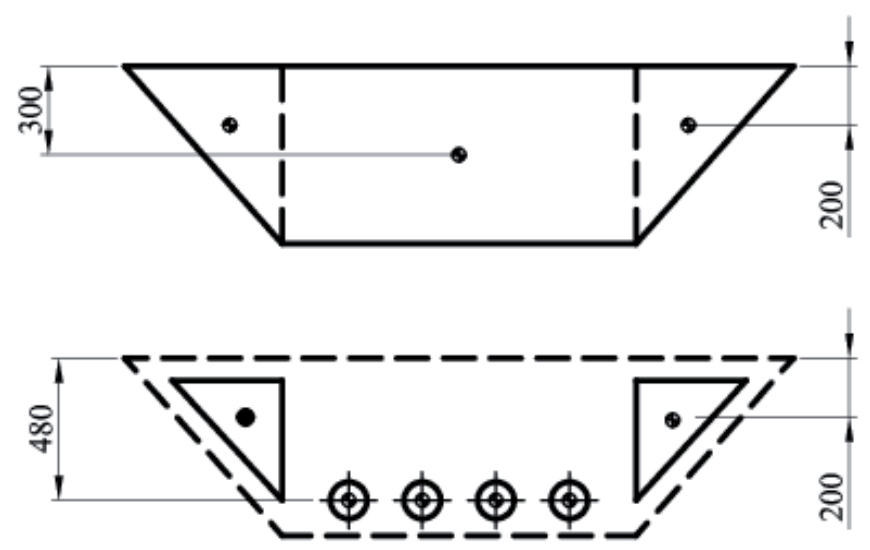

Fig. C.14. Exemple C.11

$Y_{G}=\frac{2 \cdot\left(\frac{1}{2} 535 \cdot 600\right) \cdot 200+(1200 \cdot 600) \cdot 300-2 \cdot\left(\frac{1}{2} 375 \cdot 400\right) \cdot 200-4 \cdot\left(\frac{\pi \cdot 125^{2}}{4}\right) \cdot 480}{840.037,61}$

$Y_{G}=267,54 \mathrm{~mm}$

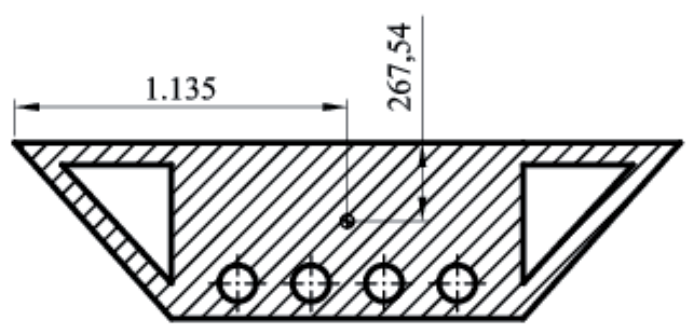

Fig. C.15. Exemple C.11

En el cas que el centre de gravetat s'haja de calcular respecte a una funció contínua $\mathrm{f}(\mathrm{x})$ (figura C.1), podrem calcular la posició del centre de gravetat:

$$
X_{G}=\frac{\iint x d A}{\iint d A}=\frac{\iint x d x d y}{\iint d x d y} \quad Y_{G}=\frac{\iint y d A}{\iint d A}=\frac{\iint y d y d x}{\iint d y d x}
$$

\section{Exemple C.12}

Trobeu la posició del centre de gravetat de la funció entre els punts $a=1$ i $b=3$ (vegeu figura C.16).

Considerem la funció i la variable $x$ com a adimensionals.

Per a fer-ho més senzill calcularem per separat les diverses integrals:

$A_{T}=\int_{a}^{b} f(x) d x=\left[4 \frac{x^{2}}{2}+3 x\right]_{1}^{3}=40,67$ 


$$
\begin{aligned}
& A_{T} \cdot X_{G}=\int_{a}^{b} \int_{0}^{f(x)} x d x d y=\int_{1}^{3} x \cdot f(x) d x=\left[x^{4}+3 \frac{x^{2}}{2}\right]_{1}^{3}=92 \\
& X_{G}=\frac{92}{40,67}=2,262
\end{aligned}
$$

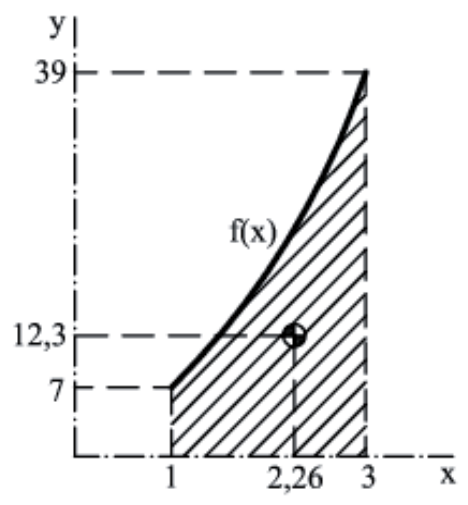

Fig. C.16. Exemple C.12

$$
\begin{aligned}
& A_{T} \cdot Y_{G}=\int_{a}^{b} \int_{0}^{\rho(x)} y d y d x=\int \frac{(f(x))^{2}}{2} d x=\int_{1}\left(8 x^{4}+12 x^{3}+4,5\right) d x \\
& A_{T} \cdot Y_{G}=\left[8 \frac{x^{5}}{5}+12 \frac{x^{3}}{3}+4,5 x\right]_{1}^{3}=500,2 \\
& Y_{G}=\frac{500,2}{40,67}=12,3
\end{aligned}
$$




\section{Problemes proposats}

C.1. Calculeu les coordenades del centre de gravetat del cos de la figura, considerant una densitat superficial de massa uniforme. Les coordenades dels punts estan en centímetres.

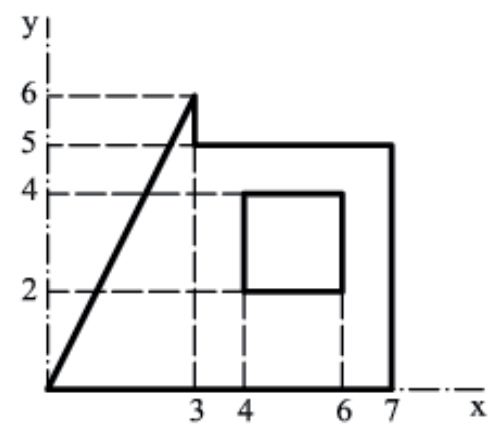

Fig. P.C.1

C.2. Calculeu les coordenades del centre de gravetat de l'àrea plana compresa entre la paràbola $\mathrm{y}=2 \mathrm{x}^{2}$, les rectes $\mathrm{x}=1 \mathrm{i} \mathrm{x}=2$ i l'eix d'abscisses. 


\section{ANNEX D}

\section{Coneixements previs - moments d'inèrcia}

\section{D.1. Introducció}

Una de les propietats més importants d'una secció transversal és el moment d'inèrcia, també anomenat segon moment d'àrea o segon moment d'inèrcia.

Físicament, el moment d'inèrcia està relacionat amb les tensions i deformacions màximes que apareixen per flexió en un element estructural i, per tant, junt amb les propietats del material, determina la resistència màxima d'un element estructural que treballa a flexió.

Les dimensions del segon moment d'àrea són longitud a la quarta potència (que no ha de ser confosa amb el concepte físic relacionat d'inèrcia rotacional, les unitats del qual són massa per longitud al quadrat).

\section{D.2. Definició}

Donada una secció plana transversal d'àrea A d'un element estructural, el segon moment d'inèrcia es defineix per a cada eix de coordenades (e) contingut en el pla de la secció (figura D.1) mitjançant la fórmula següent:

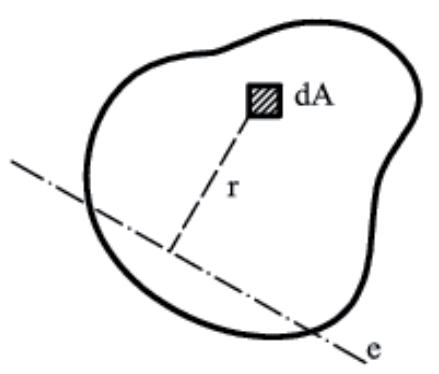

Fig. D.1

- $I_{e}$ és el moment d'inèrcia al voltant de l'eix considerat.

- $d A$ és el diferencial d'àrea de la secció $\mathrm{A}$.

- $r$ és la mínima distància de l'element donat a l'eix triat. 
Si els eixos als quals ens referim són els eixos X i Y, i l'element diferencial està situat en les coordenades genèriques $(x, y)$, el valor dels seus respectius moments d'inèrcia serà:

$$
I_{X}=\iint_{A} y^{2} d A \quad I_{Y}=\iint_{A} x^{2} d A
$$

\section{D.3. Eixos principals d'inèrcia}

Com és sabut en mecànica del sòlid rígid, la inèrcia rotacional d'un cos ve caracteritzada per un tensor anomenat tensor d'inèrcia, que en una base ortogonal s'expressa mitjançant una matriu simètrica.

Els eixos principals d'inèrcia són precisament les rectes o eixos formats per vectors propis del tensor d'inèrcia. Tenen la propietat interessant que un sòlid que gira lliurement al voltant d'un d'aquests eixos no varia la seua orientació a l'espai. En canvi, si el cos gira al voltant d'un eix arbitrari que no siga principal, el moviment d'acord amb les equacions d'Euler presentarà canvis d'orientació en forma de precessió i nutació.

En estructures, la majoria de les vegades tindrem seccions amb un o dos eixos de simetria. En el cas de dos eixos de simetria, aquests seran els eixos principals d'inèrcia. En el cas de simetria simple, l'eix de simetria serà eix principal d'inèrcia. L'altre eix serà perpendicular a aquest $\mathrm{i}$ passarà pel centre de gravetat.

\section{D.4. Altres definicions}

El moment d'inèrcia polar és el moment al voltant de l'eix perpendicular a X i Y que passa pel centre de gravetat (normalment $Z$ ). S'utilitzarà en torsió. El moment d'inèrcia polar és la suma dels moments d'inèrcia respecte d'ambdós eixos, ja que $r^{2}=x^{2}+y^{2}$.

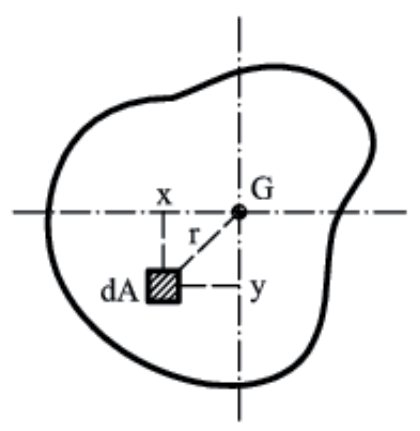

Fig D.2

$$
I_{P}=\iint_{A} r^{2} d A=\iint_{A}\left(x^{2}+y^{2}\right) d A=\iint_{A} x^{2} d A+\iint_{A} y^{2} d A=I_{Y}+I_{X}
$$


El producte d'inèrcia és bàsicament una mesura del desequilibri dinàmic.

Considerem un cilindre vertical, homogeni i equilibrat al qual se li col·loquen dos pesos iguals, separats $180^{\circ}$, i equidistants del centre de gravetat, al llarg de l'altura del cilindre, adherits a la seua superfície. La suma dels pesos no altera la posició del centre de gravetat del cilindre, i el cilindre roman equilibrat estàticament.

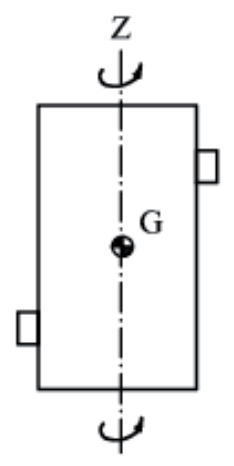

Fig. D.3

No obstant això, si fem girar el cilindre al voltant del seu eix Z, la força centrífuga actua sobre ambdós pesos, i això fa que apareguen un parell de forces. Si el cilindre està muntat en suports, aquest parell provoca una força sinusoïdal exercida sobre els suports, durant el gir del cilindre. Si el cilindre gira a l'espai, l'eix de rotació es desplaça a una posició on les forces centrífugues s'igualen (en efecte, es desplaça lleugerament cap als pesos de desequilibri). A açò, se l'anomena producte d'inèrcia.

$$
I_{X Y}=\iint_{A} x \cdot y d A
$$

Les dimensions dels moments d'inèrcia i productes d'inèrcia són sempre unitats de longitud a la quarta potència. Mentre que els moments d'inèrcia són sempre positius, els productes d'inèrcia poden ser positius, negatius o nuls.

En enginyeria estructural, el radi de gir descriu la manera en la qual l'àrea transversal o una distribució de massa es distribueix al voltant del seu eix centroidal. El radi de gir es defineix com a:

$$
i=\sqrt{\frac{I}{A}}
$$

Evidentment hi ha un radi de gir per a cada eix considerat. El radi de gir té unitats de longitud. 


\section{Exemple D.1}

Determineu els moments d'inèrcia, el producte d'inèrcia $\mathrm{i}$ els radis de gir d'una superfície rectangular respecte als eixos X i Y.

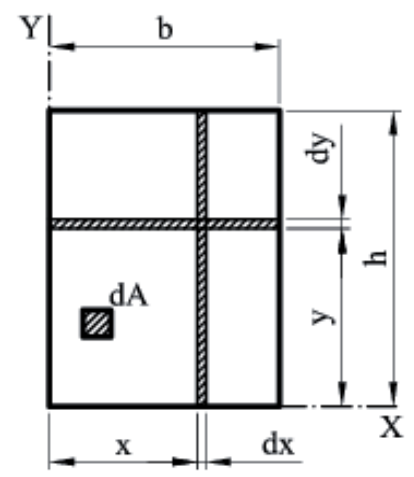

Fig. D.4

Per a calcular el moment d'inèrcia respecte a $\mathrm{X}$ triem una franja diferencial parallela a l'eix, l'àrea de la qual és $d A=b d y$, per tant:

$I_{X}=\iint_{A} y^{2} d A=\int_{0}^{h} y^{2} b d y=\frac{1}{3} b h^{3}$

Anàlogament, per a l'eix Y podem prendre la franja diferencial paral·lela a Y, d'àrea $d A=h d x$ :

$I_{Y}=\iint_{A} x^{2} d A=\int_{0}^{b} x^{2} h d x=\frac{1}{3} h b^{3}$

El producte d'inèrcia és:

$I_{X Y}=\iint_{A} x y d A=\int_{0}^{b} x d x \int_{0}^{h} y d y=\frac{1}{4} b^{2} h^{2}$

Els radis de gir:

$i_{X}=\sqrt{\frac{I_{X}}{A}}=\sqrt{\frac{1 \frac{1}{3} b h^{3}}{b h}}=\sqrt{\frac{h^{2}}{3}}=\frac{h}{\sqrt{3}}=\frac{\sqrt{3}}{3} h \quad i_{Y}=\sqrt{\frac{I_{Y}}{A}}=\sqrt{\frac{\frac{1}{3} h b^{3}}{b h}}=\sqrt{\frac{b^{2}}{3}}=\frac{b}{\sqrt{3}}=\frac{\sqrt{3}}{3} b$

\section{D.5. Moments d'inèrcia coneguts}

Habitualment, totes les formes de les seccions amb les quals ens trobarem seran divisibles en rectangles, triangles i cercles, per la qual cosa convé conéixer els moments d'inèrcia d'aquestes figures simples. A continuació podem veure els moments d'inèrcia respecte dels eixos que passen per les bases (exemple anterior) $\mathrm{i}$ dels que passen pel centre de gravetat. 


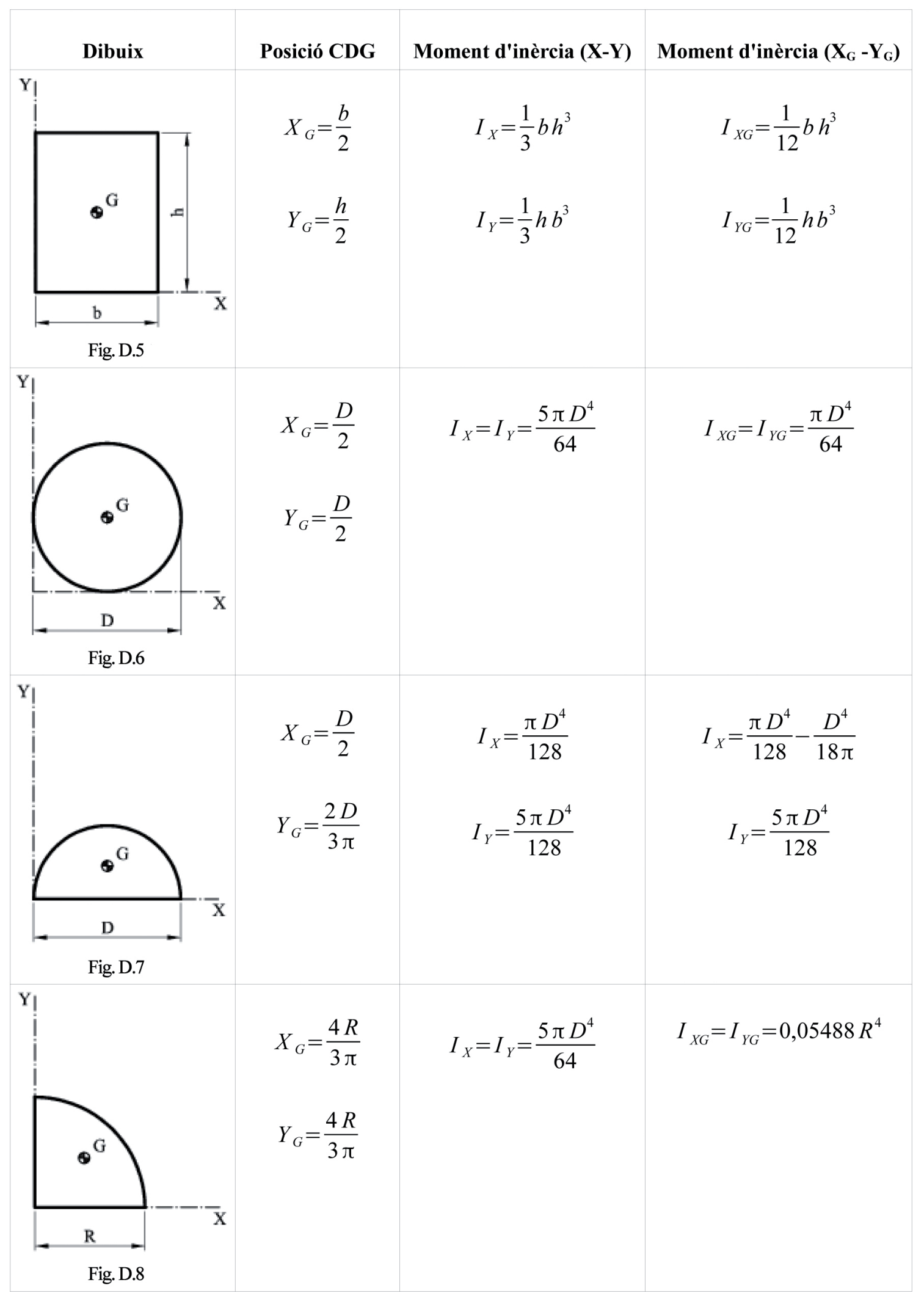




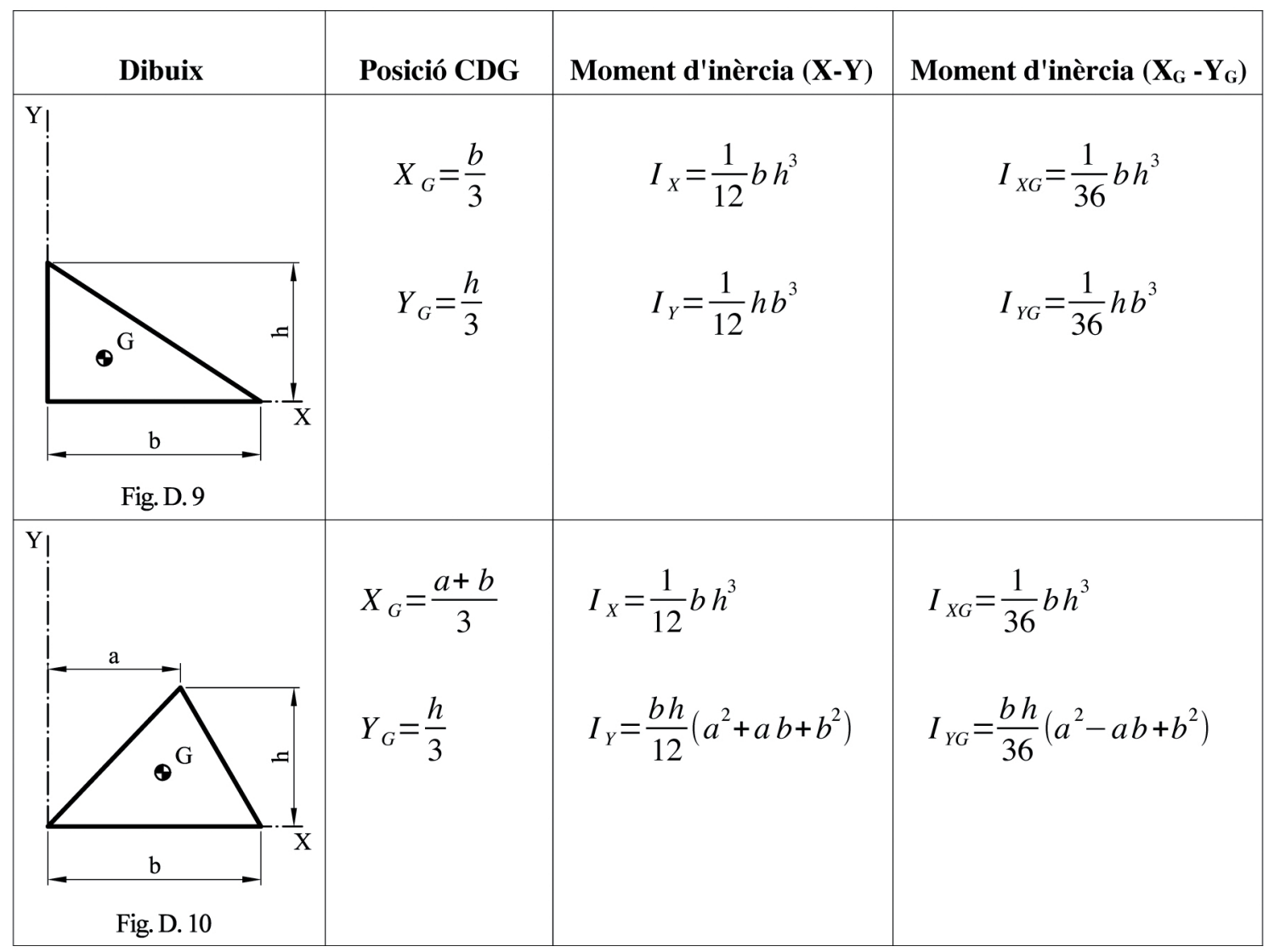

Altres vegades utilitzarem perfils comercials, i les dimensions, els moments d'inèrcia $\mathrm{i}$ altres dades corresponents a la secció vindran tabulats. Per exemple, per al perfil IPE 80:

\begin{tabular}{|c|c|c|c|c|c|c|c|c|c|c|c|c|c|c|c|c|c|c|}
\hline \multirow[b]{2}{*}{ Perfil } & \multicolumn{7}{|c|}{ Dimensions } & \multicolumn{10}{|c|}{ Termes de la secció } & \multirow{2}{*}{$\begin{array}{c}\text { Pes } \\
\mathrm{p} \\
\mathrm{kp} / \mathrm{m}\end{array}$} \\
\hline & $\begin{array}{c}\mathrm{h} \\
\mathrm{mm}\end{array}$ & $\begin{array}{c}\mathrm{b} \\
\mathrm{mm}\end{array}$ & $\begin{array}{c}\mathrm{t}_{\mathrm{w}} \\
\mathrm{mm}\end{array}$ & $\begin{array}{c}t_{f} \\
\mathrm{~mm}\end{array}$ & $\begin{array}{c}\mathrm{r} \\
\mathrm{mm}\end{array}$ & $\begin{array}{c}\mathrm{h}_{1} \\
\mathrm{~mm}\end{array}$ & $\begin{array}{c}\mathrm{u} \\
\mathrm{mm}\end{array}$ & $\begin{array}{c}\mathrm{A} \\
\mathrm{cm}^{2}\end{array}$ & $\begin{array}{c}\mathrm{S}_{\mathrm{x}} \\
\mathrm{cm}^{3}\end{array}$ & $\begin{array}{c}\mathrm{I}_{\mathrm{x}} \\
\mathrm{cm}^{4}\end{array}$ & $\begin{array}{l}W_{x} \\
\mathrm{~cm}^{3}\end{array}$ & $\begin{array}{c}\mathrm{i}_{\mathrm{x}} \\
\mathrm{cm}\end{array}$ & $\begin{array}{c}\mathrm{I}_{\mathrm{y}} \\
\mathrm{cm}^{4}\end{array}$ & $\begin{array}{l}W_{y} \\
\mathrm{~cm}^{3}\end{array}$ & $\begin{array}{c}\mathrm{i}_{\mathrm{y}} \\
\mathrm{cm}\end{array}$ & $\begin{array}{c}\mathrm{I}_{\mathrm{t}} \\
\mathrm{cm}^{4}\end{array}$ & $\begin{array}{c}\mathrm{I}_{\mathrm{a}} \\
\mathrm{cm}^{6}\end{array}$ & \\
\hline IPE 80 & 80 & 46 & 3,8 & 5,2 & 5 & 60 & 328 & 7,64 & 11,6 & 80,1 & 20,0 & 3,24 & 8,49 & 3,69 & 1,05 & 0,721 & 118 & 6,00 \\
\hline
\end{tabular}

\begin{tabular}{|l|l|}
\hline Fig. D.11. & $\begin{array}{l}\mathrm{A}=\text { Àrea de la secció. } \\
\mathrm{S}_{\mathrm{X}}=\text { Moment estàtic de mitja secció, respecte a } \mathrm{X} . \\
\mathrm{I}_{\mathrm{X}}=\text { Moment d'inèrcia de la secció, respecte a } \mathrm{X} . \\
\mathrm{W}_{\mathrm{X}}=2 \mathrm{I}_{\mathrm{X}} / \mathrm{h} \text {. Mòdul resistent de la secció, respecte a } \mathrm{X} . \\
\mathrm{I}_{\mathrm{X}}=\left(\mathrm{I}_{\mathrm{X}} / \mathrm{A}\right)^{1 / 2} \text {. Radi de gir de la secció, respecte a } \mathrm{X} . \\
\mathrm{I}_{\mathrm{Y}}=\text { Moment d'inèrcia de la secció, respecte a } \mathrm{Y} . \\
\mathrm{W}_{\mathrm{Y}}=2 \mathrm{I}_{\mathrm{Y}} / \mathrm{b} \text {. Mòdul resistent de la secció, respecte a } \mathrm{Y} . \\
\mathrm{I}_{\mathrm{Y}}=\left(\mathrm{I}_{\mathrm{Y}} / \mathrm{A}\right)^{1 / 2} \text {. Radi de gir de la secció, respecte a } \mathrm{Y} . \\
\mathrm{I}_{\mathrm{t}}=\text { Mòdul de torsió de la secció. } \\
\mathrm{I}_{\mathrm{a}}=\text { Mòdul de guerxament de la secció. } \\
\mathrm{u}=\text { Perímetre de la secció. } \\
\mathrm{h}_{1}=\text { Altura de la part plana de l'ànima. } \\
\mathrm{p}=\text { Pes per metre. }\end{array}$ \\
\hline
\end{tabular}




\section{D.6. Teorema de Steiner}

Quan coneixem el moment d'inèrcia d'una secció respecte a un eix determinat, però volem calcular el moment respecte de qualsevol altre eix paral·lel a ell, hem d'utilitzar el teorema de Steiner.

En la secció de la figura, imaginem que coneixem l'expressió del moment d'inèrcia respecte de l'eix X, calculat amb l'expressió:

$$
I_{X}=\iint_{A} y^{2} d A
$$

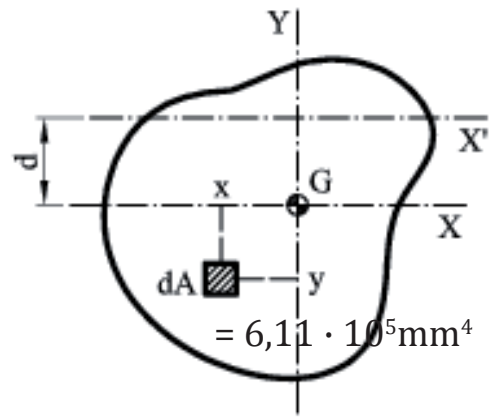

Fig. D.12

Considerem que la distància entre els dos eixos és $d$; llavors la distància des de l'element diferencial $d A$ fins al nou eix $\mathrm{X}^{\prime}$ serà: $\mathrm{y}^{\prime}=\mathrm{y}+\mathrm{d}$.

El moment d'inèrcia respecte al nou eix $X^{\prime}$ 'serà, doncs:

$$
I_{X^{\prime}}=\iint_{A} y^{\prime 2} d A=\iint_{A}(y+d)^{2} d A=\iint_{A} y^{2} d A+d^{2} \iint_{A} d A+2 d \iint_{A} y d A=I_{X}+A d^{2}
$$

La tercera integral és zero perquè la distància mitjana de tots els diferencials d'àrea respecte al centre de gravetat és nul·la per la mateixa definició de centre de masses.

En definitiva, si coneixem el moment d'inèrcia respecte a un eix determinat, podem calcular el moment d'inèrcia respecte a un altre eix, sumant al moment anterior el terme «àrea per distància entre eixos al quadrat».

$$
I_{X \prime}=I_{X}+A d^{2}
$$

Calcularem els moments d'inèrcia de les figures dels exemples en els quals calculàrem els centres de gravetat.

\section{Exemple D.2}

Calculeu els moments d'inèrcia de la figura dels exemples C.1 i C.7.

Considerem el rectangle superior. El moment d'inèrcia respecte al seu centre de gravetat és:

$I_{X G 1}=\frac{1}{12} 90 \cdot 10^{3}=7.500 \mathrm{~mm}^{4}$ 
La distància entre el centre de gravetat d'aquest rectangle i el centre de gravetat global de la secció és: $\mathrm{d}=95-72,78=22,22 \mathrm{~mm}$.

Per la qual cosa el moment d'inèrcia respecte al centre de gravetat global serà:

$I_{X 1}=I_{X G 1}+90 \cdot 10 \cdot 22,22^{2}=4,52 \cdot 10^{5} \mathrm{~mm}^{4}$

Per al segon rectangle:

$I_{X G 2}=\frac{1}{12} 8 \cdot 90^{3}=4,86 \cdot 10^{5} \mathrm{~mm}^{4} ; d=72,78-45=27,78 \mathrm{~mm}$

$I_{X 2}=I_{X G 2}+8 \cdot 90 \cdot 27,78^{2}=1,04 \cdot 10^{6} \mathrm{~mm}^{4}$

Una vegada referits ambdós moments d'inèrcia al mateix eix, podem sumar-los:

$I_{X}=I_{X 1}+I_{X 2}=1,49 \cdot 10^{6} \mathrm{~mm}^{4}$

Per a l'eix Y, en ser simètric, els eixos que passen pels centres de gravetat de les parts i del global estan alineats, per la qual cosa no cal aplicar Steiner.

$I_{Y}=I_{Y 1}+I_{Y 2}=\frac{1}{12} 10 \cdot 90^{3}+\frac{1}{12} 90 \cdot 8^{3}$

\section{Exemple D.3}

Calculeu els moments d'inèrcia de la figura dels exemples C.2 i C.8.

$I_{X G 1}=\frac{1}{36} 30 \cdot 50^{3}=1,04 \cdot 10^{5} \mathrm{~mm}^{4} ; d_{X 1}=Y_{G}-\frac{h}{3}=5,3 \mathrm{~mm}$

$I_{X 1}=I_{X G 1}+\frac{1}{2} 30 \cdot 50 \cdot 5,3^{2}=1,25 \cdot 10^{5} \mathrm{~mm}^{4}$

$I_{X G 2}=\frac{1}{12} 70 \cdot 50^{3}=7,29 \cdot 10^{5} \mathrm{~mm}^{4}: d_{X 2}=25-Y_{G}=3,03 \mathrm{~mm}$

$I_{X 2}=I_{X G 2}+70 \cdot 50 \cdot 3,03^{2}=7,61 \cdot 10^{5} \mathrm{~mm}^{4}$

$I_{X G 3}=\frac{1}{36} 50 \cdot 50^{3}=1,74 \cdot 10^{5} \mathrm{~mm}^{4} ; d_{X 3}=Y_{G}-\frac{h}{3}=5,3 \mathrm{~mm}$

$I_{X 3}=I_{X G 3}+\frac{1}{2} 50 \cdot 50 \cdot 5,3^{2}=2,09 \cdot 10^{5} \mathrm{~mm}^{4} ; I_{X}=I_{X 1}+I_{X 2}+I_{X 3}=1,09 \cdot 10^{6} \mathrm{~mm}^{4}$

$I_{Y G 1}=\frac{1}{36} 50 \cdot 30^{3}=3,75 \cdot 10^{4} \mathrm{~mm}^{4} ; d_{Y 1}=X_{G}-\frac{2 b}{3}=50,6 \mathrm{~mm}$

$I_{Y 1}=I_{Y G 1}+\frac{1}{2} 30 \cdot 50 \cdot 50,6^{2}=1,96 \cdot 10^{6} \mathrm{~mm}^{4}$

$I_{Y G 2}=\frac{1}{12} 50 \cdot 70^{3}=1,43 \cdot 10^{6} \mathrm{~mm}^{4}: d_{Y 2}=X_{G}-65=5,6 \mathrm{~mm}$

$I_{Y 2}=I_{Y G 2}+70 \cdot 50 \cdot 5,6^{2}=1,54 \cdot 10^{6} \mathrm{~mm}^{4}$

$I_{Y G 3}=\frac{1}{36} 50 \cdot 50^{3}=1,74 \cdot 10^{5} \mathrm{~mm}^{4} ; d_{Y 3}=46,07 \mathrm{~mm}$

$I_{Y 3}=I_{Y G 3}+\frac{1}{2} 50 \cdot 50 \cdot 46,07^{2}=2,83 \cdot 10^{6} \mathrm{~mm}^{4} ; I_{Y}=I_{Y 1}+I_{Y 2}+I_{Y 3}=6,32 \cdot 10^{6} \mathrm{~mm}^{4}$ 


\section{Exemple D.4}

Calculeu els moments d'inèrcia de la figura dels exemples C.3 i C.9.

En els casos en què tenim zones buides, haurem de restar el moment d'inèrcia del buit al moment d'inèrcia de la secció considerada com a massissa.

En aquest cas coincideixen els centres de gravetat amb els de les figures parcials, per la qual cosa no cal aplicar Steiner.

$$
\begin{aligned}
& I_{X 1}=\frac{1}{12} 80 \cdot 120^{3}=1,15 \cdot 10^{7} \mathrm{~mm}^{4} ; I_{X 2}=\frac{1}{12} 60 \cdot 100^{3}=5 \cdot 10^{6} \mathrm{~mm}^{4} \\
& I_{X}=I_{X 1}-I_{X 2}=6,52 \cdot 10^{6} \mathrm{~mm}^{4} \\
& I_{y 1}=\frac{1}{12} 120 \cdot 80^{3}=5,12 \cdot 10^{6} \mathrm{~mm}^{4} ; I_{Y 2}=\frac{1}{12} 100 \cdot 60^{3}=1,80 \cdot 10^{6} \mathrm{~mm}^{4} \\
& I_{Y}=I_{Y 1}-I_{Y 2}=3,32 \cdot 10^{6} \mathrm{~mm}^{4}
\end{aligned}
$$

\section{Exemple D.5}

Calculeu els moments d'inèrcia de la figura dels exemples C.4 i C.10.

$$
\begin{aligned}
& I_{X G 1}=\frac{1}{12} 80 \cdot 120^{3}=1,25 \cdot 10^{7} \mathrm{~mm}^{4} ; d_{X 1}=60-55,37=4,63 \mathrm{~mm} \\
& I_{X 1}=I_{X G 1}+80 \cdot 120 \cdot 4,63^{2}=1,17 \cdot 10^{7} \mathrm{~mm}^{4} \\
& I_{X G 2}=\frac{1}{12} 30 \cdot 50^{3}=3,12 \cdot 10^{5} \mathrm{~mm}^{4}: d_{X 2}=85-55,37=29,63 \mathrm{~mm} \\
& I_{X 2}=I_{X G 2}+30 \cdot 50 \cdot 29,63^{2}=1,63 \cdot 10^{6} \mathrm{~mm}^{4} ; I_{X}=I_{X 1}-I_{X 2}=1,01 \cdot 10^{7} \mathrm{~mm}^{4} \\
& I_{Y G 1}=\frac{1}{12} 120 \cdot 80^{3}=5,12 \cdot 10^{6} \mathrm{~mm}^{4} ; d_{Y 1}=40-37,22=2,78 \mathrm{~mm} \\
& I_{Y 1}=I_{Y G 1}+80 \cdot 120 \cdot 2,78^{2}=5,19 \cdot 10^{6} \mathrm{~mm}^{4} \\
& I_{Y G 2}=\frac{1}{12} 50 \cdot 30^{3}=1,12 \cdot 10^{5} \mathrm{~mm}^{4}: d_{Y 2}=55-37,22=17,78 \mathrm{~mm} \\
& I_{Y 2}=I_{Y G 2}+30 \cdot 50 \cdot 17,78^{2}=5,87 \cdot 10^{5} \mathrm{~mm}^{4} ; I_{Y}=I_{Y 1}-I_{Y 2}=4,61 \cdot 10^{6} \mathrm{~mm}^{4}
\end{aligned}
$$




\section{Exemple D.6}

Donada la següent secció composta per dos perfils IPE soldats, calculeu la posició del centre de gravetat $i$ els moments d'inèrcia en els dos eixos, utilitzant les dades de les taules de perfils comercials.

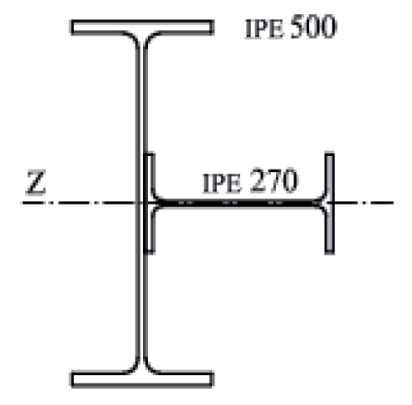

Fig. D.13. Exemple D.6. Enunciat

Habitualment en resistència de materials utilitzarem els eixos $\mathrm{Y}$ i Z per a la secció transversal, i deixarem l'eix X com l'eix longitudinal de la peça (perpendicular a la secció). Cal tindre-ho present, encara que a la taula que utilitzem s'expressen els eixos amb una altra nomenclatura.

De les taules de perfils comercials hem d'obtindre les dades següents:

$$
\begin{aligned}
& \mathrm{A}_{500}=116 \mathrm{~cm}^{2} \\
& \mathrm{~b}_{500}=200 \mathrm{~mm} \\
& \mathrm{~h}_{500}=500 \mathrm{~mm} \\
& \mathrm{t}_{\mathrm{w} 500}=10,2 \mathrm{~mm} \\
& \mathrm{I}_{\mathrm{Z} 500}=48.200 \mathrm{~cm}^{4} \\
& \mathrm{I}_{\mathrm{Y} 500}=2.140 \mathrm{~cm}^{4}
\end{aligned}
$$

$$
\begin{aligned}
& \mathrm{A}_{270}=45,9 \mathrm{~cm}^{2} \\
& \mathrm{~b}_{270}=135 \mathrm{~mm} \\
& \mathrm{~h}_{270}=270 \mathrm{~mm} \\
& \mathrm{t}_{\mathrm{w} 270}=6,6 \mathrm{~mm} \\
& \mathrm{I}_{\mathrm{Z} 270}=5.790 \mathrm{~cm}^{4} \\
& \mathrm{I}_{\mathrm{Y} 270}=420 \mathrm{~cm}^{4}
\end{aligned}
$$

Cal prestar especial atenció als eixos, ja que els que s'indiquen són els locals de cada secció, i el perfil IPE 270 el tenim girat.

En primer lloc calcularem la posició del centre de gravetat. Com veiem, hi ha una simetria total respecte a l'eix Z, per la qual cosa el centre de gravetat estarà sobre ell. $Y_{G}=0$.

Prenent com a referència el cantó inferior esquerre del conjunt:

$Z_{G}=\frac{A_{500}\left(\frac{b_{500}}{2}\right)+A_{270}\left(\frac{b_{500}}{2}+\frac{t_{w 500}}{2}+\frac{h_{270}}{2}\right)}{A_{500}+A_{270}}=13,97 \mathrm{~cm}$ 


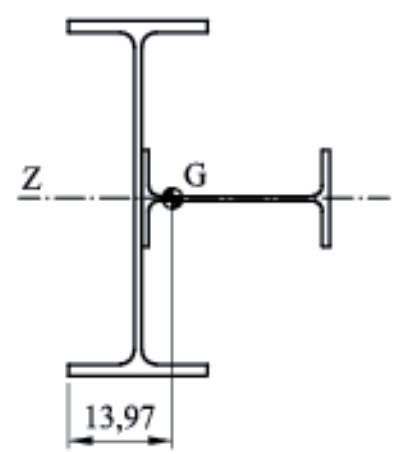

Fig. D.14. Exemple D.6. Posició del CDG

Per la simetria existent, a l'eix Z no cal aplicar el teorema de Steiner:

$I_{Z}=I_{Z 500}+I_{Y 270}=48.200+420=48.620 \mathrm{~cm}^{4}$

No obstant això, a l'eix Y sí que és necessari aplicar-lo. Calculem les distàncies entre centres de gravetat:

$$
\begin{aligned}
& d_{500}=Z_{G}-\frac{b_{500}}{2}=3,97 \mathrm{~cm} ; d_{270}=\frac{b_{500}}{2}+\frac{t_{w 500}}{2}+\frac{h_{270}}{2}-Z_{G}=10,04 \mathrm{~cm} \\
& I_{Y}=I_{Y 500}+A_{500} d_{500}^{2}+I_{Z 270}+A_{270} d_{270}^{2}=1,44 \cdot 10^{4} \mathrm{~cm}^{4}
\end{aligned}
$$




\section{Problemes proposats}

D.1. Determineu els moments d'inèrcia de la superfície que es mostra a continuació respecte als eixos Y i Z, perpendiculars entre ells, que travessen el centre de gravetat de la secció. Recordeu que quan una àrea plana té algun eix de simetria, el centre de gravetat estarà situat sobre ell.

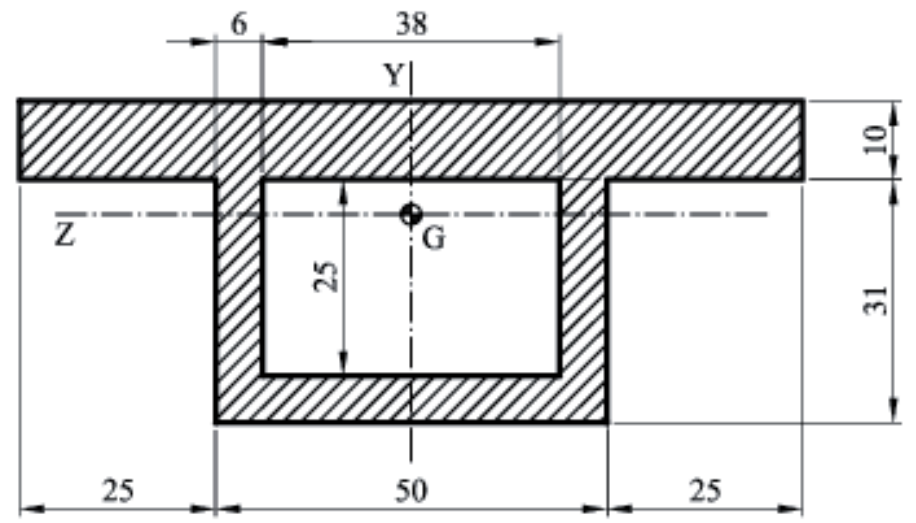

Fig. P.D.1

D.2. Donada la següent secció composta per un perfil IPE 500, que està encaixonat dins de quatre platines de gruix $16 \mathrm{~mm}$, com es veu a la figura, calculeu la posició del centre de gravetat i els moments d'inèrcia en els eixos Y i Z. Utilitzeu les dades de les taules de perfils comercials.

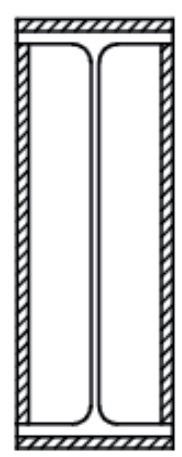

Fig. P.D.2 


\section{Solucions als problemes proposats}

\section{TEMA 1}

1.1. $\mathrm{M}_{\mathrm{OX}}=0 ; \mathrm{M}_{\mathrm{OY}}=20 \mathrm{kN} \cdot \mathrm{m} ; \mathrm{M}_{\mathrm{OZ}}=-34,8 \mathrm{kN}$.

1.2. $\mathrm{M}_{\mathrm{Z}}=8,59 \mathrm{kN} ; \mathrm{M}_{\mathrm{BC}}=-9,32 \mathrm{kN}$.

1.3. $\mathrm{R}_{\mathrm{X}}=-70 \mathrm{~N} ; \mathrm{R}_{\mathrm{Y}}=50 \mathrm{~N} ; \mathrm{R}_{\mathrm{Z}}=0 ; \mathrm{M}_{\mathrm{X}}=-10 \mathrm{~N} \cdot \mathrm{m} ; \mathrm{M}_{\mathrm{Y}}=-14 \mathrm{~N} \cdot \mathrm{m} ; \mathrm{M}_{\mathrm{Z}}=15 \mathrm{~N} \cdot \mathrm{m}$.

1.4. $\mathrm{R}_{\mathrm{AX}}=0 ; \mathrm{R}_{\mathrm{AY}}=11,5 \mathrm{kN} ; \mathrm{R}_{\mathrm{B}}=-43,5 \mathrm{kN}$.

1.5. $\mathrm{R}_{\mathrm{AX}}=0 ; \mathrm{R}_{\mathrm{AY}}=18 \mathrm{kN} ; \mathrm{M}_{\mathrm{A}}=54 \mathrm{kN} \cdot \mathrm{m}$.

1.6. $\mathrm{R}_{\mathrm{AX}}=2 \mathrm{kN} ; \mathrm{R}_{\mathrm{AY}}=0,54 \mathrm{kN} ; \mathrm{M}_{\mathrm{A}}=12 \mathrm{kN} \cdot \mathrm{m}$.

1.7. $\mathrm{R}_{\mathrm{AX}}=-15,21 \mathrm{kN} ; \mathrm{R}_{\mathrm{AY}}=-4,82 \mathrm{kN} ; \mathrm{R}_{\mathrm{B}}=5,57 \mathrm{kN}$.

\section{TEMA 2}

Durant el curs s'utilitzen programaris comercials per a la resolució de problemes de diagrames. Per aquesta raó no donem les solucions als problemes proposats del tema 2. Volem que l'alumne comprove les seues solucions mitjançant aquesta eina i que d'aquesta manera adquirisca habilitat amb l'ús d'aquests programaris. L'únic problema que no pot ser resolt amb programari és el 2.12, per al qual donem els resultats numèrics.

2.12. $\mathrm{R}_{\mathrm{A}}=38,02 \mathrm{~N} ; \mathrm{q}=99,92 \mathrm{~N} / \mathrm{m} ; \mathrm{R}_{\mathrm{C}}=87,14 \mathrm{~N} ; \mathrm{P}=49,98 \mathrm{~N} ; \mathrm{R}_{\mathrm{E}}=14,58 \mathrm{~N}$; $\mathrm{R}_{\mathrm{G}}=10,15 \mathrm{~N} ; \mathrm{M}_{\mathrm{G}}=0,54 \mathrm{~N} \cdot \mathrm{m}$.

TEMA 3

3.1. $\sigma_{1}=225 \mathrm{MPa} ; \sigma_{2}=0 ; \sigma_{3}=-75 \mathrm{MPa}$; Rankine: no; Tresca i Von Mises; sí.

3.2. $\mathrm{L}=20,031 \mathrm{~cm} ; \mathrm{D}=5,008 \mathrm{~cm} ; \sigma_{\mathrm{X}}=0<\mathrm{f}_{\mathrm{yd}}$.

3.3. $\mathrm{L}=20 \mathrm{~cm} ; \mathrm{D}=5,01 \mathrm{~cm} ; \sigma_{\mathrm{x}}=-327,6 \mathrm{MPa}>\mathrm{f}_{\mathrm{yd}}$.

3.4. a) $\left.\Delta \mathrm{T}_{\mathrm{al}}=208,33^{\circ} \mathrm{C} ; \Delta \mathrm{T}_{\mathrm{ac}}=416,67^{\circ} \mathrm{C} ; b\right) \mathrm{a}_{\mathrm{f}} \stackrel{\mathrm{yd}}{=} 12,06 \mathrm{~mm} ; \mathrm{b}_{\mathrm{f}}=10,05 \mathrm{~mm}$ (iguals en ambdós materials); c) $\Delta \mathrm{T}_{\mathrm{al}}=261,90^{\circ} \mathrm{C} ; \Delta \mathrm{T}_{\mathrm{ac}}=525,79^{\circ} \mathrm{C}$.

TEMA 4

4.1. $\mathrm{P}=5,31 \mathrm{kN} ; \tau=0,182 \mathrm{MPa}$.

4.2. $22,79^{\circ}<\theta<32,08^{\circ}$.

4.3. $\mathrm{P}=50,3 \mathrm{kN}$.

4.4. $\mathrm{Q}=32,74 ; \mathrm{u}_{\mathrm{B}}=6,98 \cdot 10^{-5} \mathrm{~m}$. 
4.5. $\mathrm{N}_{\mathrm{A} 1}=\mathrm{N}_{\mathrm{B} 5}=-25 \mathrm{kN} ; \mathrm{N}_{12}=\mathrm{N}_{45}=35,35 \mathrm{kN} ; \mathrm{N}_{13}=\mathrm{N}_{35}=-25 \mathrm{kN} ; \mathrm{N}_{23}=\mathrm{N}_{34}$ $=-35,35 \mathrm{kN} ; \mathrm{N}_{24}=50 \mathrm{kN}$.

4.6. $\sigma=216,08 \mathrm{MPa} ; \mathrm{u}_{\mathrm{D}}=-2,06 \mathrm{~mm} ; \mathrm{v}_{\mathrm{D}}=-4,17 \mathrm{~mm}$.

4.7. $\sigma=148,54 \mathrm{MPa} ; \mathrm{u}_{\mathrm{D}}=-0,943 \mathrm{~mm} ; \mathrm{v}_{\mathrm{D}}=1,415 \mathrm{~mm}$.

4.8. $\mathrm{N}_{45}=\mathrm{P} ; \mathrm{N}_{35}=-1,414 \mathrm{P} ; \mathrm{N}_{34}=\mathrm{P} ; \mathrm{N}_{13}=-\mathrm{P} ; \mathrm{N}_{41}=-1,414 \mathrm{P} ; \mathrm{N}_{42}=2 \mathrm{P}$.

4.9. $\mathrm{u}_{\mathrm{C}}=0 ; \mathrm{v}_{\mathrm{C}}=-1,134 \mathrm{~mm}$.

4.10. a) $\mathrm{s}_{\text {màx }}=-132,42 \mathrm{MPa}<\mathrm{s}_{\text {adm }}$;b) $\mathrm{v}_{\mathrm{B}}=2,77 \mathrm{~mm} ; \mathrm{v}_{\mathrm{C}}=-12,88 \mathrm{~mm}$.

4.11. $\mathrm{s}_{\text {màx }}=53,47 \mathrm{MPa} ; \delta_{\text {màx }}=0,764 \mathrm{~mm}$. El disseny és correcte, però no òptim.

4.12. a) $\mathrm{P}=212,6 \mathrm{kN}$; b) $\mathrm{R}_{\mathrm{AY}}=101,8 \mathrm{kN} ; \mathrm{R}_{\mathrm{AX}}=135,3 \mathrm{kN} ; \mathrm{R}_{\mathrm{F}}=66,9 \mathrm{kN} ; \mathrm{R}_{\mathrm{E}}=$ $109,3 \mathrm{kN} ; c) \sigma_{\mathrm{E}}=222.7 \mathrm{MPa}$.

4.13. $\mathrm{q}=22,73 \mathrm{kN} / \mathrm{m}$.

\section{TEMA 5}

5.1. $\sigma=-40 \mathrm{MPa}$, en $\mathrm{y}=5 \mathrm{~cm}, \mathrm{z}=5 \mathrm{~cm}$.

5.2. IPE 220.

5.3. IPE 600; HEB 280 .

5.4. CF $180 \times 3.0$.

5.5. IPE 200.

5.6. a) $\left.\mathrm{y}=1,442 \cdot 10^{-3}-0,822 \mathrm{z} ; b\right) \sigma_{\mathrm{A}}=-543,33 \mathrm{MPa}$ en $\mathrm{y}_{\mathrm{A}}=-\mathrm{h} / 2 ; \mathrm{z}_{\mathrm{A}}=-\mathrm{b} / 2$; $\sigma_{\mathrm{B}}=-530 \mathrm{MPa}$ en $\mathrm{y}_{\mathrm{B}}=\mathrm{h} / 2 ; \mathrm{z}_{\mathrm{B}}=\mathrm{b} / 2$.

5.7. a) $\mathrm{d}=2,485 \mathrm{~m} ; c$ ) IPE $120 ; 66,7 \%$.

5.8. Material 1: $\sigma_{\text {màx-C }}=-480 \mathrm{MPa} ; \sigma_{\text {màx-T }}=543 \mathrm{MPa}$; Material 2: $\sigma_{\text {màx-C }}=-194$ $\mathrm{MPa} ; \sigma_{\text {màx-T }}=215 \mathrm{MPa}$.

5.9. a) $\tau_{\mathrm{XY} 1}(\mathrm{y})=131668,16-2,34 \cdot 10^{7} \mathrm{y}^{2}(\mathrm{~Pa}) ; \tau_{\mathrm{XY} 2}(\mathrm{y})=53642,58-2,34$ - $\left.10^{7} \mathrm{y}^{2}(\mathrm{~Pa}) ; \tau_{\mathrm{xY} 3}(\mathrm{y})=131668,16-2,34 \cdot 107 \mathrm{y}^{2}(\mathrm{~Pa}) ; b\right) \sigma=936306,91 \mathrm{y}$ $-702230,18 \mathrm{z}(\mathrm{Pa}) ; c) \mathrm{y}=0,75 \mathrm{z} ; d) \sigma_{\mathrm{A}}=-8,78 \cdot 10^{4} \mathrm{~Pa}$ en $\mathrm{y}_{\mathrm{A}}=-7,5 \mathrm{~cm}$; $\mathrm{z}_{\mathrm{A}}=2,5 \mathrm{~cm} ; \sigma_{\mathrm{B}}=8,78 \cdot 10^{4} \mathrm{~Pa}$ en $\left.\mathrm{y}_{\mathrm{B}}=7,5 \mathrm{~cm} ; \mathrm{z}_{\mathrm{B}}=-2,5 \mathrm{~cm} ; e\right) \sigma_{1}=6,51$. $10^{4} \mathrm{~Pa} ; \sigma_{2}=-6,03 \cdot 10^{4} \mathrm{~Pa} ; \sigma_{\text {eq, vM }}=10,86 \cdot 10^{4} \mathrm{~Pa}$.

\section{TEMA 6}

6.1. $y(x)=\frac{1}{E I_{Z}}\left[\frac{p \cdot x^{3}}{6}-\frac{P \cdot a \cdot x^{2}}{2}\right] ; y_{2}(x)=\frac{1}{E \cdot I_{Z}}\left[\frac{P \cdot a^{3}}{6}-\frac{P \cdot a^{2} \cdot x}{2}\right]$.

6.2 .

a) $y_{1}(x)=\frac{1}{E I_{Z}}\left[\frac{q \cdot L \cdot x^{3}}{12}-\frac{3 \cdot q \cdot L^{2} \cdot x^{2}}{16}\right] ; y_{2}(x)=\frac{1}{E I_{Z}}\left[\frac{-q \cdot x^{4}}{24}+\frac{q \cdot L \cdot x^{3}}{6}-\frac{q \cdot L^{2} \cdot x^{2}}{4}+\frac{q \cdot L^{3} \cdot x}{48}-\frac{q \cdot L^{4}}{384}\right]$;

b) $y(L)=-5,529 \mathrm{~mm} ; \theta(L)=-1,88 \cdot 10^{-3} \mathrm{rad}$.

6.3. $\mathrm{y}(\mathrm{L} / 2)=-0,423 \mathrm{~mm}$.

6.4. $y_{1}(x)=\frac{1}{E I_{Z}}\left[-1,67 x^{3}-45,83 x\right] \quad y_{2}(x)=\frac{1}{E I_{Z}}\left[-1,67 x^{3}+10(x-1)^{2}-45,83 x\right]$.

$y_{3}(w)=\frac{1}{E I_{Z}}\left[-1,67 w^{3}-0,416 w^{4}+57,5 w-95\right]$.

$y_{4}(w)=\frac{1}{E I_{Z}}\left[-1,67 w^{3}-0,416 w^{4}+9,17(w-2)^{2}+0,416(w-2)^{4}+57,5 w-95\right]$.

$y_{5}(w)=\frac{1}{E I_{7}}\left[-1,67 w^{3}-0,416 w^{4}+9,17(w-2)^{2}+0,416(w-2)^{4}-1,67(w-3)^{3}+57,5 w-95\right]$.

Fletxa en B: $y_{1}(x=2)=-0,016 \mathrm{~m}$; fletxa en D: $y_{4}(w=3)=1,43 \cdot 10^{-3} \mathrm{~m}$. 
6.5. Reaccions: $\mathrm{R}_{\mathrm{A}}=3,542 \mathrm{kN} ; \mathrm{R}_{\mathrm{C}}=35,625 \mathrm{kN} ; \mathrm{R}_{\mathrm{E}}=2,083 \mathrm{kN}$.

Equació amb funcions de discontinuïtat:

$$
\begin{aligned}
& y(x)=\frac{1}{E I_{Z}}\left[-0,59 x^{3}+10\langle x-1\rangle^{2}-0,416\langle x-2\rangle^{4}+0,416\langle x-4\rangle^{4}+\right. \\
& \left.+5,938\langle x-4\rangle^{3}-1,667\langle x-5\rangle^{3}-11,389 x\right] .
\end{aligned}
$$

Fletxa en $\mathrm{B}: \mathrm{y}(\mathrm{x}=2)=-3,006 \cdot 10^{-3} \mathrm{~m}$; fletxa en $\mathrm{D}: \mathrm{y}(\mathrm{x}=5)=3,221 \cdot 10^{-4} \mathrm{~m}$. 6.6. $\mathrm{R}_{\mathrm{A}}=\mathrm{R}_{\mathrm{B}}=\mathrm{q} \cdot \mathrm{a}$.

6.7. Mateix resultat que els exemples 6.7. i 6.8 .

6.8. Mateix resultat que els exemples 6.9. i 6.10.

6.9. $v_{B}=\frac{9 q L^{4}}{8 E I_{Z}}$.

6.10. $v_{C}=\frac{23 P a^{3}}{24 E I_{Z}}$.

6.11. $\mathrm{b}=22,63 \mathrm{~cm} ; b) \theta=7,88 \cdot 10^{-3} \mathrm{rad}$.

6.12. $v_{D}=\frac{5 P a^{3}}{12 E I_{Z}}$.

6.13. $M_{\text {màx }}=\frac{-8}{11}$ Paen $x=2 a$.

6.14. a) $\mathrm{R}_{\mathrm{A}}=2,75 \mathrm{kN} ; \mathrm{M}_{\mathrm{A}}=3 \mathrm{kN} \cdot \mathrm{m} ; \mathrm{R}_{\mathrm{C}}=1,25 \mathrm{kN} ;$ d) $\left.\mathrm{v}_{\mathrm{B}}=6,37 \mathrm{~mm} ; e\right) \theta=5,46$ $\cdot 10^{-3} \mathrm{rad}$.

6.15. $R_{A}=R_{B}=\frac{q a}{2} ; M_{A}=M_{B}=\frac{5 a^{2}}{16}$.

6.16. $R_{A}=\frac{5 q a}{8}-\frac{3 P}{2} ; R_{B}=\frac{3 q a}{8}+\frac{5 P}{2}, M_{A}=\frac{q a^{2}}{8}-\frac{P a}{2}$.

6.17. b) $v_{D}=\frac{P a^{3}}{12 E I_{Z}}$; ) $\theta_{C}=\frac{P a^{2}}{12 E I_{Z}}$.

6.18. a) $\left.\mathrm{R}_{\mathrm{A}}=182,86 \mathrm{kN} ; \mathrm{M}_{\mathrm{A}}=300 \mathrm{kN} \cdot \mathrm{m} ; \mathrm{R}_{\mathrm{B}}=97,14 \mathrm{kN} ; b\right)$ IPE 400 ;

c) $\mathrm{v}_{\mathrm{m}}=15,67 \mathrm{~mm} ;$ d) $\mathrm{R}_{\mathrm{A}}=187,11 \mathrm{kN} ; \mathrm{M}_{\mathrm{A}}=329,74 \mathrm{kN} \cdot \mathrm{m} ; \mathrm{R}_{\mathrm{B}}=92,89 \mathrm{kN}$ :

e) no és vàlid, es necessita IPE 450 .

6.19. $\mathrm{V}=1,55 \mathrm{kN} ; \mathrm{v}_{\mathrm{B}}=6,07 \mathrm{~mm}$.

6.20. $\mathrm{Q}=1,72 \mathrm{kN} ; \mathrm{v}_{\mathrm{C}}=3,53 \mathrm{~mm}$.

TEMA 7

7.1. a) $\left.\left.\tau_{\text {gruixuda }}=191,69 \mathrm{MPa} ; b\right) \tau_{\text {prima }}=174,66 \mathrm{MPa} ; c\right) \varphi_{\mathrm{B}}=0,24 \mathrm{rad}$.

\section{TEMA 8}

8.1. 2 X IPE 270 .

8.2. $\mathrm{N}_{\mathrm{b}, \mathrm{Rd}}=1.382 \mathrm{kN}$.

8.3. HEB 280 .

8.4. a) $\mathrm{q}=11,29 \mathrm{kN} / \mathrm{m} ; b) \mathrm{q}=69,83 \mathrm{kN} / \mathrm{m}$.

8.5. a) $4.178 \mathrm{kN}$; b) $1.119 \mathrm{kN}$; c) $1.341 \mathrm{kN}$; d) $1.119 \mathrm{kN}$.

8.6. a) 2UPN120; b) 2UPN240; c) 2UPN280.

8.7. a) $\mathrm{q}=621,37 \mathrm{kN} / \mathrm{m} ;$ c) $\sigma_{\text {eqVM }}=41,72 \mathrm{MPa}$.

8.8. $2 \times$ UPN 260. 


\section{ANNEX A}

A.1. $\mathrm{q}_{\mathrm{C}}=3,14 \cdot 10^{6} \mathrm{~N} / \mathrm{m} ; \mathrm{q}_{\mathrm{X}}=5,2 \cdot 10^{6} \mathrm{~N} / \mathrm{m} ; \mathrm{q}_{\mathrm{E}}=2,84 \cdot 10^{6} \mathrm{~N} / \mathrm{m}$.

A.2. $\mathrm{q}_{\mathrm{C}}=1,68 \cdot 10^{6} \mathrm{~N} / \mathrm{m} ; \mathrm{q}_{\mathrm{X}}=1,34 \cdot 10^{6} \mathrm{~N} / \mathrm{m} ; \mathrm{q}_{\mathrm{E}}=1,23 \cdot 10^{6} \mathrm{~N} / \mathrm{m}$.

\section{ANNEX B}

B.1. $\mathrm{a}=5 \cdot 10^{-6} \mathrm{~m} ; \mathrm{b}=9,5 \cdot 10^{12} \mathrm{~km} ; \mathrm{A}_{1}=1,2 \cdot 10^{-5} \mathrm{~m}^{2} ; \mathrm{A}_{2}=3,03 \cdot 10^{3} \mathrm{hm}^{2}$; $\mathrm{V}=2,7 \cdot 10^{13} \mathrm{ml} ; \mathrm{P}=1,471 \mathrm{kN} / \mathrm{m}^{2} ; \mathrm{E}=2,1 \cdot 10^{11} \mathrm{~N} / \mathrm{mm}^{2} ; \rho=4.000 \mathrm{~kg} / \mathrm{m}^{3}$; $\theta=0,436 \mathrm{rad} ; \mathrm{t}_{1}=2,836 \mathrm{~h} ; \mathrm{t}_{2}=325.833 \mathrm{~min} ; \omega=0,126 \mathrm{rad} / \mathrm{s} ; \mu=0,005 \mathrm{~kg} / \mathrm{m} / \mathrm{s}$; $\mathrm{Q}=180 \mathrm{~m}^{3} / \mathrm{h} ; \mathrm{C}=2 \cdot 10^{-6} \mathrm{~kg} / \mathrm{m}^{3} ; \sigma=2,746 \cdot 10^{26} \mathrm{~Pa} ; \mathrm{c}_{0}=1,079 \cdot 10^{-6} \mathrm{Em} / \mathrm{h}$; $\mathrm{G}=1,271 \cdot 10^{5} \mathrm{~km} / \mathrm{h}^{2}$.

B.2. $\mathrm{h}_{1}=0,914 \mathrm{~m} ; \mathrm{A}=1,29 \cdot 10^{-3} \mathrm{~m}^{2} ; \mathrm{V}=0,866 \mathrm{~m}^{3} ; \mathrm{P}=3,447 \cdot 10^{4} \mathrm{~Pa} ; \mathrm{a}=4,572 \mathrm{~m} / \mathrm{s}^{2}$; $\rho=6,92 \cdot 10^{6} \mathrm{~kg} / \mathrm{m}^{3} ; \mathrm{V}_{1}=7,62 \mathrm{~m} / \mathrm{s} ; \mathrm{V}_{2}=31,29 \mathrm{~m} / \mathrm{s}$.

\section{ANNEX C}

C.1. $X_{\mathrm{G}}=3,92 \mathrm{~cm} ; \mathrm{Y}_{\mathrm{G}}=2,24 \mathrm{~cm}$.

C.2. $X_{\mathrm{G}}=1,607 ; \mathrm{Y}_{\mathrm{G}}=2,657$.

\section{ANNEX D}

D.1. $\mathrm{Z}_{\mathrm{G}}=0 ; \mathrm{Y}_{\mathrm{G}}=0,265 \mathrm{~m} ; \mathrm{I}_{\mathrm{Z}}=0,003 \mathrm{~m}^{4} ; \mathrm{I}_{\mathrm{Y}}=0,010 \mathrm{~m}^{4}$.

D.2. $\mathrm{I}_{\mathrm{Z}}=1,18 \cdot 10^{-3} \mathrm{~m}^{4} ; \mathrm{I}_{\mathrm{Y}}=1,68 \cdot 10^{-4} \mathrm{~m}^{4}$. 


\section{Bibliografia}

\section{Referències bàsiques}

BEDFord, A. i altres: Estática: Mecánica para ingeniería. Addison Wesley.

BeER, F. P. i altres: Mecánica vectorial para ingenieros. Estática. McGraw-Hill.

Romero García, M. i altres: Resistencia de materiales. Publicacions de la Universitat Jaume I.

VÁzQuez Fernández, M.: Mecánica para ingenieros. Estática. Noela.

\section{Bibliografia complementària}

Cervera Ruiz, M. i E. Blanco Díaz: Mecánica de estructuras: Libro 1. Resistencia de materiales. Barcelona, Edicions UPC.

Ferrer Ballester, M. i altres: Resistencia de materiales: Problemas resueltos. Barcelona, Edicions UPC.

Fitgerald, R.W.: Mecánica de materiales: Edición revisada. Alfaomega.

Gere, J. M.: Timoshenko: Resistencia de materiales. Paraninfo.

Hibbeler, R. C.: Análisis estructural. Prentice Hall.

Norris, C. H.: Análisis elemental de estructuras. McGraw-Hill.

Ortiz Berrocal, L.: Resistencia de materiales. McGraw-Hill.

Pisarenko, G. S. i altres: Manual de resistencia de materiales. MIR.

Shanley, F. R.: Mecánica de materiales. McGraw-Hill.

STIOPIN, P.: Resistencia de materiales. MIR. 